
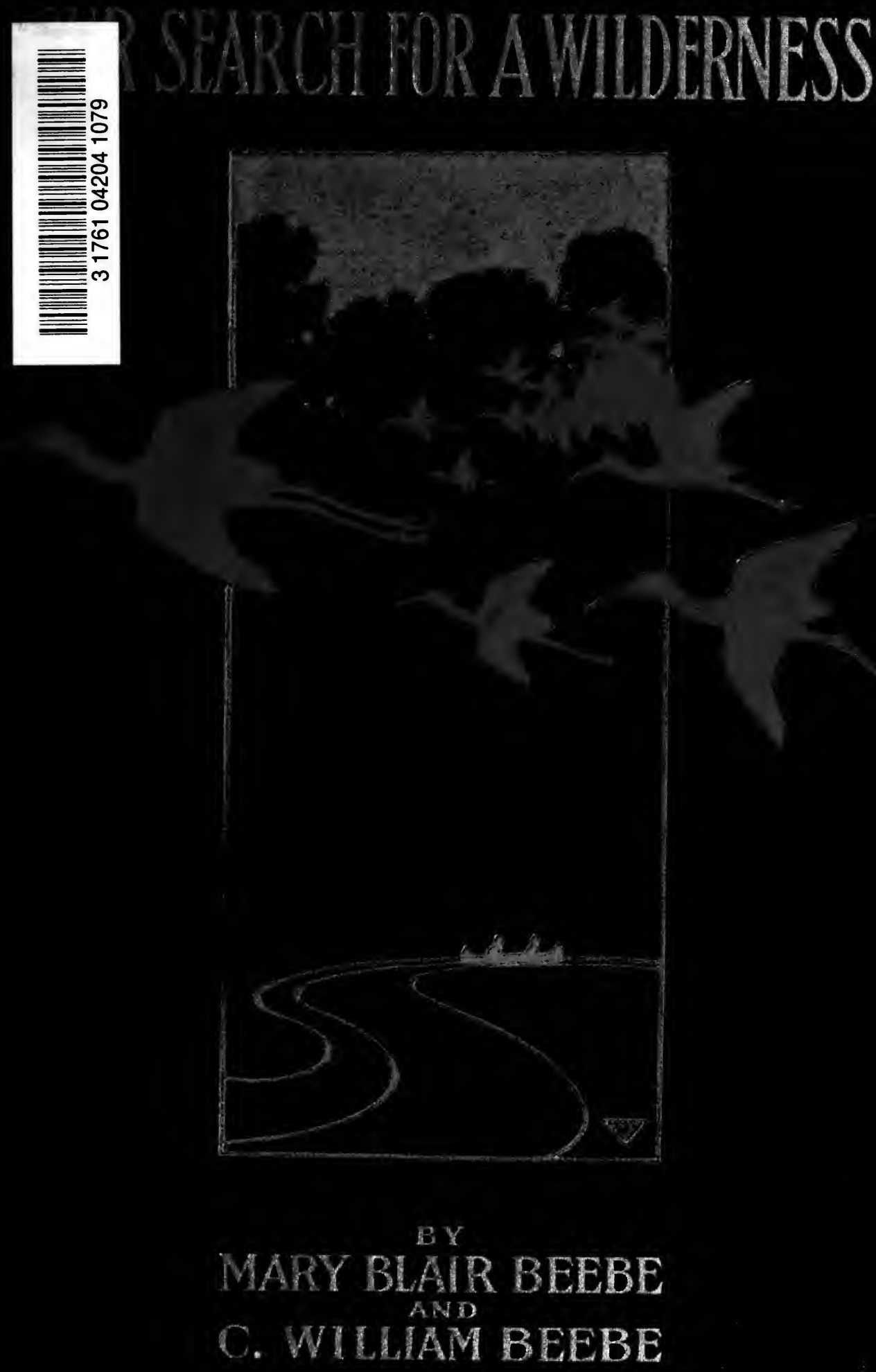



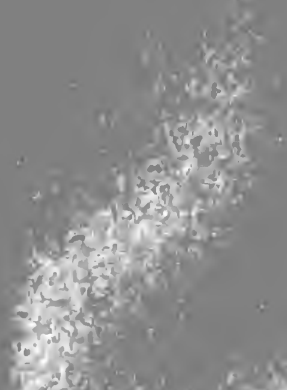

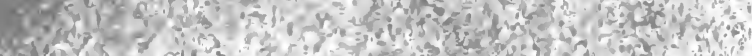
s.

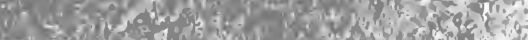

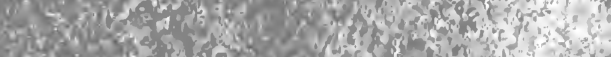

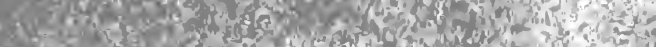

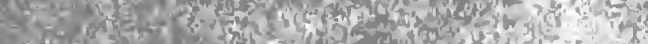

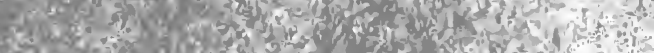

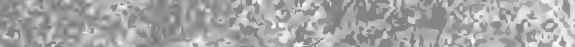

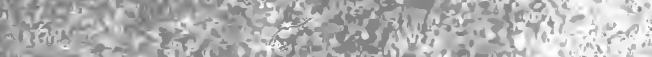

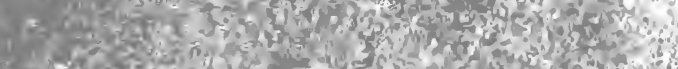
7 a

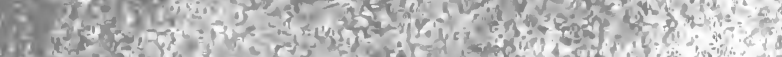

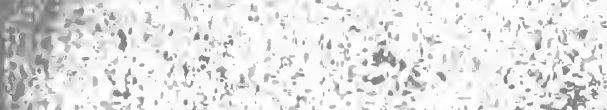

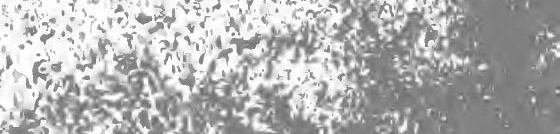
21

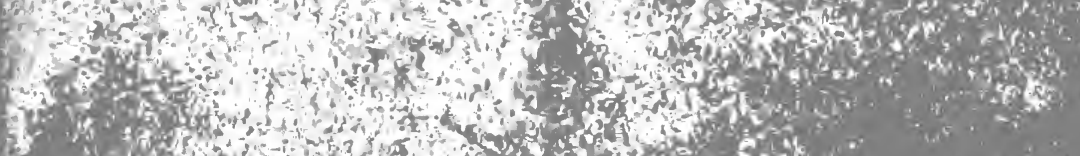

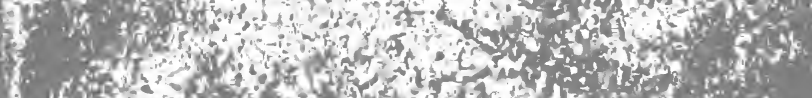

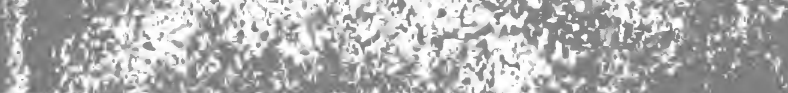

3.

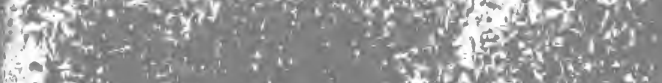

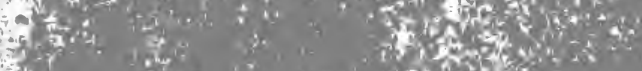

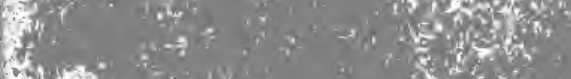



if

itiv

is is ?

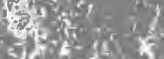

of

te 


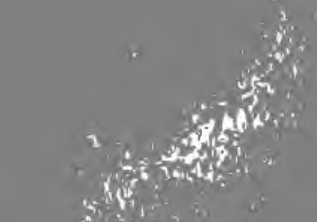

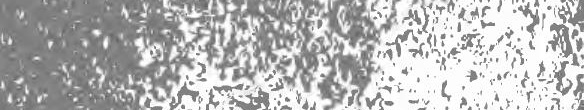

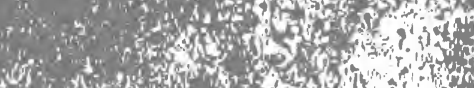

$x^{3}+x^{3}+2$

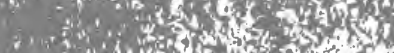
4. 3 -

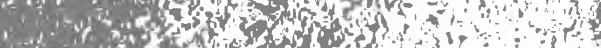

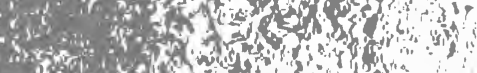

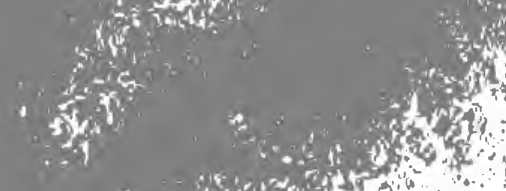

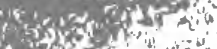

6
$i$
$i$
$i$

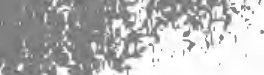
sitit?

and

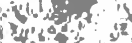

arition

sin:

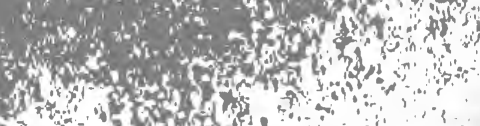

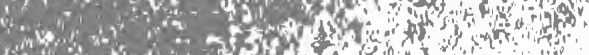

Thes

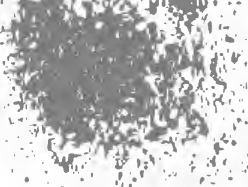

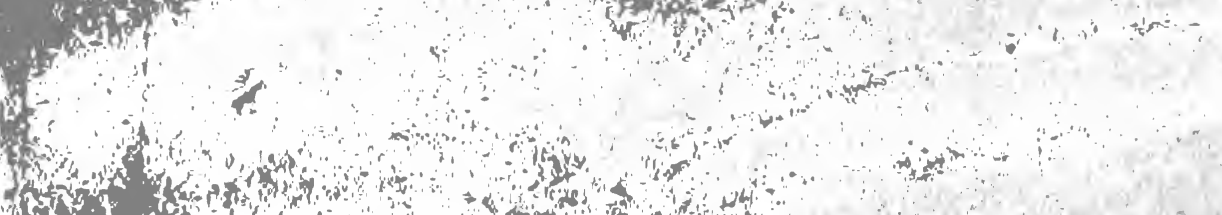




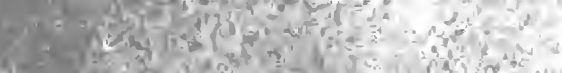

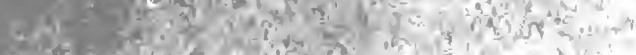

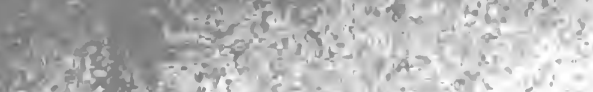

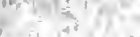

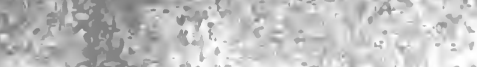

$\Leftrightarrow$ funtrits

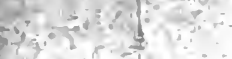

$4=-x^{2} \cdot i$

25

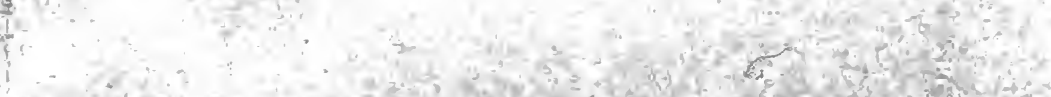

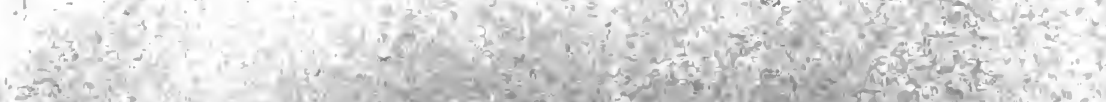

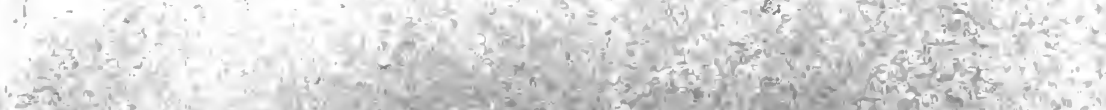

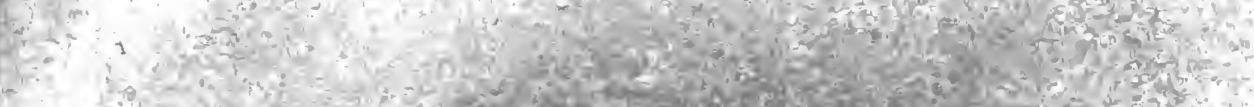

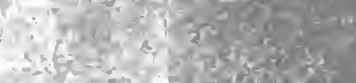

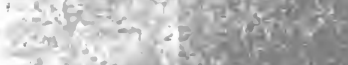

$1^{4} x^{2}+x^{2}+2$

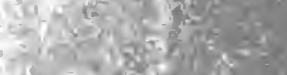

Then and

$-9+4 x^{2}=$

tis $x=2 y^{2}$

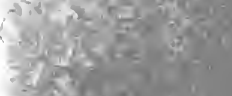

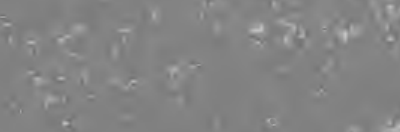

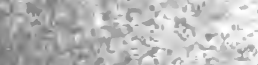

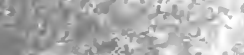

and

$4 e^{2} x^{2}$

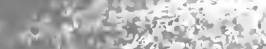

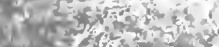

$\left.-3 \varepsilon^{2}\right)^{2}=2$
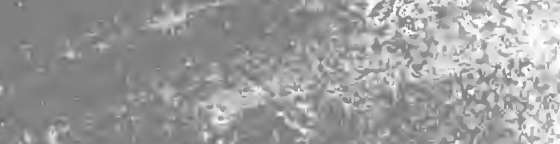

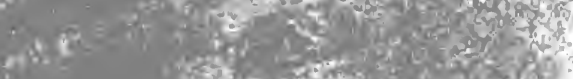

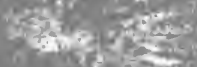

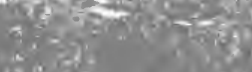

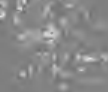

4.

1.

Natict?

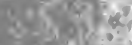

$\frac{1}{3}=$

$\frac{7}{3}=$

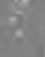

s.t.

की

atish

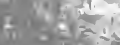

s.t.

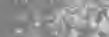

$-\sin ^{2}$

(3)

$=x$ 


\section{BY C. WILLIAM BEEBE \\ THE BIRD, ITS FORM AND FUNCTION}

With colored Frontispiece and 37r Illustrations, chiefly photographed from Life by the Author. American Nature Series. New York: Henry Holt and Company. 8vo. $\$ 3.50$ net.

\section{THE LOG OF THE SUN}

A Chronicle of Nature's Year. With fiftytwo full-page illustrations by Walter King Stone, and numerous Vignettes and photographs from Life. New York: Henry Holt and Company. 8 vo., full gilt. $\$ 6.00$ net.

\section{TWO BIRD-LOVERS IN MEXICO}

Illustrated with photographs from Life taken by the Author. Boston: Houghton Mifflin Company. 8 vo. $\$ 3.00$ net. 


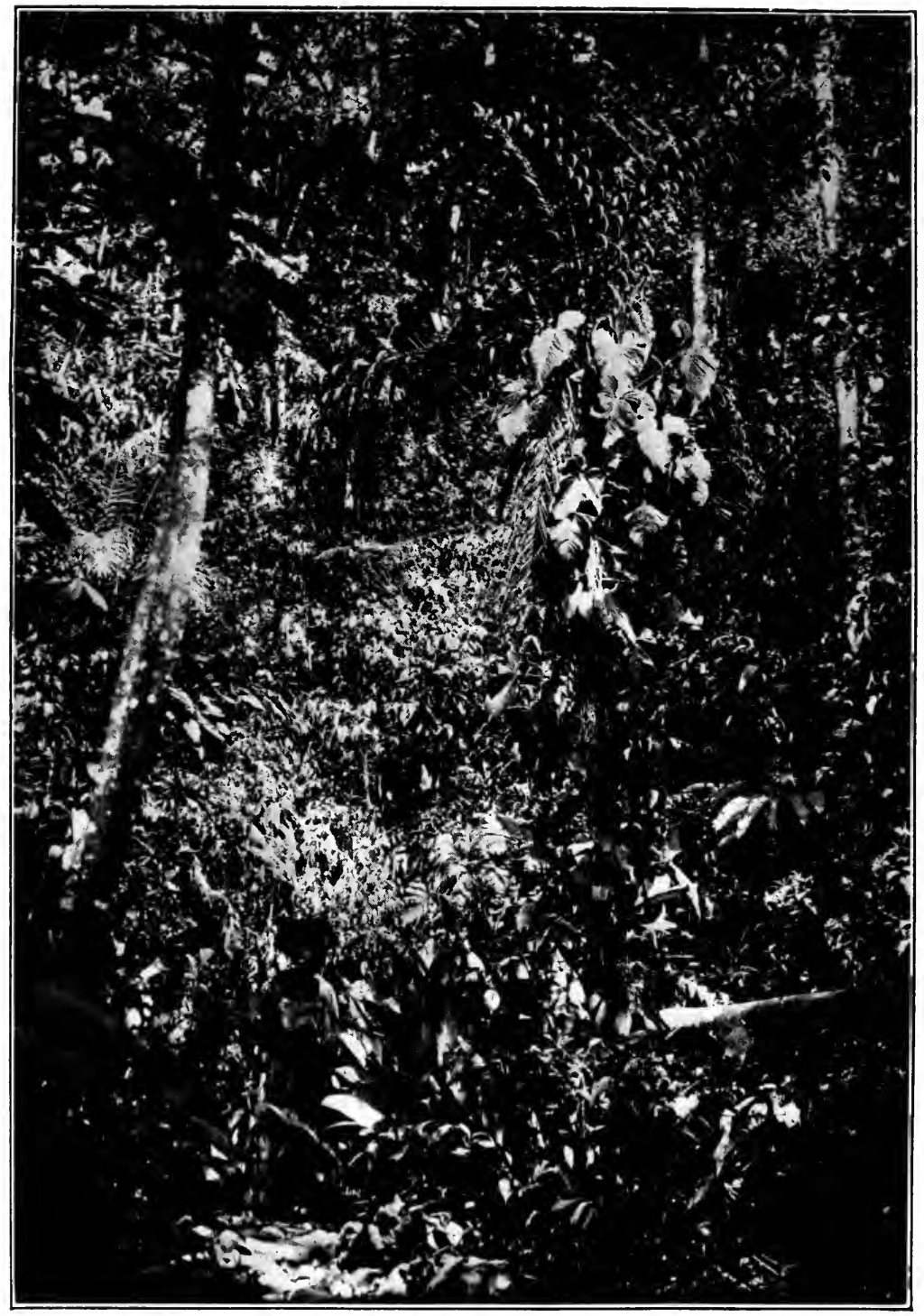

In the South AMerican Wilderness.

(Frontispicec) 


\title{
OUR SEARCH FOR A WILDERNESS
}

\author{
AN ACCOUNT OF TWO ORNITHOLOGICAL EXPEDITIONS
}

TO VENEZUELA AND TO BRITISH GUIANA

\author{
BY \\ MARY BLAIR BEEBE \\ AND \\ C. WILLIAM BEEBE, \\ Curator of Ornithology in the New I'ork Zoölogical P'ark; Fellow of the \\ New York A cademy of Sciences; Member of the A merican \\ Ornithologists' Union and Correspond. \\ ing Nember of the London \\ Zoölogical Society
}

ILLUSTRATED WITH PHOTOGRAIHS FROM LIFE

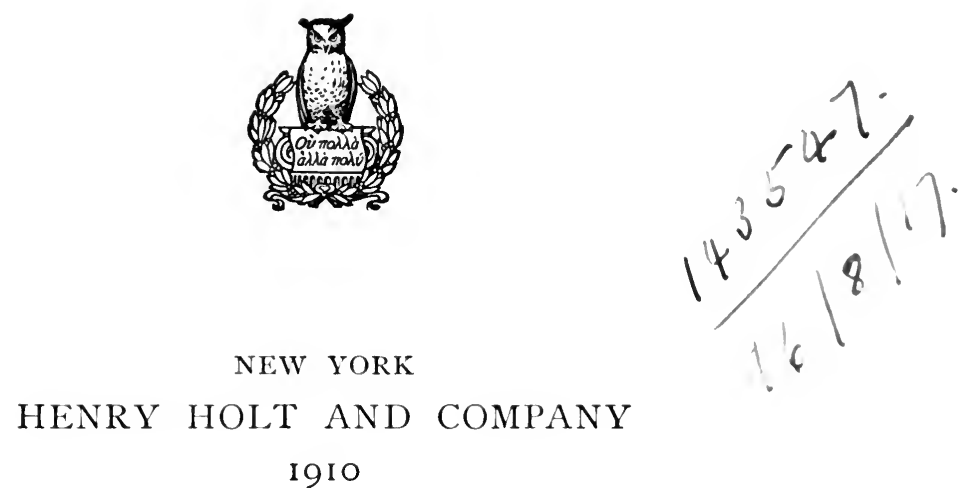


Copyright, 1910,

BY

HENRY HOLT AND COMPANY

Published April, 1910

Stanbope Press

F. H. GILSON COMPANY

BOSTON. U.S.A. 
To

JUdge AND Mrs. ROGER A. PRYOR

With the deepest affection and admiration

of

their Granddaughter

MARY BLAIR BEEBE

and of

C. WILLIAM BEEBE 



\section{PREFACE.}

In the following pages we have set down the tale of two searches for a wilderness. These two private expeditions were undertaken for the purpose of learning something about the birds and other wild creatures of countries further south than any we had yet visited. Both trips were successful; for the regions we explored were wilderness wonderlands, full of beauty, abounding in the romance which ever enhances wild creatures and wild men, and they were part of the great zoölogical "dark continent" which we hope to devote our lives to studying.

On our first search the collecting of live birds was incidental, although we brought back forty specimens of fourteen species.

On the second search, however, we took with us an assistant, Mr. Lee S. Crandall. By his assiduity in trapping and in arousing the interest of native coolie and black boys, he assembled a splendid collection of almost three hundred living birds of fifty-one species. These we brought to the New York Zoölogical Park, where no less than thirty-three species were new to the collection. In addition many small mammals and reptiles were collected.

\section{PART I.}

We left New York on February 22d, I908, on the Royal Mail Steamship "Trent," and after touching at Jamaica, Colon, Savanilla and La Guayra, we disembarked at Port of Spain, Trinidad, on March 9th. Leaving this port in a Venezuelan sloop we cruised among the caños north of the 
Orinoco Delta, and explored the country about the Venezuelan Pitch Lake - La Brea.

To Mr. Eugene André of Trinidad, we are deeply indebted for a hundred kindnesses which did much to make our trip a success. We wish also to express gratitude to Mr. Mole, Mr. Anduse and especially to the late Mr. Ellis Grell.

\section{PART II.}

On the I $5^{\text {th }}$ of February, I909, we sailed from New York on the Steamship "Coppename" of the Royal Dutch West Indian Mail, and with only a single stop - Barbadoes reached Georgetown, British Guiana, on the $24^{\text {th }}$ of the same month.

In British Guiana we made three expeditions; two as the guests of Mr. and Mrs. Gaylord Wilshire, having as our objective points two gold mines in the midst of the wilderness, the first at Hoorie in the northwest, the second on the Little Aremu in central Guiana. On these expeditions we were spared all the usual annoyances of transportation; food and servants and everything at the mines were put at our service to facilitate our study of the nature life of the country. The third trip to the savanna region further south was made at the invitation of $\mathrm{Mr}$. and Mrs. Lindley Vinton, two Americans living in Georgetown, who placed their home at our disposal while we remained in Georgetown.

During our entire stay in British Guiana we received unfailing courtesy and kindness, - from the Governor, Sir Frederick Hodgson, down to the great black hospitable wilderness police. Professor J. B. Harrison allowed us to use the old aviaries at the Botanical Gardens, and with Mr. James Rodway of the Georgetown Museum and Mr. B. Howell Jones, extended to us all the courtesies in his power. 
For figures 97, 98, 108, I44, and $5_{5} 8$ we are indebted to Dr. Hiram Bingham, and figures 83 , I09, I30, and I3 I are from photographs belonging to the New York Zoölogical Society and were taken by Mr. E. R. Sanborn. All the others were taken by ourselves with a Graflex Camera and 27 -inch Goerz lens, and a pocket Kodak, both 4 by 5 in size.

The first two chapters appeared in their original form in "Harper's Monthly Magazine," and the third chapter in "Recreation."

Our thanks are due to Dr. William T. Hornaday, Director of the New York Zoölogical Park, for the leave of absence which made possible these expeditions.

Three appendices have been added. The first is a classified list of the birds, with their scientific names, which are mentioned in the book; by no means a complete list of those observed. Reference to it is facilitated by the superior numbers affixed throughout the text to the names of the birds. The second appendix gives the native Guianan names of the commoner species of birds. The third is a list of the insects observed at Hoorie which have been identified up to the present time.

Wherever in this volume it has seemed best for any reason that certain chapters should be written by one of the authors alone, the writer's name has been given at the head of the chapter. In all chapters not thus designated the authors have collaborated.

MARY BLAIR BEEBE, C. WILLIAM BEEBE.

January, rgro. 



\section{CONTENTS.}

PART I. OUR FIRST SEARCH.

Venezuela.

PAGE

I. THE LAND OF A SINGLE TREE............ 3

II. THE LAKE OF PITCH................... $3^{2}$

III. A WOMAN'S EXPERIENCES IN VENEZUELA..... $7^{i}$

PART II. OUR SECOND SEARCH.

British Guiana.

IV. GEORGETOWN ................... II I

V. STEAMER AND LAUNCH TO HOORIE CREEK... I 34

VI. A GOLD MINE IN THE WILDERNESS......... I 65

VII. THROUGH THE COASTAL WILDERNESS WITH

INDIANS AND CANOE................ 214

VIII. THE WATER TRAIL FROM GEORGETOWN TO

AREMU ....................... 244

IX. JUNGLE LIFE AT AREMU .............. 285

X. JUNGLE LIFE AT AREMU (Continued)......... 316

XI. THE LIFE OF THE ABARY SAVANNAS ....... 350

\section{APPENDICES.}

A. CLASSIFIED LIST OF BIRDS MENTIONED IN THIS VOLUME ..................... 389

B. NATIVE GUIANAN NAMES OF BIRDS ........ 395

C. ALPHABETICAL LISTS OF BIRDS. . . . . . . . . 397

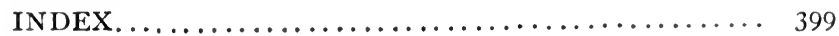


S.7.

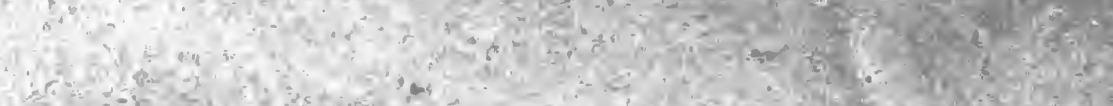

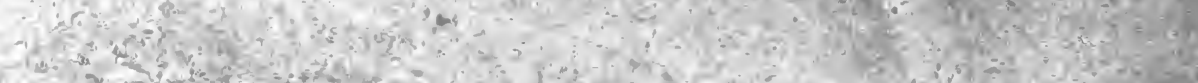

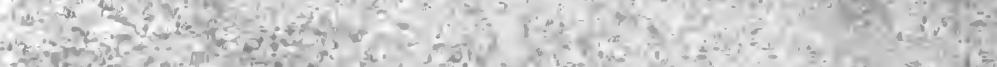

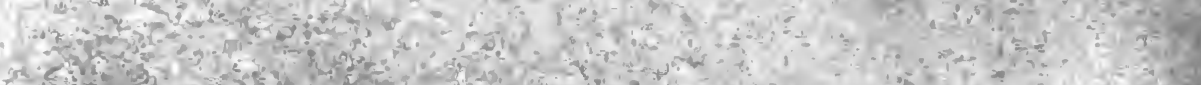

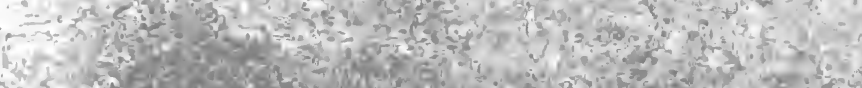

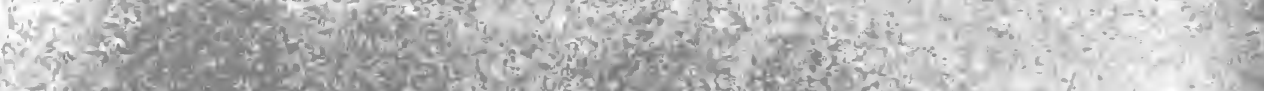

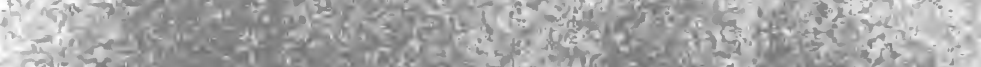

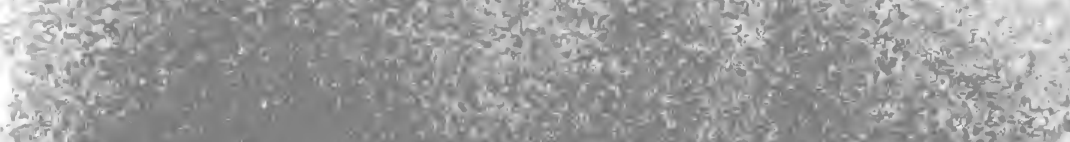

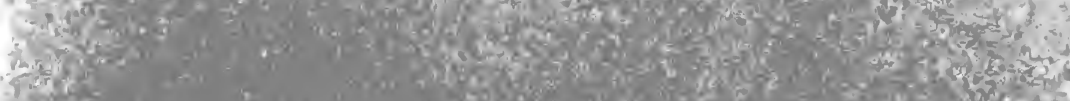
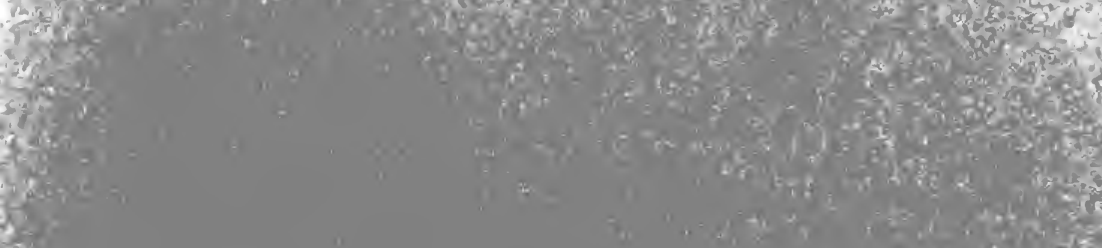

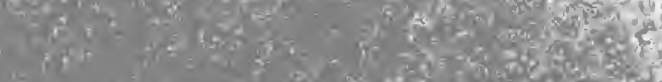

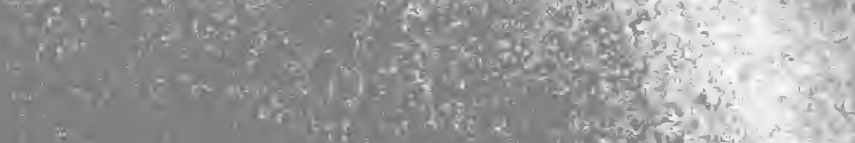
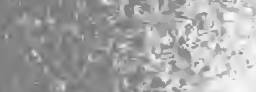

$\because 10$

Axise

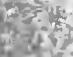

$\therefore x^{2} x^{2}$

$13020=1.2$

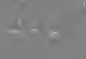

in

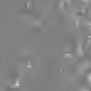

0 \&

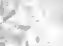

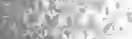

\& $\sin ^{2}$

orsen

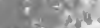

ater

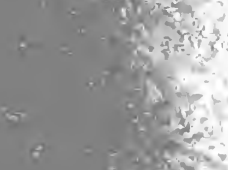

is.

inges?

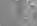

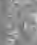

$-9$

$<2$

(3)

$+\quad$

in

to 


\section{LIST OF ILLUSTRATIONS.}

FIG.

In the South American Wilderness.

PAGE

Frontispiece

I. Map of our Trip through the Mangrove Wilderness ........ 2

2. Our Sloop entering the Mangroves................. 5

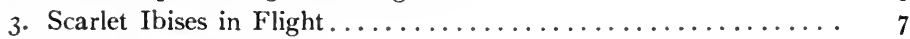

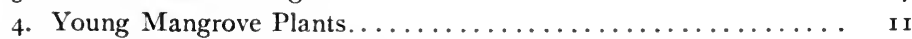

5. The Crucifix in the Catfish ....................... I3

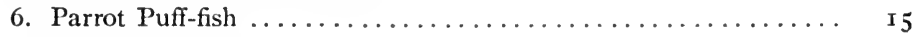

7. Four-eyed Fish......................... 6

8. Our Floating Home at La Ceiba................. I8

9. Exploring the Caños in a Dug-out............... $2 \mathrm{r}$

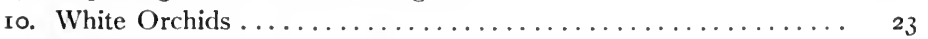

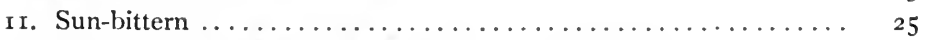

I2. Solution of the Mangrove Mystery - an Anaconda......... 27

13. Hoatzins in the Bamboos on the Guarapiche........... 28

I4. First Glimpse of the Venezuela Mountains............ 3 I

15. Colony of 150 Cassiques' Nests in One Tree............ 33

16. Nest and Eggs of Yellow-backed Cassique............. 34

17. Venezuelan Tree Porcupine .................. ${ }_{3} 6$

18. Wild Chachalaca near a Guanaco Hut............. 38

19. Scorpion and its Young taken from Milady's Shoe.......... 39

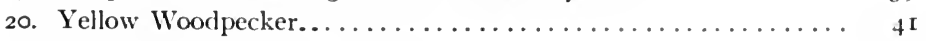

2I. Owl Butterfly on Cocoa Bark................. 42

22. Lizard Alert on Trunk of Tree................. 44

23. The Same Lizard a Moment Later, Obliterated by Change of

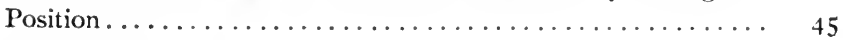

24. Nest and Eggs of Great Blue Tinamou.............. 47

25. Woodhewer clinging to the Trunk of a Tree........... 50

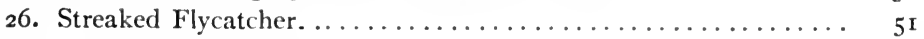

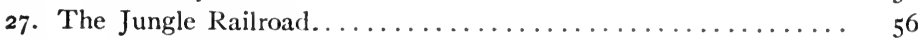

28. Spider Lilies near Pitch Lake.................. 57

29. La Brea - The Lake of Pitch ................ 59

30. The fatal "Mother of the Lake" ................ 6r

3r. White-headed Chimachima Hawk and Eta Palm.......... 62 
32. Amazon Parrot Roost, Pitch Lake.

33. The Home of the Amazon Parrot in the Middle of Pitch Lake... 64

34. Amazon Parrot at Entrance of Nest. Fifteen feet away....... $6_{5}$

35. Amazon Parrot at Entrance of Nest. Ten feet away........ 65

36. Amazon Parrot about to take Flight............... 66

37. Eggs and Young of Amazon Parrot in the Nest......... 67

38. Fish from the Pools in Pitch Lake. Aoquidens sp.......... 69

39. Fish from the Pools in Pitch Lake. Hoplias malabaricus...... 69

40. Our Sloop at Guanoco ...................... $7^{2}$

4I. Venezuelan Soldiers on the "Pontón" Guard Ship......... 76

42. Captain Truxillo paddling us up the Guarapiche past Caño Colorado............................... 78

43. Sunset in the Mangrove Wilderness................. 80

44. The Silent Savages $\ldots \ldots \ldots \ldots \ldots \ldots \ldots \ldots \ldots \ldots \ldots \ldots$ i

45. Guarauno Indians coming to trade at Caño Colorado....... 83

46. Guarauno Squaws and Child with Monkey ........... 85

47. Pitch Lake, showing freshly dug pit filled with water; an older pit filled with soft pitch, both surrounded by the hard surface

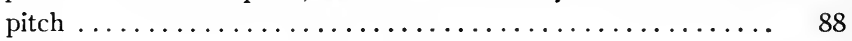

48. Digging out the Black, Waxlike Pitch............. 90

49. Loading Pitch on the Hand Cars. . . . . . . . . . . . 93

50. Mangrove Wilderness from the High Land at Guanoco....... 95

51. Inhabitants of Guanoco assembled for a Dance........... 97

52. A Palm-sheath Rocking Toy.................. 100

53. Sheath in Fig. 52, covering the Flower of a Palm......... I02

54. Priestless Chapel at Guanoco .................... 105

55. Guarauno Indian Papoose.................... 107

56. Map of our Three Expeditions into British Guiana......... I I0

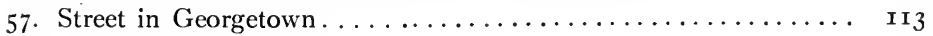

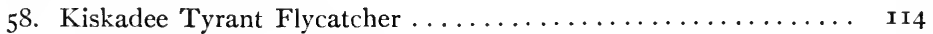

59. Coolie Woman and Negress................... II 7

6o. The Georgetown Sea-wall.................... I

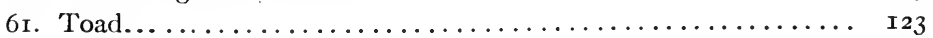

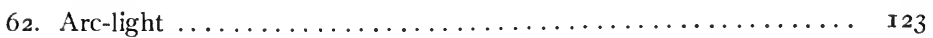

63. Victoria Regia in the Botanical Gardens.............. I 24

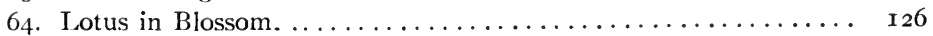

65. Taliput Palm in Blossom .................... 28

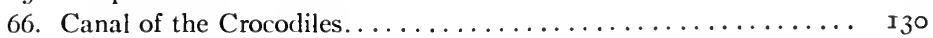

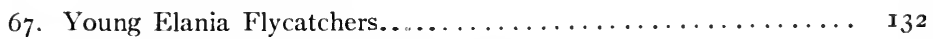

68. Typical Indian House at Morawhanna............. I36 $_{3}$

69. Three-year Olds at Home in their Wood-skin.......... 138

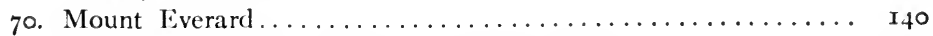

71. Sir Everard imThurn's House at Morawhanna.......... I43

72. Palm Tanager........................ 447 
73. Frederick, the Carib Indian Boy............... I $5^{2}$

74. Our Tent-boat on the Barama River............. 159

75. Indian Boys in Dug-out................... I62

76. Crossing a Stream on the Hoorie Jungle Road .......... I66

77. The Wilderness Trail..................... 168

78. Engine House and Flume of Hoorie Gold Mine......... I72

79. The "Little Giant" at Work................... I 75

80. Carib Hunter and His Children at Hoorie ............. 178

8I. Three Generations of Carib Indians. . . . . . . . . . 80

82. Mr. Wilshire and Crandall with Bushmaster .......... I82

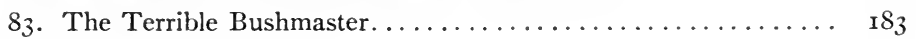

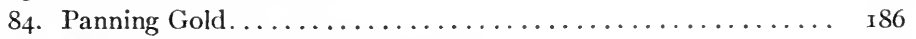

85. Whip Scorpion or Pedipalp Spider............... 190

86. A Jungle Blossom......................... 193

87. The Drowned Forest........................ 199

88. Nests of Red-backed Cassiques................... 204

89. Barama River from Farnums' House.............. 2 6

90. Scene on the Barrabarra........................ 219

9I. Wake of a Manatee swimming up River............. 22 I

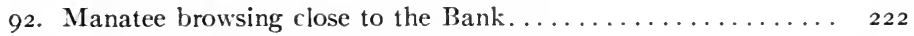

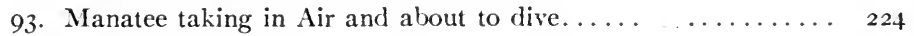

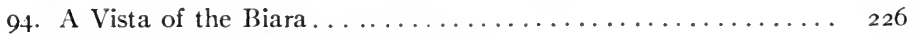

95. Father Gillett and his Indian Boys............... 228

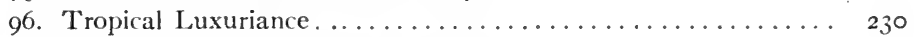

97. Capybara on the Bank of a Stream............... 232

98. South American Thatched House and Nests of Green Cas-

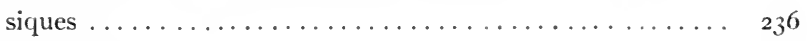

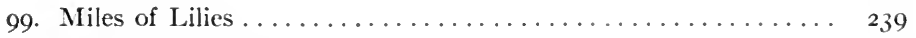

roo. The Road to Suddie ...................... 243

Ior. Gray-breasted Martins nesting on the Steamer .......... 245

102. Coolies and their Wives fishing on the Essequido......... 247

I03. Falls at Lower Camaria ........................ 249

104. A Butterfly Mimicking an Orchid................ $25^{\mathrm{I}}$

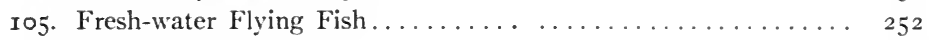

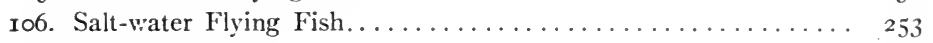

107. Cuyuni River............................ 254

108. A Herd of Eight Capybaras, Six Adult and Two Young. ..... 255

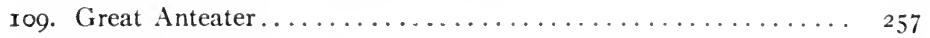

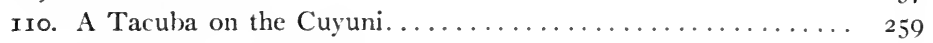

III. Rapids on the Cuyuni........................ 260

II2. Rushing the Boat into the Rapids .............. $26 \mathrm{I}$

Ir3. Warping the Boat Through the Lower Whirlpools ........ 262

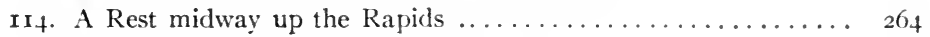

Ir 5. The Final Struggle up to Smooth Water... . . . . . . . . . 266 
FIG.

PAGE

Ir6. Shooting the Rapids at Full Speed.

270

II7. A Wilderness Passion Flower - Simitú............ 272

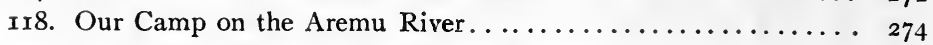

Ir9. Poling under Tacubas on the Little Aremu .......... 276

I20. Tree-ferns on the Little Aremu............... 278

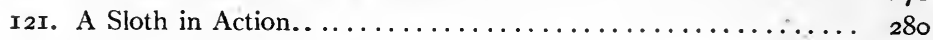

I2 2. A Sloth Asleep........................ 28 I

I23. Where only Otters and Fish can pass ............ 283

124. Aremu Gold Mine, showing Bungalow and Mine Shaft...... 286

I25. Descending the Shaft..................... 289

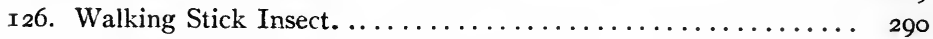

127. Scorpion and Caterpillar after their Battle ........... 292

128. Milady and the Giant Mora Tree............... 296

I29. Aërial Roots of Bush-rope. ................... 299

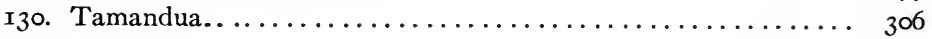

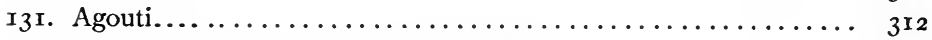

132. Nest and Eggs of White-throated Robin............ 323

133. Section of Paddle-wood Tree......................... 325

134. Phonetic Caterpillars...................... 329

I35. First Phase of Curassow Strutting, a Slow Walk with Raised

Tail. Rear View. ..................... 333

136. The Same. Side View.................... 333

137. Second Phase of Curassow Strutting ............. 335

I38. Third Phase of Curassow Strutting .............. 337

139. Golden-crowned Manakin lifted from Nest .......... 343

I40. Young Dusky Parrots.................... 344

I4I. Early Morning in the Wilderness ............... 346

I42. Indian Hunter bringing in a Peccary............. 347

I43. American Egret on the Abary River Savanna......... $35^{2}$

I44. Nest and Young of Jabiru...................... 354

I45. Gray-necked Tree-ducks rising from the Savanna........ 356

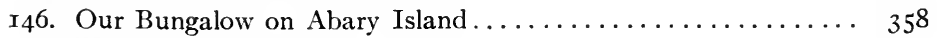

147. Map of Abary Island ........................

148. Abary River, showing High Growth on West Bank....... 362

149. Spider Lily near Abary Island.................. 363

I50. Nest of a Hoatzin in the Mucka-mucka on which these Birds

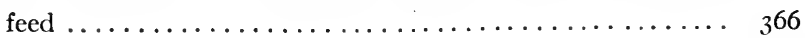

I5I. The Author Photographing Hoatzins.............. 367

152. (A) Female Hoatzin flushed from her nest; the Male Bird approaching......................... 369

r53. (B) Female Hoatzin in the same Position, the Male having flown nearer. ....................... 370

I54. (C) Male Hoatzin alarmed and about to take Flight $\ldots \ldots \ldots 372$

I55. (D) Female Hoatzin crouching to avoid Observation. ...... 373 


\section{LIST OF ILLUSTRATIONS.}

FIG.

PAGE

156. (E) Female Hoatzin taking flight, with wings fully spread; a second pair of birds leaving their nest in the back-ground . . 375

157. Flock of Eleven Hoatzins.................. 377

158. Crocodiles on a South American River Bank........... 380

159. Lagoon between Abary Island and River.............. $33^{82}$

I60. Young Spur-winged Jacana .................. 384 

PART I

\section{OUR FIRST SEARCH}

VENEZUELA 


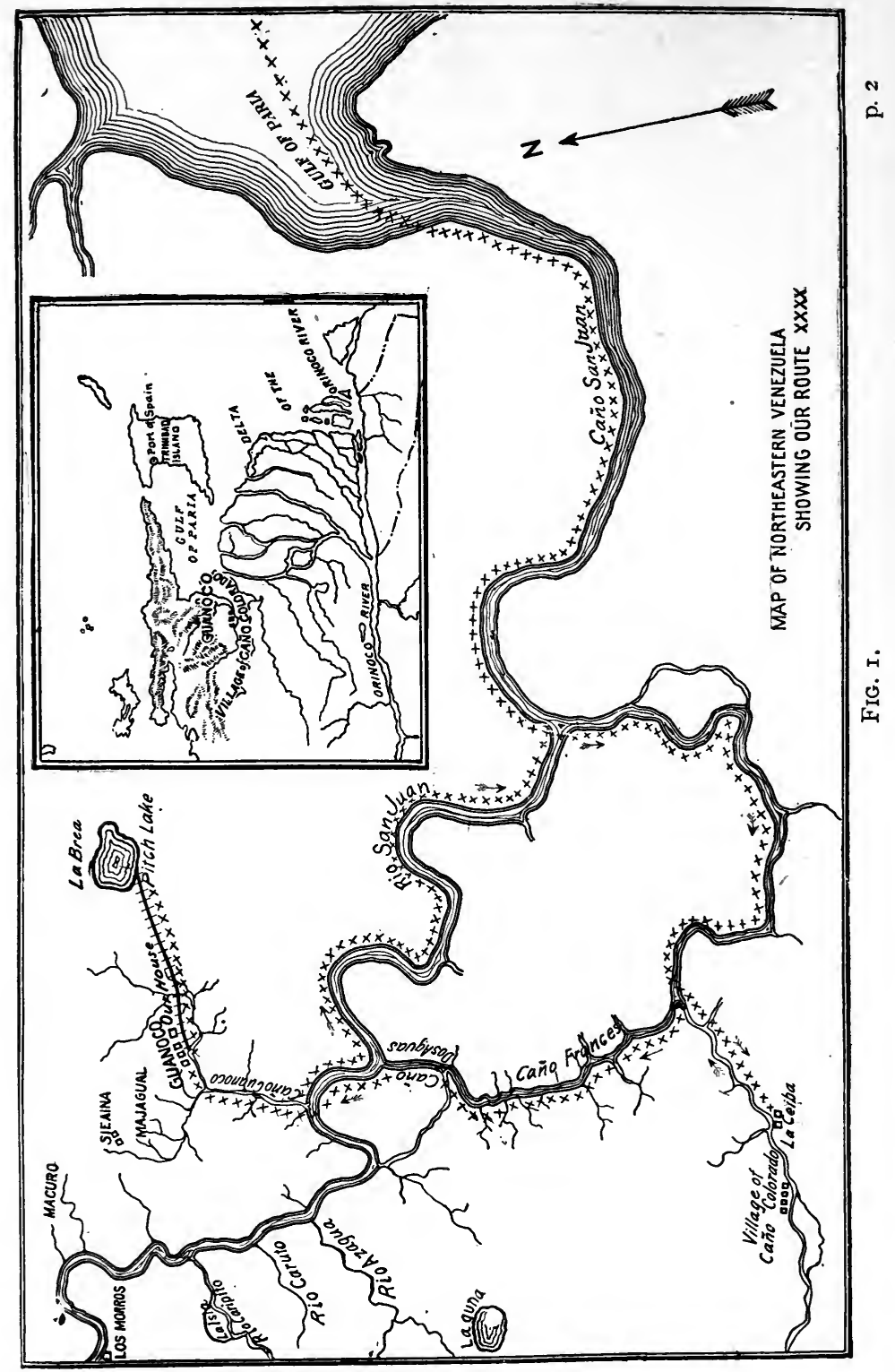




\section{OUR SEARCH FOR A WILDERNESS}

\section{CHAPTER I.}

THE LAND OF A SINGLE TREE.

NE day late in March, just as the tropical sun was sinking from view, our barefooted Spanish crew pulled up anchor from the muddy bottom of Port of Spain's harbor. Slowly the sails filled, and the spray began to fly from the bow as we steered straight into the crimson path of the sunset. Behind us the lofty Trinidad ranges glowed softly; great velvety peaks and ridges, purpled by distance, gilded by the last rays of day. Then the twilight passed swiftly as if the sun had been quenched by the waters which covered its face; the mountains became merged into the darkness of the sky, and the city of busy life behind us melted into a linear constellation of twinkling lights.

We had chartered a little sloop of twenty-one tons, the "Josefa Jacinta " (Ho-say'fah Hah-seen'tah), manned by a captain, a cook and a crew of three. At her masthead flew the flag of Venezuela. With a month's provisions in the hold and all the varied paraphernalia of a naturalist, we were headed for the northern part of the Orinoco delta in search of the primitive wilderness of which we had dreamed.

Jamaica, Colon, Savanilla, La Guayra had passed in quick succession, and we were surprised to find Trinidad the most modern and wide-awake of all. The well-appointed hotels, 
the trolleys, electric lights, museums, and newspapers of Port of Spain, the wireless station even now flashing its aërial messages from yonder peak, - all boded ill for our search for primeval conditions. Was there no spot left on earth, we wondered, which could truthfully be called an untrodden wilderness!- jungles untouched by axe or fire, where guns had not replaced bows and arrows; where the creatures of the wilderness were tame through unfamiliarity with human beings!

The Southern Cross rose and straightened its arms; the Pole Star hung low in the north. As the night wore on, an ugly sea arose and half buried our little craft in foam and spray. A cross-wind disputed our advance and the strong tide drove us out of our course. But our captain had navigated these waters for more than half a century, and we had no fears.

The following day was as wild as the night, and no living thing appeared in sky or sea, save a host of milky jelly-fish (Stomolophus meleagris). They kept below the surface, and seemed to suffer no damage from the roughness of the water. In an area of a square yard we counted twenty, and for hour after hour we passed through vast masses of them, extending to the farthest waves visible on either hand and as deep down as our eyes could penetrate - myriads upon myriads of these lowly beings, each vibrating with life, and yet unable to guide its course against the tide, or to do aught but pulsate slowly along.

Later in the day, although the water grew less rough, the whole company sank lower in the muddy depths - muddy, because the brown waters of the great Orinoco hold sway over all this gulf and scatter out at sea the sediment washed from the banks far inland.

Finally the storm passed and we saw a blue cloud to the 
north, hinting of the great mountain ranges of the Spanish Main. Ahead, a low green mist along the horizon told us we were nearing shore. This became more and more distinct until we could make out individual trees. By noon we had left the tumultuous waters of the Gulf of Paria, and were floating quietly on a broad stream between two majestic walls of green; we had entered our wilderness, and the silence

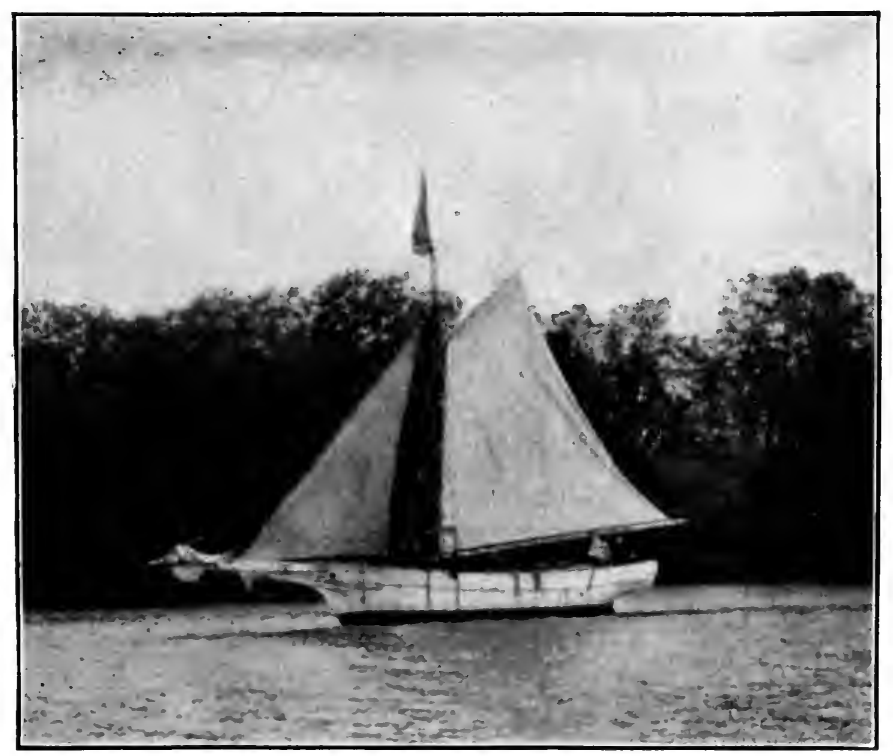

Fig. 2. OUR Sloop entering the Mangroves.

and beauty of our reception seemed all the more vivid after the noise and turbulence of the wind and water behind us.

Our first impression was of a vast solitude. It was midday, and the tide was almost at its height. With limp sails we drifted silently onward, not a sound of life coming from the green depths about us. We skirted the mangroves along the south bank, moving more and more slowly, until at last we rested motionless on the water, between the blazing 
sky overhead and the muddy depths beneath. The tide had reached its highest, and, like the living creatures of the jungle, rested in the midday heat. The captain gave a gruff order in Spanish, and the anchor splashed into the water, dragging the chain after with a sudden roar and jangle which echoed from shore to shore - jarring the silence as would a shriek of pain in a cathedral.

A chatter came from the mangroves near at hand, and high up among the dense foliage we saw the first life of the continent - a wistful little human face gazing out at us, a capuchin monkey striving with wrinkled brows to make out what we were. At his call two others came and looked; then, as our sail came down with a rattle of halyards, the trio fled through the branches with all the speed which four hands and a tail could lend.

We spent the afternoon in getting our floating home ready for use. No more waves would be encountered, so everything was unlashed. Stereo-glasses, camera-plates, and ammunition were placed ready to hand; the galley stove was moved far forward, and a mosquito-proof tent of netting was erected under the tarpaulin in the stern.

The sun had sunk low in the west when we saw a long, narrow dug-out canoe coming downstream. An Indian woman and her baby were crouched in the bow, while in the stern a naked Indian paddled swiftly and silently. His skin shone like coppery bronze in the sunlight, his long black hair was bound back from his face by a thong of hide. In front of him rested a bow and arrows and a long fish-spear. Silently he approached and in silence he passed - unheeding our salutations.

One more beauty of this wild wonderland was vouchsafed us before night fell. We had been disappointed in the birds. Where were the myriads of water-fowl of which we had heard? We had seen nothing - not a single feather. But 
THE LAND OF A SINGLE TREE.

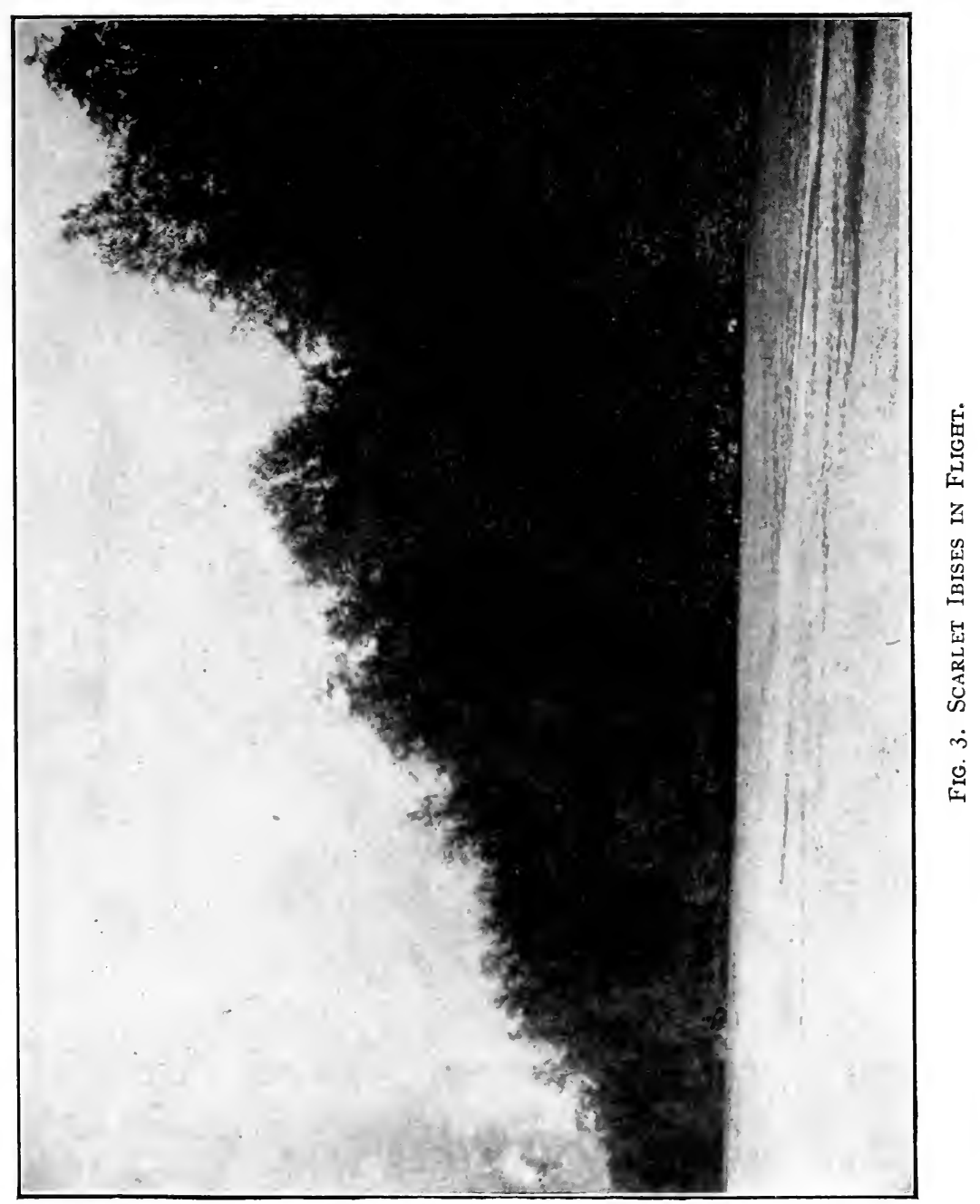


now the scene slowly changed. The tide was falling rapidly, swirling and eddying past the boat, and the roots of the mangroves began to protrude, their long stems shining black until the water dried from them. Mud-flats appeared, and suddenly, without warning, a living flame passed us and we had seen our first Scarlet Ibis $^{27}$.*

Past the dark green background of mangrove foliage the magnificent bird flew swiftly - flaming with a brilliance which shamed any pigment of human art. Blood red, intensest vermilion, deepest scarlet - all fail to hint of the living color of the bird. Before we could recover from our delight a flock of twenty followed, flying close together, with bills and feet scarlet like the plumage. They swerved from their path and alighted on the mud close to the mangroves, and began feeding at once. Then a trio of snowy-white Egrets $^{32}$ with trailing plumes floated overhead; others appeared above the tops of the trees; a host of tiny Sandpipers skimmed the surface of the water and scurried over the flats. Great Cocoi Herons ${ }^{31}$ swept majestically into view; Curlews and Plover ${ }^{18}$ assembled in myriads, lining the mud-flats at the water's edge, while here and there, like jets of flame against the mud, walked the vermilion Ibises. Terns ${ }^{14}$ with great yellow bills flew about the sloop, and Skimmers ${ }^{17}$ ploughed the surface of the tide in endless furrows. Macaws ${ }^{61}$ began to pass, shrieking as they flew, two and two together - and then night closed quickly over all. From the zenith the sun had looked down upon a stream as quiet as death; it sank upon a scene full of the animation of a myriad forms of life.

As dusk settled down and hid the shore from our eyes, another sense was aroused, and to our ears came the sounds of night in these tropical jungles - a thousand cries, moans,

* The superior figures following the names of birds throughout the volume refer to a list of their scientific names given for identification in Appendix A. 
crashes; all mysterious - unexplainable. In time we became so accustomed to them that we could distinguish repetitions and details, but this first night brought only a confused chorus of delightful mystery, now broken by a moment of silence, now rising to an awe-inspiring climax. One sound only remained clear in our memory, often repeated, now uttered in lower, now in higher tones - a terrible choking sigh. It might have been the last death gasp of some great monkey, or the pitiful utterance of hopelessness of a madman.

With the turn of the tide we raised anchor and drifted through the night - mile after mile for six hours, and then anchored again. And thus it was that we came to our wilderness.

Not until we had been in the mangrove jungle for many days did we begin to realize its vastness, its mystery, its primeval character. Just four hundred and ten years ago Christopher Columbus sailed through the gulf we had left and gazed on the dark forest in the heart of which we now were. Throughout the whole extent of the mangrove wilderness we found no hint that conditions were not as they were in 1498 .

One of the most astonishing things about the mangrove forest is the apparent diversity of its plant life. Until one actually comes within reach of trunk and leaves it is impossible to believe that all this forest is composed of a single species of plant. The foliage of some of the trees is light, of others dark; here stands a clump of pale beechlike trunks, there a dark, rough-barked individual is seen. The manner of growth of the young and old trees is so different that a confusion of mingled trees, shrubs, and vines seems to confront one. But everywhere the mangrove reigns supreme. It is the only vegetable growth which can gain a footing in 
this world of salt water. In fact, it makes its own footing, entangling and holding mud and débris about its stems, and ever blindly reaching out dangling roots, like the legs of gigantic spiders.

Far out on the tip of a lofty branch a mangrove seed will germinate, before it falls assuming the appearance of a loaded club from eight to fifteen inches in length. One day it lets go and drops like a plummet into the soft mud, where it sticks upright. Soon the tide rises, and if there is too strong a current the young plant is swept away, to perish far out at sea; but if it can maintain its hold, roots soon spring out, and the ideal of the mangrove is realized, the purpose for which all this interesting phenomena is intended: the forest has gained a few yards, and mud and leaves will soon choke out the intervening water.

The mangroves have still another method of gaining new territory. Aërial roots are thrown out from branches high in air, swinging downward and outward with a curve which sometimes wins three or four yards ahead. Like hawsers thrown from a vessel to a wharf these roots clutch at the mud beneath, but where the current runs swiftly they swing and dangle in vain, until they have grown so heavy that they touch bottom some distance downstream. We made use of these dangling roots as anchors for our canoe, bending the elastic unattached end upward and springing it over the gunwale.

Throughout all this great region there is not a foot of solid ground. In one place we pushed a tall shoot some eight feet in height straight down through the mud, and it went out of sight. A man falling on this mud, out of reach of aid, would vanish as in a quick-sand. So the wild creatures of the mangroves must either swim, fly, or climb. No terrestrial beings can exist there. We once selected a favorable place, and for fifty yards made our way over the roots and branches 
THE LAND OF A SINGLE TREE.

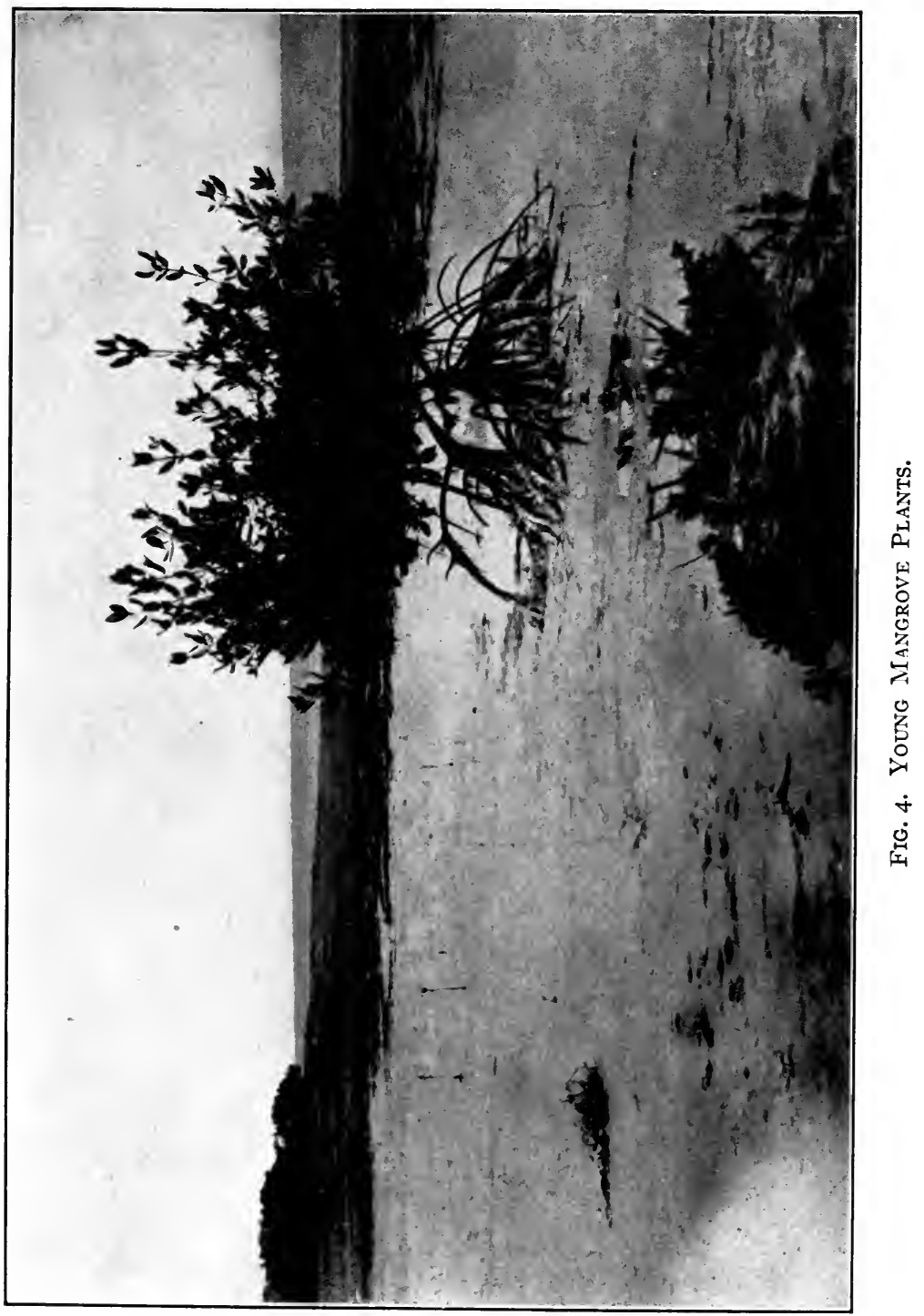


before exhaustion and an impassable gap of mud and water stopped all progress. As never before we realized how safe from man are the denizens of these strange swamps. Monkeys fled swiftly before us, birds rose and flew overhead, while we painfully crept and pulled ourselves along over the slippery stems.

More wonderful even than the coral polyps are these mangroves, for by this plant alone all this region has been rescued from the sea and built up into land. In future years, as the mud banks become higher and are fertilized by the everfalling leaves, other growths will appear, and finally the coast of the continent will be thus extended by many scores of miles of fertile soil.

A network of narrow channels stretches through this wilderness and allowed us to explore the far interior in our shallow curiara or dug-out. Thus we spent days and weeks in search of the creatures which lived in this land of a single tree, and here we learned how delightful the climate of such a region can be. Every night we slept under blankets, and during the day the temperature ranged from $66^{\circ}$ at five and six o'clock in the morning to about $86^{\circ}$ at noon, although we were within nine degrees of the equator.* One could paddle all day with more comfort than on a hot summer day in the north. By day mosquitoes were generally absent, and only a

* Actual temperatures (Fahrenheit) taken in the mangrove forest on board the sloop are as follows:

$$
\begin{array}{rr}
\text { March } 3 \text { oth - } & \\
5.30 \text { A.M. } & 66^{\circ} \\
9.30 & 86^{\circ} \\
\text { I I. } 30 & 86^{\circ} \\
\text { I.30 P.M. } 86^{\circ} \\
7.00 \quad 78^{\circ}
\end{array}
$$

March 3 Ist -

$$
\begin{aligned}
& 5.30 \text { A.M. } 7^{1^{\circ}} \\
& 6.30 \quad 72^{\circ}
\end{aligned}
$$

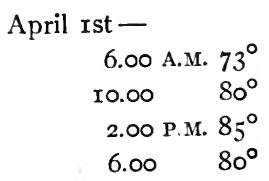

April 2nd -

5.30 A.M. $69^{\circ}$

$7.3 \circ \quad 77^{\circ}$ 
few biting flies reminded us of the "terrible insect scourges". of the tropics. Life was delightfully new and strange, with the spice of danger ever attendant upon the exploration of unknown lands.

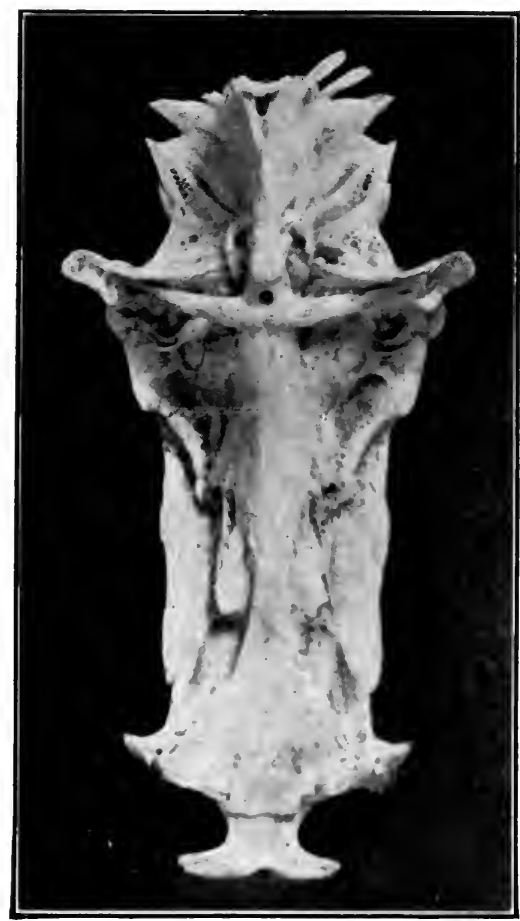

Fig. 5. The Crucifix in the Catfish.

The fishes attracted our attention from the first. When we came on deck before sunrise for a plunge, our little vessel would be surrounded by hosts of catfish (Psendauchenipterus nodosus) all, like our sloop, headed upstream against the tide. They would bite indifferently at bait, a bit of cloth, or a bare hook, and were delicious eating. On the bottom our hooks would sometimes be taken by great fierce-whiskered cats, 
bedecked with long streamers, which gave no end of trouble before they were quieted. They were pale yellow, and the head and back were encased in bone; Maestro - the cook called them the crucifix fish, and later showed us why. On the under surface of the bony armor is a large cross with a halo about it just above the arms. The crew never caught one of these fish without making the sign of the cross in their right palm.

When the tide was half down the funniest of puff-fishes (Calomesus psittacus), or tambourines as the Captain called them, would take our bait. They were from three to five inches long, white below, and pale greenish above crossed by seven black bands, the first across the mouth and the seventh at the tip of the caudal fin. There was also a black patch at the base of the pectoral fins. The iris was bright lemon yellow. When gently scratched on the lower parts, or sometimes even when just lifted from the water they would swell up into a round ball. They were covered with short, stiff bristles which stood on end when the fish was inflated, and their comical appearance was increased by the four rodent-like incisor teeth in the front of the mouth. When thus inflated with air they were helpless for a time, and if thrown back, floated belly upward at the mercy of the wind and current, until they were able to collapse to normal size.

On one of our first excursions among the mangroves in our small canoe we made a most interesting discovery. Here and there, sprawled out on the mud-flats, were small crocodiles, and occasionally a large one would rush off into the water at our approach. Hugging the edge of the tide where the ripples lapped back and forth on the black ooze were many other living creatures. For a long time we could not make them out, but finally, drifting silently upon a whole school, we knew them for four-eyed fish (Anableps anableps) strange creatures which we had hoped to see. 
We came to a tiny bayou, shaped like a bottle, from which four Little Blue Herons ${ }^{34}$ flew as we approached. We placed our dug-out corklike athwart the mouth and anchored with our crossed paddles. The air was warm, bees hummed about the tiny four-parted flowers of the mangroves, and a great blue morpho butterfly flapped past, mirrored in the water beneath. Then came tragedy - never far off in this land of superabundant life. A small clay-colored crocodile

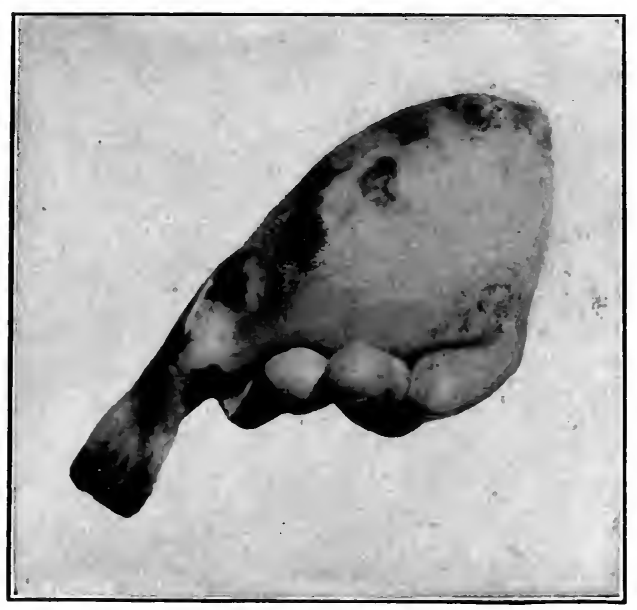

Fig. 6. Parrot Puff-pish.

made a sudden rush at a ripple, and a quartet of four-eyes shot from the water in frantic fear. One was slower than the rest, and the fierce jaws of the diminutive reptile just grazed him. Another fell back downward in the ooze, and in a twinkling was caught and dragged into the depths. No wonder the poor little four-eyes are ever on the lookout for danger and spend most of their time where they merge with the ripples along the shore, when such enemies are on the watch for them! 
A whir of wings sounded, and a Kingfisher ${ }^{69}$ alighted within arm's reach. But such a Kingfisher! - the veriest mite, clad in a robe of brilliant emerald and orange. So small was he that it seemed as if the tiniest of minnows must choke him. He seemed to be of the same opinion, for while we watched him he caught only the insects which passed him in mid-air or which were floating on the water.

By far the most numerous, and in their way the most interesting of the mangroves' inhabitants, were the crabs.

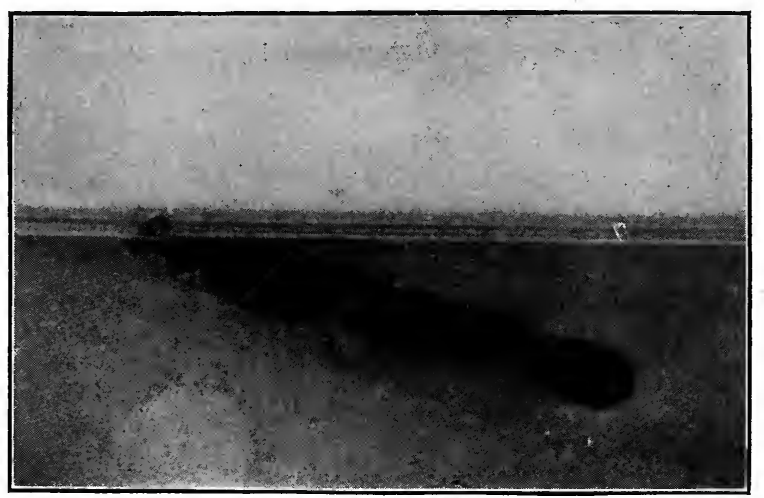

Fig. 7. Four-eyed Fish.

There were untold millions of them, all small, all active and keen of vision. If we sat quietly, they would appear from everywhere, peeping out like little gnomes from their perches on the mangroves, forever playing their noiseless little fiddles. These tiny tree-folk not only played, but danced. Let us picture a scene constantly enacted, so close to us that we could all but touch the performers. Two crabs approach each other, now fiddling vigorously, now waving their diminutive pincers back and forth over their heads as a balletdancer waves her arms. They move never in straight lines, but sideways, now running back a few steps, now forward, 
until at last they meet, and each grasping the other's claws, raises them aloft, and then for five minutes they circle about in most ludicrous imitation of a waltz. All this usually takes place on the lower surface of a mangrove trunk, the inverted position apparently making no less secure the footing of the little dancers. We could not decide whether this performance was in the nature of courtship or just pure play.

What we did discover concerning the lives of these crabs was full of interest. Hundreds of the smallest-sized ones lived in holes in the mud, and when the tide went down they came out and ran about - intent on some all-important business of their little existence. Another class of larger individuals had their holes near the roots of the mangroves, one (rarely two) good-sized crab apparently taking possession of each root. Here he disported himself, running up and down, from the water into the air with no change in speed, and here, strangest of all, he grew to resemble his home root. There was as great diversity among the roots as among the larger trunks - whitish, black, mottled, and all intervening shades. It was a fact, of which we had hundreds of daily proofs, that the crabs were so like their particular root that of ten we could not detect the quiescent crustacean when within a foot of our faces.

There was one group of five black roots forming a rough circle about a single mottled root. As we approached, a crab ran down each stalk into the water, and as we peered down and saw them go into their holes, we could at a glance tell the mottled crab from the five black ones. Even the roots which were as yet a foot or more above the bottom mud each had their occupant, which thus had to swim upward from his hole before he could grasp his swaying perch.

A third class of crabs lived among the higher trunks and branches of the mangroves, and, except where there was a highroad of some large trunk dipping into the water, these 
less fortunate fellows had to scamper in frantic haste up the roots of their larger brethren. The indignant owner would rush at the trespasser with uplifted pincers, sometimes forcing him to leap for his life. Where an unusually large tree was frequented by many crabs, their carapaces bore a close

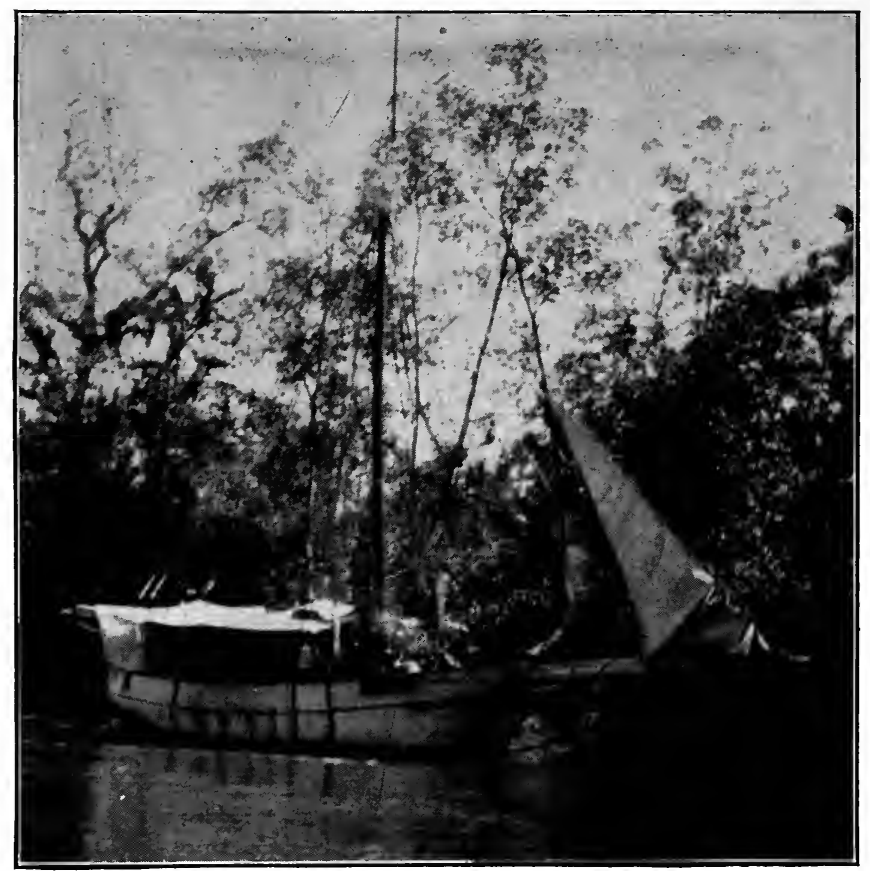

Fig. 8. Our Floating Home at la Ceiba.

resemblance to its pattern and hue, but among these more aërial and roving crabs the mimicry was, on the whole, less striking than among the sedentary class. In the latter, protective coloration was carried to a greater degree of perfection than I have ever seen it elsewhere. These were loath to leave their roots and swim, preferring to run swiftly down until they reached the mud. This habit made it easy to catch them, 
merely by taking the end of the root aboard and shaking it, when the unsuspecting crab would rush down in all haste into a pail or jar held at the bottom.

They have many enemies, not only among fish, reptiles, and birds, but even some of the mammals, such as opossums and monkeys, catch and devour them in large numbers. We saw a beautiful Hawk, ${ }^{54}$ bright chestnut in color, with a pale creamy head and black throat, dashing at them and skilfully catching the unfortunate crabs in one outstretched foot.

Scores of other beings of still more lowly degree swarmed about us, but as the tide lapped out of our little bayou, the four-eyes again attracted our attention. They began to get restless, swimming back and forth and shuffling over the mud, until at last in desperation at the ebbing of their element, they made a dash to get past us into the open water of the caño. Some dived, but so buoyant are they that they can scarcely stay below a second, and soon popped up on the surface again. Others scrambled, rolled, and squirmed along over the ooze on each side of us, many making good progress and escaping. We caught several and placed them in an aquarium for study. When hard pressed in deep water these curious fish progress by a series of leaps - up on their tail end and down again, up and down again, describing a series of curves and making very fast time.

When examined closely we see that these fish have only two eyes, but these are divided in such a way that there appear to be double that number. There are two distinct pupils, one elevated above the head like the eyes of a frog, the other separated by a band of tissue and below the water-line. So when the fish floats in its normal position at the surface the upper pupils, fitted for vision in the air, watch for danger above, while the lower pair keeps a submarine lookout for insect food and aquatic enemies. 
Monkeys are perfectly at home in this land of branches, the ever-cautious capuchins and now and then a long-limbed spider monkey swinging through the trees with as easy a motion as the flight of a bird. Biggest of all are the great red howlers, who keep to the deeper, more narrow channels, and in the evening and again at dawn send their voices to the farthest limits of the mangroves. They do not howl, they roar, and the sound is perfectly suited to such a wilderness as this. Before the first signs of day light up the east, a low, soft moaning comes through the forest, like the forewarning of a storm through pine trees. This gains in volume and depth until it becomes a roar. It is no wind now, nor like anything one ever hears in the north; it is a deep, grating, rumbling roar - a voice of the tropics; a hint of the long-past ages when speech was yet unformed. We grew to love the rhythm of this wild music, and it will always be for us the memory-awakening sound of the tropical wilderness.

The wealth of life in this region was evident when we began to explore a river flowing down from the highlands in the far-distant interior of Venezuela. One could spend a year here and not begin to exhaust the wonders on every hand.

With every high tide the Captain would pull up anchor and shift our craft a little upstream, until at last our keel touched bottom and we could go no farther. We anchored firmly and buoyed ourselves by ropes to the nearest trees so as to keep on an even keel. This, our home for a time, was in a little bight of the Guarapiche (War-ah-pee'chy) River, where two tumbled-down, long deserted Indian huts still retained the name of La Ceiba. We were so close to the left bank that at low tide we could walk ashore on oars laid down over the mud. Here the birds came and fed and bathed, here the howling monkeys roared over our very heads and Macaws swung and shrieked at us. 


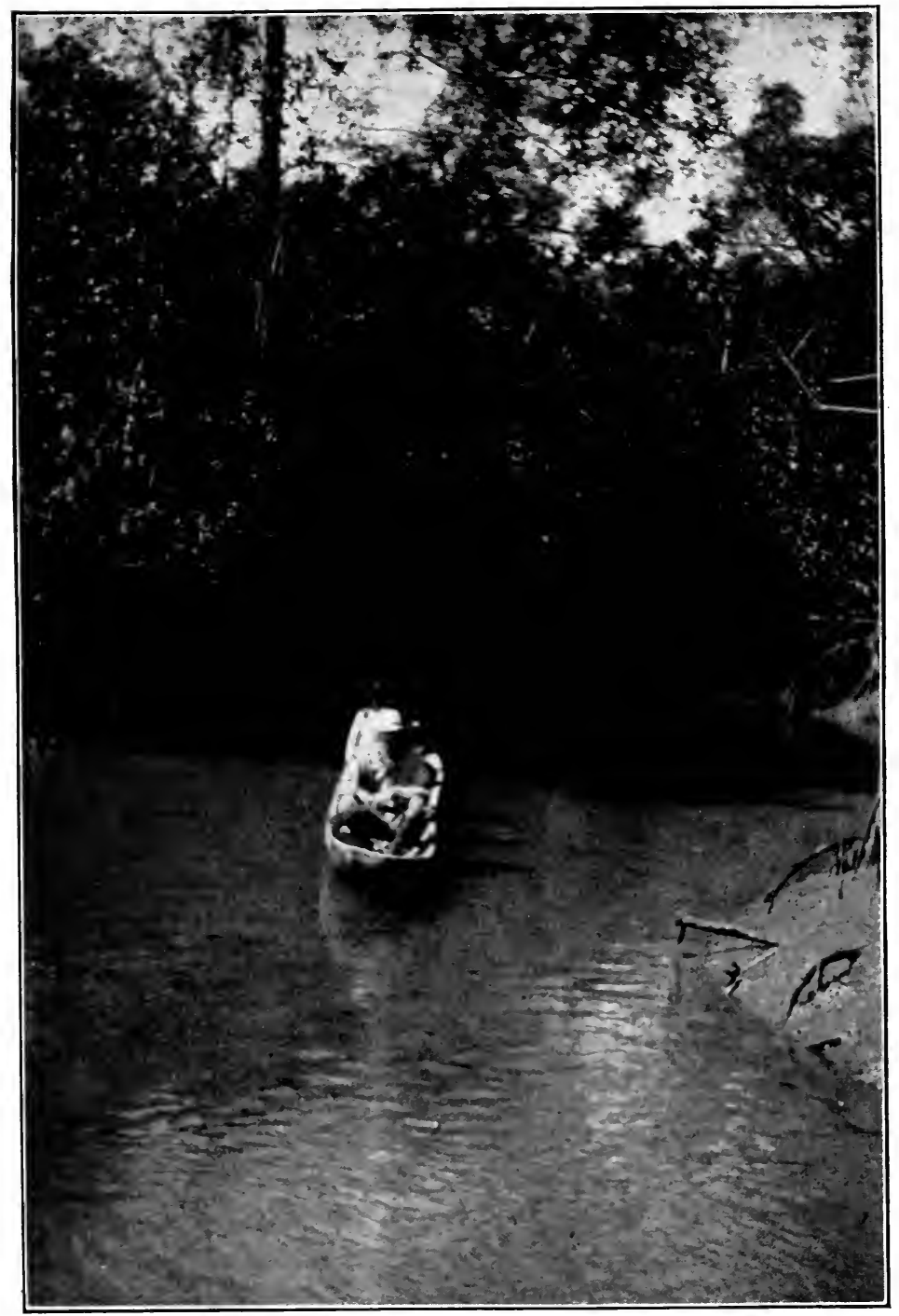

Fig. 9. Exploring the Caños in a Dug-out. 
One night, during a heavy downpour of rain, we were suddenly awakened by a medley of cries, imprecations, shrieks and yells. Flashing the strong electric bulb we saw through the sheets of rain a very large curiara run afoul of our shore line; piled high with luggage, with several screaming women perched high on the bundles and boxes. Four pigs, tied feet upward, swelled the chorus in their fear of a watery grave and four men told us what they thought of us in the present and where they hoped we would spend the future centuries until the world's end. Our Captain was out of his hammock in a moment and in tremendous basso profundo he silenced all, save the pigs, and rapidly gave directions to our crew to row upstream against the swirling current, clear the curiara and shift it outside the danger zone. Between breaths, he incidentally described minutely to the terrified natives what he knew would be the ultimate fate of such fools as tried to descend a river on the wrong side. It was a miracle that the whole outfit did not overturn - a narrow dug-out, measuring about twenty feet in length by two in width, striking full force against a rope in the blackness of the storm.

Early in the morning the roaring of the monkeys would awaken us, and after a hasty breakfast we would start out in our little boat. At this time everything is dripping and fresh with dew, and there is a bite and tang in the air which reminds us of Canadian dawns. It is still dusk, and the lines of mangroves on either side show only as black walls. For some minutes hardly a sound breaks the stillness except the distant roars and the drip, drip of our paddles. Then a sudden splashing and breaking of branches shows that we are discovered by a pair or more of capybaras (Hydrochoerus capybara), those enormous rodents which would pass as guinea pigs in Gulliver's land of giants. Now an overhanging branch drenches us as we brush against it, and as it is pushed aside a whole armful of orchids comes away, the 
pure white blossoms (Epidendrum fragrans) filling the caño with their sweetness. Now the delicate foliage of a palm is silhouetted for a moment against the brightening eastern sky, and a mass of great convolvulous blossoms shines out from the shore. By this we know that we are not many miles from dry ground, and other growths are already beginning to dispute the dominance of the mangroves.

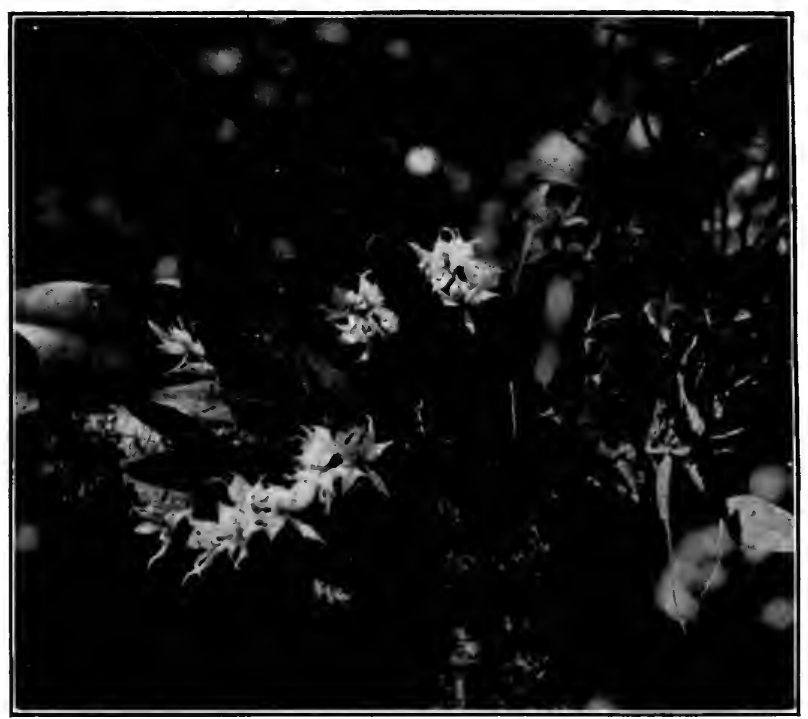

Fig. IO. White ORCHIDS.

Silence again, to be broken by one of the most remarkable and startling outbursts of sound which any living creature in the world can utter. A series of unconnected sighs, shrieks, screams, and metallic trumpet-like notes suddenly breaking forth apparently within thirty feet, is surely excuse enough for being startled. The hubbub ceases as abruptly as it began; then again it breaks out, now seeming to come from all directions, even from overhead. The author of all 
this is the Chachalaca - a bird not larger than a common fowl, but with a longer tail. It spends most of its time on the ground or among the lower branches of the trees in the swamps. It was seldom that we caught sight of one, but we shall never forget the first time we heard their diabolical chorus.

The sun's rays now light up the narrow path of water ahead of us, and a thousand creatures seem to awaken and give voice at once. Two splendid Yellow and Blue Macaws ${ }^{61}$ fly high overhead, their screams softened by the distance; a flock of great white-billed, Red-crested Woodpeckers ${ }^{88}$ drum and call; from the bank comes the rolling cry of the Tinamou and the sweet, penetrating double note of the Sunbittern $^{24}$; Hummingbirds squeak in their flight as they shake the dew-drops from the orchids above us; squirrels with fur of orange and gray scramble through the branches, fleeing before the little capuchin monkeys. Then, one after another, three splendid Swallow-tailed Kites ${ }^{58}$ dash past us at full speed, brushing the surface of the water and floating upward again.

Swallows, ${ }^{119}$ emerald and white, catch the flies which hover near us; a big yellow-breasted Flycatcher alights for a moment on the bow of our boat - and a tropical day is fairly begun. These and a hundred other creatures about us bathe, sing, and seek their food during the fresh hours of early morning. Then, as the sun rises higher and its heat draws a hush over all, the notes of the birds die away, leaving the insect vocalists supreme. Butterflies click here and there, a loud humming tells of huge wasps winging their way on murderous missions, but above all rises the chant of the cicadas. The commonest of these grinds out harsh, reverberating tones - whir-r-r-r-r-r! wh-r-r! wh-r-r! wh-r-r! wh-r-r! rolling the r's in the first utterance for a minute or more, then ending in a series of short, abrupt whirs. 
Then another cicada, a giant species, sends his call through the jungle; he has two strings to his bow, one a half-note higher than the other, and on these he plays for five minutes at a time. It is Chinese music to the very tone. Sometimes his tune ends in a rising shriek, and we know that one of the big blue wasps has descended on him and stabbed him in the midst of his love-song.

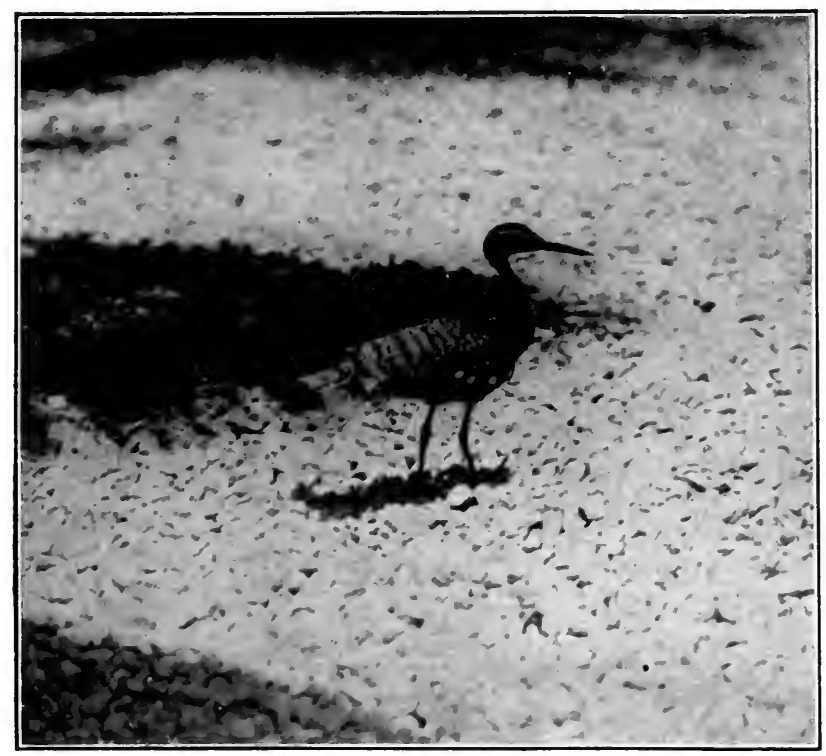

Fig. II. SUUN-BitTERn.

The day wears on, and even the cicadas become quiet. The sun is overhead and the air full of tropical heat. In the shade it is always comfortable, and in the full glare of the sun one perspires so freely that the heat is hardly felt.

As we paddle lazily along, a great Tegu Lizard (Teius nigropunctatas) scrambles slowly along the bank; now crawling over a muddy expanse, now taking to the water to avoid a 
bushy tangle, folding back his legs and swimming with long graceful sweeps of his tail. As we watch him he leaps at several little crabs and catches them before they can escape into their holes.

We eat our luncheon in the shade of a clay bank, the first hint of dry land. we have seen along the caño, and here we watch the little crocodiles basking in the sun and the crabs scuttling over the mud. A bird of iridescent green and orange swoops down to our very faces, and hangs swinging in a loop of a tiny liana on the face of the bank. The next instant it vanishes into the earth, darting into a hole hardly larger than the crab-holes around it. We have found the home of a Jacamar. ${ }^{86}$ At the end of the short tunnel are four round white eggs laid on the bare clay.

While examining the nest we hear at our very feet the terrible night noise - the muffled choking sigh which has come to us every night since we entered the mangrove wilderness. We are standing in our narrow dug-out, which the least movement will overturn, and for an instant it is indeed a question whether we can control ourselves enough to keep it from filling. Now the mystery solves itself as a large anaconda (Eunectes murinus) nine or ten feet long, slowly winds out from a hole in the bank beneath the surface of the water and slips into the depths of the muddy current. Then the tide laps a little lower, and a big bubble of air, caught in the entrance of the serpent's lair, frees itself with a sudden gasping sob. When the tide is rising or falling over these large openings in the mud, the air escapes from time to time with the terrifying sound which has so long puzzled us. Our mysterious nocturnal creature is thus explained away in the prosaic light of day.

An hour later as our dug-out rounds a sharp bend in the caño, there comes to our ears a series of rasping cries hoarse and creaking as of unoiled wheels. The glasses show 


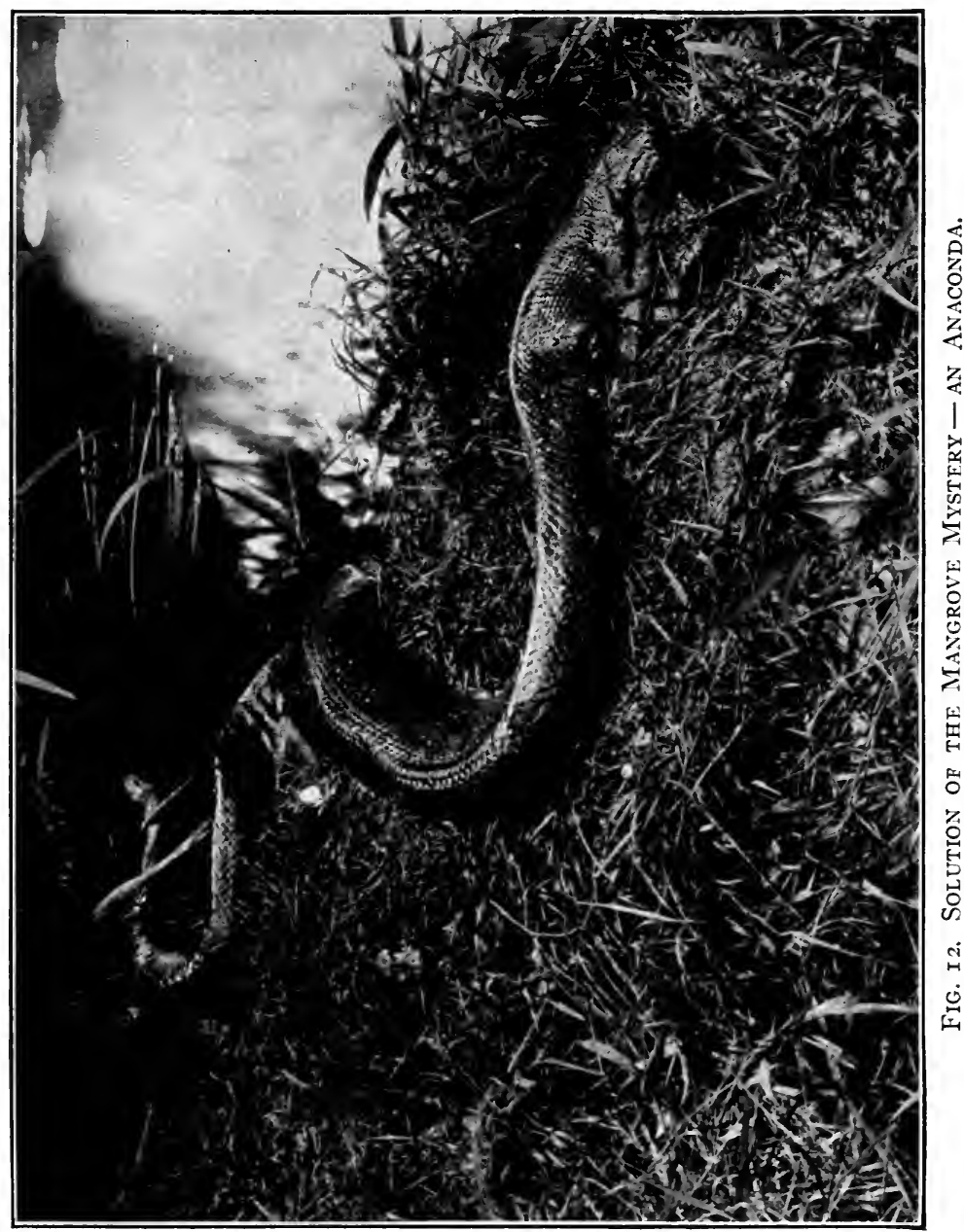


a flock of large, brown, fowl-like birds in a clump of bushes overhanging the water. Their barred wings and tall, delicate crests tell us that they are the bird of all others which we had hoped to see and study. We are floating within a hundred feet of a flock of Hoatzins ${ }^{11}$ - the strange reptile-like, living fossils which are found only in this part of the world, and which are closely related to no other living bird.

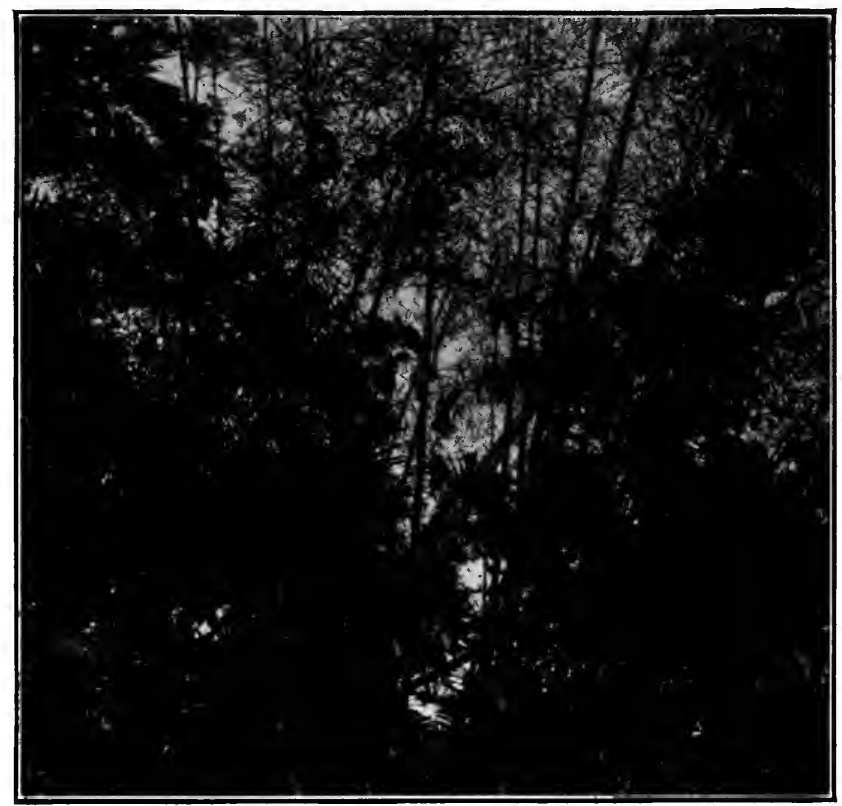

Fig. I3. Hoatzins in the Bamboos on the Guarapiche.

As we draw near, the birds flutter through the foliage as if their wings were broken. We find that this is their usual mode of progression, and for a most interesting reason. Soon after the young Hoatzins are hatched and while yet unfledged they are able to leave the nest and climb about the branches, and in this they are greatly aided by the use of the wings as arms and hands. The three fingers of the wing are 
each armed with a reptile-like claw, and at the approach of danger the birds climb actively about like squirrels or lizards.

It has usually been thought that when they grow up they lose all these reptilian habits and behave as conventional feathered bipeds should. But we find that while, of course, the fingers are deeply hidden beneath the long flight-feathers of the wing, yet these very feathers are often used, fingerlike, in forcing aside thick vines, the birds thus clambering and pushing their way along.

It was with the keenest delight of the pioneer and discoverer that we watched these rare creatures. Although they do not nest until July and August, yet we found them in the very trees and bushes which held the remains of last year's nests, thus revealing their sedentary life during the rest of the year. And day after day and week after week we learned to know that they would be found in this or that tree and nowhere else; they were veritable feathered sloths. They fed chiefly upon leaves, but fish also entered into the bill of fare of at least one individual.

We shot two, one for the skin and the other for the skeleton, and we found the plumage in a very worn and ragged condition, the wing feathers especially so, where the branches and leaves had rubbed and worn away the barbs. Throughout the noonday heat these birds were always to be found in the foliage overhanging the water, ready when disturbed to flop and thrash a few yards through the mangroves and bamboos.

After many days of pure delight, our note-books filled and our photographic plates more than half gone, we decided to see something of the Venezuelan dry land. We would go on and on until we had left the mangroves with all their unpeopled mystery behind us, and see what new surprises the villages of the Guarauno (War-ah-oo'no) Indians and the jungles of the foot-hills would afford.

At nine o'clock one night, when the stars alone cast a faint 
weird light over everything, we sent two of the crew ahead in the rowboat to keep our bow straight, and then began a long night of noiseless drifting with the tide. It was a night to remain forever in our memory. The men relieved their monotonous towing with strange wailing chants; on each side the mangroves slipped past, black and menacing; invisible creatures snorted and splashed in sudden terror as we rounded each turn; great fireflies burned on the trees and were reflected in the water, and to our ears came the roars of the four-handed folk, the calls and screams of night birds, the metallic clinks of insects, and ever the gasps and chokings of the serpents' burrows - hardly less sinister now that we had solved their mystery.

Throughout all the night we passed up one caño, down another, past miles and miles of black foliage, all alike to us, almost indistinguishable in the starlight, yet early next morning as we rose to rout the cloud of mosquitoes about our head nets, the captain said in his soft Spanish tongue, "The mountains of my country should be in sight ahead." And, indeed, an hour later, as the day dawned, we could discern the blue haze in the north which marked the high land out.

Toucans, big Muscovy Ducks ${ }^{43}$ and Snakebirds ${ }^{48}$ flew past us; great brown Woodpeckers and flights of Parrakeets swung across the caño; dolphins played around us, but we heeded them little, all eager to press on and see the new land.

So we sat far up in the bow and watched the mountains take form and the palms upon them become ever more distinct. From a land of mystery untrodden by man, we were soon to come upon a bit of land so prized by man that nations had almost gone to war over it - La Brea (Bray'ah), the strange lake of pitch hidden in the heart of the forest, with its strange birds and fish and animals; lying on the borderland between the foot-hills of the northern Andes and the world of mangroves which for many days had held us so safely in its heart. 
THE LAND OF A SINGLE TREE.

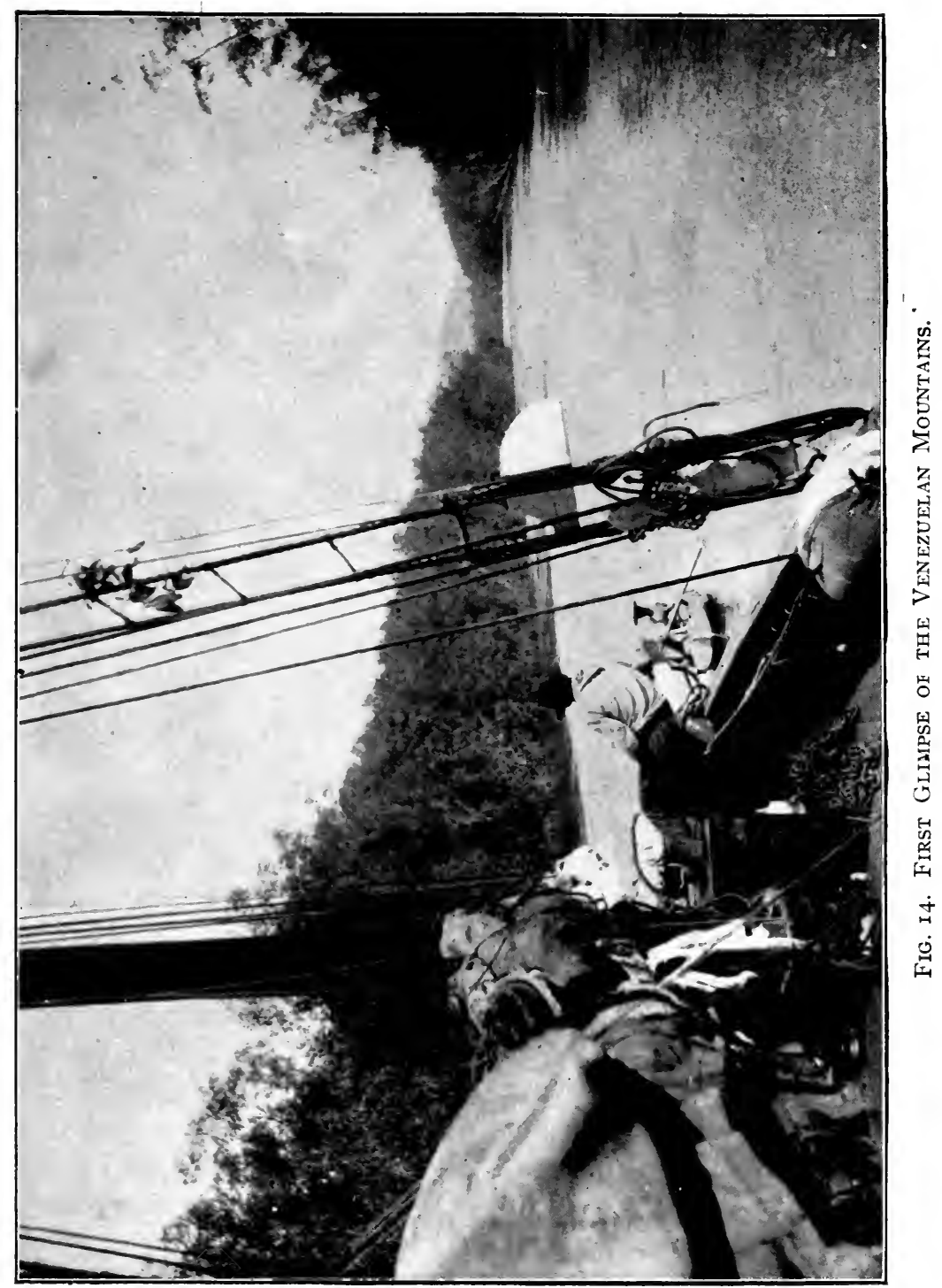




\section{CHAPTER II.}

\section{THE LAKE OF PITCH.}

ERETOFORE we had sailed and paddled through a
land of mangroves and water, where, with the exception of one or two tiny muddy islets in the forest, there was no solid ground. One day the last of innumerable turns of a narrow caño brought our sloop in sight of real earth - the first dry land of eastern Venezuela. A rough wooden wharf supporting a narrow-gauge line of rails appeared, and beyond rose a steep hill, dotted here and there with little thatched huts, each clinging to a niche scooped out of the clay. We were at the village of Guanoco (Wah-no'co), the shipping point of the pitch lake. A few steps beyond the last hut and one was in the primeval forest - so limited is man's influence in this region of rapidly growing plants.

For five miles the little toy rails zigzagged their uneven way through the jungle. On one side was swamp, into which one could penetrate but a short distance before encountering the advance-guard of the mangroves, the front of the vast host which stretched eastward mile after mile to the sea. West of the track the land rose ten or twenty feet in many places, but even where level it soon lost its swampy character. At the end of the line the strange pitch lake itself appeared as a great plain, on the borderland between low swamps and the foot-hills of the mountains. This was our trampingground, and we found it a veritable wonderland of birds and beasts and flowers.

One of the first things which attracted our attention were the Orioles or Cassiques ${ }^{151}$ — great black and yellow beauties with 
long whitish beaks and an infinitely varied vocabulary. In the north our eyes are gladdened by the sight of a single pair of Orioles flying about their nest in the elm; here in a single tree there were sometimes over one hundred and fifty inhabited nests, most of which were two feet or more in length. The more we watched these birds the more interesting they

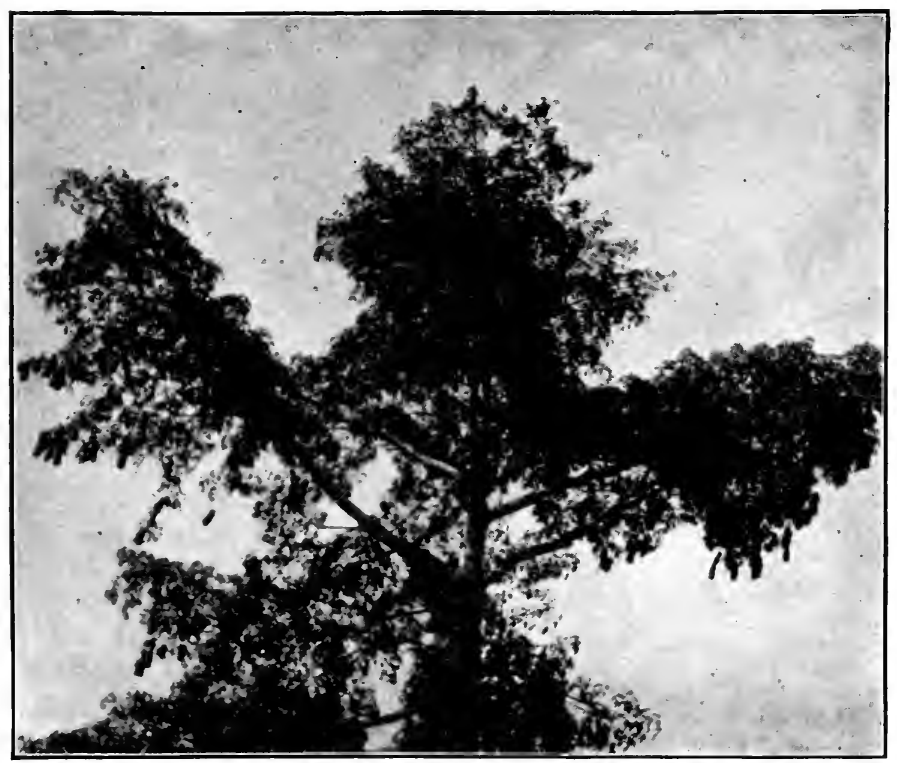

Fig. i5. Colony of i5o Cassiques' Nests in One Tree.

became. They showed a real intelligence in the selection of a site for their nests. Monkeys, tree-snakes, opossums, and other bird-eating creatures were abundant hereabouts, and for a colony of these conspicuous birds to conceal their nests successfully would be impossible. So their homes are swung out in full view of all. But one or two precautions are always taken. Either the birds choose a solitary tree which fairly overhangs some thatched hut, or else the colony is clustered 
close about one of the great wasps' nests which are seen here and there high up among the branches of the forest.

The Indians and native Venezuelans never trouble the birds, which have been quick to realize and take advantage

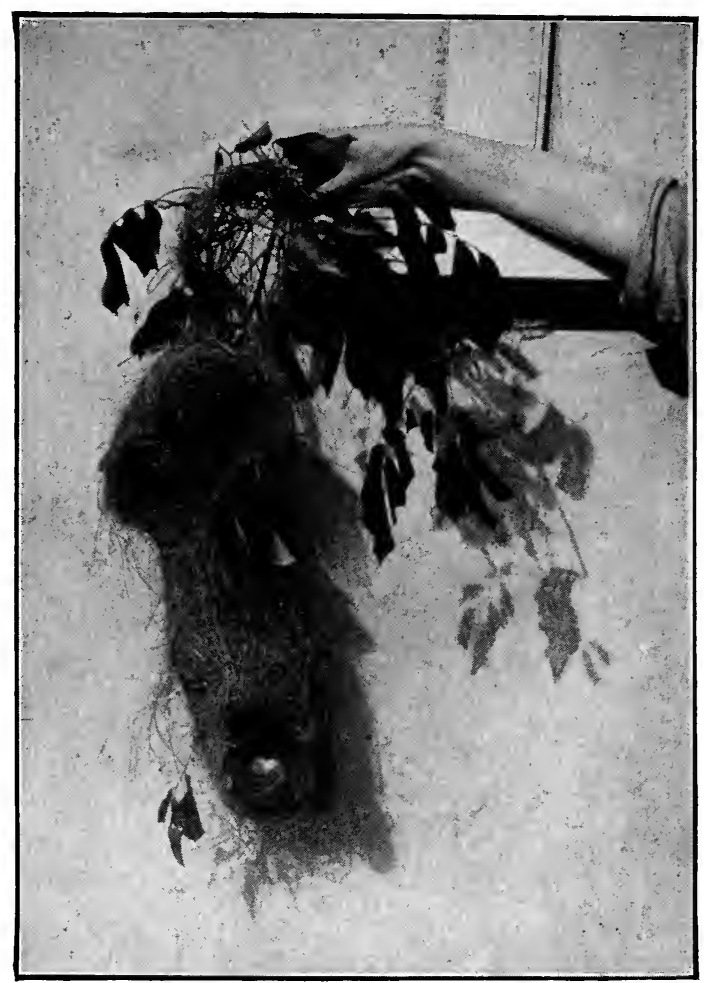

Fig. 16. Nest and Eggs of Yellow-backed Cássique.

Observe the Extra Shelter Roof. The lower opening was made to show the egg chamber.

of this fact, and weave their nests and care for their young almost within arm's reach of the thatched roofs. No monkey dares venture here, and the mongrel dogs keep off all the small nocturnal carnivores.

But a colony of Cassiques which chooses to live in the 
jungle itself would have short shrift, were it not for the strange communal guardianship of the wasps. These insects are usually large and venomous, and one sting would be enough to kill a bird; indeed, a severe fever often ensues when a man has been stung by half a dozen. So the birds must in some way be immune to the attacks of the wasps. Perhaps their wonderfully complete armor of feathers, scales, and horny beak accounts for this, while their quickness of vision and of action enables them to save their eyelids their one unprotected spot. Although the Cassiques cannot have learned from experience of the terrible wounds which the wasps can inflict, yet they are keenly alive to the advantages to be derived from close association with them.

The wasp's nest is built far out on the tip of the limb of some forest tree, and the long pendent homes of the Cassiques are placed close to it, sometimes eight or ten on the same branch, and others on neighboring limbs, so near that the homes of insects and birds rattle against each other when the wind blows.

One such community was placed rather near the ground, where we could watch the inhabitants closely. Frequently when one or two of the big birds returned to their nests with a rush and a headlong plunge into the entrance, the whole branch shook violently. Yet the wasps showed no excitement or alarm; their subdued buzzing did not rise in tone. But when I reached up and moved the branch gently downward, the angry hum which came forth sent me into the underbrush in haste. From a safe distance I could see the wasps circling about in quick spurts which meant trouble to any intruder, while the excited Cassiques squeaked and screamed their loudest. Whether the slight motion I gave to the branch was unusual enough to arouse the insects, or whether they took their cue from the cries and actions of the alarmed birds, I cannot say. 
The nests are beautifully woven, of very tough palm leaf shreds and grass stems, in shape like tall vases, bulging at the bottom to give room for the eggs and young birds, and with an entrance at the side near the top. We found still another instance of the unusual ability of these birds to adapt themselves to changing conditions. Those nests which were already deserted or with young ready to fly had simple rounded tops arching over to protect the entrance

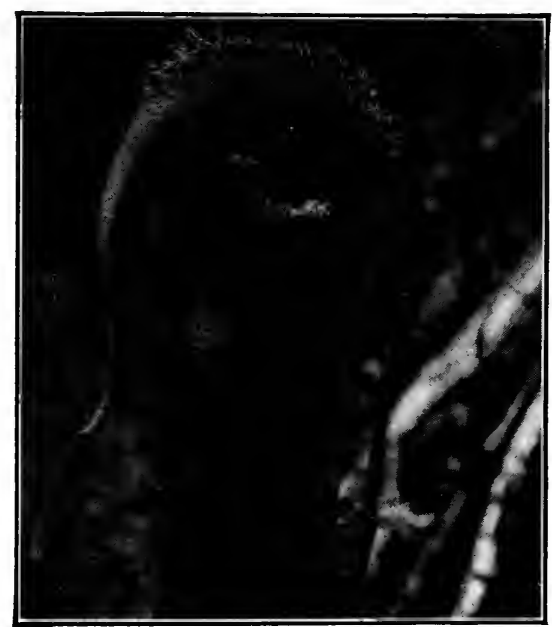

Fig. I7. Venezuelan Tree Porcupine.

from the sun; but in the nests which were in process of construction, now at the beginning of the rainy season in early April, there appeared an additional chamber with a dense roof of thatch, in which one of the parents, the male at least in one case, passed the nights, safe from the torrents of sudden rain.

Another larger species of Cassique, ${ }^{150}$ dull green in color, built solitary nests, three feet or more in length, but seldom near the homes of men or wasps. Here and there in the 
jungle some lofty tree raised its huge white bole free of vine and liana, and smooth as a marble column, towering far above all its fellows; and out on the very tip of one of its swaying branches the nest was woven - safe from all treeclimbing enemies. The notes of these birds were like deep resonant cowbells, ringing through the jungle, clear and metallic.

During our stay in the village of Guanoco we had abundant opportunity to observe the relations of a tiny hamlet like this to the great world of primeval nature all around. The jungle pressed close, instantly filling any neglected corner with a tangle of vines and shrubs, ever ready to sweep over all and reforest the little clearings about the huts.

Sloths were rare near the village, as it had long been a favorite Sunday amusement to go out and bring in one or more of these defenceless creatures for dinner. But tree porcupines (Sphingurus prehensilis), with bare, prehensile tails and faces like little manatees, were common, as were those gentle little creatures of the night, kinkajous (Cercoleptes caudivolvulus), or "couchi-couchis" as the Indians call them. Catching porcupines and sloths is about as exciting sport as picking blackberries; the porcupine being too confident in its battery of spines to attempt to escape; the sloth relying with pathetic faith on its wonderful resemblance to a bunch of moss or leaves.

The "English Sparrows" of the village were beautiful olive-green Palm Tanagers ${ }^{144}$ and great sulphur-breasted Flycatchers ${ }^{102}$ which shrieked Kiss-ka-dee! at you as you passed by. The French in Trinidad tell you that the bird says Qu'est-ce-qu'il-dit? but the Spaniard, true to his poetic temperament, says, "No, Señor, el pájaro dice 'Cristofué!", which seemed especially appropriate at this Easter season.

Every day one or two wild Chachalacas ${ }^{7}$ would fly from 
the jungle to an open space near one of the huts and feed fearlessly with the chickens for an hour or longer.

To our northern minds the most remarkable thing was the innumerable variety of all forms of life. Seldom did we find many individuals of any one species, but always there was a constantly changing panorama. We would make a careful list of birds seen near our house, noting certain ones for

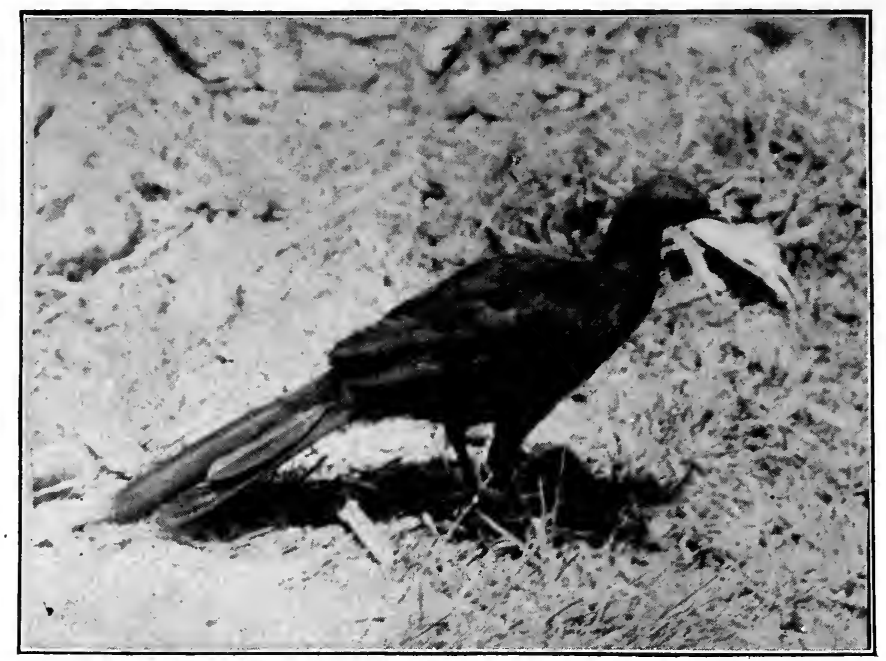

Fig. I8. Wild Chachalaca near a Guanoco Hut.

future study, and the following day scarcely one of these would be visible, but in their place birds of strange form and colors. The same was true of the insects and the result was as bewildering as it was fascinating. Our habits of observation had all to be changed. Except when birds were actually nesting, we could never be sure of seeing the same species twice, although there was never any doubt that each day would add many new forms to our lists.

Though we tramped for miles along the narrow Indian trails and spent many days in swamps and dark jungles, yet 
we were troubled scarcely at all with noxious insects. "Jiggers" there were in moderate numbers but one could "collect" more in one day in Virginia than in a month here at this season. During our entire stay we saw only about three or four minute ticks, while mosquitoes were absent, except at night. If we dug in rotten logs, we were sure to unearth centipedes and scorpions, many of them, -- but otherwise we

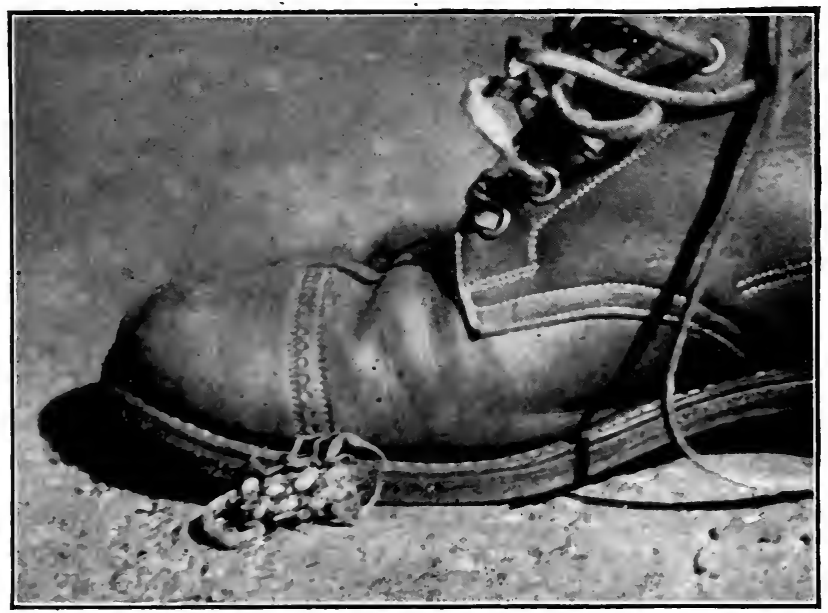

Fig. i9. Scorpion and its Young taken from Mrlady's Shoe.

rarely saw them. Once, indeed, a mother scorpion (Centrurus margaritatus) with half a hundred young ones on her back was discovered in a shoe, bringing to mind the old nursery rhyme.

We found that much of the jungle was almost impenetrable, and on one of our first excursions we were fortunate enough to find a means of making the birds come to us from the deeper recesses of the forest. As we left the doorway, a silent little shadow fitted into the pommerosa tree in front of us, and soon among the glossy leaves came a sound which we 
had heard day and night, but the author of which had thus far evaded us. It is impossible to put into words, but it may be imitated by a monotone whistle, of about four notes to the second, of A above middle $\mathrm{C}$. The glasses showed a mite of a Pygmy Owl ${ }^{60}$ glaring at us with wide yellow eyes, and firmly clutching a dead bird, half as large as himself. Later, when standing at the edge of an impenetrable tangle of thorny vines and vainly trying to discover what bird was singing in loud, ringing tones within it, we thought of the fierce little owl, and concealing ourselves, gave the call of Glaucidium. The effect was instantaneous; the song near us ceased, and with angry cries a pair of beautiful Black-capped Mockingthrushes ${ }^{126}$ flew almost overhead. Black-tailed Euphonias ${ }^{138}$ and Grassfinches followed, Bananaquits ${ }^{137}$ whirred about us, and within a few minutes thirty or forty birds had testified to the hatred in which the little Owl is held.

A great surprise to our northern eyes was the Yellow Woodpecker ${ }^{30}$ not uncommon here, and clad in bright yellow plumage from crest to tail. It was very conspicuous in flight, but when it alighted, merged with the lichened bark and spots of sunlight. One bird was very tame and frequented a tree close by our window.

One of our first walks led us through a narrow valley or gorge to the westward, shaded by ranks of tall palms and with isolated banana and cocoa plants, hinting of native Indian clearings long since overwhelmed by the luxuriant jungle growth. Wasps and other Hymenoptera outnumbered other insects at this season, and one could have collected scores of different species in a few hours. A few Heliconia butterflies drifted across our path, and now and then a giant morpho shot past like a meteor of iridescent blue. Other great butterflies (Caligo ilioneus) were iridescent blue and brown above, while the under sides of their wings were mottled and with a great eye-spot on each of the hind wings, 
which gives them the name of the owl butterfly. But however much, in an insect cabinet, the expanded reverse of the wings suggests the face of an owl, the spot, as we observed it in the forest, seemed rather to render the insect invisible. These great fellows would shoot up to a lichen-covered trunk and drop lightly upon it, and unless one's eyes had followed

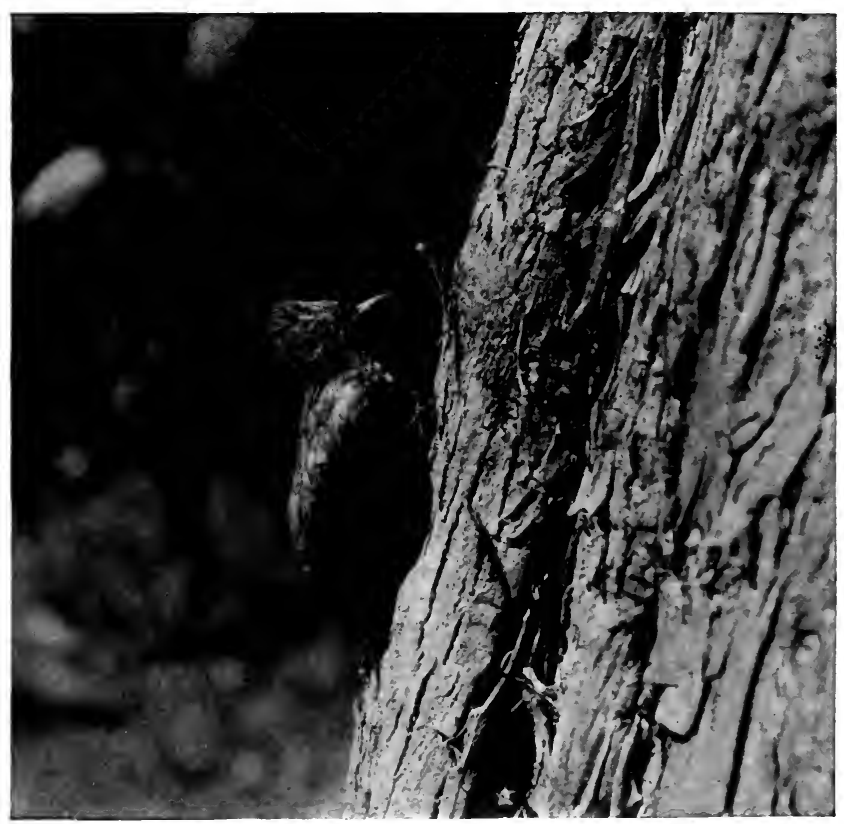

Fig. 20. Yel.low WoOdpecker.

closely, the butterfly vanished like magic. Creeping up to one we secured its picture, the mottlings on its wings merging it with the lichens, and its owl-eyes becoming the painted facsimiles of darkened knotholes, or of little atoll-like fungus rings.

One is constantly impressed by the abundance and variety of these protective adaptations. Instead of one's eyes be- 
coming more accustomed and trained in detecting these deceptions, the puzzles increase, and one becomes suspicious of everything. Every few minutes we are halted by a curled leaf which resembles some great caterpillar, or by a partly decayed fruit which may prove to be a curiously marked

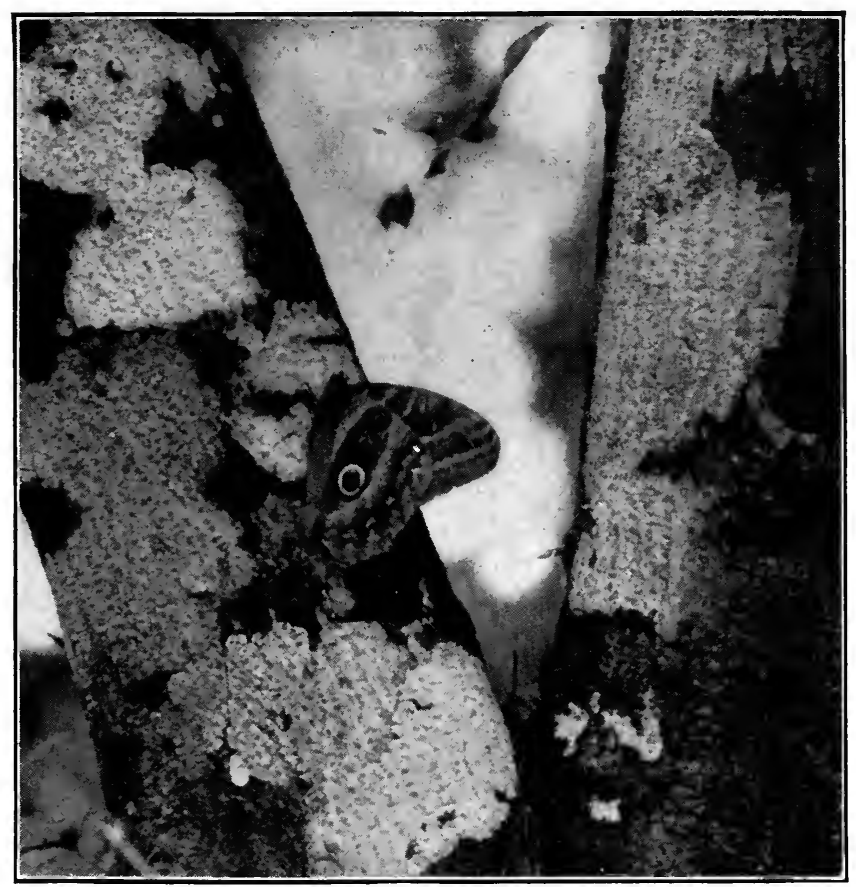

Fig. 21. Owl Butterfly on Cocoa Bark.

beetle. Many of these are such exact counterparts that we have to touch them to undeceive ourselves. After seeing some bats hung in the shadows between the buttressed bases of great trees, we imagine them in every patch of moss or dried leaves.

The resemblance to inanimate objects is never violated and often remarkably heightened by the little creatures of fur, 
feather, scale or armor of chitin. The bats never alight in a close compact mass, but each isolated, with its wings partly spread, and often extended irregularly, one webbed hand higher or farther out than the other, thus presenting a dull, irregular outline, at which we should never have looked twice, had not the little beasties become frightened and flown. A butterfly (Peridromia feronia), mottled and pearly on the upper side, snaps clicking to a lichened trunk and alights head downward with wings flat. Beneath they are white and conspicuous. The inverted position allows the hinder wings to be pressed flat to the surface of the bark, while the slight shadow caused by the prominence of the body in front is thus below and invisible. Another, brilliant red on the upper side and irregularly marked below, never alights, as far as our experience went, except on some lichened trunk. In this case however the wings were held tightly together, and the insect always in a head downward position. The insect took to wing so quickly that only a hint of the red was visible.

We never could tell what new form of protective resemblance would next come under our notice. Here and there in the woods we found trees which had fallen in a clear space and had torn out their roots in the fall, forming a great bank of earth and mould, held together by the network of root fibres. Hanging suspended by slender root tendrils were many small pellets of earth slowly swaying and disintegrating. We found that some of these were not mere accidents of inorganic forces, but were the nests of a small mud wasp made in a roughly circular form and moulded to one of the many rootlets.

Lizards perhaps more than any other group of backboned animals become part and parcel of their surroundings in form and color. We sometimes found dull gray and green fellows on the trunks of trees or the ends of half rotten logs, which 
almost defied the efforts of the eye to disentangle them from the lichens and moss amid which they clung. When one of these did move it was with such celerity that the eye unconsciously swept onward, impelled by momentum, and overshot the spot where it stopped. Then another careful search was necessary to rediscover

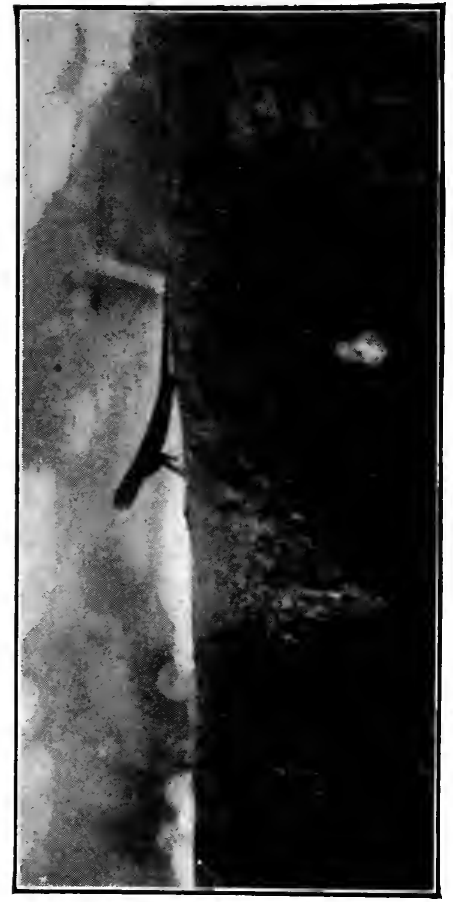

Fig. 22. Lizard Alert on Trunk OF TREE.

spot of sunshine; if his perch is in sunlight, the tiny, headless body conveys no hint of a living bird.

His cousin, the White-breasted, is black and white and the four outer feathers of the wing are very narrow and curved. These are the strings upon which he plays an reolian song 
of love, for every time he takes to flight a loud humming sound is produced. The females are dull olive in color but easily recognizable by their orange feet and legs. Sometimes three suitors would buzz and hum together about one of these sombre little ladies in the gloom of the gorge.

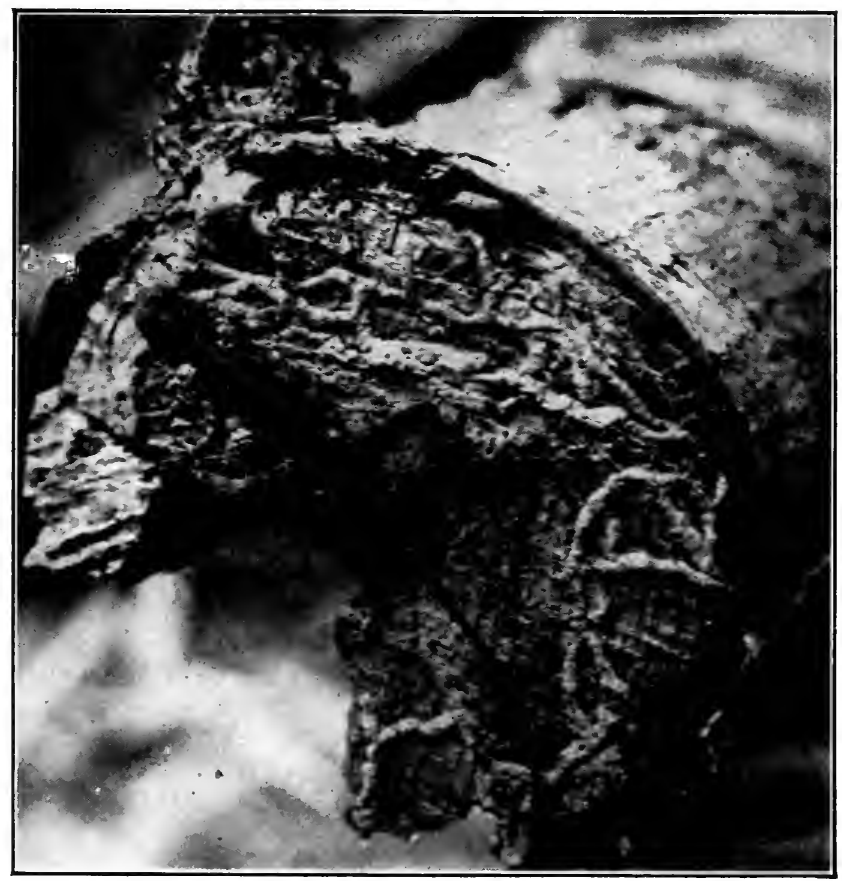

Fig. 23. The Same Lizard a Moment Latér, Obliterated by Change of Position.

The rotten trees and palm stubs were filled with interesting insects; big black palm weevils (Rhyncophorus palmatum) an inch and a half long, and huge brown cockroaches three inches from head to wing-tip (Blaberus trapezoideus). With a machete we cut open one log, which was like bread in consistency, and found two centipedes, three scorpions, one 
of them a whip scorpion, a huge beetle larva, a small snake, with a faint band about its neck (Homalocranium melanocephalum) and most interesting of all, a Peripatus.

Perhaps the reader here wonders to himself what a Peripatus is, and it is a pity that this most important creature has no common name. We may call it a worm-like caterpillar or a caterpillar-like worm, for its claim to fame rests upon its position as a so-called missing link. We know that in long ages past the ancestor of the butterflies, beetles, wasps, spiders and crabs was a worm-like creature, primitive in structure and in no way hinting of the beautiful organisms which were to be evolved in succeeding epochs. Hiding away from light, in the warm moisture of decaying wood, the little Peripatus has lived on and on, age after age, with little apparent change, until we find it to-day combining the simpler characters of the lowly worms with those of the vastly higher caterpillars.

The Péripatus which we unearthed, or rather unlogged, was of a rich, dark reddish hue. It was caterpillar-like in general appearance, but not divided into segments, while the number of its very simple feet and its method of progression brought to mind the millipedes. The long, slender antennæ were constantly in motion; changing and extending, feeling about and retracting.

Glancing at the leaf of a low shrub, we saw what we supposed to be two bits of dried, rolled-up leaf entangled in a strand of spider web and being whirled about by the wind. When we saw that this motion continued after the breeze had died down, we became interested. We discovered that the two objects were tineid moths of a dark pearl color, waltzing about with the most graceful and airy motion imaginable. With closed wings they whirled round and round by means of their legs alone, and, most remarkably, both going in the same direction, although this was frequently changed, the 
reversal being almost instantaneous and without an instant's loss of the smoothness of the rhythm. Now and then their circles overlapped, but at the first danger of collision the tiny dervishes both retreated without stopping their dance. Presently one flew away, and the other shifted to another leaf

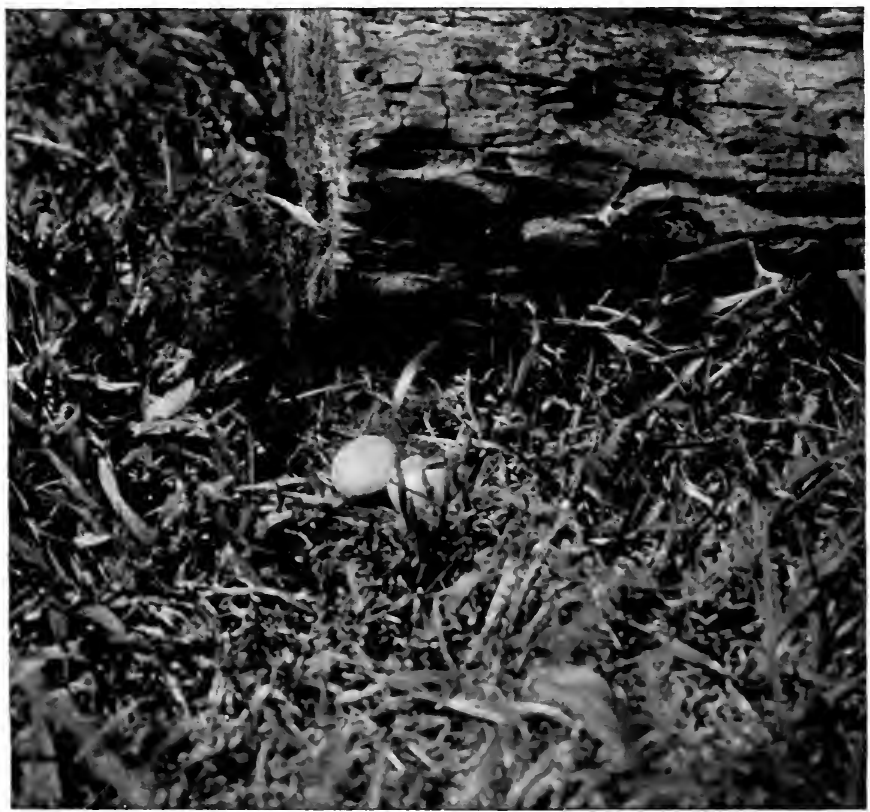

Fig. 24. Nest and Eggs of Great Blue Tinamou.

near by, and recommenced his waltz alone. It was a surprise to find these little winged millers in the rôle of graceful dancers. The reason of it remained a mystery.

These incidents are quoted as some among the myriad interesting doings of the little folk which we observed in the heart of these great jungles. As we walked on, virgin forest surrounded us, with great trees centuries old, chained and netted together by miles upon miles of lianas. Now and 
then we entered a clear glade festooned by-a maze of ropes and cables, with here and there a lofty monkey-ladder leading upward by a wavy series of narrow steps. The cicadas filled the air with the oriental droning of their song, and a big Red-crested Woodpecker ${ }^{88}$ called loudly from a halfrotted, vine-choked tree. From the undergrowth came a soft rolling trill, a crescendo of power and sweetness, and when our Indian carrier whispered, "Gallina del monte," we knew we were listening to the call of a Great Blue Tinamou one of those strange birds looking like brown, tailless fowls, but of so generalized a type that they form in many ways a link between the ostrich-like forms and the rest of the bird world. The bird which was calling soon became silent, but creeping slowly along we were fortunate enough to discover its nest on a bit of sunny turf near the end of a log in a partially overgrown clearing. All the delights of bird-nesting seemed consummated the moment we caught sight of the two wonderful eggs before us. The nest was merely a hollow scratched in the grass, but the sun was reflected from two shining spheres of metallic greenish blue, like two huge turquoises polished as by the wheel of a lapidary. Never were such eggs; they seemed of hard burnished metal, more akin to the stones lying about them than to the organic world, and yet, even as we looked, there appeared a tiny fracture, and in a few minutes the beak of a Tinamou chick had broken through to the outer air. The glistening cradle of stone would soon fall apart and give to the tropical world another life - one more mote among the millions upon millions about us.

Now and then we would come across a huge low mound, clear of undergrowth, dotted with holes from which welltrodden paths led off in every direction. Some of these were six inches in width, so that we could easily walk in them. A twig poked down the holes and twisted about would come up covered with angry ants, great brownish-black fellows 
with a grip like a bulldog. Even this simile fails, for these insects will allow their heads to be pulled off before they will let go.

Everywhere the ants attracted our attention; huge black giants (Neoponera commutata), which seemed never to have anything to do but parade slowly up and down the trunks of trees; and the ever-busy parasol-ants, hustling along in single file, waving their green banners and clinging faithfully to them while falling down terrific precipices three or four inches deep. We dug into their nests and found their fungi gardens, one part of which would be freshly planted with neat black balls of chewed-up green leaves, while in another part the fungus was well grown - a meshwork of gray strands whose fruit was ready to be plucked and eaten.

The hunting-ants (Eciton) surpassed all the others in interest. Day after day we would come across their great armies, and we spent many hours of keen enjoyment watching their advance. We had read of their appearance and habits; we had heard them compared to Goths and hordes of savages, but no description prepares one for the actual sight. We watched in particular one large army which carried on its operations only a short distance from our house.

Long before we came within sight of the ants themselves their presence would be heralded by the flock of birds which kept just in advance, feeding upon the insects which flew up from the van of the ant legions. In one such assemblage most of the birds were Woodhewers, big, cinnamon-colored, creeper-like birds which hitched up the tree trunks and now and then swooped down to the ground, snatched an insect and swung back to the trunk. This flock of birds showed other methods of feeding; Hummingbirds appeared from nowhere, dashed down to a tiny insect and vanished into space; Anis ${ }^{80}$ blundered along, looking as if their wings and 
tails were too loosely attached for use; Ant-birds crept low through the bushes and carried their prey to a twig to eat; two American Redstarts ${ }^{128 b}$ and several Tyrant Flycatchers caught their prey by a sudden dart and a snap of the beak. One species in particular, the Streaked Flycatcher, ${ }^{105}$ was always attendant on the ants and always fearless, watching us and yet never missing a chance to snap up a passing insect.

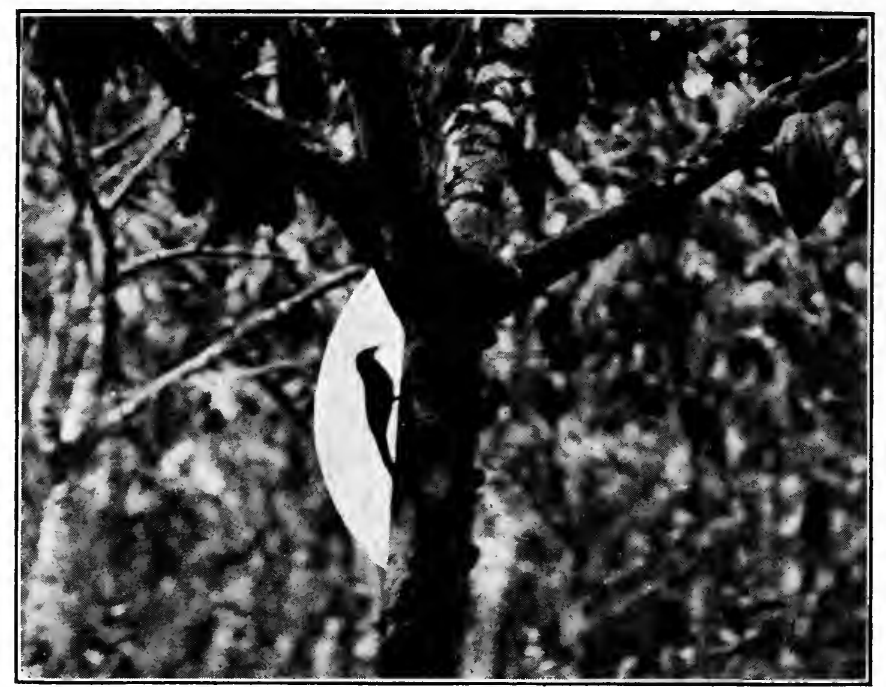

Fig. 25. Woodhewer clinging to the Trunk of a Tree.

As we drew nearer, a strange rustling sound reached our ears, like the regular pattering of raindrops, and before we knew it we were standing in the midst of thousands of active ants, whose rushing and scrambling about over the dead leaves caused the loud rustling. In a few seconds twenty or thirty ants had climbed upon and above our shoes, and their sharp, nipping bites sent us in haste to the flanks of the army, where we freed ourselves from the fierce creatures. 
These ants are not large, varying from a fifth to a third of an inch in length, dark in color, with lighter red abdomens.

Until one becomes accustomed to these scenes of carnage the sight is really terrible, especially when one lies down flat and takes an ant's-eye view of the field of battle. Yet such is the fierceness and savage fury on one side and hopeless terror or frantic efforts to escape on the part of the victims that it needs but little imagination to stir deeply onc's sympathies.

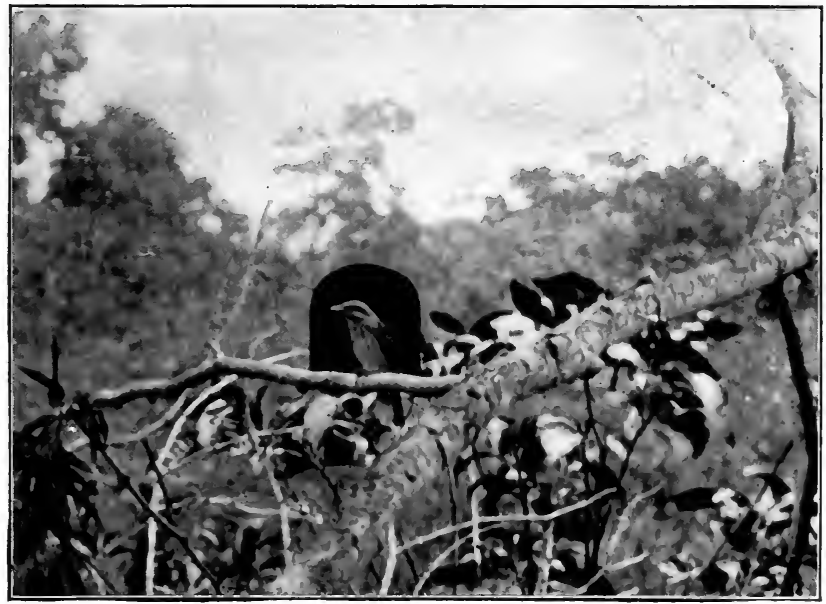

Fig. 26. Streaked Flycatcher.

In place of the steady advance of a well-drilled army, presenting a solid front of serried ranks, the formation of the hunting-ants may be compared to an innumerable host of cavalry scouts who quarter the ground in every direction, the whole army slowly advancing and including new territory in the scene of operations. Frequent flurries or louder rustlings follow the discovery and the subsequent terrible struggle of some quarry of noble size - a huge beetle or mighty lizard. 
One fact impressed us from the first: every creature aroused by the ants seemed to know instinctively of the awful danger. Whether through odor or sight or sound, the alarm always carried its full meaning. Insects which ordinarily would escape the collecting net by a single quick motion, here dashed away with such terror that they often flew against our clothes or a tree, and were hurled to the ground. Lizards took shelter under our shoes or shot off like streaks of light for many yards. Our presence and that of the predatory birds was disregarded in the efforts to avoid the danger which generations of inherited experience had made the most vivid in life.

Insects which usually feigned death as a means of escape, when disturbed by these ants used all the motor organs given them by nature to flee from the dreaded foe. Escape seemed to be the result of accident with all wingless creatures, even with those possessing good eyesight, for the first blind terrified rush as often carried them to certain death in the thickest of the host as it did to safety in the van or on one side of the ant army. Even wings were not a surety of escape. Twice I saw moths arise heavily from their hidingplaces with a half-dozen of the little fiends clinging to their legs and wings. One was snapped up, ants and all, by a big Flycatcher, and the other fell among the quartermaster's brigade in the rear, where every ant within reach dropped his load and hurled himself upon the newcomer.

Here and there one might observe good-sized balls of ants rolling about, and in the centre would be some hard-cased beetle or other insect, who gave up only after killing and maiming a score of his assailants.

We dropped five big black ants into the midst of the marauders, and witnessed a combat as thrilling as the contest between the Greeks and Persians. Four of the insects alighted on a small rounded stone over which three hunting- 
ants were scurrying. Without hesitation the black giants fell upon the brown warriors and tore them limb from limb, with the loss of only half a leg. This is not a very serious handicap, when one has five and a half robust limbs left! The fifth big fellow dropped upon a mass of ants piled like football-players upon a struggling scorpion, whose sting was lashing the air in vain. The big ant started another ripple upon this pool of death, which soon smoothed away, leaving no recognizable trace of him. But the quartet of big-jawed fellows on their rock citadel fought successfully and well. No ant which crept to the top ever lived to return for help. The four flew at him like wolves and bit him to death. Soon a ring of hunting-ants formed around the stone, all motionless except for a frantic twiddling of antennæ. They were apparently excited by the smell of the blood of their dead fellows, and only rarely did one venture now and then to scale the summit. When we left, two hours afterward, the army had passed, and left the stone and its four doughty defenders, who showed no immediate intention of leaving their fortress.

The ground over which the hunting-ants passed was absolutely bare of life, and, contrary to the rule in human armies, it was among the camp-followers and foragers that the most perfect discipline reigned. In the rear of the main army were lines upon lines of ants laden with the spoils: legs, bodies, and heads of insects and spiders, bits of scaly skin of lizard or turtle, joints of centipedes and scorpions, and here and there a piece of ragged but gaudy butterflywing borne aloft like the captured standard of some opposing force.

We followed three lines of supply-carriers and found that they converged on some sheltered hollow in a tree or under a boulder or root. Here were massed countless hordes of ants clinging together like a swarm of bees. In the centre were the queen, eggs, and young of these nomadic savages, resting 
thus temporarily until the far-distant scouts should report another shelter, when the whole community would shift to the new home, farther along on the line of march.

The army in which we were especially interested seemed to be carrying on their hunting in a rough circle about the temporary home, and perhaps this is a common habit. Certain ants apparently serve some function of direction or means of communication, for they keep to one place for a half hour at a time and twiddle their antennæ with every ant which approaches.

It was when the hunting-ants discovered the nests of other species of ants that warfare, true to its name, was waged. One could watch as from a balloon, mimic Waterloos and Gettysburgs, and sad to relate, in the case of inoffensive species, plunder, murder, and abduction by the wholesale. After studying the ways of these merciless creatures, we could seldom walk through the quiet, sunlit jungle, with blossoming orchids everywhere overhead and the songs of birds and pleasant hum of insects in our ears, without thinking of the tragedies without number ever going on around us.

Used as we were only to the small lightning bugs of our northern summer nights, the big luminous elater beetles (Pyrophorus sp.) were ever of interest. The two thoracic lights are placed on the outer posterior edges and give out a pale greenish glow of great intensity. We could easily see to read and write by their light, and by placing a half dozen of these insects in a glass we could use them instead of our electric flash.

When we examined them carefully we were surprised to find that there was another area of illumination on the abdomen, below and just behind the insertion of the third pair of legs. When fully illuminated this area was brilliant and of a figure so shape. The light however was radically different from that of the thorax, being yellowish, and candle- 
like, giving an illusory impression of an opening from the incandescent interior of the insect. When the insect settles to rest the only visible illumination is from the pair of thoracic lights, but in flight the abdominal searchlight comes into play, burning brightly with a strong yellowish glare quite different from the green thoracic lights.

As we lay at night half asleep we would sometimes be awakened by the droning of one or two big elaters, whose intermittent flashes would illumine the whole room. More than once we had to capture the intruders with the butterfly net and banish them before we could get any sleep.

We chloroformed two of these luminous beetles and pinned them in an insect box. Two evenings afterward when we had occasion to add more insects, the box was opened and to our surprise the little lanterns were still aglow and hardly less brilliant than when the insects were alive. They had been dead forty-eight hours and yet their light still shone ghostly white, lighting up the other insects in the box.

One evening we found a tiny wire worm, the larva of some small species of elater, which was highly phosphorescent. Although only about one-half of an inch in length, the whole head, the posterior segment and a spot on the side of each of the others was bright. Watched as it moved smoothly and rapidly along, it reminded us of a ship passing at a distance at night with the lights streaming from the port-holes.

Our trips to the pitch lake on the early morning engine will never be forgotten. A warning toot from the diminutive whistle hurries us through our breakfast, and we hasten to the track and see our cameras and guns loaded on one of the little square wooden "empties." We mount the wood-filled tender of the engine, which with many complaining creaks and jolts get under way, backing slowly around the curve which hides the last sign of civilization and buries us in the jungle. 
For nearly twenty years these little toy engines have bustled and elbowed their way over the snaky rails, until the jungle and its people have come to look upon this narrow winding steel path as part of the general order of things. The underbrush creeps close, and only the constant whipping of the engines and cars beats down the growth between the rails.

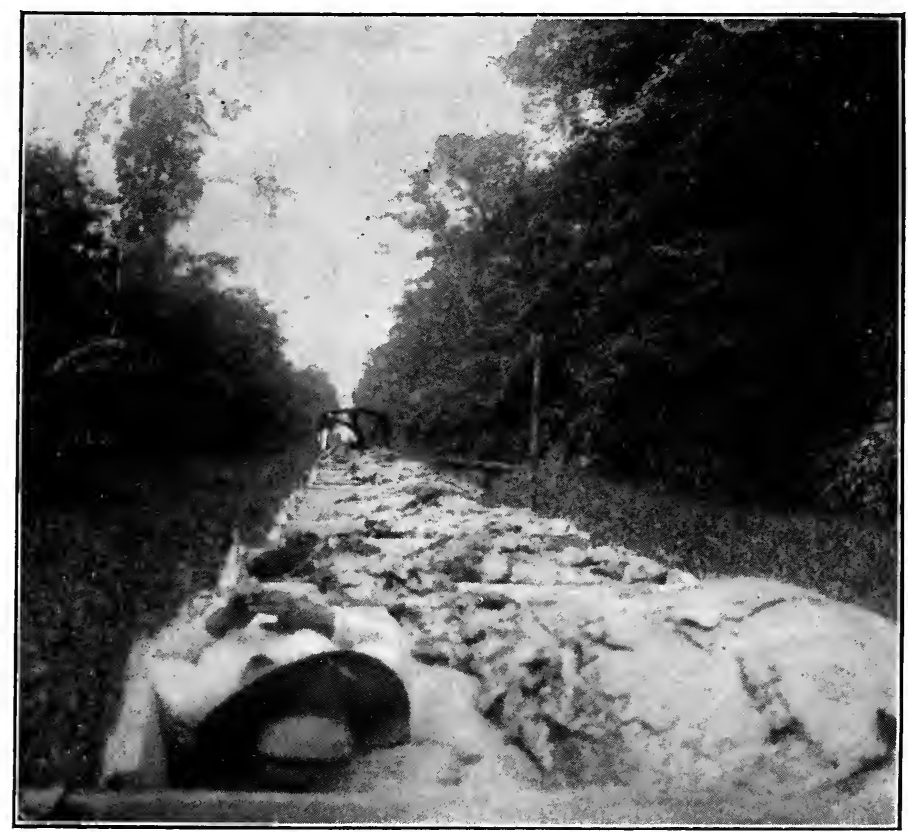

Fig. 27. The Jungle Railroad.

As we start, the last bats of night dash into the dark jungle, and their diurnal prototypes, a flock of graceful Palm Swifts, ${ }^{71}$ swoop about overhead. To our ears there comes the finale of the morning chorus of distant red howlers and the first deep-toned bellings of the giant Cassiques.

All along the line, beasts and birds show their lack of fear of the rumbling cars. A party of chattering little monkeys 
sit and gibber at us and rub their dew-drenched fur. Their parents and great-grandparents had found nothing to fear in this strange thing which, five times each day, crawls back and forth on its narrow trail, and why should they do more than look and wonder? As we come in sight of the muddy banks of the little river, a great Parrot shrieks in derision at

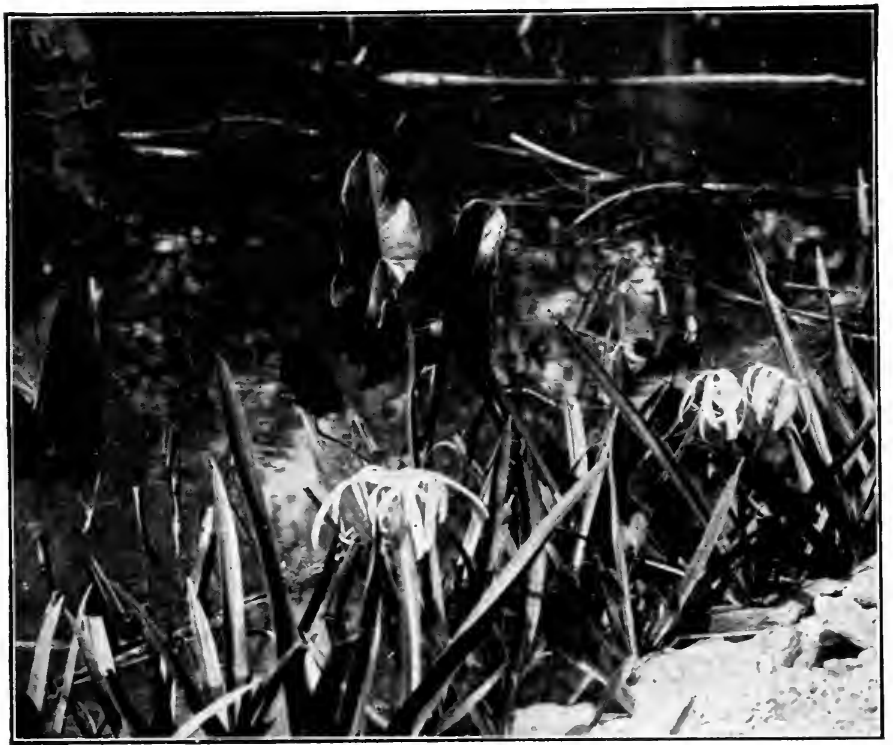

Fig. 28. Spider Lilies near Pitch Lake.

us from the top of a dead stub by the track, executing slow somersaults for our benefit. Instinctively we look for a chain on its leg and a food cup near by! A splash draws our eyes downward, and from a maelstrom of muddy water shoots a villainous sting ray. A school of little staring foureyes skips over the water, and near the swampy, farther bank, a sprawling half-grown crocodile watches us - as quiet as a stranded log. 
The air blows cool and damp on our faces, and we long for the keen power of scent of a dog. Even to our dull nostrils every turn of the road is full of interest. A swamp, thickly starred with dainty spider-lilies, comes into view, and we inhale draughts of sweetest incense; Easter Sunday is at hand, and the very wilderness reminds us of it.

With every breath of air the great palm leaves flick myriads of drops to the underbrush below, with a sound as of heavy rain. The trunks are black and soaked, and there is not a dry frond for miles. A sudden curve brings another loop of the river into view, with a foreground of scuttling crabs and mangrove seedlings. Here a wave of coarse, salty, marsh smell fills our lungs - not stagnant, but redolent of the distant sea; the smell that makes one's blood leap. The next quarter-mile is covered with lilies again. From their perfume we enter a zone of recently cut grass - and the incense brings to mind northern hay-fields and the sweetgrass baskets of the Indians. What new pains and pleasures would be ours could we possess the power of scent of some of the "lower" animals!

Temperate succeed tropical vistas; we see what at first appears to be a grove of young chestnuts rising from rhododendrons and guinea-grass. A Spotted Sandpiper ${ }^{22}$ heightens the illusion, and the picture is complete when a familiar milkweed butterfly floats by and alights on a red and yellow tansy. But just then a Macaw shrieks from a near-by treethe road-bed turns and reveals a tangle of palms and scarlet heliconias - a monkey climbs up a leaf large enough to shelter half a hundred of his kind. Strange palm fruits come into view, some like enormous clusters or bunches of grapes each fruit as large as an orange; or again a huge feathery, dependent frond of dust-brown blossom and fruit protected by an overhanging spathe like a huge umbrella.

The jungle never gives up the struggle against the invading 


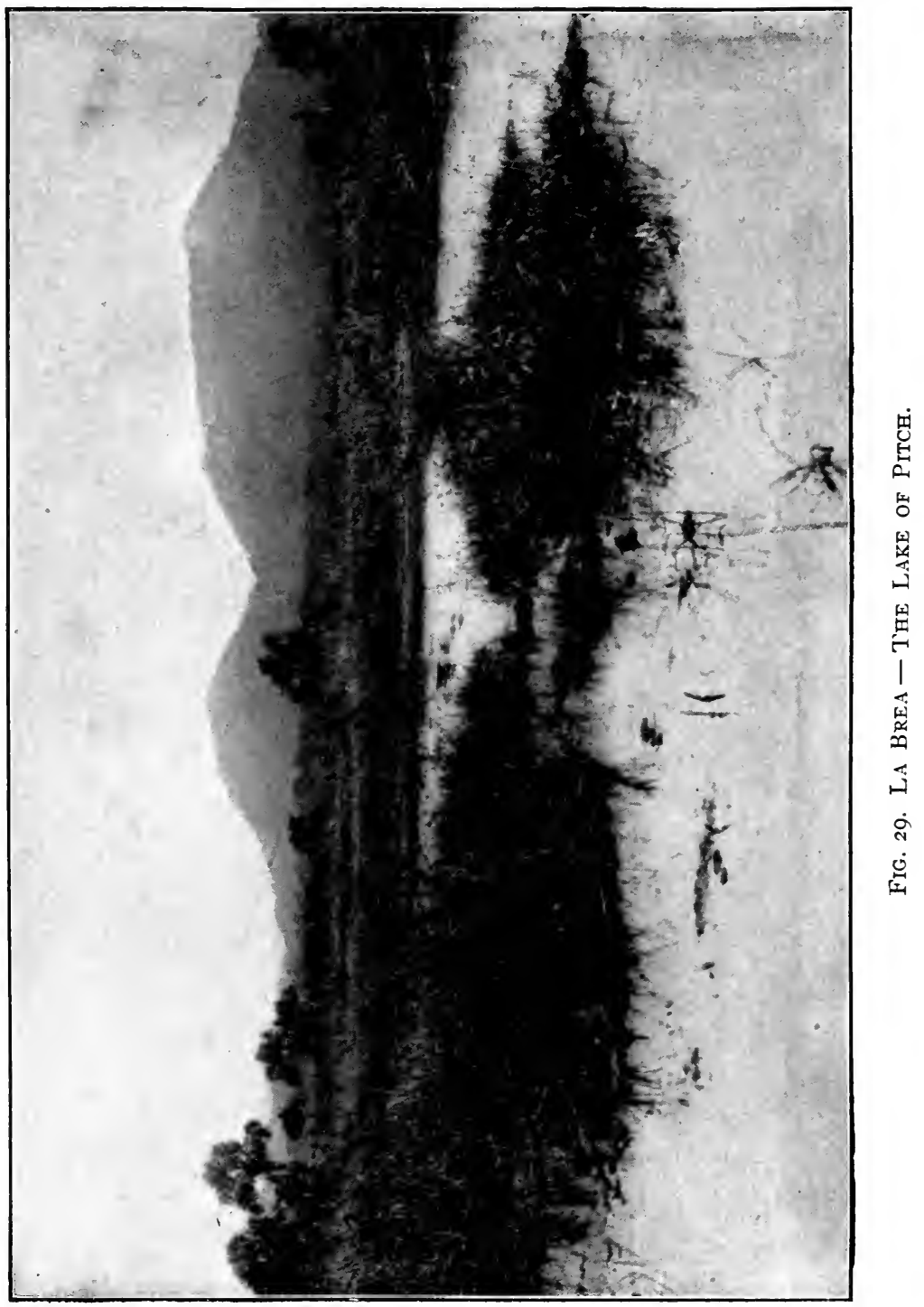


rails. Beneath the cars the constant friction only dwarfs the growth, and we find here miniature plants blooming, fruiting, and scattering seed; plants which elsewhere reach a height of five or six feet. It is an interesting case of quick adaptation to unfavorable conditions.

The vegetation presses on every inch of the track, striving ever to close up the long scar through the heart of the forest, and only by systematic cutting is the way kept open. The advance of the jungle host is most interesting. Thirty feet from the rails the growth is primeval, a dense mass of entangled and interlaced vines, shrubs, palms, and giant trees, the boles of the latter shooting up and up through the mass and bursting into bloom high overhead. Nearer the track we find a phalanx of green banners and the wonderfully brilliant red and yellow flower stalks of the quick-growing heliconias. In front are the rough scouts, the real advanceguard of strong, thorny vines growing in close entanglement - a living chevaux-de-frise, inconspicuous and yet offering the greatest resistance. Under this shelter the larger but slower-growing components of the jungle take root and gather vigor, until, if not cut out with the hardest labor, they soon rear their heads from their nursery of vines and brambles, and the shining rails vanish from view.

All the creatures of the forest cross and recross the track freely, even in front of an approaching train. Water-fowl, Sun-bitterns ${ }^{24}$ and the weird-voiced Trumpeters ${ }^{25}$ walk up and down, and flocks of Seedeaters ${ }^{132}$ drift here and there, gleaning seed from between the rails. The Trumpeters were a great surprise to us, as this is the first instance of their being found north of the Orinoco River. One day we see the leaves part, and a long, low-shouldered reddish form slouches across before us, without even a glance at us, and we know it for the first South American puma (Felis concolor) which we have seen. Another "red lion," as 
the natives called it, with two cubs, was seen not long before.

Only the sloth is barred. He comes close to the endless swath; he wanders from tree to tree up and down, peering dully out across the track, but he cannot cross. The twenty-foot treeless embankment is as impregnable to him as a sheer wall of rock. With a weird cry he turns back and starts in another direction through the branches.

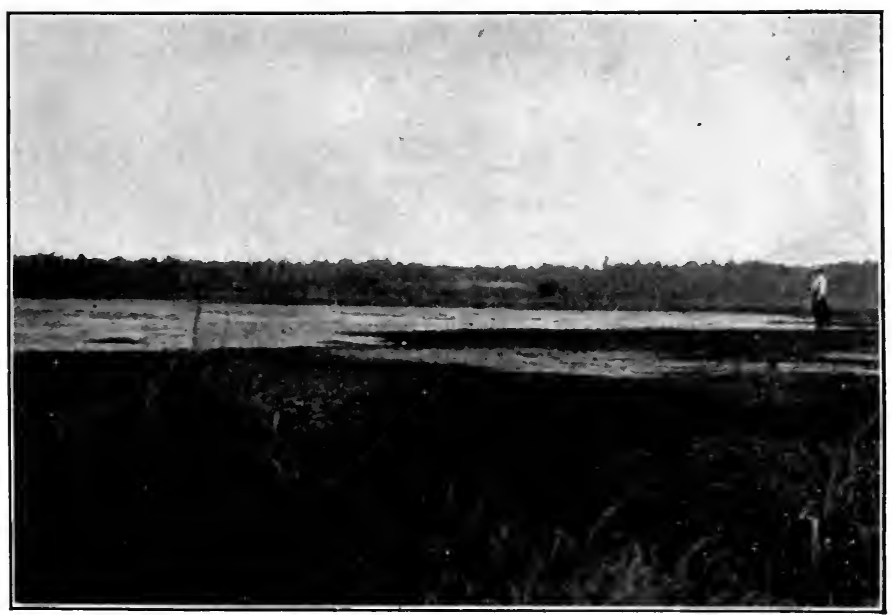

Fig. 30. The Fatal "Mother of the Lake."

We reach the lake long before the dew is dried and before the freshness of the dawn is dissipated. Hurrying over the planks and the temporary rails laid for the workman's handcars, we push on a half-mile or more to the southward, where nothing hints of man's proximity. To the north and west are irregular peaks running off into a blue and misty range the foot-hills of the Spanish Main. To the south the high woods are close to us and tower high overhead, but even with the eye of yonder lofty, soaring Vulture we could see no 
mountains in that direction - nothing but flat, green miles of mangroves, stretching to the horizon over the immense delta of the Orinoco. The pitch lake itself is surrounded on all sides by dense forests, the front ranks of which are made up of the marvellously tall and graceful moriche palms. There is one oasis in this pitchy expanse - Parrot Island it

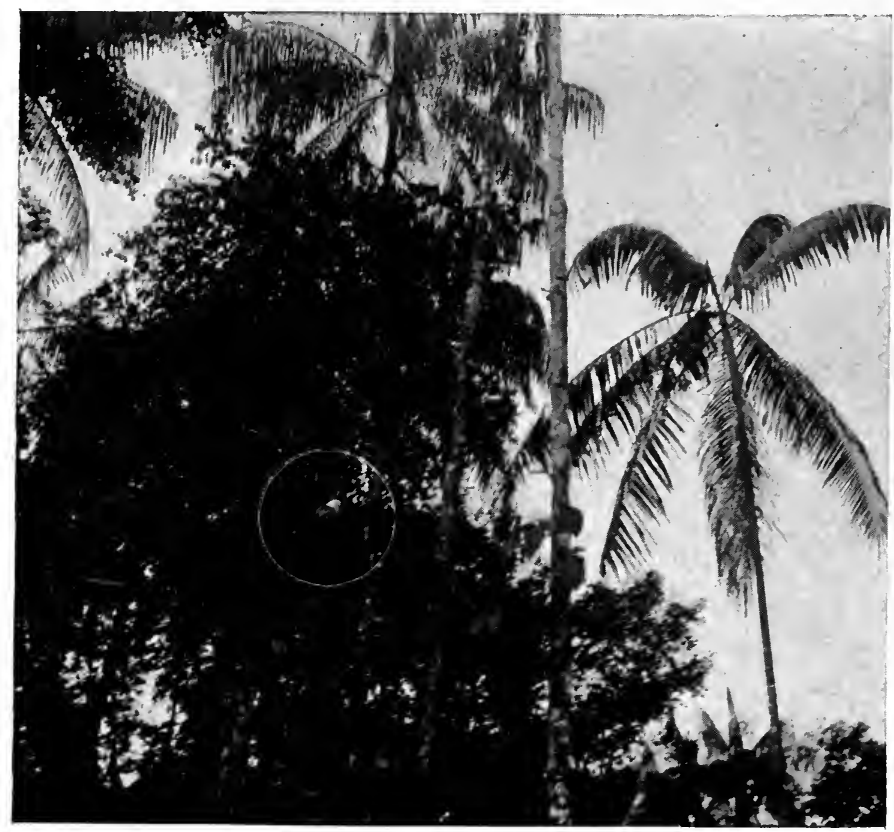

Fig. 3r. White-headed Chimachima Hawk and Eta Palm.

may be called. To this shelter, guarded on all sides by soft, quaking pitch, Amazon Parrots come at dusk by hundreds, roosting there until the next morning.

Near the northern edge is the "mother of the lake," just above the deep-hidden source of supply, where the pitch is always soft, and where no vegetation grows. It is a veritable pool of death, and nothing can enter it and live. The lizards 
and heavy-bodied insects which scamper over the rim are often clogged and drawn down to death. A jaguar, leaping after a Jacana, slipped in shortly before we came and made a terrible fight for life. Half blinded, its struggles carried it only farther outward, but fortunately the end came mercifully soon.

All the rest of the lake is a varied expanse of black pitch

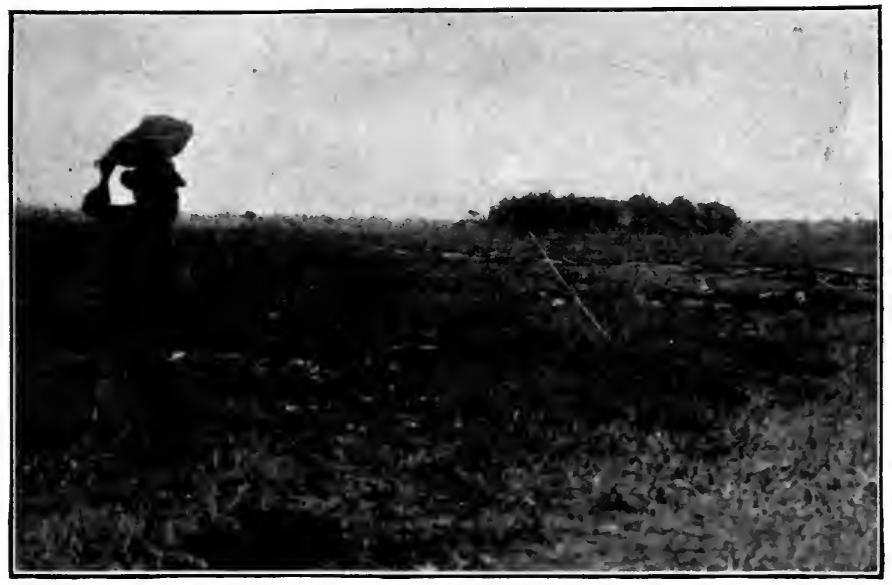

Frg. 32. Amazon Parrot Roost, Pitch Lake.

bubbles, short grass, clumps of fern and sedge, with occasional isolated palms. Flowers of many kinds and colors spring from the heart of the raw pitch itself. Jacanas ${ }^{23}$ rise before us with loud cries and flashing wings of gold. One may walk over the lake at will, morning and evening, but in the heat of midday, in many places, one's shoes sink quickly unless one keeps constantly on the move.

White is not a very common color in nature, and yet here, in striking contrast with the inky blackness of the pitch, most of the birds show large patches of this color. In the dis- 
tance are always to be seen Snowy Egrets ${ }^{33}$ and immature Blue Herons ${ }^{34}$ - spots of purest white, while near at hand, absurdly tame, a big hawk forever soars slowly about or

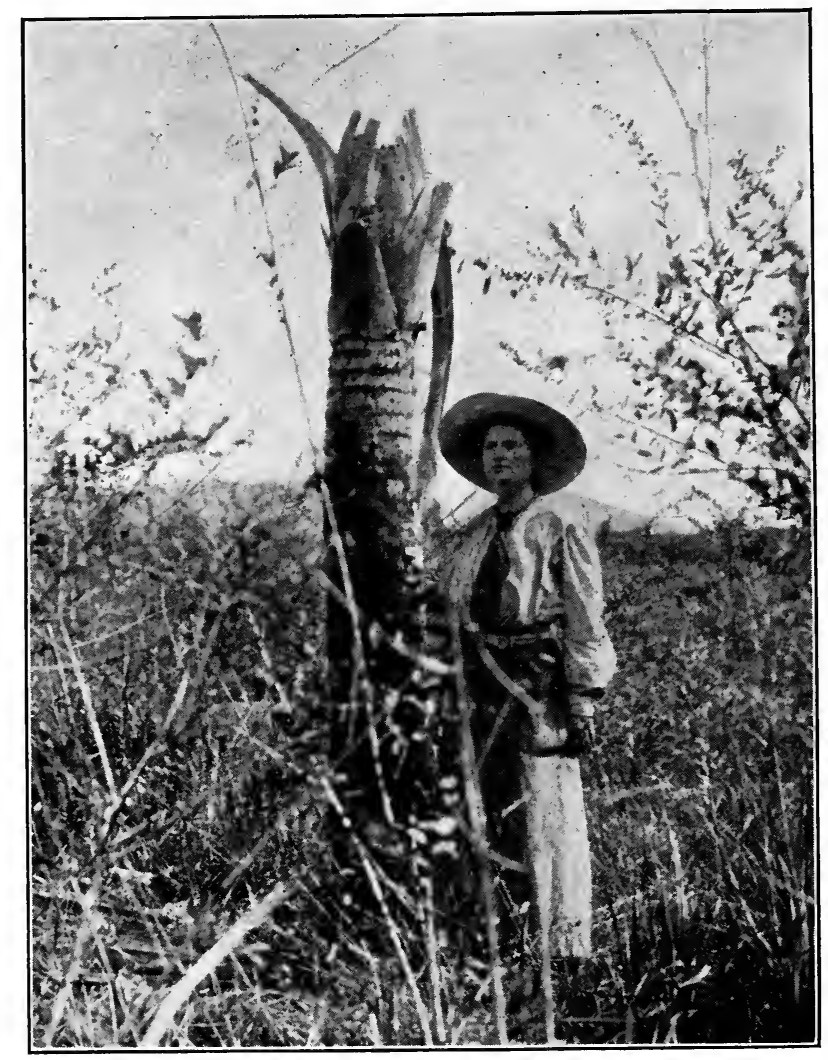

Fig. 33. The Home of the Amazon Parrot in the Middle of Pitch LaKe.

perches on some great frond of a tall palm. It is a Whiteheaded Chimachima Hawk ${ }^{56}$ with plumage of white, save for back, wings, and tail.

The two most abundant small birds are chicfly white in 
color. Both are Flycatchers, one with white head and neck - White-headed Marsh Flycatcher ${ }^{98}$ - perching in the reeds and making fierce sallies after passing insects, while even more beautiful and conspicuous are the little terrestrial Flycatchers - White-shouldered Ground Flycatchers ${ }^{97}$ or "Cotton Birds" - which scurry along the ground over
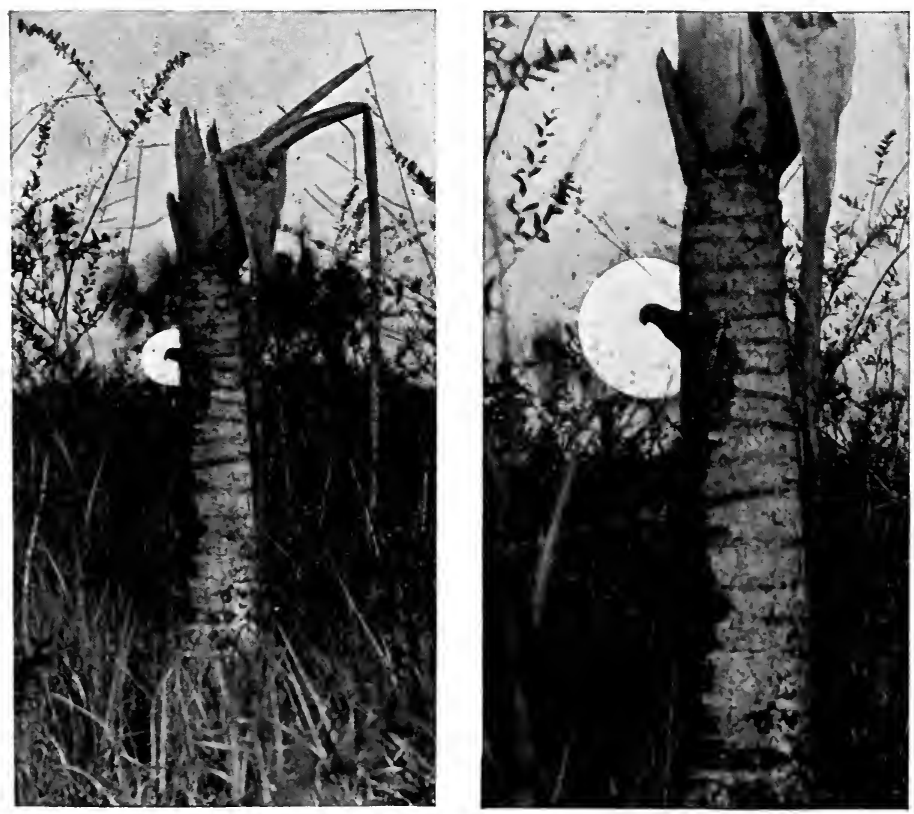

Amazon Parrot at Entrance of Nest.

Fig. 34. Fifteen feet aivay.

Fig. 35. TEN FEET AWAY.

pitch and fallen logs. Their tails continually wag from side to side, and they come within a few feet of us, uttering low inquiring notes: pit! pit! 'They too are clad in white, except for back, nape, wings, and tail.

We follow one about, watching it through the groundglass of the camera, when we blunder into a thicket of dry, 
crackling twigs. A sudden rustling sound draws our attention, and we look up and find ourselves within a few feet of a dry palm stub. Around the roughened stringy bark peers a green head with wide, yellow eyes, and we stiffen into immobility. The position is anything but comfortable; thorns are scratching us, flies are tickling our faces, but we

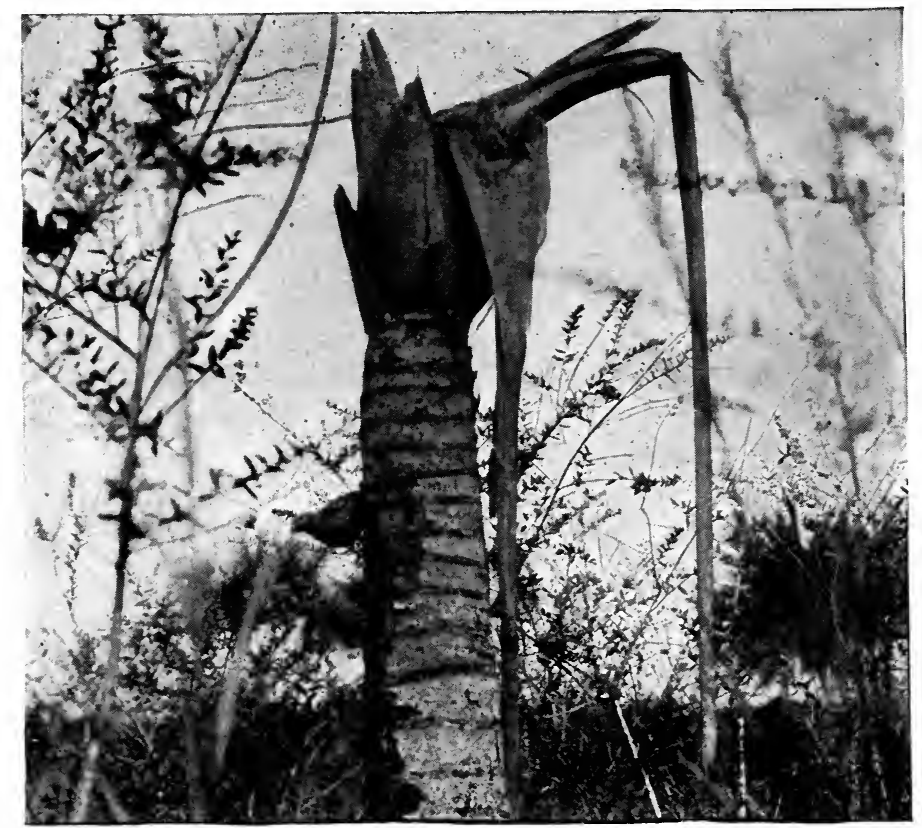

Fig. 36. Amazon Parrot about to take Flight.

dare not move. After five minutes, which seem hours, the big Yellow-fronted Amazon Parrot ${ }^{64}$ withdraws, and we hear a scuttling within the stub. Silently and with the greatest caution we step backward, and after a rest we arrange our plan of attack.

These birds usually nest in hollows in the tops of the tallest, most inaccessible trees, and this is a golden opportunity 
- one in a lifetime - for a photograph of a Parrot at home.

The entrance is rectangular, about three by six inches, and some five feet above the ground. Painfully I pick my way to the side of the stub, and bracing myself, focus on that spot

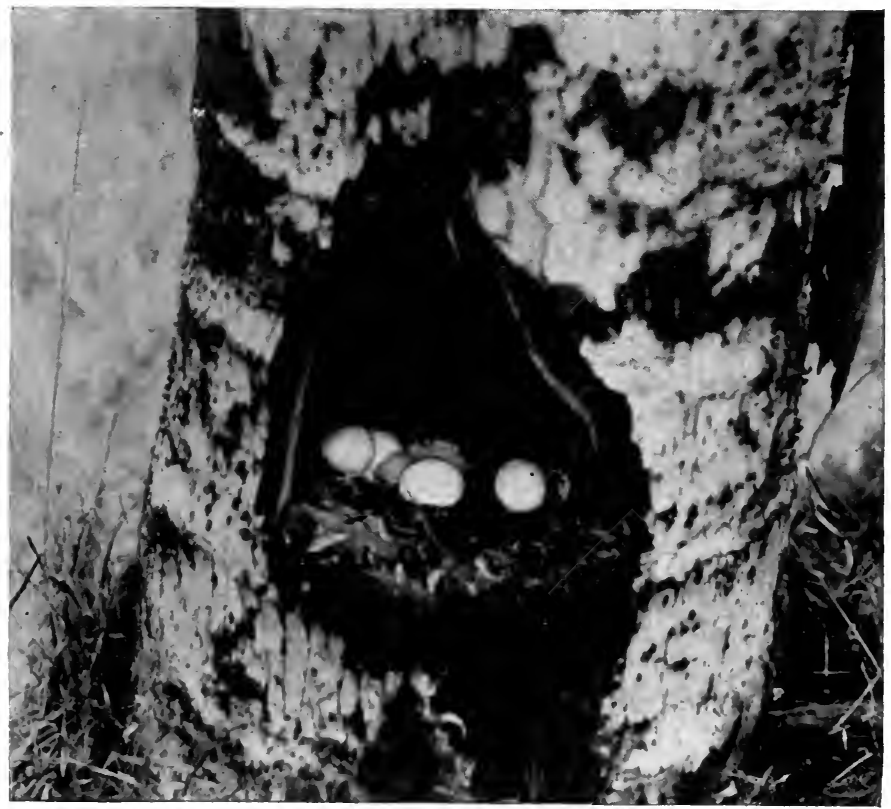

Fig. 37. Eggs and Young of Amazon Parrot in the Nest.

of black on the trunk. Then Milady rustles the weeds in the rear of the stub. Again a rustling, and on the ground-glass of my Graflex flashes the green head. Snap! I have her! and with the slowest of motions I change plates. While she is engrossed with the disturber in the rear I advance a step and get another picture. Then screwing up my speed-button, I push slowly forward, and just as she is about to hurl herself 
from the stub I secure a third photograph. Off she goes to the nearest palms, shrieking at the top of her lungs, and is joined by her mate.

We cut a hole in the trunk near the ground, and there find the nest of the parrot. Three white eggs, one of which is pipped, and a young bird just hatched reward us, all resting on a bed of chips. The diminutive polly is scantily clothed with white down, and while in the shade lies motionless. When a ray of warm sunlight strikes it the little fellow becomes uneasy and crawls and tumbles about until it escapes from the unwelcome heat. During its activity it keeps up a continuous, low, raucous cry like the mew of a catbird. Far out on the expanse of black pitch - six feet in the depth of this dark cavity! - this little squawking mite surely had a strange babyhood to fit it for its future life in the sunlight among the palms.

It was the Yellow-fronted Amazon Parrot, ${ }^{64}$ a common species with dealers everywhere, but we shall never see one in a cage, uttering inane requests for crackers, without thinking of the interesting family we discovered at the pitch lake.

We found strange fish in the pools of water scattered over the lake. Some must have wriggled their way over dry land for some distance to get there. There were round, sunfishlike fellows (Aequidens) and others, long and slender, with wicked-looking teeth (Hoplias malabaricus). Most curious of all were the Loricates or armored catfish, with a double row of large overlapping scales enclosing their body from head to tail. Like the Hoatzins among the birds, these fish are strange relics of the past, preserved almost unchanged from the ancient fossil Devonian forms.

Days passed like hours in this wonderland, and the time for returning to civilization came all too soon. The strange living beings which filled jungle and air and water, 
THE LAKE OF PITCH.

Fish from the Pools in Pitch Lake.

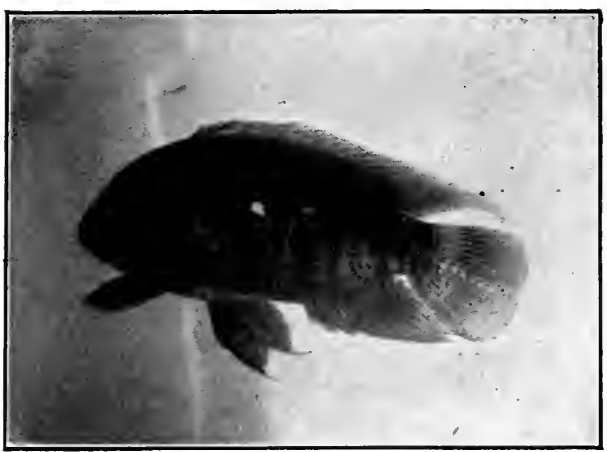

FIG. 38 . Aequidens sp.

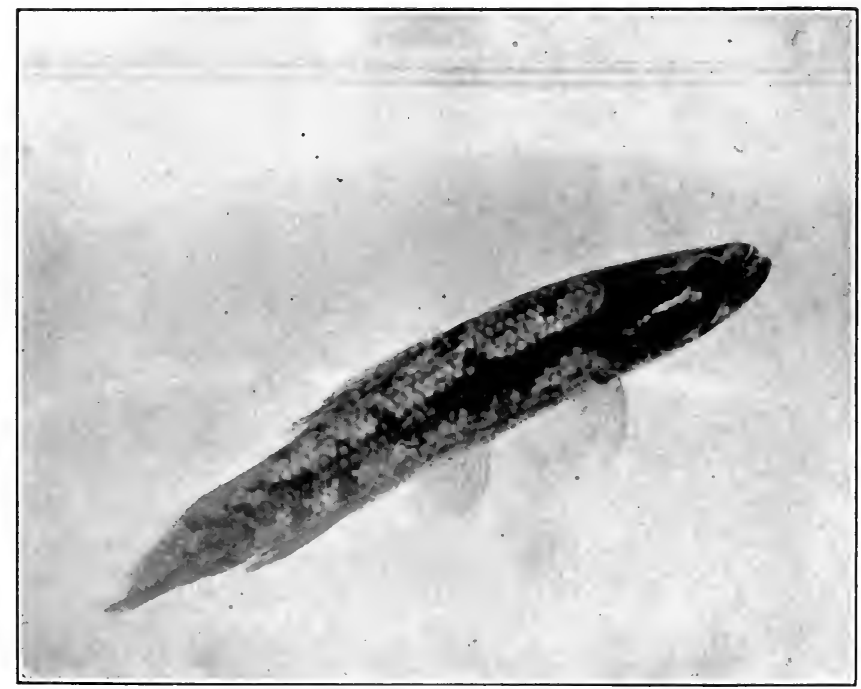

FIG. 39. Hoplias malabaricus. 
made us long for the leisure of months instead of weeks, in which to study all the infinite variety of life which surrounded us.

Our last view of Venezuela was like the first - a panorama of silent, majestic green walls, guarding a stream of brilliant copper; every one of the untold myriads of beating hearts beyond the walls resting silent in the noonday heat, waiting for the coolness of evening to awaken them to activity. To some it would bring song and happiness with nest and mate, to some combat, to others death. 


\section{CHAPTER III.}

\section{A WOMAN'S EXPERIENCES IN VENEZUELA.}

\section{(By Mary Blair Beebe.)}

$T^{H E}$ doings of the creatures in fur, feathers and scales 1 kept us keenly interested from morning to night, yet in our wilderness search there were many unnatural history experiences - some disagreeable, others thrilling - but all so wholly delightful in their charm of strangeness to the woman who enjoyed them that the picture of our wilderness seems incomplete without them.

Life on board a Venezuelan sloop is quite unlike any other experience in the world. Neither the woman who sits under the awning of a luxurious yacht nor her more adventurous sister who sails her own catboat over turbulent waters can form any idea of the daily life aboard such a craft.

The night we set forth in our tiny sloop from the Island of Trinidad, headed for an unexplored part of the Orinoco delta, it was hard to realize that we were at last bound for South America, the land of our dreams. As you know we were, for the present, owners of a sloop flying the Venezuelan flag and manned by five men, of whom only the Captain knew a word of English. The charm of exploration and adventure laid a spell upon us both - El Señor Naturalista and me-and we watched in silence the sunset sky and the dim receding shores of Trinidad.

But there was a certain stern reality about that first night aboard the "Josefa Jacinta" that soon broke in upon our reveries. When we descended to the tiny cabin to unpack, 
the sloop had begun to pitch heavily and we set ourselves to solve the problems of unstable equilibrium, which constantly shifting angles of $30^{\circ}$ to $40^{\circ}$ presented in both floor and walls. By courtesy we called our domicile a cabin, and we found that it would hold two people - at a pinch!

We unearthed our unused pneumatic mattresses and rigged up our gilded foot pump. For fifteen minutes W-

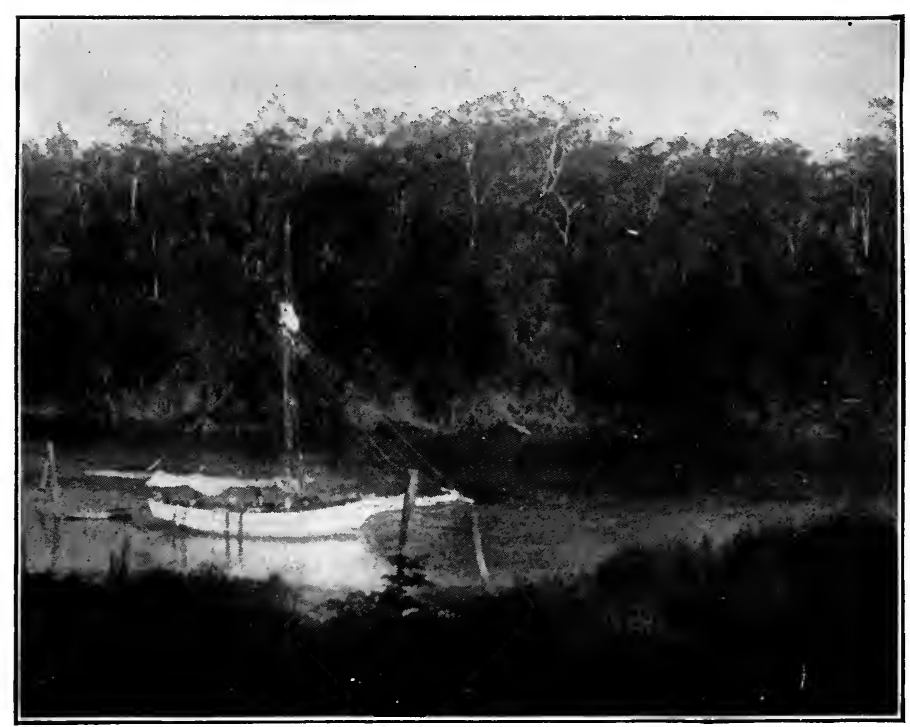

Fig. 40. Our Sloop at Guanoco.

worked, then the mate was called and took a hand. Were we on a sinking ship and manning the pumps for our lives, greater exertions could not have been made, and the reward was a thin film of air within the rubber bed. Then we unscrewed the decorative but useless contrivance, and Wbegan to blow. This proved effective, and in a few minutes we had placed the soft, air-filled cushions in our respective bunks. We dubbed these bunks catacombs at once, for the 
tiny niches into which we later crept were more like the vaults of a tomb than aught else.

I doubt if either of us will ever forget that first night. Beneath the flooring and behind the planked sides of the vessel was a mysterious underworld, densely populated by rats of most sportive disposition. How they managed to live there we never discovered, for we neither caught sight of one throughout the voyage, nor were we ever troubled by raids on biscuits or other edibles.

There seemed to be some kind of a running track extending around the hidden depths of the sloop. A race would start near the stern, the contestants tearing around W_-'s bunk; then the footfalls would die out toward the bow to become audible almost at once on my side - a medley of sound indicating a mob of invisible rushing creatures, galloping down a mysterious homestretch. For some time we expected the goal of each race to be some part of ourselves or our luggage, but the "heat" would invariably end on the under side of the partition within a few inches of my ear, and then would follow a general mêlée and fight, punctuated with shrill squeaks and squeals and vicious blows and sounds of tumbling, rolling bodies. Were we in the mood we might have learned much of rat vocabulary. But we did not then know that these strenuous rodents never penetrated to the upper portions of the sloop and this uncertainty kept alive our interest in their manœuvers throughout the night.

Silence was unknown during this first night, and while the rats were resting, other things occupied our minds and kept away ennui - and sleep. The gurgle and splash of bilge water was a steady accompaniment of the pitch and toss of the sloop, while now and then a sinister trickling came to our ears. We called up to the captain and inquired about it, and were assured that it was "only a leak!" He had looked for it many times, but could not locate it. This gave us food for thought, 
besides adding decidedly to the slowness of the ticking of the watch marking the passage of the hours of darkness. I lay in my berth as long as I could endure it; dreaming now and then of being buried alive, then rising with a start and striking my head against the coffin lid of my catacomb. At last I abandoned it for the floor of the cabin, sloping and under five feet in total length though it was. I found it was better to be huddled in a forlorn little bundle on the floor than in that hole which by no stretch of the imagination could be called a berth.

Overhead the crew worked fitfully all night long. I could move the hatch curtain, look up and see the sturdy old Captain with his hand on the rudder - a picture which was to become familiar to us through many nights. What a picturesque old figure he was - rugged and stern, yet as gentle and courteous as any gentleman of the old schooland bearing his three-score and eight years with wonderful vigor. Now and then his deep voice would rise above the roar of wind and waves in hoarse commands in Spanish to the crew. Then he would push the rudder hard up, the boom would swing over with a jerk which made the whole sloop tremble and a wave would wash over the deck and send a trickle of cold drops down upon my face. Smothered exclamations from the crew and the sound of their bare feet splashing along the deck would end the audible part of the manœuvre. Then I would shift to meet the new angle of the floor and wait for the next race of the rats.

Now and then the Captain would reach behind the hatch curtain for his watch and examine its dripping face by the light of the candle in the compass box. "Faltan las cinco a la una," he would mutter, and I knew that midnight had passed and that somewhere in our wake, morning was on its way to end this night of nights. The tempest increased and tossed our sloop like a flying leaf. Sometimes it seemed as 
if we never would right ourselves after heeling far over into the depths. But the calm face of our helmsman dispelled all uneasiness, and I lay staring into the darkness, feeling myself the veriest atom amid this fierce tumult.

To this moment I cannot tell how long it took us to get from Trinidad to Venezuela across that awful Gulf of Paria. To me it seemed an endless space of time-day succeeding night - with choppy seas, ominous noises in the pitching cabin, hot sleepy hours on deck in the shade of the sail, with the great green waves forever rolling after and breaking partly over us. By the Captain's reckoning, however, it was the noon of only the second day which revealed the distant shore, and soon we forgot all the discomforts of the past hours in the wonderful beauty of the scene before us - the still, brassy waters and the rich green mangroves.

Entering the wide Caño San Juan we dropped anchor in the lee of a solitary guard ship, a poor derelict, a rusty and worn-out freighter, whose last days were to be spent here in the calm waters at the edge of the mangrove forest. Our little sloop was soon over-run with young custom-house officials from the guard ship, curious but courteous, and far more appreciative of the stiff rounds of rum which our Captain willingly served to them under our direction, than of our gilt-sealed letters of introduction.

If we would but take their photographs on board the "Pontón," they would row us close along the shore while we waited for the "fulling tide," as the Captain called it. Of course we agreed. Shouldering their rusty muskets they stood in a row to be photographed, - young inexperienced boys, whose idle days on the derelict were spent in drinking, smoking cigarettes and lying in hammocks playing the mandolin, watching for the rare sloop or schooner which might enter Venezuela by this desolate and unfrequented caño.

We promised to send them the pictures; but Captain Trux- 
illo said afterwards with a sad shake of his head that they would have lost their positions long before the pictures could reach them. No one ever stayed long; there was always someone to carry reports to Castro of treachery and plotting, and there would be new faces on the "Pontón," to stay a little while and then to disappear like their predecessors.

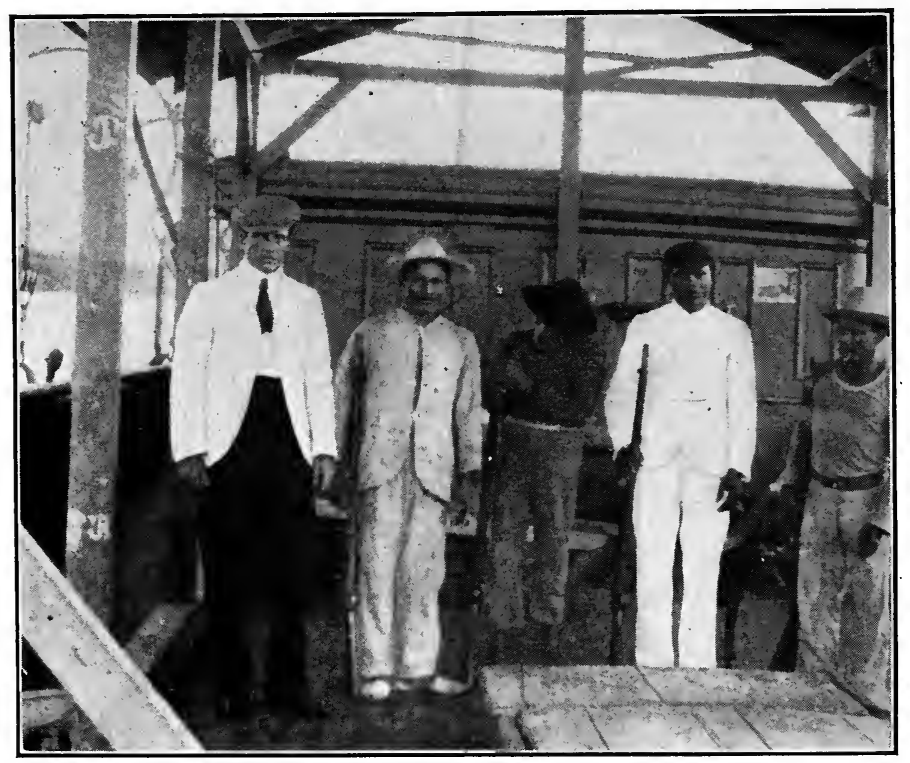

Fig. 4t. Venezuelan Soldiers on the "Pontón" Guard Ship.

Now for many days the sloop was our home, and the innumerable gleaming caños of the delta our highways. By day we explored the mangroves in our curiara or dug-out, and by night we slept the dreamless sleep of healthful outdoor life, safe from the persecution of the humming Anopheles outside our netting on the after deck. When midday heat or sudden rain drove the wild creatures from our view I studied our motley crew and found them a never-failing source of entertainment. 
The tally of the crew must begin with Filo, the mate, a huge black creole, speaking Spanish besides his own strange vernacular; then there were two sailors from the Island of Margarita, and Antonio, cook by profession, admitting some Dutch blood, but of unknown extraction and decidedly uncertain disposition. The cook on board a Venezuelan craft is always given the respectful title of Maestro ( $\mathrm{Mai}^{\prime}$ stro), so Maestro he always was to us. Maestro as an individual was an interesting psychological study. Although he probably never heard of such a thing as a labor union, yet he was the embodied spirit of one. He declared, in terms that left no possibility of misunderstanding, that he was cook, not sailor, and that he would do nothing but cook. He would cook cheerfully over a stove that smoked like Dante's Inferno, but when called upon in an emergency to help hoist a sail, he would fly into a violent torrent of angry Spanish. Later when the temper had spent itself he would often go and do what was asked of him. I have seen many high tempers, but never one that quite equalled Maestro's. There were times when he would draw his huge cutlass or machete on the Captain. For a long time these were all false alarms, but at last Maestro threatened once too often and so seriously that he was discharged on the spot, and left marooned in a little Indian village with no means of returning to Trinidad. But this was at the end of our voyage.

Maestro in his patched and faded shirt, with sleeves rolled to the elbow, still more patched trousers rolled to the knee, bare as to feet, a crownless hat on one side of his head, an ancient and odoriferous pipe hanging from his mouth, a big machete at his side, in the capacity of cook would make the most shiftless housekeeper gasp with horror. I often wondered why he so persistently declared himself cocinero, not marinero, for he could hardly have been a greater failure in any calling than he was in that of chef. Among the most valued 
of my memories are some mental pictures of Maestro, which, while I live, I can never manage to forget.

I often shut my eyes and see him with streaming eyes stirring some fearful concoction over the little stove; or again on his knees mixing dough for the leaden dumplings to be boiled in the pig-tail stew which appeared at every meal. We so often wished we had brought graham flour. White flour does show the dirt so! Still another picture is Maestro

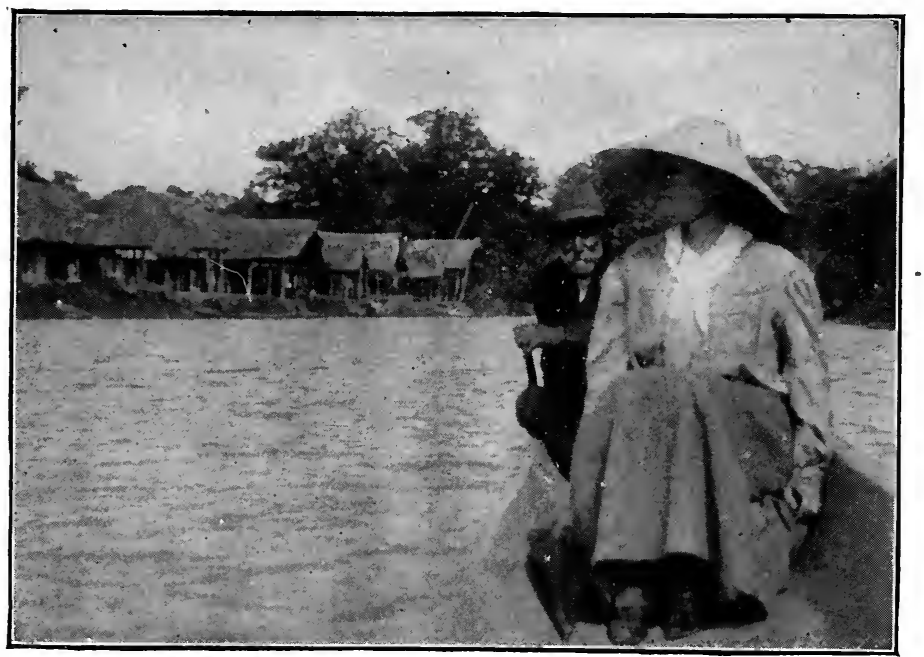

Fig. 42 Captain Truxillo padding us up the Guarapiche past Caño Colorado.

washing the table-cloth. This was a piece of oilcloth, originally white, and Maestro's method of washing it was to spread it on the deck, pour water over it, dance upon it in his bare feet, to the accompaniment of some weird chant, and finally hang it on the rail to dry! No doubt after this proceeding he felt as self satisfied as the most pompous and well-trained English butler.

In justice, I must say that Maestro did make one or two 
edible dishes; he could boil the native vegetables, yam, tania and kuch-kuch and he made very good cornmeal mush. Then after a long, happy day on the caños we were always hungry, and happiness and honest hunger overlook a multitude of sins. Besides, whatever was lacking in Maestro's bill of fare was compensated by the dried soups, cocoa, crackers and preserves from our own stores. So we managed one way or another to keep the wolf from the door, or perhaps more appropriately I should say, the crocodile from the companionway.

As in two weeks the crew had consumed provisions planned by the Captain to last a month, the Captain purchased a hundred pounds of beef from a dug-out full of Indians which passed us one day on the river. This Maestro salted plentifully and then hung up in the sun to cure. Long strips of it were suspended from the rigging, from the boom, and over the railing, and whole entomological collections buzzed noisily about them. For a few days we felt as though we were living in a butcher's shop; and a butcher's shop in a tropical climate is a thing to be avoided. At first we were inclined to resent this impromptu meat market. It was not only disagreeable but it was in the way. Then came the thought - suppose it were fish; and we were so grateful to be spared that, that we cheerfully submitted to a sloop draped with strips of meat, as a house is festooned with smilax at Christmas. As long as the larder was low the Captain had known no peace of mind for fear his crew would desert us and the sloop. So the purchase of such a delicacy as meat was a successful piece of strategy.

With all their faults, there is among the Venezuelans, as among the Mexicans, a certain chivalry toward women; and so I never felt the least alarm at being left alone on the sloop with the crew, while the Captain and my husband went off up the river. 'The great dusky Creole mate would put my 
stool in a shady spot, and, figuratively, lay himself at my feet to serve me, and Maestro - even pugnacious Maestrowould weave wonderful baskets for me of the roots of the mangrove; baskets in nests of twelve, each fitting snugly within the other and all gayly dyed with the Venezuelan colors, the

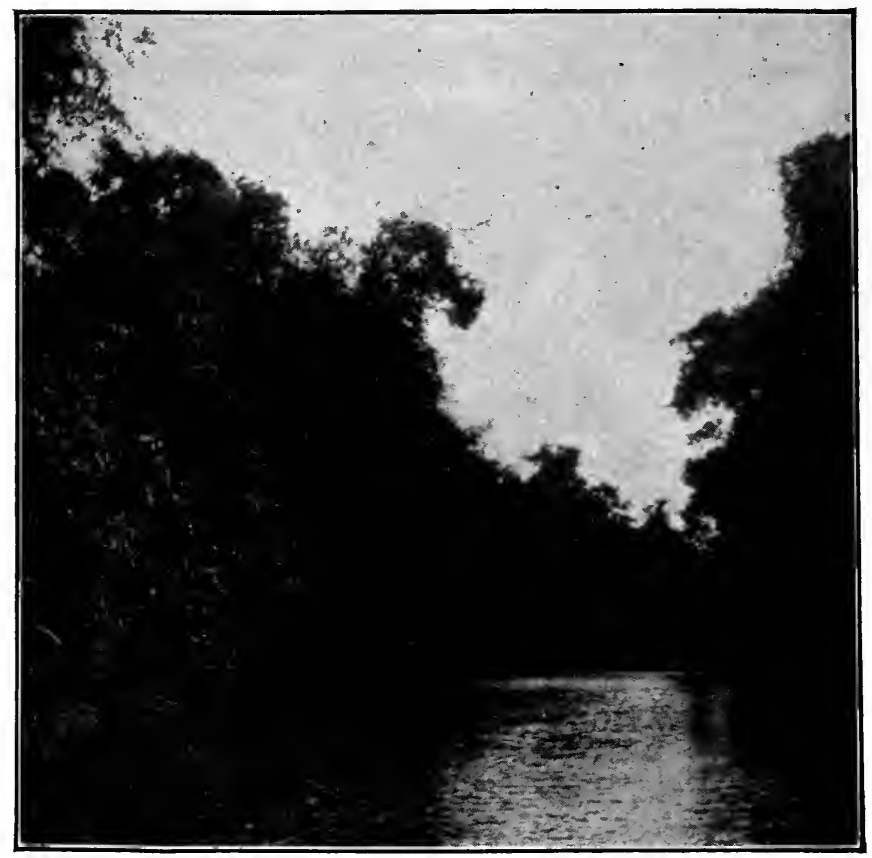

Fig. 43. Sunset in the Mangrove Wilderness.

pigments being extracted from the leaves or stems of unknown wild plants.

The time passed all too quickly with each day spent on the Guarapiche river - a gleaming stage, with a setting of green trees, brilliant flowers and fragrant orchids, and an everchanging plot with ever-changing actors. Of them all, man was the least important. There were populous villages of 


\section{A WOMAN'S EXPERIENCES IN VENEZUELA. 8I}

Hoatzins and great wandering tribes of Scarlet Ibises and Plovers; Herons, much occupied with their unsocial and taciturn calling as fishermen, stood silent and solitary in secluded pools. With all this wild life the river teemed. It was only with the rising and falling of the tide that man entered upon the scene; and so quietly, so much a part of

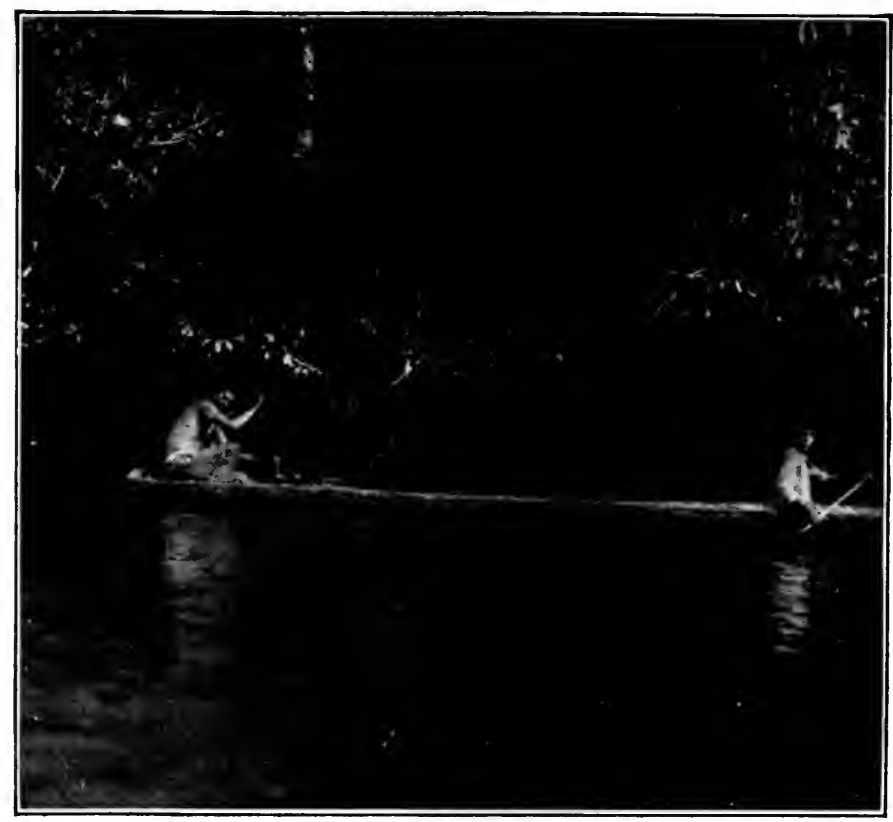

Fig. 44. The Silent Savages.

nature, that one hardly felt any difference between him and the forest folk. In a silently, swiftly moving curiara he woukl glide under the shadows of the overhanging mangroves. Sometimes the curiara would be a merchant ressel, laden with ollas, fruit, etc., with its destination Maturin, many miles away in the interior. Again its only occupant was a fisherman, as silent as the Herons themselves. Like a Heron 
also he would station himself near a shady pool, and sit all day, motionless save for the changing of bait or the pulling in of a fish. With the turning of the tide the line would be drawn up, the fish covered with cool green leaves and the curiara would move away, the bronze figure of its owner skilfully guiding it up the winding river.

Occasionally the fisherman was accompanied by his squaw, hardly to be distinguished from him, and in the bow there was often the little naked figure of a child playing with a mite of a tame monkey, or both sound asleep with their arms wrapped about each other. All that these simple folk ask of life is one fish to eat, another with which to buy cassava and a yard of cotton cloth.

In the brief tropical twilight we would hastily make preparations for the night, spreading our air-beds on deck, hanging over them a white mosquito canopy and putting our electric flashlight and revolver at hand. After the first two nights we had abandoned the cabin, which had added to its other discomforts the fact that all the mosquitoes of the caño had selected it as their abode. Never were nights more beautiful than those which we spent on the deck of that little sloop, and never was sleep more dreamless and peaceful.

In the darkness of early evening, before the moon rose, we would sit on deck munching sugar-cane while the Captain told us many a tale of his young days, when he was the prosperous owner of a schooner twice the size of the "Josefa Jacinta" and when smuggling brought adventure and yellow gold in abundance. He was full of legend and superstition. He told us of aged men and women, both among the Indians and the Spaniards, who he declared can by a peculiar whistle call together all the snakes in the vicinity and then by incantations so hypnotize them that they can he handled with impunity. The owner of a hacienda will sometimes employ one of these charmers to call together the snakes, which can 
A WOMAN'S EXPERIENCES IN VENEZUELA. 83

then be killed. The performers themselves, however, will never harm a snake. He told many a story of black magic arts, in which he firmly believed, of sending to one's enemies scourges of rats or deadly diseases or departed spirits to make life unendurable.

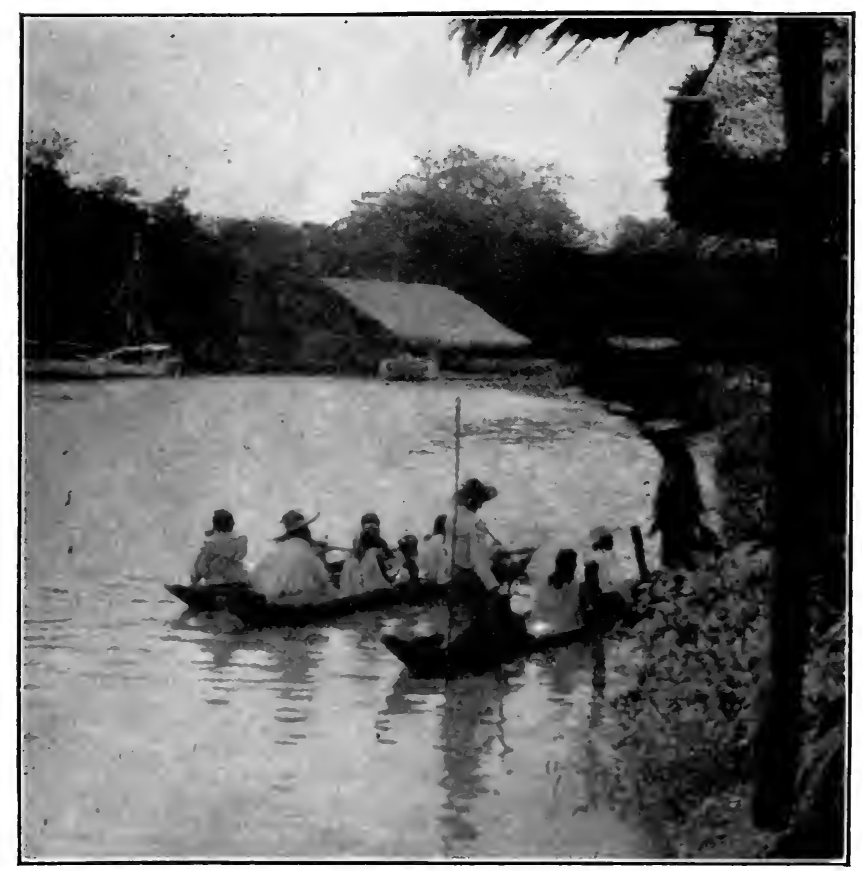

Fig. 45. Guarauno Indians coming to trade at Caño Colorado.

Finally the crew would roll up in their blankets in the bow, the Captain would disappear beneath his mosquitaro, which would tremble and quake in the moonlight until he lay quiet in his hammock. We would creep beneath our tent of netting to write up the last notes of the day or to listen to the sounds of the night. From the bow would come a low murmur of voices in some weird chanting song until the 
Captain roared out for all hands to go to sleep. But he would not practice what he preached for he always talked himself to sleep, sometimes in English, or in Spanish or again in Creole, while now and then he would mingle all three.

By day one would not have suspected Filo, the mate, of being a person of romance; but under the spell of the tropical moonlight he would often tell stories to the crew; stories in which the heroine was always "Muy preciosa, muy joven, muy linda," - very charming, very young and very beautiful. She would set difficult tasks for her many lovers, and her favored suitor would be the one who most bravely bore himself under the tests. I remember one tale to which the crew listened with awe; in which one of the lovers was to lie all night in the cathedral, stiff and still like a corpse; another was to go to the same cathedral on the same night dressed in winding sheets like a ghost; another was to represent the angel of death, while a fourth impersonated the devil; and a fifth was sent as an ordinary man. Of course none of them were to know of the others having been sent by the fair heroine of the story; and of course the fortunate lover was the one who showed no terror and passed the night quietly in the church, returning in the morning to claim his bride.

The story had its dramatic situations and Filo made the most of them. Even Maestro was moved to utter a low "Dios mio!" at the description of the entrance of the ghost, the angel of death and finally the devil; at which the poor corpse, who had been shaking with fear through it all, started up and fled in terror.

Filo's story lost nothing in his telling and the superstitious crew went very soberly to rest that night. W-_ and I lay, as we so often did, staring wonderingly out into the night, - the marvellous tropical night.

It was all like a dream; the shining water of the caño, the deep, mysterious forest growing down to the water's edge, the 
cries of unknown birds and beasts, the impressive southern cross and the extraordinary brilliancy of the moonlight shining down upon the tiny deck of the "Josefa Jacinta," and upon us and the sleeping forms of its dusky crew.

We were sometimes awakened in the night by a sudden bright light in our faces. It was Maestro making a fire, in

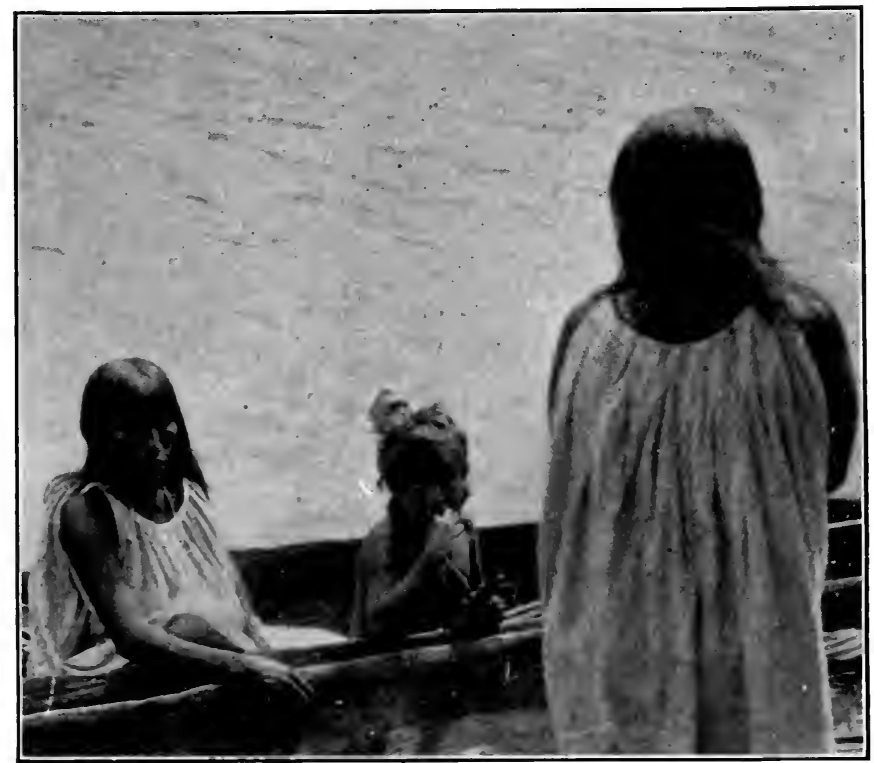

Fig. 46. Guarauno Squaws and Child with Monkey.

which operation he used alarming quantities of kerosene, to prepare the midnight repast for the crew, who whenever they woke in the night would call loudly "Maestro-café!"

Again the sound of an unusually heavy downpour of tropical rain on the tarpaulin overhead would waken us, and I would occasionally discover that my feet were in a puddle of water. A shifting of beds to prevent our being drowned while we slept would invariably result in our feet being 
higher than our heads, and because of the horde of mosquitoes which found their way in while the beds were being moved, the rest of that night would be sleepless.

With the dawn came the roar of the howling monkeys; a dainty Tigana $^{24}$ picked its way among the mud-flats; a flock of Hervidores ${ }^{80}$ - which being translated means "boilers," an appellation perhaps suggested by the notes of these black Cuckoos - bubbled away as cheerily as a bright kettle on a breakfast table. And with these sounds of the dawn all our troubles of the night were forgotten.

After weeks of solitude in the mangrove jungles our prow was headed inland and a long night of silent drifting with the tide brought us to the mouth of the Guanoco River. Here the Captain and the unruly crew at dawn had their usual heated argument as to the management of the boat, with the result that they nearly ran her aground - one of the many narrow escapes which had happened so often as to create but little interest on our part.

Guanoco was a river of bends, around each one of which the Captain assured us we would see the village. But it was twilight before we turned the final bend and saw picturesque Guanoco at the hour of vespertino - a hill rising steep and blue, with the silvery river at its foot and a cluster of little thatched huts perched one above another on the hillside.

It was delightful to feel solid ground under one's feet again and we could hardly get over our accustomed walk of "three steps and over-board."

Here in our wilderness we found an unexpected home. Through the kindness of our cordial friends in Trinidad Mr. Eugene André and Mr. Ellis Grell - we had letters to the men in charge of the pitch lake at Guanoco and it was to this great lake that the tiny settlement of Guanoco owed its being.

As soon as we reached the wharf, a young Venezuelan 
came on board, introducing himself as Señor Bernardo Lugo y Escobar, - one of the officials of the Pitch Lake Company, and explaining that Mr. Grell had written him that we might possibly come to Guanoco and that we were to be entertained at the headquarters for as long as we chose to stay. Mr. Lugo was most urgent in his hospitality and I. knew well of what the sloop dinner would consist. Maestro and I would hold a perfectly futile consultation in which we would decide upon the only possible menu-funche (which is the Venezuelan name for cornmeal mush), dried pea soup and cocoa. I must explain that the lack of variety in our larder was due to the fact that we had expected to be able to supplement our canned goods with fresh fish and game, both of which proved difficult to obtain, the latter because of the impossibility in this vast swamp of ever finding the game after it was shot. The experience taught us the useful lesson which every camper and explorer learns sooner or later, sometimes alas! too late - never to depend upon the game of the country, but always to plan your provisions as if game did not exist. Then when one gets it, it comes as an unexpected luxury.

But to return to my visions of a good dinner in the preparation of which I had no part or responsibility. Perhaps there would also be the luxury of a real bath. I was roused from these attractive reflections by the voice of the Captain politely refusing Mr. Lugo's invitation for the night, and saying that we would not go ashore until the next day. Whereupon I diplomatically remarked in English, - that Mr. Lugo might not understand, - that I thought Mr. Lugo's feelings would be hurt if we refused, and as long as we were to go the next day and there was nothing to be gained by spending the night on the sloop, why not gratify him by going at once.

And so it came about that in a few minutes more we were at "Headquarters." As the house was quite invisible from the 
water, we had imagined that we were to go to one of the thatched huts which we had seen from the river.

To our surprise, around the base of the hill we found ourselves going up a pretty palm bordered walk which led to a low, massive, fort-like building.

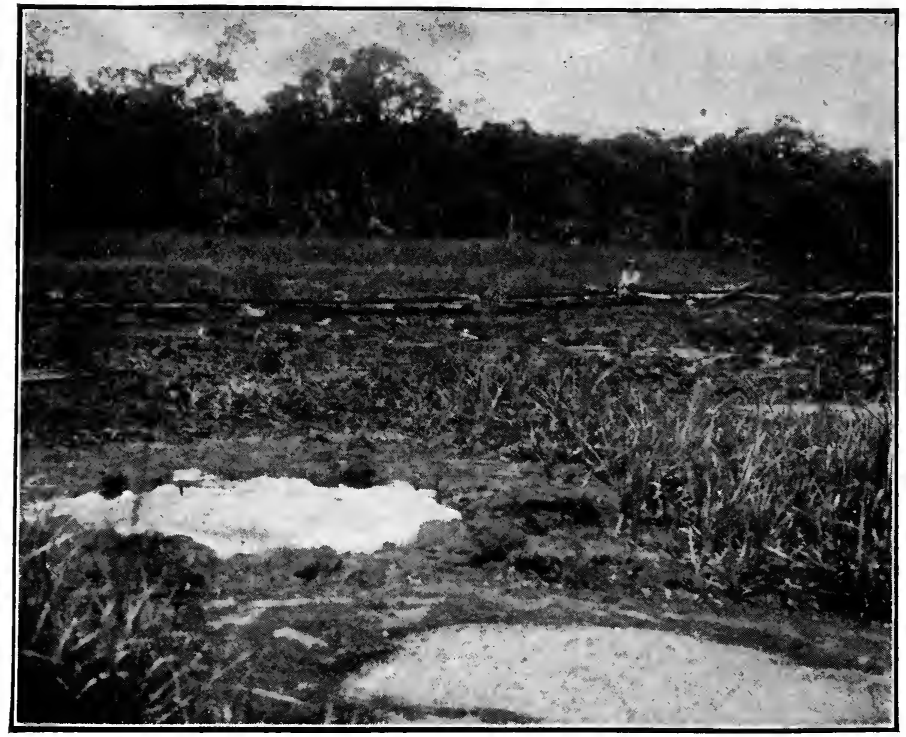

Fig. 47. Pitch Lake, Showing freshly dug pit filled with Water; AN OLDER PIT FILLED WITH SOFT PITCH, BOTH SURROUNDED BY THE HARD SURFACE PITCH.

In the broad open hall were comfortable rocking chairs, in striking contrast to the sloop on which we had taken turns sitting on the one stool which the little craft possessed. In the patio was a table laid for dinner - with a big black Trinidad negro bringing in steaming dishes.

There is no hospitality anywhere quite equal to that of the wilderness. Your host does not arrange your visit from the Saturday to the Monday, fitting you in between a multitude 
of other engagements. A wilderness welcome is as genial and inevitable as the tropical sunshine. Your visit is an event a mile-stone in the long road of lonely months of exile months which sometimes lengthen into years. Our very interesting friend Mr. Eugene André of Trinidad told us that on one of his many orchid-hunting expeditions he had chanced to land at a certain God-forsaken little port on the west coast of Colombia. Mr. André had wondered why the fare to this port from Panama should be $\$ 30$ - while the return passage was \$Ioo. The problem was solved after he had seen the port - desolate, barren, inaccessible and fever and insect ridden - one might be induced to pay $\$ 30$ to get there provided one knew not what manner of place it was. But to get away - one would pay any sum and gladly. So it is that the little coastwise steamboat company calmly demands \$roo to return the unfortunate traveller to Panama - and gets it.

At this forlorn spot there were stationed two young men, I forget now in what capacity, who for many months had not seen an intelligent human being. Into the empty monotony of their lives, Mr. André appeared. It mattered not to those lonely young men who he was, nor where he came from. His welcome was - "Stay with us. Stay a year - or ten years. We know all about each other. We've talked about everything until there is nothing left to say - we even know how much sugar we each like in our tea and who our great grandmothers were, and who we think wrote Shakespeare's plays; - and we are so bored and so glad to see a new face."

Thus it is that everywhere in the South American wilderness the English-speaking stranger is made welcome by his kind, and we found Guanoco no exception to this rule.

The pretty Spanish greeting is - "The house is yours" and during our stay at the Pitch Lake, the headquarters became really ours. We were given the best room; the servants 
were put at our disposal: and best of all we were perfectly free to come and go as we pleased; and with everything done to facilitate our work. All this we owed also to the instructions of Mr. Ellis Grell, who was then financing the Pitch Lake Company and to the kindness of Mr. Lynch and Mr. Stoute, two young West Indians employed by the company.

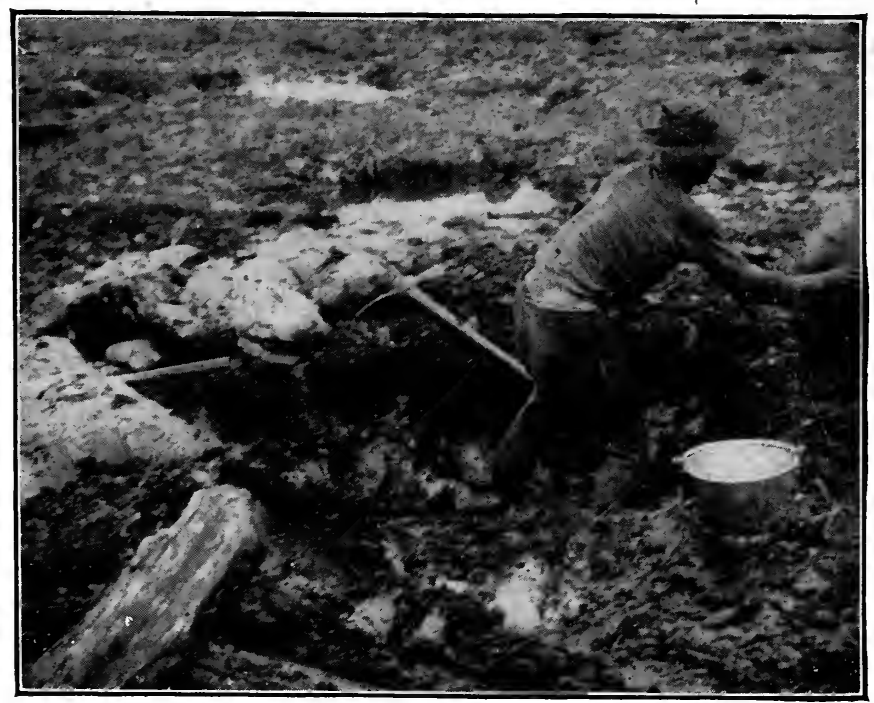

Fig. 48. Digging out the Black, Waxlike Pitch.

We were tired that first night at Guanoco. The night before had been a hard one - sailing all night long, with the boom swinging back and forth and making impossible the hanging of our mosquito nets. All through the night the Captain and his crew worked. Down the narrow river the Captain skilfully guided the sloop in the darkness of a moonless night, following the line of the trees against the sky to mark the channel. His commanding old voice rang from stern to bow, the orders being there repeated by the mate to the sailors who were towing us, and who paused in the 
wild melody which they chanted through that wonderful night, to listen and obey. It was a difficult and dangerous task the guiding of that sloop down so narrow and winding a river: and even the unruly crew were obedient that night, rendering the homage which in time of danger the ignorant unconsciously yield to a superior intelligence.

When we wondered at the Captain's confidence, he replied in his deep voice, "Ah yes! - but I am old here and I know these caños as I do my house." And indeed here the curtain had risen upon his life and here it was likely to fall at the end of the last act.

When finally quite exhausted we had laid down upon the deck to sleep, it was to fall into so profound a slumber that the mosquitoes devoured us unmolested, in spite of our head nets which proved insufficient protection.

So it was that on that first night at Guanoco we were very tired. I sat lazily rocking in the cool evening breeze, annointing my irritating bites with Tango, a preparation dependent upon faith cure for its healing properties - and listening to the desultory talk of the young men. The conversation was desultory, however, only so long as the Venezuelan element of the household was present. On this occasion that element was represented by the young Mr. Lugo who had met us at the wharf. After he had gone out on some errand the story of Pitch Lake was poured into our interested ears. It was a story of intrigue and revolution and treason quite worthy of some mediæval court. First there was the passive Venezuelan possession; then the active, enterprising, money-making reign of the North American; having as its natural result the jealousy of Castro, his oppression and injustice to the American Company; their rebellion, in which they aided a great revolution against Castro; his revenge being to seize the property and put it in charge of Venezuelans. Then came the departure of the American 
Company, which had done so much to develop the Pitch Lake, followed by the arrival of the Venezuelans appointed by the Government - men who knew just about as much about managing a great Pitch Lake as they did about guiding an aëroplane. We were told of the time long before the advent of the Lugo family - when for weeks it was necessary to live always on the alert, with revolver ever ready for defence; when the very men with whom one sat down at table were capable of attempting to poison the food, in order to free themselves of English-speaking men, who might perhaps witness some ugly deed of treachery or defalcation.

This is the very long story in a nutshell. We began then to understand why the house was so fort-like in structure. It had been built to withstand assault. Only a few months before our visit it had been attacked by a party of Revolutionists who hoped to find money in the company safe; and five men had been killed and several injured.

This thrilling tale was told in the emotionless matter-offact way in which one might describe the moves in a game of chess.

From the moment our sloop sailed out of the harbor of Port of Spain the memory of the old familiar every-day world had seemed to grow dimmer and dimmer. Was it possible that there really was such a place as New York City, with its clanging street-cars, its trains and subways and elevated roads thronged with people, en masse all as much alike as an army of ants? At that very hour the New York Theatres were pouring their gay crowds into the brilliantly lighted streets. How far away it all seemed, down there in the great primeval forest of another continent! We walked out under the stars to the edge of the forest, black and mysterious, teeming with the hidden life, which we were so eager to study. Our world, for the present, was this forest wilderness, stretching unbroken for mile upon mile, with only the 
twinkling lights of Guanoco to remind us of human habitations. I dreamed that night of being stabbed in the back by a howling monkey, while the safe of the Pitch Lake Company was broken into by a band of shrieking Macaws!

On the morning after our arrival at Guanoco we sorrowfully said good-by to the "Josefa Jacinta." As we watched her sail away we consoled ourselves by planning another and a longer trip on her - a trip which never took place. Looking back after almost two years I realize that life can bring me

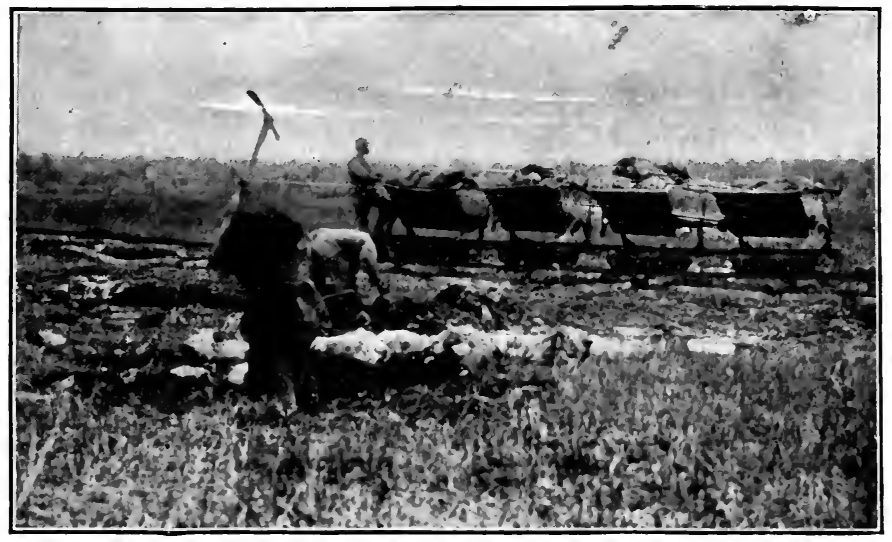

Fig. 49. Loading Pitch on the Hand Cars.

few experiences more full of interest and charm than those days on a little Venezuelan sloop exploring the mysterious untrodden mangroves! "How could you enjoy it?" I am often asked: but the trifling discomforts were all in the day's work and more than compensated by the beauty and freedom and wonder of it all. They served to make us know that it was not all a dream.

Our days at Guanoco began early and were full to overflowing of interest and of work. In the heat of midday we pressed flowers, skinned birds and wrote up our journals, 
but in spite of being so busy, we found time to get a little into the atmosphere of the human life.

Here is the daily program at the lake of pitch, - this little outpost of humanity, deep hidden in the tropical jungle. At daybreak the group of sheds and thatched huts gives up a horde of Trinidadian negroes; great black fellows, giants in strength, children in mind. Amid a perfect medley of excitement and uproar, breakfast is prepared. We hear sounds which must mean at least the violent death of several, and as one listens to the shrieks and groans, the imagination easily supplies the terrible blows and struggles. But a closer look only shows one of these great children down on his knees, calling on everything which occurs to him or enters his vision to witness that he did not steal the sixpence from Napoleon, of which some one has accused him, perhaps in jest.

Yet all this is calmness compared to the later rush for the best cars to use in the day's work. It would delight a Sophomore's heart to see the mêlée. But somehow all is straightened out and off go the hand trucks, crawling along the rickety rails out over the lake, like beads sliding along a string. Here a car has reached the end of the line. The negro selects a place fairly clear of vegetation, takes his broad adze, and shears away the upper few inches of roots and mould. Then with deep swift strokes he outlines a big chunk of the shiny black gum, cuts it loose, and carries it on his head to his car. So malleable is the pitch that by the time he has half filled the little iron truck the pitch has settled down and filled all interstices. He trundles back the car and dumps it into one of the larger wooden trucks which will take it to Guanoco. He now receives a check which is redeemable for fifteen cents and the first link in the commercialization of the pitch is finished. Along the wavering line of temporary rails over which the hand-cars are pushed back and 
A WOMAN'S EXPERIENCES IN• VENEZUELA. 95

forth, are dozens of grave-like holes. Those nearer the railroad end are smooth-edged and filled with soft pitch on which as yet no vegetation has taken root. Farther along they are filled with water, and still farther we find them in the process of being excavated.

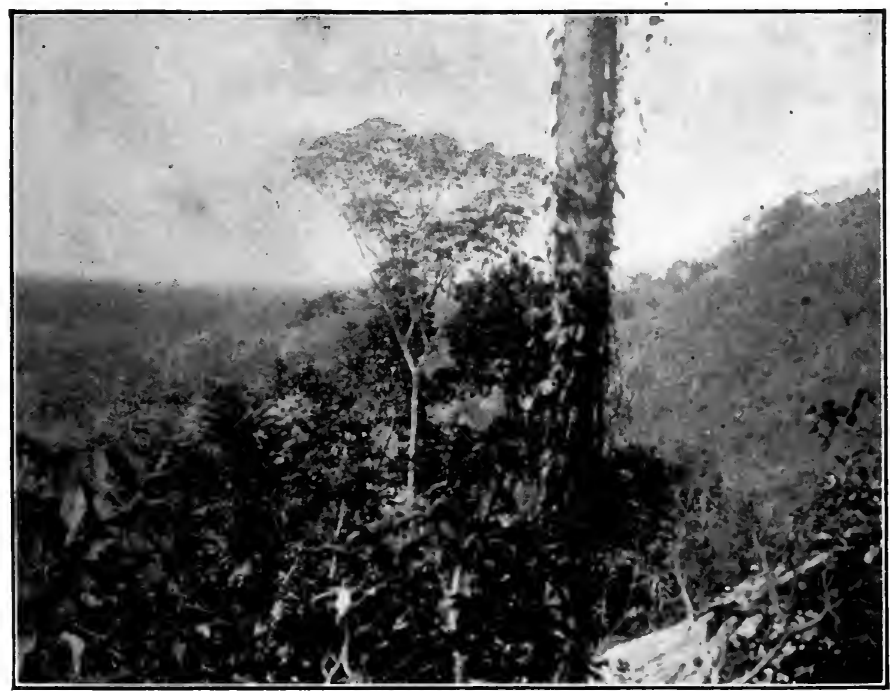

Fig. 50. Mangrove Wilderness from the High Land at Guanoco.

The men dig down until they have reached a depth of five or six feet, and then start in a new place. The hole is filled by the first rain; water-bugs fly to the little pool, frogs lay their eggs in it, queer fish wriggle their way to it and for a brief space it supports a considerable aquatic life. Then new soft pitch begins to ooze up and in a few more weeks the plug of viscid black gum has reached the level of the ground and the scar is soon healed over by a thin growth of grass.

In the rainy season the holes fill at once with water, and indeed the whole plain is immersed to the depth of 
a foot or more; then the men have to work up to their waists in water, chopping beneath the surface, prying the pieces loose with their toes and tearing the chunks off by taking long breaths and reaching far down for a few seconds at a time.

When we cross our asphalt streets and smell the tarry odor and feel its softness under a mid-summer's sun, let us think of the strange lake in the tropical wilderness.

The table talk at "Headquarters," was often most amusing. Torrents of Spanish eloquence and gesticulations kept our English ears ever on the alert to follow the meaning, and our sense of humor ever under strict control to preserve well-bred gravity when such statements were made as "Venezuela leads not only all the South American countries, but all those of North America as well, in literature, art, science and commerce. When our General Blank went to New York the greatest ovation ever paid any general in the world was given him. New York remained amazed!"

Once only did I look amused and I have never quite recovered from my mortification at thus disgracing myself. Whatever the faults of the Spaniard may be, he never smiles when he is not intended to; not even at the laughable mistakes which we foreigners make when we are learning his beautiful language. I try to say in extenuation of my unseemly mirth that the Spaniard has no sense of humor and that we should very much prefer having him laugh at our mistakes and letting us correct them. But all to no purpose. I know that I did not behave like a well conducted Venezolana, and nothing can alter that fact.

The three Venezuelans had been put in charge of the Pitch Lake, - because their "Sister's husband's niece" harl power in the court of Castro. Among their regular duties they included singing airs from the operas, reading 
A WOMAN'S EXPERIENCES IN VENEZUELA. 97

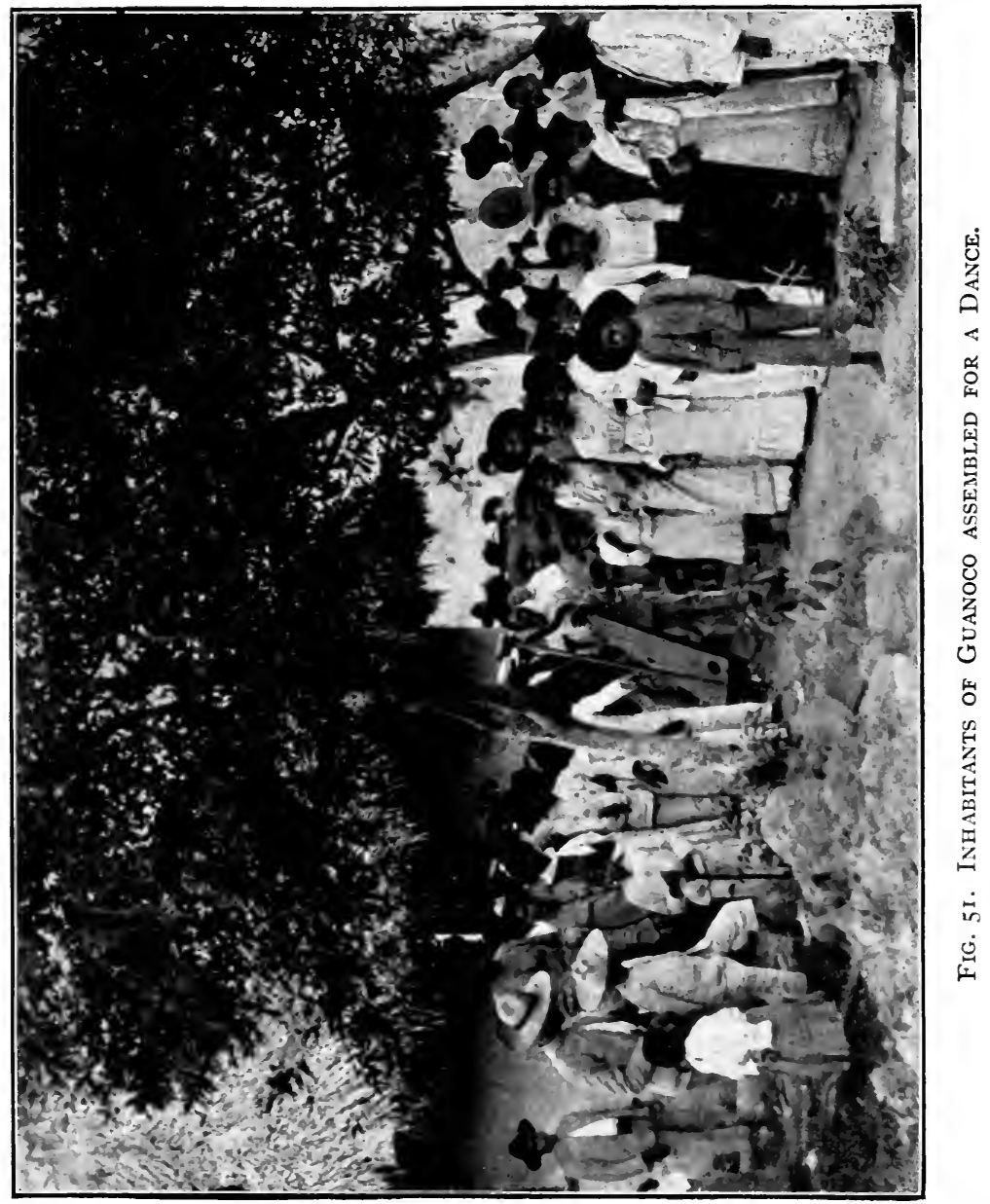


Don Quixote and the Caracas newspapers and playing dominos.

They had provided themselves with elaborate costumes for the rôle; they carried big revolvers and wore huge green and white cork helmets, khaki riding clothes, puttees, spurs, and carried riding whips. There was not a horse within fifty miles! No horse, even had there been one, could penetrate the tiny forest trails about Guanoco.

In the dancing sunlight and shadows and the orchidfragrant air it was hard to picture spilt blood and intrigue and treachery, and harder still to prophesy the sad times that were to come upon Guanoco. Yet while we were there the air teemed with revolutionary rumors. The Jefe civil, as the chief magistrate was called, was off day after day investigating first one suspicion and then another, returning utterly spent with the exhaustion of unresting days and nights upon the trail. Revolutionists had attempted to land guns on the near-by coast. There had been a skirmish and several men had been killed.

All the available guns and ammunition were gotten together and every night the doors were barred securely; for what the revolutionists chiefly needed was money, and should there be an uprising in northeastern Venezuela, the Pitch Lake headquarters would be the first point of attack. It was in charge of Castro sympathizers, there might be large sums of money in the Company's safe and it was practically unprotected.

In the meantime diplomatic relations between our United States and Venezuela had been severed and one morning a United States battleship was discovered lying quietly in the harbor of La Guayra. The numbers of la Constitucional a month old when they reached us - were beginning to talk of war and to boast of the ease with which Venezuela would erase the United States of America from the face of the globe. Bitter things were said about the sister republic in 
the north. And there we were living on the bone of contention itself.

It was about this time that I began to see the advisability of being more than ordinarily civil; and so it happened that I was led into playing cards for the first and only time for money and that on a Sunday! We had been working almost incessantly and I had begun to feel that, even if it was to Mr. Grell that we were indebted for the hospitality, it was not quite nice for us to appear only at " feeding time," particularly as our long days out of doors gave us such appalling appetites. So on this occasion when I was asked to make a fourth at cards, I saw no way out of it. Moreover, the battleship lay in the harbor of La Guayra, and my countrymen were in sad disfavor in Venezuela. W - had ignominiously deserted and gone to bed, so there was only one sleepy little woman left to uphold the honor of a great nation!

The game was "Siete y media," _ " seven and a half." I forget the rules now. I only remember that they seemed very intricate as explained to me in Spanish. Fortunately for me, the stakes were low, for I steadily lost all the time. "Grano por grano la gallina come," quoted Mr. Lugo, - " grain by grain the hen eats."

Later he remarked how he hated to win from the señorita but the señorita observed that he hated it much as the famous walrus wept for the oysters while -

\footnotetext{
" . . . he sorted out

Those of the largest size, Holding his pocket-handkerchief

Before his streaming eyes."
}

I was wofully tired and sleepy. I did not at all know the etiquette of gambling! And I thought the loser must not be a "quitter" - even if the extent of her losses was only "dos reales," or twenty-five cents. So I played on until at midnight the game was declared over. 
It is well that virtue is its own reward, as it has no other, for I was told the next morning by a husband who had had a perfectly good night's sleep - that I was a very foolish person indeed to sit up playing cards with those men, and that the loser could always stop: it was the winner who must not propose it.

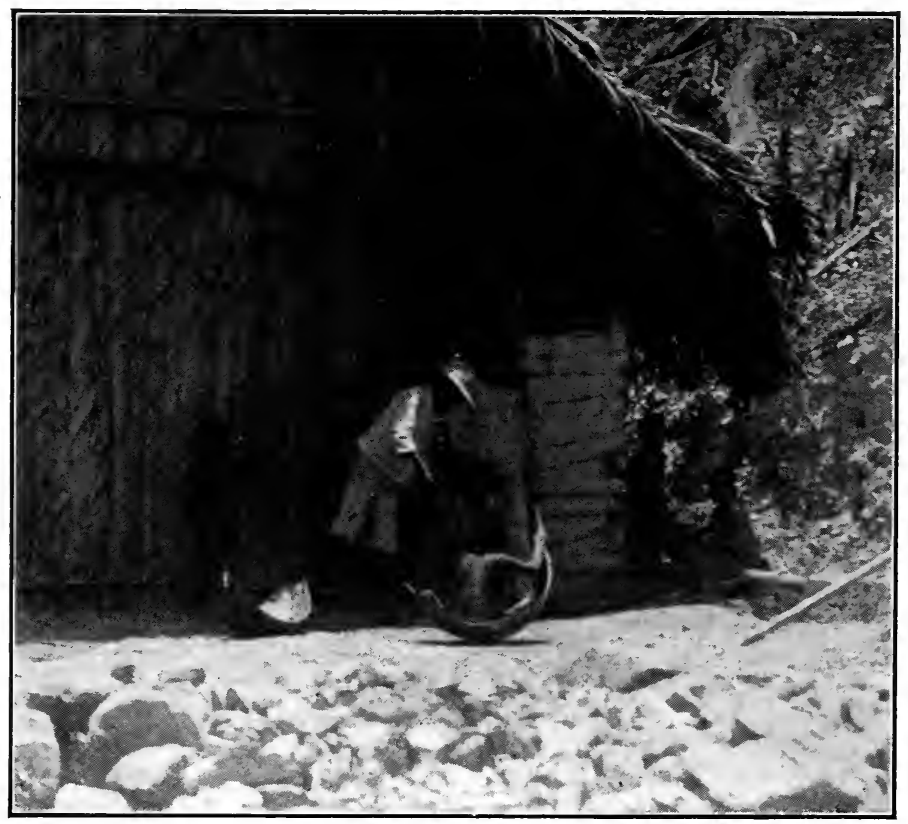

Fig. 52. A Palm-Sheath Rocking Toy.

The negroes from the Pitch Lake always came down on Saturday nights and serenaded us with wild Creole airs, and at the sound of the quaterns and violins huge hairy tarantulas would come forth from their hiding-places in our rooms and creep briskly here and there over walls and floor. We were greatly interested in this effect of the vibrations of sound, but we never bothered the great creatures in their strange " taren- 
telles," and they paid no attention to us. The venomous effect of the bites of all these eight or hundred-legged beings is greatly exaggerated, and there is absolutely no serious danger to a healthy person with good red blood in his veins; in some of the half-starved, rum-drinking natives the scratch of a pin would induce blood-poisoning.

Labor was easily secured in Guanoco. The morning after our arrival we expressed a wish to employ a boy to act as attendant, carrying camera, gun, butterfly net, etc., when we went on our long tramps. One of the young men at headquarters went to the door and called "muchacho," and at once a small boy appeared. I should have judged his age to be between eleven and twelve; but he himself did not know. He said his grandmother was "keeping his age." A charming idea is that Venezuelan custom of having some responsible member of the family keep all the ages. Think of being able to say truthfully that you really do not know how old you are! But then a Venezuelan woman never confesses to more than twenty-seven, no matter what may have been the flight of time.

Our small servant's name proved to be Maximiliano Romero, and with supreme self possession, boldly spitting to the right and left, he professed himself willing to enter our service. Like a true Venezuelan he used expectoration to punctuate all his remarks. What a quaint little figure he was, topped by a huge straw hat with a high peaked crown; the hat the work of the little brown hands of Max himself, for he was a hatmaker by profession. His face was alert but very grave. He rarely smiled, but when he did it was in no half-hearted way, but with an abandon of childish glee. I found myself devoting a good deal of valuable time to trying to bring into being that charming smile of Maximiliano's. One never knew just what would touch the right chord. Once he went off into gales of merriment at the escape of a lizard which we 
were trying to photograph. He always saw the funny side of our mishaps.

Max showed plainly in what esteem he held naturalists. The first day he went out with us he was neatly dressed in dark blue jeans. When he appeared on the second morning we did not recognize him. A small ragamuffin stood before us, stamping like a pony to drive away the flies, which hovered

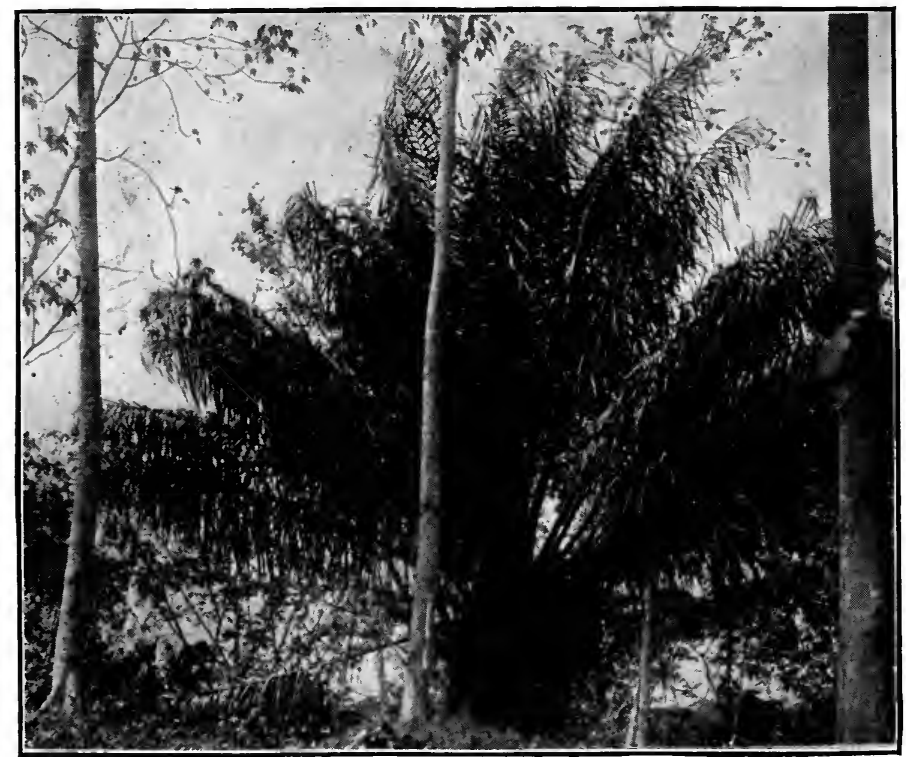

Fig. 53. Sheath in Fig. 52, covering the Flower of a Palm.

about his ankles. His clothes were a mass of rags - it was impossible to say what had been the original color or material. Max had taken our measure and decided that people who tramped through the "bush" as we did were not worthy of anything better than rags.

Sometimes in the jungle we would meet Indian women who, living far in the interior, were on their way to Guanoco to buy machetes, fish-hooks and other articles of civilization. 
They would always stop and make friends with us, with childlike curiosity asking where we came from, and why we wanted birds and lizards and butterflies, and murmuring the words dear to every woman's heart in all lands, "Que jovencita!" which literally translated is "What a young little thing !" Very simple-hearted are these poor Indian women and so hard are their lives that at a very early age do they cease to be jovencita.

We would often meet the wandering tribes of Guarauno Indians, who live nearly always upon the march, carrying all their worldly possessions upon their backs and sleeping wherever night happens to find them. They very rarely knew even a word of Spanish and shunned any intercourse with strangers, scorning the inventions of civilization and using the poisoned arrows of their ancestors.

One Sunday morning one of the laborers at the near-by Pitch Lake, bearing the pious name of José de Jesus Zamoro, came into headquarters to invite us to a dance that afternoon at his house. The house of Zamoro had nothing particularly to recommend it as a ballroom; for the floor was of dirt, the ceiling low and the walls windowless. But it was crowded; the air stifling and the dancers dripping with perspiration. The music was wild and strange, the man who shook the maracas - an instrument consisting of two gourds filled with dried seeds which is shaken in time to the music - often breaking into a weird song, making up the words as he went along, with some joke about each dancer. As the songster's zeal waxed high he described himself as being so great that "where he stood the earth trembled."

Between dances the ladies' last partners were supposed to take them into the next room where drinks were for sale. This was the explanation of Zamoro's zeal for dances: music and dance hall were free, but a substantial profit came from the drinks. 
The ball gowns had but one beauty - that of originality. There was always an unfortunate hiatus between bodices and skirts, which was partly concealed by the long straight black hair which hung down the backs of the women. The shoes were in a piteous condition, never the right size, very seldom mates and not infrequently both were for the same foot. But all the skirts had trains and all ears bore ear-rings. We were told that these women often danced all day and all night, until they became perfectly dazed, their feet moving mechanically in time to the music of the national dance the joropa, which is a cross between a clog dance and a waltz.

We saw dancing the women whose curiara had so narrowly escaped a fatal collision with our sloop in the Guarapiche. The Captain had said they were leaving Maturin "to operate some speculation in Guanoco - perhaps even to find husbands." And here among so many men, for the population of Guanoco was chiefly composed of men employed at the lake, surely there was hope, even for adventuresses so black and uncouth as these. Here also we met one of Guanoco's most amusing characters, a big black Trinidad negro. He was full of the superiority of one who had seen the world; for he had once been to England as stateroom steward on one of the big steamers. He now dropped his h's, called his wife "Lady Mackáy" and on Sundays wore a monocle.

It was twilight as we walked home through the little settlement. At one of the huts two little naked babies were playing "rock-a-by" in the great curved sheaths which protect the blossom of the moriche, or eta palm. At another a child came out and sang a little Spanish song for us - all about her sins and the confession she must make to the priest, the refrain being "Mi penetencia! mi penetencia"! and she sang it with her small hands clasped and her head devoutly bowed. A few coins made the wee penitent superlatively happy. Her mother must have taught her the song, for in Guanoco there 
A WOMAN'S EXPERIENCES IN VENEZUELA. IO5

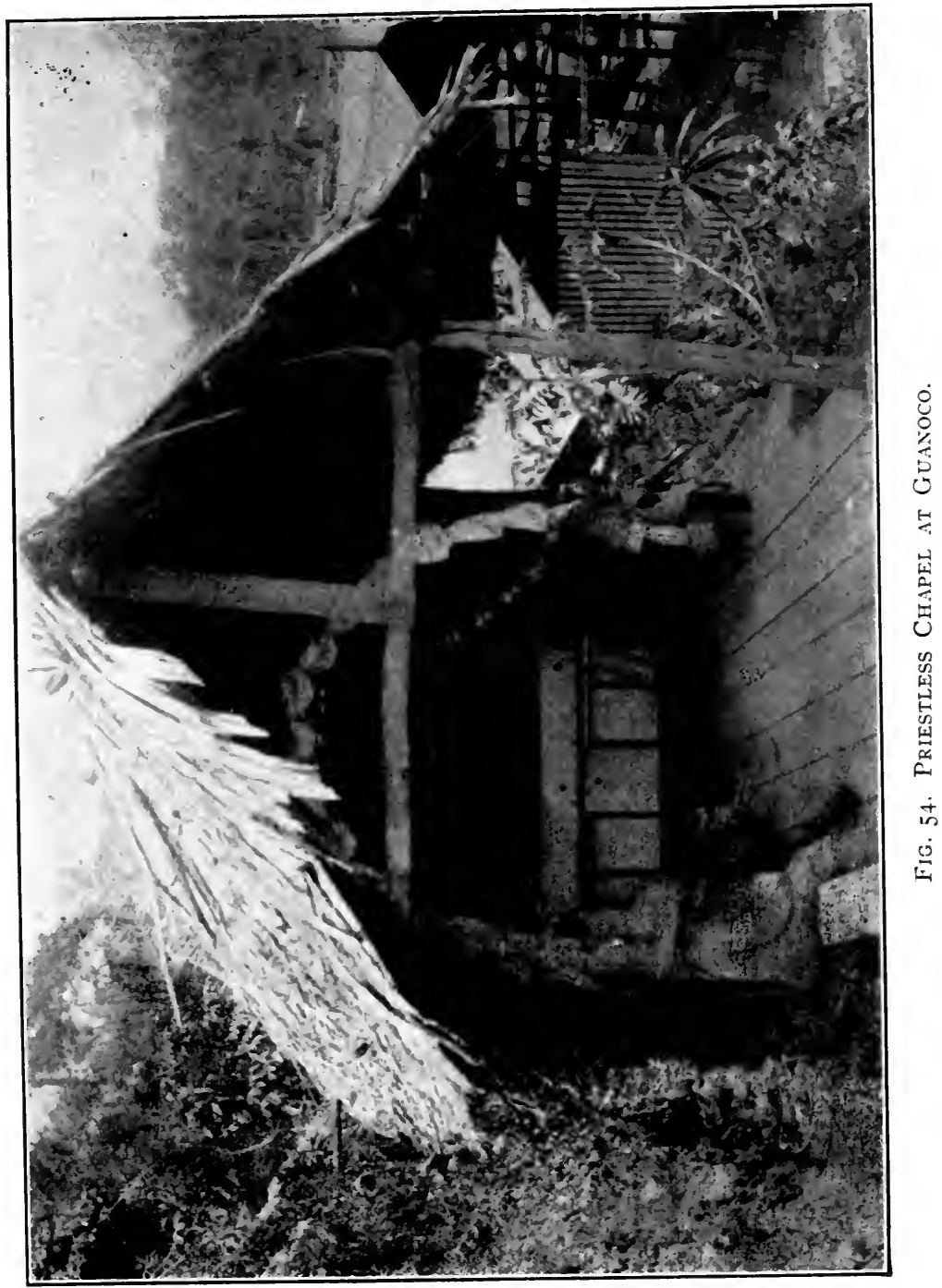


was no priest, no school, no doctor. The two young West Indians at headquarters (neither much more than twenty years old) officiated at all funerals, being Catholic or Protestant, in Spanish or English, as the case demanded. They prescribed for all diseases, from the prevalent fever to the woman who was suffering greatly, but could give no more definite description of her trouble than that she had a "pain that walked."

I could never understand the fever so common at Guanoco: for I never knew a place more free from mosquitoes and from insects of every description. We were continually in the sun and often in the rain, yet we both kept in perfect health.

The women of the village had converted a small open shed in to a chapel, with an altar, on which were all the offerings they could make, a few candles, some bits of gilt paper and tinsel, a rude wooden cross and a wretched little chromo of the Virgin. Here, as we passed, we saw the women kneeling, for where else could they take their troubles!

At last our Venezuelan experiences were a thing of the past, and we were homeward bound, leaving behind us the dear delightful never-know-what's-going-to-happen life; and realizing, as our ship cut her way through the countless "knots" of dashing waves, that as Maximiliano had said with a shake of his head, when we laughingly asked him if he did not want to go with us, "esta tan léjos" — it is so far!

$* \quad * \quad * \quad * * \quad * \quad * \quad * \quad *$

Much has happened at Guanoco since the days of our visit.

Very soon after our departure, Castro fearing the smouldering revolutionary plots in Trinidad, ordered all the ports of eastern Venezuela closed. Later came the deadly bubonic plague sealing for many months all the ports of the unfortunate country. Then indeed trouble descended upon poor little Guanoco. It was an essentially non-agricultural part 
of the country. The one industry had been the digging of pitch, the company's boat plying between Guanoco and Trinidad having brought all necessary supplies. Now with all communication cut off the people were in a pitcous condition.

In the revolution of the Wheel of Fate - which whirls so rapidly in Venezuela, - the Lugo family had been deposed and a new Venezuelan administrator appointed in their

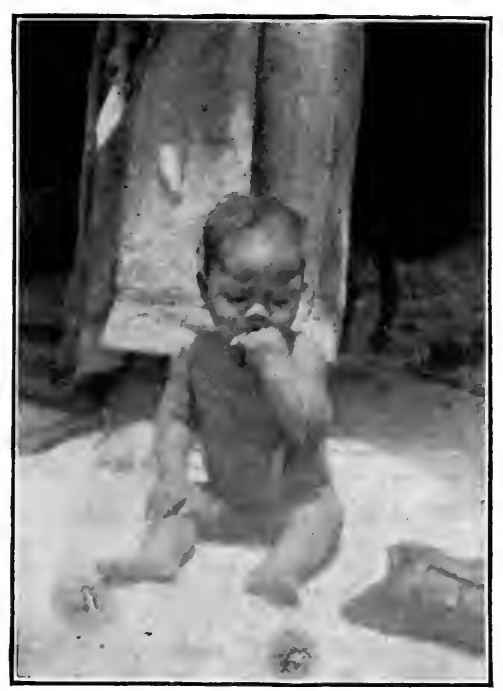

Fig. 55. Guarauno Indian Papoose.

place. Having known the Lugos, I like to think that they would have been less heartless than their successor, who, so the report goes, sold what supplies there were to the starving people at cruelly exorbitant prices.

No matter how much one may love Nature, one cannot help feeling how unmoved she is in the face of suffering. Human beings might starve and sicken and die at Guanoco, but the sunshine would be just as warm and glowing and the wind in the palm trees just as musical as ever. 
With the cutting off of communication between Venezuela and Trinidad, Captain Truxillo's occupation was gone. The "Josefa Jacinta" no longer plied busily back and forth between Port of Spain and Maturin, driving a brisk trade in hammocks, groceries and hides; and so at last she passed from the possession of Captain Truxillo to that of some more prosperous trader who could afford to wait for the reopening of commerce.

For a year our old Captain watched his little vessel guided out of the harbor of Port of Spain, with a strange hand at the helm, and a strange voice in command. Then one day she sailed away never to return - but to be run aground and lost on a desolate and lonely part of the Venezuelan coast.

What became of her new Captain and crew we never heard. We knew only that the "Josefa Jacinta" was lost, and that we could never sail her again, except on dream caños in a phantom wilderness. 


\section{PART II \\ OUR SECOND SEARCH \\ BRITISH GUIANA}




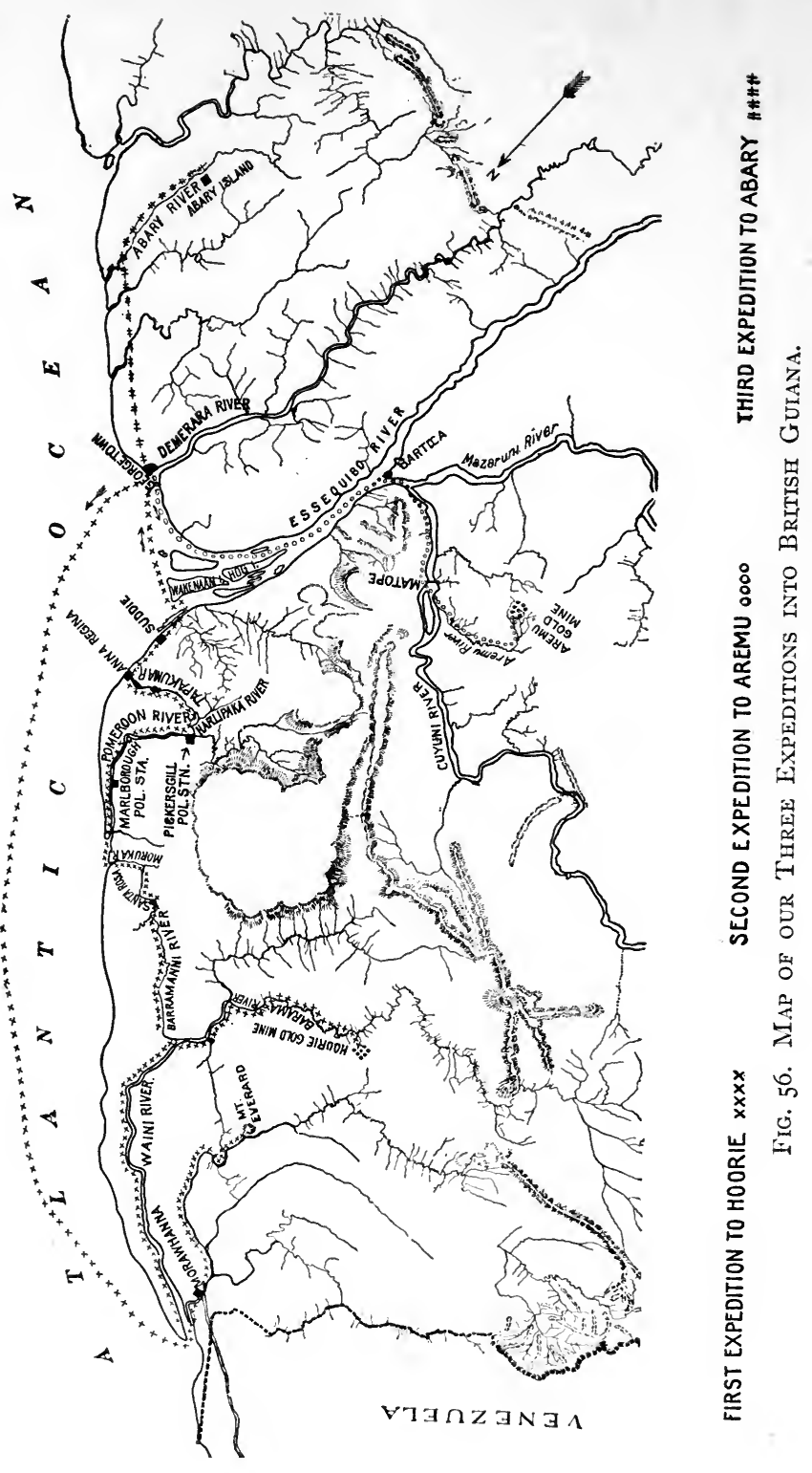

p. IIO 


\section{CHAPTER IV.}

\section{GEORGETOWN.}

A NOTHER year has slipped past and again we are A southward bound, toward that Mecca - the tropics which never ceases to call us. The time is the fifteenth of February, I909; the place, the Royal Dutch Mail Steamship "Coppename."

Nine days out from New York at three o'clock in the morning we are roused suddenly from sleep by a gentle roaring in our ears. When we have gained partial consciousness we realize it is the basso-profundo whisper of good Captain Haasnoot summoning us to the bridge. We ask no questions for we have learned that the voice of the genial Dutchman means something worth while, whether it is raised in a thunderous roar of "Hofmeister!" or as now in gentler accents. Wrapped in flapping blankets, we climb the steep ladder to the bridge, there to enjoy for half an hour a most wonderful display of phosphorescence - eren excelling that often visible in the Bay of Fundy. The Captain in all his world-wide sea-faring has never seen anything to equal it.

We are only a short distance off the shore of British Guiana and the ocean is thick with sediment from the rivers. The sky is overcast and no light comes from the moon and stars, and yet the whole sea is plainly visible. The horizon glows with a dull, yellow flare against the jet black sky, and the myriad foam-caps shimmer as with brighter flames. The quenching of these in the opaque water gives a vivid impression of an enormous conflagration half hidden behind billows of smoke. 
At day-break Georgetown is in sight - a low, flat line of wharfs, with a background of galvanized tin roofs and tall bending palm trees. Never was a fairyland set in so prosaic a frame!

With what mingled feelings our little ship's family lean on the rail and scan the shore! To some the thought comes of the miracles of yellow gold and precious stones hidden deep beneath the primitive forests; to other sea-weary travellers the stability of the shore appeals most; while we two watch for the first hint of bird life. Our desire is gratified before that of any of the others, for over the water there comes the first morning call of the great yellow Tyrant ${ }^{101}-K i s-k a-d e e !$ bringing a hundred memories of the tropics.

As we steam slowly up to the wharf a small flock of Graybreasted Martins ${ }^{122}$ twitters above our heads, a Black Vulture ${ }^{51}$ swings over the tin roofs, the jubilant song of a Guiana House Wren ${ }^{124}$ reaches our ear, and our Second Search has begun.

To those who seek for wildernesses there is not much of interest in Georgetown, save the museum and the botanical garden. Yet there is no doubt that the city is one of the most attractive in the tropics, and when the inhabitants are aroused to a sense of the opportunities which they are throwing away, it will become a famous tourist resort; awakening the country to new life and bringing shekels to the coffers of its merchants. Hotels and mosquitoes are the two keys to the situation - the one to be acquired, the other banished. When this is done, the many popular winter resorts will be hard put to it to retain their lucrative migrants from the North. The inhabitants of Georgetown have one regrettable failing - an unreasoning fear and dread of their own country. They cling to their narrow strip of coastal territory, where they work and play, live and die, many of them without ever having been five miles away 
from the sea. The majority of the inhabitants of French Guiana are convicts, chained for life to their prisons; here the good people of British Guiana bind themselves with imaginary bonds and picture their wonderful land as teeming with serpents and heaven-knows-what other terrors.

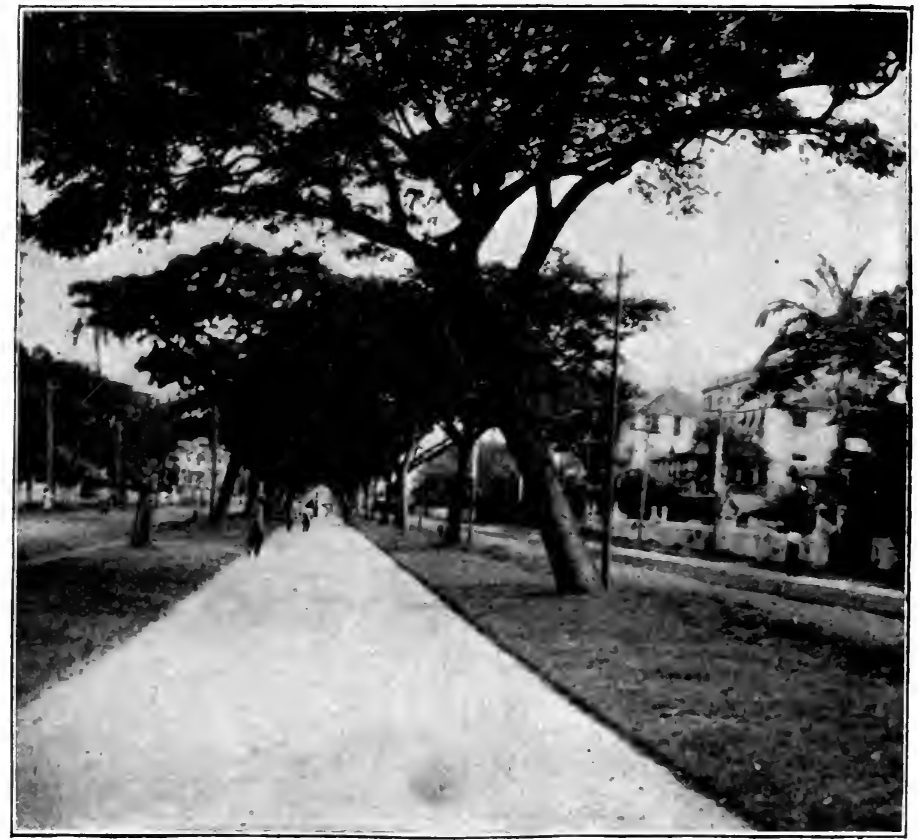

Fig. 57. Street in Georgetown.

Another unfortunate failing is the firm conviction of some of the influential citizens that there is no truth in the mosquito theory as a cause of malaria and yellow fever.

A distinguished English scientist, recently sent to investigate yellow fever in Barbados and British Guiana, was holding up as an example to the citizens of Georgetown the Barbadian custom of keeping fishes in their water cisterns; explaining that the fishes devoured the mosquito larvæ and 
thus kept down the number of mosquitoes. A Barbadian who chanced to be in the audience interrupted the scientist by saying, "Oh, but that is not the reason they put fishes in the cisterns. It is to make sure the water has not been poisoned by some enemy"!

Until the mosquito is exterminated in Georgetown the tourist will prefer to go elsewhere, even though that be to a less beautiful spot.

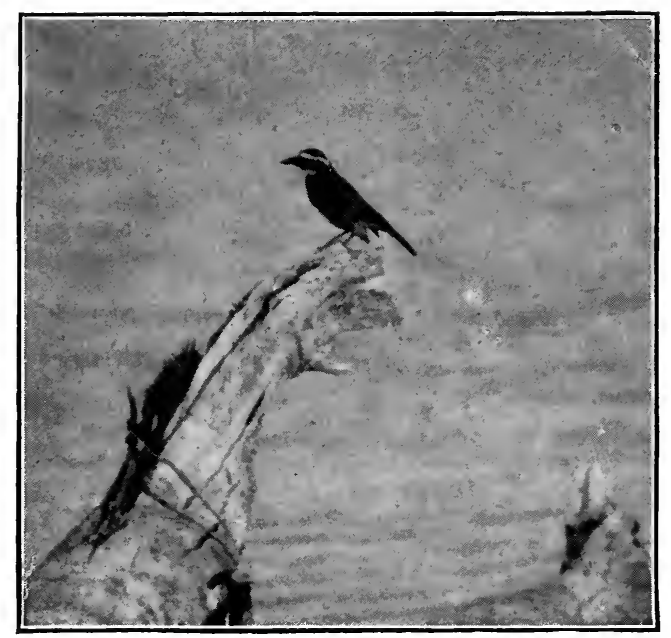

Fig. 58. Kiskadee Tyrant Flycatcher.

We were advised to spend all our time in Georgetown, where we might drink pink swizzles (than which no worse medicine exists!) or read in the cool library, or study the natural history of the country impaled on pins or stuffed with cotton (both of which are improving occupations but can be done quite as well in New York). Every moment spent in streets of human making seemed sacrilege when the real wilderness the wilderness of Waterton, of Schomburgk and of im Thurn - beckoned to us just beyond. 
Armed with proper letters of introduction and travelling in the name of science, one is treated with all courtesy by Guiana officials. The customs give no trouble, save that one pays a deposit of twelve per cent on cameras, guns and cartridges.

We were glad to find that the most difficult privilege to obtain is a permit to collect birds, and the very stringent laws in this respect are an honor to the Governor and his colonial officials.* Thanks to the absence of the plume and general millinery hunter, the game hog and the wholesale collector, birds are abundant and tame. We were in the colony just two months and shot only about one hundred specimens, all of which were secured because of some special

* In looking over the laws of the colony I found the following IVild Birds' Protection Ordinance. I have added the explanatory names in parentheses. (C. IV. B.)

List of Wild Birds absolutely protected.

$\begin{array}{lll}\text { Black Witch (Ani) } & \text { Ground Dove } & \begin{array}{l}\text { Qu'est-ce qu'il dit (Kiskadee) } \\ \text { Campanero (Bell Bird) }\end{array} \\ \text { Jacamar } & \text { Shrike } \\ \text { Carrion Crow (Vulture) } & \text { Hawk } & \text { Sun Bird (Sun Bittern) } \\ \text { Cassique } & \text { Heron } & \text { Sparrow } \\ \text { Cock-of-the-Rock } & \text { Hummingbird } & \text { Swallow } \\ \text { Cotinga } & \text { Hutu (Motmot) } & \text { Tanager } \\ \text { Crane (Heron) } & \text { Kingfisher } & \text { Thrush } \\ \text { Creeper (Woodhewer) } & \text { Kite } & \text { Toucan } \\ \text { Egret } & \text { Macaw } & \text { Trogan } \\ \text { Flycatcher } & \text { Manakin } & \text { Troupial } \\ \text { Gauldin (Heron) } & \text { Martin } & \text { Woodpecker } \\ \text { Goatsucker } & \text { Ow! } & \text { Wren } \\ \text { Grass Bird } & \text { Parroquet } & \text { Vulture }\end{array}$

List of Wild Birds protected from April ist to Sept ist.

\begin{tabular}{|c|c|c|}
\hline Bittern & Hanaqua (Chachalaca) & Plover \\
\hline Curlew & Maam (Tinamou) & Powis (Curassow) \\
\hline Curri-curri (Scarlet Ibis) & Maroudi (Guan) & Quail \\
\hline Douraquara (Partridge) & Negro-cop (Jabiru) & Snipe \\
\hline Dove (other than Ground & Parrot & Spur-wing (Jacana) \\
\hline Dove) & Pigeon & $\begin{array}{l}\text { Trumpet-bird } \\
\text { Wild Duck }\end{array}$ \\
\hline
\end{tabular}


interest. We brought home some two hundred and eighty live birds which are now housed in the New York Zoölogical Park.

Once off the single wharf-lined, business street of Georgetown, one is instantly struck by the beauty of the place. Green trees, flowering vines and shrubs are everywhere, half hiding the ugly, tropical architecture. The streets are all wide, some with gravel walks down the centre, shaded with the graceful saman trees; others with central trenches filled with the beautiful Victoria regia - here a native.

Two species of big Tyrant Flycatchers ${ }^{101,}{ }^{103}$ are the English Sparrows of the city and White-breasted Robins, ${ }^{128}$ Palm ${ }^{144}$ and Silver-beak ${ }^{140}$ Tanagers perch on the limbs of trees at one's very window.

Although we are anxious to start on our first expedition into the "bush," as the primeval forests of the interior are called, yet a week passes very pleasantly in the city itself.

The street life is a passing pageant, full of interest and of the charm of novelty for the Northerner. Carriages roll past in which sit very correctly dressed and typical English women; still others are filled with creoles, some to all appearances perfectly white, others in which the infusion of negro blood is very apparent. Many of the creole women have a certain languid beauty and a good deal of grace and selfpossession. The passing of the liveried carriage of the Governor causes a ripple of excitement. It is five o'clock, the fashionable hour for driving, and all these equipages are bound for the sea-wall, where the occupants sit and listen to an excellent band, enjoy the sea breeze and chat with their neighbors about the all-important happenings of the social set of Georgetown; while the pale-faced children dig in the sand or run shrieking with glee from an incoming wave, just as do their rosy contemporaries of the North. 
Another picture is the coolie in his loose, white garments and turban and his sinewy, bare, brown legs. He gazes at you as calmly and as unmoved as though you were not. Even the lowest coolie bears about him this unconscious dignity of an ancient race and a civilization that was old when we were but beginning.
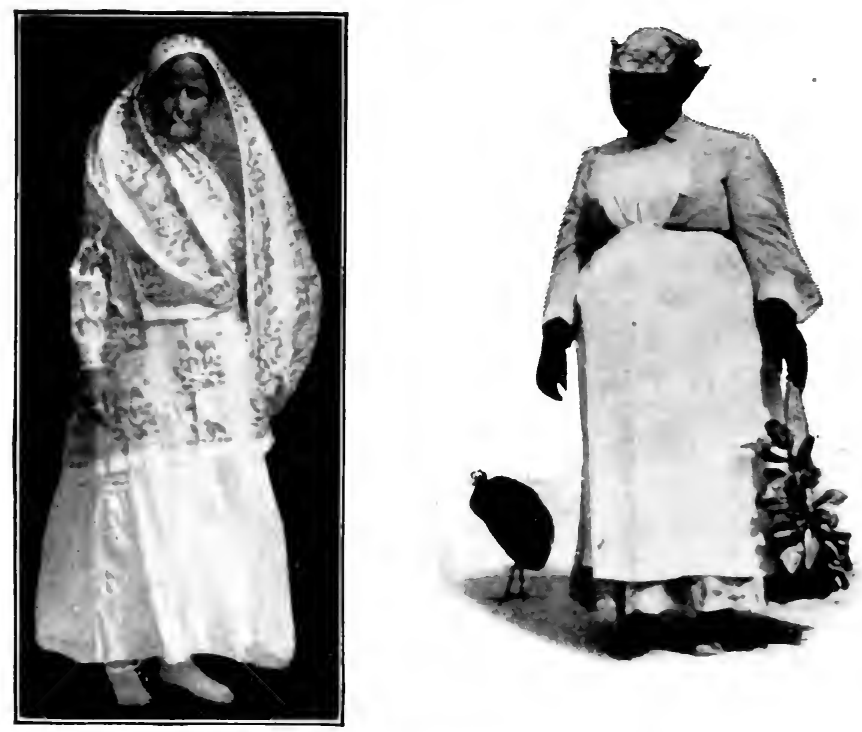

Fig. 59. Coolie IVoman and Negress.

The coolie women make a vivid spot of color in our pageant - like some glowing tropical flower. Many of them are beautiful in feature and all are graceful in bearing. There never were women who so perfectly understood the art of walking. They swing along erect and lithe with a springing step and perfect coördination of every muscle. Their heary bracelets and anklets tinkle musically as they move; their gay red and yellow and blue scarfs flutter in the 
breeze. The poise of their bodies reflects the perfect calm and repose of their smooth, brown faces.

What an antithesis they are to the ponderous old black women who are striding along, with bedraggled skirts gathered up in a roll around their massive waists. They are untidy and slatternly in dress, heavy and awkward in movement in comparison with the straight, slim, coolie women. They are full of loud laughter and talk and song. At every street corner they gather in friendly, jovial groups, while the coolie women are strangely silent and reserved. No wonder that these two races so hate and scorn one another, for in temperament they are as far apart as the poles!

The British Guiana blacks were to us an unending source of interest and amusement. They were always courteous and kindly and most original. Even when swearing at each other their manner was always polite and each anathema ended with a civil "Suh!" Their dialect was at first very difficult to understand, but when our ears became familiar with it we found it singularly attractive. All the a's are broad, even in such words as bad and man; while the intonation is indescribable, the verbs in a sentence being always emphasized and given a slight rising inflection, as for example, "I have been to Berbice." An interrogation is often not at all indicated by the form of a question, but merely by the rising inflection, as - "These are nice?" The general effect of their speech is a very musical and distinctive intonation.

Always the irrepressible spirit of the black rises serenely above all the vicissitudes of life. A black woman from Arakaka was sentenced to a month in jail. Upon her return she was welcomed by a crowd of friends, all eager to hear something of that mysterious jail, to which none of them were sure they might not some day go. To their questions "How was it? how was it?" the heroine of the occasion 
replied with great dignity, "Me chile, dey see I was a lady an' dey didn' give me de same work as de other prisoners." Later, on a trip down the river, the same woman, meeting the magistrate who had sentenced her, proudly remarked, "Now I travel by meself"; her only previous experience in travelling having been under the escort of the police!

Many of the blacks have far advanced cases of elephantiasis. In a five minutes' walk one will see a half dozen examples of this deadly disease; but it takes more than elephantiasis or jail to sadden the volatile spirits of the negro!

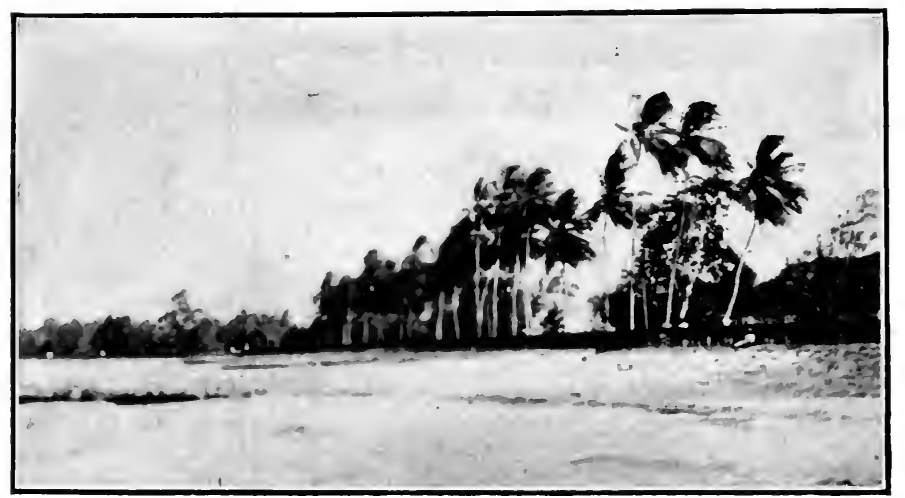

Fig. 6o. The Georgetown Sea-wall.

Cosmopolitan as is the street pageant of Georgetown, it is, however, not so much so as that of Port of Spain. The coolies are even more numerous there than here, and in addition to the same sort of English and negro life, there is also an American, Spanish and French element. One hears on all sides the pretty French patois, and the musical Spanish of the South American is a constant delight. This large Spanish and French population make Port of Spain a decidedly Catholic city, and priests and nuns in unfamiliar garbs are always a part of the picture. 
It is very hard for us Northerners to realize that the course of a tropical day is much the same the year around. Here is a Georgetown day as we found it in February. At 5.30 A.M. it is still dark and the only sound is an occasional raucous crow from chanticleer. Soon a subdued murmur of sound is heard and this remains unchanged in volume for some time. Then the sunrise gun booms in the distance; a Kiskadee shrieks just outside our window; a score of others answer him; church chimes ring out; noisy coolie carts rattle past; negroes sing, dogs bark; an excellent brass band strikes up a two-step and amid all this pandemonium of sound the sun literally leaps above the horizon and instantly fills the world with brilliant color. The scene changes like magic; there is no dawn or dusk, night gives place to day without intermission. The temperature morning and evening is about $76^{\circ}$.

Woven amid all the harsh cries of Kiskadees and Tanagers is heard the sweet warbling of the little House Wrens, reminding us of our singers of the North, and bubbling over with the same crisp, vocal vitality which we hear in early Spring in our own country.

Like the morning, the tropical day itself is one of extremes. The morning dawns fresh and bracing; until nine o'clock one walks briskly, breathes deeply and can hardly realize that he is at sea-level within seven degrees of the equator. It is April and May in the calendar of one's feelings. Then for an hour or two June reigns, and finally from eleven to five o'clock in the afternoon it is hot, sultry August. In the shade, however, it is always comfortable. From three o'clock on we experience the coolness of October and until darkness shuts suddenly down about half-past six - like the snuffing out of a candle - the temperature is perfect. The nights are delightfully cool. Mosquitoes are bad only in the houses and at night one's net is a protection. The humidity is high but 
it is far more bearable than that of a summer in New York City, contrary to our usual idea of the tropics.

The manner of rain in the tropics is peculiar: the atmosphere may be ablaze with brilliant sunshine, when a slight haze appears in the air and suddenly one realizes that a fine gentle rain is falling. This may cease as imperceptibly as it began, or increase to a terrific downpour - to give place perhaps a few minutes later to the clear tropic glare again.

Before taking leave of Georgetown we must mention the three chief points of attraction. The sea-wall comes first and, as we have said, a most pleasant custom of the natives is to drive there in late afternoon and sit in their carriages. The concrete break-water is of vital importance to the town itself as a portion of the streets are below sea-level. The broad summit forms a mile or more of promenade, with a sandy beach on one side, lapped with waves which strive ever to break, but cannot because of the thick sediment which they hold in suspense. On the other side a double row of tall, graceful palms adds a touch of tropical beauty.

The residences near the sea-wall are the coolest and most pleasant in the town and are practically free from mosquitoes. We spent more than one delightful evening in the garden at Kitty Villa as the guests of our charming American friends, Mr. and Mrs. Howell. From the open, veranda-like rooms one may watch the Yellow Orioles, ${ }^{159}$ the Brown-breasted Pygmy Grosbeaks, ${ }^{129}$ the Anis and Kiskadees going to roost. Just before dusk scores of the small Black Vultures ${ }^{51}$ appear, flying singly, or in twos and threes low over the trees and palms westward to some general roost. About this time the bats and the lightning bugs arrive, large numbers of very tiny bats hawking about after insects, and several large fruit-eaters with wings spreading almost two feet across. These haunt the fruit-laden sapadillo trees, and as the method of feeding of 
these curious creatures does not seem to be generally known we watch it with interest. One of the big fellows flits here and there, nipping first one fruit and then another. At last when a sweet or fully ripe one is found, the bat swoops up to it, alights head downward, and half enveloping it with his wings, bites away frantically for two or three seconds and then dashes off. This is repeated until darkness settles down, but never does the wary bat linger over his feast.

In the north the sight of a single bat darting along on its eccentric way is not uncommon, but here we were soon to become accustomed to the sight of scores, some pursuing insects, or feeding on fruits, or waiting and watching for a chance to drink the blood of men and animals. More than twenty-five species have been found here within a few miles of the coast. Small Owls and nocturnal insectivorous birds are somewhat rare, and thus the bats have few foes and little competition in their aërial life.

Late in the evening as we drive slowly homeward from the sea-wall we discover another interesting microcosm of the tropics. The road is well lighted with arc-lamps - sources of irresistible attraction to numberless insects, many of which drop stunned to the earth beneath. Some genius among the Georgetown toads has discovered this fact and passed the word along, until now one finds a circle of expectant amphibians squatted beneath each arc-light, with eyes and hopes lifted to the shining globe overhead. Now and then an unfortunate insect falls within the magic circle, when a toad leaps lazily forward and devours the morsel with one lightninglike flick of the tongue. Many of these toads (Bufo agua) are enormous fellows, a good hatful, standing full eight inches from their pudgy toes to their staring eyes, all comical, dignified, fat and sluggish, barely hopping aside in time to avoid the horse and carriage. 
To a visiting naturalist the museum is the place of greatest interest, and although the animals and birds are faded and poorly mounted, yet they are representative of the fauna of the country and are hence of great value in accustoming one's eyes to the strange forms of life. The present Curator, Mr. James Rodway, did everything in his power to aid us, and we are indebted to him for many kindnesses. Although he is primarily

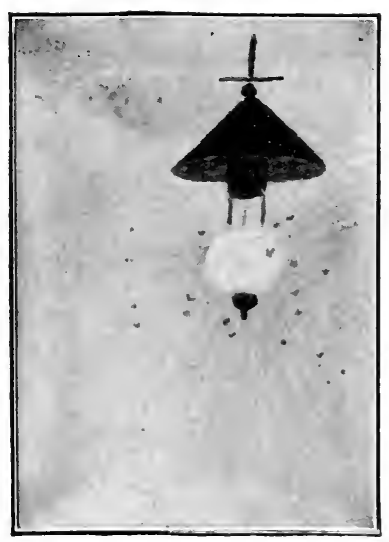

FIG. 6I.

a botanist, entomology occupies his attention at present, and the supply of species of the various orders of insects living in this region seems well-nigh inexhaustible. Mr. Rodway is a good example of the healthfulness of British Guiana, for he has lived there thirty-nine years and has been ill only one day. He accounts for this by his teetotalism, but perhaps the next person we meet will inform us that a half dozen swizzles a day are absolutely necessary to keep the breath of life within the body!

The Botanical Gardens, un-

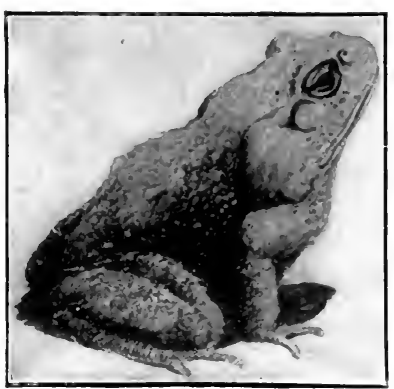

FIG. 62. der the able direction of Prof. J. B. Harrison, are a great credit to the colony. With beautiful vistas of palms and ornamental shrubs they combine smooth expanses of green lawns - a rare feature in a tropical landscape. Ponds and ditches are filled with Victoria regia and lotus, save one where 
I24 OUR SEARCH FOR A WILDERNESS.

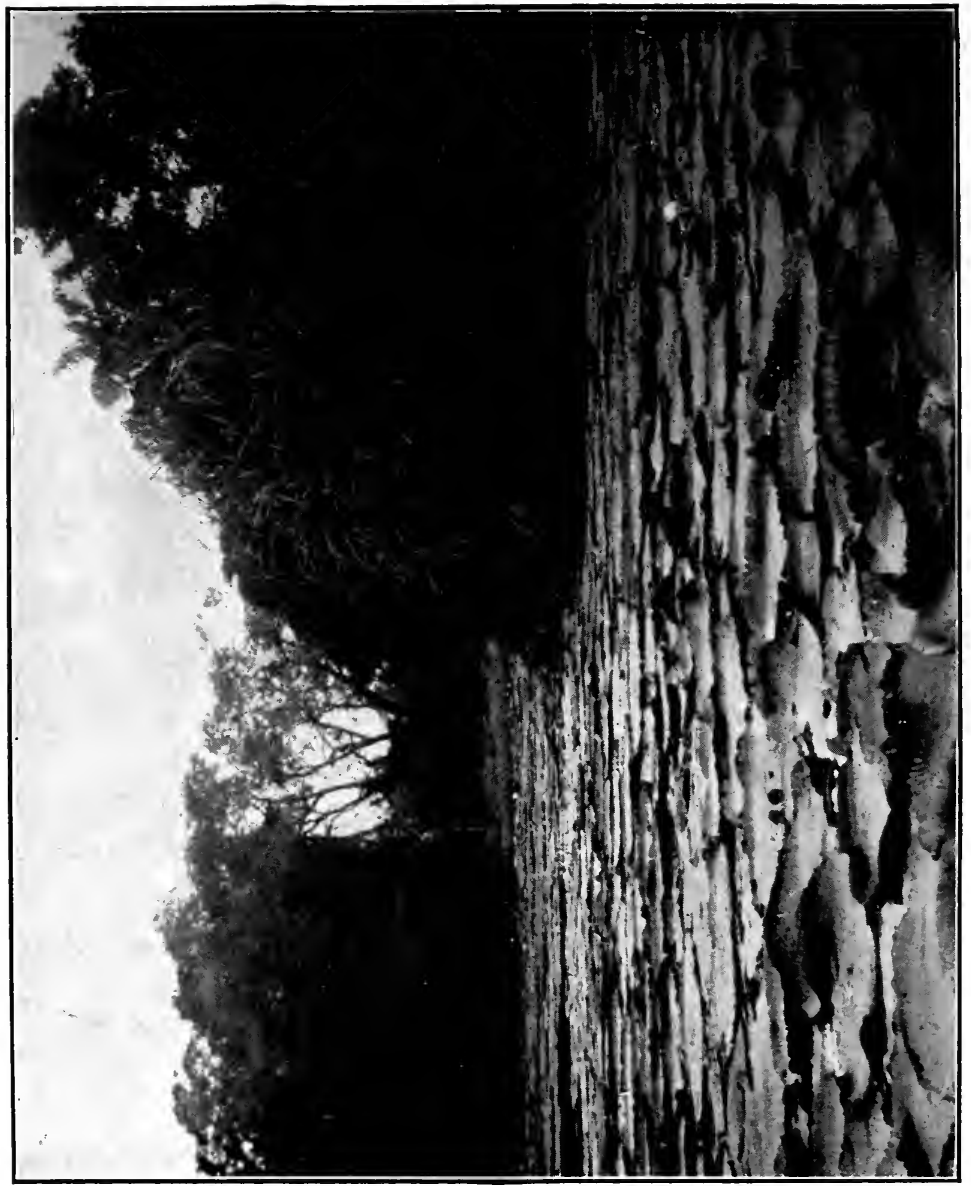

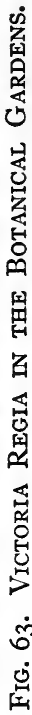


a number of manatees keep the aquatic vegetation cropped close. A wonderful palm was in blossom at the time of our visit - a Taliput with a mass of bloom twelve feet in height which had begun to flower the month before. Governor Hodgson and Prof. Harrison gave us the freedom of the garden and placed at our disposal five circular aviaries which proved of inestimable value in housing the living birds which we were able to secure.

Here Mr. Lee S. Crandall, our assistant, made his trapping headquarters after our return from our first inland expedition and here we spent many afternoons among the fields and bypaths.

We soon found that bird-trapping in the tropics is a task beset by many difficulties. The extreme heat between the hours of ten and four o'clock make even the "tackiest" lime nearly as thin as water, and hardly capable of holding even the diminutive "doctor-bird" as the natives call the Hummingbirds. The call-birds, which are confined in very small cages, or cribs, cannot endure the high temperature under these conditions, and soon succumb if left out in the sun. Operations, therefore, must be confined to the few hours immediately following sunrise, and preceding sunset.

Another feature, very trying to the bird-catcher, is the habit which most of the birds have of going singly or in pairs. A few of the Icterine birds, such as the Yellow-headed Blackbird, ${ }^{154}$ Cowbird, ${ }^{153}$ Little Boat-tailed Grackle, ${ }^{160}$ and most of the Cassiques, feed usually in flocks, sometimes of great size. In the deep bush of the interior it is the habit of birds of many species to search together for food, following a set route, and keeping closely to their time schedule. But ordinary call-birds and "set-ups" are not for these.

This gregarious habit among widely varying birds is, however, at times, a great aid to the trapper. A cage con- 


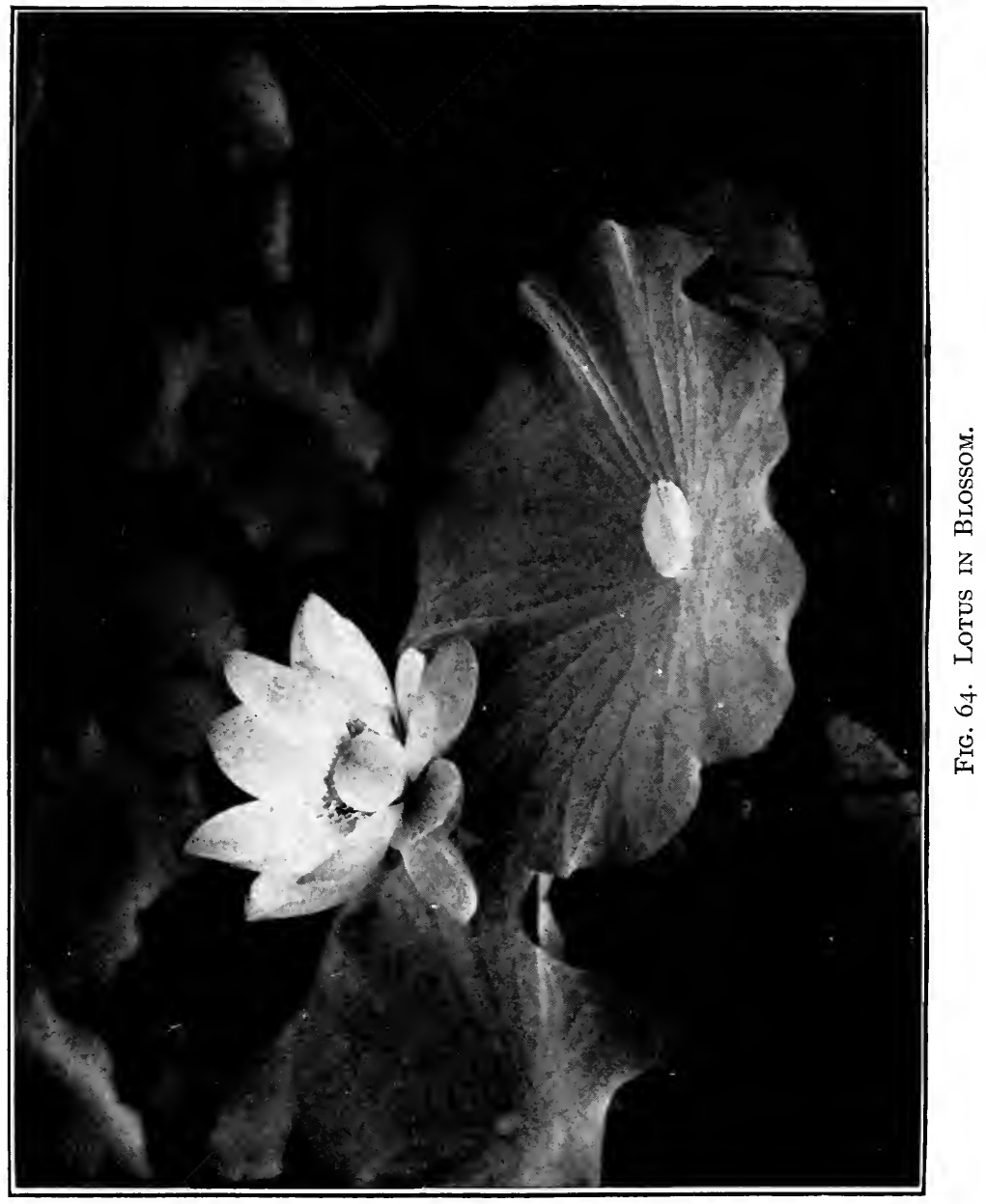


taining a Yellow-bellied Calliste ${ }^{142}$ was one day placed in a tree about twenty feet high, and limed twigs arranged on neighboring branches. In two hours in the morning, two specimens of the same species, three Blue Tanagers, ${ }^{143}$ two Black-faced Callistes, ${ }^{141}$ two Toua-touas or Brownbreasted Pygmy Grosbeaks, ${ }^{129}$ and one Yellow Oriole ${ }^{159}$ were taken. The various species of Tanagers and Orioles are much more gregarious in feeding habits than the Finches, hence the variety caught. The Toua-touas were purely accidental visitors. The Finches can rarely be taken by a call-bird not of the same species.

The black or coolie boy who makes his living at catching birds at "tuppence" each, sets out at daylight with his two or three call-birds in their cribs, arranged on a stick. Arrived at some secluded spot, where he has heard the song of an intended rictim, he sets his call-birds on upright sticks of two or three feet in length and places on the top of each cage a strong wire, heavily smeared with the gum of the sapadillo. This wire is very carefully twisted so that it cannot by any possibility become loosened. This is, of course, contrary to the ethics of all good bird-catchers, for if the bird falls to the ground with its stick, it is much more certain to be secured, and less liable to injure itself. However, this is British Guiana.

Having made his "set-up," the youth steals softly back and conceals himself a short distance away. As soon as left to themselves, the birds, if they be experienced, commence their song. Soon, an answering call is heard. Instantly the decoys cease their song, and send forth their sharp call-notes. Soon the curious stranger appears, perhaps a fine adult male, full of eagerness for a battle. If this be the case the songs are again resumed, and the climax of the concert is almost certain to be the capture of the challenger. If the visitor be a coy female, the seductive call-notes 
are continued, and, though the time required may be greater, she is nearly as certain to be captured. Callow youngsters out for their first exploring trip, are of course the easiest

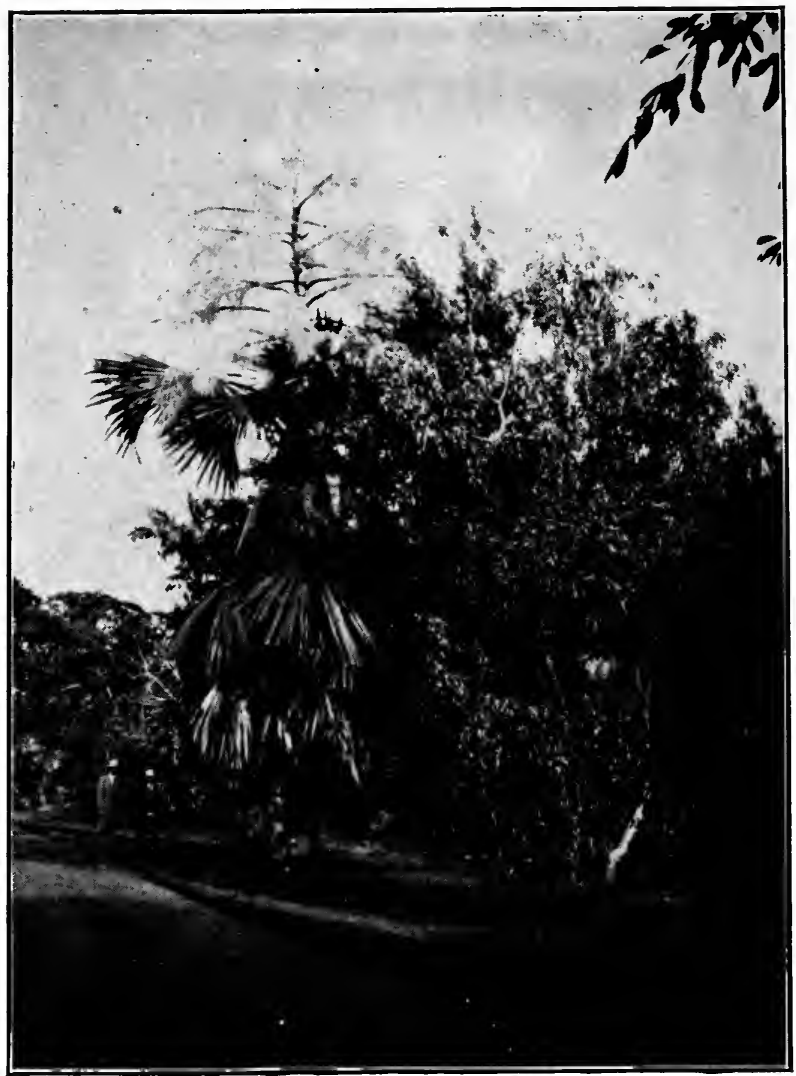

Fig. 65. Taliput Palm in Blossom.

victims. But when the trapper has taken a bird or two from this locality he must move on or give up for the day, for he will take no more.

The trapping methods of these people are, of course, 
very primitive. They know nothing of clap-nets; they laugh at the idea of catching birds with an Owl, as practised successfully in the North. A black boy will bend his gummed wire securely on a likely twig, and lie all day on his back in the shade, hoping that a bird may light on it. Birds to whose capture they are not equal are very apt to be "licked" - stunned by a bullet from a sling-shot - and foisted on the unwary purchaser. These unfortunates, of course, rarely live more than a day or two.

No regard is shown for nesting birds or nestlings. Cassiques and Orioles are captured by adjusting a string about the mouth of the long pendulous nest, and closing it tightly when the bird has entered to hover its eggs. In two instances, a black boy was seen to capture the female from her nest, by creeping up and dropping his hat over her.

Some use is made of primitive trap-cages, which are baited with plantain or sliced mangoes. Tanagers or "sackies" and various Orioles are taken in this manner.

These simple people have, of course, no knowledge whatever of proper food for insectivorous or frugivorous birds. Various fruits, preferably plantain, are used, and it is truly surprising how long some individuals will survive on this too acid food. Mr. Howie King, Government Agent of the Northwest District, actually kept a specimen of the Yellow Oriole ${ }^{159}$ for over seven years on a strictly fruit diet!

Birds and other creatures were very abundant and tame in the Botanical Gardens. Guiana Green Herons ${ }^{38}$ or "Shypooks" as the coolies call them, Spur-winged Jacanas ${ }^{23}$ and Gallinules ${ }^{13}$ walked here and there, the latter leading their dark-hued young orer the Regia pads. Small crocodiles basked half out of the water, none over three feet in length, as abundant as turtles in a northern mill-pond. Several huge water buffalo, imported from the East Indies, looked strangely out of place in this hemisphere. Butter- 
I30 OUR SEARCH FOR A WILDERNESS.

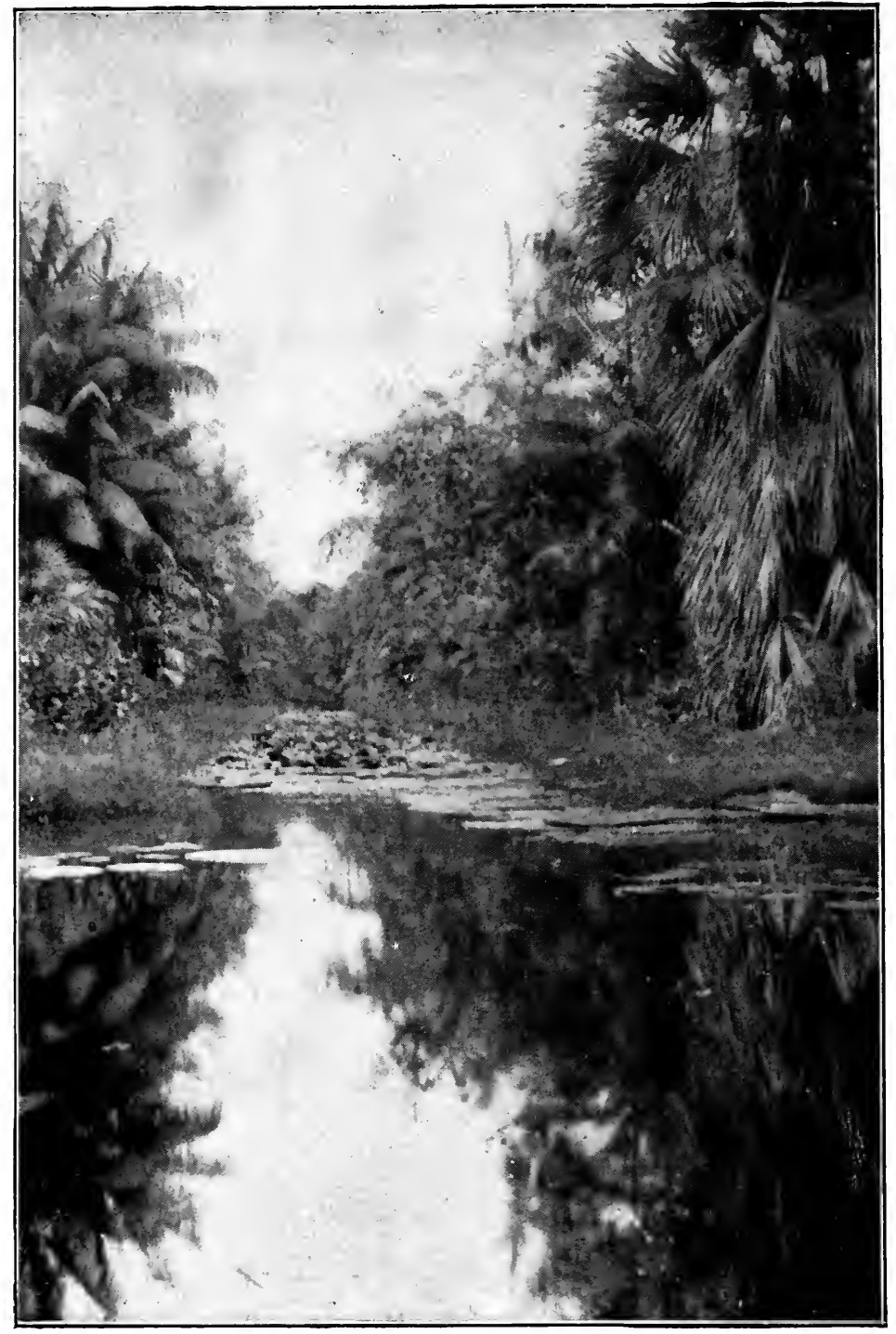

Fig. 66. Canal of the Crocodiles. 
flies were scarce although a great variety of flowers were in profusion everywhere.

April seems to be the height of the breeding season for many birds. In one tree we found two wasps' nests, and nests with eggs or young of the following six species of birds; the Red-winged Ground Dove, ${ }^{9}$ the Great ${ }^{101}$ and Lesser ${ }^{103}$ Kiskadees, White-shouldered Ground Fly-catcher or "Cottonbird," ${ }^{97}$ Gray Tody-flycatcher or "Pipitoori" " ${ }^{99}$ and Cinereus Becard. ${ }^{114}$

Chestnut Cuckoos of two species, ${ }^{77},{ }^{78}$ all four Kiskadees, ${ }^{101,}{ }^{103,}{ }^{104,}{ }^{106}$ Caracaras, ${ }^{53}$ Black-faced Tanagers or "Bucktown Sackies," ${ }^{141}$ Woodhewers, Elanias ${ }^{100}$ and other Flycatchers are a few among many birds which we were sure of seeing on every walk, while Anis, both great ${ }^{79}$ and small ${ }^{80}$ were everywhere.

The Botanical Gardens are ideal for experimental botanical work and sugar cane in scores of varieties is being kept under observation. It is hard to believe that the delicate grass which we see springing up in the ditched fields will grow into the lofty and waving stalks of sugar cane. It is exceedingly variable and should afford excellent material for experimental study. The original yellow-stalked cane develops red and purple streaks in many combinations, due apparently to difference in soils. Cane sent to Louisiana will, within twelve years, produce much larger nodes owing to the plant having to fruit in six months instead of eleven or twelve. The stalk, however, does not gain correspondingly in diameter; so there is no increase in sugar capacity. Tropical plants can in many cases adapt themselves to shorter, northern summers, but temperate perennials soon die in the tropics from exhaustion, lacking their annual period of rest.

The climatic conditions along the coast of British Guiana are peculiar, in that they simulate conditions usually existing at an altitude of two or three thousand feet. One result of 
this is seen in the flourishing tree-ferns planted in the Botanical Gardens.

Insects were not particularly abundant in Georgetown, that is, for a tropical country. One day Mr. Rodway, with his accustomed kindness, brought us two very interesting chrysalids of the swallow-tailed butterfly, Papilio polydamus, illustrating the remarkable color variation in this species. Both were found in his yard, a few feet from each other, one

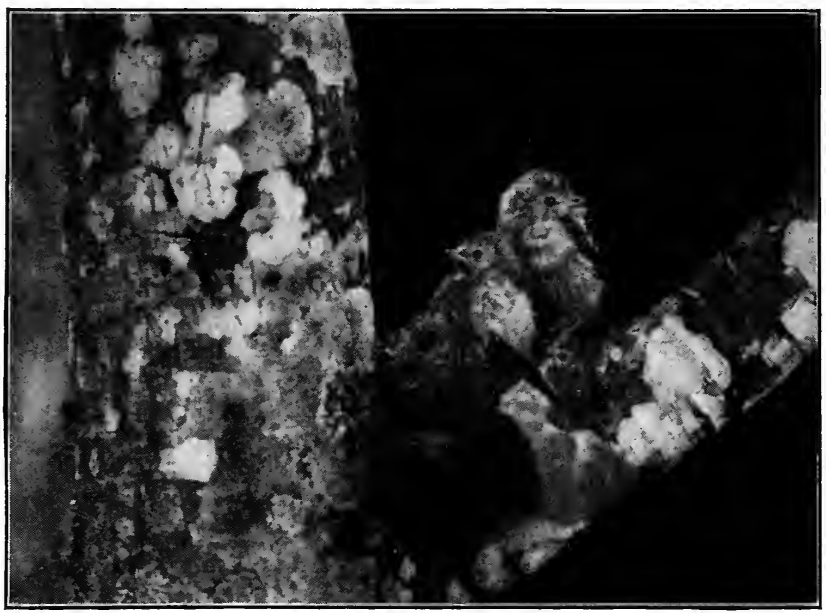

Fig. 67. Young Elania Flycatchers.

suspended among green leaves and the other on a wooden stairway which was painted a brick-red. One of the chrysalids was leaf-green in color while the other was brown with brick-red trimmings!

There was one remarkable exception to the scarcity of insects in Georgetown. Late in February, a moth-like Homopterus insect, Poeciloptera phalaenoides, was present in enormous numbers on the Saman trees which line many of the streets. The largest individuals had wings almost an inch in length of a light cream color, covered for about half 
their expanse with two masses of black dots. These were the males. The females were wingless and their bodies were covered with a long dense cottony secretion. The eggs and larvæ which lined thousands of the twigs were also protected by this white material. One could hardly walk without crushing these insects, so numerous were they. The only birds we observed feeding on them were Anis and domestic fowls.

The middle of April found these insects as abundant as ever, still hatching in myriads, but by the $22 \mathrm{~d}$ of the month the broods on the main streets seemed to be diminishing, although the hordes infesting the trees at the entrance of the Botanical Gardens were on the increase. Noticing that there seemed to be interesting nodes of variation in the number and patterns of the dots on the wings of the males, we set a Coolie boy to gathering them for future study and he soon had a thousand or more in a jar of alcohol. 


\section{CHAPTER V.}

\section{STEAMER AND LAUNCH TO HOORIE CREEK.}

WHEN we left New York we had planned to go up the Demerara River from Georgetown and spend our time on the Essequibo and Potaro. We had the good fortune, however, to take the same steamer with Mr. and Mrs. Gaylord Wilshire who were paying their annual visit to their two large gold concessions. The previous year they had travelled over many of the larger rivers and when we heard their glowing accounts of the northern and western wilderness compared to the rather thinned out "bush" and more travelled route of the Demarara, and were asked to join their party in going first to the Hoorie Mine in the northwest and then to the Aremu Mine in central Guiana, we hesitated not a moment.

We left the Georgetown stelling, or wharf, at noon on March 2d, on the little steamer "Mazaruni" for the long coastwise trip to Morawhanna. Leaving the harbor flock of Laughing Gulls ${ }^{16}$ behind, we steered straight out to sea for several hours before turning to the northwest. The water all along the coast is very shallow and is so filled with sediment that even in a heavy gale the waves break but little. We passed the mouth of the Essequibo, thirtyfive miles in width, with the two great islands, Wakenaam and Leguan, fairly in the centre of the mouth. The night. was rough and windy and the little tub rolled wildly.

At five o'clock next morning we were steaming slowly between two walls of green which brought vividly to mind our Venezuclan trip of last year. A few other plants were intermingled with the mangroves, but the solid ranks of the 
latter were unbroken. The colors were as wonderful as ever; the rich dark green on either hand, bright copper beneath and azure above. A few hours later we entered Mora Passage and here palms began to rear their heads over the other foliage. The air was cool and bracing, we breathed deeply and watched for the first signs of life. A half dozen Muscovy Ducks ${ }^{43}$ swung past, the giant master of the flock in the lead, their white wing mirrors flashing as they flew. Two Amazon Parrots rose ahead of us and the shore was alive with tiny white moths fluttering over the water.

Morawhanna is within five miles of the Venezuela boundary, and politically is important as being the chief Government Station for the Northwest District, and being the entrance post for the gold fields of this region. As we tied up to the primitive wharf, Indians in their dug-outs or woodskins appeared in numbers, bringing fish, rubber and other things for trade to the little Chinese store. Morawhanna itself consists of a straggling line of thatched huts extending irregularly along the bank and inland between the marshy spots.

A short walk on shore showed the inhabitants to be Indians, blacks and half-breeds. Birds were abundant, especially Yellow-bellied Callistes, ${ }^{1+2}$ Honey Creepers, Tanagers, and the four commoner species of Kiskadee Tyrants ${ }^{101}, 103,104,108$. A large Skimmer ${ }^{17}$ flew past the boat and later we saw several flocks.

We expected to meet the launch from the Hoorie Mine, but as it had not yet arrived, we boarded the steamer again and went on with it to the end of its route at Mount Everard. We left Morawhanna at half-past ten in the morning and reached our destination five hours later. Although all this country is low and marshy, yet the White Mangrove and the Courida, or Red Mangrove, here give place to a variegated forest growth, and we soon saw our first Mora trees,- huge 


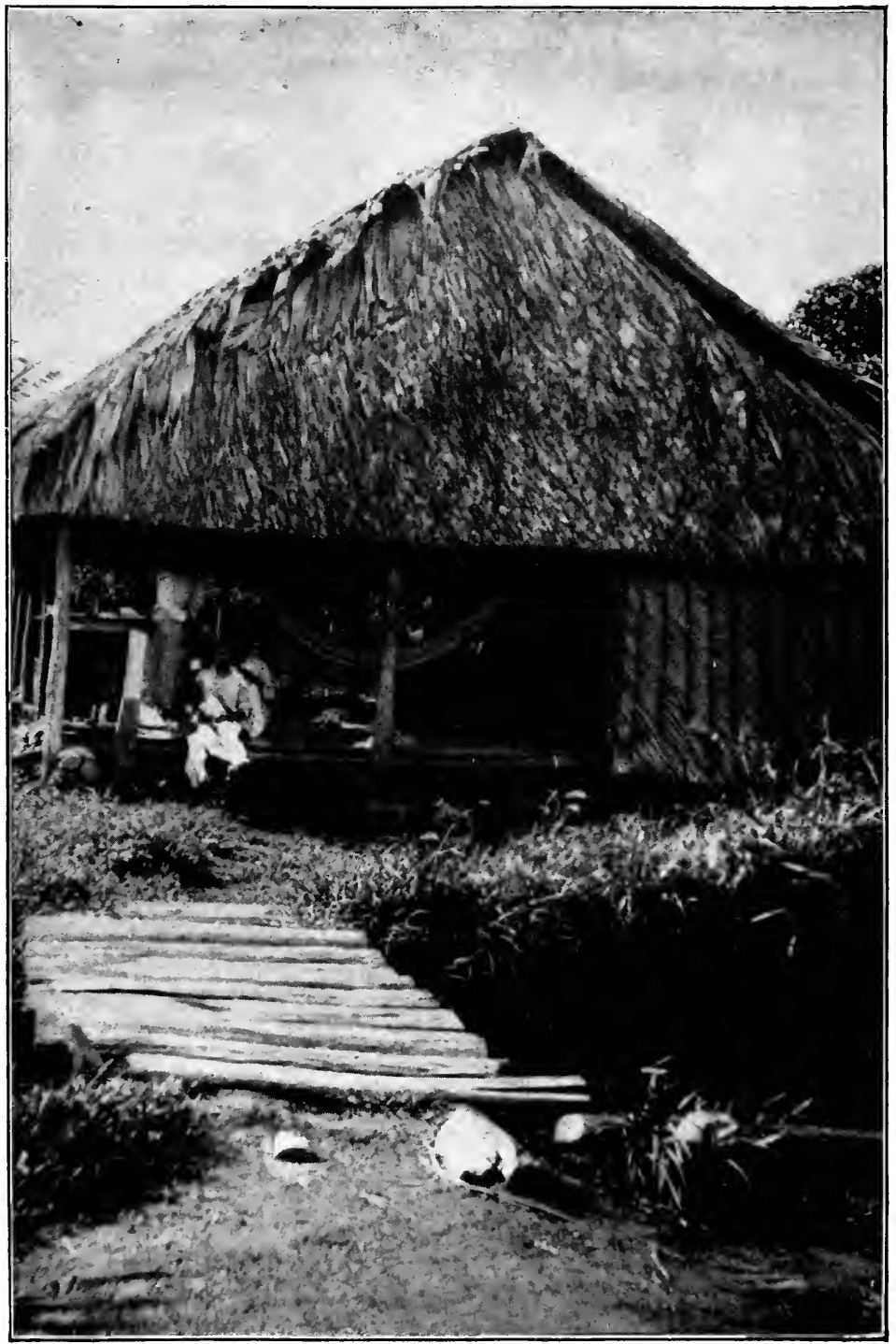

Frg. 68. 'Typical Indian House at Morawhanna. 
we thought them, but to be dwarfed by the inland giants of our succeeding expeditions. The walls of vegetation were seventy or eighty feet in height, draped by vines, while dead branches protruded here and there from the water near shore. Many Snake-birds ${ }^{48}$ were perched on these snags, from which they dropped silently into the water at our approach and swam off with body immersed.

Blue-and-Yellow Macaws ${ }^{61}$ were common - always as usual in multiples of two. We observed them a half dozen times in different reaches of the river, four in the first group, then eight, two, six, four and two. A trio of American Egrets ${ }^{32}$ kept flying ahead of us for several miles, hemmed in by the lofty walls of foliage, alighting now and then and waiting for the steamer. At last when only ten yards distant they rose and floated over our heads.

Once a splendid Guiana Crested Eagle ${ }^{57}$ flew past and alighted on a dead tree, and twice we saw small colonies of Yellow ${ }^{151}$ and Red-backed ${ }^{152}$ Cassiques nesting in isolated Mora trees out in the water; a new method of protection on the part of these intelligent birds. At occasional intervals a nesting pair of White-throated Kingbirds ${ }^{108}$ was seen, but no other of the Tyrants which are so common about houses in this region. The event of the day came when we caught a flash of white from a Buzzard floating high overhead and our stereos showed a King Vulture ${ }^{50}$ circling slowly around, craning his wattled head down at us as he drifted past. We had never expected to see this bird near the coast and indeed we saw no others during our entire stay in Guiana.

As we steamed past a wind-break we caught a momentary glimpse of two wee naked Indian children paddling away in a wood-skin while behind them their bronze-skinned parents watched us silent'y.

Mount Everard lies about fifty miles from Morawhanna up the Barima River and consists of a ramshackle hotel and 
several logies - the latter being mere open sheds from whose rafters hammocks may be hung. The whole country hereabouts is low, except at this point where two small conical hills arise - one on each side of the river - bearing the highsounding names of Mounts Everard and Terminus. The forest has been partly cleared from these and we attempted to explore the neighboring country. We soon gave it up as the underbrush was too thick, and even when we forced a way

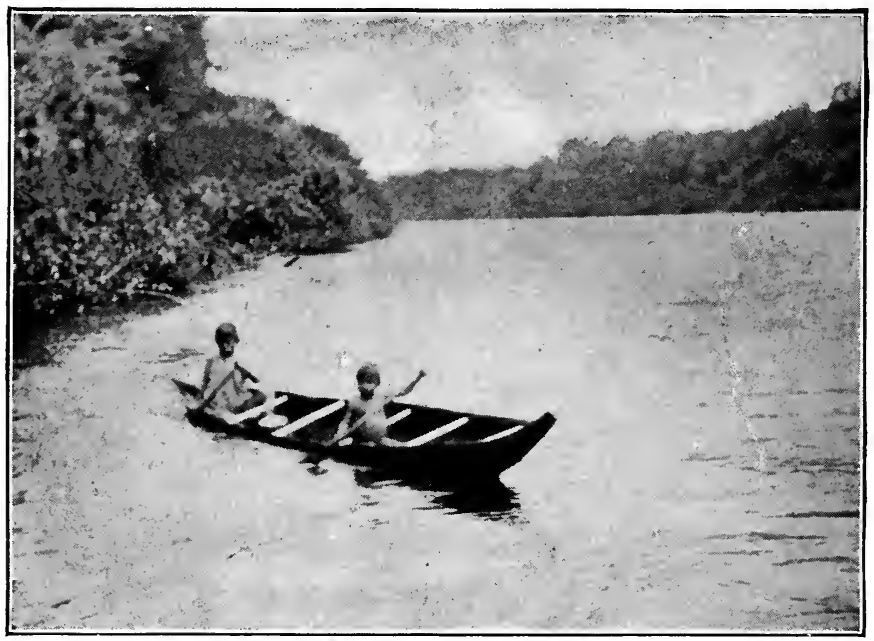

Fig. 69. Three-Year Olds at Homs in their Wood-Skin.

through it there was no footing but muddy water. Cowpaths led over the "mounts" which seemed to be composed of red, sticky clay. Half way up Mount Everard we found an enormous terrestrial ants' nest, some fifteen feet across, bare of vegetation and with well-marked roads, four to six inches wide, leading out into the jungle. A little prodding with a stick brought out scores of huge-jawed soldiers (Atta cephalotes).

The most interesting birds were the well-named Magpie 
Tanagers which flashed past now and then. The long, graduated tail, the glossy black and white plumage and the conspicuous white iris mark this as one of the most striking of the Tanagers. The call-note was loud and harsh but the tones of those we saw in captivity and of one individual which we brought back alive were pleasant and modulated.

Euphonias, Blue, ${ }^{143}$ Palm, ${ }^{144}$ and Silver-beak ${ }^{146}$ Tanagers and Red-underwing Doves ${ }^{10}$ were all nesting close to the settlement, while in a good-sized tree whose branches were brushing against the "hotel "windows were some hundred nests of Cassiques - the Red ${ }^{152}$ and the Yellow-backed ${ }^{151}$ in about equal numbers. When the two were seen fighting, the Red-backed seemed invariably to have the better of it. The natives here think the different colors mark the two sexes.

Just before sunset the wharf at Mount Everard began to show signs of life. All day it had been deserted, a few small flat-bottomed boats, which we came later to know by the native name of ballyhoos, being moored idly against the dock; but now as the day drew to a close, groups of Indians and negroes gathered. We hung over the railing of our boat and watched them as lazily and as curiously as they watched us. Then the quiet air was rent with a medley of grunts and squeals and brays, the cries and shouts of human beings rising above all the other sounds, as a large party of men appeared escorting one scrawny cow, one lean but energetic hog, and finally one donkey, in whose being was concentrated all the stubborness to which his race is heir. The problem was to load these beasts into one of the waiting ballyhoos. The ballyhoo was small, the current was moving it to and fro, and the cow and the donkey and the hog were not minded to go a-voyaging. As the negro always talks to his beast of burden as though it were his intellectual and social equal, so in this case men approached the animals with all manner of 
I4O OUR SEARCH FOR A WILDERNESS.

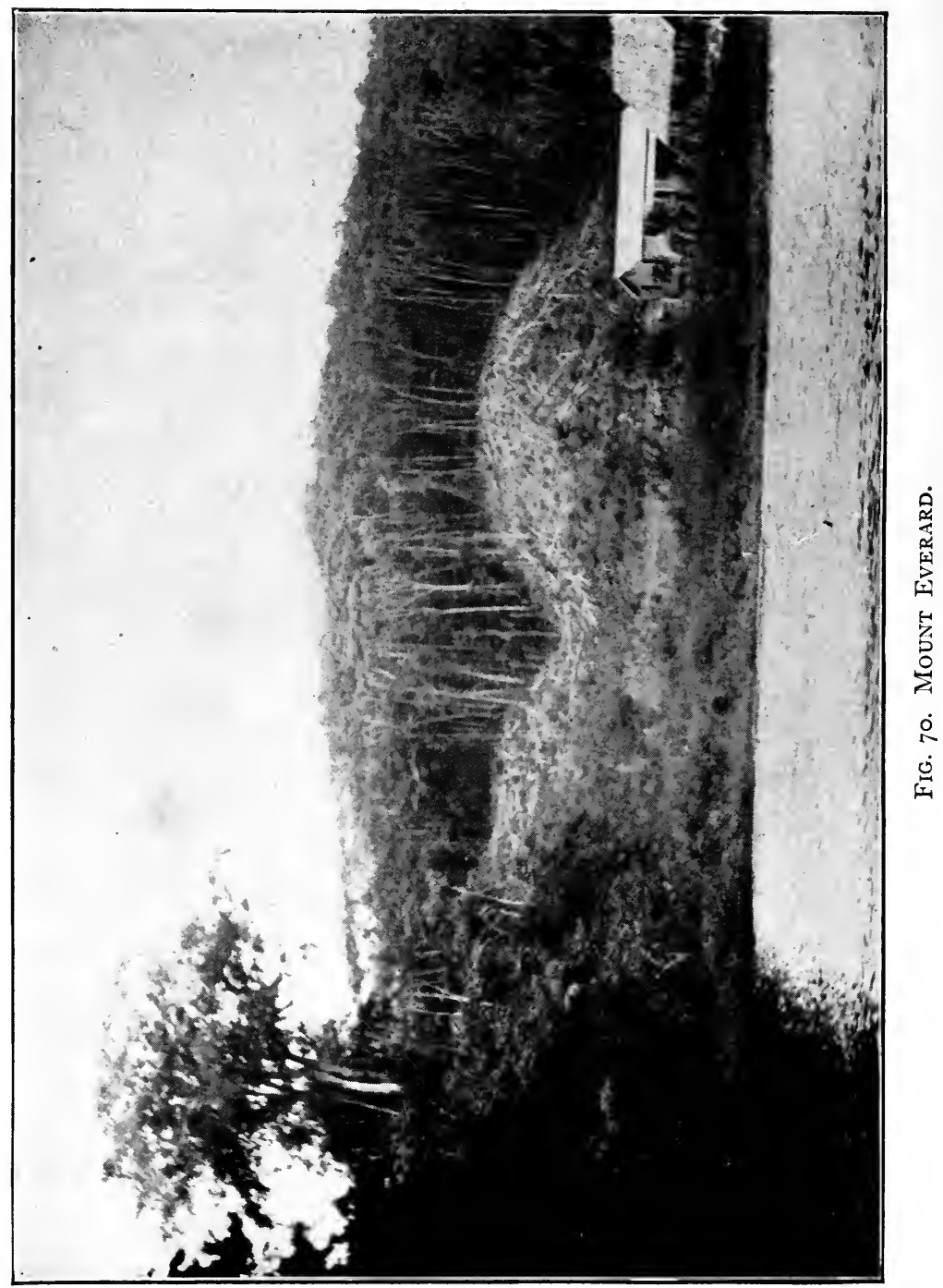


reasonable argument, explaining where they were going and the importance of an early start and appealing to all that was noble and estimable, emphasizing everything with a choice selection of expletives combined with physical force. Finally after pushing and prodding the ill-fated cow they succeeded in half shoving, half throwing it into the boat. After many struggles the loudly indignant hog followed. When at last the donkey had been safely embarked we wondered if that little craft would ever reach its destination, with so heavy and protesting a load: when to our surprise the big black, who had been most vociferous and active in the recent mêlée, wiped his dripping forehead and stood calling "Possengers! Possengers! all aboad"! with as grand an air as though he were the chief steward on a great ocean liner. The "possengers" proved to be half a dozen buxom negresses, who with many a coy glance and feminine shriek of terror allowed the big black proprietor to help them from the dock to the boat, now rocking violently beneath the restless feet of the animals.

Finally the ballyhoo moved slowly up stream, bound for a distant mine in the far interior, and another boat laden with bananas followed. An Indian paddled swiftly past in his wood-skin. Then darkness fell as suddenly as the dropping of a stage curtain; and we turned away from the river drama back to our life on board the "Mazaruni."

While awaiting the dinner bell we slung our hammocks along the deck, that through the meal we might know that they were swinging gently in the velvet night air, all ready for our comfortably tired selves.

The night was clear and the blacks worked for several hours in the moonlight, unloading cargo. Not a mosquito came to mar the beauty of the night. Indeed the natives said they were never troublesome here at Mount Everard. In our hammocks as we rocked to sleep we thought drowsily of the 
dear Venezuelan wilderness of last year. We were so glad to be sleeping again in the open under the canopy of the southern sky. At last we felt that we were on the threshold of another wilderness.

At four o'clock in the morning we awoke and heard far off through the jungle, the old, familiar howling of the red "baboons." About five a rooster crowed on board and was answered by several on shore, and this seemed to awaken a black who began singing from his hammock in a logie, when a score of others took up the wild refrain and kept it up until daylight. With the sudden rush of light came the distant bubbling of 'Twa-twas, those little thick-billed pygmy Grosbeaks, ${ }^{130}$ and the cackling hubbub of the Cassique colony.

Returning to Morawhanna we were made welcome at the home of Mr. Howie King the Government Agent, while waiting for our Hoorie launch. The government house is well built and belonged formerly to Sir Everard im Thurn. It is surrounded by a garden which must once have been magnificent and which Mr. King is attempting to restore, clearing away the undergrowth which has long overrun the beautiful shrubs and flowering plants. The house is built on the extreme southern end of a great island which extends in a northwest direction for about fifty miles far into Venezuela territory, Mora Passage lying between it and Morawhanna proper. Flowers were abundant, attracting many insects and these in turn birds of a score or more species. Kiskadees were nesting in low Bois Immortelle trees, Yellow-backed Cassiques or Bunyahs, in a great saman overhanging the house; while in the garden were Seed-eaters of several kinds, together with Blue and Palm Tanagers and the beautiful Moriche Orioles. ${ }^{158}$ Guiana House Wrens ${ }^{124}$ were nesting indoors on the ceiling rafters and under the deep eaves of the half veranda, half sitting-room was a beautiful pendent nest 
of the Feather-toed Swift ${ }^{71}$ composed entirely of feathery seed plumes. It was a straight symmetrical column about three inches in diameter and fourteen inches long, suspended from the palm thatch, not half a foot from a hanging, open-comb wasps' nest. The upper ten inches of the nest was built and occupied just six months ago in September, and a brood of

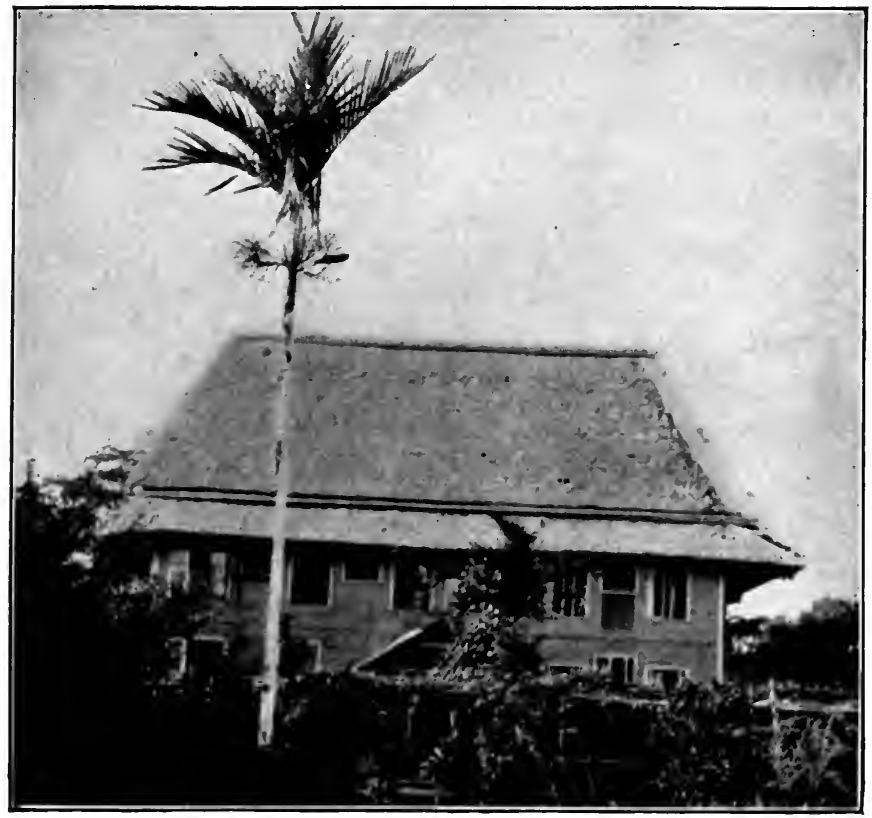

Fig. 7I. Sir Everard im Thurv's House at Morawhanna.

two young were reared. Now the birds had returned and were preparing to nest again, having already added four inches of pure white seed-plumes, easily distinguished from the older, browner, weathered portion. They came to the nest every hour with a beakful of plumes and pressed them into position while fluttering in mid air, evidently utilizing their saliva as a cementing substance. In the interims between their visits, 
Hummingbirds, - sometimes two at once - came and filched nesting material from the lower end, fraying it out very appreciably. Their nests were attached to the lesser stems of a dense clump of bamboo in the garden.

This Swift was common on all the Guiana rivers, hawking with Swallows over the water. Seen on the wing it appears glossy black with a white throat and collar.

It was the height of the season of courtship of the Palm Tanagers ${ }^{144}$ and they were noisy and bold. A caged female proved to be a source of great attraction and several wild ones kept coming to the cage. We trapped two and they made themselves at home within a few minutes. There was considerable variation, some being gray, almost a bluish gray, while in others the green was strongly dominant.

The chickens and ducks were taken by two kinds of opossums, one, large, ill-smelling and living in the bamboos, and the other very small and rat-like. Game was abundant here and tapirs, Tinamous and Guans were shot for food. The mudflats were inhabited by a host of crabs; most of them exactly like our little fiddlers, while others were larger and blue or yellow in color.

Sand-flies and mosquitoes were present in small numbers, the latter troublesome enough for hammock nets at night, but the worst pest hereabouts was the bête-rouge which abounded in the grass both at Mount Everard and here. Nowhere else did we suffer so much from the fiendish little beasts. Like sea-sickness or an earthquake, bête-rouge is a great leveller of mankind, like a common disaster doing more to make men "free and equal" than all the constitutions and doctrines ever signed. In a bête-rouge infested region the conversation is sooner or later sure to turn upon the subject of these little red mites. Everyone you meet has his or her particular pet remedy to prescribe. The subject under 
discussion may be the coolie immigration laws, or the proper scientific name for some species of orchid or who is to be the next Governor - but some sharp-eyed fellow sufferer is certain to detect the guilty look upon one's face which translated into words would be "My ankles are devoured by bêterouge!" and then the assembled company begins to discuss the topic of really vital interest.

We tried all the remedies - Scrubb's ammonia, dry soap, wet salt, wet soda, alcohol, resinol ointment, chloroform camphor, - to little purpose beyond very temporary relief. Finally we reached the stage when good manners were thrown to the winds and every victim scratched at will, despite the fact that it eventually aggravated the trouble. There was developed an individuality in the method so that at long distances we were able to recognize one another by the characteristic motions of discomfort!

Then came the discovery of crab-oil, which is an ounce of prevention and not a cure. Rubbed on before going out, no sane bête-rouge will attack you. Crab-oil is made of the nut of the crab-wood tree and it is greasy and sticky and has a disagreeable, rancid odor, which is very lasting. One of us hinted that it was a question whether the remedy were not worse than the disease. She even objected to having bottles of crab-oil rolled for safety in packing, in her very limited supply of clothing. She was promptly pronounced "finnicky" by her "better half" who was righteously indignant and surprised at discovering so unexpected a quality in her. But then he, more than anyone else, was afflicted with bêterouge; and so could not be expected to see anything at all objectionable in the odor of the crab-oil to which he owed so much relief. It does unquestionably give relief. Well protected with crab-oil one can bid defiance to the annoying little pests, which an old gentleman whom we chanced to meet in our travels persistently and seriously called "bête noir," 
under the delusion that that was their proper and very appropriate name.

Mr King's garden was a constant source of interest because of the flowers, the insects and the birds. In the top of a dead shrub a good-sized yellow flowered orchid had been tied. This, during the last rainy season, had evidently dropped seeds, some of which had clung to the branches beneath and then sprouted. When we saw them, there were twenty or more of these diminutive orchids scattered over the shrub, each with four tiny clinging rootlets, a threeparted leaflet and in the centre one blossom as big as the entire plant, the whole not larger than a shilling.

Two large species of lizards lived in the garden, the common iguana which climbed the trees and fed on leaves and buds, and another, called locally Salapenta (Teius nigropunctatus), which included carrion, chicks and even fish in its bill of fare. They would now and then dive into a small pond and appear with a small fish in their jaws.

The last evening of our stay at Mr. King's we spent sitting on the wharf looking out over Mora Passage. The ripples died from the wake of the steamer as she vanished around a bend on her way back to Georgetown. A cool refreshing breeze blew toward us as the sun's light faded and a dense flock of more than a hundred Amazon Parrots flew overhead. Our shadows changed from sharp black outlines thrown on the water before us to faint gray shapes, moon-cast on the crab-wood boards behind.

The tangle of palms and liana-draped trees across the Passage became more indistinct and the brilliant moonlight lit up the swirling brown current. An Indian boy passed silently in a narrow curiara. We were his friendswe had given him sixpence and he was off to the little store amid the low thatched huts a few hundred yards down the river, which marked Morawhanna. We knew him only as 
Frederick, for no white person would ever be told his real name - that of some animal or bird - as such disclosure is against all Indian custom, from the fear of thereby giving others evil power over them. He gave us a quick, shy, half smile, and then all light died from his Mongolian features and he peered sternly into the darkness ahead. Well had he

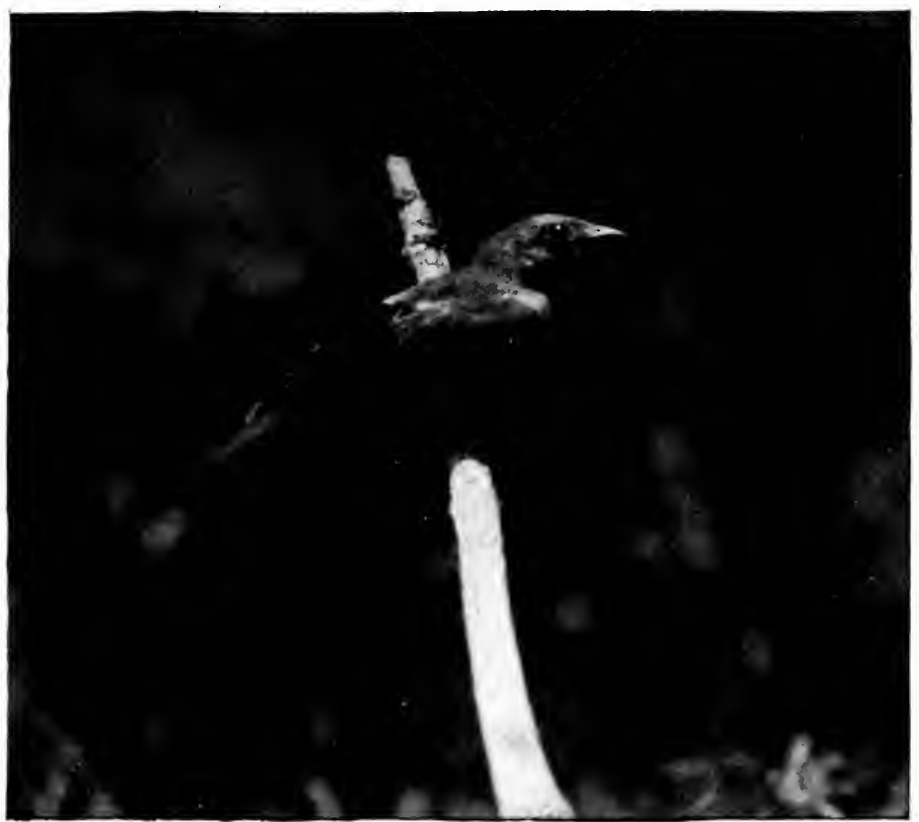

Fig. 72. Palm Tanager.

need of fear and caution. We may be sure his purchases were made stealthily and his quick return was certain, for death watched for him in a hundred places.

The day before, he had testified against three of his tribe the Caribs - for the murder of his father, and now the stern hand of English justice had closed and the chief murderer was eating his heart out somewhere in a cell beyond the 
bend of the river. No more could Frederick mingle with his tribe, and on his knees and in tears he had begged Mr. King to keep him and shelter him on the Government Island. The vendetta would follow him through life and it was almost certain he would be killed sooner or later.

The calm of the evening was perfect, undisturbed by all this hidden tragedy. When the moon was well clear of the trees, some great frog hidden in the swamp began his rhythmical kronk! kronk! kronk! and tiny bats dashed about, splashing the surface of the water as they drank or snatched floating insects.

The $y a p$ ! yap! of a passing but invisible Skimmer came faintly, and the throbbing roll of a second kind of frog rumbled out of the dusk across the river. The moonlight became ever stronger and now a Kiskadee called sleepily from his great untidy nest in the distant village. A sharp whiplash of sound came to our ears and we knew that a Parauque ${ }^{70}$ had awakened from his diurnal slumber. An answering cry sounded near at hand in the garden and we could distinguish the two connected tones. The splash of paddles announced the return of the rest of our party as an Indian woman began a droning song from the fire before her hut a few yards away.

Impatient as we were to get into the real "bush," the days at Morawhanna were delightful. From Mr. King we learned a great deal about England's government of this out-of-the-world colony. We were especially interested in the protection of the indentured coolie. In the first place the coolie labor market is never allowed to become overcrowded. Each employer sends in an order for the exact number of workmen which he requires, so that the supply brought over is never greater than the demand. The coolie gets free passage from India to South America, and is guaranteed work at a minimum wage of a shilling a day, 
including his food. On his arrival the immigration agent assigns him to a certain estate, where his term of indenture is five years, his wage being increased as his capacity for work becomes greater. During his term of service he can leave the estate only by permission, and he must never be found at large without his pass book.

At the end of five years the coolie is free to work where he pleases, or to take up a grant of land of his own. After five years more of residence he may return to India free of charge if he so wishes. As the coolie is very thrifty and can live on threepence a day, his menu being rice and water, at the expiration of his ten years, in addition to having earned his living and supported his family, he has often saved up as much as two thousand dollars.

Throughout his term of indenture the English government looks after him. He always has good medical care free, and the law watches over him with scrupulous vigilance, secing that he is justly treated by his employer, and that no advantage is taken of his ignorance and inexperience. When the coolie leaves India he, of course, loses caste, but as they all fall proportionately, each moving down one in the social scale, a proper balance is preserved. The coolie returning to India, however, finds himself a disgraced outcast. To regain his position in society he must pay large sums of money to the priests; and so it is that he returns to his native land only to be robbed of his hard-earned savings, often returning to South America as a re-indentured man, to start life again. In order to discourage his return to India, the government offers him the money equivalent to his return passage. Many of the coolies take advantage of this and make South America their permanent home, taking up grants of their own and living in greater peace and prosperity than would ever have been possible for them in India.

The population of Morawhanna is composed of coolies, 
Indians and blacks, who look to the magistrate as a sort of all powerful father to whom they bring troubles of every conceivable kind.

As we were sitting at breakfast one day an aged coolie man was seen hanging around the door. He must see Mr. King on a most important matter, which proved to be a delicate one indeed. His wife had fallen in love with another man and what was he to do? Such troubles are very common among the coolies. Instead of avenging himself upon the man who dared to alienate his wife's affections, the coolie invariably murders his wife, the favorite method being to chop her up "particularly small."

In this instance the wife was young and good looking, and her grievance was that her husband expected her to assume the entire support of him and his family, and she declared she would rather die than go back to him. The only solution of the problem was to hurry the woman off on the afternoon boat to Georgetown, in order to save her from murder and her husband from execution.

They are all very fond of bringing their wrongs into court. An irate Indian woman will appear, bringing a charge against the dressmaker who has made her wedding dress too short. Dress of any description is the most recent of acquisitions with the Indian woman, but having acquired it she intends that her wedding gown shall fulfill all the requirements of Dame Fashion, so far as she knows them.

The gown in question has been brought into court as incontrovertible evidence. Should she not put it on and prove to the magistrate, who cries in despair that he knows nothing of the proper length of wedding gowns and calls in another dressmaker for expert opinion. The two dressmakers stand together and the case is dismissed. This is quoted to show the infinite patience with which the magistrate treats each case, however trivial. 
The commissioner of health brings a charge against a coolie man, on the ground that he has allowed the drains near his hut to become clogged and so endangered the Public Health. Mr. King reads the indictment in impressive, magisterial tones, accusing the offender of having permitted his drains to become foul. Foul is evidently the one word which conveys any meaning to the coolie, who exclaims in a tone of relief that he has never kept any "fowls"! In British Guiana the arm of the law must have a sense of humor as well as of justice!

We often wondered what was going on behind the impassive face of little Frederick. Did he live in constant terror or did he sometimes forget it all in the light-hearted pleasure of a child? The man convicted of his father's murder was a peaiman - or medicine man, who is held in great awe and reverence by his tribe. So Frederick's betrayal was doubly criminal in the eyes of the superstitious Indians.

Frederick had been brought down to Morawhanna at Christmas - a little naked savage knowing not a word of English. When at a loss for a word he always fell back upon the civil "Sir" which Mr. King had taught him. As white women were rare in Morawhanna he had never learned the feminine of "Sir." It was very amusing to see him serving at table, going all around asking with great dignity, "What will you have, Suh?" regardless of the sex of the guest. Mr. King had taught him to knock before entering a room. He was childishly delighted with the new accomplishment and knocked on both entering and leaving the room. We discovered that he had spent our sixpence on a belt which it seems was the desire of his heart - already so sophisticated!

The dazed stoicism of the convicted Indian was infinitely pathetic to us. This terrible thing called the Law is so incomprehensible to him. He cannot understand it. When 
a convicted comrade is taken down to Georgetown to execution, his friends and family realize only that he has gone away in a boat to some mysterious place from which he never returns. As far as the moral effect of an execution is concerned, there is none.

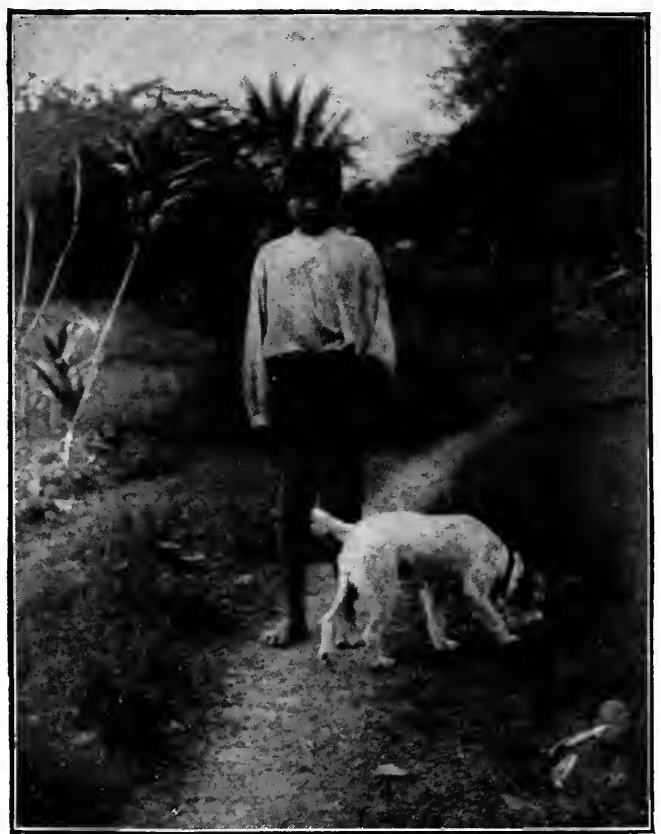

Fig. 73. Frederick, the Carib Indian Boy.

Into the absolutely natural life of the Indian, with the simple and perfectly comprehended tribal laws, has come so much that is confusing; - the new religion, the relations of the laborer to the employer, the wearing of clothes and the strange and powerful law. The Indian is a creature of the present moment, instantly acting upon every desire, working when he wishes to work, and quietly dropping 
all work and departing when he so desires. What can he - the creature of Nature - know of all this puzzling civilization?

At noon on March 6th we embarked on the three days' tent-boat journey from Morawhanna to Hoorie Mine. A thirty-foot launch was the motor power and alongside this the big tent-boat was lashed, while several Indians hitched their wood-skins behind as boys hitch sleds to a passing sleigh.

The baggage was stored fore and aft and, perched on a pile in the bow, we prepared for our first real day of observation along the rivers of the Northwest. We retraced our way northward through Mora Passage, frightening as we went, a flock of seven Scarlet Ibises. ${ }^{27}$ They kept close together and were evidently a single family, as two were in fully adult plumage, while the others were only three quarters grown, and feathered wholly in brown and white.

About three o'clock in the afternoon we reached the Waini River, but instead of turning toward the mouth and the open ocean which we could see to the northwest, we steered eastward up stream. Although the outlet of several large rivers, the Waini, in its lower reaches, is little more than a great salt water tidal inlet, or caño.

At Mora Passage the Waini is about two miles wide and through the choppy waters of the falling tide we steered straight across to the north shore. Between the waters of this river and the ocean extends a long narrow strip of marshy mangrove, for at least forty miles. Both the White and the Red Mangrove are found here, the latter predominating, and this is the breeding sanctuary of the hosts of birds which haunt the mud-flats at low tide and fill the trees with a gorgeous display of color when the feeding grounds are covered at high tide. 
For the next three hours we were enchanted by a constantly changing panorama of bird life, which in extent and variety can seldom be equalled elsewhere.

While crossing the Waini several Swallow-tailed Kites ${ }^{58}$ soared screaming overhead, occasionally swooping past for a nearer look at us. As we skirted the great mangrove forest, birds flew up ahead, few at first but in constantly increasing numbers, until several hundred were in sight at once. They showed little fear and were apparently content to vibrate slowly along between launch and shore, accompanying us for fifteen or twenty miles.

By far the greater number were Little Blue Herons, ${ }^{34}$ the pure white immature and the slaty blue adults being equally numerous. The latter were very inconspicuous among the foliage, while the former stood out like marble statues against green velvet. The coloring showed great asymmetrical variation, and one young bird with a single blue feather in the right wing was so tame that it kept almost abreast of our flotilla. The irregularity of moult resulted in most remarkable patterns, as in several birds, each of which had one white and one bluish wing.

Half a dozen Yellow-crowned Night Herons ${ }^{36}$ were seen and twenty or thirty of the ill-named Louisianas. ${ }^{35}$ A few Great-billed Terns ${ }^{14}$ accompanied the herons and later in the afternoon we began flushing Snowy Egrets ${ }^{33}$ in ever increasing numbers. No American Egrets were seen. All along the coast were small flocks of Scarlet Ibises, ${ }^{27}$ from three to thirty in number, and in an hour we had driven together no less than four hundred. The majority were full plumaged birds clad in burning vermilion, but many were young in moult. We secured a young female in an interesting condition of moult. In the stomach were found the two chelæ or claws of a small crustacean, each about one-third of an inch in length. The wings were wholly of the immature 
brown, except for one tiny under-edge covert in the right wing. The back, lower breast and under tail-coverts were fairly scarlet and active moult was in progress on the head and neck.

We know that in captivity these birds fade out, usually in a single moult, from the most vivid scarlet to a pale salmon hue, but as to the cause we are still in the dark. The same is true of American Flamingos and Spoonbills. During this trip we made certain of a fact which helps slightly to clear this problem - this being that Scarlet Ibises fade as quickly and completely when in captivity in their native country as in the north. This is confirmed by many birds kept formerly in Georgetown and also on the Island of Marajo at the mouth of the Amazon.

We have noticed an interesting fact in regard to this fading out of birds in captivity. Whether the salmon tints appear in the first moult, or more gradually in several, the lesser wing-coverts and the upper and under tail-coverts are the last to loose the scarlet color, retaining it sometimes for five or six years. These feathers in the nearly related but pale Roseate Spoonbill are those which are normally scarlet, and this resemblance may be more than a coincidence.

About four o'clock we were surprised to see a large black and white bird with long gray beak and red legs fly up from a mud-flat ahead and swing outward and around us. The glasses showed a Maguari Stork ${ }^{29}$ in full breeding color; even the red caruncles around the eye and the long, filmy neck feathers being visible. We had never expected to see the bird away from the pampas of the interior and the sight of the splendid Stork was most exciting. It is almost as large as the Jabiru, white with black wings, scapulars and tail and is one of the most picturesque of the larger waders.

We have had a pair of these birds alive for some time and have observed a curious thing about the tail. The real tail- 
feathers are forked, swallow-like, while the intervening space is filled up with the long, stiff under tail-coverts. In flight the whole are spread, making a parti-colored fan of some eighteen feathers instead of the usual six pairs. These under tail-coverts are a full inch longer than the regular tail feathers and seem to be usurping their function.

Two old friends of northern waters appeared in small numbers, Ospreys ${ }^{59}$ circling about high in the air with now and then a meteor-like dive, while Spotted Sandpipers ${ }^{22}$ looped from one headland to another ahead of us.

At half-past four in the afternoon we had our first sight of the great flocks of birds which seem characteristic of this season. Quite high in air, clear of the tops of the tallest trees we saw a black cloud of birds approaching. We soon made them out to be Greater Anis, ${ }^{79}$ or as the natives called them "Big Witch" or "Jumbie Birds." When first seen they were in a dense, compact mass headed straight toward us.

Their flight was uniform, each bird giving three to six flaps and then sailing ahead for several seconds. Hundreds doing this at once made the sight a most striking one, while it was enhanced by their long, wedge-shaped tails, high arched beaks, bright yellow eyes, and the iridescence of their dark plumage as the slanting rays of the sun struck them. We counted up to a thousand in the van and then gave up - there were at the very least four thousand birds in the flock.

The approach of the puffing launch and our great escort of Ibises and Herons disconcerted them and the entire company broke up, most of them descending, turning on their course and fleeing ahead of us for several miles. Their mode of flight changed completely, the birds flying close to the water, barely skimming its surface and swinging up every few yards to alight on a low branch.

A piece of wood thrown among a mass of them would cause great dismay, and they dashed down into the nearest foliage 
as if a Hawk had appeared. Little by little they drifted past, flying rapidly near shore, and continuing in the direction which they had originally chosen. A few of the birds were moulting, but by far the greater number were in perfect plumage.

The flock had the appearance of being on some sort of migration rather than assembling at a nightly roost. About Georgetown and the settlements and clearings in general, this Greater Ani was much rarer then the small Smooth. billed species, ${ }^{80}$ twenty of the latter being seen to one of the former. These aberrant Cuckoos are most interesting birds and several females are said to combine, building a single hollow nest of sticks in which the eggs are hatched.

Hardly had the last Ani passed out of sight when a second cloud of birds appeared far ahead, and before we had approached near enough to identify them a shrill chorus came to our ears; a horde of Blue-headed Parrots ${ }^{65}$ were on their way up the coast. They behaved in much the same way as the Anis, but were more numerous: an estimate far below the truth gave eight thousand. Closely massed though most of them were, yet the eternal two and two formation of the tribe of Parrots was never lost, and even when the vanguard, terrified by our puffing launch, whee'ed and dashed back through the ranks behind, each Parrot flew always close to its mate. Once later on, when only a few scores were left near us, we saw several perched in a bare tree close to a Hawk, like a Sparrow Hawk in size, but neither species paid any attention to the other's presence.

The Parrots screamed unceasingly and near the main body the noise was terrific - a shrill deafening roar, as from a dozen factory whistles. Until long after dark they flew back and forth around us, sometimes attempting to alight in a tree and falling from branch to branch almost to the water, before securing a foot or beak-hold. For several hours perfect pandemonium reigned around us. 
Whether these two phenomena of flocking birds indicated merely a nightly roosting habit or an actual, more or less local migration, they were of the greatest interest, and spectacular in the extreme. Our opinion inclines decidedly toward the latter theory, as they both differed greatly from the regular roosting flights which we observed elsewhere.

Long after dark, about nine o'clock, in the faint light of the cloud-dimmed moon, we caught glimpses of occasional ghostly forms flitting silently past, and when we flashed our powerful electric light upon them, the feathered ghosts would emit frightened squawks; revealed as Snowy Egrets or young Blue Herons. Here and there among the mangroves, large lightning bugs flashed. At last we rolled up in our blankets and slept on the thwarts, to dream of the unnumbered legions of Anis and Parrots far off behind us in the blackness of the mangrove jungle.

In a soft steady rain we steamed all next morning up the Waini, seeing few signs of life, except three Toucans which flew across at Barrimani Police Station. At noon we reached Farnum's at the junction of the Waini and Barama rivers. Mr. and Mrs. Farnum live in a small house perched on the very summit of a symmetrically rounded hill - the first elevation we had seen in this flat region. There is a tiny store at the foot of the hill, and a saw-mill, and in the grass of the clearing, bête-rouge lie in patient wait for the passer-by. Mrs. Farnum told us that "Hummingbirds" flew into the peaked roof of the house almost every day and died. The natives call by this name all the species of Honey Creepers, and a Yellow-winged ${ }^{136}$ male was picked up from the floor during our visit.

We found later that this was such a common occurrence that in almost all the houses there were instruments for getting rid of the bewildered, fluttering birds. The more cruel used only a long stick with which the birds were struck 
STEAMER AND LAUNCH TO HOORIE CREEK. I 59

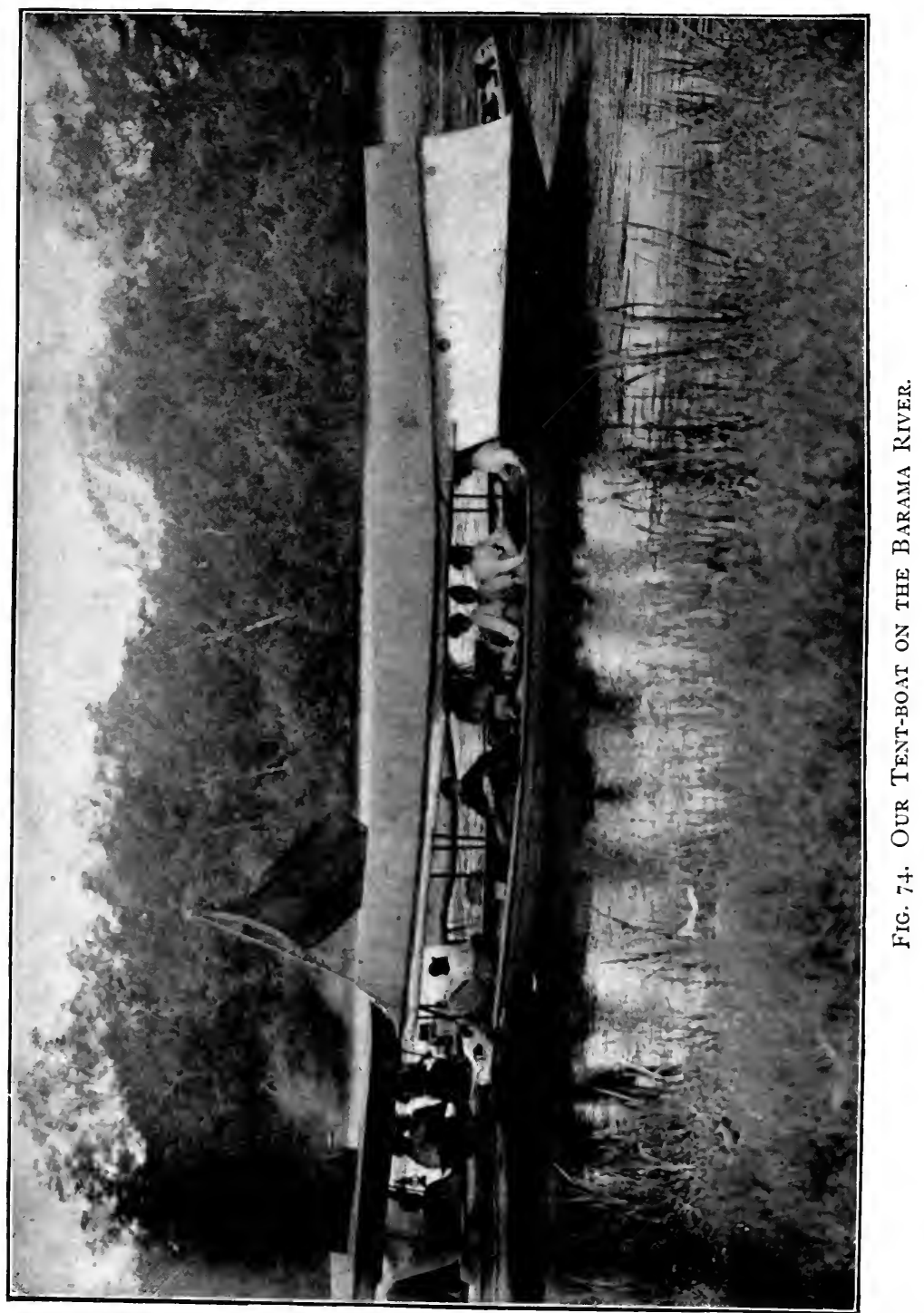


down, but the more humanely inclined had nets on the end of long poles. As many as seven Honey Creepers are occasionally entrapped at one time. They do not seem to know how to fly toward light and liberty after getting up among the dark rafters.

The fauna of this exceedingly marshy region was different from that higher up. Agoutis and pacas are abundant but capybaras do not come this side of Barramanni Police Station. Deer and peccaries are very rare. Jaguars are unknown but ocelots are occasionally found, a young one having been killed under the house at Christmas. It lived in a burrow and took a chicken each night until it was killed.

Many fish were seen playing about the tent-boat as it was tied to the wharf, and among others were scores of small pipe-fish. Mr. Crandall caught a small round sun-fish-like form, brilliantly colored and with a most wicked looking set of triangular teeth. As he was about to take the fish off the hook it deliberately twisted itself in the direction of his hand and bit his finger, taking a piece out with one snip of its four razor-like incisors. This was our introduction to the famous Perai or Carib Fish (Serrasalmo scapularis) which seems to fear nothing, man, crocodile or fish, and a school of which can disable any creature in a very short time.

At this point we left the Waini and turned off into the Barama. We had followed the Waini day and night for about sixty miles, until, from a stream of two miles or more in width, it had narrowed to little more then one hundred yards.

We left Farnum's at three in the afternoon and steamed slowly up the Barama for twelve hours, tying up to the bank from three to seven in the early morning. We slept but little, for the strange wonderland which opened up before us. At nine o'clock the full moon rose and the beauty of the wilderness became indescribable. In the north - along the 
rivers of the Canadian forest - the spruces and firs are clean-trunked, tapering to tall, isolated, symmetrical summits. Here the very opposite conditions exist; solid massive walls of black foliage, with almost never a glimpse of trunk and bark. Most characteristic are the long, slender bushropes or lianas. In the forest they are thick, gnarled and knotted; there we get the vivid feeling of serpentine struggles in the terribly slow but none the less remorseless striving for light and air, but along the rivers the lianas are pendent threads or cables - straight as plummets and often a hundred feet in length. These give a decorative aspect to the scene unlike any other type of forest - temperate or northern.

In the moonlight the appearance of the walls of foliage is like painted scenery. Their blackness and impenetrability give a feeling of flatness and the summit outlines are crudely regular. The dominant sound at night along the Barama was a sweet tinkling as of tiny bells, all in unison and harmony, but with a range of at least four half-tones. The tree-toads clinging here and there to leaves and flowers throughout the jungle fill this whole region with the melody of their chimes; striking the minutes as if with a thousand tiny anvils, and only too often leading some enemy to their hiding places.

We woke at early dusk and climbing out upon the bow of the tent-boat watched the coming of the tropical day. The medley of fairy bells was still bravely ringing, but as the dawn approached, the little nocturnal musicians ceased tolling and the chorus died out with a few faint, final tinkles. Six o'clock, and the sunshine upon the tree-tops brought a burst of sound from the Woodhewers, a succession of twelve to twenty loud, ringing tones in a rapidly descending scale Canyon Wren-like and taken up continuously from far and near. The very tang and crispness of the early dawn seemed to inspire the quality of their notes. 
As soon as it was light, Swallows were seen in numbers, small, dark steel-blue in color with a striking band of white across the breast. These beautiful Banded Swallows ${ }^{118}$ kept at first to two levels in the air; close to the water, fairly skimming its surface, and high up above the tallest trees marking I suppose the early morning distribution of gnats and other insects. Most delicate and fairy-like they appeared when perched on some great orchid-hung dead branch protruding from the water.

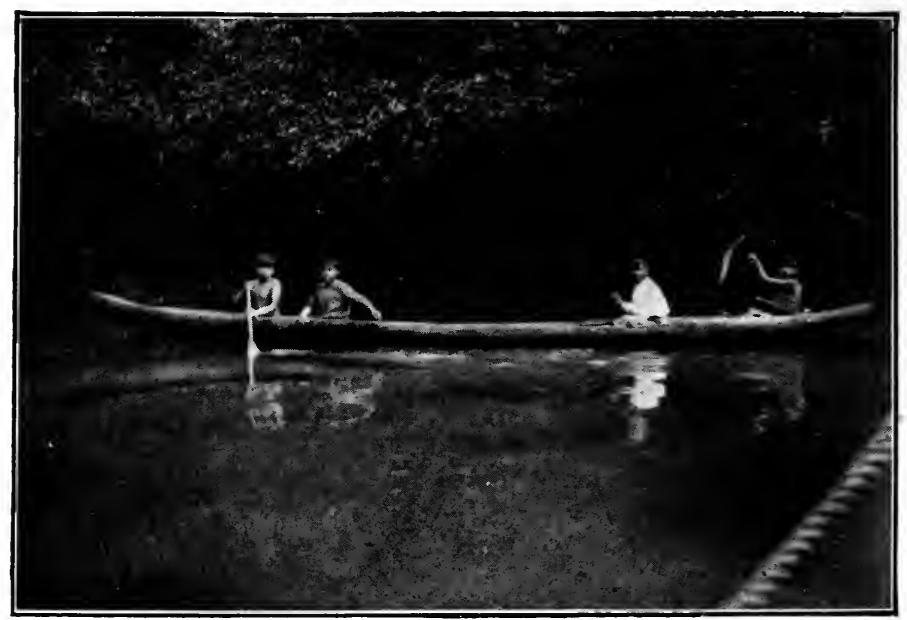

Fig. 75. Indian Boys IN Dug-out.

We can find no adjectives to express the beauty and calm of the cool, early morning on these tropical rivers. Myriads - untold myriads - of leaves and branches surround us like the lofty walls of a canyon. We have used the words wall in this connection many times and no other word seems to be so suitable. All sense of flatness is lost in the light of the dawn; and instead we see these living walls now as infinitely softened; but still the eye cannot penetrate the intricate tangle. Not a breath of air stirs the smallest leaf. It is like the fairy river 
of an enchanted country - all Nature quiet and resting with only the brown current ever slipping silently past, here and there foam-flecked or bearing some tiny aquatic plant with its rosette of downy leaves.

Then, - the lush tropical nature rushing ever to extremes - comes a deluge of virile life upon the scene. A great fish leaps far upward, shattering the surface, pursued by a fierce, brown-coated otter, almost as large as a man. A half dozen green Parrots throb screaming past in pairs; two big Redbreasted King-fishers ${ }^{67}$ spring from their perch and come leaping toward us through the air, suddenly wheeling up almost in a somersault and down like two meteors into the water.

We leave our bushy moorings at last and keep on up the river with the tide, passing the English mission of Father Carey-Elwis, which, like Farnum's, is built on a hill, isolated amid the great expanse of flat marshy jungle. A dozen little naked Indian lads shriek in sheer excitement and rush down to the water's edge to watch us pass, peering fearfully out from behind trees like little gnomes.

From here on butterflies became very abundant; many large Yellows and Oranges and Morphos of two kinds, one altogether iridescent blue, the other blue and black. As the little vocal messages of the tree-frogs are carried far and wide through the jungle at night, so in the sunshine the morphos, like heliographs of azure, flash silently from bend to bend of the river. Conspicuous among the great Mora and Purple-heart trees were the white-barked Silk Cottons. Large yellow tubular blossoms and masses of purple pea blooms tint the trees here and there.

The Indians along the river were catching two kinds of fish; one a silvery mullet about six inches long called Bashew, and a catfish of the same size. The latter was most formidable in appearance but actually harmless. Four slender 
barbels of medium size depended from the lower jaw, while two pigmented ones extended forward from the upper jaw and were so long that when pressed back they reached to the tail.

Rain fell irregularly during the day, but so gently and so softly that we hardly knew when it began and when it ended. It never chilled but rather refreshed. About noon a third migrational flocking of birds was noticed; seventy-two large South American Black Hawks ${ }^{55}$ circling slowly around, setting their wings after a while and sailing off to the west as one bird.

The action and reaction among the vegetation was often as striking as among more active organisms. Where parasitic aërial roots had descended seventy or eighty feet and touched the water near shore, vines had somehow managed to reach out and throw a tendril about the roots, take hold and climb circle upon circle to the top. The palm trees alone of all the forest growth seemed universally free from parasitic plants and climbing vines.

Above the mission, coincident with the increase of butterflies and the appearance of occasional sand-banks, palm trees disappeared without apparent reason. The river narrowed as we ascended until it was only fifty yards across and the bends increased in angle and number. Now and then we passed a cut-off where the stream had cut through one of its own bends and made a new bed for itself.

A small opening in the wall of verdure was hailed as Hoorie Creek and, dropping behind the launch, we were towed a mile or more up its tortuous length, now and then running aground or rather "atree," as it was only thirty feet wide and as sinuous as a serpent. We tied fast to a big overhanging tree which marked the end of our journey by water and, all excitement, leaped ashore. 


\section{CHAPTER VI.}

\section{A GOLD MINE IN THE WILDERNESS.}

WE loaded our tin canisters, clothing bags, guns and cameras on a cart which was waiting and set out along the bush trail, three and a half miles to the gold mine. The trail led through a great swampy forest with a clear brook occasionally crossing it, and for the sake of the wagon which had to transport all supplies, it was corduroyed in the worst places with small saplings or quartered trunks. We had all donned cheap tennis shoes which proved on this and all later occasions to be perfect footwear for the tropics. The rubber soles allow one to obtain sure footing in slippery places and a wetting matters nothing. If one walks far enough the shoes dry on one's feet, or at camp a new pair may be slipped on in a moment and next day the old ones are none the worse for the soaking. Here snake-proof and water-proof shoes are as useless as they are uncomfortable.

It was amusing to see how quickly the regard for mud and water left even those of our party who were taking their first dip into the real "bush." For the first few yards all picked their way carefully. There was even a pair of storm rubbers leaving its checkered print on the forest mould! Then some one stepped on the loose end of a corduroy sapling which rose in air and fell with a sharp spat. Everyone dodged the shower of mud and straightway went over ankles in water. The cool fluid trickled between our toes and we all laughed with relief. The rubbers found an early grave in the mudhole and we all strode happily along, wishing we had a hundred eyes, to see all that was going on around and above us. 


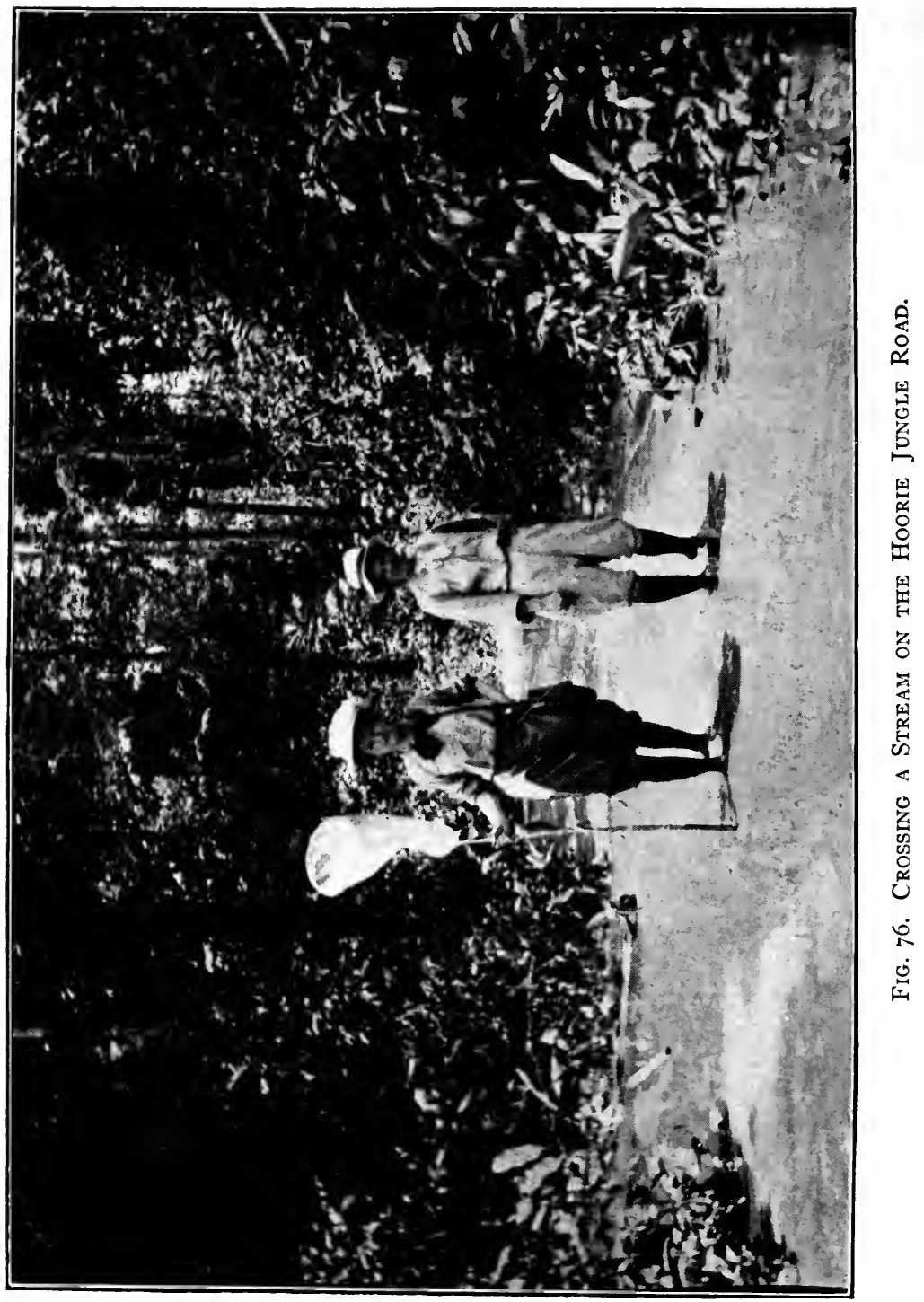


A perfect medley of calls and cries came from the tree-tops high overhead as we tramped along. In places the trees were magnificent, looking like a maze of columns in some great cathedral, roofed over with a lofty dome of foliage. On this first walk the final impression was of a host of strange sights and sounds, a few of which we were able to disentangle on succeeding days. We had poured over Waterton, Schomburgk and Bates but we realized anew the utter futility of trying to reconstruct with pen and ink the grandeur and beauty, and forever and always the mystery, of a tropical forest.

Then from the heart of the wilderness we came suddenly upon man's handiwork; the tiny, twenty acre clearing of the gold mine. On the outskirts of the forest were the frail, frond-roofed shelters which marked the homes of the Indians and the rough mud and thatch huts of the black laborers. A dam was thrown across the narrow valley and on the rim of the jungle lake thus made, was the powerful electric engine. This great thing of vibrating wheels and pistons seemed strangely out of place in the wilderness. As we watched, it seemed to take on a semblance of dull life. Stolid-faced, naked Indians fed it vast quantities of cord wood, and in return it sucked up a great pipeful of water from the lake. The pipe lay quietly on trestles, winding up and around a low hill out of sight, giving no hint of the terrific rush of water within.

Following the pipe line we turn a sudden corner on the hill-top and the heart of the clearing lies at our feet. At the end of the pipe, far below, a man stands, barely able to guicle and shift the mighty spout of water which gushes forth. Half the hill has been torn away by the irresistible stream, which shoots upward in a majestic column and dashes with a roar against the cliff of clay and rubble. The ever-widening gorge which the water has eaten into the hill glows in 
the sunlight with bright-colored strata. On each side the red clay is dominant, while between runs the strip of pale gray which holds the precious nuggets.

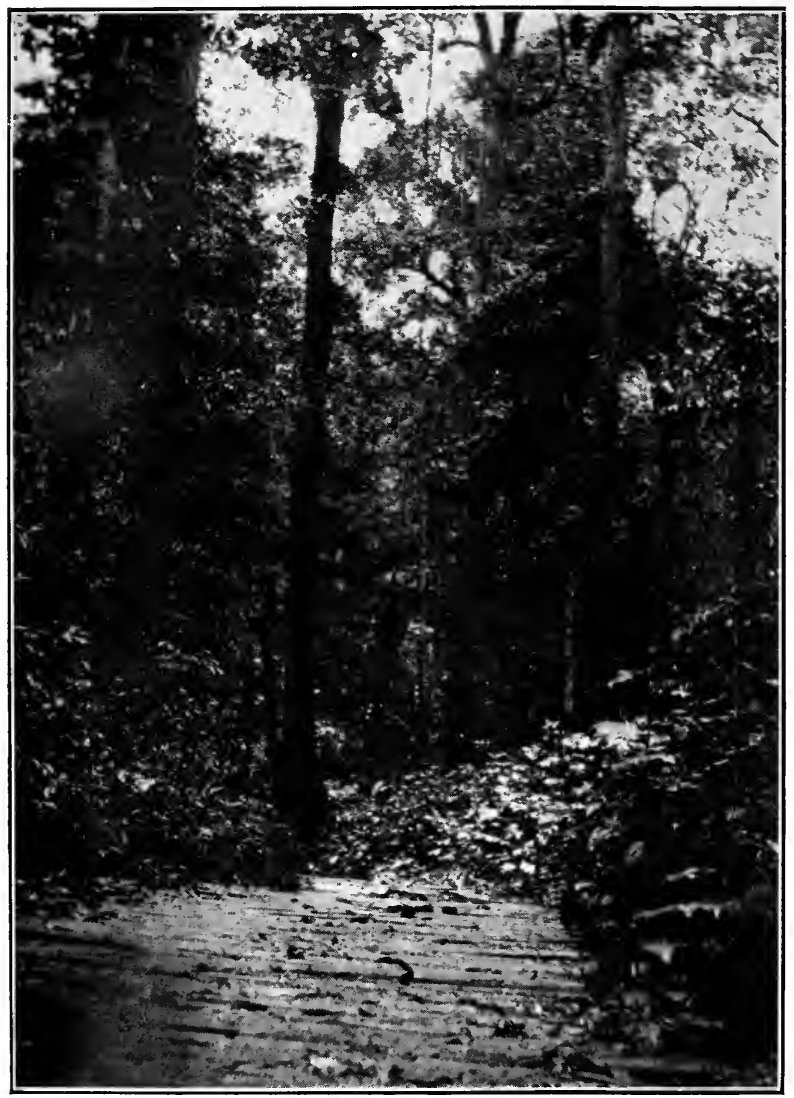

Fig. 77. The Wilderness Trail.

It is an ochreous clay carrying free gold. The rock is in place and perfectly decomposed to a depth of seventy-five or one hundred fect. This decomposition is the result of the constant infiltration of warm rains carrying carbonic 
acid and humous acids from the rapidly decaying tropical vegetation. Through the clay are scattered nodules of impure limonite.

In a tumbling, falling mass the muddy water washes back upon its path, confined in a trough under the pipe, and as it goes it gives up its yellow burden. As the grains and nuggets drop to the bottom they touch the mercury and behold! to the eye they are no longer gold but silver!

As we had been impressed by the grandeur of the forest, so we now began to see the romance of the wonderful gold deep hidden beneath the centuries of jungle growth. Gold, which we had known only in form of coin or ring, now assumed a new beauty and meaning. Here, amid the great trees, the beautiful birds and insects, the Indians as yet unspoiled by civilization, one could thoroughly enjoy such "money-making." One hears of gold mines all one's life, but until one actually sees the metal taken from its resting place where it has laid since the earth was young, the word means but little.

Beyond the golden gorge with the roaring "little giant" ever filling it with spray, was a second hill topped with the bungalow which we were to call home. Beyond this the jungle began again.

After a delicious shower-bath we slung our hammocks on the veranda and sat on the hillside in the moonlight for an hour or more, watching the nig'th shift at work, one or two men guiding the stream beneath flickering arc-lights, others puddling the down rushing torrent. Just beneath us in the dark shadow of a bush lay the coolie night watchman, with the inscrutable face of his race, keeping watch over the long, snaky flume, at the bottom of which the quicksilver was ever engulfing the precious metal.

Later we slept the dreamless hammock sleep of the tropics, lulled by the dull droning roar of the water dashing against 
the clay - a sound which echoed through the jungle and gained in volume until we drowsily knew we were listening to the howling of the red baboons. Even this invasion of man merged harmoniously with the sounds of the wilderness.

\section{LIFE ABOUT THE BUNGALOW.}

We remained at Hoorie just seven days - only long enough to begin to look beneath the surface and realize what a veritable wonderland it was for scientist or nature lover.

On the last day of our stay we wrote in our journal; "Hoorie is a perfect health resort; temperature good*; no mosquitoes; food excellent; splendid place for laboratory work; interesting insect life superabundant; birds and lizards abundant; snakes rare; perai, electric eels and manatees in the creek; peccary, deer, red howlers, armadillos, sloths and ant-eaters within short distance of bungalow." What more could be asked?

The bungalow was a well-built house with wide veranda, perched on the cleared summit of a low hill sloping evenly in all directions; the thick bush and shrubby undergrowth beginning about one hundred feet down the hillside.

We shall not attempt to describe or even mention the many varieties of creatures which haunted the clearing, but leaving these for our scientific reports, we shall speak only of those which are especially interesting.

When one enters a vast forested wilderness such as this, and makes a good-sized clearing, the inmates of the forest are bound to be affected. The most timid ones flee at the

* The average daily temperature during our stay was as follows :

$\begin{array}{rlll}6.30 \text { A.M. } & 68^{\circ} & 2.00 \text { P.M. } & 81^{\circ} \\ 7.30 & 71^{\circ} & 5.00 & 74^{\circ} \\ 8.00 & 72^{\circ} & 7.00 & 73^{\circ} \\ 10.00 & 76^{\circ} & 9.30 & 71^{\circ} \\ 12.00 & 77^{\circ} & & \end{array}$


first stroke of the axe; others, swayed by curiosity, return again and again to watch the interlopers. A third class, learning somehow of the new settlement, come post haste and make themselves at home. These are chiefly birds, which, seldom or never found living in the heart of the jungle, are as keen as Vultures to spy out a new clearing. They must follow the canoes and trail, else it is impossible to imagine how they learn of new outposts - whether a simple Indian hammock shelter and cassava field, or a great commercial undertaking such as this gold mine.

To begin with the birds, the Hoorie clearing possessed two pairs of Blue, ${ }^{143}$ three pairs of Palm, ${ }^{144}$ and five pairs of Silverbeak ${ }^{146}$ Tanagers, besides six Blue-backed Seedeaters. ${ }^{131}$ None of these are forest birds and all nest in brushy places.

The Blue Tanagers are clad in delicate, varying shades of pale blue; the Palm Tanagers in dull olive green, but both make up in noisy sibilant cries what they lack in color. The Silverbeaks are beautiful, shading from rich wine color to black, and with conspicuous silvery blue beaks. The little Seedeaters were the most familiar birds about the bungalow, coming to the steps to feed on fallen seeds.

One of the first things which caught our eye were several brilliantly iridescent green birds, insect-catching, among the brush near the house. These were Paradise Jacamars, ${ }^{8,5}$ and they had their homes in the clay banks of the rivulets, deep buried in the narrow valleys which abounded in the forest.

Each bird had two or more favorite twigs. When bughunting flagged at one post they flew with a long swoop to the second point of vantage. Our assistant, Crandall, observing this, laid a limed twig across the lookout perch and in a short time had caught two male birds. Their mates called loudly for a time, then disappeared. Before night both had returned with new mates, which we left in peace. 


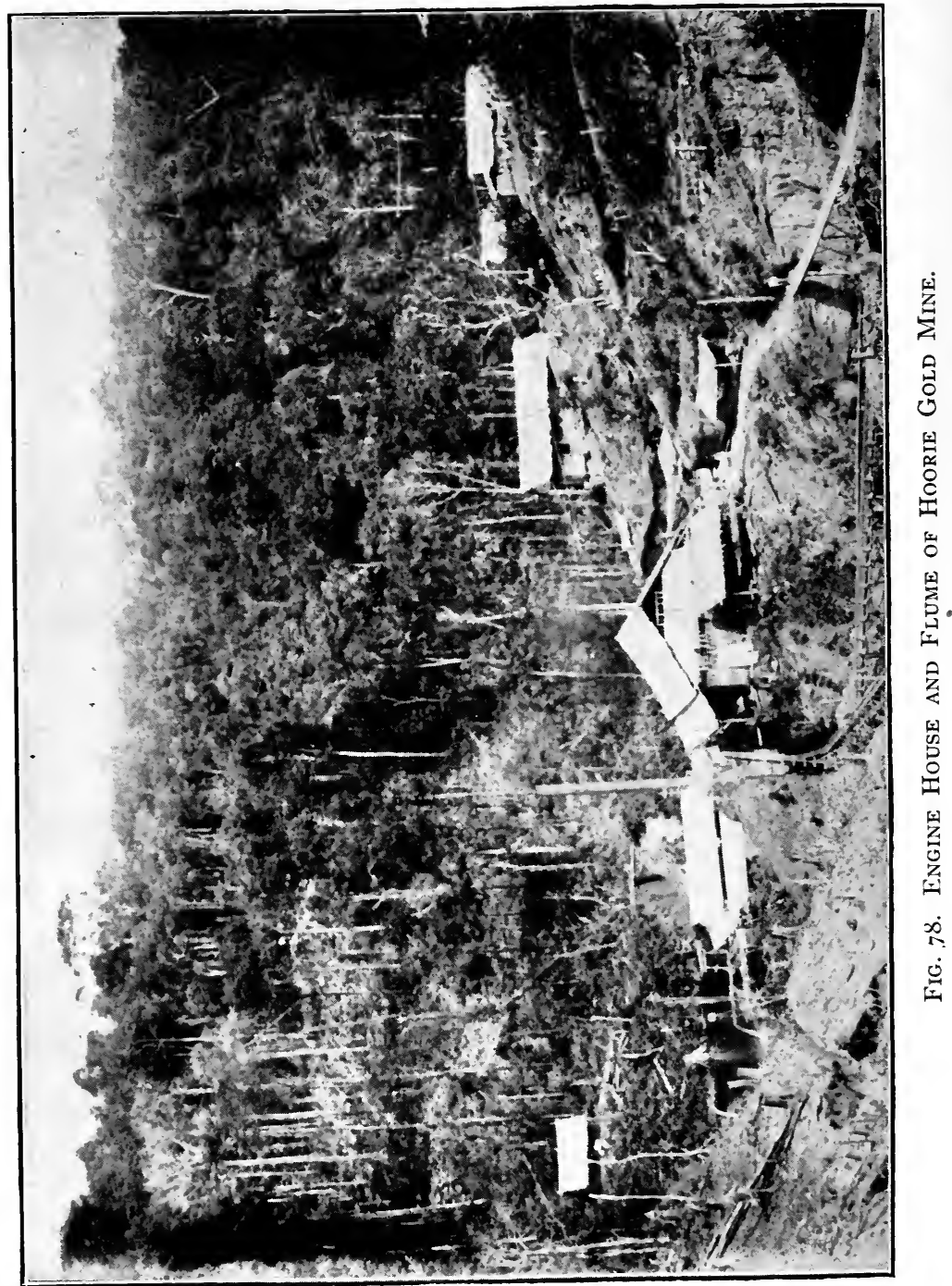


They were tame and allowed us to approach within eight or ten feet before flying to their alternate perches. Their feet are small and weak and they have a hunched up look as they perch in wait, turning the head rapidly in every direction and now and then swooping like a flash after some tiny insect, engulfing it with a loud snap of the mandibles. Their call-note is a sharp, repeated pip! pip! pip! pip!

These birds welcome the clearing, as it means an increased supply of insect food. They learn the value even of the opening made by the fall of a single tree deep in the jungle, and here and elsewhere we noticed that a single pair of Jacamars would keep busy day after day in the patch of sunlight let in by the death of some forest giant. Jacamars form a rather compact group of some twenty species; in habit like Flycatchers; in appearance and nest like Kingfishers, but in structure more c'osely related to Toucans and Woodpeckers.

Even in the short time which we spent at Hoorie we learned to expect a regular daily movement on the part of many of the birds. Early each morning a flock of about a dozen splendid Jays worked slowly around the edge of the clearing, at last disappearing behind the bungalow into the woods. In the north this would not be an unusual sight, but it must be remembered that members of the Jay family, like the Wood Warblers, are rarely seen in the tropics. Crows and Ravens are entirely absent from South America, and but two species of Jays find their way into British Guiana.

Our Hoorie birds were Lavender Jays ${ }^{161}$ and although so far from the home of their family they were no whit the less Jay-like. They constantly hailed each other with a varied vocabulary of harsh cries and calls, and now and then held a morsel of food between the toes and pounded it vigorously. They flapped but seldom, passing with short sailing flights from branch to branch not far from the ground. 
At night they returned rather more rapidly - less absorbed in feeding - probably to some roosting place of which they alone knew. With them, night and morning, were a few Red-backed Bunyahs or Cassiques, ${ }^{152}$ early nesters from the colony at the dam, of which more anon. The two species seemed to associate closely, although it was evident that it was the Bunyahs which had taken up with the sturdy pioneers from the North.

A short distance away from the bungalow a huge Mora stood in the forest looking down on all the trees around. The lightning bolt which had torn off its bark and killed it, had also consumed its dense clothing of parasitic vines and bush-ropes. So now it stood with naked, clean wood high above the sea of foliage, and within a day after our arrival we had christened it the Toucan Mora.

In the evening, about on the stroke of seven, the first comers would arrive - a trio of Black-banded Aracaris ${ }^{84}$ which alight and preen their feathers. These may remain quiet for about twenty minutes, but more often take to flight at the approach of a screaming flock of eight or ten Mealy Amazon Parrots ${ }^{{ }^{63}}$ which scatter over the branches. But the other species of Toucans are now awake and soon the Parrots are in turn driven off, and four or five big-billed fellows usurp the dead Mora and sun themselves or call loudly to the Vultures swinging high overhead. There are two species of these larger Toucans, the Red-billed ${ }^{81}$ and the Sulphur and Whitebreasted, ${ }^{82}$ and they seem to live together amicably, but war with the small Aracaris. The notes of the Red-billed Toucans are like the yapping of a puppy, uttered in pairs and differing slightly, thus, yap! yip! yap! yip! The great mandibles are opened and thrown upward at each utterance. The brilliant white-breasted birds call loudly kiok! kiok! in a high, shrill tone very unlike that of their fellows.

Morning and evening the Toucans and Parrots pass, 
always alighting on the dead Mora, while during the day we detect them deep in the jungle, feeding in the tops of the trees and sending down to us their calls, yap!, kiok! or squawk! as the case may be.

A fourth species, the Red-breasted Toucan ${ }^{83}$ was occasionally seen high in the tree tops. These birds had two distinct

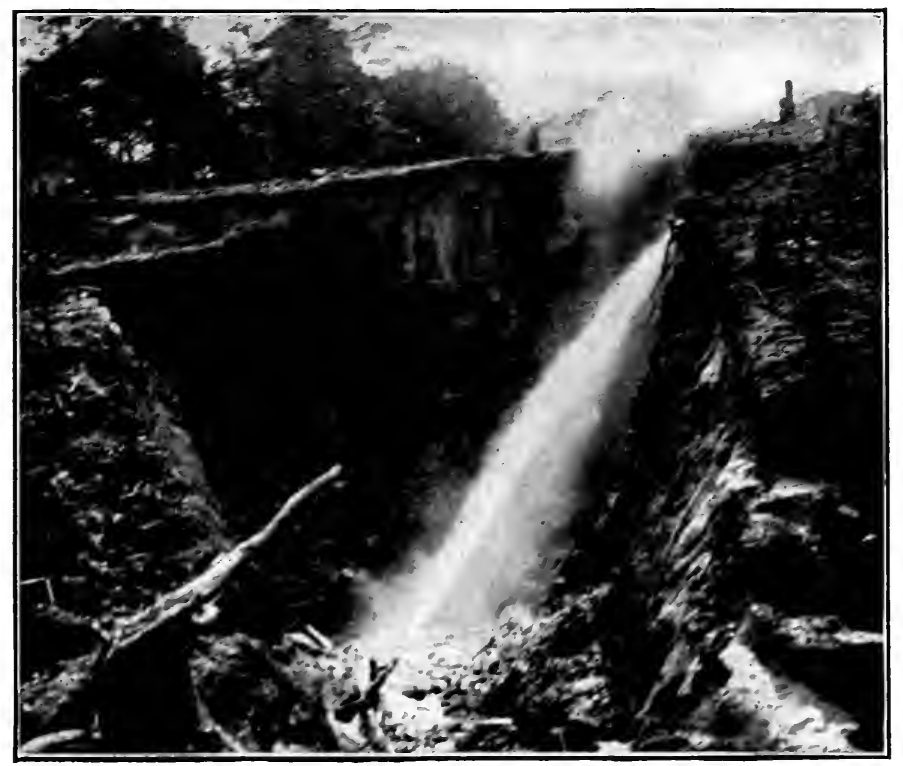

Fig. 79. The "Little Giant" at Work.

utterances, one a frog-like croak, and the other a doubletoned shrill cry, the two tones being $\mathrm{B}$ and $\mathrm{B}$ 节above middle $\mathrm{C}$.

Early in the evenings, about six o' clock, all the Banded Swallows ${ }^{118}$ of the surrounding region passed overhead in a dense flock, two or three hundred in all, soaring with a steady, halfsailing flight very different from the dashing swoops which carry them over the lake when feeding during the day. Now they are headed northward to some safe roosting place and 
with no thought of passing gnats. The myriads of graceful, glossy blue forms, each crossed on the breast with a band of white, made a most beautiful sight. In the morning their return flight was by twos and threes, with rapid darts here and there. Hunger now permitted no dressing of ranks or close formation. During the day none were to be seen about the bungalow, but only on the lake or a'ong the creek bed. The unfortunate gnats which hummed in the bungalow clearing were attended to by the little Feather-toed Palm Swifts, ${ }^{71}$ which were most abundant.

Among thè, hosts of smaller birds which haunted the treetops at the edge of the clearing, the Black-faced Green Grosbeaks ${ }^{135}$ were especially noticeable. In color they reminded one of immature male Orchard Orioles, being yellowish green with black throat and face. They fed morning and evening on the reddish berries of a great vine which ripened its fruit in the tree-tops, and here their song was repeated over and over, a rattling buzz, like the rapid stroke of a stick along the palings of a fence, followed by three liquid, whip-like notes, thus:

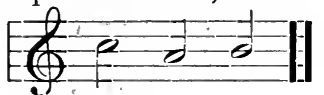

The buzz part of the song also did duty as the call-note.

Once or twice each day we would be treated to a glimpse of the wonderful Pompadour Cotingas. ${ }^{116}$ A flock of four male birds would flash overhead and swing up to some lofty perch, wary, silent, but of exquisite color. The whole body was of a brilliant reddish purple - rich wine color - with wings of purest white. Silhouetted against the blue sky as they were perched close together, they might have been Starlings or Blackbirds as far as color went, but when they all shot off into the air and showed up against the green leaves they fairly blazed - the yellow eyes, the scintillating purple plumage, and the dazzling white wings. The last flash of the wings before they were folded out of sight was a 
most efficient protection as it seemed to hold the vision, so that several moments elapsed before the perching bird itself could be located.

The sombre, ashy females were not observed; certainly they never joined in the flights with the quartet of males. In the latter sex, a half dozen or more of the greater wing coverts are stiffened and the webs curved around almost into little tubes. We know practically nothing of the wild habits of the Pompadour Cotinga but a most remarkable thing about the color is that, by the application of a little heat, it turns from deep reddish purple to pale yellow. It is rather interesting to compare this with the changing of the Purple Finch from rose-red to yellowish in captivity. The Chatterers or Cotingas form one of the most interesting tropical families of birds, and we lost no opportunity of studying closely all which we observed. At Hoorie, beside the Pompadour Cotingas we saw the Black-tailed Tityra. ${ }^{113}$ In Mexico we had seen a closely related species and here again were the strange "Frog-birds," with a little more black on the cap and tail.

We first observed a pair near the colony of Red-backed Bunyahs in the creek bed, but as we were leaving the bungalow for the last time, our farewell was made all the harder by discovering that the Tityras had begun to nest in a small dead stub standing alone in the centre of the vegetable garden and not twenty yards from the bungalow.

The birds were having a hard time of it, carrying stiff, fourinch twigs into a three-inch hole, but they were succeeding, showing that they knew better than to hold the twig by the centre. The whole head to below the eyes and including the upper nape was black, while the bare skin of the face and the basal two-thirds of the beak were bright red. The male was uniformly pale bluish white, while his mate was distinguished by many rather faint streaks of black on the breast, 
I78 OUR SEARCH FOR A WILDERNESS.

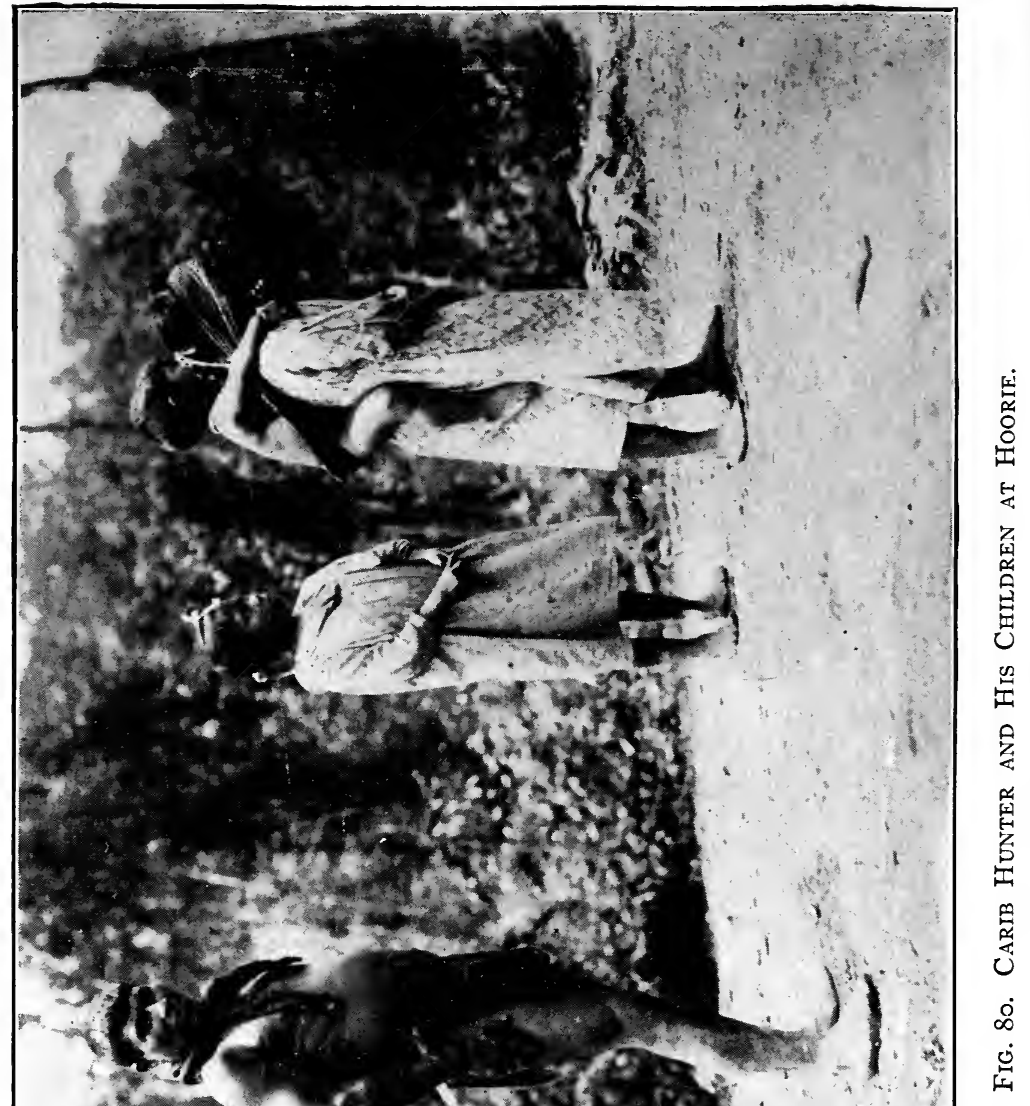


sides, and under parts. Both birds alternated in carrying the nesting material and in arranging it, remaining silent as long as we watched them. The nesting stub was about six inches in diameter and the hole thirty feet above the ground.

These birds lack the bright hues of most of their relatives, but have the family trait of possessing some queer trick of plumage. While the first flight feather of the wing is perfectly normal, measuring about three and a half inches in length, the second is a mere parody of a feather, tapering to a point and reaching a length of less than two inches. Only the true lover of birds will realize what an effort it took to tear ourselves away from this pair of birds, whose eggs and young appear to be as yet undescribed.

Two Marail Guans ${ }^{6}$ and a Trumpeter ${ }^{25}$ were interesting inmates of the hen-yard and made no effort to escape, although they were full-winged and had the run of the clearing. The Trumpeter went to roost each night at 5.30 as purictually as if he had a watch under his wing. He slept standing on one leg, resting on the first joints of his front toes, his head drawn back behind his wing.

Often on our walks we would come across an Indian hut, so hidden away in the depths of the dense forest that its discovery was merely a matter of chance. Most of these huts consisted simply of four poles covered by the rudest sort of a palm-thatched roof. The house furnishing was as primitive as the house itself - a hammock for each member of the family; varying in size in proportion to that of their owners, like the chairs of the historic nursery characters the "Three Bears." One or two calabashes or guords, several hand-woven baskets of cassava bread, some strips of dried fish and a smoky fire completed the picture.

The entire domestic life of these Indian establishments went on perfectly openly and quite unaffected by our curious 


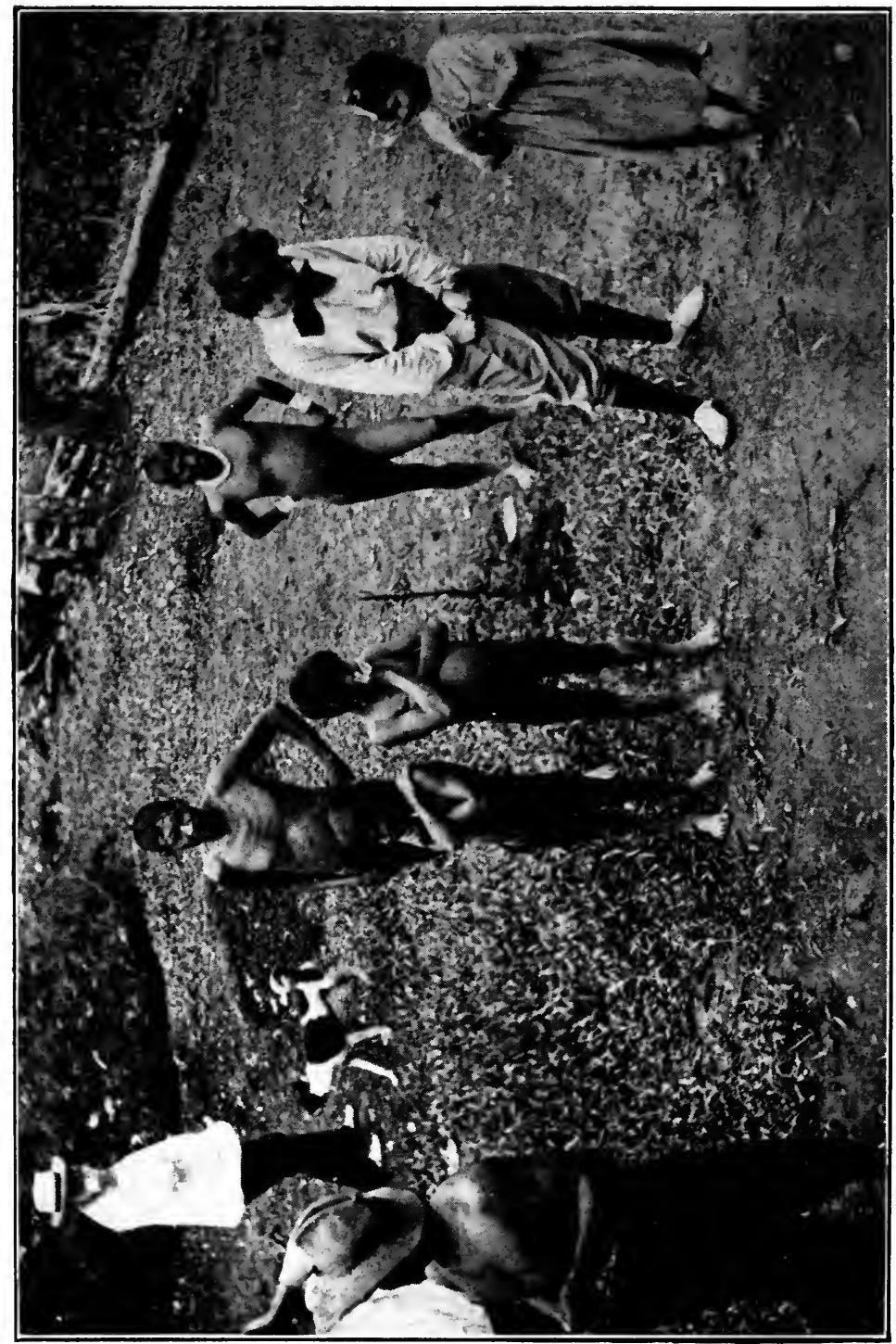


scrutiny. We rarely saw the Indian men at home; they were off hunting, or fishing, or perhaps employed by the mine as woodcutters. The women were always busy, cooking, planting cassava, spinning cotton, weaving hammocks and baskets and bead aprons, necklaces and bracelets. We could never resist the temptation to stop and make friends with them. The gift of a cigarette won their hearts and we invariably found them very gentle and kindly. 'Their costumes were extraordinary. Those who had been presented with the garments of civilization proudly wore them, though they were nothing more than short, loose slips. But the majority wore their native dress - consisting chiefly of beads; certainly far more healthful and suitable for them than the unaccustomed clothing given them by the missionaries. The children were lovable little picces of bronze, very smooth and glossy. They would often come softly up and slip their small hands in ours, looking up at us with shy wonder.

In one of the huts we watched with amusement the wee-est of Indian girls trying to drive away a huge rooster who was pervading the hut. The child could not have been more than two years old - but she was already thoroughly feminine, waving her small arms valiantly at the intruder and then running away terrified to bury her head in her mother's hammock, until she could summon courage for another attack upon the enemy.

As time went on and news of our arrival spread, Indians from huts far distant in the forest made expeditions to come and look at us; as curious about us as was the small boy living up on the Essequibo River who saved up his "bits" and took a long journey down the river to see a horse. He had heard that there were such creatures but he wished to investigate for himself. So tours were made to see us and we were inspected by wondering eyes to whom white women were as strange as were horses to the little "bush" lad. 


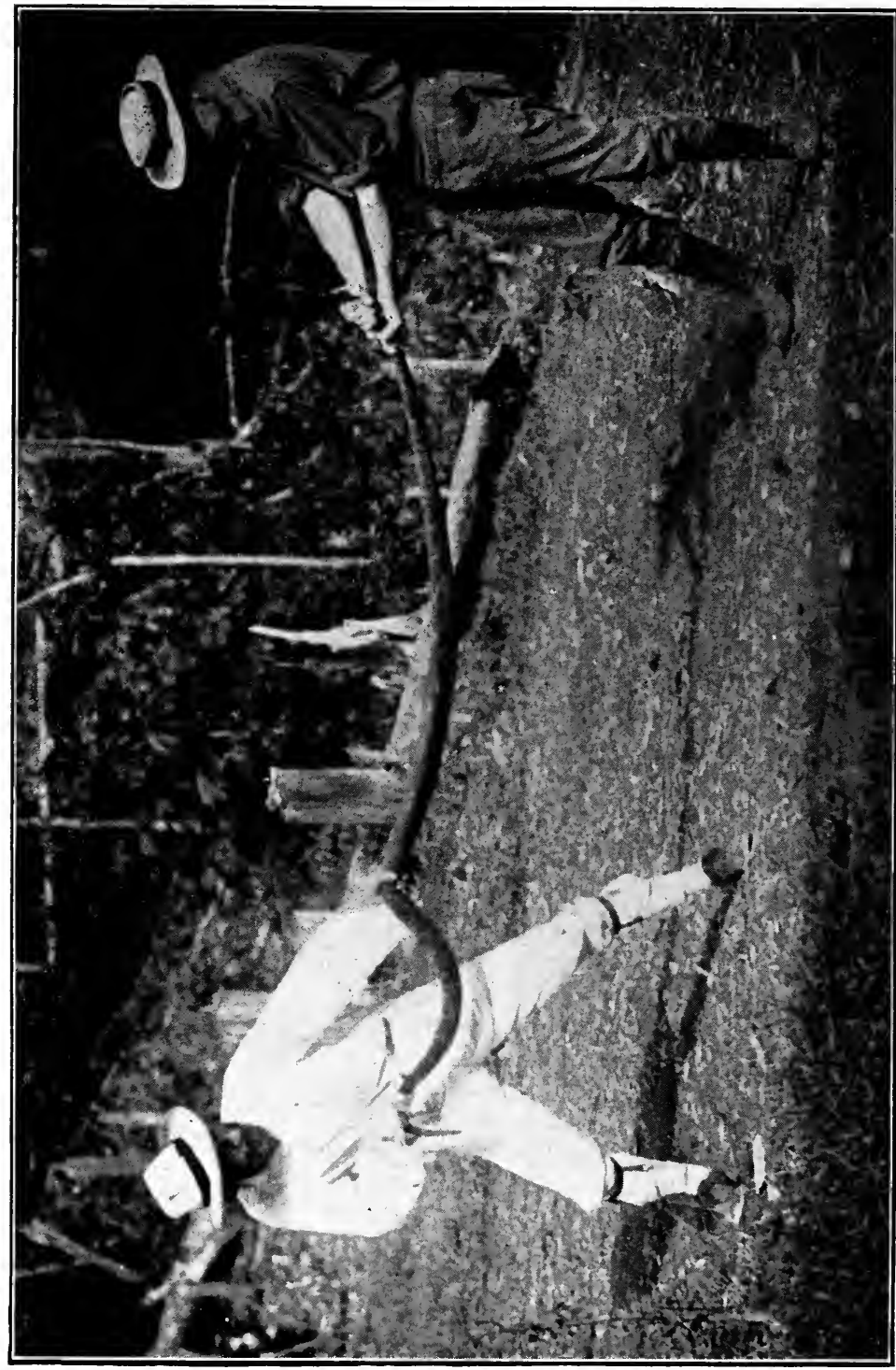

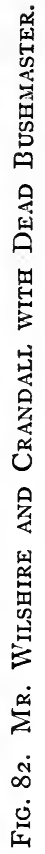




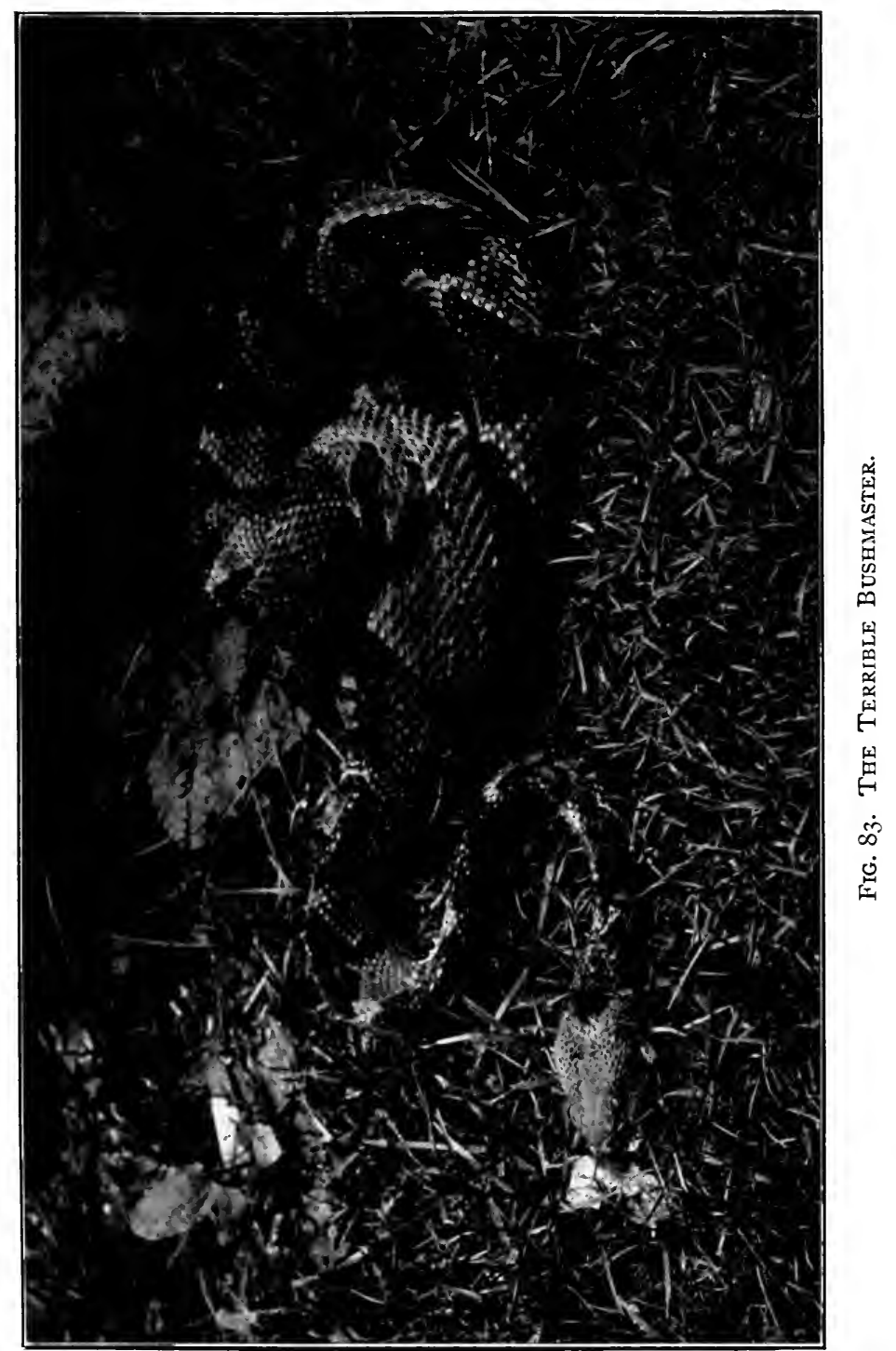


One day at the bungalow we found a group of Indian children gathered about the door of the modern bathroom which Mr. Wilshire had had fitted up. It was all a great puzzle to the little dwellers in the forest. To amuse them we took them in and turned on and off the shower bath, trying to explain what it was, but all to no purpose. To them a bath meant "me wash skin in river"; while the showerbath was merely an interesting scientific phenomenon - the mysterious white beings were making rain at their own will!

We were disappointed at not getting more photographs of the Indians. Their prejudice against being photographed is a deep-rooted superstition. They feel that it gives you a superhuman power over them. Indians often ran like deer through the woods when we pointed the camera at them and it was only by passing around candy to those who came to the bungalow and so diverting their attention from the dreaded camera, that we secured any pictures at all.

We encountered but one poisonous serpent, and that one by proxy. A big bushmaster or couanacouchi, all but dead, was brought to the house one day by an Indian who had speared it. It had been found coiled up on the forest leaves and was so like them in color that the Indian had nearly trod upon it. Although we searched thoroughly we could never find a second specimen.

\section{A DAY IN THE JUNGLE NEAR HOORIE.}

The region about Hoorie consists chiefly of small but steep hills, some isolated with a few hundred yards of flat land about them, others close together and separated by deep, narrow valleys with running water at the bottom. All drain into Hoorie Creek which from the mine clearing runs in a fairly straight direction through flat, marshy land to the Barama River up which we had come. The whole country is, of course, completely covered with a thick forest, of good- 
sized trees, which are heavily draped with vines and parasitic plants, although these are not dense enough to shut out the sunlight. Thus in many places a heavy undergrowth is found, making it difficult to get about, while the steep ascents and equally precipitous descents into the numerous intersecting valleys make extended exploration an arduous task, especially in the directions away from Hoorie Creek. But in this land of superabundant life, one needs but a short walk to fill one's note-book with interesting facts. Let us spend a day in the jungle.

In light marching order, with glasses and note-books only, we started out in the direction of the great pit of golden gravel, and finding Nasua, the coolie, we persuaded him to pan a few shovelfuls of earth from the surface of the ground within reach of the spray of the water spouting up towards us.

It was fascinating to watch his slender deft fingers and his skilful manipulation of the gold pan. Filling it to overflowing with gray or red clay, he half sank it beneath the surface of a little pool and began rocking and turning it. Soon the large pebbles were all eliminated and only a muddy sediment left. This was washed and revolved until there seemed nothing but clear water, when as the last dirt was flowed over the rim there came the flash of the golden grains. Pressing his fingers on these, the pan was reversed for a moment, and then dipping his finger tips in the clear water of our glass vial the yellow grains sank swiftly to the bottom. Sometimes only a half penny's worth would reward us, while again as much as a shilling's value would be shown.

Passing over the ridge we saw before us a deep and very narrow valley with precipitous sides, down which we slid and crawled, hanging on to vines and saplings to break our descent. At the bottom we found an interesting advance in the evolution of gold mining over the simplest form of gold panning. Two blacks were operating a "Long Tom," which in 
mining vernacular is the name for a six by two, heavy, coarse, metal sieve set obliquely in the channel of a small brook. The gold-bearing gravel and clay is shovelled into it and puddled with a hoe, and the gold settles to the bottom to be later panned. Thus division of labor enters in - one black shovelling while his partner puddles. We asked them how

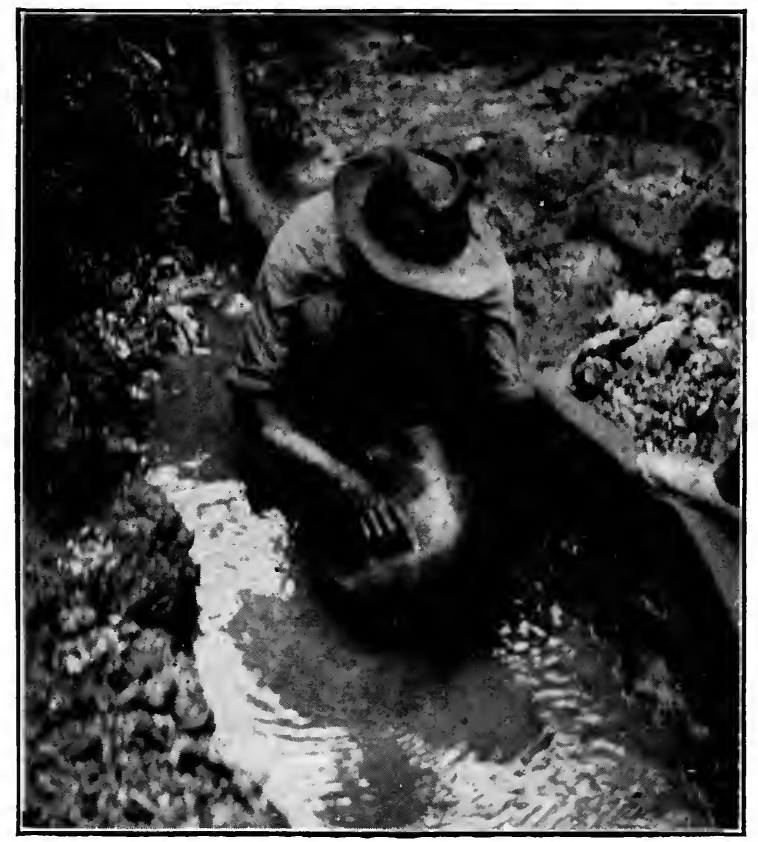

Fig. 84. Panning Gold.

much they were getting out and, as usual, they said "almost nothing," or a few shillings' worth at the most! This was to avoid any danger of their tiny holdings being considered too valuable and taken away from them. Mr. Wilshire took a pan here on another day and unearthed a tiny nugget, worth perhaps two shillings, much to the blacks' discomfiture, who hastened to explain that such an opulent 
find was indeed rare. The poor fellows at best make little enough and it was pitiful to see the tiny packets of gold dust which they brought to the company's store at the end of the week to exchange for food or credit checks. The universal Guianan name for this type of independent miner is "porkknocker," the explanation being that by knocking the rocks to pieces, they find just enough gold to procure the pork upon which they live.

They are allowed to work on side streams near the large mining operations, their total taking of gold being relatively insignificant, while they sometimes locate valuable deposits in the course of their wanderings. They are a jolly, happygo-lucky type, apparently careless of their luck and invariably optimistic of the future.

A naturalist would find it difficult to keep his attention fixed on "Pan" or "Long Tom" in this narrow glade, for great iridescent blue morpho butterflies are floating about everywhere among the lights and shadows. From some tall trees a continual shower of whirling objects are falling, some white, others purple. Catching one we find it to be a narrow petaled, five parted; star-like blossom (Petraa arborea), weighted by a slender stem. When thrown up into the air they revolve like horizontal pin-wheels, falling slowly and forming a most remarkable rain of color. Forcing our way up the opposite slope and on through the underbrush we come out on the corduroy road half a mile from the mine.

As a corduroy sapling turns and splashes the water under foot, a cloud of orange and white butterflies arises and scatters through the woods. Suddenly through the warm damp stillness there rings out a piercing, three-syllabled cry, which was to become for us the vocal spirit of the Guiana wilderness. Day after day we heard it wherever the unbroken primeval forest reigned, but never near the haunts of 
man. This, with the roar of the red baboon and the celestial theme of the Quadrille Bird, forms the trilogy most cherished in our memory of all the Guiana sounds.

We are listening to the call of the Gold or Greenheart Bird, ${ }^{115}$ another member of the Cotingas or Chatterers, which is as remarkable for its voice as it is lacking in brilliant colors. Loud as the call is, it is very ventriloquil and difficult to locate. When directly beneath the sound it seems to come from the tops of the highest trees, a hundred feet up, whereas in all probability the bird is not more than twentyfive feet above our heads. It sits motionless but the violence of its utterance makes the whole branch vibrate. We soon learn that to search and find the bird directly is impossible, but by letting the eyes take in as large a field as possible, the vibration from the vocal effort is easily discernible.

The male Goldbird is uniformly ashy or slate-colored, slightly darker above, very Solitaire-like both in color and size. The female is distinguished by a shade of rufous on the wing-coverts and the tips of the flight feathers. With such coloring it is not strange that the bird becomes invisible amid the dark shadows of the lower branches.

The natives know this bird as the $P e$-pe-yo from its call, and Goldbird from the fact that all pork-knockers believe it is never found far from deposits of gold; while the theory that it usually utters its call from a greenheart tree accounts for its third name.

Its note is typical of our American tropics, where highly developed song is rare, but single loud, metallic or liquid syllables are the rule. The bird has two introductory phrases which heretofore seem to have escaped the notice of observers. Indeed, until one noticed the invariable sequence of the two sets of notes, it would never be suspected that they proceeded from the same bird. The introductory phrases are low and muffled and yet have considerable carrying power. 
They possess the indescribable vibrating chord-like quality of the Veery's song which defies all description. Musically they may be written thus:

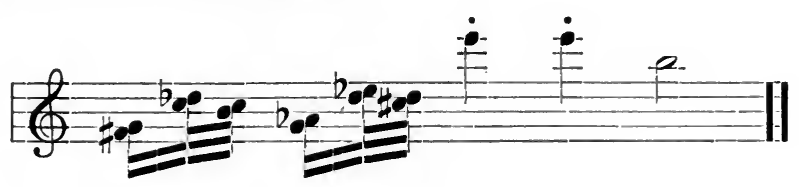

Almost instantly follow the three notes of the call or song. They are of tremendous strength and exceedingly liquid and piercing. The nearest imitation is to whistle the syllables wheé! wheé! o! as loudly as possible. We never tire of listening. The bird overhead calls so loudly that our ears tingle; another answers, then a third and a fourth, far away in the dim recesses of the forest.

Many miles inland near the wonderful plateau of Roraima lives another species of Goldbird, similar to ours except for a bright rosy pink collar around the neck. We saw nothing of this beautiful Cotinga, but one of the Goldbirds which we secured had a distinct but irregular collar of rufous, hinting of a not distant relationship.

A short distance along the corduroy road we came upon a half dozen naked Indians cutting away underbush, preparatory to making a new road bed. It was a delight to watch their sinewy bodies bend and strain, moving here and there through the thorns and sharp twigs with never a scratch. They came across many curious creatures among the rotting trunks and leaf mould, and when they learned we were interested, they would tie their captives with liana threads, or imprison them in clever leaf boxes, and save them for us. The most weird looking of these were gigantic whip scorpions or pedipalp spiders (Admetus pumilio) like brobdignagian daddy-long-legs, which crawled painfully about on their slender legs and never showed an inclination to bite. 'They 
were of great size, stretching some eight and a half inches across. The three hinder pairs of legs were normal and used for walking, while the fourth pair was attenuated and functioned as feelers - the "whips"- measuring full ten inches in length. The jaws were most terrible organs, three inches

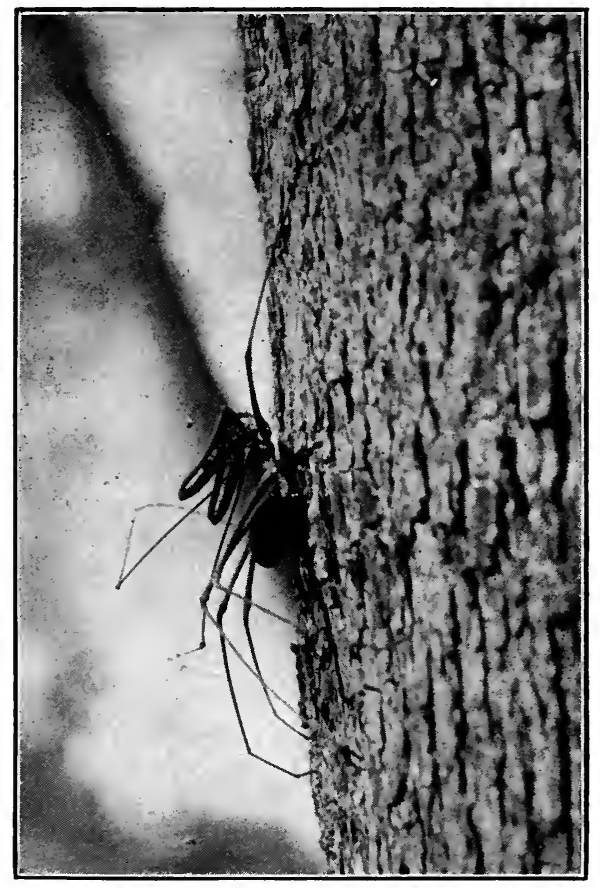

Fig. 85. Whip Scorpion or Pedipal. Spider.

long, dove-tailed with wicked spines, while the tips ended in villainous fangs.

A few hundred yards farther we came to a small clearing where the squaws were cooking dinner. The houses of these happy people are of the simplest construction. Four poles support a roof covered with loose palm thatch, open on all 
sides. The hammocks are hung beneath this and an open fire is built in the centre. The Guiana Indians are unequalled exponents of the simple life.

In the deep jungle we are constantly impressed with the straightness of all the trunks. The lianas and bush-ropes may be scalloped or spiral, or with a multitude of little steps like the Monkey Ladder, and still easily reach the life-giving light high overhead. But the trees can afford no bends or curves or gnarly trunks; they rise like temple columns. Cell must be on cell, each to aid in the life race upward. There are seldom high winds here in this great calm hothouse. Everywhere between the great trunks - whitish in the Crabwood, smoothed and noded in the Congo Pump, and deeply fluted in the Paddlewoods - between all these mast-like forms, are draped the slender ratline threads and cables of the aërial rigging.

We seat ourselves on a prostrate trunk free of scorpions, at one side of the corduroy road, and watch and listen. Beside us on a tiny, dull red Mora sprout, eating voraciously is a caterpillar, branched and rebranched with a maze of nettle-hairs, while near it is another - a fuzzy fellow - who gives us one of the most unexpected surprises of the whole trip. As we first see him he is palest lavender in color, covered with long straight hairs, longer than those of our familiar black and brown woolly bear caterpillar of the north. Five minutes later we look again and see a third caterpillar or no, it is the second one, but remarkably changed - a creature flat and immovable, covered with a score of recurved pink tufts of curled hair. The caterpillar chameleon has flattened his longer pelage of lavender into a thin line of prostrate down, bringing into view the recurved pink tufts, and thus has become an entirely different object, both as to shape, color and pattern. There must be a special set of muscles controlling these hairs. Even if a bird had appetite 
to digest such an unsavory hirsute object, it would well be dismayed at the transformation.

Everywhere we observe examples of protective form or coloration. On the under side of a branch in front of us are what appear to be many tufts of blackish moss - until we brush against some of it and a few of the tufts resolve into dense bunches of caterpillars. Others which we touch on purpose to see if they be caterpillars or not, deceive us doubly by retaining their vegetable character.

On the ground at our feet are scattered seed sheaths which have fallen from the branches high overhead. There are myriads of them. Suddenly one takes legs to itself and moves and only after examining it closely do we know it for a beautiful brown elater, a beetle (Semiotus ligneus) embossed with pale ivory - a perfect living counterpart of the arboreal seed sheaths strewn all about. Words completely fail to give an idea of the wonder and delight of having one's senses set at naught by these devices of nature. After being taken in by several, we imagine we see them everywhere in innocent leaves or bit of lichens!

Many travellers - Wallace and Bates among them speak often of the scarcity of flowers in the tropics, but here at Hoorie and on our later expeditions we were hardly ever out of sight of blossoms. A few feet behind us, as we sit on the log, are two Solomon-seal-like plants (Castus sp.) eighteen inches high, with the stem and leaves growing in a wide ascending spiral-making one revolution throughout its course. A sheaf of flower heads appears at the top of the plant with a single white open flower, giving forth the sweetest perfume. Bellshaped, it is formed by a single sweeping petal, the edges apposed along the summit, and the mouth rimmed with the finest hair-like fringe. The slit in the upper part is protected by a second narrow petal recurved at the tip, showing the heart within. Such a blossom would be a splendid addition 
to our conservatories, and a vast harvest awaits the grower of tropical plants other than orchids.

Now, the morning half gone, rain falls - a gentle mist, light as dew, refreshing and pleasant.

Through the drops to the blossom comes a great morpho butterfly of blue tinsel, soon followed by a big yellow papilio.

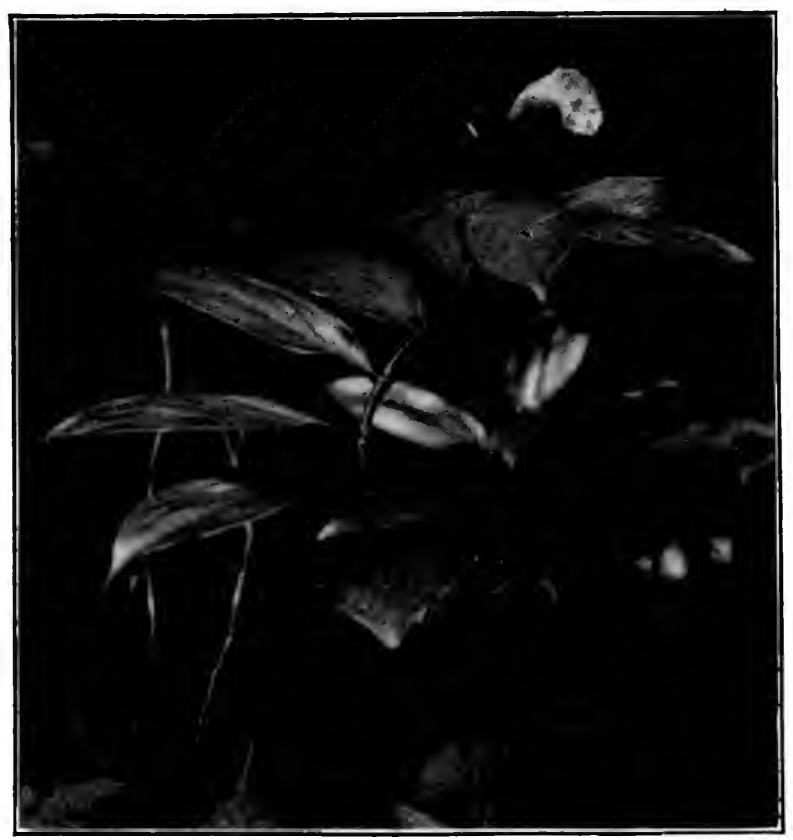

Fig. 86. A Jungle Blossom.

A tiny white butterfly, bordered with black, dashes up and attacks the papilio with fury, driving it away, as a Kingbird vanquishes a Hawk.

Just as we are about to arise, a Goldbird calls in the distance and then without warning a beautiful song rings out close at hand-six or eight clear descending notes like the early morning chant of the Woodhewer, but even more 
liquid, running together at the last into a maze of warbling which continues for eight or ten seconds - then ceases, and the liquid notes form an exquisite finale of a trio of sweet phrases. The singer is invisible; we never learn what it is, but it deserves a place near the head of the songsters even of temperate climes. As we walk along, Toucans and other birds fly high overhead with whirring beats of their drenched wings. Woodhewers loop from trunk to trunk and peer at us as we pass, while Ant-birds fly here and there. In all our tramps through thick jungles, these two latter families are in the majority, the former hitching up the trunks like brown Woodpeckers of various sizes, the latter simulating Wrens, Warblers and Sparrows in action and often in voice.

One, a White-shouldered Pygmy Ant-bird, ${ }^{91}$ now flits ahead of us, tiny as a Wren, slate-colored, with white dots on the lesser coverts of the wings and a dotted bar across the wings. The flanks and under wings are white and although ordinarily concealed, yet the little fellow flirts his wings every second, thus flashing out the color, and making himself most conspicuous. His call-note is low and inarticulate, but he occasionally lisps a pleasing little song; chu! chu! chuiwee!

We enter a deep narrow gully, our feet sinking deep in moss and mould, trip over a hidden root and, looking back, see a magnificent rhinoceros beetle which we have disturbed, feebly kicking his six legs in the air. In these deep valleys the air is saturated with reeking odors woody, spicy and mouldy and altogether delightful. Moss grows on the stems of the plants like wide radiating fans of delicate green lace. In these places we find the commonest palms which grow near Hoorie - stemless, with fronds springing fernlike from the ground.

Leaving the vicinity of the trail we start out through the heart of the jungle, keeping by compass in a general northwest direction. Here the trees increase in size and grow 
almost thirty feet apart, the intervening space being filled with lesser growth, parasitic lianas and huge ferns eight to twelve feet in height, tree-ferns in size but not in mode of growth.

The rain now increases and we plod happily along drenched to the skin, giving ourselves up to the delight of a walk in a tropical downpour. Serenely oblivious of pools and dripping branches, we trudge along until finally a tacuba over a creek breaks with our weight and we splash in up to our waists. Indeed we had long ago become accustomed to such drenchings, for during our stay at Hoorie the days were alternate sunshine and shower. In starting out for a long tramp we never thought of taking any protection against the rain. The only thing to be shielded was the precious camera. What matters a wetting when one is perfectly dressed for whatever may happen!

A word must be said here from the woman's point of view about the costume which was adopted as being absolutely suited to the bush life. In the first place it was light - so light that one never felt the burden of a single superfluous ounce of weight, and when thus freed from the drag of heavy clothing one would come in unfatigued from tramps which would have been impossible for a woman in orthodox dress, no matter how short the skirt. But in the light khaki knickerbockers, loose negligee shirts of scotch flannel or fibrous cellular cloth, stockings and tennis shoes and a waterproof felt hat, one was ready for anything. If soaked by a sudden downpour, a few minute's walk in the sun would dry one; if walking difficult tacubas, or clambering over huge fallen trees, of which there were any number throughout the forest, or climbing precipitous and slippery hills one was never hampered by unsuitable dress.

Of course there are many wildernesses where it is unnecessary for a woman to wear knickerbockers and where there is no 
reason why she should defy public prejudice by doing so; but the woman who attempts to tramp through the South American jungle will find that safety and comfort make them absolutely essential

One realized as never before with what handicaps woman has tried to follow the footsteps of man; with the result that physical exhaustion has robbed her of all the joys of life in the open.

Returning to our day in the jungle; we tramped silently over the sodden ground, now and then sending some panic-stricken Macaw or Parrot screeching from its roost. After an hour the rain ceased and the sun shone brightly, but where we were, many yards beneath the vast mat of tree-top foliage, only single spots and splashes of light broke the solid shadows. For a long distance we trod silently on deep mould and moss, and not a sound of beast or bird broke the stillness As we crossed a swirling creek on the trunk of a mighty fallen tree, something fluttered ahead. We could not see what it was. Closer we came and still the object remained indistinct; we seemed to see a butterfly and yet it appeared impossible. At last we marked it down on a fern frond and crept up until our eyes were within two feet. Nothing was visible but the graceful lacery of the frond, until a slanting beam of sunlight struck it and there, close efore us, the ghost/of a butterfly! It spread fully three inches but was holly transparent save for three tiny spots of azure near the dge of the hind wings (Haetera piera). As we hake it it to a double-headed flower of scarlet, an henit,aligh sep, whe seclet of the flower and the green of the leaf werd as diftingt as 1 seen through thin mica, while Re laint gray hare of the jnsect's wings were marked only by the indistinct reination. The appearance of this ghostly butt Cly amid the silence dnd hwe-inspiring stillness of the reeking was most impressive. 
Then came an interruption, so sudden and unrelenting that it seemed to reach to the very heart of nature. A Red "Baboon" raised his voice less than fifty yards away, and even the leaves seemed to tremble with the violence of the outburst of sound. A long, deep, rasping, vibrating roar, followed by a guttural inhalation hardly less powerful. After a dozen connected roars and inbreathings the sound descended to a slow crescendo, almost died away and then broke out with renewed force.

We crept swiftly toward the sound, treading as softly as possible and soon, in a high bulletwood, we saw three of the big red monkeys. The male passed on out of sight, and the second, a medium-sized animal, followed. The third was a mother with her baby clinging tightly to her back. She climbed slowly, showing her rich light golden red fur and beard, while the arms and legs of her dark-furred baby were revealed as lines of darker color around her body.

Twenty minutes later we stalked another roaring male, and found four in this troop. We saw two of the females giving voice with the leader, shrill falsettos which became audible only during the less deafening inspiration.

We tried to think of a simile for the voice of this monkey and could only recur to that which always came to mind the roar of wind, ushering in a cyclone or terrific gale. And yet there was ever present to the ear the feeling of something living - as if mingled with the elemental roar was the howl of a male jaguar. No sound ever affected us quite as this; seeming always to prestige some unnamed danger. While it lasted, the sense of peace which had been inspired by the calmness and silence of the jungle gave place to a hidden portent of evil. Yet we loved it, and the savage delight which we took in this and other wilderness sounds made our pulses leap. 


\section{THE DROWNED FOREST.}

At the engine house a ten foot dam had been thrown across the Hoorie Creek bed, and the apparently slight cause had brought about wide reaching effects; this slight raising of the water throwing back the creek in many directions. One could hardly call it a lake as there was no wide body of water, and yet it had a shore line of more than ten miles, reaching out a long finger-like extension up every side valley. The original creek was only a few feet wide and the jungle grew down to the very bank. So now the trees were deep under water.

All which were below the new level were dead, standing like an array of tall bare ghosts compared to the luxuriant forest all about. When on a rise of ground, one could trace the course of the lake by the lines of naked branches. And when steering one's canoe between the leafless trunks, the effect was most startling. The sunlight came through in a way different from any tropical forest. Every leaf had fallen, leaving the trees as bare as in a northern winter and stripping the vines and bush-ropes, but the condition of the parasites and air-plants was most interesting. All those which were truly parasitic, living on the life-sap of their hosts, were of course also dead, but the orchids and other air-plants were flourishing - showing as large tufts or sprays of light green here and there. In places the branches had a beaded effect, so numerous and yet so isolated were the epiphytes.

We drifted silently along, by the impetus of a touch of the paddle on a passing trunk. Orchids were in blossom, and ferns, mosses and lichens ran riot in orange, brown and ivory patches on the tree-trunks. Muricots and the fierce perai were abundant here, and now and then some fish broke water, throwing rings of light into the shadowy places. 
Spiders, ants and a host of other wingless insects were crawling on many of the trunks, made captive by the flood. Their inability to walk on the water was evident when we knocked some of them off, so they must have lived on their island trees for the last year, the time of existence of the dam. The spiders were legion in species, hardly two alike,

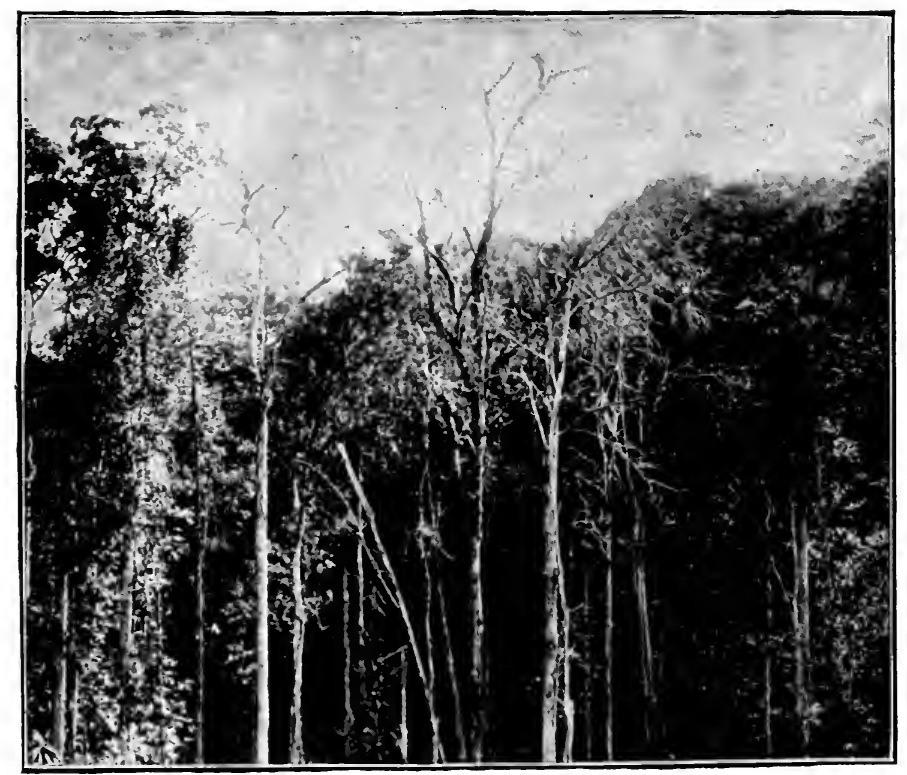

Fig. 87. The Drowned Forest.

from minute ones, shaped like nothing else under heaven, with relatively enormous hooks and thorns on their brightly colored abdomens, to giant tarantulas, who stood up and threatened us before beating a dignified retreat.

The increase of water had attracted many water-loving birds, and great Rufous Kingfishers ${ }^{67}$ swung past us, strongwinged, beautiful birds, carrying on their business of life in a virile, unhesitating way. Between the trunks flashed 
the White-banded Swallows ${ }^{118}$ now hovering before a trunk and snatching a spider, now dipping at full speed for a floating gnat. A hollow rattling drew our attention upward, and there, gazing intently down at us, was a splendid Woodpecker - the Guiana Ivory-bill, ${ }^{89}$ close kin to our Ivory-bill of the Florida swamps. Imagine a big Woodpecker with dark brown back, wings and tail, while the long erect crest, head, neck and breast are bright scarlet, shading into rich rufous on the under parts! Such a beauty looked down at us, and then without sign of fear dived into a hole.

The. Indians, passing several times a day, with loads of cord wood in their ballyhoos or flat-bottomed boats, were familiar with the Woodpecker and asserted that the bird had no mate. It was a male and although we visited the place several times no female ever appeared. The dead tree which held the nest was called Aramaca by the Indians, and was about a foot and a half in diameter, with the entrance not less than sixty feet above the water. A living tree like it on the bank near by had obtuse entire leaves and large, brown, slightly curved pods. The trunk was rotten, especially at the water line, and as it could not have remained standing much longer, we decided to investigate the home of this little-known bird.

We hailed the first Indians who appeared and set them to work felling the tree. The Woodpecker flew out at the first stroke of the axe, and remained close by, showing little fear or anxiety. We landed and the Indians made the trunk fall in our direction. It struck the water with a terrific splash, breaking into several lengths, and finally coming to rest with the hole upward. Running out along the floating $\log$ we found that the nest contained a single bird, with no trace of addled eggs or other young. The opening was a circle, four inches in diameter, and the cavity fourteen inches deep. The young bird was about five days old, featherless 
and downless, but the sprouting feather tracts were very distinct.

On the edge of the branches of the lower mandible, about three-quarters of the way to their base, were two round, white knobs or warts, and a large white patch like an abnormally large egg-tooth was at the tip of each mandible. These structures were undoubtedly direction marks for aiding the parent in finding the mouth of the young bird in the darkness of the nest chamber. When the mouth was open they formed the four corners, with the throat cavity in the centre.

A most remarkable collection of creatures gathered on the upper side of their wrecked tree, tenants of the bark and wood for the last year. Two small green-headed lizards made flying leaps and escaped ashore. But marooned for life were several species of bark beetles (Nyctobates giganteus and Paxillus leachii), a huge boring beetle, and spiders galore. We noticed a slight disturbance among the bits of floating bark and pith, and scooped up a most wonderful creature a true bug, perfectly flat, with the sides of its body drawn out into irregular flat serrations, while in color it was the very essence of lichened bark or dead leaf. Placed on a piece of wood it instantly drew in its legs and clung tightly. If it had not been frightened by the water we could have handled it a dozen times without knowing it was an insect.

A few yards away a pair of Mealy Amazon Parrots ${ }^{63}$ were shrieking and flying restlessly about a great Mora tree, but we could not discover their nest. On our way home a dainty Blue Honey Creeper ${ }^{136 a}$ alighted on the bow of our canoe; rich deep blue except for wings, tail and throat which were black. The feet and legs were clear yellow, showing most conspicuously against the plumage.

A pair of Great Green Cassiques ${ }^{150}$ had swung their four-foot pendent nest from the tallest limb of a tree standing in the water, and we spent ten minutes watching the male 
court his mate. As he uttered his incoherent medley of liquid cowbell-like notes, he bent his neck, thrusting his head far downward and forward, and at the same time throwing both wings forward and around in a semicircle. As this curious action was completed, the vocal utterance came to a close and the performance was over. The early stages in the evolution of such a courtship may be observed in our common Cowbird of the north, and a further developed stage in the little Guiana Cowbird.

\section{THE CITY OF THE CASSIQUES.}

On the first day of our arrival, even before we came in sight of the clearing, we heard the cries of the splendid big Orioles or Cassiques, known all over Guiana as Bunyahs. In the creek bed below the dam, but within the radius of the clearing, stood a medium sized tree and among its branches a colony of Scarlet-backed Cassiques ${ }^{152}$ were flying back and forth from their nests.

We made a mental note of them at the time but passed on without giving them more than a glance. Later near the bungalow we occasionally saw them in small numbers associating, as we have already stated, with the Lavender Jays. ${ }^{161}$

As we wished to take a number of young Cassiques back to New York with us and to study the colony as thoroughly as we could in the space of a week's time, we started out early one morning for the Cassiques' tree. The long pendent nests were all seventy feet or more from the ground. Taking the rusty climbing irons from their case, we recalled vividly the last time they had been in use - a cold June day in Nova Scotia, when the nesting hole of a Three-toed Woodpecker had been the goal. How different were these tropical surroundings! 
Bravely the start up the tree was made; jab and pull, jab and pull, while the straps pressed in on ankle and knee, giving that peculiar sensation that cannot be described, but which every climbing naturalist knows so well. Ten, twenty, thirty feet were scaled, and then one's hand on the opposite side of the trunk broke through some tiny earthen tunnels, and, like many an unfortunate telegraph-line-man, struck a live wire. At least, the sensation was very much the same, only the electric shocks were here progressive, and when they had reached the elbow, they were seen to be a numerous and enthusiastically defensive horde of ants. At one end a pair of jaws gave a firm point of leverage and attachment, whereby the insect could secure a footing while operating the sting from the opposite end of his anatomy.

There have been martyrs to science as well as religion, but much as one might desire to look into those nests only forty feet above, it may be doubted if any man could have controlled his feelings and coördinated his muscles sufficiently to continue the ascent. The details of the descent were hazy; an exceedingly rough trunk seemed to shoot upward through one's embrace until the ground was reached and the Cassiques screamed their delight.

They had seen many of the four-handed folk foiled in a similar manner, and now this new enemy, who scaled the trunk with two hands and two spurs was equally baffled by the tiny allies of the birds!

But study the colony we must, and selecting a line of soft, springy underbrush, we had an Indian drop the tree on it. A cloud of screaming Cassiques followed it to earth, scattering only as we ran up and began to gather the young birds. Out of the first nest there rushed a lizard about a foot in length, brown, with head and fore-legs bright green. He scurried like a streak of light across the red tailings, the speed sending him up on his hind legs, so that his track was bipedal. 
Before we describe the condition of the colony as we found it when we reached the fallen tree, it will be interesting to record its early history as far as we know it. This was the first year of this colony of Cassiques, as last year there were none nearer the clearing than the mouth of Hoorie Creek,

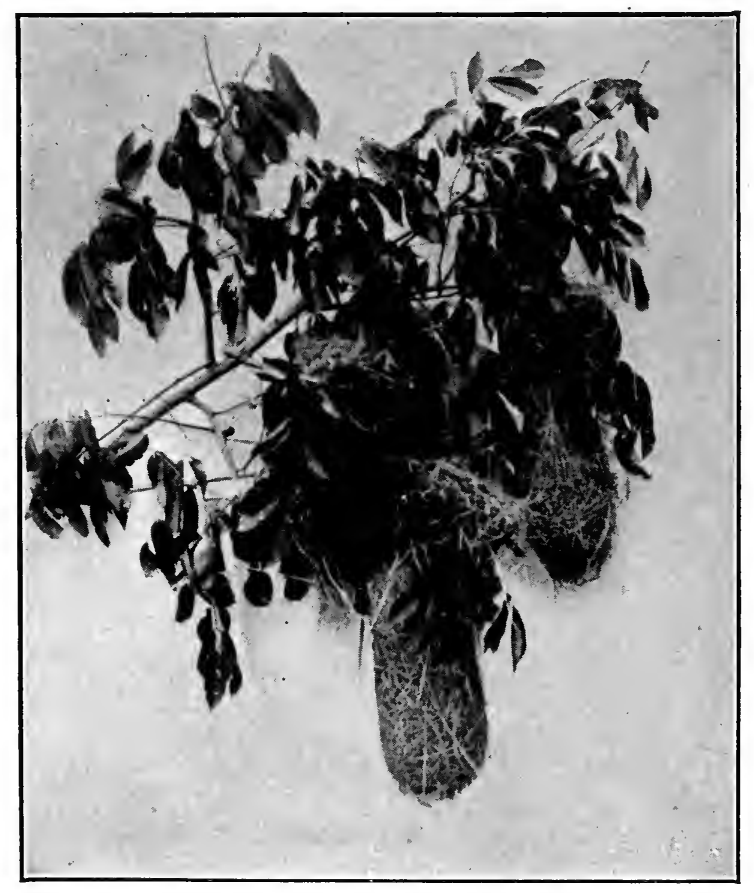

Fis. 88. Nests of Red-Backed Cassiques.

three and one-half miles away, where in a tree, overhanging the house of a black, a colony has been in existence for two years. Three months ago, in January, one Scarlet-backed Cassique was observed in the clearing at the mine, but it soon vanished. Within a few days, however, a number of these birds appeared, perhaps guided by the solitary scout. 
They set to work at once, establishing their new colony in the tree which we had cut down. So at the time we began to study this colony, it could not have been older than three months.

The tree stood alone in the centre of the tailings from the gold washing and 20 or 30 feet away from all the surrounding trees. The finely sifted sediment of the tailings had broadened out the water of the creek bed so that it flowed delta-like on both sides of the tree. With their characteristic intelligence, the Cassiques had taken advantage of this unusual condition, and were thus guarded from enemies, by the water, by the isolation from other trees and by the far more formidable stinging ants which probably for many years had had their home on the trunk of the tree. The little bird city as we found it contained 39 homes; three-quarters of which were on one branch, 70 feet from the ground, while ro were suspended from a smaller branch, a few feet lower down. Of the 39 nests, 4 were only half finished, while ro were empty, having been already used and deserted this season. The others may be divided as follows:

One nest contained an addled egg; white with brownish spots chiefly at the larger end.

One nest had one egg containing a week old embryo.

Two nests each had a skeleton of a well grown young bird; one of which had been caught about the neck, and the other about the legs by fine flexible tendrils which had caused their deaths.

There were altogether 28 young birds: 9 full-fledged, I6 with feathers just appearing, while 3 were recently hatched. They were distributed as follows:

I4 nests contained I young bird.

7 nests contained 2 young birds. 
The special distribution was as follows:

Number and Condition of Young.

2 well-fledged young in

I well-fledged young in

2 partly fledged young in

I partly fledged young in

2 newly hatched birds in

I newly hatched bird in
Number of Nests.

2 nests.

5 nests.

4 nests.

8 nests.

I nest.

I nest.

The nests were typically Cassique-like, made of stout rootlets and grasses, while at the lower end was a cup-shaped lining of very fine grass and root hairs, forming a soft bedding. The nests varied from thirteen to eighteen inches in length, and all but five had an upper roosting chamber, built on above the entrance. These five were built directly beneath a group of others, and the bases of the ones above served as protecting roofs. This was a most interesting adaptation to varying conditions. Just before felling the tree we noticed in several instances that both parents shared in the work of bringing food to the young ones. Almost all of the young were uninjured by the fall of the tree. Three were thrown out of the nests and these we chloroformed in order to find what their food had been. The stomach of one was crammed with white seeds of two kinds; one nearly round and about as large as the head of a pin, while the others were longer, perhaps one-third of an inch in length. Mingled with these seeds were remains of numerous insects; beetles, grasshoppers and caterpillars. The two other birds, which were younger, and almost bare of feathers, had received chiefly animal food, as follows:-

I. A three-inch, smooth caterpillar, medium sized spider, many small bugs, and a mass of berry seeds.

2. Several one-inch cut-worms; spider; small iridescent beetle; yellow butterfly; a few berry seeds. 
The young birds were almost without down, the adult plumage being outlined very shortly after hatching. In a bird of only four or five days the dull orange or yellowish color of the rump feathers shows plainly. When these break through their sheaths, the color is a dull rose; becoming redder as the feathers increase in length, but not attaining the brilliant scarlet of the parent birds until the succeeding moult. When full grown, these birds measure about ten inches in length and are glossy black in color, save only for the brilliant scarlet rump. The bill is a conspicuous greenish white, while the feet are black. The eyes of the nestling are dark hazel in color, while in the old birds the iris is of a most beautiful greenish blue.

The voice of the very young birds is a shrill incessant peep! peep! when they are gaping for food, but the half-fledged youngsters utter solitary harsher notes under the same conditions. The five fully fledged birds had learned what fear was and instead of feeding, crouched down at the bottom of the artificial nest which Mr. Crandall made for them But hunger overcame fear and before night all had taken food. We kept an Indian busy gathering a berry or fruit which looked, tasted and smelled much like a miniature tomato. The leaves of this low plant are large, deeply incised and studded above and below with numerous thorns. The plant is from three to six feet in height, is abundant in the clearing, and forms the favorite vegetable food of the Cassiques. In addition to this, the young birds had a few mealworms and ants' eggs from our small store, and all the soft insects which our Indian could capture. After two full days of grasshopper catching, the pride of the noble red-man began to feel itself injured, and additional inducements in the way of tobacco were needed to sustain his interest in his orthopterous pursuits.

On the following day the oldest of the young Cassiques 
flew feebly to a low perch and nothing could induce him to return to his fellows again. He uttered isolated call-notes, which however, at the approach of food, merged at once into the baby scream.

We had carried the young Cassiques a third of a mile to the veranda of the bungalow, where they were put out of sight and sound of their parents; yet early next morning four Cassiques had discovered their offspring and were flying back and forth close to the house carrying food in their beaks. In an hour no fewer than twenty Cassiques had collected, and on placing the young out in a low tree, the parents came at once and fed them.

One bird which we watched carefully brought masses of caterpillars which it inserted within the wide mouth of the young. Although the young birds were mixed up, five or six of the same size being placed together in one artificial nest, yet there was no question about recognition on the part of the old birds. At least there was no reckless undirected feeding; certain young were fed by certain adults.

The second day after we had taken the young birds, no Cassiques came to feed them, and we found the reason was that the entire flock had begun to found a new colony in the very nearest tree to the one we had cut down, about twenty feet away. This too was isolated and protected both by shallow water and by the vicious tunneling ants.

Some of the new nests must have been started the day before, as the roost chambers were complete and in several the top of the nest itself was finished. The rains had been rather heavy for a few days and may have influenced the early building of the shelters above the nest. To the three or four inches of nest the birds were bringing beakfuls of fibres, both sexes working energetically. We were glad to know that our wholesale destruction of the first colony site had wrought no permanent change. At the rate the birds were building, the 
second colony would be in a flourishing state in another two weeks.

These Red-backed Cassiques ${ }^{152}$ together with their near relatives the Yellow-backs ${ }^{153}$ are most interesting birds, and a careful study of the growth and daily routine of a colony would yield most valuable results. They seem to trust more to the presence of man as a protection against enemies than to the guardianship of wasps, but both methods are to be found. We traced these birds all the way up the Barama, and from what we could learn, none were found higher up, the colony at Hoorie Mine being the farthest outpost.

\section{NIGHT LIFE.}

Owing to our brief stay and the difficulty of exploration in this hilly and densely underwooded country, we gained little thorough knowledge of the vertebrate fauna hereabouts. The phase of tropical life which, during the week of our stay, was most striking, was the wonderful host of insects attracted by the electric lights in the evening. The bungalow contained four large rooms, two on each side of a wide central passage, extending through the house - a kind of interior veranda, open front and back. This was the dining room, where every day we feasted upon delicious dishes of peccary, tinamou, curassow and paca, or " bush-hog," "maam," "powie" and "labba," as we learned to call them in the vernacular.

Here during the evening meal, after the lights were turned on, came legions of the most curious, the most beautiful winged creatures imaginable. We all turned entomologists and never tired of admiring the wonderful colors, and bizarre shapes which night after night were revealed in never-ending array. The first night Crandall sent up an excited call of "Get a vial! Get a vial!" and this became our vesper slogan. From the yard, or veranda, or room, or kitchen hut, would come the call from some of our party, "Get a vial!" and the 
one nearest the array of bottles in the improvised laboratory would hasten to the aid of the discoverer, who would probably be found with eyes glued to some strange creature and blindly reaching out behind for the approaching vial, in which to capture his prize.

There were few insects of very small size and many indeed were gigantic, as judged by our standards of the north. None were unpleasant and they seldom attempted suicide in soup or cocoa. They were content to flutter a moment about the electric globe and drop quietly to the white tablecloth. Praying mantises, or " rar-hosses" as our southern negroes call them, would whirr in and climb awkwardly over the bouquets of flowers, swaying from side to side and now and then reaching out for some passing insect, with a sudden unflexing of those murderous, deceptive fore-legs. One which flew on the table was a new species, which has been named Stagmomantis hoorie.* If exercise during meals is good for one's digestion then we were hygienic in the extreme, for twenty times in succession we would have to go to the veranda laboratory to chloroform our captives.

The second evening, although a heavy rain was falling, a bewildering number of moths, mostly small but of exquisite patterns, dashed in between the drops. There were almost never two alike; indeed among one hundred species captured on two evenings, there were but two duplicates.

It is folly to try to describe with any exactness the beauty, even of the commonest, plainest insect, and how much more impossible to convey an accurate idea of these tropical beauties. Think of a sapling near an electric light covered with fifty or sixty exquisite moon moths (Thysania agrippina) pale creamy white, banded and looped with lines of brown - none less than nine inches in spread of wing and many reaching an even foot across.

*Zoölogica, Vol. I, No. 4, page I23. 
The hawk-moths that came to our table were all different, all beautiful; one a study in pale yellow; another variegated green with blended purples and red (Argeus labruscae) on the hinder wings. This one too bore on its eyes the long shaft of a pollen stalk from some night flowering orchid.

Then a moth would come, recalling somewhat the Promethea and Polyphemus of our childhood's collecting, but with great transparent mirrors in the centre of the wings (Attacus [Hesperia] erycina); next, two as different as possible but which we learned later were sexes of the same species (Dirphia tarquinia) - the female, large, plain brown with a forked streak of light across the fore-wings: her mate a full third smaller with rosy hind-wings and fore-wings frosted white, save for two conspicuous circles at the fork of his white lightning.

On the third evening there were fewer moths, but many more beetles and grasshopper-like insects. Green was the predominating color among the moths this evening - from palest yellow-green to darkest bottle-green. In some the green had a border sending ray-like lines across all four wings. Yellow and white were the colors almost always present in combination with the green, the yellow being usually confined to the hinder wings. A stain of gold was sometimes laid over the green, and in one beauty the green seemed to have been spattered at hazard over a milky-white surface. This proved to be a female of a species known only from a single male (Racheolopha nivetacta), the female proving to be twice as large as her mate.

Instead of burying the insects in enve'opes or mounting them in the orthodox way with the fore-wings raised unnaturally until the hind edge is at right angles to the body, we merely supported the wings, and allowed them to dry in the natural position. By doing this we usually lost sight of part of the hinder wing, but we gained the true relation of the 
spots and patterns on the fore-wings to those on the thorax and the result was in many instances surprising. For example, when spread, the fore-wings of one tiny moth (Pronola fraterna) showed two meaningless black spots forming each one-third of a circle. When closed naturally, these united with the black abdomen to form a perfect black circle stamped upon a mat of velvety cream color.

All words are inadequate to describe these exquisite creatures; one with the lightning flash of gold across its cloudy background; another, enscribed with Chinese hieroglyphics; a third of lavender, yellow and russet mosaics set about large transparent windows of opalescent blue.* One of the most exquisite was a little moth (Chrysocestis fimbriaria) spreading less than an inch, with wings of iridescent mother-of-pearl rimmed with dull golden, on which was set a score of embossed beads of the most brilliant gilt, flashing as no gem ever flashed.

If one could spend a season here studying the motions alone of these insects, it would well repay him. One moth, iridescent with a broad border of black (Eudioptis hyalinata), curled the abdomen straight up into the air, and separated its extremity into a wide-spread tuft of hairs. These radiated like the tentacles of a sea anemone, and when the whole was waved about, it looked like some strange crawling caterpillar, holding its head high above the prostrate wings of the moth.

The last evening, as if to make our departure still harder, the insects increased in number. Walking sticks five and six inches in length skimmed through the air, their bodies, legs and wings dark in color and ornamented with irregular scales and projections, until their resemblance to a jaggedbarked twig was perfection. If this species were represented by thousands of individuals in its haunts, birds or four-footed

* Both of these moths proved to be new to science, both as to species and genus and have been named respectively Hositea gynaecia and Zaevizus calocore. Zoölogica, Vol. I, No. 4. 
enemies would soon learn to detect even such an exact counterfeit, and the protective value would be lost. But in the tropics the infinite variety is the key-note to success in protective adaptation. On the table-cloth at one time would be perfect green leaves (katydid-like orthopters), green leaves with large worm-eaten defects or spottings (some of the mantises) and many brown, lichened leaves and twigs (moths and walking sticks). Even if two of the same species appeared at once, the chances were that one would be much the larger and of an entirely different shade with a distinct individual pattern of mimic defects.

Big owl moths (Hyperchiria liberia, H. nausica, Automeria cinctistriga and others) alternated with trec-hoppers of all sizes with branched and rebranched horns rising from their thoraxes (Hemiptycha [Umbonia] spinosa and others). The prize of one evening was a grasshopper (Pterochroya ocellata) which came in on the sleeve of the coolie butler. It had alighted on the white cloth as he crossed the yard between the kitchen and the house. Its wide, jagged forewings met closely above the back, forming a half green, half brown leaf, complete even to the mid and side ribs. On the hind wings were what we could merely guess were either sexual ornaments or warning markings, visible only in flight. The ground color of these translucent wings was a finely mottled yellow and brown, while painted on the pleated surface were two eye-spots like those upon the feathers of a Peacock-pheasant, a dark velvety shaded portion with a delicately shaded ocellus at one edge.

The last insect captured was a tree-hopper as big as a cicada, mottled and marbled on the fore-wings, and stained scarlet on the hinder.

In Appendix C, pages 397, 398, I have added a list of a few of the moths and Orthoptera collected on the dining table at Hoorie, which have been identified. 


\section{CHAPTER VII.}

\section{THROUGH THE COASTAL WILDERNESS WITH INDIANS AND CANOE.}

\section{$T$}

HE most interesting observation we made on the launch trip from Hoorie Creek down the Barama River, was of a flocking of more than two hundred big green Cassiques ${ }^{\mathbf{1 5 0}}$ the birds of the liquid cow-bell notes, which passed low overhead with a roar of cackling voices, and a loud whistling of wings, bound for some safe roosting place - still another species to exhibit this common roosting habit.

We found Farnum's deserted, the family having gone down to Georgetown, so we took possession of the empty house; swinging our hammocks on the porch and watching the sun sink over the river, with the dark forest beyond, growing ever darker. As we had been told that there were no mosquitoes, we had not hung our hammock nets, and the droning hum of these miserable pests kept us awake for hours. From across the river came the discontinuous, labored puffs of an overloaded freight train pulling up a grade. Now and then the wheels would slip and four or five chugs would come in quick succession. One could imagine the heavy trail of smoke and sparks, the shining rails and the long line of heavy, slowly moving cars - then the sound ceased, and far down the river another frog took up the chugging. Now and then the voice of a red "baboon" came to our ears; and continually the mosquitoes "zooned" and on the floor below our hammocks the dog whined unceasingly as he scratched his bête rouge. When we opened our eyes, 
lightning bugs of several candle-power flashed above us in the thatch of the porch, and by their light we could see big tarantulas dragging their prey here and there, seeming ready to drop with fatigue at any moment. All the sounds of the wilderness are lulling, save that of mosquitoes when one is netless. Many times that night we wished ourselves back in the boat.

We had heard that there was a coast-wise way of returning to Georgetown; threading little-known rivers and creeks in a small canoe. The idea of exploring those charming little creeks at which all through the journey we had looked with longing, was fascinating to us, and we owe this realization of our dreams to Mrs. Wilshire, who planned the trip and gave it to us as a surprise. This proved to be the most wonderful canoe voyage which any of us had ever taken. For five days we were paddled, portaged, towed and pushed through a wonderland abounding in rarely beautiful birds, butterflies and orchids. We slept at night under our tiny tarpaulin, or invaded, and were made welcome at little isolated Indian missions. Our pen falters at the thought of attempting to give any idea of the wonders of that trip, but day by day we set down our impressions as best we could and here are some of them.

It was almost noon on the I6th of March before we had our men, luggage and canoe in readiness to start. Pushing off we said good-by to the rest of the party; including Crandall and his precious cargo of Red-backed Cassiques and other live birds. They were to return via Morawhanna and the "Mazaruni" direct to Georgetown.

We secured a little canoe, or ballyhoo, about fifteen feet long, with a tarpaulin stretched over the centre. In the bow were four Indian paddlers, two men and two boys, while in the stern as steersman and paddler was a splendidly built Carib Indian, Marciano, chief of the Hoorie woodmen. 
2I6 OUR SEARCH FOR A WILDERNESS.

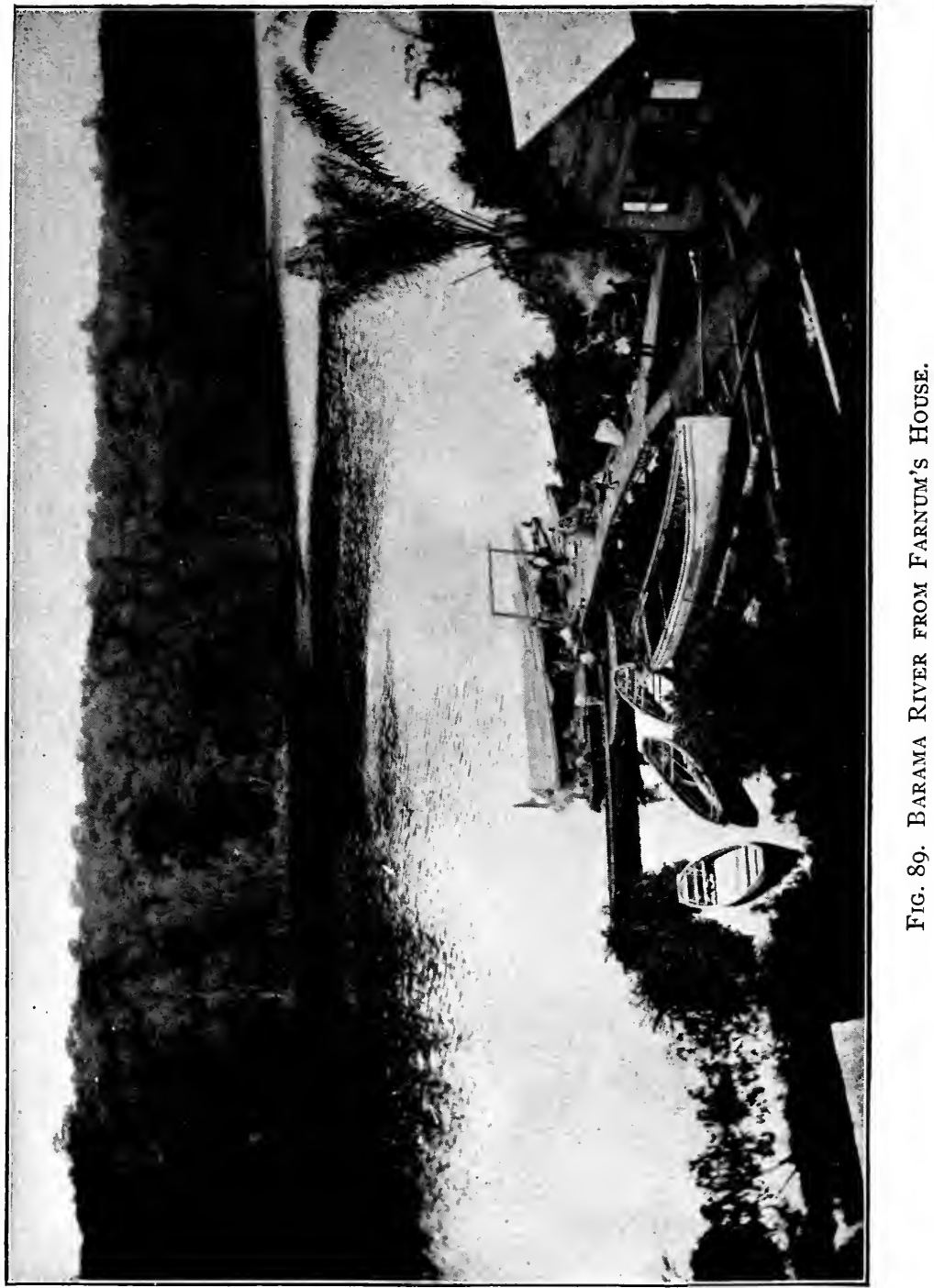


Amidships was piled our luggage and we distributed ourselves over and around the clothing bags and larder boxes. Mr. and Mrs. Wilshire and we two composed the list of passengers, and the unceasing pleasure of those five days was a good test of mutual congeniality and adaptability to "bush-travel."

The stroke adopted by our Indians was a peculiar one, which we were to hear all day and often throughout the night, for these men of the wilderness, short and stocky in build, seemed tireless, and hour after hour they would keep hard at work, sometimes for as much as thirty-six hours at a stretch, with only a brief nap or two.

The Indian paddle rhythm set by little Pedro, the younger boy in the bow, accentuated every other stroke, the tempo of the strokes becoming more and more rapid, until, when further speed was impossible, one stroke was suddenly omitted, and the gap thus formed marked the new slow tempo, which in turn, in the course of fifteen to twenty strokes of the paddle, would work up to a climax and the former rhythm begin again. All kept perfect time, the new change not being inaugurated on any exact stroke, but the others seeming to know instinctively when it would come. Whether they were eating, talking or looking behind them it was the same, all changed as one man.

Two or three hours after starting, we made a landing in order that the Indians could cook their breakfast, invariably composed of a combination of pork, dried fish, rice and cassava. This menu was varied only when one or more of the ingredients happened not to be procurable. Sometimes for many days the Guiana Indians worked hard upon nothing but cassava. The jungle was thick about the little clearing which they made for a fire, and word passed rapidly along the lines of parasol ants that manna was available in the form of rice and bread crumbs. A few minutes after a bit 
of food was thrown down it would mysteriously take legs to itself and begin to walk away, the motor power being myriads of these interesting insects. Big-headed soldiers patrolled all along the winding trail of foragers, troubling no one unless they were disturbed or the workers attacked. Several species of orchids, Brassias and others unknown to us, were in blossom all about us.

On we went again, becoming more and more delighted with our method of travel. There was no puffing, smelly kerosene engine, no clatter of many tongues; and we were close to the water with nothing overhead between us and the sky, or the overhanging branches. The typical river birds paid little attention to our silent craft; and we were able to watch Giant Kingfishers, ${ }^{67}$ Guiana Cormorants, ${ }^{47}$ Snake-birds, ${ }^{48}$ Parrakeets and Swallows at close range.

In sheltered places along the bank our canoe pushed through unbroken masses of the floating rosettes of leaves, known as the Shell Flower (Pistia stratiodes). The leaves are shell-shaped, thick, strongly ribbed and light velvety green in color, covered with a coat of short, dense hairs which repel the water so that when pushed beneath the surface the plant bobs up as dry as before. Thousands of these little plants become detached from their sheltered bays and are carried out to sea where they decay and disappear. Small Water Hyacinths were less common.

The river was full from recent rains in the interior, and in some places for several hundred yards the surface was thickly covered with innumerable small yellow blossoms splashed with scarlet at their hearts, while every now and then a large purple pea-blossom would be seen. These had doubtless fallen from the tree-tops where the river was narrower and the vines and branches overhung the stream. Many insects were carried down afloat on the blossoms and now and then a great hairy tarantula would appear, with 
each of his eight feet in a blossom, trying to keep his balance until he could reach solid ground again.

Agami Herons, ${ }^{39}$ beautiful in their plumage of glossy green, chestnut and blue, were standing here and there in

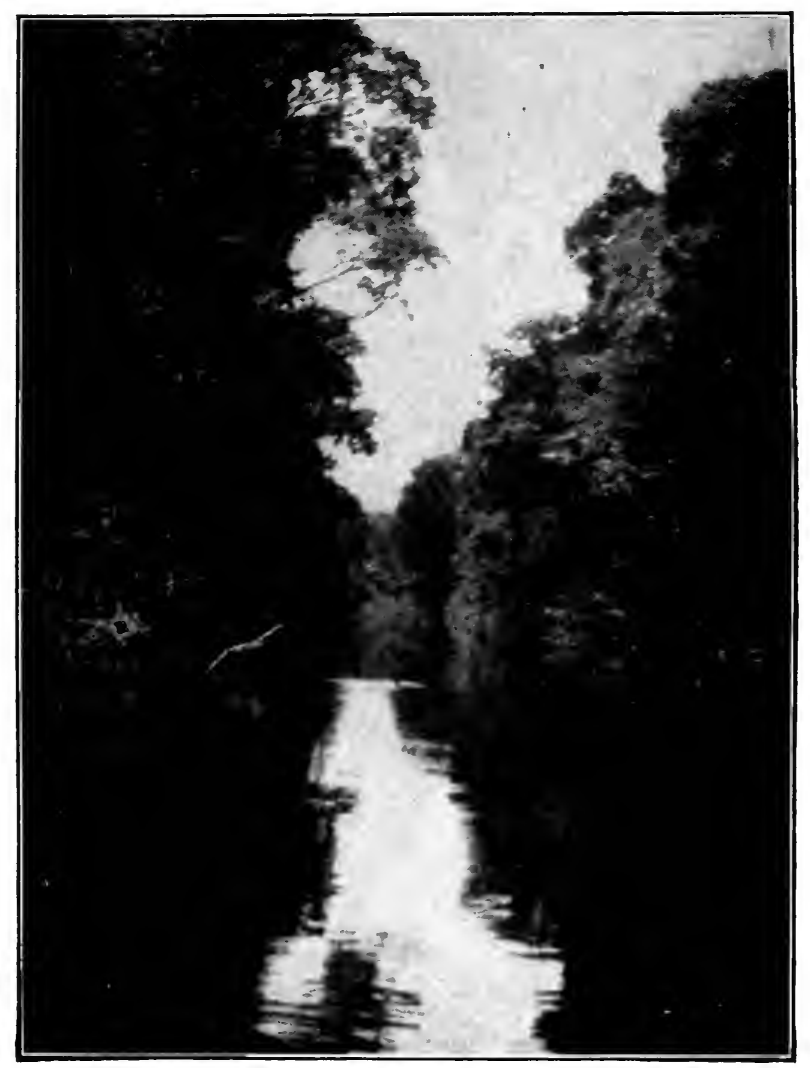

Fig. 9o. Scene on the Barrabarra.

the shallows snatching the insects from the petals as they floated past.

At four o'clock in the afternoon we left the Barramanni River which had averaged about two hundred feet in width, 
and entered the charming little Biara, which was only about sixty feet from shore to shore. Here the vegetation was very dense, water lilies in hundreds with curious, serrated leaves and a profusion of the sweetest of flowers. We were paddling through literally a river of water-lilies. Clavillina blooms hung low over our faces; wild cocoa pods showed rich brown among the foliage. Mucka-mucka with its great heart-shaped leaves was everywhere, a plant which on a later trip was to interest us as forming the food of the Hoatzin. The air was filled with the sweet penetrating calls of the Goldbirds ${ }^{115}$ and Woodhewers and now and then the puppylike yaps of Toucans. ${ }^{81}$ Pendent nests were numerous, built so far out over the water that we could touch them as we passed, thus safe from marauding monkey and opossum.

The stream was dotted with islets, varying from a few inches to as many yards. in circumference, crowded with ferns and graceful sedges, all perfectly reflected in the mirrorlike water. One such islet of the smallest size was crowned with a single-petalled, white calla lily, surrounded by a host of tiny purple orchid blossoms; a square foot of perfect beauty and perfume set in the ebony water. Seldom were we out of sight of flowering orchid, vine, bush or tree. Orchids were in the ascendant and our tarpaulin brushed against long Golden Showers, graceful shoots of Cattleyas and curious green Spider Orchids.

There seems to be no autumn in this land, and death comes only to single leaves, while the variegated scarlet and yellow hues of new sprouting foliage made brilliant every bend of the stream. The Moriche or Eta Palm is dominant here and the vegetation of these lesser streams is dense and bushy, -intimate and delightful, rather than grand and aweinspiring as along the forest rim of the Barama.

Toucans and Ant-birds clarted across the water ahead of us; tree-ferns stretched out their graceful fronds and 
sifted their pollen down upon us. The bird songs of this region are not long and elaborate, but there was no dearth of most delightful, liquid phrases, usually loud and penetrating. Six songs, all wholly unlike one another, reached us that day, all unknown, mysterious. We steered close to the bank and picked a wild cocoa pod but found it unripe and the beans had only a raw aroma. Two long-snouted weevils crawled

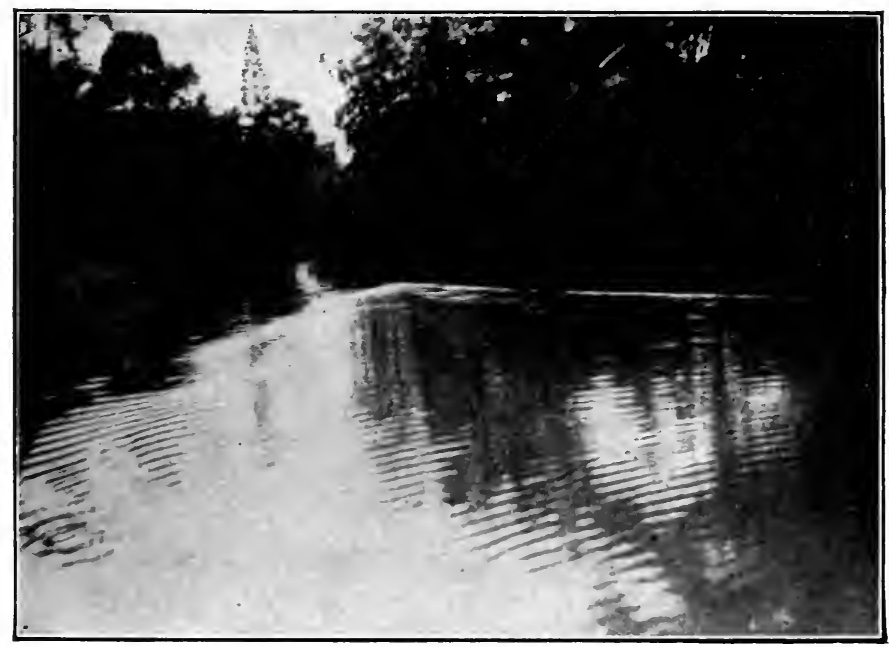

Fig. 91. Wake of a Manatee swiming up River.

from the heart of the pod, one of the myriad hidden forms of life of this wonderland.

Now and then we passed a little open grassy savanna where the water was no longer brown, but a clear black from the steeping of the decaying vegetation.

In many places the water leaves showed where manatees had been browsing, and occasionally we caught sight of the huge ungainly creatures, as they swam slowly up stream or nosed the vegetation along the bank. 
All this and much else we passed in an hour, and at five o'clock entered a third stream - the Barrabarra. The whole country hereabouts is swampy, so when at dark we stopped for our evening meal we did not land but rested quietly among the lily pads. The Indians ate, as they did every-

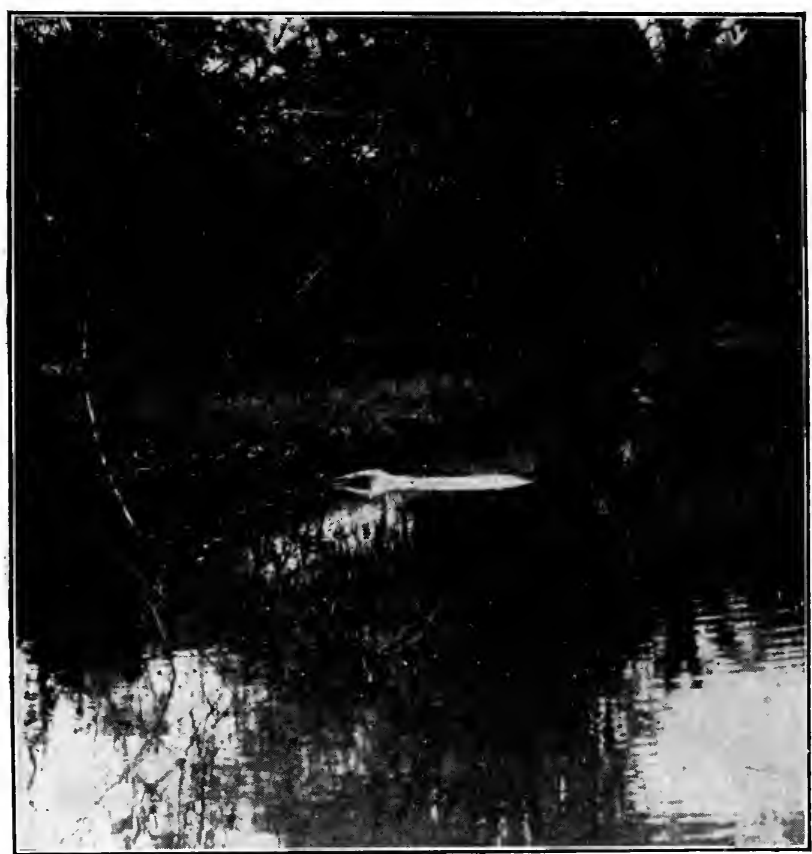

Fig. 92. Manatee browsing close to the Bank.

thing else, silently, with only now and then some low guttural ejaculation.

We flashed our powerful electric light upon the lily pads and found that the water was full of active life. Scores of little fishes were resting motionless in the thin film of water covering the lily leaves, some with the basal half of the body and two lines up and down from the eyes, black. Marciano 
called them Salaver. In addition to other very slender fish, there were numbers of little fresh-water prawns shooting about among the maze of fanwort beneath the pads. The glint of strange shapes came to us - tiny Cyclops and others which the human eye was powerless to name without a microscope. We sat in the darkness listening to the sounds of the swampy jungle. Not a mosquito hummed, and the frogs eclipsed all other, lesser noises, calling in basso and treble, with tinkling bells and a clear ringing chime like the æolian singing of a telegraph wire.

Marciano climbed back to his seat in the stern, gave an order and the paddles pushed sluggishly through the pads, carrying fear and tumult to thousands of little aquatic lives. The next four hours we shall never forget as long as we live. On and on we went through the pitchy darkness, guided solely by the light of the little bow lantern. The bush ropes ahead stood out in sharp silhouette like giant serpents coiled in mid-air across our path. The night seemed to press in on our tiny atom of life. The shadows of the waving arms of the paddlers were thrown on the foliage behind the boat, looking like some huge spider-like thing forever following it. The sheets and drops of water thrown up by the Indians gleamed like molten silver.

The open savannas increased in size and extended farther on each side than the shaft of electric light could carry. Great tufts of pampas grass towered high above our hearls, drooping gracefully outward in all directions. The channel narrowed and the lily blossoms increased until the water was thickly studded with them. Their odor hung heary on the air and when one of the blossoms itself was smelled, the perfume was as sweet and as overpowering as chloroform. During the day they had been all but odorless. For miles we pushed through the tangle of water plants; in places the men having to drag and push the boat over the reeds and grasses, crushing 


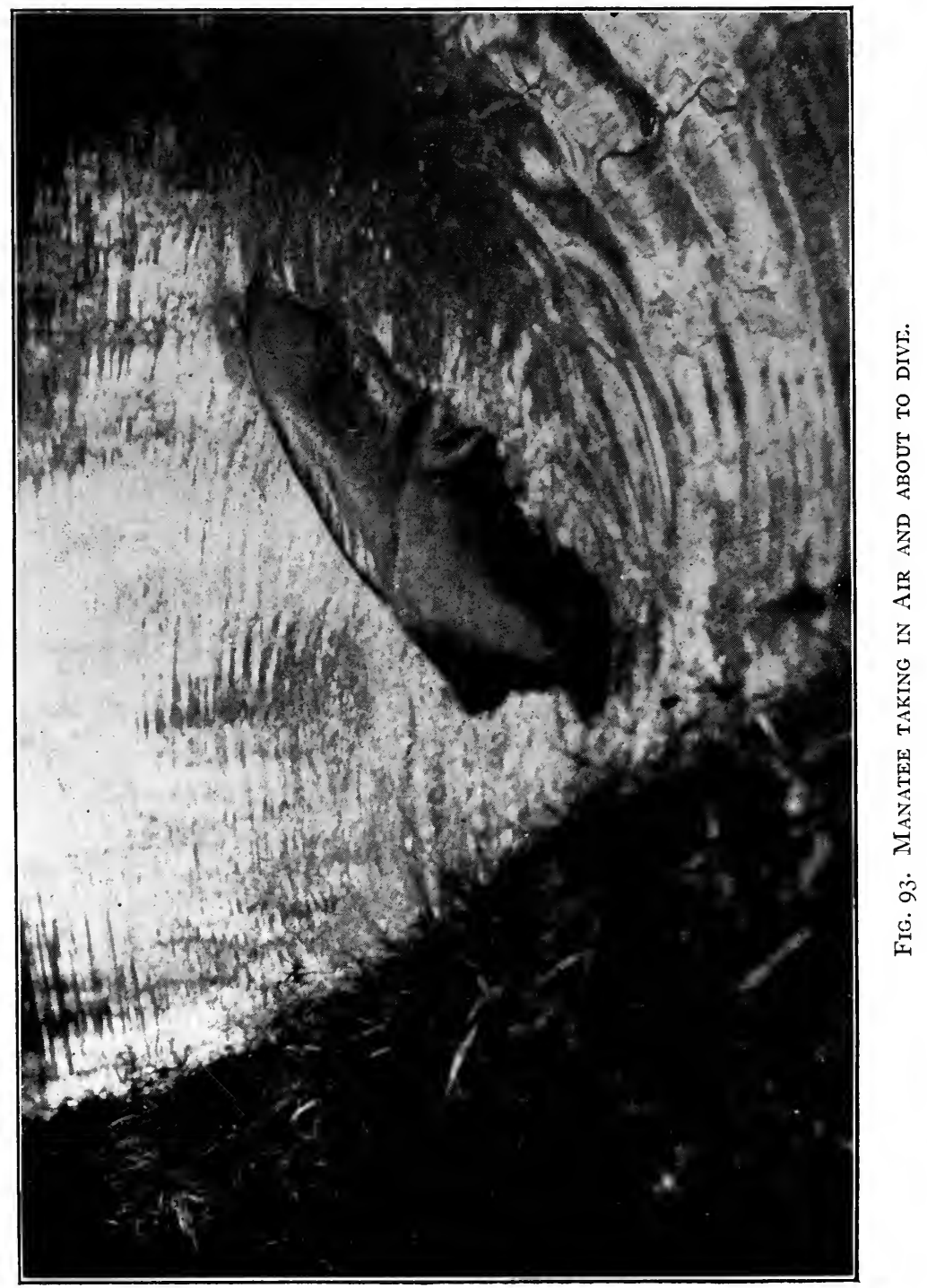


scores of spider lilies with the keel. This is the back-water divide between the rivers which flow northward into the Waini and those which flow to the south. During the dry season this route becomes impassable.

Later we came to open pond-like spaces and here we found another species of water lily with a smaller flower and a smooth-edged leaf with maroon colored under side. Owls, large moths and bats occasionally flitted across the field of light.

It was half-past ten at night when Marciano told us that we were turning into the Morooka River. We were to follow this river down to the very sea, but here it was barely distinguishable as a narrow channel through the grass and reeds. Another hour passed and several dark forms loomed up in the dim light of our lantern, and when we reached them we found that they were boats tied to a rough sort of landing.

We climbed out and stumbled sleepily about, getting the cramped feeling out of our bodies. Then when the Indians had tied up the boat and slung our hammock bags over their backs, we followed them up the long avenue of lofty cocoanut palms which stretched down to the water's edge. We felt our way slowly in the darkness, walking stiffly and uncertainly after the cramped position in which we had been compelled to sit for so many hours.

At last Marciano held high his lantern and we saw towering before us a huge white cross. Instinctively we all paused reverently. Whatever one's faith may be, it is impossible to come thus upon the symbol of a great and ancient church, standing in the midst of a vast and primeval wilderness, without a feeling of awe and reverence. There in the teeming ceaseless life of the wilderness was the mystery of creation: and there stood the white cross, a symbol of man's attempt to solve the tremendous problem of creation and immortality. 
The light revealed a crude little church with an adjoining building standing behind the cross. To this other building the Indians led us. We knocked gently, then harder, then pounded. No response! Half a dozen dogs gathered and howled mournfully. At last finding a side door ajar, we entered a spacious room, part dining-room, part school-room,

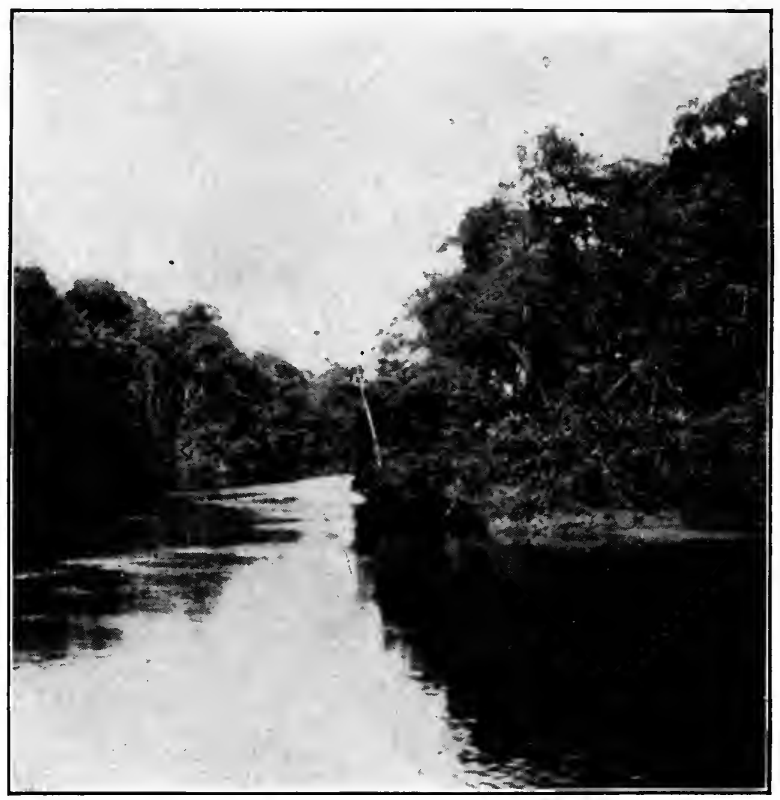

Fig. 94. A Vista of the Biara.

with a loom and a half-finished Indian hammock in one corner. We called and shouted, we pounded on the floor and walls, and at last from the distance - upstairs - came an answering roar. Down to us came the jolliest priest we ever hope to meet. Two strange men and women had invaded his castle at midnight, routing him out of well-earned rest, and yet his welcome was as warm as though we were expected 
friends. Our jovial host furnished us with lights, and gave us permission to sling our hammocks from the rafters of the great school-room. About one o'clock in the morning we rolled into our swinging couches completely tired out. But sleep was not to be had at once. An ominous gritting squeak was heard, then another, and our faces were softly fanned by invisible wings. "Vampires!" came the exclamation from the furthermost hammock. "Never mind them," answered a sleepy voice from Mr. Wilshire's hammock; "doctors say bleeding is healthful!" The scientist echoed his sentiments but in vain. We had to dive down into the clothing bags and pull out the hammock nets. Now these articles are somewhat difficult to adjust under the best of conditions and this night they were perversity itself.

We found that in the packing at Hoorie, the nets had become mixed and two were of an unknown pattern, with apparently no entrance hole except at the ends. A hammock net is shaped like a buttoned up coat with the hammock running through the sleeve portions. It is an acrobatic feat not soon to be forgotten, when one is dead tired and in the dark, and has to enter his net by climbing up to the end of the hammock rope and sliding down through a small, long shute of netting! It was two in the morning before we were settled, and as we finally dropped asleep a score of fierce little demon faces were squeaking and gibbering at us.

At six o'clock the following morning we were awakened by a dozen little naked Indian boys flitting silently about, peering at us like tiny copper elves, or like human incarnations of the bats which had hovered about us during the night. Going outdoors in the dusk we heard a perfect medley of bird notes, Wrens, Thrushes, Tanagers, Seedeaters, all giving voice at once, while from the farther end of the cocoanut walk came a chorus from a colony of Yellow-backed Cassiques. ${ }^{151}$ We saw the mission cat teasing something and took from her 
a tiny oppossum with fur of richest brown, and no larger than a mouse. The little creature was unhurt, but played 'possum until it recovered from its fear when it made itself at home in a small suitcase.

When our jolly priest appeared to wish us good-morning, the little Indian lads bowed their bronze figures reverently and

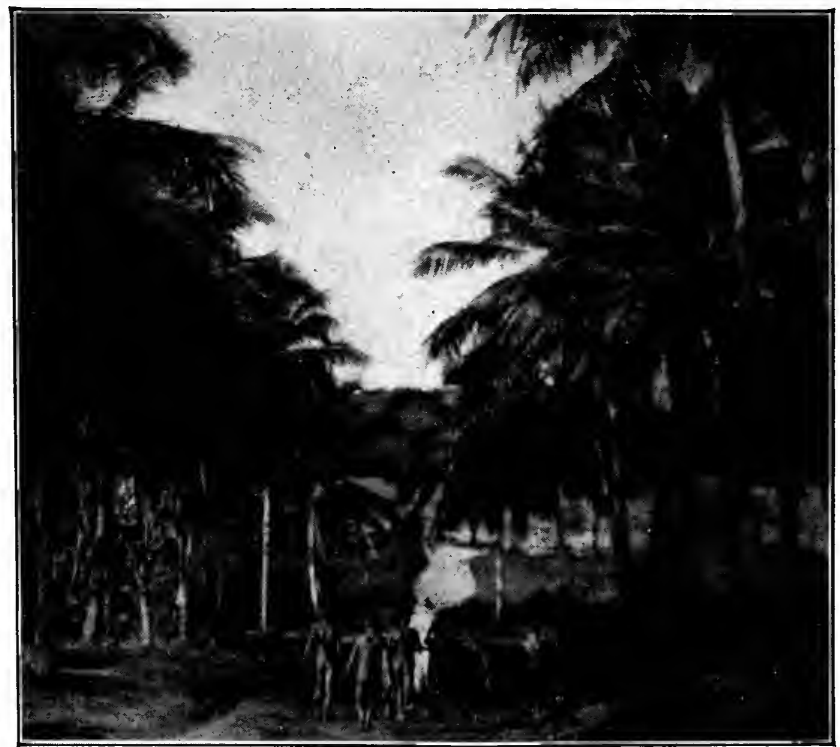

Fig. 95. Father Gillett and his Indian Boys.

kissed his hand. Some of them busied themselves weaving a hammock, while others set the table and later served us at breakfast. Our priest was like the genial monk of a mediæval story. He was delightful with his tribe of small Indian boys, ordering them about in a great voice but with his eyes beaming with affection for them. "Man alive!" he would shout, "bring the finger-bowls!" And to our amazement, the wee naked valet not only knew what finger-bowls were, 
but actually produced them, passing them around the table with colossal dignity.

"That man's a linguist," the Father added; "he speaks English, Spanish and several Indian dialects."

The good Father's heart was overflowing with kindness toward every living thing. He could not even bear to see his cat waiting hungrily for her breakfast, but ordered his small butler at once to give her some milk.

We wondered why the Father's Indian boys had such straight, slim, well-proportioned figures, instead of the unwieldy "cassava-stomachs" so characteristic of the little savage Indians. With a twinkle in his eye the Father told us that his first step in converting the small Indian lad to Christianity was a huge dose of castor oil; then regular hours and regular meals of nourishing food, instead of allowing them to munch cassava all day. Then one might proceed by teaching them the doctrine, and always a useful trade, while after that was achieved there was plenty of time for a more literary education, if the individual warranted it. He had reason to be proud of his method, for in all our travels we never met a missionary whose works "spoke louder" than those of Father Gillett; for the most successful and worthy Indians in the colony had been trained by him. Some of them had become excellent engineers, others priests and still others had learned good trades.

After breakfast the Father took us through the chapel, followed by his dusky little tribe, all crossing themselves piously before the altar. He showed us with pride the decorations of the altar and the ceiling, all the work of himself and his little Indians. The ceiling represented the dome of heaven, bright blue, and dotted with a multitude of white stars.

When we called our little Pedro, the youngest of our Indian paddlers, to tell Marciano that we were ready, Father 


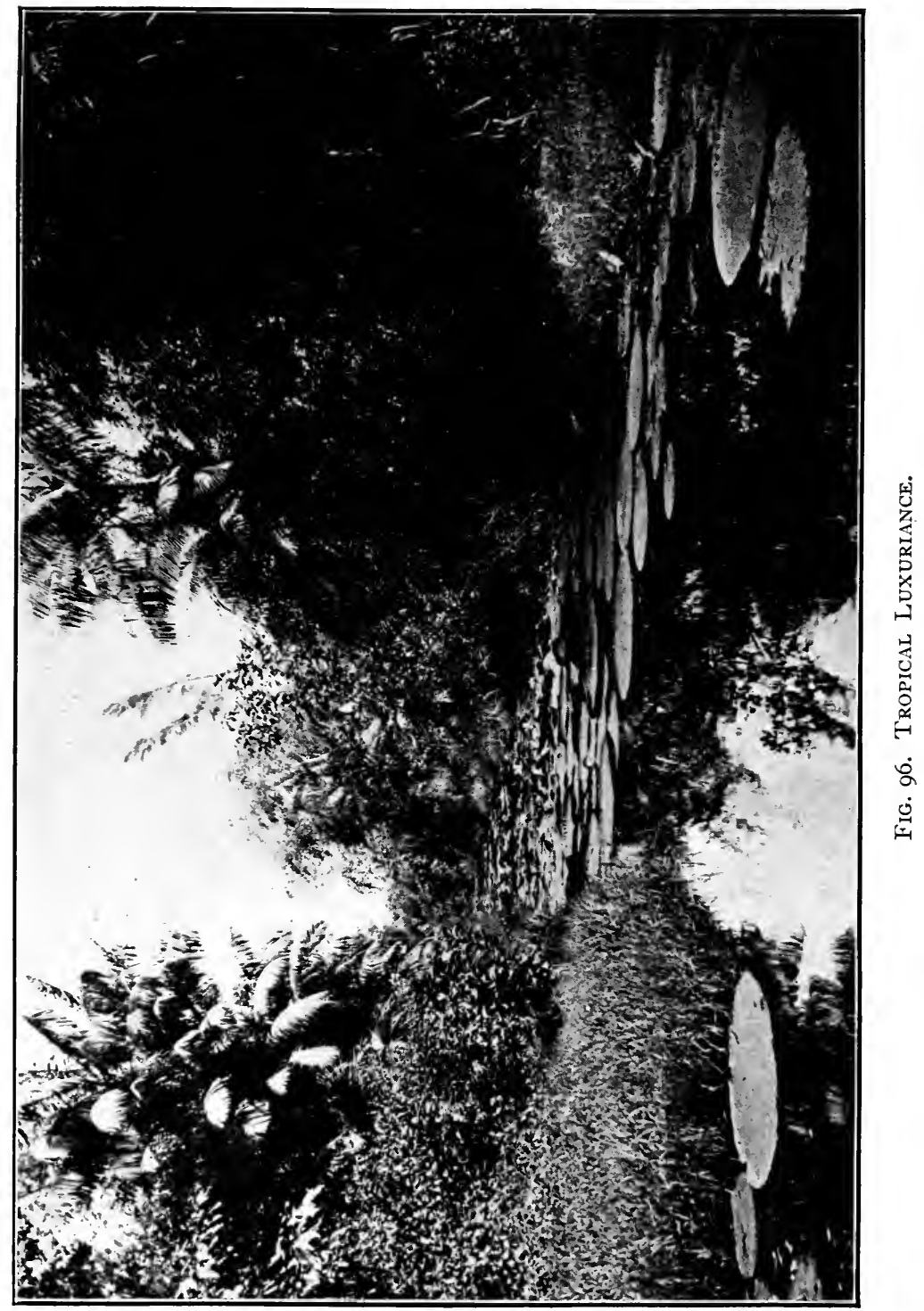


Gillett's eyes filled with tears and he said, "Is your name Pedro? I lost a lovely Pedro. He died of fever last Easter. I did not know I could miss him so much. He used to talk to me. He was not like other Indian boys. He loved to talk." Then turning to us he added simply, "It is a lonely life sometimes, you know."

We were told that white women had never before passed through that part of British Guiana. So unexpectedly did we arrive at midnight, and so early did we depart next morning that perhaps our visit seems as unreal to the good Father as it sometimes does to us - like a very vivid dream which we can never forget. He loaded us with gifts of cocoanuts and fruit and in the fresh coolness of early morning we again set forth on our journey.

Just as we were paddling away, the Father ordered all his small boys into the water for their regular morning swim. Head first they went, splashing about as gayly as a school of strange copper-colored fish.

We found as we went on that the Marooka changed rapidly in character. It was no wider but the water lilies and pampas grass disappeared and a softer, finer grass covered the marsh, dotted with a host of purple and yellow flowers rising from some aquatic plant. Isolated trees became more numerous, and great Woodpeckers, resembling our splendid Ivory-bills, looped here and there. Swallowtailed Kites ${ }^{58}$ dipped and soared and Kiskadees ${ }^{101}$ shrieked near the occasional huts of the Indians.

At noon we lunched on erbswurst and jam at a Protestant Mission - Warramuri - where a small colony of Redbacked Cassiques were established. A school of about fifty Indian children were studying and reciting at the top of their lungs.

We left in an hour and from here on the Marooka widened and consequently lost somewhat in interest. The low eleva- 


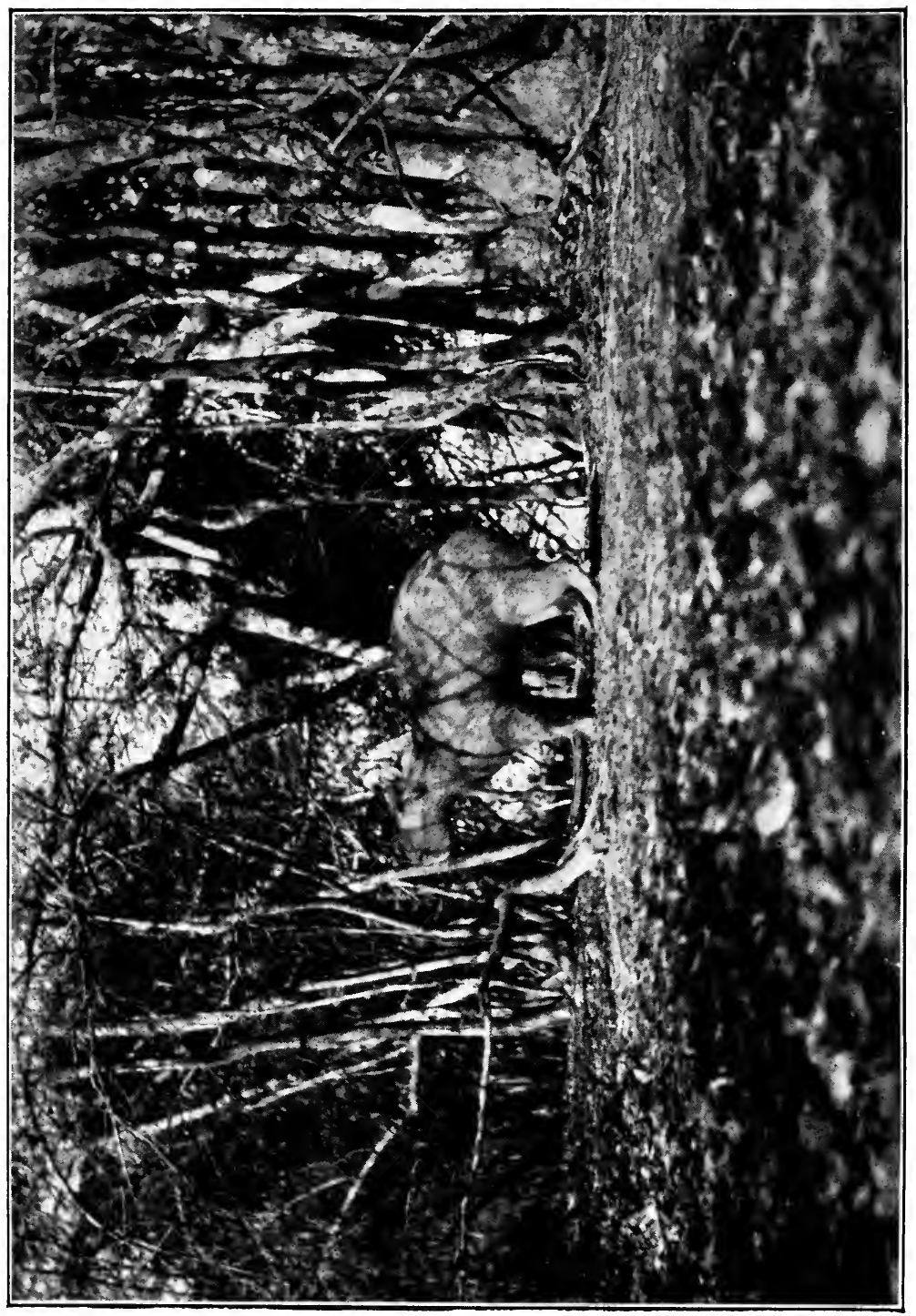

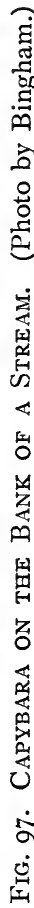


tion on which the English Mission is built is composed wholly of fine white sand, and beyond this mangroves began to appear and the foliag a became less diversified.

We landed for an hour at a small cocoanut plantation and found a most ingenious method of improving time and space until the main crops should yield. Rice was planted in long narrow trenches which are flooded twice a day. Between these trenches the young cocoanut palms are placed, and in the spaces separating the palms, cassava and coffee are grown, while between them in turn and around the edge of the trenches were plantain and tania. The catch crops are thus made to pay for the price of the land and labor. Land - virgin forest - can be empoldered and ditched for $\$ 35$ an acre. The first year's two rice crops will repay this and continue to do so for five years, when the cocoanuts will yield a regular income for fifty or sixty years. This, at least, is the calculation of the agriculturist.

Deer, peccaries and capybara are found on this little clearing, and we saw several of the latter animals running about among the underbrush on the bank. Mealy Amazon Parrots ${ }^{63}$ were nesting in an inaccessible stub. Ant-birds of several species were by far the most abundant birds. Everywhere the undergrowth was flaming with sharp-pointed scarlet blossoms on long stalks which a native called Wild Plantains.

Below the plantation, mangroves composed the only vegetation visible along the banks of the river, and before long our canoe began to rise and fall with the swell of the sea. For days the smell of the damp tropical marshes had filled the air, and now we sniffed eagerly at the invigorating salt breeze. We lowered the tarpaulin, tied everything fast and prepared bailers under the lirection of Marciano.

At last, rounding a curve of the river we came in sight of the sea $-\mathrm{a}$ vast stretch of turbulent brown water. A 
Cocoi Heron ${ }^{31}$ and an American Egret ${ }^{32}$ flew away with protesting croaks, and we began to pitch and toss as we turned south, beyond the outermost sprawling mangrove roots.

We had been warned on no account to make this part of the trip with other than full-blooded Indian paddlers, and when we saw the need for steady, skilful work, we were indeed glad that we had Marciano and his good crew. The waves were too muddy to break, but they rolled high over the low rail of our canoe and we were soon soaked through and had to bail steadily to keep the frail craft from filling. In the midst of all the excitement three splendid Flamingos ${ }^{42}$ flew overhead, one close behind the other, necks and legs extended to the full. We watched them until our eyes ached, and then a dash of several quarts of salt, muddy water in our faces, brought us suddenly back to grim reality. After we had paddled three or four miles, we entered the broad mouth of the Pomeroon, turned close in along shore and finding a sheltered bight, waited for the turning of the tide and to give our Indians a much-needed rest. The heavily laden canoe had given them a hard paddle against wind and tide, and we were to travel onward throughout all the night.

As dusk settled down a Frigate-bird ${ }^{49}$ swooped past, followed by a large flock of several hundred Boat-billed Herons ${ }^{37}$ croaking like their relatives the Night Herons, and on their way doubtless from some roosting place to their nocturnal feeding grounds; for as they reached the water they scattered, some going up the river, others along the shore.

From the east, straight across the whole width of the Pomeroon came another great flocking, a host of Mealy Amazon Parrots ${ }^{63}$ flying as usual two and two close together - by hundreds and by thousands. They turned south along our bank and flew inland, and were joined, almost over the spot where our canoe was moored, by another great multitude of their kind, coming steadily down 
the coast. At the very lowest estimate there were eight or ten thousand parrots. Once and only once we saw a solitary individual unaccompanied by a mate. While still in view he attempted to attach himself to a pair of birds, whereupon both dashed at the unfortunate intruder and drove him headlong out of sight below the level of the branches. It is indeed a serious thing to loose one's mate if one is a parrot! To be a widow or a widower is to be an outcast.

At ten minutes past six the parrots vanished in the dusk and true to its name a "six o'clock bee," a species of large cicada, sent out its shrill whistle from the mangrove to which our canoe was tied. Here for the first time since we left Farnum's we encountered mosquitoes and sand flies, but oil of tar did much to discourage them. It is a curious fact that although the prevailing wind blows in the direction from which we had come, yet these troublesome insects are said never to pass beyond the line of the Pomeroon's mouth.

After an hour of paddling we stopped for a supply of water at a tiny Portuguese store built on piles, and going by the name of Poc-a-poo. It was a weird little place with rows of tiny shelves on which were bottles of lemon soda which was remarkably good, and an assortment of ribbons, knives and paddles for trade with the Indians. We purchased some well-made Carib Indian baskets and, stumbling over a caged Guan ${ }^{6}$ or Maroodic as they called it, ordered it sent to Georgetown, where it appeared the following week and is now a contented inmate of the New York Zoölogical Park.

At nine o'clock we started on our all-night parddle up the Pomeroon. Like most tropical nights near the sea the air was chilly. We rolled up in our blankets, and anointed our faces with the tar oil. The scientist chose as his night's couch one of the long sloping side seats. The slope was only a fraction of a degree, but gravity and drowsiness would 


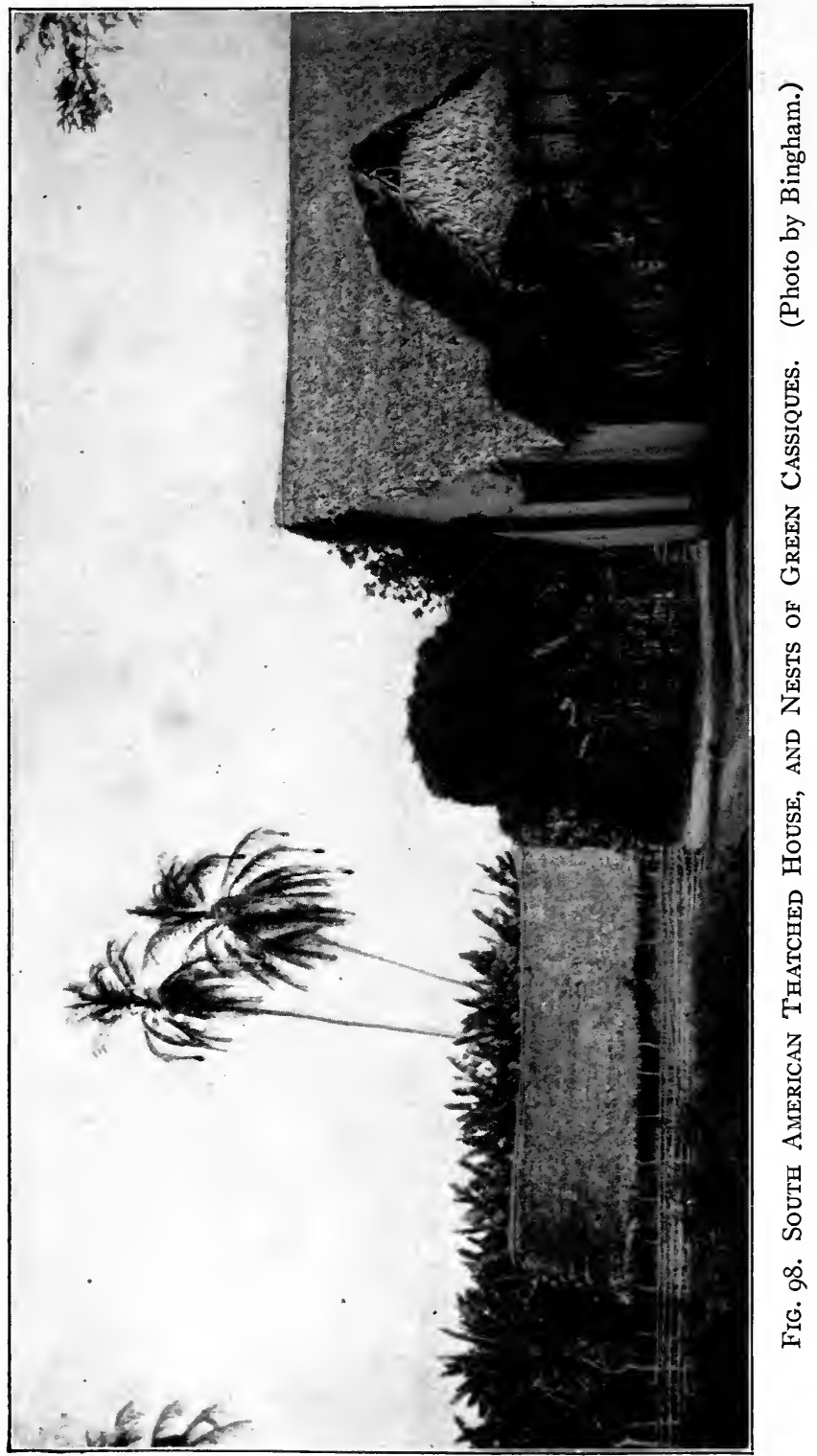


invariably cause the downfall of the occupant of the seat, much to the disturbance of the canoe's equilibrium.

As we lay and listened to the strange rhythm of the paddles, and watched the brown current swash past the side of the boat, we thought of all the exciting scenes this river and this coast had witnessed: - the ill-fated search for El Dorado by Sir Walter Raleigh; then the capture and recapture of the colony no less than three times by Dutch and British. Later came a period of great prosperity when hundreds of sugar plantations yielded great profits to their owners and the social life was as gay as that of our old Virginia. Then followed the ruin of the sugar industry, bands of run-away slaves taking to the wilderness; and now to-day, the chimneys of the old mills are often the only marks of former civilization which the jungle has not obliterated.

We skirted the mangroves for hours and saw nothing but an endless succession of those weird stilted plants, while scores of four-eyed fish skipped and slithered over the mud, or dashed across our bow, attracted by the glow of our lantern. In the electric light they looked pale and ghostly against the black mud.

At midnight we passed a light which showed the location of Marlborough Police Station. Two hours later we heard weird music from a tom-tom and a four-toned fife or flute. Crude as it was, it had a wild melody and the syncopated, or "rag," time was perfect. We could see the hut near the water and hear the shouts of the dancers as we passed down the centre of the river. We were hailed by a canoe of halfdrunken negroes who put off and wished to accompany us up the river. Marciano gave a low command and one of the Indians muffled the lantern; then all swung together in a new rhythm - the full-speed paddle-rhythm of the Caribs - and we fairly flew through the water. After every five minutes spurt our crew rested for a few seconds to locate our 
unwelcome pursuers. At first they cursed us and paddled furiously, but their tipsy efforts were no match for our lithe red-men and the negroes soon dropped out of sight and hearing.

There was no moon but throughout all the night whenever we awoke, the southern cross gleamed brilliantly down at us, and almost in the zenith Orion stood ever poised in his gigantic stride. As usual frogs and toads furnished most of the nocturnal music, and we spent an hour or more in classifying the various utterances. Among them was the Telegraph Toad who spoke in a regular make-and-break Morse code, sending his wireless messages to his mate. Another, heard more rarely, was what we called the Wingbeat Frog. This species gave out a muffled throbbing roar like the hurried wing-beats of a Swan in full flight. It would last for five seconds, to be answered instantly by another across the river.

From the wonderland of the narrow Biara, we had come out upon the boundless expanse of the ocean, passing thence to this splendid river a half mile across. But we had far from finished the experiences and variety of this ever-to-be remembered trip.

At daybreak we pushed through a tangled mass of lilies and water hyacinths into a tiny caño or creek, and in a soft rain, while the tired Indians slept beneath protecting palm leaves, we cooked erbswurst and cocoa. The morning chorus was infinitely sweet, from flocks of invisible songsters, - a trembling descending chord of three notes, rising at the end in a plaintive, questioning way.

At eight o'clock we went on again, the Indians apparently perfectly rested after their two hours' sleep. The Pomeroon narrowed to about a hundred yards, mangroves disappeared and mucka-mucka with its oblong, pineapple-like fruit, took their place. Flowers were abundant, - white convol- 
vulus; wild sorrel, pink with deep carollas; large yellow blossoms with scarlet hearts, and many other varieties. Foureyed fish were still common and Great Rufous Cuckoos, ${ }^{77}$ Lesser Kiskadees ${ }^{103}$ and Swallow-tailed Kites ${ }^{58}$ were building nests.

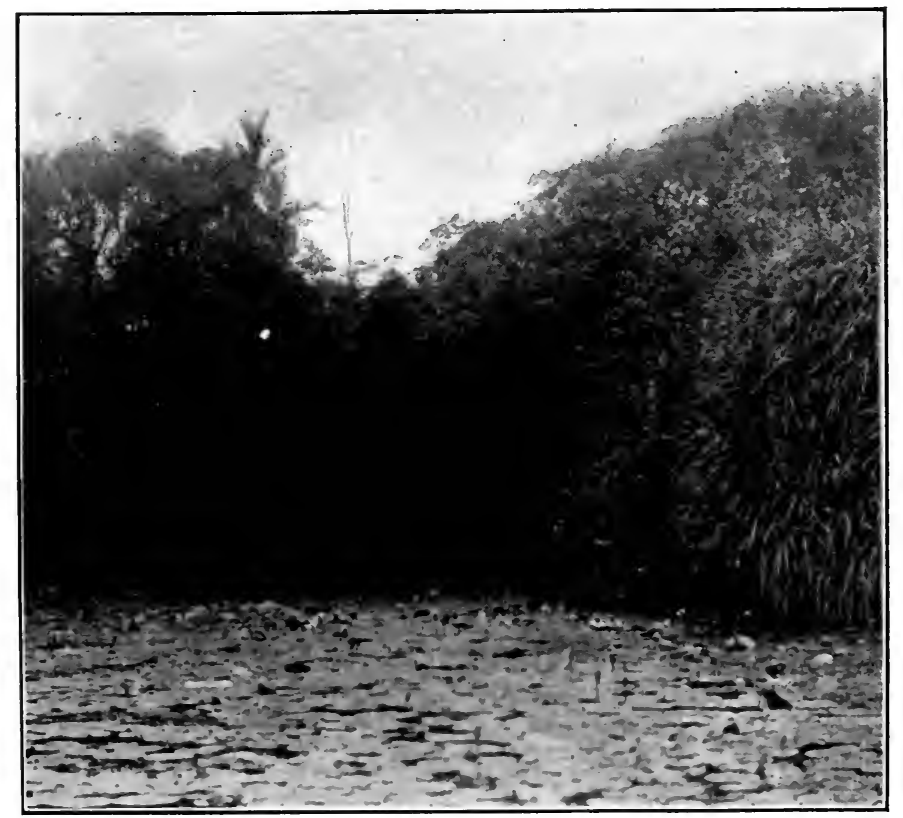

Fig. 99. Miles of Lilies.

At Pickersgill Police Station we stopped for lunch. These posts are the sole representatives of law and order in the wilderness, and here the semi-military organization of negro police have their quarters. Most of them are men of unusually large size, and in disposition they are pleasant and obliging. They never failed to do their best to make us comfortable. The duty of these men is varied. Besides being responsible for the good conduct of the inhabitants of their 
districts, they keep account of shipments and all passing boats and passengers, and stand ready to run down, or rather paddle down, fugitives from justice. At each post are little rooms reserved for travellers, and here any strangers with proper credentials are at liberty to swing their hammocks and make themselves at home. The sergeant had just trapped a half dozen pretty blue and yellow Violet Euphonia Tanagers ${ }^{140}$ in a mango tree near the station. The usual colony of Yellow-backed Cassiques ${ }^{151}$ was deserted at the time of our visit, but had been occupied twice during the last year. Lying half in the water in front of the house was an anaconda fifteen feet long which had just been shot. We purchased thirty bananas for fourpence, and with fried bananas and bacon, the unfailing and never cloying erbswurst, jam, educator crackers and lime squash, we had a meal fit for the gods.

At this point we left the Pomeroon and turned up the Harlipiaka for two hours, then into the last real river of our trip, the Tapakuma. This river was only about seventy-five feet wide and with vegetation neither grand nor very luxuriant, principally eta palms and mucka-mucka. Wild cocoa and clavillina blossoms were everywhere and numerous Lesser Kiskadees ${ }^{103}$ were building. Many small, deserted estates appeared as the river grew narrower, and morpho butterflies and Silver-beak Tanagers ${ }^{146}$ haunted the half-overgrown ruins. Catching sight of a snake on an overhanging branch, we persuaded Marciano to steer close to it, but as we reached out to seize it, our Indian's fears overcame him and he swung out quickly, the serpent making its escape into the water. It was a harmless species about five feet long, and yellowbrown in color. With the exception of the dead anaconda, it was the only snake we had seen on our trip. When we commented on this, Marciano relieved his feelings in two words, "Me glad!" 
It was dead high tide, although the water was fresh backed up by the salt tide farther down. The surface seemed to be covered with rubbish, and at first glance it looked as unsavoury as the water in a New York ferry slip! But when we examined it, the flotsam proved to be composed of a host of various nuts and seeds, many of which were beginning to send out roots and leaflets. They were of all shapes and sizes - from large flat disk-like pods and round vegetable-ivory nuts, to smaller ones covered with corrugated husks, fluted or polished like metal.

The river became still more narrow, and twisted and turned to every point of the compass. Flowers were abundant and we noted at least twenty species with large and conspicuous blooms. A blue-bell blossom was especially characteristic of the Tapakuma, growing up from the water six to thirty inches. There were few lilies and the predominating tree was one with sensitive foliage, which went to sleep in the late afternoon. Several species of orchids in full flower were common, and from one branch we pulled into the canoe a string of a dozen plants of a most fragrant white orchid Epidendrum nocturnum. The whole region was very different from that of the Biara but no less interesting.

Just before sunset we came to the fairyland of Tapakuma Lake. We had zigzagged through many miles of tortuous channels, with copper-colored Indian hunters passing us now and then, silently in their small canoes. At last we came to a portage - a gentle slope up which our canoe was dragged, over the divide and into the great grassy expanse of water savanna, in the centre of which is the dark deep lake.

We walked a few yards into the woods to sce some "falls" which turned out to be only a moderately foamy rapid, and on the way we disturbed a large troop of monkeys which limbed off slowly through the branches; and then hurried 
back to our boat, for we were still far from Anna Regina, where we planned to spend the night.

On and on we went, the darkness settling quickly down. A new Castanet Frog raised its voice. This was really remarkable - a syncopated Oriental rhythm, clicking musically, and held by one frog for only a minute or two when another instantly took up the little tune. This shifting of place, the music sounding first here, then farther on, made it seem as if some invisible dancer were swiftly whirling over the reeds and tules. One could hear the clicking of the castanets and the tinkling of anklets, and the thought was made more vivid as a bejewelled coolie woman passed us in a long narrow dug-out, paddled swiftly by her husband.

The water was very high and a wide new channel among the grasses so confused Marciano that we paddled for an hour before we realized that we were lost. We changed direction and guided ourselves by the stars, passing some dense grass through which we had to push laboriously. At last Marciano sent a clear, penetrating call through the night and the coolie answered, far ahead and to the left. We called twice after that and then came into a canal, and soon were alongside two canoes blocked by a lock. We would have as soon expected to find a motor car here in the wilderness as a canal lock, but nevertheless there was a canal lock with no one to operate it. By our combined efforts we opened it, passed through and found ourselves surrounded by miles of sugarcane fields. We had entered the back door; as it were, of the great sugar plantation of Anna Regina, one of the few which are still in operation. We were on the home stretch and the Indian boys towed us the remaining distance, running at full speed, tumbling head over heels into the water; and forgetting for once their usual Indian stolidness, they giggled and chattered as if they were out for a lark, instead of having paddled a heavily laden canoe on thirty-six hour stretches! 
At midnight we reached the end of the canal, and a hundred yards up a road we found the Anna Regina police station. The guard turned out, cleared away the judge's bench and witness box in the courtroom and laid blankets for us on the benches, as there were no rafters for our hammock ropes. Our Indians would not come near the dreaded prison house, but left our baggage at the entrance. They said good-by as they were to start back at once. We had grown to have a real affection for these simple men and boys, and found them

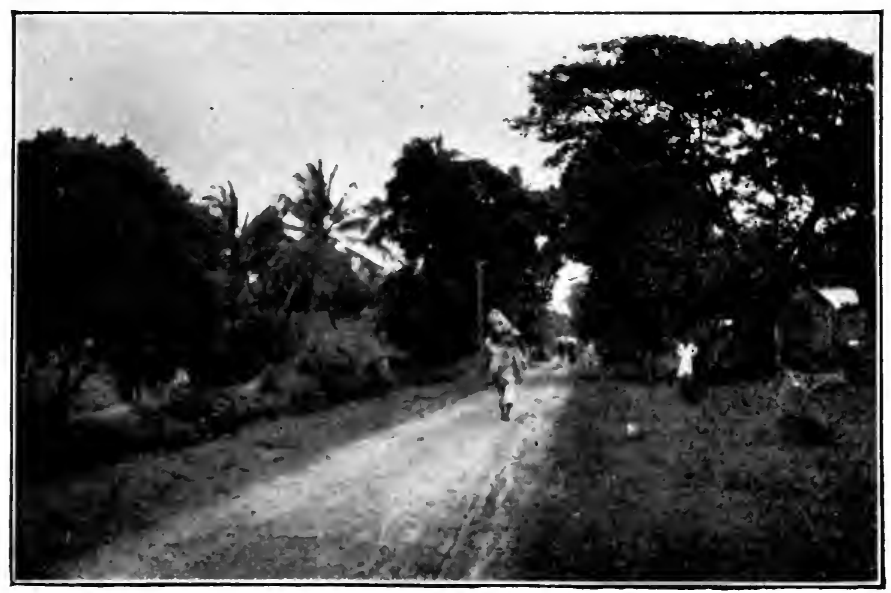

Fig. 100. The Road to Suddie.

the best of travelling companions, silent, courteous and wonderful workers. May the time come when Marciano will again pilot us through that beautiful region to which no pen or camera can do the slightest justice!

The following morning after a walk through the neighboring coolie village of Henrietta, where we purchased some Yellow-bellied Callistes ${ }^{142}$ and other birds, we secured a carriage, with a horse and a mule as motor power, and drove to Suddie, taking the steamer thence down the Essequibo River to Georgetown. 


\section{CHAPTER VIII.}

\section{THE WATER TRAIL FROM GEORGETOWN TO AREMU.}

$W^{E}$ allowed ourselves only forty-eight hours in Georgetown to unpack our specimens and prepare for our second expedition into the "bush." This time we were to leave the coast and strike straight inland, passing up the Essequibo River to Bartica, thence via the Mazaruni and Cuyuni to the Aremu and the Little Aremu rivers. Near the head-waters of this last stream was the gold mine which marked our journey's end, deep within the wilderness.

On the morning of March 23d, we left Georgetown on one of Sproston's steamers en route for Bartica. A pair of Graybreasted Martins ${ }^{122}$ accompanied us, and we found that they were nesting in an angle between two beams of the main deck covering. Young birds were in the nest, so the Martins must have accompanied the steamer on many of the alternate day trips between Georgetown and Bartica. Not only this but the river boat exchanges routes every two weeks with her sister steamer which is plying on the outside northwest route to Morawhanna, the fortnightly change from fresh to salt water doing away with all need for keel cleaning. So these birds had started their nest while the boat was making her sea trips. During much of the time we were on the boats the birds kept flying out to each side over the water in pursuit of insects for their brood. They sometimes went far ahead or out of sight a half mile to shore.

After entering the wide estuary mouth of the Essequibo we passed Leguan and Hog islands, each over ten miles in 
length, while above these a succession of smaller islands appeared. The river is about three miles in width, fringed with mangroves, and we saw no life on shore save occasional Cocoi Herons ${ }^{31}$ feeding on the flats.

The Essequibo is the largest river in the colony and rises in the extreme south, somewhere in the Acarai Mountains near the equator, some six hundred miles inland. Like all the great rivers of this region it is navigable by steamers for

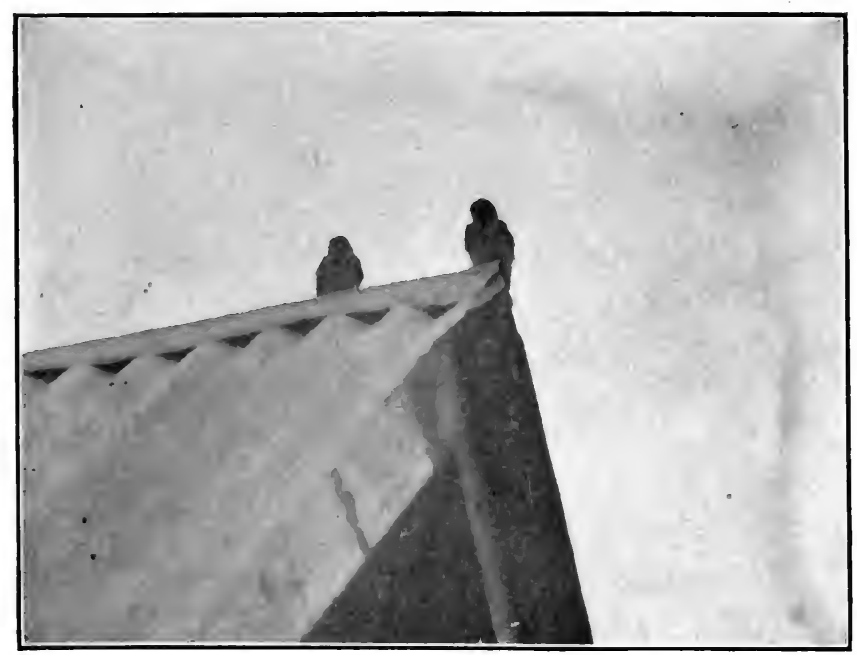

Fig. ior. GraY-breasted Martins nesting on the Steaner.

only a short distance, rapids and cataracts barring the way about fifty miles above the mouth. 'The first great tributary' is the Mazaruni, entering from the southwest and touching with its uttermost head-waters the very base of that mysterious lofty plateau, Roraima, on the borders of Brazil.

We landed at the very apex of the point of land between the Essequibo and Mazaruni rivers, - the village of Bartica or Bartica Grove. It is a most dilapidated place, half in 
ruins, a single street of miserable houses filled with blacks and coolies.

We were invited to spend the night at the house of an Englishman, Mr. Withers, enjoying again the unfailing hospitality of the wilderness. In a launch we proceeded three miles up the Mazaruni, and climbing a steep hill, denuded of its forest, we turned and revelled in the magnificent view. A small, heavily-wooded island in the foreground broke the surface of the shining waters, and beyond, the two mighty rivers rolled ceaselessly, joining their floods with hardly a ripple. Directly across, on the opposite shore of the Mazaruni, the picturesque white buildings of the penal colony could be seen, looking more like the hotels and cottages of some watering place than like prisons. If one must be imprisoned for life there are few places one would prefer to this!

An American company had obtained a concession of some seven thousand acres for the purpose of raising sisel hemp, and Mr. Withers was in charge of this important undertaking. His home, on the crest of the hill, overlooked the surrounding rolling country, six hundred acres of which had already been cleared during the preceding nine months and planted in the valuable fibre plant. Here again we found a most ingenious system of catch crops, peanuts, castor beans and corn, surrounding but not interfering with the slower growing sisel. Their success was yet to be proven.

A careful study of the effect on animal and plant life of this clearing away of the forest would yield much of interest. Many sloths with young were caught when the trees were being felled, and Goldbirds, Woodhewers, Parrots and other forest birds had now retired some distance from the clearing. The antlers of two deer shot here were simple spikes. Insects of all kinds had greatly increased, and caterpillars of strange shapes and colors were legion in number and doing their 
best to undo the labor of the agriculturists. Insect-eating birds of certain types had increased enormously, and Graybreasted Martins, ${ }^{122}$ Barn ${ }^{121}$ and Variegated ${ }^{119}$ Swallows filled the air, while Kiskadee Tyrants of three species, ${ }^{101,}{ }^{103,}{ }^{104}$ other Flycatchers, House Wrens, ${ }^{124}$ Seedeaters, Hummingbirds and Honey Creepers were abundant, swooping over the open fields, snatching insects from the air, or leaves, or ground, according to the method of hunting of each species. The

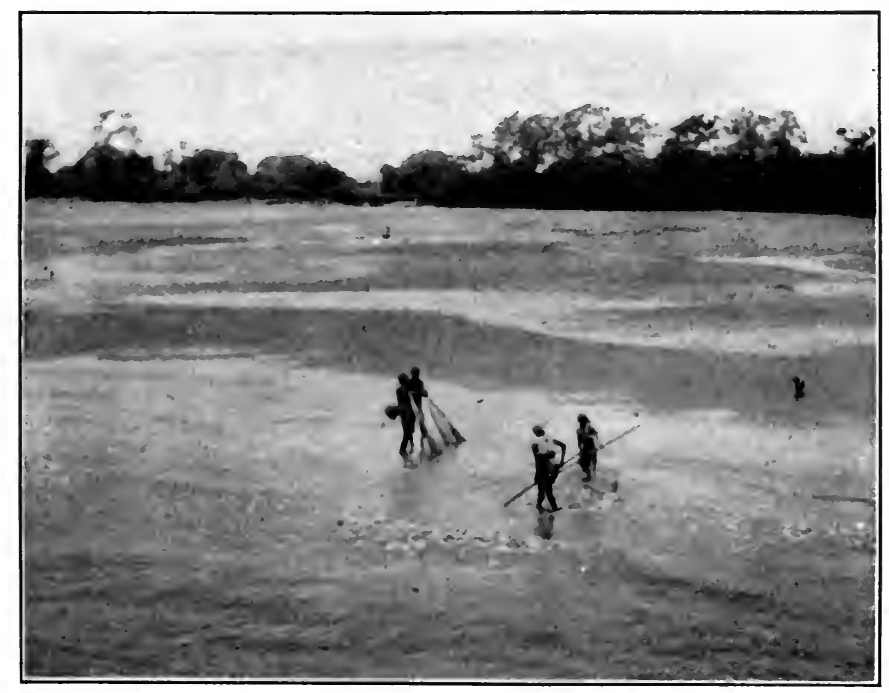

Fig. I02. Coolies and their Wives fishing in the Essequibo.

Honey Creepers ${ }^{136 a}$ were continually getting into trouble here as elsewhere in the darkened upper roof space of the house, . and many had to be caught and liberated daily.

Small snakes and toads are also said to have increased, due doubtless to the increase of insect food, but the abundance of agoutis or acouris was unfortunately only too evidently due to the supply of succulent vegetables.

This evening the regular afternoon wind continued until 
late, and it was too cool to walk about without a coat. The wind sounded anything but tropical, howling around the eaves of the house like a northern blizzard. The moon rose about nine o'clock - a great flat-sided ball of orange, lighting up the pale bare fields but throwing all the jungle into blackest shadow. Soon the light became stronger and the two southern crosses paled from view, the false one higher up, kite like, and the vera cruz, low and resting on its side.

"Sproston's" is a company which controls many of the steamer and launch lines of the colony, and gives remarkably good as well as reasonable service. When the day comes that the tourist learns of the beauties of this country, the transportation lines will become of immense value. Now they depend principally on the many American concessions and other interests for freight, and upon pork-knockers and bovianders for passengers.

At nine o'clock on the following morning, travelling again on one of Sproston's launches, we left Mr. Withers and proceeded up the Mazaruni, in about an hour reaching the point of its confluence with the Cuyuni. This was as beautiful as the junction of the Essequibo and the Mazaruni which we had left. Turning up the Cuyuni we went on and on through a region of indescribable beauty. The noble river spreads out in a wide smooth expanse, - a tropical Hudson with palisades of trees. It is very shallow and when the water is low there is little but tide at this point. Hence mangroves are dominant, becoming, however, smaller and less numerous as we proceeded. At eleven o'clock we reached the beautiful falls at Lower Camaria Landing and went ashore to find a delicious breakfast prepared for us by the genial and hospitable Mr. French and served by his aged man-servant, who was christened Swan, but who was familiarly known throughout the colony as "French's Boy." 
WATER TRAIL FROM GEORGETOWN TO AREMU. 249

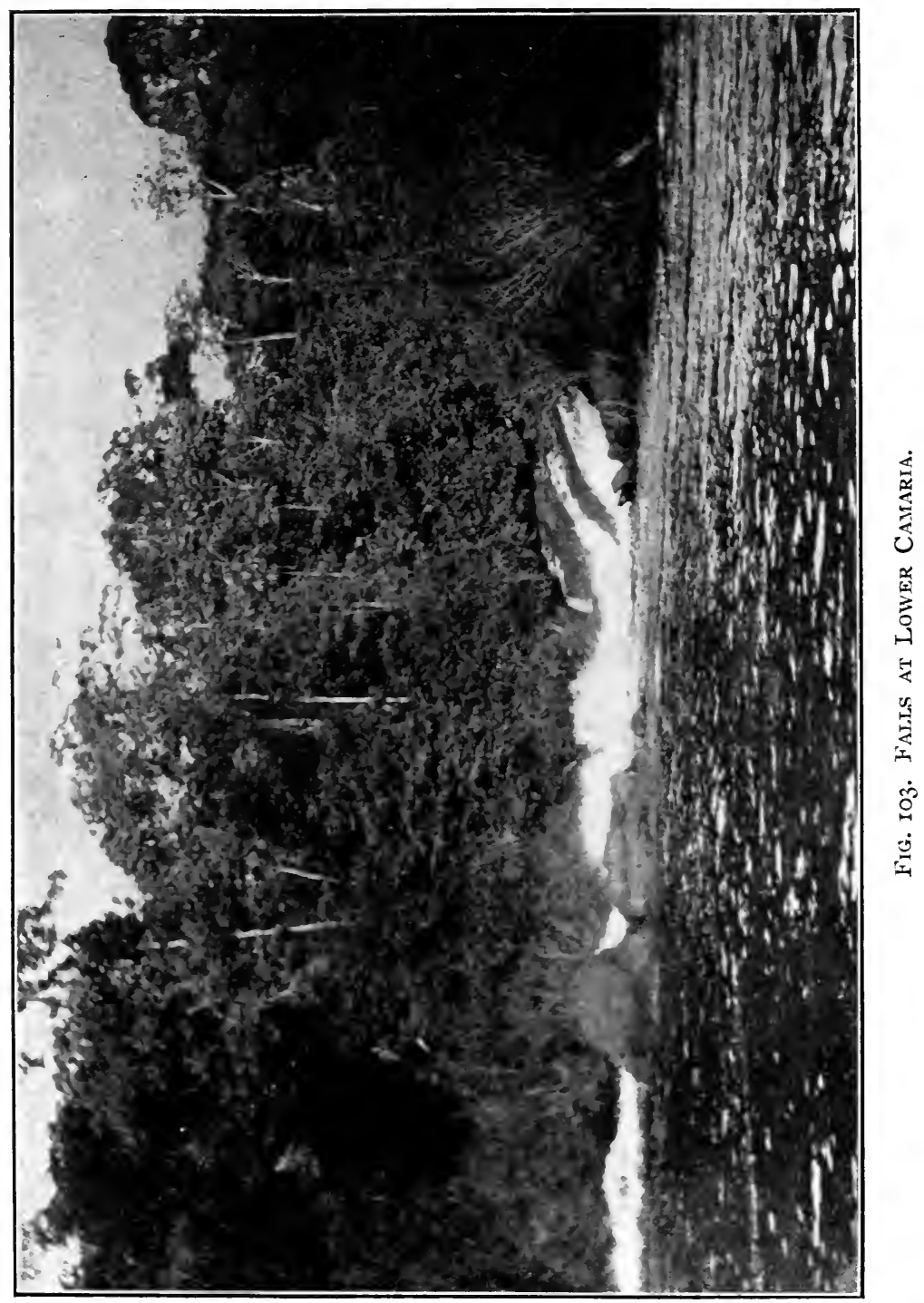


At Camaria a series of all but impassable rapids and falls occurs, and a portage of three and a half miles is necessary. A well-made sandy wagon trail points the way, rising gradually and then slowly descending again. At the top of the rise the sand is of the finest and whitest quality. Butterflies were extremely abundant along this wood road, a dozen splendid blue Morphos being sometimes in sight at once.

One interesting species of butterfly (Castina licus) was very common, flying along ahead of us with short spurts and alighting on bare twigs, just within the shadow of the jungle. They were dark brownish above, tinted with dull orange and green and with four broad streaks of white acros3 the wings. They were perfectly protected in the positions of rest which they chose on small bare twigs, the brown merging invisibly with the dark recesses of the undergrowth beyond, while the white markings exactly simulated a white orchid blossom, sprouting, as so many of them do, from a leafless stem. As the mule cart passed laden with our luggage, we seized the Graflex camera and secured the accompanying photograph. In spite of their protective colors and mode of resting, the wings of almost all had been nipped by birds, and we saw one fall a victim to a Flycatcher. The characteristic birds of this trail were Swallow-tailed Kites ${ }^{58}$ and Yellow-bellied Trogons, ${ }^{76}$ the former soaring overhead every few minutes and the latter dashing from cluster to cluster of berries.

In the middle of the afternoon our walk brought us to Upper Camaria, where we were again on the bank of the Cuyuni. Here, tied to a gigantic Mora tree, a second launch awaited us, and from here to our second night's stopping place at Matope we stopped only once, at Tiger Island, to take a few "pork-knockers" on board. Although there were only three small, hut-like houses here, there was the invariable colony of Yellow-backed Cassiques. ${ }^{151}$ 
The tide was blocked by the succession of falls and rapids, and so at Upper Camaria the whole character of the vegetation was changed. Mangroves had vanished and in their place were mucka-mucka and other aquatic growths, backed by the solid walls of trees and vines.

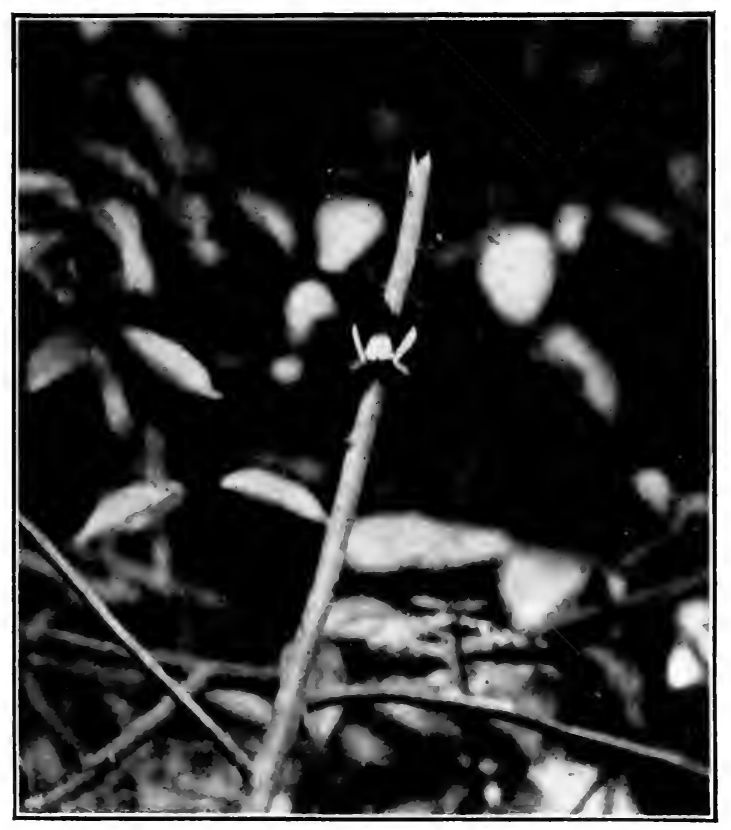

Fig. ro4. A Butterfly mimeking an OrChid.

Snakebirds ${ }^{48}$ were perched in solitary state at frequent intervals along the banks, - silent, sinister looking, craning their necks out at us and either dropping quietly into the water and sinking from view or flapping heavily upward. Ordinarily their flight is very pelican-like; six or eight flaps, then a short scale, but when they once reach a high altitude, they soar most gracefully with set wings, first in a wide, slow 
circle, then with a sudden straight rush, then a circle and so on, all apparently without a single wing beat. When thus high in air they have a most peculiar arrow-shaped appearance; thin sharp beak, slender neck and body, and broad, fanshaped tail.

While the launch was puffing slowly along we saw one of the most unexpected sights of the trip - a fresh-water flying fish Carnegiella strigatus. It did not leave the surface entirely but skimmed steadily along in a straight line with the tip of the deep keel of the abdomen just cutting the

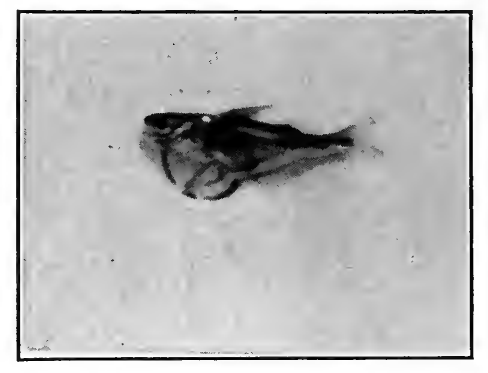

Fig. 105. Fresh-water Flying Fish.

surface. It was small, not more than two inches long, and of the greatest interest to us at that time, as we did not then know that such a thing as a fresh-water flying fish existed. To see a silvery little form break from the mirror-like surface of the river and go skimming off through the air left us amazed.

These fish were silvery in color, marked with irregular black markings, with long, wing-like pectoral fins and a remarkably deep keel, like the keel of a racing yacht.

As we went on, the walls of foliage became higher and more dense, stretching up, far up above our heads, until the topmost branches were from one hundred to one hundred and twentyfive feet above the water. Majestic vistas opened out ahead 
of us, and now and then great solid banks of flowers hung like huge tapestries upon the foliage walls. One white flower with a plume-like tuft of long slender stamens, filled whole bends of the river with its sweet perfume and formed aërial banks of bloom fifty feet square. We saw here for the first time the Green River Ibises ${ }^{26}$ looking dull black in the sunlight. They were of the same size as Scarlet Ibises but with a shorter tail, and flapped more slowly in flight.

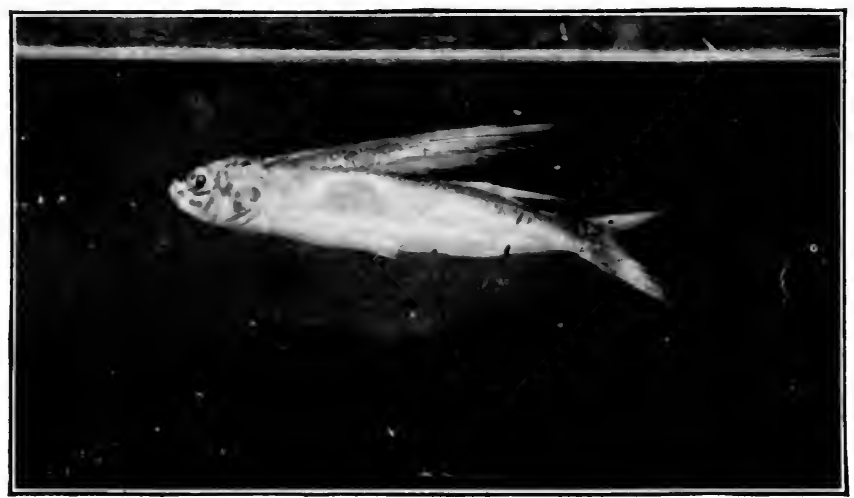

Fig. io6. Salit-water Flying Fish.

Just before dusk we reached the house of the government agent of this district, Mr. Nicholson, and were made welcome at his little home in the heart of the wilderness. The house is on a steep bluff of red clay, changing to yellow near the water and commanding a fine view up and down the river. Below, the river is smooth and shining, while a quarter of a mile above the house a mass of tumbling white water blocks further progress and marks the second portage.

In the yard near the house one passes through a cluster of young fruit trees and here two small colonies of Yellow backed Cassiques ${ }^{151}$ had located, clustering their pendent nests almost within arm's reach about two big nests of sting- 
ing ants. At dusk several hundred Smooth-billed Anis ${ }^{80}$ dropped into a clump of bamboo and with much racket and squabbling settled for the night.

This region is wholly undisturbed, the few "pork-knockers" and Indians who pass keeping entirely to the river. Mr. Nicholson told us that Capybaras (Hydrochoerus capybara)

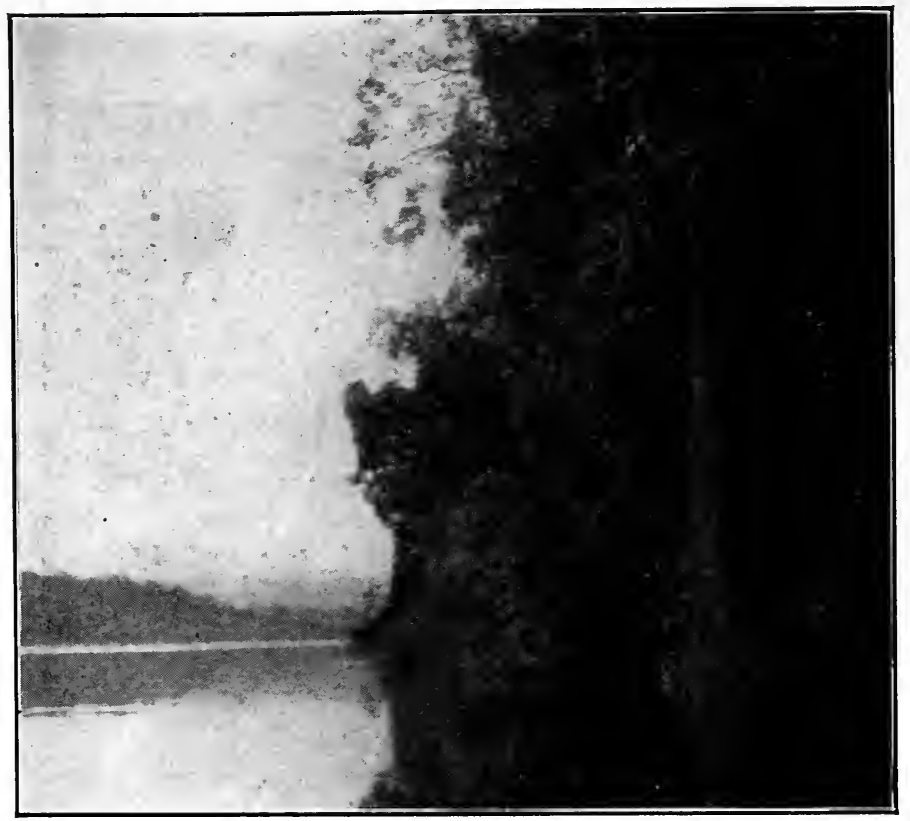

Fig. I07. Cuyuni River.

came every night and raided the vegetable garden, and we had good evidence of this. Pushing through the bush a short distance downstream at dusk, we saw a small herd of these creatures appear and distribute themselves over the banks. Some waded along the shallows, or swam out and dived, to come up with a mouthful of alga. Others climbed the clay slope and disappeared into the jungle. They seemed like 
reincarnations of some of the great unwieldy prehistoric beasts - restorations of those bones by which alone we know of their existence in past ages. It was too dark to photograph these giant rodents, but by the kindness of Dr. Bingham we are able to show several splendid photographs of Capybaras, taken in their haunts.

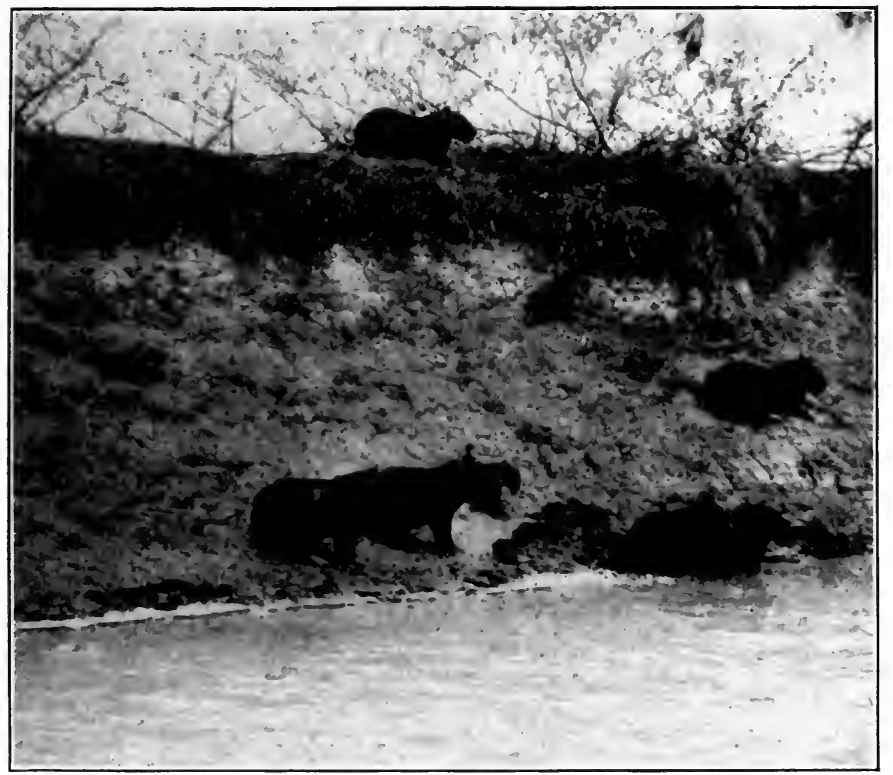

Fig. 108. A Herd of Eight Capybaras, Six Adult and Two Young. Notice the Snout of a Crocodile in the Water on the Left.

(Photo by Bingham.)

The Indian hunter at Matope finds abundance of game within a mile of the house; two kinds of deer, tapir, peccary, and of course Curassows and Guans. Trumpeters ${ }^{25}$ are often heard from the house but are considered too tough for fool.

We talked, chiefly by signs, with the Arowak Indian hunter who had just come in with a Bush-hog or Peccary (Dicotyles tajacu). As soon as the animal is killed, the gland 
on the lower back is cut out, a piece of skin being removed about four by eight inches. If this is not done immediately, the flesh will become musky and unfit to eat. The hunter was familiar with the rare White-lipped Peccary (Dicotyles labiatus), which he described as larger than the common kind and going in small families of two to five individuals. This was a dangerous animal, and more than once he had been treed by them, whereas the Common Peccary was timid and harmless except when wounded or cornered.

Mr. Nicholson had recently seen a full-grown Great Anteater (Myrmecophaga jubata) swimming the river, and curiously enough we later witnessed a similar performance where the banks were about a third of a mile apart. The creature was making fair headway, although drifting rapidly, and was completely immersed save for the elongated snout and head, and the upper part of the bushy tail, which waggled frantically with the efforts the anteater was making.

Mr. Nicholson promised to obtain some living Trumpeters for us and later kept his word by sending one to New York a few months after we left. There are gold diggings near here which were worked by the Dutch in 1625 . In the earlier days of the English occupancy, gold smuggling was an everyday occurrence at Bartica, and Mr. Nicholson had to take extraordinary precautions to guard against it. He would scrape a line under the keel of a boat from stem to stern, by this means often discovering hidden bags of gold. Many a coopful of innocent looking fowls, brought down by the "pork-knockers," were slain by the government inspectors and found to have their crops and gizzards filled with the precious yellow grain. Cartridges were a favorite means of smuggling, the powder being removed and replaced with gold. There is no longer any attempt at smuggling now as it does not pay. 
WATER TRAIL FROM GEORGETOWN TO AREMU. 257

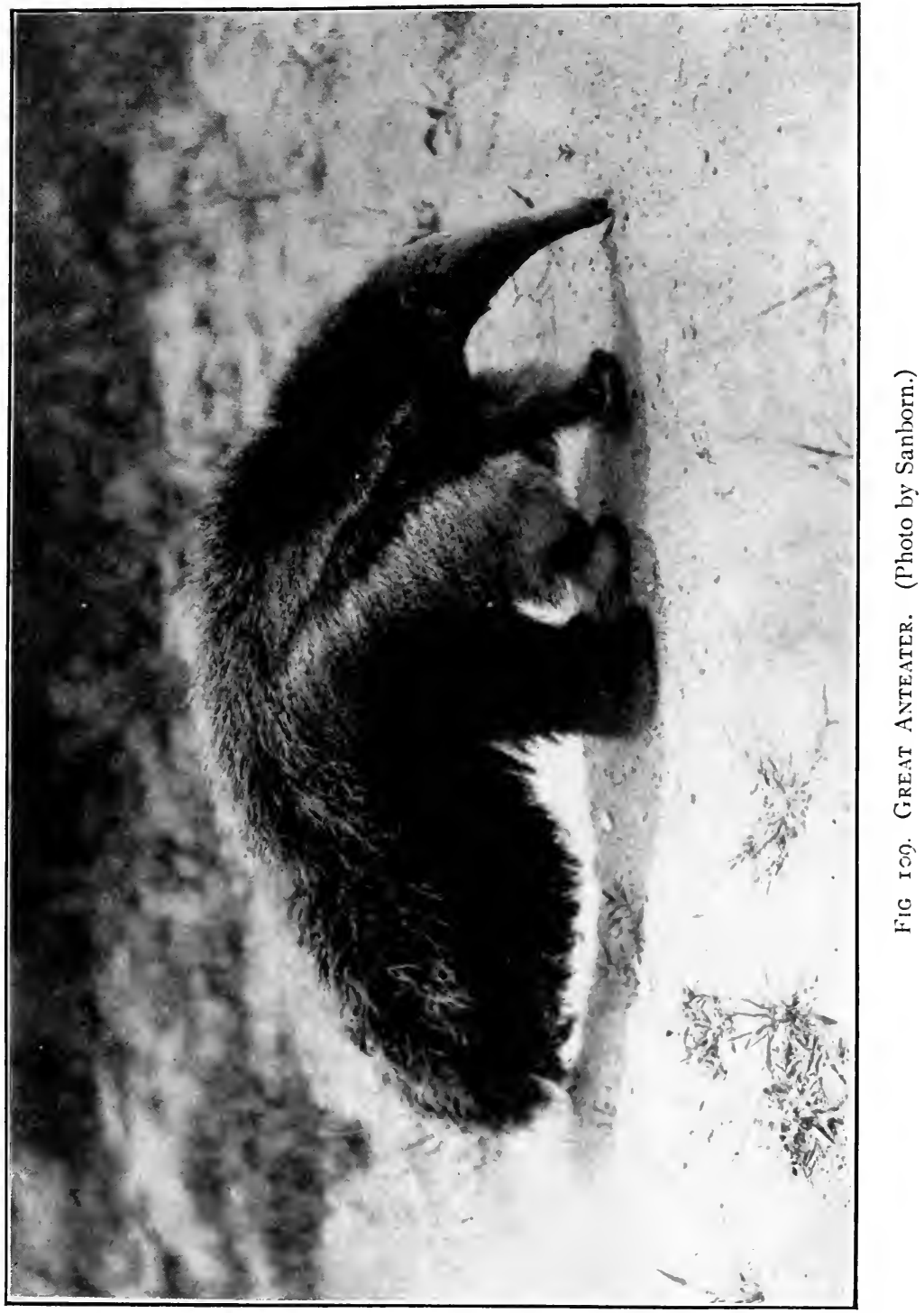


Vampires (Desmodus rufus) are so abundant at Matope that every evening one of the servants collects the chair cushions on the veranda and packs them under an upturned chair. Otherwise, the dogs, bitten while sleeping on these cushions, would ruin them with their blood. We swung our hammocks on the veranda and kept one light burning, and although the bats squeaked shrilly throughout the night, none of us were bitten.

Early next morning we packed up and set out, and in a few minutes a launch landed us at the foot of the falls. This portage was only about a hundred yards in length, bringing us to Perseverance Landing. Here were several tent-boats, most of them filled with " pork-knockers." We stored our luggage in the one reserved for us and climbed into a tent ballyhoo with ten paddlers in addition to the bowman and steersman - all big, powerful, piratical looking blacks, except the steersman, who was an Indian. Now came the most exciting part of our trip, passing up the series of rapids which filled the whole bed of the river. It took us until noon to pass them. A smooth expanse of water would indicate depth sufficient to float a steamer. Then a bar of granite would appear, rising on shore into huge boulders and forming a series of foaming, tumbling waves across the river. In such a place there were numerous small islands and the width increased greatly, while the water everywhere was shallow, with channels ramifying here and there.

As we approached one of these rapids the bowman stood up and the men braced themselves for the tremendous exertion. Starting with a slow, steady stroke, this became quicker and quicker as the white water was reached, then the bowman, using his long paddle lever-like against the thwart, held the ballyhoo steady, while the men drove her through the swirling water. The current became stronger and stronger, the canoe seemed to slow down, be stationary, 
WATER TRAIL FROM GEORGETOWN TO AREMU. 259

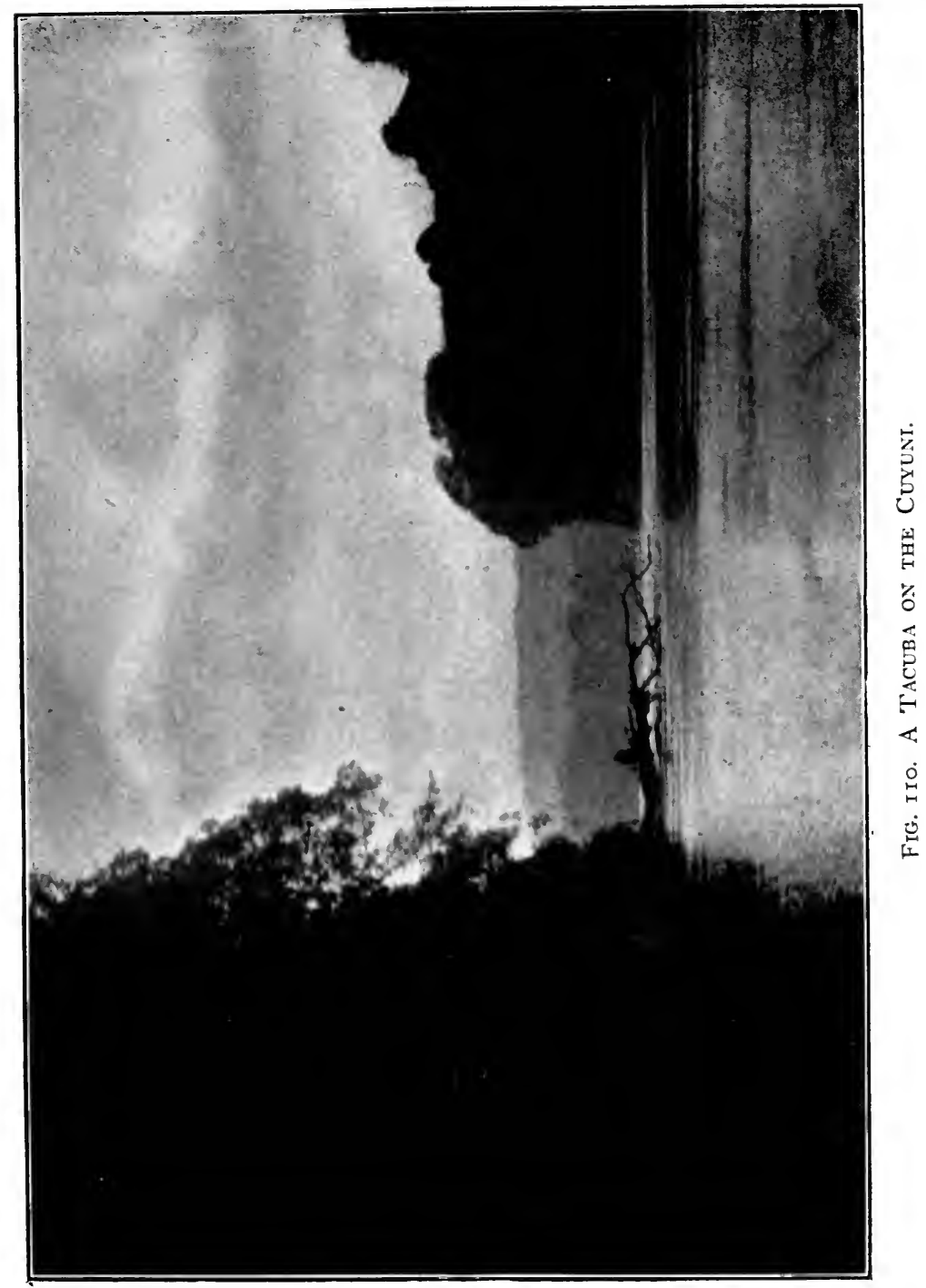




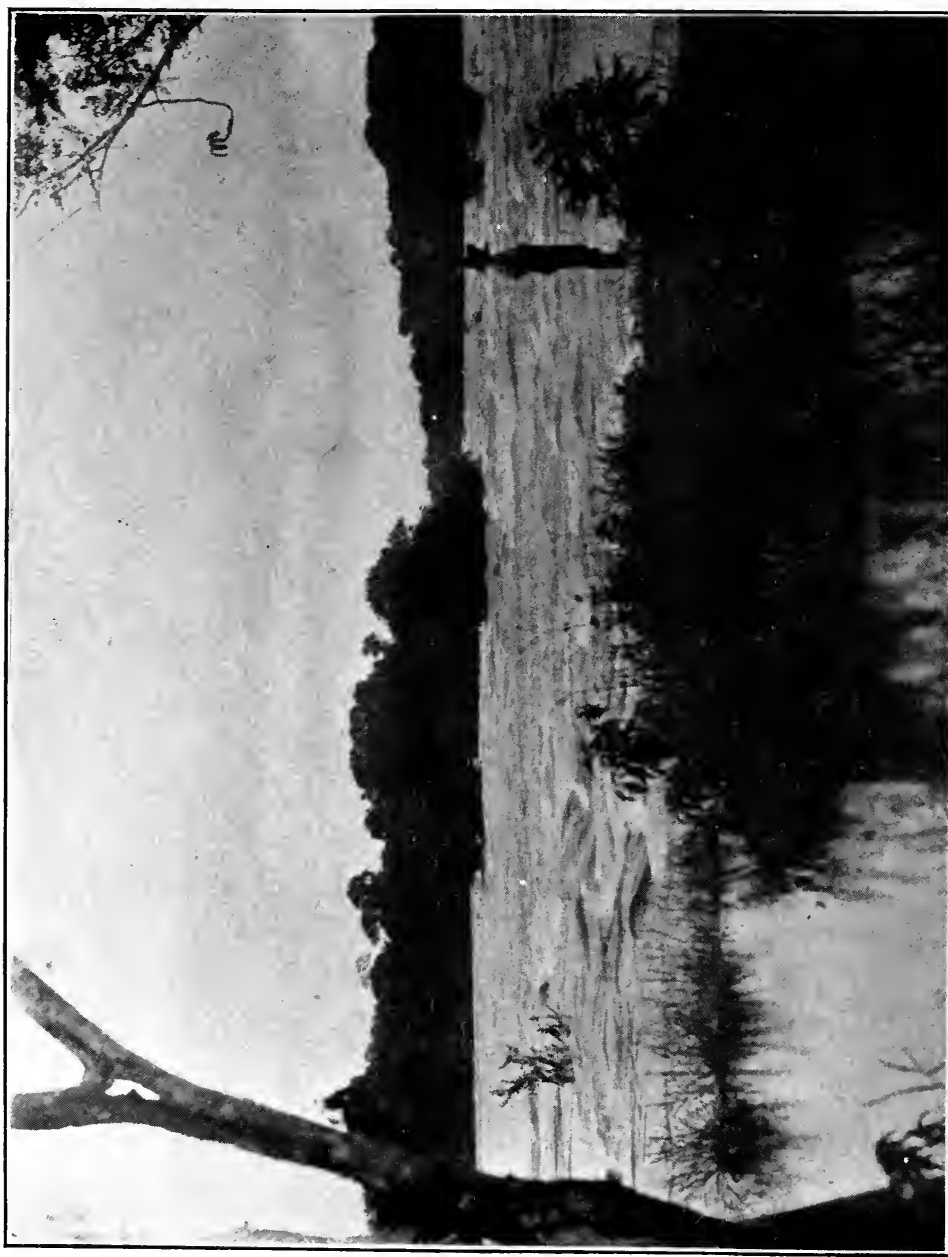

要 
WATER TRAIL FROM GEORGETOWN TO AREMU. 26I

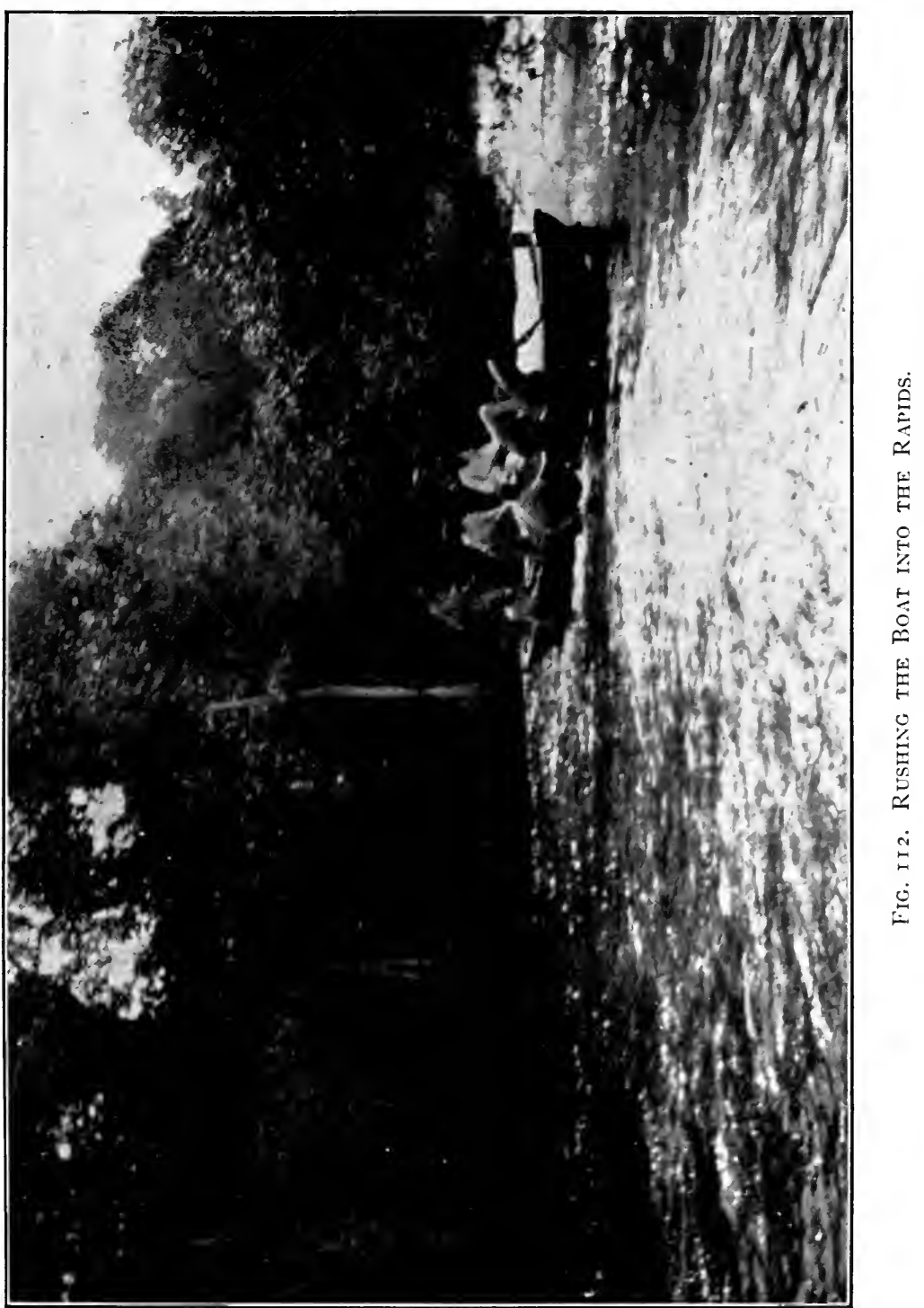




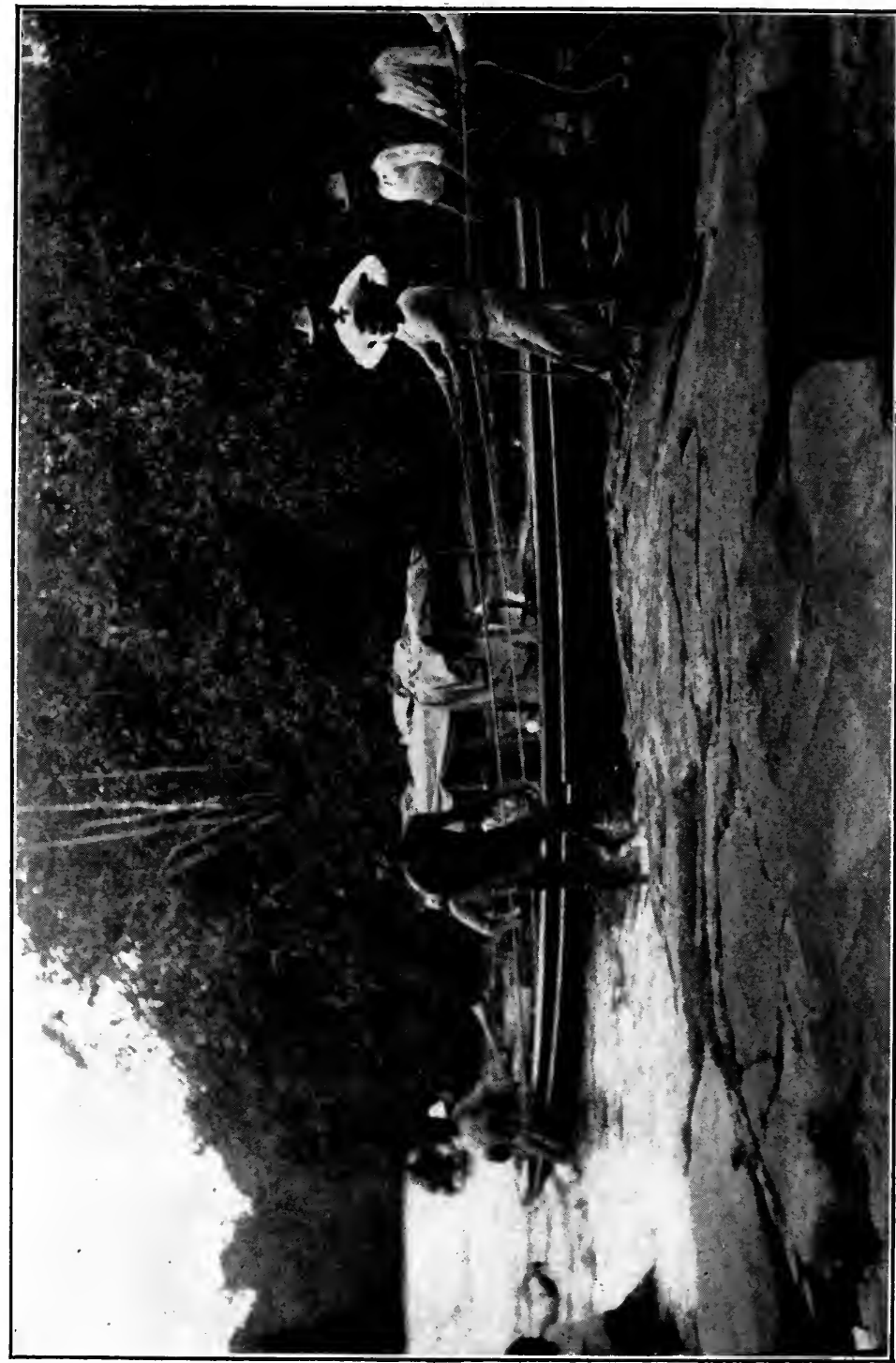

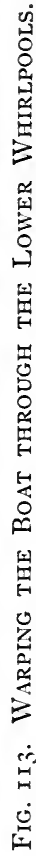


even to slide back a foot or two. Then the great black backs, glistening with perspiration, would twist and bend in a final effort and the boat would shoot forward into the quiet eddy at the foot of the rapid, with the water swirling past on each side.

Now, at a word from the steersman, the blacks tumbled overboard, hastily getting out heavy rope cables, which one or two of the most powerful took in their teeth or tied around their waists and carried to some projecting rock as far ahead as possible. After they had fought their way up to the rock they tied the rope securely and now all hands took hold, some of the rope, others of the boat, and pushed and pulled her up through the boiling torrent.

In one or two cases it was possible to zigzag up through the less formidable shallows. After a particularly difficult piece of paddling we would rest in some backwater for a few minutes and have time to look about us. Every snag held its complement of vampires which took to wing only when we were very close. Solitary Sandpipers ${ }^{21}$ and Parauques ${ }^{70}$ were abundant, the latter apparently nesting on the numerous little sand-bars, and swooping near the boat or swinging up to a bare branch where they perched lengthwise and watched us with half-shut eyes.

The rocky islets were covered with the low Water Guava (Psidium fluviatile), and the rocks which are usually covered with shallow water or those within reach of the falls were studded with thousands of little starry flowers. In other places masses of delicate pink blossoms raised their heads above the shining mat of green submerged leaves which fairly carpeted the pools. The beds of pink, green and white amid the pools reminded us strongly of the manycolored sponges, hydroids and anemones in a tidal pool of the Bay of Fundy or a reef off a Florida Key. These aquatic flowers, far out from shore, gave forth a sweet perfume 


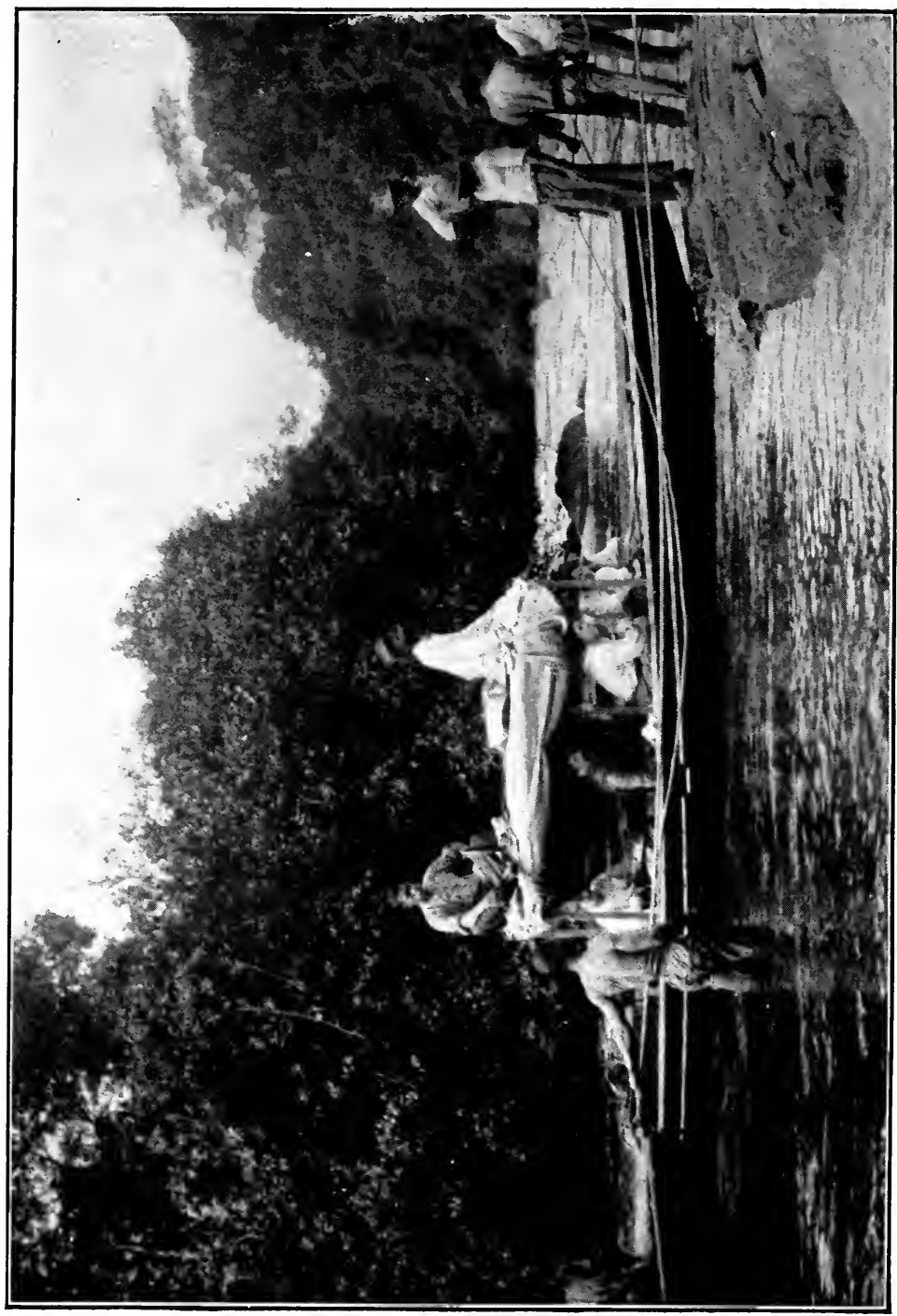

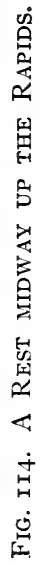


attracting flies, bees and even butterflies, which flitted through the mist, just clearing the foaming water.

Now and then small reddish-brown crocodiles were seen sunning themselves on the sand-bars. One, not more than three feet in length, paid no attention to the revolver shots which threw up the water close to him. The little flying fish became more numerous as we went on, skimming here and there in the smooth pools. Twice we saw one dash at an insect, once a large bee and the second time a butterfly, but they were less successful in their insect hunting than the Swallows - both the Banded ${ }^{118}$ and the Variegated ${ }^{119}$ which swooped across our bow. Whenever we went close to a bank we saw multitudes of a new flower, with its graceful rebarbed stamens, looking like the falling lines of sparks from a rocket.

We lunched to-day on a splendid outcropping of rock on the left bank, after chasing into the cracks some big and remarkably colored tarantulas, with light red bodies and dark legs.

One of the most delightful surprises on this trip was the boat songs of the blacks. How we wished afterwards that we had written down the words and music at the time. One melody remains clear in our memory:
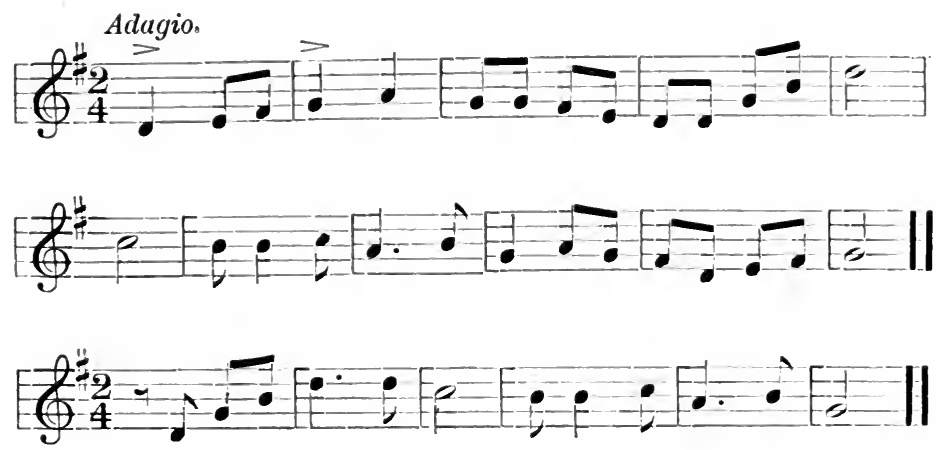


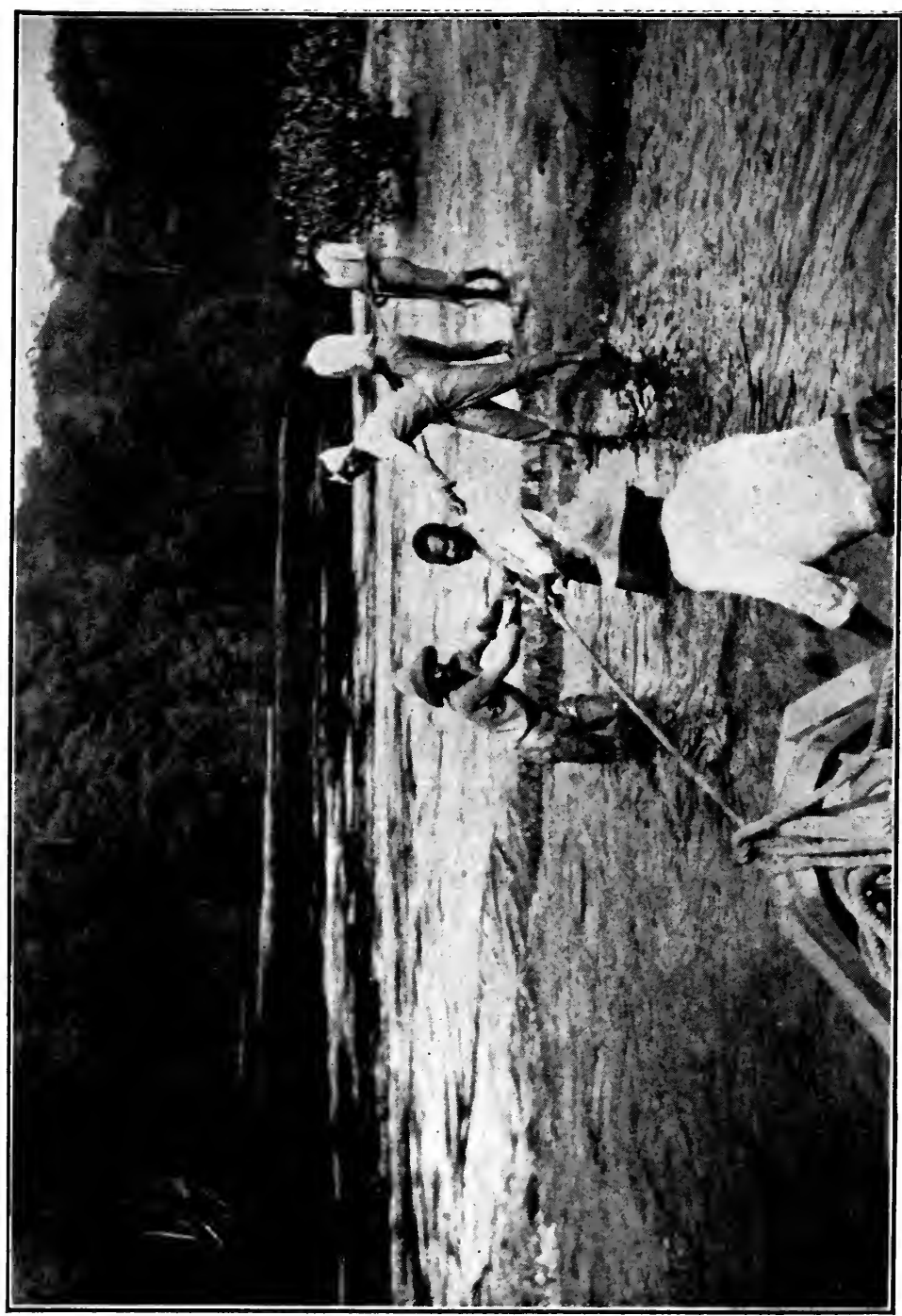

总 
The words of the songs were delightful. One never-ending refrain imparted the original and thrilling information that

"A long time ago is a veree long time."

Another song was the Stevedore's Shantée. Then all would break out in a wild harmony.

"Dat citee hotel is de place wha I dwell,

Fare thee well - fare thee well - my citee hotel, My citee hotel - my citee hotel."

The one of which we never tired was all about "Salina mya dear," and we made the men sing it over and over until they were breathless.

Like all negroes they were full of spirits and childish humor. Their paddling was splendid but terribly wasteful of strength, as at the end of each stroke they gave a strong upward jerk, sending a shower of drops into the air. Our luggage ballyhoo was sometimes abreast of us across the river and when the sunlight was reflected from the eight circles of water thrown into the air at each stroke, the sight was a beautiful one.

When we returned several weeks later, the shooting of these rapids was as exciting as had been the ascent. There was no slow difficult paddling or dragging up of the ballyhoo, but a swift shooting downward, giving fleeting views of tall walls of verdure, innumerable islets, great smooth-faced rocks around which our canoe slid, perilously close, her keel sometimes scraping the algæ on the bottom. We shot here and there from side to side of the river, back and forth, guided by the stolid-faced Indian in the bow. Now and then we would turn completely around in order to keep to a deep channel which bent on itself at an acute angle. Then a moment's breathing in slack water before the men gave way again, either to hold back with all their might or to put every ounce of strength into their work to keep the boat steady in her course, as we ran parallel to a double line of seething, 
trembling waves, to enter which would have been instant destruction.

We would pass by a half dozen smooth-looking false channels, to enter the single safe one, perhaps far across under the lee of the opposite shore. A pilot not acquainted with every foot of the way would have overturned us instantly. The Indian would head our bow into the roughest part of the water apparently in sheer foolhardiness, but always the waves broke under us and tossed us like a chip over the jagged rocks. A cross current in the maelstrom would tear our bow out of its course, and at a cry from the steersman, all ten backs would bend as one and fairly lift the boat back into her course. As before, Macaws shrieked overhead, Cocoi Herons ${ }^{31}$ stood watching us like statues and the little flying fish rose from our bow and ploughed their furrows to right and left. But all passed as a swiftly-moving kaleidoscope, as instantaneous side-lights upon the great white tumbling mass of water which ever boiled and surged about us.

At noon of the day of our ascent we entered the Big Aremu River, a side tributary of the Cuyuni not more than a hundred feet wide, and an hour later we grounded at Aremu Landing. Here we said good-by to Sproston's launch and paddlers, and from here on were transported by Mr. Wilshire's own men and boats. We slung our hammocks that night in an openwork, thatched and wattled house, the company's storehouse, after a delicious swim in the cool water.

No insects came about the vampire-discouraging lantern at night and no evening choruses of birds were heard except a family of Red-billed Toucans. ${ }^{81}$ The iridescent rough-backed green beetles, known to jewelry makers as Brazilian Beetles (Mesomphalia discors), were abundant on a vine near the house.

As on our former expedition on the rivers of the northwest we found that as the streams became smaller, their interest 
increased. The Cuyuni is awe-inspiring and grand beyond words, but the banks of the Aremu, closing in little by little as we ascended, brought us into more intimate contact with the creatures of jungle and forest.

We started up the stream in an open ballyhoo of smaller size, at first with paddles, but changing to poles when the water became shallower. Snags, or tacubas as is the more euphonious native name, became abundant and sometimes stretched far out over our heads. Flying fish skimmed in all directions and vampires (Desmodus rufus) in scores flew from the dead branches projecting from the water. They choose a small-sized one, say two inches in diameter, and alight, one below the other, with heads raised, watching us. Like little animated sun-dials they revolve on their perches as the sun passes over, keeping the wood between them and the bright light. Many of the snags had bits of dead leaves and other débris clinging to them, brought down and lodged by the last freshet, and it was not until we almost put our hand on them and the bats flew, that we could tell whether we were looking at a cluster of vampires or dead leaves. There were hundreds throughout the course of the river, so it is a widespread diurnal roosting habit of these fierce little creatures. The blacks in this part of the country call the vampires "Dr. Blairs," after a certain colonial doctor of the olden times whose favorite method of treatment was blood-letting.

Swallows in the early morning filled the air above the river with a cloud of rapidly moving forms. Orchids in full bloom were abundant, long shoots of Golden Showers, the sweet Epidendrum odoratum and many others unknown to us, all drenched with dew and filling the river canyon with fragrance. Three species of Kingfishers ${ }^{67,68,69}$ and big Yellow-bellied Trogons ${ }^{76}$ appeared now and then. The trees were taller than any we had yet seen, many of the moras and cumacas being much over a hundred feet from base to top. 
At noon we stopped for breakfast in a primeval forest with rather thin underbrush. Many small scarab beetles (Canthon semiopacus) were resting in the hollows of leaves with their branched antennæ raised, waiting apparently for some hint of an odor which should summon them to their mission

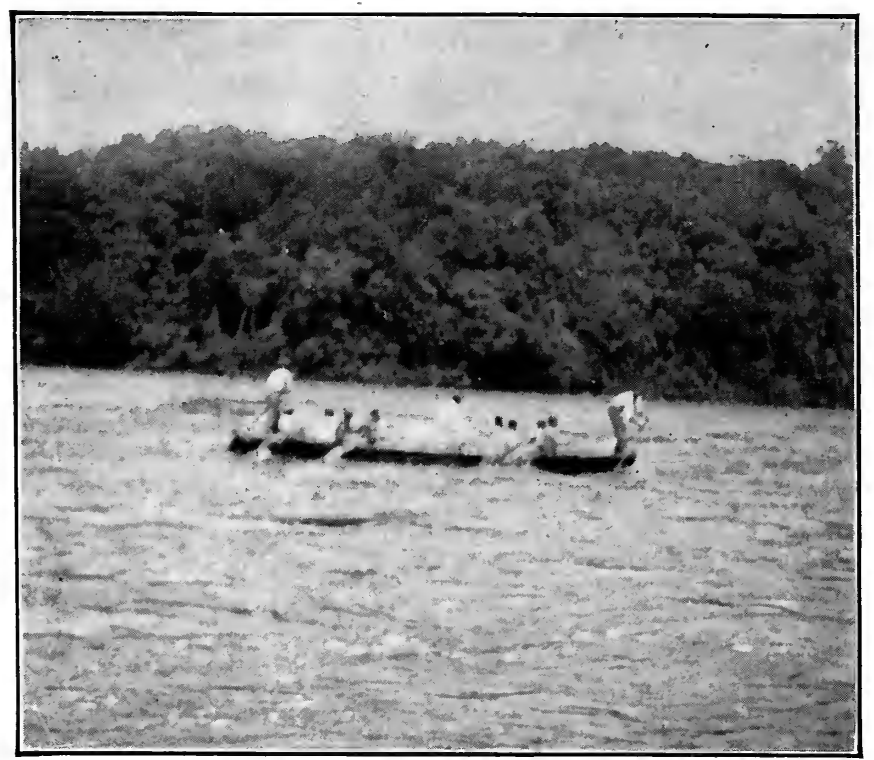

Fig. im6. Shooting the Rapids at Full Speed.

of life - the depositing of their eggs in decaying flesh. Spinning through the aisles made by the giant columns of treetrunks, were curious translucent pin-wheels, and not until we captured one in the butterfly net did we realize we were looking at the same attenuated forest dragon-flies (Mecistogaster sp.) which had deceived us so completely five years ago in Mexico.* The movement of the long, narrow wings, with the spot of white at the tips was, to the eye, a circular revolving whirl, with the needle-sized body trailing

* Two Bird-lovers in Mexico, pp. 239-24r. 
behind. The white spots revolved rapidly, while the rest of the wings became a mere gray haze. These weird creatures, apparently so ethereal and fragile, were hunting for spiders, and their method was regular and methodical. From under leaves or from the heart of widespread webs, good-sized spiders were snatched. A momentary juggling with the strong legs, a single nip and the spider minus its abdomen dropped to the mould, while the dragon-fly alighted and sucked the juices of its victim. If we drew near one of these spiders on its web, it instantly darted away, sliding down a silken cable to the ground or dashing into some crevice, but the approach of the hovering dragon-fly, although rather deliberate, was unheeded, the spider remaining quiet until snatched from its place.

On a tiny jungle creek we alarmed several large, bluntnosed brown lizards, with low dorsal crests, which ran up into the branches to escape us. In this respect they differed from the big iguanas which always dropped with a resounding splash into the water at our approach.

Near some wild plum trees whose fruit was ripe, we found tracks of deer, agoutis and some of the smaller cats. 'The fruit was yellow and oblong in shape with a large stone, and tasted the way a tonca bean smells - bitter and yet sweet a strange concentrated essence of the tropics which excited one, in that it differed so completely from the taste of any other fruit.

Morphos became more abundant from this point on. Some were wholly iridescent blue above - a blinding, flashing mirror of azure; others were crossed by a broad band of black, while in a third species the blue was reduced to a narrow bar down the centre of the wing. Great yellow swallow-tailed butterflies and exquisite smaller ones flew about us. The crocodiles of the Aremu were all small, none over three feet, and were all black in color. 
As we went on we were impressed with the amount of work which had been necessary to open up this river for the passage of ballyhoos laden with mine machinery. Six months ago it had been impassable, except for small Indian canoes,

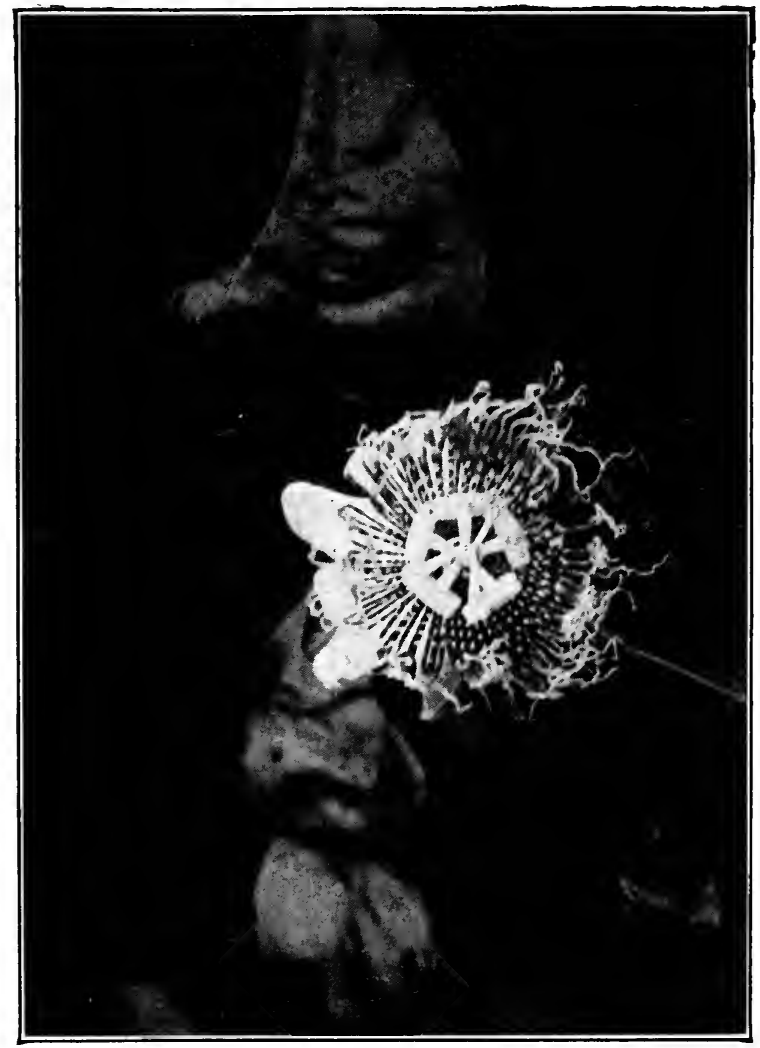

Fig. il7. A Wilderness Passion Flower - Simitú.

and these had often to be dragged ashore and around obstructions. Now the little channel had been opened, and although for the most part completely overhung with interlacing vines and branches, yet our ballyhoo wound in and out around the 
tacubas with but little hindrance. The cost of opening it had been more than $\$_{15}, \infty 00$. Huge tree-trunks had to be sawn through, but even then, the wood of many species having greater specific gravity than water, the trunks would sink to the bottom like stones, offering a greater obstruction than before. Dynamite was then used to clear them from the bed of the stream.

In the early afternoon, a beautiful dull-red passion flower on a climbing vine became common, and we found that its fruit was edible and called by the natives Simitú. Although apparently so much at home here, this plant, known as the Water Lemon (Passiflora laurifolia), is really an escape from cultivation.

The river twisted and turned in every direction and the banks were four to eight feet in height with sloping bars of sand on the inside bends. Palms were rather scarce, their place, in appearance at least, being taken by the tall, slender Congo pump trees with deeply serrated rosettes of leaves. Tree-ferns appeared in ever increasing numbers and stretched their graceful fronds from the banks far out over our heads.

During midday, silence filled these river glades, both birds and insects resting quietly in the heat, and the only sound was the regular scraping of the poles against the sides of the ballyhoo. The heat was not oppressive except in the glaring sunshine on the water, but such exposure was rare in these deeply forested recesses. We had had no rain thus far and the temperature of the mornings and evenings was delightfully cool. At night we could scarcely keep warm rolled in a hammock in a thick blanket. Unpleasant insects were entirely absent, and yet we were travelling in the heart of a tropical wilderness, which most of us have pictured as a sizzling, steaming hot-house, teeming with venomous reptiles and stinging bugs of all descriptions.

About three o'clock, the Goldbirds ${ }^{115}$ began calling and 
274 OUR SEARCH FOR A WILDERNESS.

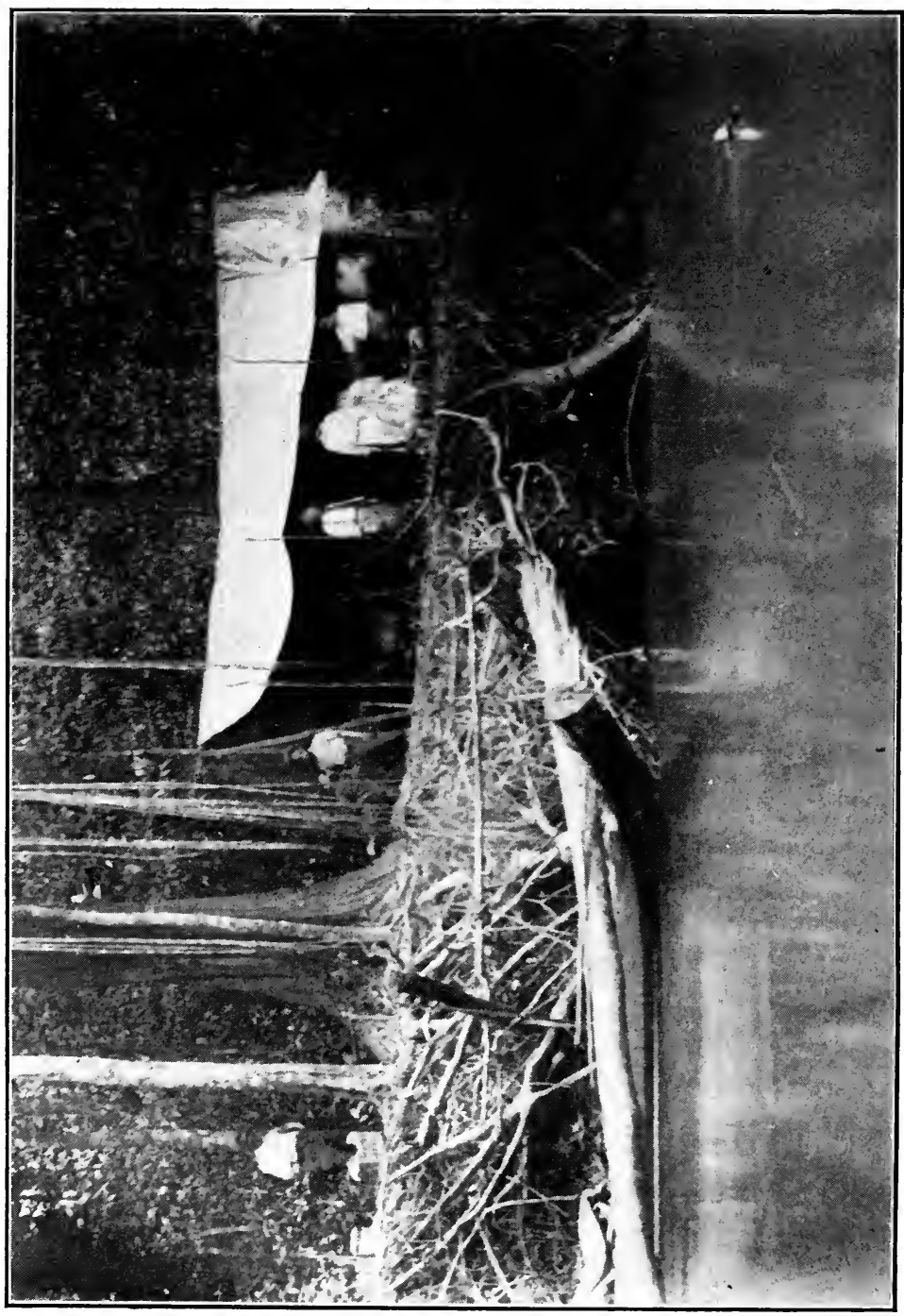

䍃 
some other species with a single loud whistle. A Cormorant rose with heavy wing-beats ahead of us, and when we flushed it the second time we shot it. It was the little Guiana Cormorant ${ }^{47}$ only twenty-eight inches in length, with eyes of dull green. A deer broke away from the bank at the sound of the shot and dashed off.

That night we made camp in the jungle. A skeleton shelter roof of poles was thrown up, over which was stretched a tarpaulin, coming to within six or seven feet of the ground all around. Then a double row of stout stakes was driven into the leaf mould along each side and the hammocks slung from them. They were springy, and one swung not only sideways but with a slight end for end motion that made every movement easy.

While we were making camp we were hailed by a passing ballyhoo, the occupant of which proved to be Mr. Fowler, the head of the Colony Department of Lands and Mines, who had been at the mine on a tour of inspection and was now on his way back to Georgetown. Hospitable Mrs. Wilshire at once invited him to come over from his camping place farther downstream and dine with us. A dinner party in the "bush!" We all shared the feeling of festivity. 'The men hastily constructed a table of the trunks of young saplings, while the rest of the party hung lighted lanterns from the overhanging branches. Directly in front of the camp was a tall, straight Copa tree drape- with long hanging bush ropes dangling from the lowest branches, seventy or eighty feet up the trunk. The base sent out thin, far-reaching buttresses, the intervals between which formed natural seats and closets for our guns and bags. Mr. Fowler's Indian hunter brought in several Curassows which we added to the Cormorant for dinner. Mr. Fowler had seen a Bush-master (Lachesis mutus) a few hundred yards upstream, the first poisonous snake of which we had heard on this trip. We 


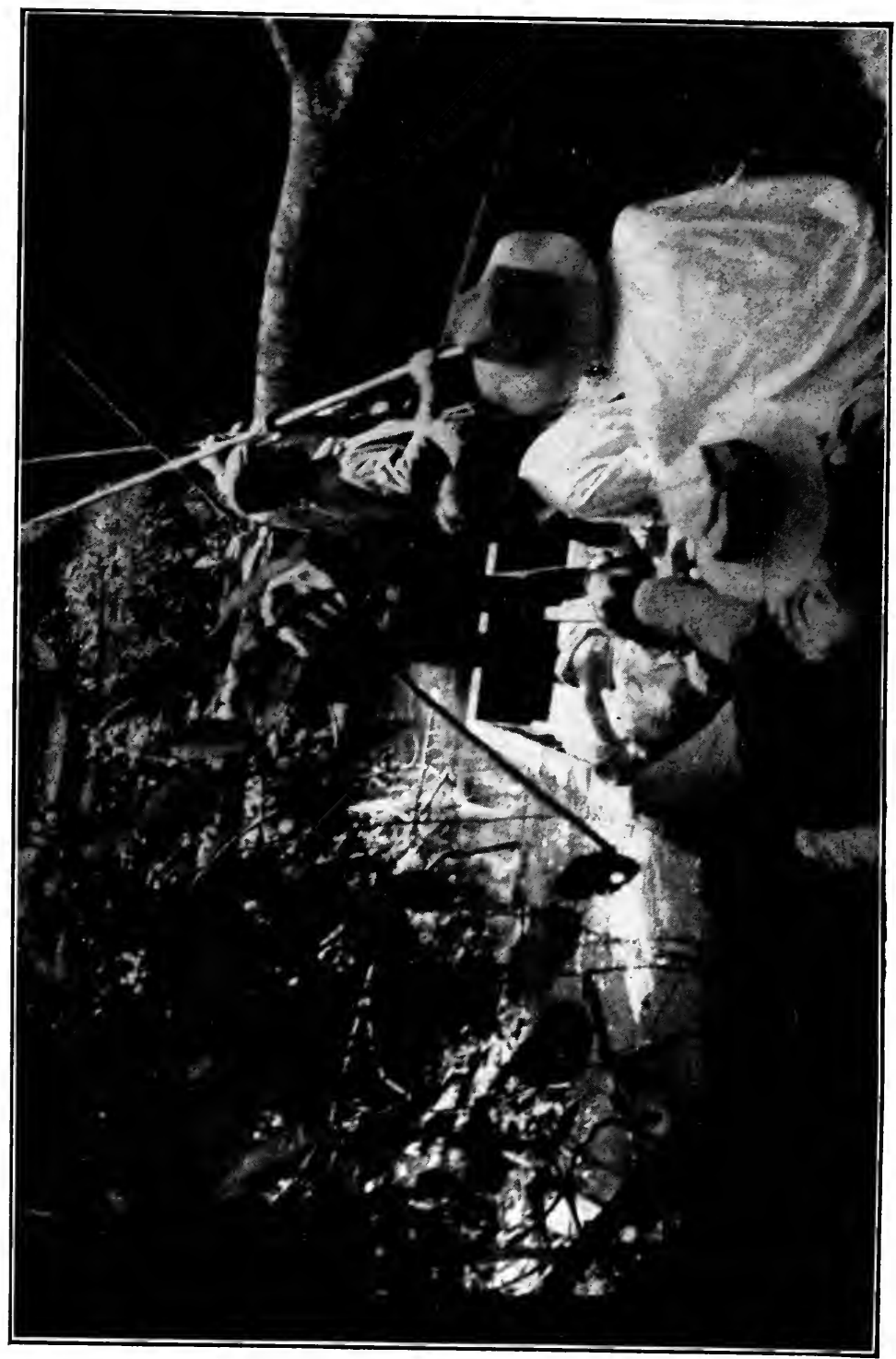

 
had a merry dinner, Mr. Fowler telling us many an interesting story of his early days in the colony.

The jungle around our camp was alive with sound all night - frogs chiefly; the wing-beating fellows, the heavily loaded freight engines, the bleating calves and a new kind which raised its loud and continuous voice in choking roars. One's imagination pictured death struggles between man-like monkeys and other creatures, the qualities of human and bestial voices were so blended in this utterance. Vampires flew about back and forth under our shelter but none bit us. So strange and wonderful was this night in the "bush" that for many hours sleep was impossible.

Early next morning a light rain fell for an hour and through it we photographed our night's camp. As the sun shone dimly through the mist a chorus arose - Woodhewers, Parrots, Macaws and in the distance the ever thrilling moan of the red "baboons."

The last black pushed off with his pole about eight o'clock and we settled ourselves for our last day of river travel. The stream became narrower and more diversified, in places being not more than twenty-five feet from bank to bank, then spreading out to twice that width with strange keellike sharp rocks projecting from its surface. We elbowed our way through a perfect maze of dovetailed tacubas and slanting tree-trunks, which we went around or rubbed along or scraped over. Sometimes we all had to crouch flat down to the level of the gunwale to pass under a low trunk, or again even to climb out on to the $\log$ and down into the ballyhoo on the other side. Now and then a pole would be wrenched from a negro's hand as the current or impetus of the boat twisted it to one side, or the man himself would be flicked overboard amid roars of laughter from his mates, who, when he climbed dripping on board again, would inquire the cause for the sudden desertion of his post. 


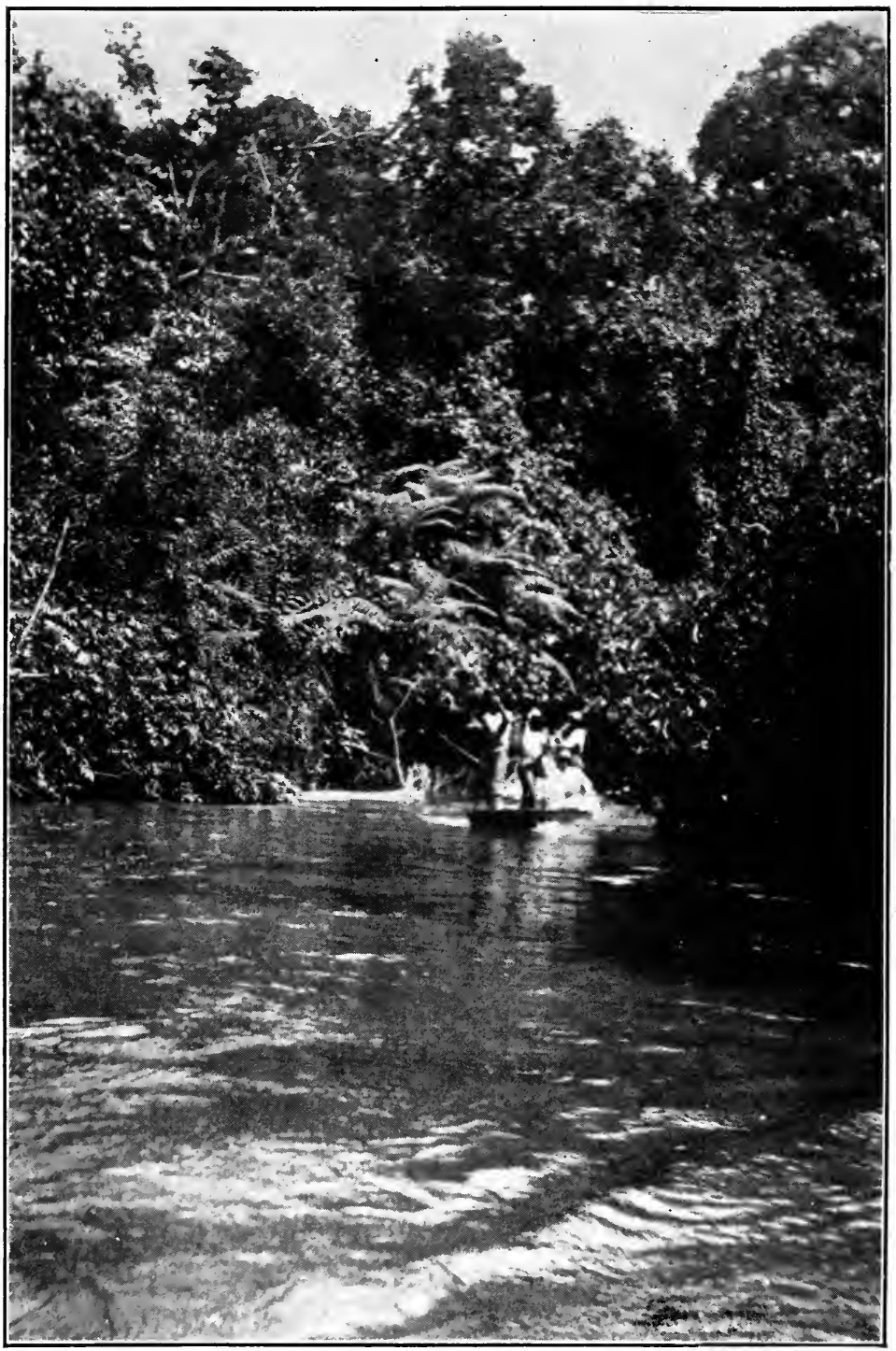

Fig. i 20. Tree-ferns on the Little $A$ renu. 
These tacubas, which are really fallen trees, are the most apparent danger in the jungle, although the chances of accident from them are very slight. Along the bank were many slanting trees, bound sooner or later to give way. On our return journey down the Aremu we passed, or rather scraped under, a huge trunk which completely spanned the creek. It must have fallen about two days before and we had to push through a perfect tangle of orchids and lianas.

Tree-ferns twelve feet high draped the banks; spiders of weird shapes dropped upon us, buoyed up by their long silken cables; brush-tipped aërial roots dangling at the ends of plummet lines fifty feet long were drawn from stem to stern of the boat and across the pages of our journals as we wrote.

Half an hour after starting we discovered a Three-toed Sloth (Choloepus) high up in a tree almost over the water. Mr. Howell shot the creature and we found it to be of large size, with long reddish-brown hair. The face, expressionless as it always is in these animals, had small eyes of a warm hazel color. Later we had it cooked and found it quite palatable.

In many of these tropical growths the new or first leafshoots are pale or brilliant red, this holding good in the case of the giant moras, several trees with locust-like foliage, and even the flat, leaf-vines, Monstera or shingle plants, crawling up the trunks. One small tree with entire leaves and covered with sweet-scented tassel-shaped flowers, had at least half its foliage of a pale yellow-green. This is the spring of this region in so far as such a region of never ending warmth and moisture may be said to have a spring. On every hand flowers were in abundance. All were unknown to us, but most were of large size and varied odor and color. All the tales of the rarity of flowers in the tropics had not fitted in with our experiences. 
In the course of three bends of the river, during some fifteen minutes' observation, we observed the following in masses of sufficient size to catch the eye far off and add a decided color tone to the spot where they grew: purple pea-

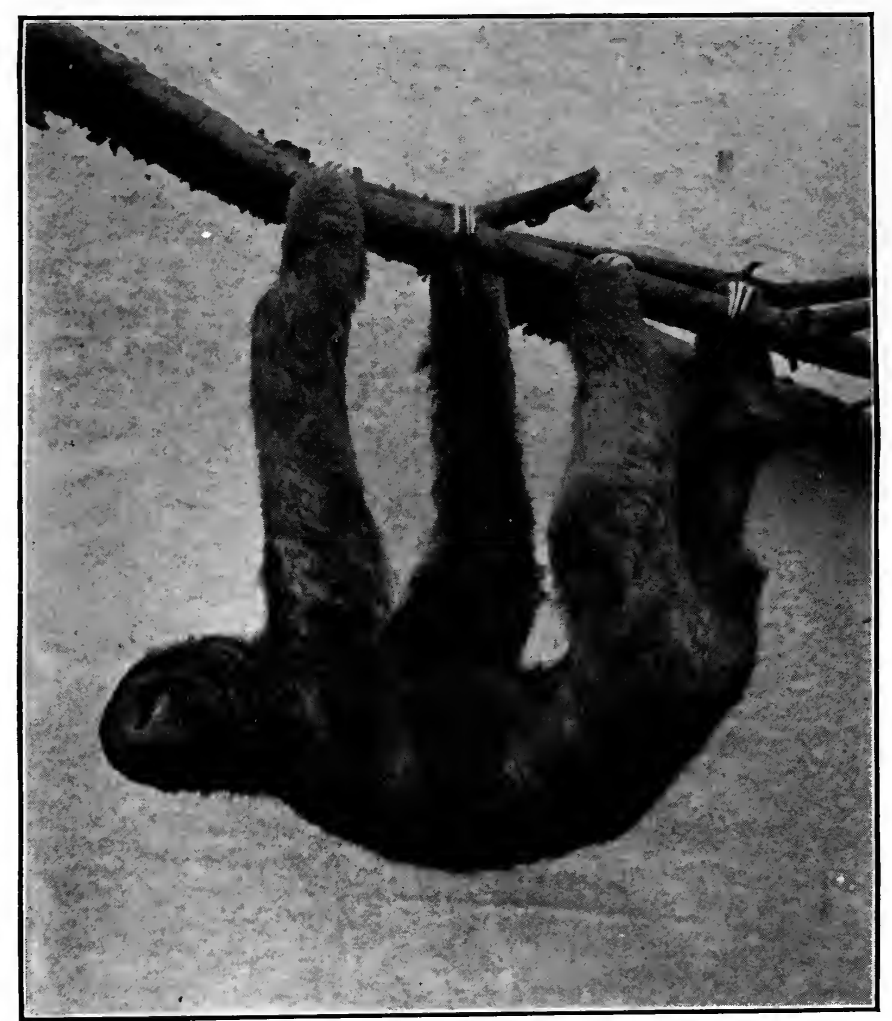

Fig. I21. A Sloth in Action.

blooms in wisteria-like bunches; falling-star white flowers; pink two-petalled ground flowers in dense clumps; spider lilies, the large kind; red passion flowers; white tubular blooms; five-parted purple star-shaped flowers; wild cotton, in enormous masses of bloom, resembling clematis and as 
WATER TRAIL FROM GEORGETOWN TO AREMU. 28I

fragrant; long thin racemes of very fragrant, dull greenish white flowers; brush-like purple blooms, white at the base, growing sessile on the trunks, with an edible fruit, which the blacks call "Waika."

This list is exclusive of all the many inconspicuous flowers and all orchids, which were seldom out of sight. Its value

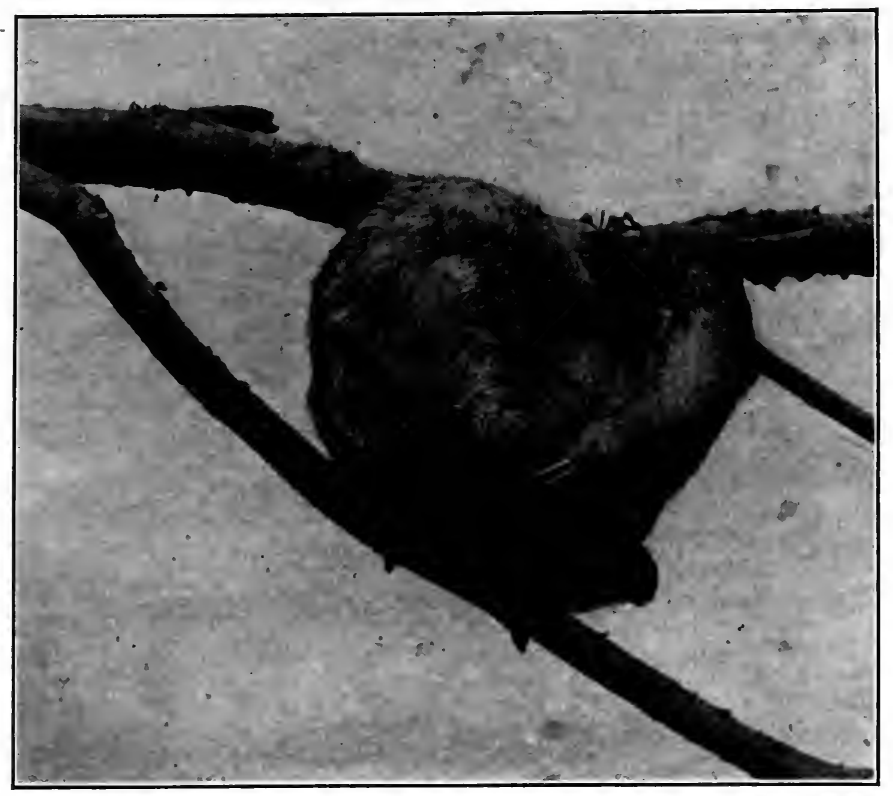

Fig. I22. A Sloth Asleep.

lies only in giving the faintest of hints of the wonderful beauty of these jungle water trails.

On these upper reaches of the stream the two water birds most in evidence were Tiger Bitterns ${ }^{40}$ and Great Rufous Kingfishers. ${ }^{67}$ One could write pages trying to describe a single vista of this beautiful region and yet give only a hint of its charm. In one place a mighty loop of a lofty bush 
rope or monkey ladder with ornate woody frills decorating the edges, hangs swaying high in air across the stream. Several other giant vines have caught hold and have wormed their way in serpentine folds along the first great swing. In the spaces between these huge living cables, seeds and parasitic plants have taken root and grown, filling up the network with their aërial bulbs and in turn furnishing rootholds for an innumerable variety of flowers, ferns, orchids, mosses and lichens. The mosses are long and fan-shaped like some species of coral, and the lichens are red, pink, gray and white. The whole forms, high over our heads, an enormous hanging garden which no human ingenuity could duplicate.

Two hours after starting we reached the place called Two Mouths and turned into the Little Aremu. In no place is this stream more than twenty-five feet wide, with low, sloping sandy or clay banks facing steep ones, first on the right, then on the left side, according to the bend of the stream and the force of the current. As we went along a splendid male Crested Curassow ${ }^{4}$ flew up and was shot, to be added to our menu. Before we came in sight it was clucking softly.

A splash around a bend, and sharp claw and toe marks showed where a capybara (Hydrochoerus capybara) had just entered the water, and from here on we found such tracks common on every sandy bank.

We were amused at our steersman's occasional orders to the crew. In places where the current was swift and poling was very difficult he would shout in a most woful and despairing voice "O Lord!", giving us quite a start. We eventually found that he was intending this ejaculation for "Pole-hard!"

Black-shelled mollusks were common on submerged logs, and on the banks above the water line were scores of curious spiders and insects, while dragon-flies of a half dozen or more species darted swiftly about. Throughout the morning we 
WATER TRAIL FROM GEORGETOWN TO AREMU. 283

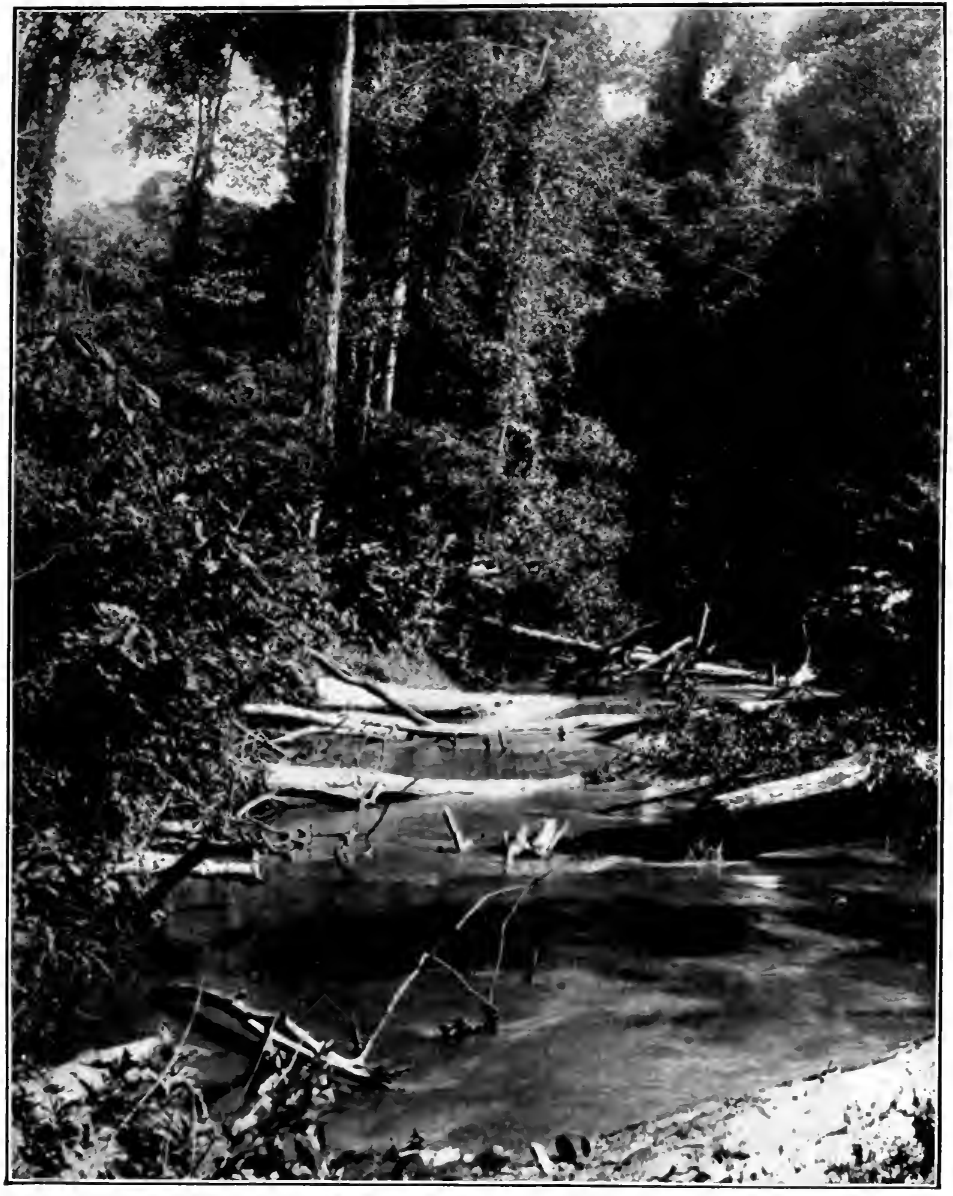

Fig. I23. Where ONLy Otters and Fish Can pass. 
were never out of hearing of the hammering of Woodpeckers, or the cooing of Doves or the laughing, descending scales of Woodhewers. The Chinese music of the cicadas came to our ears, a sound which recalled vividly the forests of Venezuela.

The water was now at a medium level, but after heavy rains when it is high, all the great tacubas six feet above our heads are submerged and much of the land along the river banks becomes a swamp.

Farther upstream when the water became very shallow and the stream narrowed to twelve or fifteen feet, some of us left the ballyhoo in order to make the work of the blacks easier, and took to the trail. After a fifteen minutes' walk we saw the glimmer of sunshine through the trees and knew that we had reached the gold mine of the Little Aremu. 


\section{CHAPTER IX.}

\section{JUNGLE LIFE AT AREMU.}

SOME PAGES FROM MY DIARY.

(By C. William Beebe.)

$\mathrm{E}^{\mathrm{v}}$ VEN more to the Gold Mine of Aremu than to Hoorie is the application " island " or "oasis " in the jungle, appropriate. The clearing is about twenty acres in extent, approximately circular, with the magnificent forest trees crowding densely to the very edge. The bungalow and mine shaft are on the summit of a symmetrical hill, which slopes evenly and steeply down on all sides. The hill is about a hundred feet in height and yet the trees far down at the foot tower high above it.

The concession includes about seven and a half square miles, and in many places where the rock outcrops, well paying deposits of gold are visible. At Aremu there is a soft quartz ledge about eight feet wide running almost vertically and rich in gold. Often the metal is visible and a small lens shows the yellow crystals encrusting the white matrix.

The first day at Aremu we went down in the mining bucket, two and two - each clinging to the wire cable and balancing the opposite person. Down and down went the swaying bucket, slowly revolving - the heat and sunshine of the upper air replaced by the cool darkness - damp and chilly with rich earthen, clayey smells. Eighty-five feet below the surface the four leads began, one a hundred feet along the vein. This consists of a ferrugineous gold-bear- 


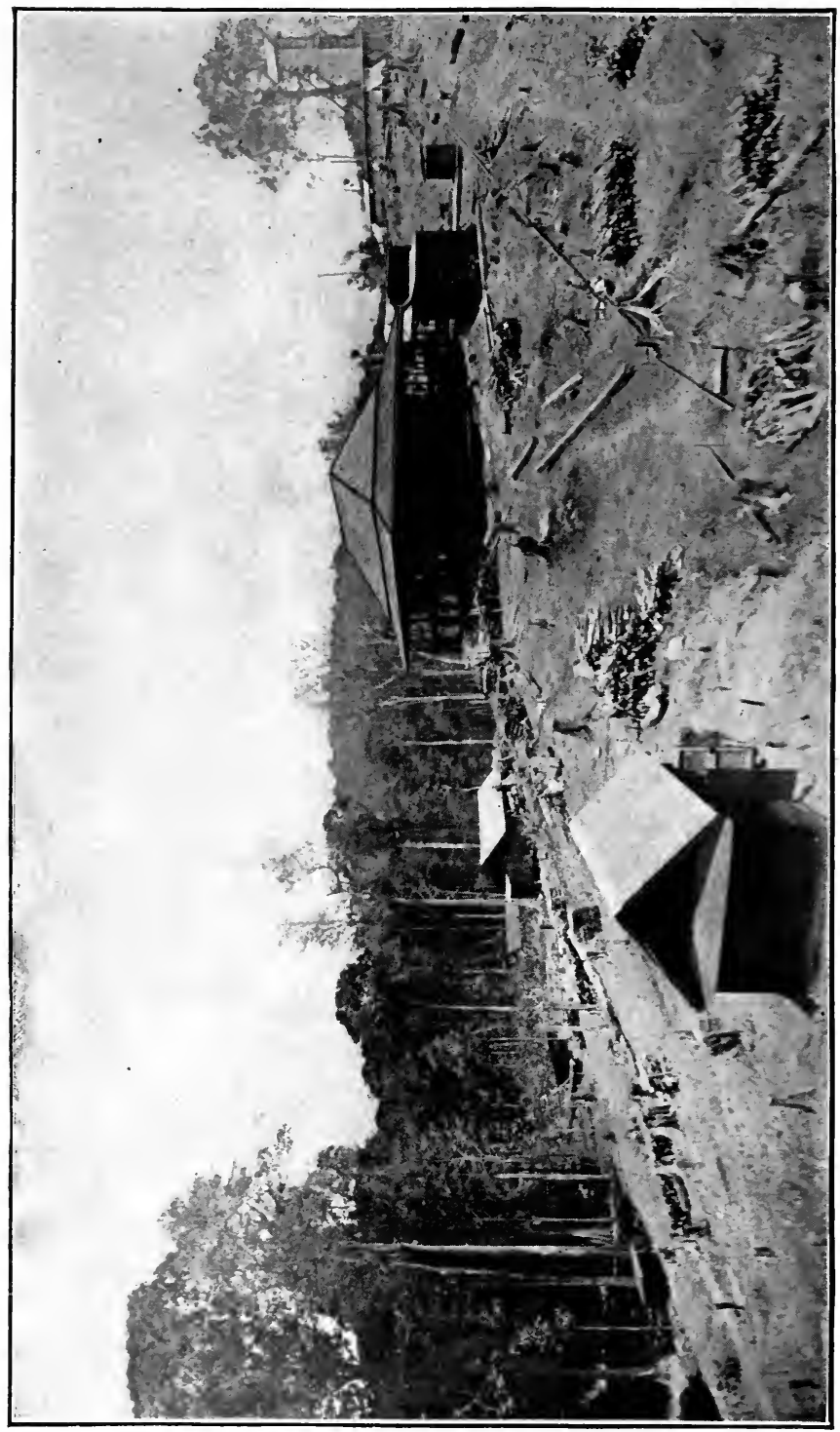

星 
ing quartz, somewhat decomposed by the dissolving out of several of its constituents. The candles shed a flickering light on the slimy, dripping walls and for a few moments one felt completely confused - so hard was it to stand there shivering and yet realize that a few yards overhead was brilliant tropical light and sunshine, gaudy birds and butterflies. One seemed in a wholly different world.

But though forever buried in dripping darkness, there were as bright colors here as in the living creatures above ground. Each side of the quartz vein ran an endless series of beautifully stratified, decomposed, talc-like clays; purest white, orange, slate-colored, pink, blue, yellow and brown - one hue succeeding another like some strange fossil rainbow.

Outside near the bottom of the hill, two gaping holes showed where the blacks who discovered the gold years ago worked the ledge by hand - leaving even in their tailings enough gold to make it well worth working over. Now electric stamps, run by great boilers, do the work, all brought up the Little Aremu bit by bit, with the greatest labor, at seasons of high water.

Here as at Hoorie a few pork-knockers were allowed to locate their diminutive claims and glean what superficial metal they could from surface deposits. A mile away to the west was a large outcropping known as "England" and here four or five blacks were working. On each Saturday night they would bring their little packets of gold to the store to receive credit checks or receipts. Once as we were crouching in the jungle watching some "cushie" or parasol ants, two of these black pork-knockers passed within a yard without seeing us, each with his little bundle of worldly belongings on his head, topped by a wooden gold pan.

I have mentioned panning as the most primitive method of mining, next to which comes the "Long Tom." At "England" we found a third advance - a method of breaking up 
partly decomposed gold-bearing quartz. A deep narrow pit showed where the material was found, shovelfuls being thrown up on two successive ledges before it reached the surface. It was then carried to an open thatched roof beneath which was a primitive, two-man power stamp. This was nothing but a gigantic hammer made of two logs, the hammer part covered with metal, and the handle hung in a socket, so that the centre of gravity lay toward the head. Two men, balancing themselves by clinging to uprights, stepped in unison on the tip of the handle, their combined weight depressing it and raising the head; then stepping off suddenly the hammer came down with great force on a pile of broken gold-quartz, fed into a hardened hollow beneath it. This mining enterprise required no less than five men, and they were taking out about $\$ 1.20$ each a day.

Comparing the division of labor among men with that among cells, we may liken the single "pork-knocker" to an Amoeba, where a single man and a single cell perform all the necessary functions; the Long Tom with two men is like the simpler sponges - where one set of cells secretes the skeleton of spicules, giving shape to the whole, and another set lashes the water and absorbs the tiny bits of food. The crusher' with its five men, each performing his individual labor, corresponds to some slightly higher organism - a jelly-fish or anemone, - while the electrically run stamps, employing several score of men, is like the complex cell machinery of a beetle or butterfly.

The Aremu Mine clearing had been in existence only about six months, and the trees which were felled had been sawed up or burnt so that there was no such abundance of wood-loving insects as at Hoorie. At night a few Longicorn beetles would appear and buzz about, but almost no moths. In fact during our whole stay only one moth of large size was seen. One small species of moth, with wings of a general rusty-red, 
a light line along the front margin and spreading only an inch, appeared in numbers on the evening of April 2d. The following day we saw many of the Gray-rumped Swifts snatching them from the bushes in the clearing. I brought

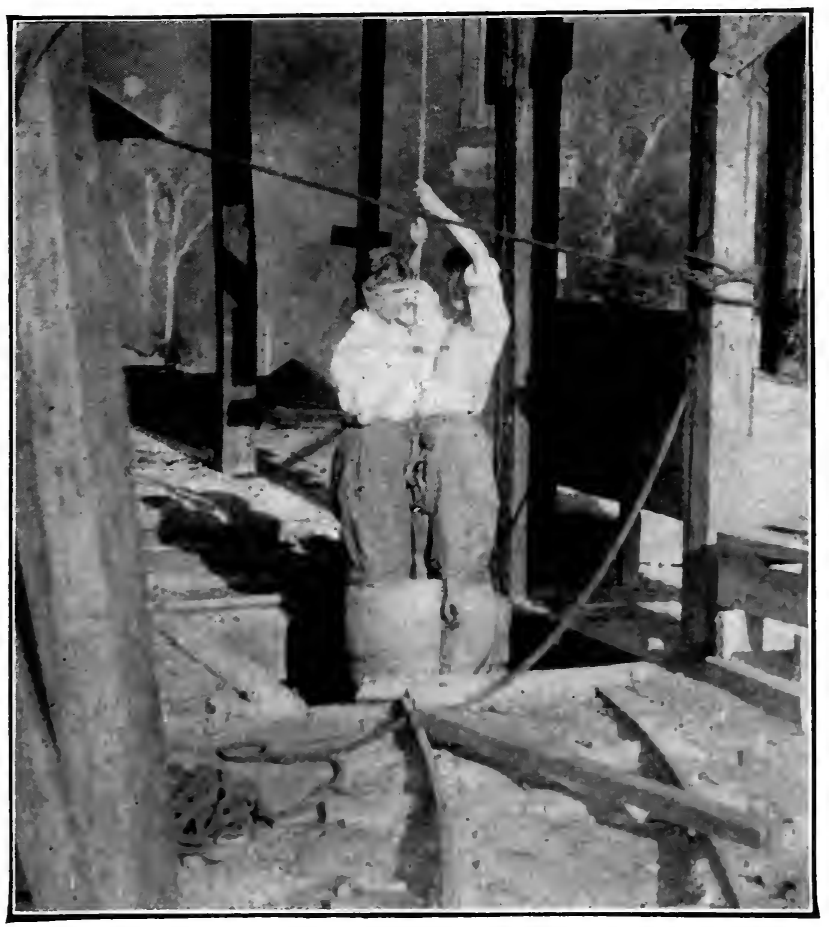

Fig. I25. Descending the Shaft.

a single specimen back and found it was a species new to science, which has been named Capnodes albicosta.*

Walking sticks and mantises were more abundant. Some of the former had well-developed wings on which they whirred about the bungalow; others had none at all or reduced to a scale-like vestige. In an individual of a third

* Zoologica, Vol. I, No. 4. 
group the wings, while perfect, were pitiful affairs, mere mockeries of pinions, barely an inch in extent, while the body of the insect was almost five inches in length. When thrown into the air the poor "stick" expanded his wings to the fullest but wholly in vain. There was just sufficient

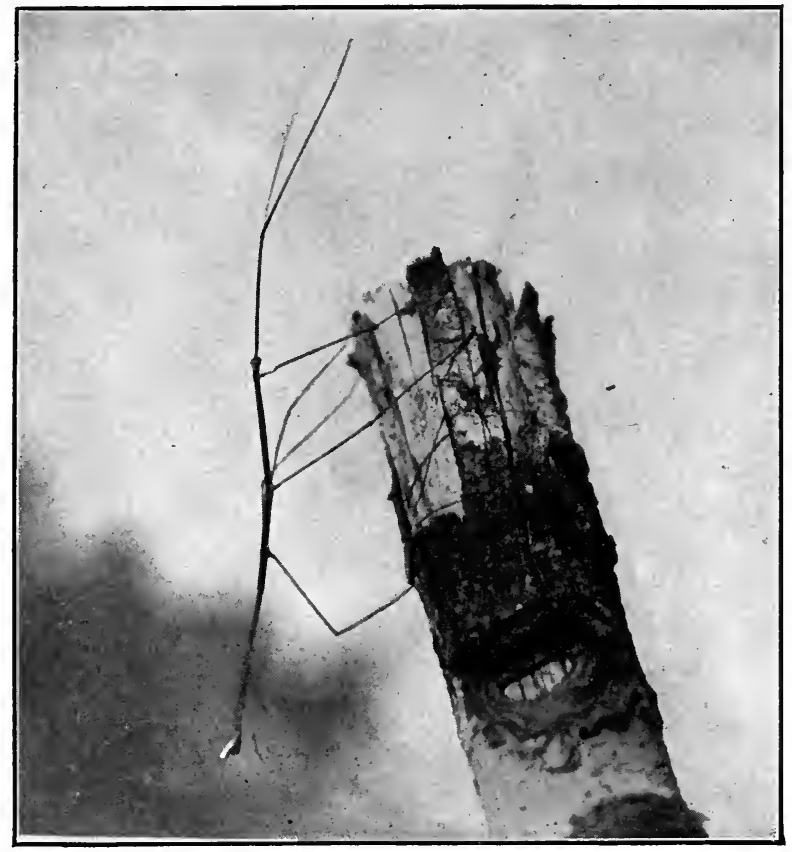

Fig. I26. Walking Stick Insect.

spread of wing to act as a parachute and allow him to scale safely to the ground.

We watched him several days and never tired of his peculiar walk, swaying from side to side. Often when at rest the front pair of legs would be extended parallel with the antenna, along the anterior line of the body, making the imitation twig eight inches over all (Fig. I26). 
As we walked through the jungle wood roads close to the clearing, large forest dragon-flies, small tiger beetles (Odontochila confusa, O. cayennensis and O. lacordairei) and a few yellow-spotted Heliconias were the most noticeable insects. One or two of the giant metallic Buprestid beetles (Euchroma goliath) were sure to be seen flying about the fallen trees, and our Indian hunter invariably made a dash at them, and as invariably missed the active, alert creatures.

Passing by a great mora stump in the clearing, our attention was attracted one day by a large caterpillar hanging dangling about two feet from the ground, squirming and wriggling vigorously. We ran up and saw a most interesting sight. Through a hole, about three quarters of an inch in diameter, protruded one of the claws of a good-sized scorpion. These villainous pincers had a secure grip on two of the long head spines of the caterpillar, which was dangling helplessly. As the latter wriggled, the scorpion made attempt after attempt to draw its victim inside the hole, a most absurd thing, as from tip to tip of spines the caterpillar measured almost two inches across. After watching this tableau I caught the scorpion's claw in a pair of pliers, drew him out, and, Milady holding him up with the caterpillar, I photographed them together.

The caterpillar was a most gorgeous creature; pale green, fading into yellowish at the posterior edge of each segment, while the movable joints were dark brown. On the seven posterior segments there were six rows of branched spines, the stalks pale orange and the branches pale blue - the three colors, green, orange and blue, making a most harmonious combination. On the anterior five segments there were two additional rows of spines, small ones, low down on the sides. The eight spines on the head segment pointed forward, projecting beyond the head. The longest spines were on the second, third and caudal segment and were 
over three quarters of an inch. All the blue branchlets ended in a dark, tiny needle point, and they stung like nettles as we found when we accidentally touched some.

I had never heard of a contest between two such creatures, and should think the scorpion must have been hard put to it for food, to make frantic attempts to secure such a prickly mouthful.

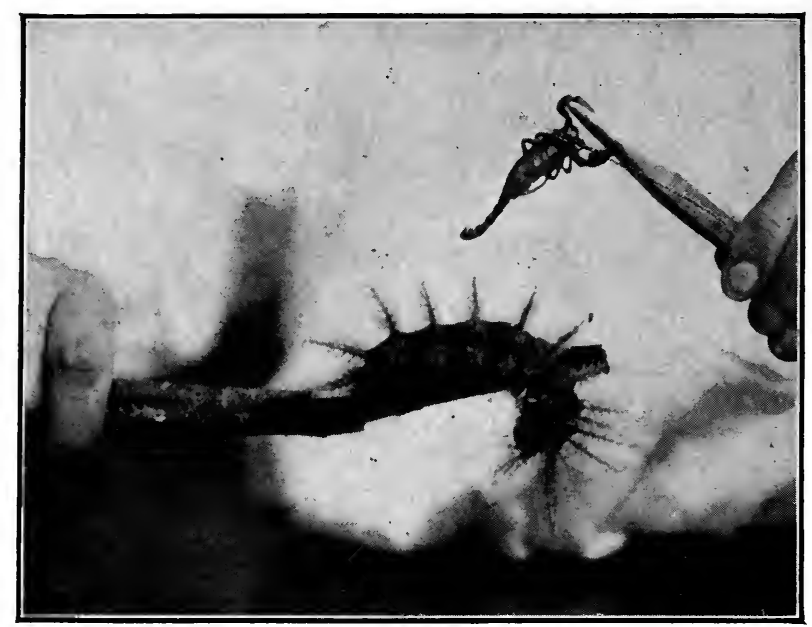

Fig. I27. Scorpion and Caterpillar after their Battle.

South of the bungalow, scrubby bush had been allowed to grow up and here was a scattering of non-forest birds; three pairs of Silver-beak Tanagers ${ }^{146}$ and a pair of Seedeaters. ${ }^{131}$ Gray-rumped Swifts ${ }^{72}$ coursed over the clearing and Toucans, Macaws and Orange-headed Vultures ${ }^{52}$ were occasionally seen from the bungalow, while a pair of splendid Red-crested Woodpeckers ${ }^{88}$ hammered the trunks and leaped from tree to tree all through the day.

In the clearing itself we saw little of mammalian life, although we dined daily on all the bush meat from bush-pig 
to acourie. The whitened bones of an ocelot lay in perfect arrangement at the edge of the clearing fifty yards from the bungalow, picked clean by ants but for some unaccountable reason untouched by Vultures. The animal had been shot at night, chicken stealing.

At daybreak the red howlers came to the edge of the clearing and awakened us from our slumbers by their wonderfully weird chant.

Jaguars were not seen or heard, except one reported by the mail carrier who runs between Aremu and Perseverance Landing. Some years ago an Indian near here found a litter of jaguar cubs containing two normally colored and one black individual. The latter was purchased by a colonist and sent to the London Zoo.

A dull-colored, harmless snake, four feet long, with two rows of keeled scales along the back, was the only serpent we found in or near the clearing. Lizards were everywhere and one very large iguana inhabited a bit of wood-road, but evaded all our efforts to add him to our mess pot.

The Amphibians alone in this region would well repay months of study. Our brief visit gave us only a glimpse of them. The commonest frog in the jungle near the clearing was a medium sized, dark-bodied one (Dendrobates trivittatus) with green legs and two pale green bands, one running around the front edge of the head, back over the eyes and down the sides of the body; the second line being beneath the first. The under parts were covered with blue lines and mottlings. The first half dozen seen were normal in appearance, but then one was encountered which instantly drew my attention. A closer look showed that the back of the animal was covered with a solid mass of living tadpoles, each over half an inch in length. When I urged him into a jar, two tadpoles were scraped off and wriggled vigorously. When put into water they sank to the bottom and made no attempt to swim, 
although the tail fins were well developed and there was as yet no trace of limbs.

I kept this frog in a box with wet earth and a puddle of water, and two days later half the tadpoles had left his back and were swimming strongly in the muddy water. They were attached to the back of their parent only by their sucking disks, and the object of the strange association seemed only temporary and not intended to last until the tadpoles became adult. They would probably drop off and swim away one by one when their father entered some forest pool. This species of frog was very active and capable of remarkably long jumps.

As I shall mention later, the sharp eyes of my Indian hunter spied a most remarkable frog in the jungle one day, which I brought home in my pocket. Its scheme of protective form and color was perfect - the hue of dried leaves and withered mosses, with deeply serrated sides and a high irregular ridge over each eye. I placed it among some dried leaves and tried to focus on it with my Graflex, but could not find it. Then I stooped down and although the frog had not moved and I knew the square yard within which it was resting, it took me a full minute before I located it, and optically disentangled it from its surroundings. I have never seen such a case of complete dissolution and disappearance. When I alarmed it, the frog closed its eyes - thus obliterating the dark spots of its irides, and then little by little opened them again.

Every evening at half past five o'clock we would troop down to the stream and swim and paddle about on the sand bars in the half day - half moonlight. The water was cool and refreshing and the temperature of the air invigorating at this hour, and to lie on one's back and look up at the lofty moras and other trees stretching their branches fifty yards or more overhead was a sensation never to be forgotten. 
We spent ten days at the Aremu Mine, and it speaks weil for the working possibilities of this region that I was able to rise at five o'clock in the morning and with intervals only for meals, keep up steady work - exploring, photographing and skinning until ten o'clock at night, when usually the last skin would be rolled up or the last note written. I would then tumble, happyand dead tired, into bed and know nothing until the low signal of our Indian hunter summoned me in the dusk of the following morning. I worked harder than I ought to have done even in our northern countries and yet felt no ill effects.

What impressed me chiefly in regard to the birds of this region was, first the abundance, and second, the great variety. In the course of the ten days of our stay, we identified 80 species of birds, and observed at least a full two hundred more which we were unable to classify except as to family or genus. Wishing to study the birds alive I refrained from shooting as much as possible and chose to make this expedition rather one of preparation in learning what tropical wood-craft I could from an excellent Indian hunter, than of gathering a collection and thereby a lengthy list of mere names. When, sometime in the future, we return to this splendid field of study and spend months in careful observation of some such limited region, we may hope to add something of real value to our knowledge of the ecology of these most interesting forms of tropical life. We have the results of the collector, par-excellence, in our museum cases of thousands of tropical bird-skins. Now let us learn something of the environment and life history of the living birds themselves.

It is against my rule to write in diary form, but owing to the limited time we spent at Aremu and the series of events, some of which extended over two or three days, I have made an exception in this case and will put down a few of the incidents of jungle life in the order in which I observed 


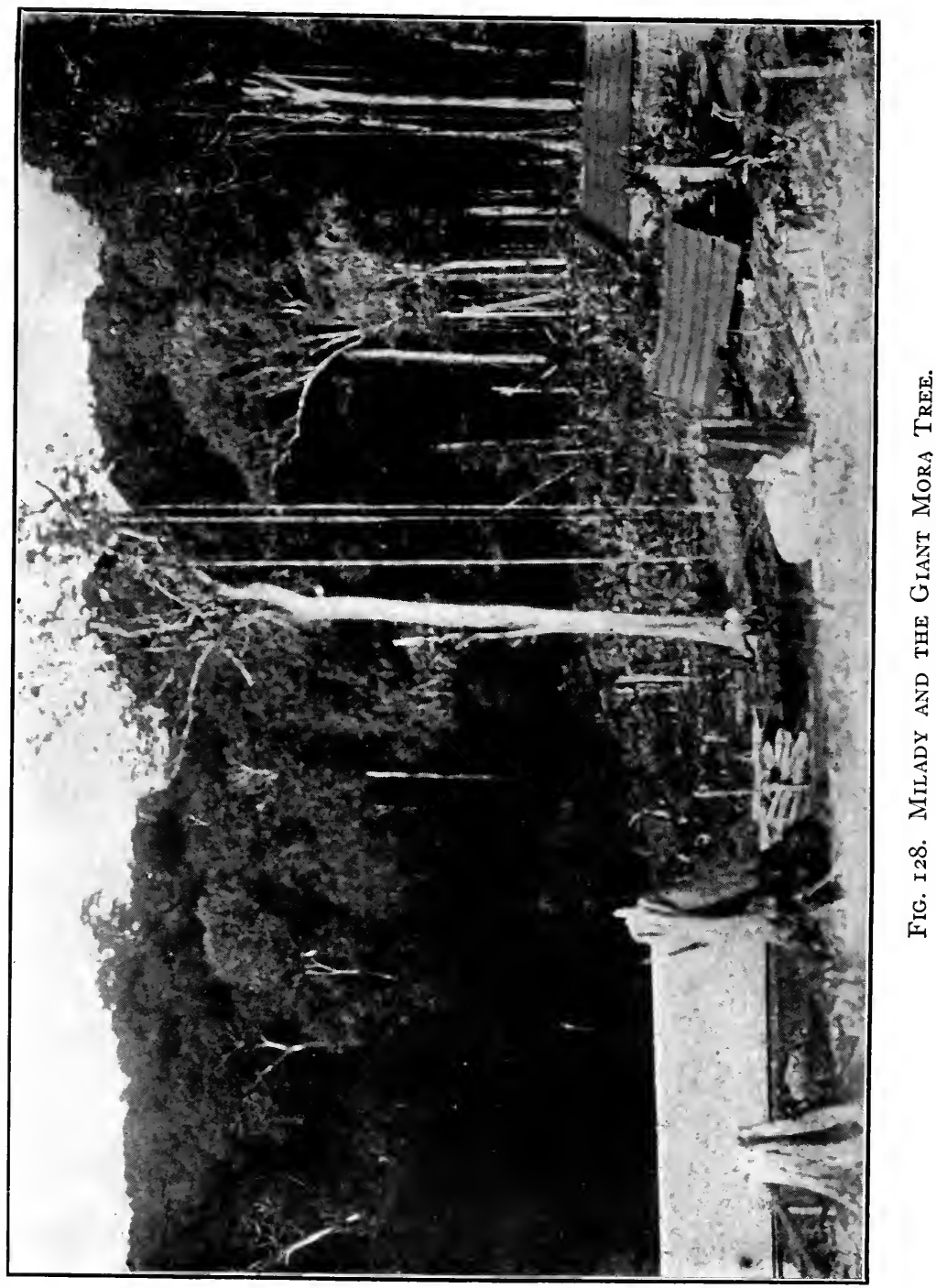


them. Far from giving all the observations made here on birds and other creatures, I have included only those of greatest interest, which will convey an idea of the conditions of life here as compared to those in our northern woods and forests.

MARCH 28th. - Leaving the house before noon I crossed the Little Aremu by a foot bridge, at the western edge of the clearing. The stream here flows gently and smoothly; it is from one to four feet deep, and ten to fifteen feet wide. Following it upstream, one is stopped within a few yards by a perfect tangle and maze of interlocked vines and trunks showing what it was like lower down before the hand of man hewed and blasted a free channel. The forest about the mine clearing is probably near the extreme, even of tropical growth. One feels absolutely dwarfed as one gazes up - far up, at the lofty branches, where birds like tiny insects are flying about, in a world by themselves. The trunks are clean, hard and straight as marble columns and the undergrowth is thin, giving access in almost any direction, yet dense enough to harbor many species of birds and animals.

Turning south along a wood road, I started on my first tramp into the jungle. It was the hottest part of the day, but there was all the difference in the world between sun and shade, and here in the recesses of the forest it was pleasantly cool, and birds and insects were abundant.

One of the first sounds which came to my ears was a loud, intermittent rustling among the dried leaves, marked now and then by a low grunt. Crawling up quietly behind a great mossy log, I peered over and was surprised to find that I had been stalking a huge tortoise. I certainly might reasonably have expected to see a mammal instead of a reptile, as our tortoises of the north are not in the habit of attracting our attention by their vocal efforts. This was a 
South American Tortoise (Testudo tabulata) of the largest size, not far from two feet in length, and he was busy rooting in the ground for some small nuts which had fallen in great quantities from the tree overhead and settled among the débris of the leaf mould. The shell of the tortoise was high and arched, dark brown in color with a bright yellow centre in each shield. There were two deep abrasions on the shell, apparently caused by the teeth of some carnivore.

These tortoises were very common and we had many delicious soups and stews made of their meat. They were, however, heavy and awkward to carry and we never bothered to bring them home unless on the return journey and near the clearing. In one individual we found eight eggs about to be deposited.

My wood road led up a gentle incline down which logs had been skidded, and after a half mile it merged gradually into the jungle. At the last sign of the axe I sat down on a fallen trunk and quietly waited. Three Blue Honey Creepers ${ }^{136 a}$ - two males and one green female, - dashed here and there in the branches close overhead. They uttered sharp cheeps, until the males flew at each other and began fighting furiously - ascending for fifty feet in a whirling spiral of hazy blue and black, and then clinching and falling to earth, where they clung together claw to claw, and pecked viciously and in silence, their beautiful plumage disheveled and broken. The lady - heartless cause of all this terrible strife - cheeped in low tones overhead and nonchalantly plucked invisible dainties from the undersides of leaves. I took a step toward the combatants and they separated and vanished, the lady, be it noted, following swiftly in their wake.

Close upon this melodrama came a fairy Manakin, black with a conspicuous white chin. I never saw another and cannot identify it, distinctly marked though it was. Through the forest came the low belling of Green Cassiques; ${ }^{150}$ then 
no sound save the drowsy hum of insects high overhead. The most frequent noise came from falling leaves, twigs and branches - yes, leaves, for "gently as a falling leaf " in this tropic world might mean, "like the stroke of a sledge hammer!" The realization comes again, as a yellow leaf eddies

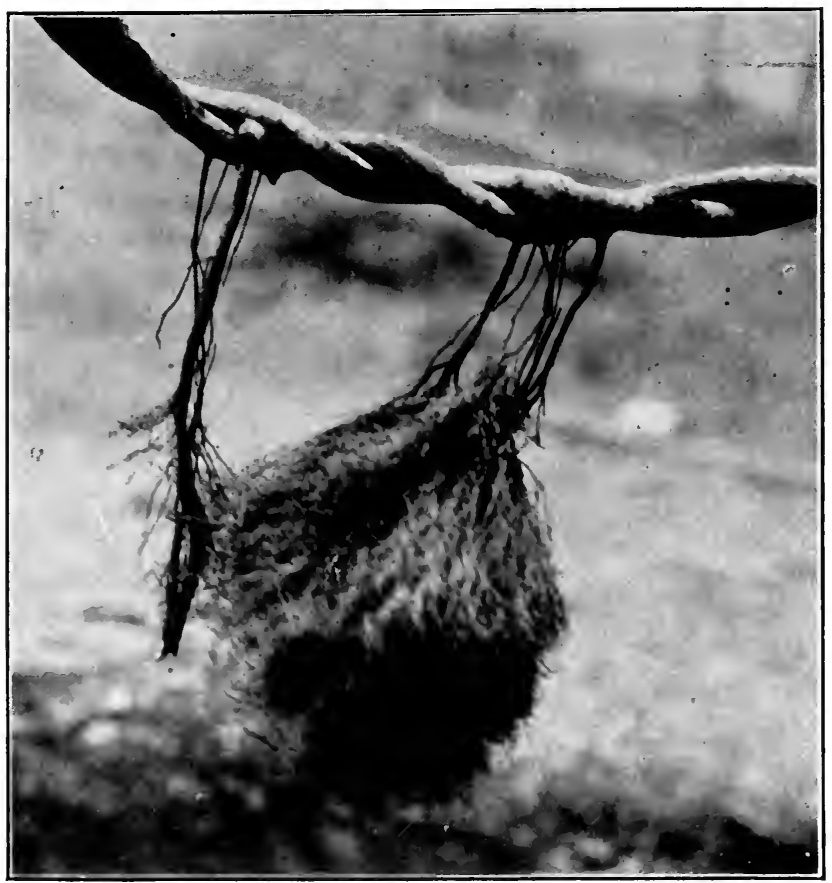

Fig. I 29. Ä̈rial RoOts OF Bush-Rope.

past my seat, that autumn is distributed throughout the whole year, while the freshly opening pink and reddish shoots on every hand show that spring is never absent.

I observed something circling about in an opening to my left and on examining it found a peculiar flat cake-like wasp nest, with the solitary pair of owners (Polybia sp.) on the rim. 
It was attached to the extremity of a long, slender bushthread dangling from a great distance above. There was not a breath of air and the secret of the circling motion the nest moving irregularly in an ellipse of about ten feet was not solved until with my glasses I made out a small monkey - a marmoset apparently - clinging to a branch near where the bush-thread started. The little creature had found some store of food in a hollow or crevice of the bark. To get his hand in, he was compelled to push aside the dangling curtain of aërial root-threads, and this occasional motion was enough to send the end, far below, sailing around in a large circle.

As I resumed my seat, a great beetle, like a polished emerald, alighted close beside me,- not heavy and blundering, like a June-bug or scarab, but nervous, flicking its wings wasp-like, ready at an instant's alarm to whirr away as swiftly as light. A beautifully marked Longicorn beetle buzzed past and alighted ten feet up a sapling, leaving me eying it enviously, atremble with all my boyhood's collecting ardor. Heliconias sailed slowly past and one of the beautiful transparent jungle butterflies alighted at my feet, with only a few dots of azure revealing the position of the wings. White and yellow butterflies floated high in air, where a hundred kinds of flowers flashed out among the green foliage.

Lizards were abundant in this little clearing, slipping along fallen trees with sudden rushes and halts, or tearing madly after each other with loud rustlings through the fallen leaves. Some were beautifully colored, splashed with blue, orange and green; while other dark ones had a network of delicate light lines crossing the back, cutting the creatures up into likenesses of small lichened leaves.

When the sun shone out brightly, two or three minute midges danced before my eyes - otherwise I was free from the " insect scourges" of the tropics! 
The trees on this and all later days constantly drew from us exclamations of delight. They were magnificent, aweinspiring, and if I could think of any stronger word of appreciation I should apply it at once to them. Their immensity and apparent age made one reflect upon the transiency of animal and human existence. Even the long-lived Parrots and Macaws perching on their branches seemed like mayflies of a day compared with these giants of the jungle, which had watched century upon century pass.

As I looked at the circle of trees bordering the clearing a clearing which itself was the result of the felling of only one such giant - the great variety of trees was at once noticeable. Near relatives - brothers and sisters, or fathers and sons could not exist within each other's shadow. So it was that a dozen kinds were visible from my seat. One splendid fellow sent up a perfectly rounded grayish column, one hundred and fifty feet or more, propped with a single great fox-colored buttress, sweeping gracefully out from the weaker side of the ground hold of the trunk, like the train of a court lady's dress.

Another column was round but deeply fluted, the trunk being rimmed with a succession of scallops, while in a third tree known as Paddle-wood, this was carried to an extreme, the trunk being little more than the point of juncture of a dozen thin blade-like sheets of wood. The whole was of a beautiful leaden-gray color.

The moras were the biggest and tallest trees within sight, and sent out huge buttresses, twenty feet in all directions with space between them for a good-sized room. The impression of security was perfect - it seemed as if the strongest of winds could never overcome such a reinforced structure.

Hearing near at hand the strange cicada whirr! which we have described in a previous chapter (page 23), I watched for the insect and soon traced the sound to a very large 
cicada high up on the trunk of a tree. Wishing to identify it and lacking other means of getting it, I backed away some distance and brought it down with a 22 calibre shot cartridge. It is a remarkable country indeed where one goes gunning for bugs! And not only this, but I only winged my game! one pellet of lead breaking the main vein of the right wing, bringing the insect to the ground where it buzzed and flopped about until I caught and chloroformed it.

It was a beautiful species almost three inches in length with transparent wings marbled with wavy black markings, and with the thorax and abdomen ornamented with tufts of golden and brown hair (Cicada grossa).

Keeping to the left through the open underbrush I intersected another wood road, then swung around and at last entered the clearing from the southeast. Hearing a rustling I suspected another tortoise, and was about to pass on when I saw leaves and twigs flying into the air behind a log. Creeping from tree to tree I saw that the commotion was made by a trio of Ant-thrushes or, as I prefer to call them, Antbirds. They took the leaves and leaf mould in their beaks and threw them over their backs, all three working side by side, covering a width of about two feet. They were Woodcock Antbirds, ${ }^{93}$ reminding one, in the general tone of coloration of the upper parts, of that bird. The chin and throat were black bordered with white which extended up the sides of the neck and forward over the eyes. The tail was short and often held erect over the back, while the strong legs and feet proclaimed them terrestrial rather than arboreal. When flying or excited, a row of white spots flashed out from all the wing feathers save the first two primaries, but when the wings were closed only buff markings were visible. Now and then two of the birds would spy some morsel of food at the same instant and a tussel would ensue. With angry scolding cries the two contestants would strike at each other with 
their beaks, with wings wide spread and the elongated feathers of the back raised and parted, exposing the conspicuous white base of the plumes, almost like a rosette. These white stars were very conspicuous amid the dark shadows of the forest floor, vanishing instantly when the wings were lowered. This color was not visible in flight. Many of the species of this group of birds have a similar concealed dorsal spot, and it must serve some definite purpose. When the matter of dispute was devoured or had crawled away into safety, the quarrel was at once forgotten and the birds began scratching peacefully side by side as before.

A short distance beyond I encountered what I found later was the most common assemblage of birds to be found in this region - a flock of Antbirds and Woodhewers, with a few other species, such as Flycatchers and Tanagers. One could not take even a short walk in the forest hereabouts without observing several such flocks, numbering from a dozen to fifty or more individuals.

The Antbirds comprise a family, Formicariidae, of which more than two hundred and fifty species are known. They are rather generalized passerine birds, which are found only in the tropical forests of northern South America. Inconspicuous in color and retiring in habits it is only when one becomes familiar with these tropical jungles that one realizes how numerous these birds really are. Their notes are usually uttered only at intervals and are often difficult to locate. They creep silently among the lower branches or, as we have seen, search the ground for the insects which form their food. The name Ant-thrush is rather a misnomer, for they are not Thrushes, and while they are always attendant upon the swarms of hunting ants yet they seldom feed upon the ants themselves, but on the insects stirred up by the ferocious insects.

We know but little about the nesting habits of these birds, 
and we were unable to locate a nest during our brief stay although we knew that several were breeding near the clearing.

Like most other tropical families, Antbirds have been compelled by competition to specialize, and we find some Shrike-like in habits as well as appearance; others resembling the long-legged Pittas of the East Indies, while the majority parallel Wrens, Warblers or Thrushes.

The Woodhewers of the well-named family Dendrocolaptidae, or Tree-chisellers, form with the Antbirds a considerable percentage of the smaller forest birds of this region. There are not far from three hundred forms of these birds, all of dull colors - rufous or brown tones prevailing.

Woodhewers in the main parallel the Woodpeckers, and especially the Brown Creepers, in their method of obtaining food. Their claws and feet are strong, the legs short, and the tail feathers in the majority of species are stiff and spinelike. They hitch up the trunks of trees, finding their food in the chinks and crevices of bark, but not boring into the wood like Woodpeckers. While the stiff tails show that all have probably descended from tree-creeping ancestors, some Woodhewers have deserted the trunks and have become Warbler-like in haunt and habit. Such a one is the Cinnamon Spine-tail ${ }^{94}$ or "Rootie" (p. 379). In the tropical forest however, Woodhewers differ but little in their method of locomotion, and one or more of these fox-colored birds hitching up a great trunk is one of the commonest sights. There is remarkable adaptiveness in the bills, some being stout and blunt, others long and curved.

The notes of these birds are, with the calls of the Toucans and Cotingas, among those most frequently heard. In the early morning especially, the sweet descending scales of single notes from various parts of the forest forms a feature which is seldom lacking. 
Just before I reached the clearing I flushed two labbas or pacas (Coelogenys paca) which ran squealing almost from under my feet. These are rodents, looking like giant Guinea-pigs about two feet in length, with brown fur spotted with white. Their flesh is the most delicate of all the "bush meat."

Mr. Howell followed my tracks later in the afternoon and brought home a Tamandua, or Lesser Anteater (Tamandua tetradactyla), which he shot in a tree. This creature is rather sloth like in color and in development of its claws, but its tail is prehensile, and nothing more unlike could be imagined than the heads of the two animals, that of the sloth short, round and blunt; the anteater's long, slim and pointed.

MARCH 29th.-We had an excellent illustration this morning of how easily one can get a totally wrong idea of the animal and bird life of a tropical forest. Nine of us started out along a faint trail used by black "pork-knockers," which, after several miles of twisting and turning, led to an outcropping of gold, known as "England," all on Mr. Wilshire's concession. Throughout the whole tramp, although we lagged behind, we noted not a single bird or animal of interest save for a scattering of Toucans and Parrots. Every living creature fled before us or remained hidden. One might thus tramp across a continent and report the tropics to be barren of life, except in the tree-tops. Not only this, but the few birds which flew over or were otherwise seen momentarily were without exception brilliantly colored, and this would help to sustain the wide-spread impression that tropical birds are invariably of bright plumage, which is very untrue. There are really more dull-colored than brilliant birds in the tropics.

At last I slip aside, let my companions go on, and make a detour to the left of the trail. Here in the heart of the jungle 
306 OUR SEARCH FOR A WILDERNESS.

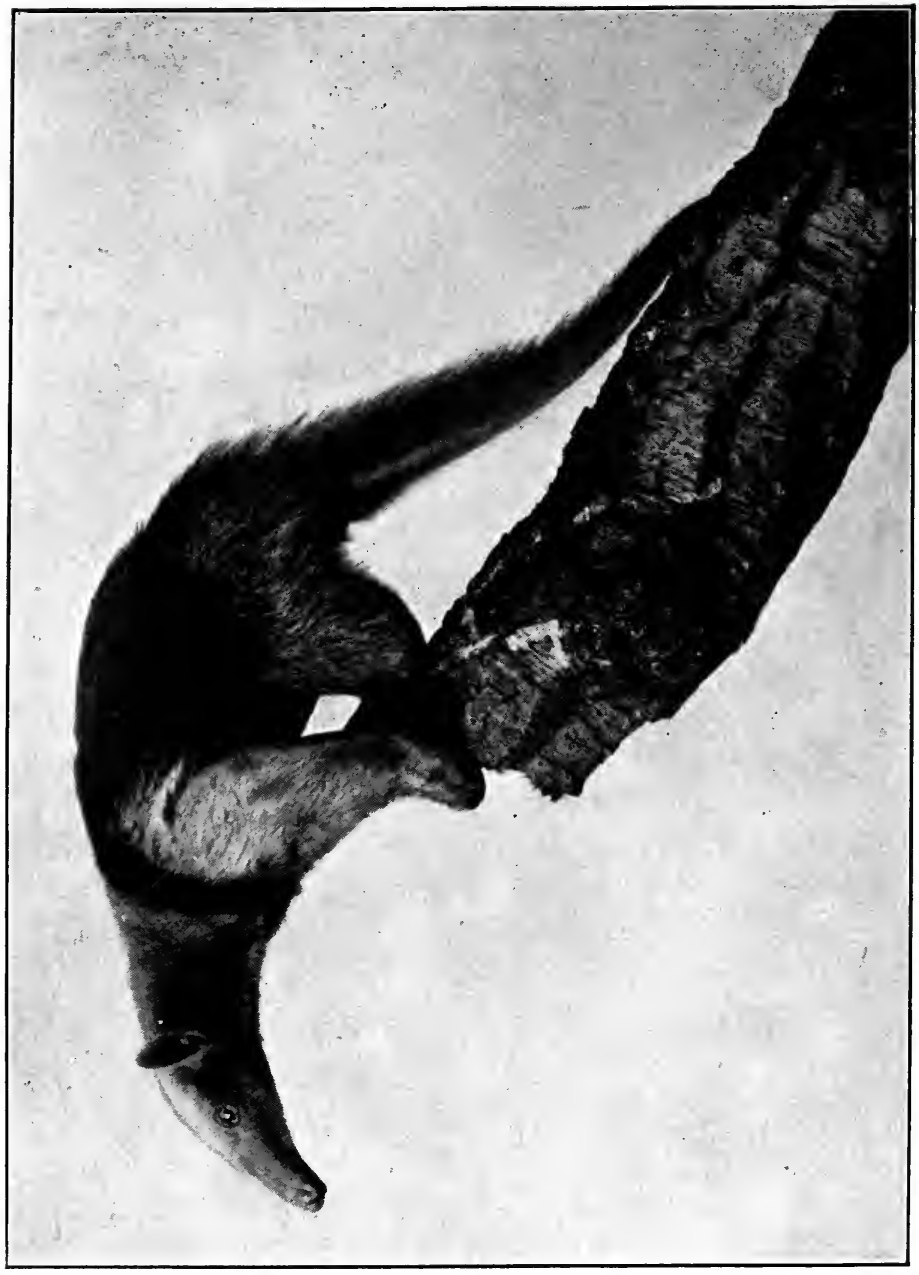

 
I discover an overgrown clearing with the skeleton of a hut in the centre. The ruin itself is a thing of exquisite beauty, the half-decayed uprights and roof saplings being interlaced and overhung with vines, the brilliant scarlet, poppy-like passion flowers crowning all. From the blossoms comes a busy hum of insects, in sharp contrast to the silence of the trail along which we have come. In the virgin forest there is ever sharp contrast. Brilliant bits of sunlight alternate with blackest shadow; deathly silence is broken by the earpiercing call of the Goldbird; the dull earthy smell of the mould is suddenly permeated by the rare sweet incense of some blossom or the penetrating musk of an animal or some huge hemipterous insect.

In a clearing - even a deserted one like this and only a few yards in extent - all is toned down. The odors are diffused and difficult to analyze; the droning of bees alternates only with the sharper whirr of a Hummingbird's wings, either the brown White-eyebrowed one, ${ }^{73}$ or the beauty with long sweeping tail. ${ }^{75}$ The Rufous-breasted Hummingbirds ${ }^{74}$ are abundant here and have quite a sweet song, a trill of twelve or fifteen notes, slow at first but rapidly increasing and ascending.

The half hidden framework of the hut with the collapsed shelf and table, tell of man's past presence; so do the papaw, sugar-cane and banana run riot; and suddenly we hear the sweet rollicking song of a little House Wren, ${ }^{124}$ man's follower, filling the deserted glade with sweetness; probably hoping that soon he will return and reclaim this fast vanishing oasis. For when the trees and vines - already reaching up over the papaw and bananas - close densely in, as they surely will, the jungle will become sovereign again, and then the pair of tiny birds will flee. Not for them are the dark silences, the tall sombre trunks. Their jubilant little souls crave light and companionship. Many of the birds of 
the tropical jungle have sweet single notes and calls - but most have harsh primitive voices. All are characterized by a solemnity or plaintiveness of tone, and none that I can recall have the joyful theme which fills the song of this little pioneer from more civilized regions; a song which is out of place away from mankind. Their sweetness has touched the heart of the native Guianans, who call these Wrens God-birds.

It is nine o'clock, cloudy and cool, and I am sitting near the old hut and write on a trunk fallen across the trail. A shuffling of feet comes to my ears and soon a good-sized opossum, but smaller than ours of the north, trots swiftly toward me. Not until he gets within arm's reach does he realize that something is wrong. I sit as immovable as stone and he puts a grimy little hand on the very edge of this journal. His nose works furiously, his rat-like beady eyes fairly bulge. Then he turns, just as I grab at his tail, but his hind claws scratch my arm so severely that I loose him, and he flees back on his trail - rolling awkwardly along but making remarkably good time. He was probably on his way home after an early morning's hunt. 'Thus the jungle folk have already begun to close in on this deserted clearing.

An hour later as I am kneeling quietly some six feet from the $\log$, busy liberating a beautiful little butterfly from the tangle of a spider's web, I am surprised to see the same opossum trot past. I know him because he has a kink in one ear. To see what the little fellow would do I leap toward him, but he has encountered me once and come to no harm, so he will not be turned back again. Instead of dodging me, the opossum only increases his speed, crosses the log, drops out of sight among the bushes, snorts twice to himself, and is swallowed up forever by the dark jungle. This log is apparently his regular highway, and he chooses to risk my apparently fierce onslaught and to run over the 
opened journal, bag, hat and gun, rather than change to a new path along another tree trunk a few feet farther along the trail.

We mortals sometimes have faint hints of coming events, and as I was leaving the clearing I instinctively kept all my senses on the alert. I had proceeded only a few yards into the jungle when some of the sweetest flute-like notes I have ever heard came from a patch of underbrush ahead. What could it be! I knew that no human being could whistle like that, and when they were repeated I realized how coarse any flute would sound in comparison. Nothing in this world but a bird could utter such wonderful notes. My memory recalled descriptions of the Quadrille-bird ${ }^{125}$ and I knew I was at last listening to it.

Our northern ravines have their Hermit Thrush; the canyons of Mexico are transfigured by the melody of the Solitaire and here in the deepest, darkest jungles in the world arises the spirit of the forest in song - the hymn of the Necklaced Jungle Wren. Dropping everything which would impede my progress, I crawled slowly and silently over the soft mould until I was close to the patch of thick brush. Then I waited and prayed, and the gods of the Naturalist were good, and a little brown form flitted up to a low branch and from the feathered throat came the incomparable tones of the fairy flute. The bird sang a phrase (I) of six to ten notes at a time. This was repeated several times, when an entirely new theme (II) was begun, which was given only once, then a third (III) and fourth were tried. Each note was distinct, and of the sweetest, most silvery character imaginable. In all but two phrases the invariable end consisted of two notes exactly an octave apart, the last like an ethereal harmonic. Twice the tones were loud and penetrating, twice they came so faintly that one's ear could hardly disentangle them from the silence. 
Birds with scale-like songs are far from uncommon: in the north the Field Sparrow; in Mexico the Canyon Wren; here the Woodhewers, but this was wholly new, phrase after phrase each differing from the preceding. How I longed for a phonograph! I scrawled a staff on a bit of paper and pin-pricked the notes where they seemed to come and reproduce them here. But what a parody they are, be they whistled or played!

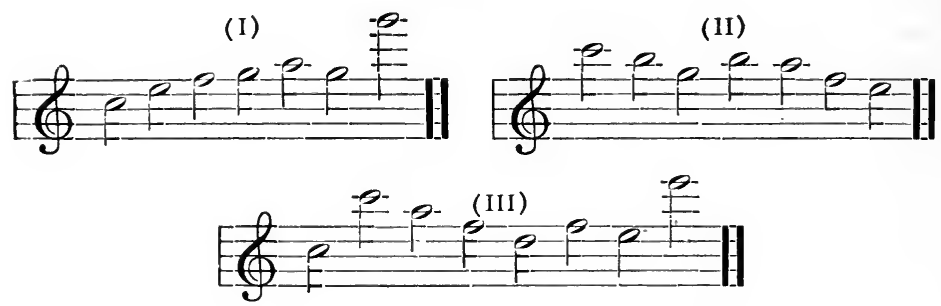

The Necklaced Jungle Wren, ${ }^{125}$ or Quadrille-bird as the natives know it, is a true Wren barely four inches in length, brown above, with a black collar spangled with white. The face, throat and breast are rich rufous, with the lower parts pale brown. This is the singer. The song no man may describe!

A small deer sprang up at my left, and I had walked some distance in that direction when I suddenly realized that I had missed the trail, and had been following an imaginary opening through the jungle. On closer examination this proved to be a deer trail leading to a small spring of clear water. I will never forget the first thought of terror at being lost in this endless forest. In one direction a few miles away lay the bungalow; in the opposite direction one might wander for weeks without meeting even an Indian. As this thought came I espied a little scarab beetle resting in the hollow of a leaf, who, as I looked, climbed slowly to the rim, wriggled his antennx and took to wing. What a wonderful power of 
scent it was which was directing him straight as a magnet, to some far distant bit of decaying flesh, and with what marvellous vision the Vulture high overhead spied me and hung for a moment watching me through a break in the foliage! How dull and inefficient seemed all my organs of sense in such a crisis as this. For a few moments I devoted myself to discovering which was north, and from which direction I had come. The cloudy sky and the sameness of all the vistas through the jungle completely foiled me, and I had to give it up and ignominiously unravel my puzzle deliberately and unromantically. I stuck my long-handled butterfly net in the ground and began to describe circles about it widening them gradually, until on the third round I intersected the trail and went on my way.

The danger of being lost is by no means an imaginary one, and even with a compass it is sometimes difficult to retrace one's tracks. The Indians themselves have to guard against becoming confused when in a new region. Before I reached the main trail, and met the returning party, I saw a number of the exquisite White-capped Manakins, ${ }^{109}$ clad in shining black save for their snowy caps. Their flight, unlike their white-breasted cousins which we met in Venezuela, was noiseless. They were far from silent however, twanging their little vocal chords in an apology for a song - a wheezy, grasshopper-like buzz. The females were silent, sombre little beings - dull olive green above, with a grayish cap and paler below.

After lunch at one o'clock in the afternoon, I started out again and climbed to the summit of a densely forested hill, southeast of the mine clearing. The tree-tops were filled with birds and not for a moment was I entirely out of sight or sound of one or more species. A few yards from the clearing I followed up an excited cackling and found a pair of splendid Red-crested Woodpeckers. ${ }^{88}$ They had a nest in 
a tall dead stub and were trying to dislodge an iguana which was steadily crawling up a neighboring branch. A moment after I came into sight one of them struck the lizard with

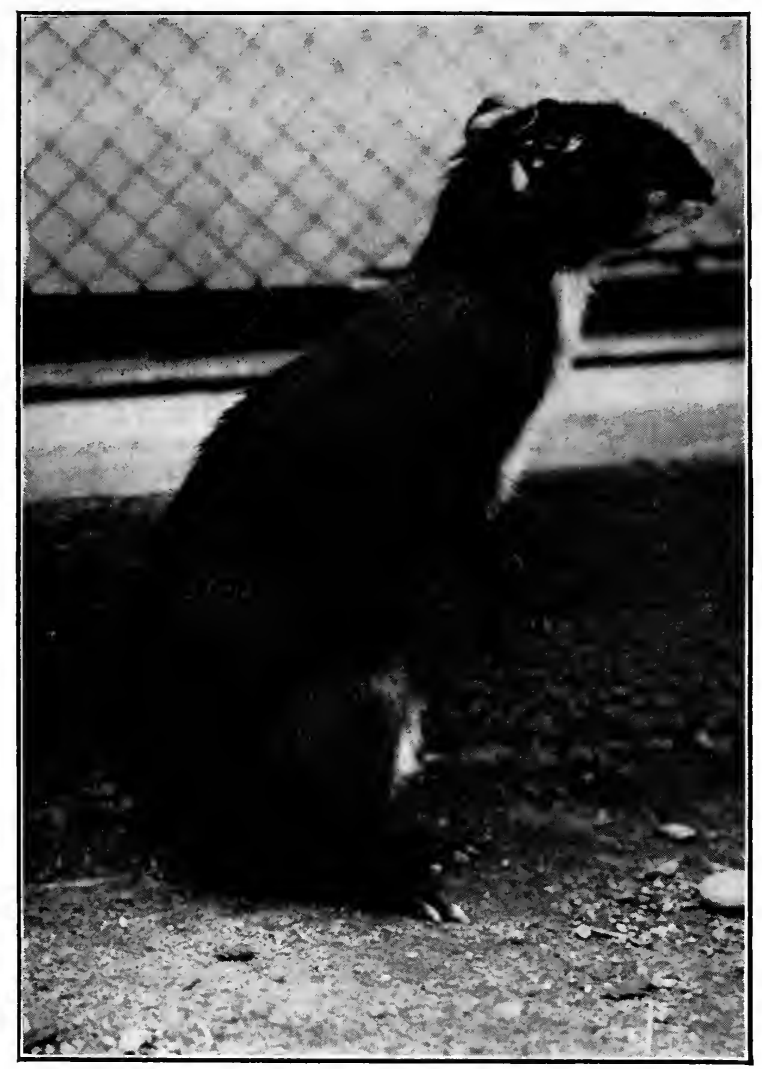

Fig. I3I. Agoutr. (Photo by Sanborn.)

its wings, whereupon the iguana reared up and lunged with open mouth, the birds then ceasing their attack upon the inoffensive saurian.

What splendid birds the Woodpeckers are - strong, active, full of vitality and enthusiasm over life. These were big fel- 
lows, black above, variegated on shoulders and head with white; thickly barred below and with a long crest of blazing scarlet. They spent much of their time near the bungalow, and when they drummed steadily their scarlet head-plumes seemed a living flaming haze.

Near the summit of the hill a tall Silverballi had been felled and sawed by hand into boards. This had made a small clearing like the one I visited yesterday. The trees were filled with many species of birds attracted by the abundant insect life, some of which I knew and made notes upon, while most were unknown to me. A group of tiny feathered beings was busy catching midges near the top of one of the highest trees, their sharp cheeps! coming faintly down to me. Hopeless of ever observing them at closer range, I secured one and found it to be a Buff-tailed Tyrantlet. ${ }^{107}$ This waif of the upper air was less than three and a half inches in length with rather unusual coloring, the fore part of the body gray, the back, wings, lower breast and tail rufous. Its claim to the Flycatcher family was proved by the broad beak and remarkably long bristles. One must have an aëroplane or, more practically, an observing station in the tree-tops to study these and a hundred other interesting birds at close range. With a couple of hundred spikes as a ladder, I intend some day to make one of these mighty trees give up many of its secrets.

As I was about to seat myself on the ground beyond the clearing, a big Guan ${ }^{5}$ or Maroodie, as we learned to call it here, arose with a loud cackling cry and a rush of wings. Simultaneously a dark-colored animal slipped into a hole freshly excavated some twenty feet away.

I lay prone, waiting for some other unexpected manifestation of life, but all was quict. Then I prepared to watch for the reappearance of the unknown burrowing creature, and pressed my face close among the ferns where I could just see 
the entrance. A minute passed and directly across my line of vision, a few inches away from my face, crawled, as rapidly as it could move, a very large caterpillar almost four inches in length. Never have I seen a more remarkable looking one. Its ground color was a peculiar dark wine-red or purple, like the plumage of the Pompadour Cotinga. From the sides of the back projected brush-like tufts of red and black hair, while a continuous line of dense golden hair extended out from the body just above the feet. Over six segments was drawn a pale yellow pattern of the most delicate lacelike markings, a dainty network different on each segment. Altogether it was a wondrous creature and entirely put the burrowing mammal out of mind.

I carried it to our improvised laboratory on the veranda of the bungalow, but it refused food of all description, and day by day became smaller in size and duller in color. Instead of dying, it transformed one night into a large, beautiful chrysalid, yellow-green with a pale bloom over the surface. It was an inch and a half in length, thick-set in the centre and tapering rapidly. The joint between the fifth and sixth segments was hinged and the terminal portion would swing vigorously from side to side. The spiracle on the sixth segment was cream colored and much longer than the others, while the bottom of the chrysalid ended in two short, brownish spines. Seventeen days later in Georgetown, a beautiful orange-shaded Morpho butterfly emerged. I looked it up in a curious old volume, "The Insects of Suriname" by Madame Merriam, written many years ago, and found it was a rare insect, Morpho metellus, light orange on the fore-wings, shading toward the body into pale green and on the hinder wings to velvety black. From tip to tip it spreads six inches.

On this tramp I heard at least a dozen unusually loud or musical calls and whistles, new to me, which I could not trace to their authors. In one case, however, I was successful. 
Creeping up to a low, thick patch of brush, a splendid scarlet bird flew out and alighted twenty yards away, again giving utterance to its characteristic loud whistle. To-day I was contented with listening and watching, but later I secured the bird as I could not otherwise identify it. It was what I have christened the Black-headed Scarlet Grosbeak, ${ }^{134}$ differing from the description of this species in being $8 \frac{3}{8}$ instead of $7 \frac{1}{2}$ inches in length. It was scarlet below, dull red above, with a scarlet necklace and a jet black head and throat. A yellowish female showed herself for only a moment. The whistle was loud and penetrating, but sweet in quality. The first theme had three distinct phrases which may be represented thus:

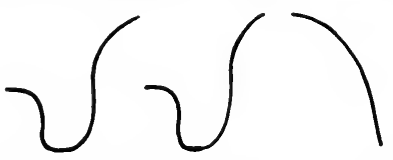

The second consisted of three scales, the first ascending one being more abrupt than the succeeding ones, thus:

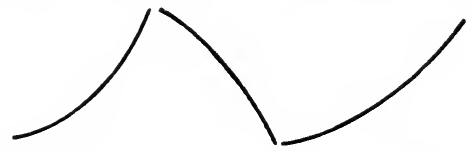

When the first bird ceased, another took up the whistle as long as I remained near the place. What splendid birds these would be in an aviary, striking both in color and notes. The nest, eggs and young, as is the case with so many South American birds, are unknown.

Goldbirds ${ }^{115}$ were calling all through the woods, and when one paid close attention, considerable variation was apparent in their notes. One individual uttered the wheé! wheé! o! twice in quick succession with the two introductory phrases (vide page i 89) only before the first call. This was repeated three times and then the bird reverted to the usual single utterance. On my way home two agoutis sprang up before me and I secured one for the general mess. 


\section{CHAPTER X.}

\section{JUNGLE LIFE AT AREMU.}

\section{SOME PAGES FROM MY DIARY '(continued).}

(By C. William Beebe.)

$\mathrm{H}^{\mathrm{OR}}$ our supply of meat we depended altogether upon F the efforts of an Indian hunter who made daily excursions from the clearing after game, and who never failed to come back heavily laden with some one of eight or ten varieties of edible birds or mammals. He was an Arrawak, going by the name of Francis, his real Indian name being of course never revealed. Like most of the Indians we met, he was quiet, serious and taciturn, but I had the good fortune early to win his approbation and to satisfy him that, while my hunting clothes were no match for his copper-colored skin in stalking animals, yet I could manage to get through the woods without any great noise or bustle. The only personal information I could obtain from him was that he was born on the upper Mazaruni, had a brother and two sisters and was "'bout four hand" (twenty) years old. He got fifty cents a day and his food for hunting and slept in a tiny hammock swung beneath the bungalow floor. The Indian hunter at Hoorie was paid sixty-eight cents a day without rations.

Francis and I had some interesting tramps together and one of my most enjoyable memories of these great tropical jungles is of this little red-man, short, well-built, muscular and absolutely tireless. I found him to be a great help in searching for certain rare birds and animals, and I learned a good deal of jungle craft from him. As one example among many 
things, I noticed that he never stepped on a log or fallen tree, and it was not until I had crashed through and hurt my ankle on one which had been undermined by ants that I realized how excellent a rule this was. A log of apparently the hardest wood might be but a shell thin as paper. The facility with which Francis found his way about in rain as well as sunshine was a puzzle, until by careful watching I found he was constantly making new trails by breaking, in the direction of the trail, tiny twigs, the leaves of which were of a slightly different color beneath. Such a mark every fifteen or twenty feet was almost a hopeless clue for me at first, although ultimately I learned to discover them more readily. As the breaking made no noise and was accomplished by the least motion of the hand, it was long before I detected it. When I went out alone I chose to leave a "blaze" every ten feet!

MARCH 3 oth. - At daybreak we started out on our first tramp, I with camera, bag, gun and glasses. Half a mile from the clearing I cached the camera and bag, the pace being such that I could not keep up while carrying them. I have hunted in Canada and elsewhere with first-rate guides and backwoodsmen, but this was a very different matter. From the moment we entered the jungle the whole demeanor of Francis was changed. He walked like a cat and never for a moment relaxed his vigilance, and therein he differed from a white man, who would unconsciously relax when he thought game was still some distance away. His figure slipped silently on ahead of me, flowing under trunks, passing around the densest clumps of underbrush, while I followed and imitated as best I could, learning every minute more than I had ever known of the art of effacing oneself in the wilderness. Every step was made carefully and the entire field of view ahead swept, and every significant sound noted. A branch would fall with a series of resounding crashes and the Indian would apparently not hear it, while a cracking twig or a low rustle 
which I could scarcely detect would lead him off in an entirely new direction, not necessarily toward the sound, but often to flank it or get to leeward of it. During the first two or three hours we would give our whole attention to hunting, but when the day's supply was provided, we then stalked the birds and wild creatures and watched them, as closely as we could.

Our first tramp was in a general south or southeast direction, passing over a succession of hills, five in all, three of which were high and quite steep, but all of about the same diameter with regular slopes and flat, narrow valleys. These were mostly swampy, or if dry had a stream flowing slowly along the middle. Agoutis were abundant in such places and we could always depend on obtaining them when desired.

As we left the bungalow I had laughingly asked Mrs. Wilshire what meat she desired for dinner and she said "Venison." So when I told Francis, in the broken English which we must use in talking to these Indians, that we must get deer, he nodded and disdained the agoutis. If I had said, "Francis, we must be sure to get deer to-day in preference to other game," he would have understood not a word. But "Shoot-um deer, eh? no accourie, no labba, no maipurie," outlined the day's work perfectly in his mind. I was rather reluctant to use this $u m ! u g h$ ! language at first; it savored too much of theatrical Indian dialect or of "penny dreadful" wild-west jargon, but it soon became perfectly natural and was really necessary.

After a half-hour's walk Francis motioned me to take the greatest care, and pressed my shoulder lower until I was almost on my knees while we slowly crept around a great mora trunk. He pointed steadily ahead, but after a threeminute scrutiny I could discern not a sign of life. Then he raised his gun and fired, and set loose a half dozen feathered bombs, or so it sounded as a flock of nearly full-grown 
Guiana Crested Tinamou ${ }^{2}$ arose with a roar. I secured one with a quick snap shot and we tied up the brace of birds with a slender tough bush-thread. Fastening head, feet and wings together, the Indian tied them ingeniously around his waist, the birds hanging down behind out of the way.

At the sound of the guns three tiny male Purple-throated Euphonias ${ }^{138}$ clad in purple jackets, yellow caps and waistcoats, came down to see what the noise was about. They were ridiculously tame and sang their simple chattering song in our very faces.

In the fourth valley we found a perfect maze of agouti tracks mingled with the fresh imprint of a tapir's feet. Francis showed me the spot where he had shot one of these "bush-cows" the week before. A few yards beyond we found a deer's track and in some way the Indian seemed to know that the animal was close at hand. We crawled silently for twenty or thirty yards through a shallow creek, then separated and crept along the slope, one on each side. A sudden rustling of vines came from a bend in the stream and we both caught sight of the bright rufous flanks of a deer. We secured it and then for some reason Francis remained perfectly quiet for five minutes while a delightful bit of wilderness life appeared close to me.

The smoke from my gun was still clinging to the great fern fronds overhead, when a second deer, a doe, walked fearlessly past along the opposite slope, stopping to nibble at a leaf now and then, and at last vanished in the underbrush. I was about to climb down to the deer we had shot when I heard a splash and a weak little bleat, and, looking at a pool ahead, there I spied the tiniest of fawns standing in the shallows, looking full at me, and now then splashing the water.

I whistled and the little thing started toward me fearlessly, standing knee-deep in the water, its tiny rufous form decor- 
ated with three lines of spots, every one of which was perfectly reflected in the water. Suddenly with a snort and a stamp the mother took one leap over a bush, her eyes staring in terror at me, then turned and vanished. In some way she had infused the spirit of fear into her offspring, for with a bleat which was almost a shriek the little fellow galloped madly, awkwardly after her, tripping every few steps as he turned his head to see if this awful thing was pursuing. I never saw such an instantaneous change from confidence to fear in any creature. The most remarkable thing was that the mother and fawn had not taken fright at the roar of the guns in their very ears. The very loudness and proximity must have had a numbing effect on the organs of hearing. I found that Francis had seen the second deer after shooting at the first, and had lain flat while she walked so near him, that, as he showed me by her tracks, he could have reached out his hand and touched her as she pássed.

We know but little of the deer of this region, and I took some notes on this first Savanna Deer (Odocoileus savannarum) which we obtained for the mess. It was a male without horns, and of a uniform rich rufous above with grayish-brown heac', and the legs up to the hock mousecolor. The tip and under side of the tail and inner thighs were white, while the rufous color was continuous around the breast and belly. The deer stood $24 \frac{1}{2}$ inches high at the shoulder and weighed 70 pounds. It had been feeding on leaves and on a great number of seeds of the Kakaralli tree, much like the mora. The seeds look like nutmeg in the mace, and two grow in each husk.

The skill and rapidity with which Francis prepared the animal for carrying was remarkable. He removed eightfoot strips of bark from a small tree which he called Mahoo and stripped off the tough pliable inner layer. With this he bound the legs and head together, then tied a broad band of 
bark about the body leaving it loose at the top. I hoisted up the deer and he put his arms and shoulders through the tied legs as if it had been a pack bag and slipped the loose band of bark across his forehead, like the tump-lines of the Canadian Indians.

A gentle cool breeze was blowing down the narrow valley and the blood from cleaning the animal had not been exposed five minutes when a line of burying beetles and yellow wasps began coming up-wind to the feast. Such a summons calls them far and wide from their vantage points on leaves and branches, where we see them so frequently in walking through the jungle. Before fifteen minutes had passed, an Orangeheaded Vulture ${ }^{52}$ appeared soaring over the little opening in ever lessening circles. He too had responded, but as much by sight as by scent, to the welcome meal.

On the way home we frightened a group of large weasellike creatures which we found to be Tayras (Galictis barbara) or, as the natives call them, Hackas. Seven ran rapidly away snarling and I secured one. They had been feeding on big grubs which they had nosed out among the dead leaves, a rather remarkable occupation for creatures of the fierce Mustelidæ family. The fur was dark-brown with a white spot on the breast, while the tail was long and bushy.

Before we reached the clearing a Quadrille Bird ${ }^{125}$ sang to us from the heart of a tangled swamp, a new theme differing from any $I$ had heard:

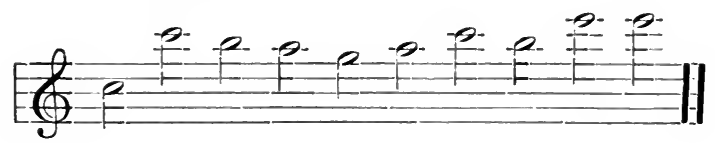

During the four mile walk to the clearing there was hardly a minute when we were out of sight or sound of birds. Big Blue Tinamou ${ }^{1}$ and Jacupeba Guans ${ }^{5}$ boomed up before us; Woodpeckers and Manakins of several species called 
and flew here and there, while we passed flock after flock of Antbirds, Woodhewers, Flycatchers and Tanagers. One bird which I secured, the Wallace Olive Manakin, ${ }^{112}$ was altogether of a dull olive, with none of the brilliant color patches of its congeners. When I went to pick up the specimen I saw a curious jointed band lying across it and found a sixinch centipede on the bird. The Manakin must have fallen across the path of the Myriapod as it was crawling over the jungle floor. While wrapping up this bird, a flock of tiny Brown-fronted Jungle Vireos ${ }^{1283}$ flew close to us, uttering a song like a diminutive alarm clock, Whirrrrrrrrrr-chee! Whirrrrrrrrrrrrr-chee! Francis shot one, which was hardly more than four inches in length, olive-green above, paler below. Those who think that all tropical birds are brightly colored should see the great number of species of sober little fellows like these.

MARCH 3 Ist. - Francis and I started out in a light rain at daybreak in search of Trumpeters and howling monkeys. The cook was well supplied with meat so we did not intend to bother with game. With the help of Goeldi's plates of Brazilian birds and much crude attempt at sketching I had taught Francis what creatures I wished especially to see.

About three hundred yards from the clearing Francis pointed out a beautiful nest of a White-throated Robin ${ }^{\mathbf{1 2}}$. made of green, growing moss, and placed close to the trunk of a tree, about six feet from the ground. We marked the spot and went on, but a day or two later I returned and examined it more carefully. This Thrush is olive brown above, pale below with a streaked chin and throat like our northern Robin. Its most characteristic mark, however, is a patch of pure white on the upper breast, which flashes out like a star among the shadows of the jungle. The parent was shy and would slip off at my approach, but return as silently if I walked away for a minute. When I prepared to photo- 
graph the nest she thought something was seriously wrong and voiced her alarm with a sharp cut! cut! When I focussed close to her home, her anger got the better of her and she scolded me roundly with harsh notes, repeated in phrases of seven, chack-chack-chack-chack-chack-chack-chack!

The nest touched the trunk of the tree, but rested on a loop of a two-inch bush rope or liana, which swung against

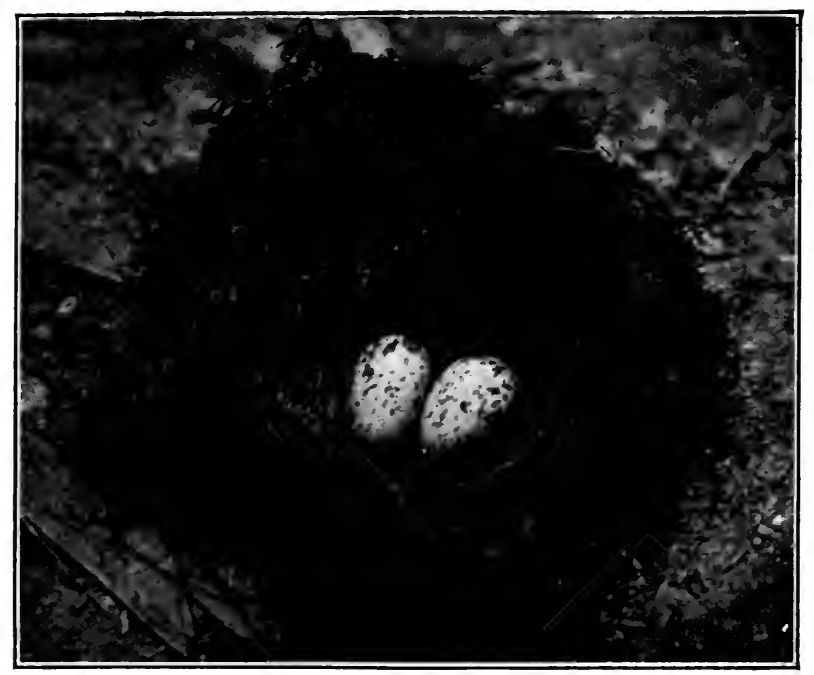

Fig. I32. Nest and Eggs of White-thronted Robin.

the bark, binding one tree to another. Just below was a fungoid excrescence larger than the nest itself. 'The nest was a double one, the new one being built directly on the older. The latter was composed of dry dead moss, while the new one was fresh and green. There were two eggs, pale blue-green, thickly spotted with brown of various shades, much more densely at the larger end.

We found this Robin was a common breeder hereabouts and discovered four other nests, all within a half mile of 
the clearing, yet all in deep jungle. The parents differed radically in their actions; two allowing us to inspect their treasures without fear, while two others became terrified if we approached within twenty feet of their nest.

To return to our Trumpeter and howling monkey hunt; it rained much of the morning, but for the most part only a drizzle. Francis said that wet weather made bad hunting except for deer and bush-cow or tapir, chiefly because the continual noise made by the falling rain-drops made it difficult to hear the rustlings of birds and animals.

I thoroughly enjoyed this new aspect of the jungle world. As usual small birds were fairly abundant, of which apparently 99 per cent. were Antbirds or Woodhewers. The most common Antbird in the valleys was the Scaly-backed, slate-colored except for the feathers of the back, wings and tail which were black tipped with white. At one place two dozen of these little birds must have been in sight, uttering sharp, snapping calls, and clinging, like Marsh Wrens, to upright stems in the low underbrush.

Every now and then we came across a good-sized hole with fresh earth thrown out at the entrance. Francis said that this was made by a "Yāsee" and he recognized an armadillo when I drew it.

Suddenly the rain came down in sheets, and streamed through the dense foliage. Francis gave me his gun, ran to a tooroo palm, a species which has no stem but sends its leaves, fern-like, from a base level with the earth. He cut off five stalks with as many blows of his knife, brought them to me and stuck them upright in the fork of a low branch. We stood under them for half an hour and never a drop came through, although three inches out in any direction the rain was falling in torrents. It was a wonderful example of a waterproof shelter put up in about thirty seconds. Can we blame these Indians for a general lack of industry, when 
game is as easy to obtain as we found it, and when one may build a house in a half a minute with a few knife strokes!

During the entire downpour we saw only a Long-tailed Hummingbird ${ }^{75}$ which unconcernedly searched the undersides of leaves for insects. Francis said its nest was hung on the side of the tip of a tooroo frond. A fluted tree of large size near us he called ballicusan, saying it was used for making paddles like ruruli. A section would look something like this:

The folds when cut off are so thin that a very little additional shaping forms them into blades.

As we were walking along after the shower, several twigs fell on us, which would have been unnoticed by me, as leaves and even branches are continually

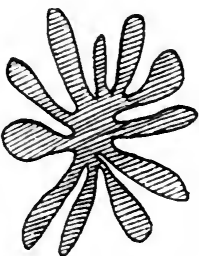

Fig. I33. Section OF PADDLE-WOOD TREE. dropping in these forests. But Francis looked up at once and whispering "Baboon" pointed to where a great male red howler (Mycetes seniculus) was walking slowly along a branch overhead. A carefully aimed shot brought it to earth, stone dead. It was a magnificent specimen weighing just twenty pounds and the hyoid bone protruded like an exaggerated Adam's apple.*

These howling monkeys are of course not really baboons, as these latter monkeys live only in the Old World and

* The color of the back and sides was a light gold, shading into dark maroon or red on the head, tail and limbs. The skin of the face, ears, palms and scantily haired under parts was dark slate. The eyes were hazel brown. The total length was $50 \frac{1}{2}$ inches, 25 of which consisted of the tail. The bare prehensile portion along the lower side of the tail extended $11 \frac{1}{2}$ inches backward from the tip. The forearm and hand was 16 inches long; the hind leg 18 inches. The hair of the beard was $1 \frac{3}{4}$ inches long. The Monkey had been feeding on leaves and some kind of fruit with stones like cherry pits. 
have short tails; while the howlers are members of the American family Cebidæ.

They are of a low type of intelligence and will not live long in captivity, being morose and sullen, very unlike other smaller South American primates. The hyoid bones in the throat are enlarged to form a great thin-walled bony drum, which is the chief instrument in the production of their wonderful voice.

There were two females and a smaller male in this party, but I got no clear sight of the others after I shot the old one. As in the case of the deer, tiny burying beetles began coming within two minutes after the blood of the baboon had been splashed on the leaves. We had walked for ten or fifteen minutes after shooting the monkey when we heard an infantile roar from the remaining male. This the old one would never have allowed, so we had an interesting example of the almost immediate usurping of the leadership by a young animal, at the death of presumably its parent.

Francis had remarkable eyesight, and when he once realized that I was interested in small birds and other objects he would silently point out everything in our path. In this way I found a remarkable frog which was so protected by its color and markings that I should never have discovered it by myself. I have mentioned it before as being of good size, earthern brown in color, with a tall, thin leaf-like ridge on the head over each eye and a row of light-grey tubercles like fringe down each side of the body. From the tip of the nose to the tail extended a narrow, pale bluish line and externally there seemed to be almost no differentiation between head and body.

I heard Red-billed Toucans ${ }^{81}$ calling in a high tree and stalking them, succeeded in shooting two, both males, one younger than the other. The coloring of their beaks was wonderfully brilliant and variegated. Their notes were of 
the Robin-song type, Phéo-pha! although the resemblance to a puppy's voice was also strong. They had been feeding on seeds with a pinkish pulp which Francis called suluwafaddy.

There were three Toucans in this group and when the first old bird was shot the others returned and called continuously and loudly. The third also came back to the same tree and I found that this was the adult female.

In this case as always, I did not take the life of a living creature without some good reason: for sport, never - but either as food, or as in this instance as the only way to solve a problem of scientific interest. I had noticed trios of Toucans in many places and wondered whether the third bird was an extra female or young. On the following day I observed no fewer than five separate trios of Toucans of two species, and now that I knew the dull-colored upper tailcoverts were a clue to the young bird of the year, my high power stereo glasses showed me a single young in each instance. We know practically nothing of the nesting habits of this group except from vague accounts. So it is certain that in this region the rule is that only one young bird is reared to maturity.

The loud hollow whirring of the wings of these birds often drew our eyes up to the tree-tops and we had many opportunities of watching them feed. The commonest way was for them to creep out as far as they dared to the branch tips and then crane their necks and bills to reach the fruit. But often they adopted a more spectacular methorl. A trio would beat heavily into a berry-laden tree and perch quietly a few moments, looking carefully in all directions for danger, overhead for hawks and eagles, beneath and around for monkeys, opossums and snakes. Then one would launch out, make a flying leap at a pendent cluster of fruit, clutch it frantically with its feet, and dangle and sway for ten seconds at a time - reaching out the while and filling its bill with 
the berries. Then when the bird dropped exhausted to a branch below, it would swallow what it had gathered.

After shooting the Toucans. I leaned my gun against a patch of black moss on a tree trunk. To my astonishment the moss whirled outward and back, and then I saw it was a host of caterpillars crowded as densely as they could be in a patch three feet high and forming a semicircle about the six-inch trunk. They were covered with black, branched, stinging hairs, with two longer tufted ones on the segments near the head. As Francis said, "Um wurrum's hairs bite hard!"

I began experimenting with their reaction motions. I found that any sst sound or hiss, the snapping of fingers, whistling, hand clapping, or pounding on the metal or wood of my gun, caused absolutely no response on the part of the caterpillars. No matter how close to the creatures or how loud or sudden was the sound, unless they were touched they did not move. On the contrary, any utterance of such sounds as bis! bow! bing! buzz! even when so low as hardly to rise above a whisper, caused every caterpillar of the many hundreds to react as one. The head with the long tufted appendage was jerked quickly backward, then down, and on the edges of the mass from side to side. Those in the centre, because of their position, had only the up and down flick. The effect as a whole was indescribable. An inconspicuous growth of moss was transformed like a flash into a seething, rearing mass of waving caterpillars. A suggestion, altogether theoretical, is that the reaction to the buzzy sounds may hint that the chief danger feared by these caterpillars is the fatal buzz of the wings of the ichneumon fly.

This evening we added baboon and bill-bird to our venison, and were surprised to find the former tender and by no means devoid of taste. The Toucans were tough, but more than one of us came back for a second helping of "howler" 
- in spite of the cannibalistic chaff with which we were regaled!

The rain had increased in amount successively during the last three days and to-night a new sound was added to our

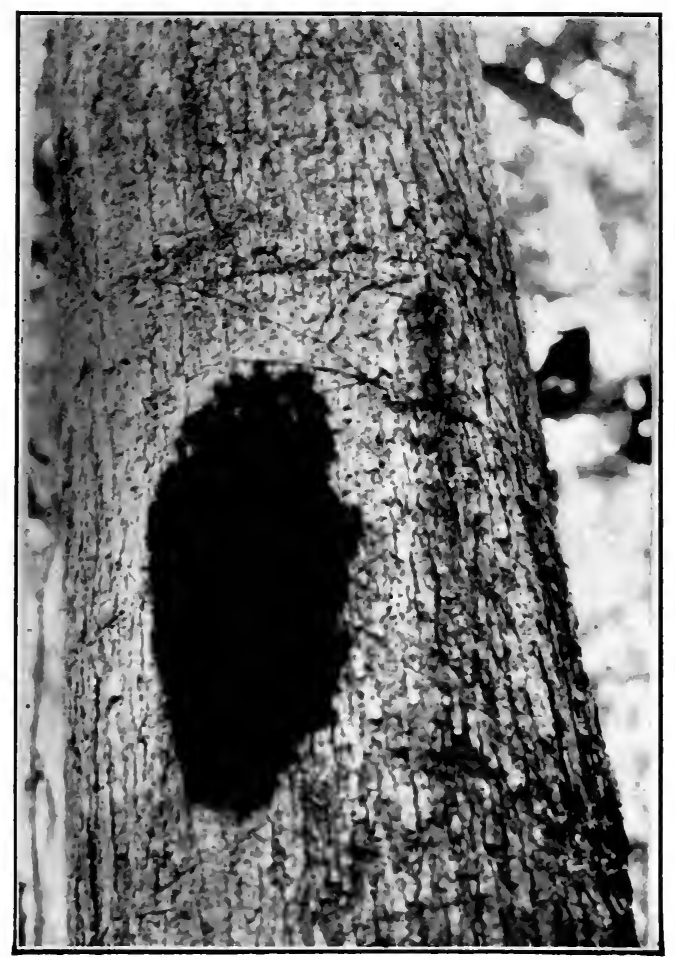

Fig. I34. Phonetic Caterpillars.

nocturnal chorus - the Bubbling or Gurgling Frogs, which, by the score, vented their joyful emotions in energetic gulps from the jungle at the edge of the clearing.

APRIL Ist. - Having missed finding Trumpeters yesterday, Francis promised them for to-day and we took a long tramp full of incident as usual. We circled to the north, swinging 
around beyond the first two valleys and then turning and describing a second curve intersecting the first. Two of the Jungle Wrens or Quadrille Birds ${ }^{125}$ sang their incomparable strains, each with a theme of its own. The first had two phrases which it uttered alternately, thus;

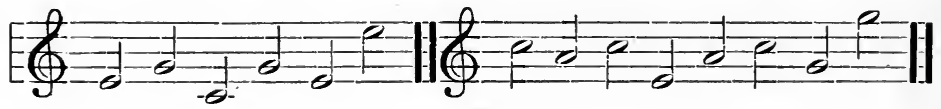

There is absolutely no other bird song with which to compare it. The timbre, when heard at a distance, is that of the Wood Thrush quality - sweet, liquid and altogether ethereal. But the distinctness of the notes and their remarkably intricate trios and gradations are wholly unique. Three or four large species of Antbirds ran rapidly here and there, holding their short tails erect and jerking them frequently, thus presenting a decidedly ralline appearance.

We saw several Little Tinamous ${ }^{3}$ in the course of the day, one of which I shot. When the cook cleaned it in the evening, he found an egg about to be laid. Several days later a short distance from the clearing, a bird of this species was flushed from a slight hollow between the buttresses of a mora. The following day when the bird flew from the same spot it was found that an egg had been deposited. It was of a burnished purple color and was $35 \times 45 \mathrm{~mm}$. in size. Although we knew that the egg had been laid less than twentyfour hours before, yet it contained an embryo corresponding to a four day chick. This fact, in the case of these generalized birds, may have some significance when we remember the advanced state of embryonic development characterizing the newly laid eggs of many reptiles.

After an hour or more of the most careful stalking in a low swampy valley, we heard the unmistakable thunderings of Trumpeters ${ }^{25}$ or Warracabras, and my blood leaped in response. Long before I could hear them, Francis had 
distinguished the low booming note amid all the other jungle sounds. I had studied specimens for months in the north and had searched in vain for any definite account of their habits. And now, although the briefness of my stay would permit of almost no chance for real investigation, yet here at any rate were the birds themselves in their native haunts. At last we flushed two which flew down from their perch with a sudden whirr of wings and ran swiftly out of sight. As they flew they uttered the familiar Chack! chack!

These interesting birds have no near relations, but form a Sub-order by themselves. They run very swiftly but seldom use their wings, and although they swim quite well, rivers of any size are never crossed. Large flocks are sometimes met with, but the birds travel more often in small parties. They feed on the ground and roost in the tall trees. The voice has many variations but the sound from which the name is derived is very loud and sonorous, and can be heard at a great distance. Trumpeters are very common pets among the Indians, to whom they become greatly attached, and although given full liberty in the midst of the dense bush they never attempt to return to their former homes. When standing upright, the Trumpeter reaches a height of from I 8 to 20 inches. The head and neck are black and covered with soft velvety feathers, about a quarter of an inch in length, and slightly recurved. On the upper part of the breast and the lower part of the neck a purplish iridescence appears on the feathers while the rest of the plumage is entirely black, with the exception of a brownish band across the back, and the grayish plume-like secondaries. The tail is very soft and does not exceed four inches in length and is indeed hidden by the wing feathers.

I made careful inquiry concerning the nesting of the Common Trumpeter. So-called biographers have credited it with nesting on the ground or in a hole high up a tree; of 
laying from two to ten or more eggs, which in the words of the describers are white, dirty-white, or green!

I questioned Francis at various times and could never get him to vary his answers. He said that the Trumpeter nested in the hollow of a tree and laid three, four or five white eggs.

On another occasion I questioned the Indian who hunted for Mr. Nicholson at Matope and he said the Warracabra builds a nest of leaves well up in a tree and lays five white eggs.

While waiting for the Trumpeters we heard the strange Bare-headed Cotinga ${ }^{117}$ or Calf-bird. The note has been compared to the lowing of a cow, but to me it seemed much more musical, resembling the humming of a goblet when one's moistened finger is rubbed around the rim. The bird is yellowish brown with a bare head and keeps to the tops of the trees. It is not shy however and can easily be approached and watched with the glass.

The most interesting discovery I made to-day was the elaborate courtship and challenge performance of the Crested Curassow. ${ }^{4}$ In a low bit of valley with thick underbrush we put up a deer which dashed off before we could catch more than a glimpse of it. It was followed by two agoutis, one of which we gathered in for dinner. The note of alarm of these rodents is a loud nasal Wa a $\breve{a} a \bar{a} h !$ Then Francis clutched my arm and by listening intently I could just hear a faint low mumbling. It might have been a bumble bee a few feet away, but the Indian pointed to the east and said "Powies-Warracabras! Me go shootum labba." Which very plainly meant that there were Curassows and Trumpeters near me and that he would leave me to stalk and study them, while he went to secure a toothsome paca for dinner.

I cached my gun, in fact everything but my glasses, and began creeping as silently as possible down the course of 
the little valley. Francis, quietly amused, smiled as I tied my handkerchief tenderfoot fashion to my gun; expressing quite as much as a multitude of chaffing remarks could have done.
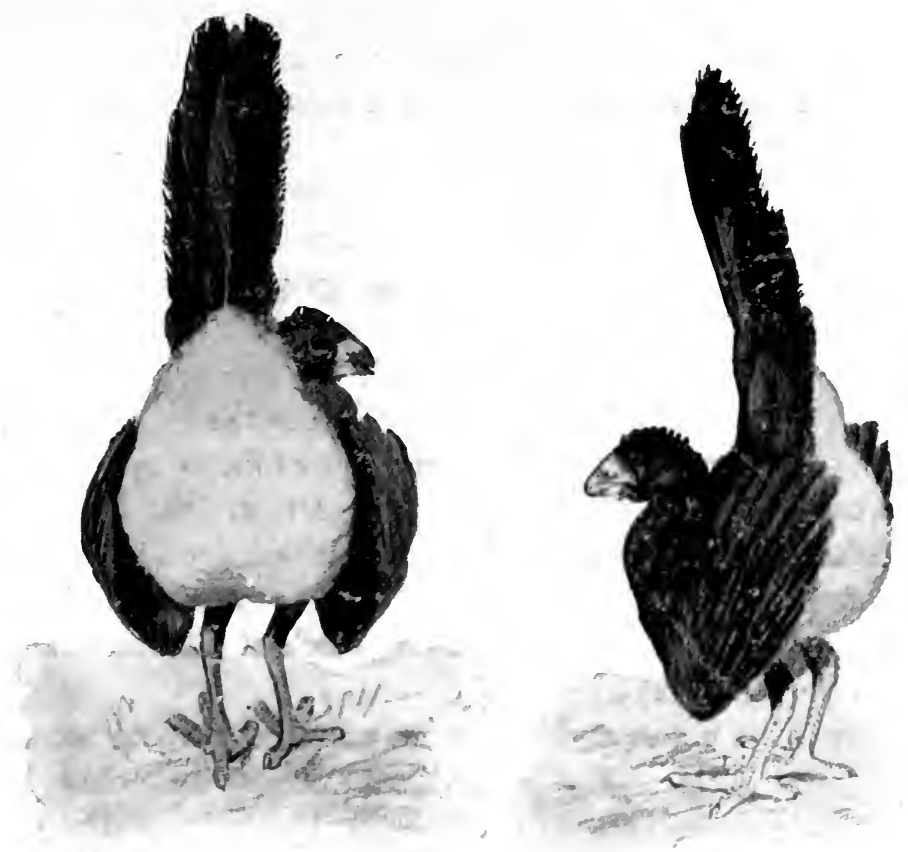

First Phase of Curassow Strutting, a Slow Walk with Raised Tall. FIG. 135. Rear view. Fig. 136. Side view.

Foot by foot I pushed through or crawied under fallen trees and tangled vines and tree-ferns, close to the hot steaming forest mould, with the low distant booming becoming ever more distinct. The rentriloquial quality completely deceived me, and long after I thought to see the performer I went on and on for many yards. At last I turned to the south to gain the shelter of a great fallen tree which had 
begun to merge its rotten wood with the débris of the jungle floor. I shall never forget pushing aside a mass of beautiful green orchids and slipping into a great hollow made by a second tree which had fallen athwart the first. Just beyond were three Crested Curassows, ${ }^{4}$ a male and two females, the latter busy scratching among the dead leaves, while the male was devoting himself to a most remarkable performance.*

The splendid bird walks slowly up and down the clear space which he has chosen. The entire body is tilted far forward, the breast low and the wings pointing down in front, the wrist portion, or shoulder as it is often wrongly called, dropping almost to the ground. The wing tips lie flat upon the back, and the tail is raised, while the head is held high, almost touching the back and tips of the wings. The tail, carrying out the line of the back, points straight upward, and the white belly, flanks and especially the under tail-coverts are fluffed out to their greatest extent, forming a most conspicuous white mark against the black of the remaining plumage. (Fig. I35.)

Now from a tree near by comes a low penetrating moan or muffled boom. The bird in front of me at once changes his whole demeanor. He continues his walking but it assumes more of a mincing character, uttering all the while several notes, like low but shrill squeaks or gurgles, mingled with snorts and snores, all rather subdued. These

* There were several intervening branches, and two or three links in the performance were not clear until I returned north.

Col. Anthony R. Kuser has most kindly put his splendid aviaries at Bernardsville, New Jersey, at my disposal for scientific investigation, and here, for a month or more after our return, a male Curassow would go through this whole performance for the benefit of anyone who would watch him. After the various "stunts" had been performed, he would fly at the feet of the observer and, wrapping his wings about one's shoes, would peck savagely at the shoestrings. From this and other indications I decided that the performance is more in the nature of a challenge than a courtship display. 
seem rather hit or miss, there being no regular sequence or similarity of the utterances. Several times these sounds are interrupted by the bird stopping, appearing to pick up something, and then to dash its head violently against its back, producing a low champing sound which scems to excite the females, who otherwise are wholly indifferent. Try as I may I can make nothing of this action, and later it

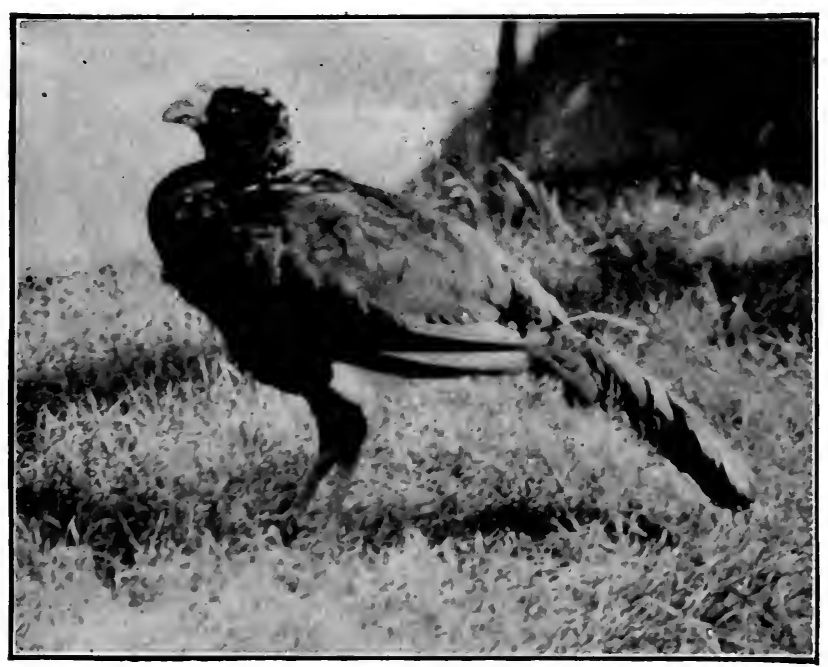

Second Phase of Curassow Strutting.

Fig. r37. Standing with Pebble in Beak, striking the Head against the Back.

is an indiscreet, impatient movement of mine at such a juncture that ultimately frightens the birds and ends my observations. I was delighted therefore when observing the Curassow in the north to see the bird repeatedly pick up pebbles or a feather or twig and champ them in its bill just as the wild bird did. The clicking sound resulted only when a hard object was picked up, but the dull thuds were made by the skull of the bird striking violently against its dorsal 
vertebræ, the object it had picked up being held meanwhile in its bill. (Fig. I37.)

The wild Curassow soon drops whatever it has picked up and claps its wings together seven or eight times over its back, making a loud slapping sound. It then turns its back on its rival in the tree, plucks nervously at the wings, right and left, for a full minute or longer, and then reaches convulsively forward several times, with its head and neck, the bill being wide open, gulping in a great quantity of air. Its abdominal air-sacs swell, its wings are lowered and rounded out until the bird appears half as large again as usual. Thus it stands, half squatting with lowered head and tail, and within a period of five to ten seconds utters usually four notes of the deepest and most penetrating character. Now that I am within a few yards, they sound no louder than when several hundred yards away. The exertion put forth shows this vocal effort to be a strenuous one, and at the second performance the tones are rather low and confused. But the normal utterance, this climax of the whole challenge, is as follows:

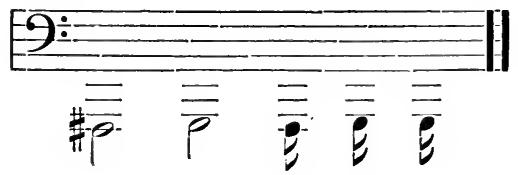

This may be imitated by anyone with a deep bass voice by humming the syllables $U m$, um, um-um-um, to the notes as I have written them.

During this period the actor, as observed in the captive specimen, seems almost in a trance, standing with half closed eyes, oblivious even of a hand resting on the feathers of his back, and the recovery is slow, the bird seeming dazed for a short time.

As I lay concealed in the Guiana forest, the whole performance was repeated five times in twelve minutes, the 
Curassow appearing most excited after it had finished the challenge call. It frequently ran to the hens and walked about them, while the captive bird which I observed paid no attention to the hens, but showed off to human visitors and devoted himself to attacks upon their footwear.

No part of the performance was ever omitted. Invariably he turned his back on his rival or observer, invariably he first walked and snorted, then champed and clapped his

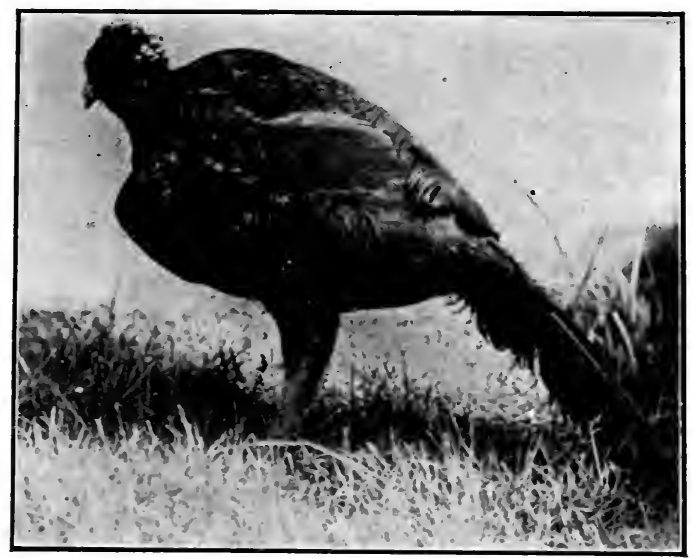

Third Phase of Curassow Strutting.

FIG. ${ }^{3} 8$. Back turned, Wings lowered, Air-sacs inflated, uttering the penetrating Challenge Call.

wings, and finally sent out his challenge. As I have said, one may closely imitate this call, and the birds, as I learned on another occasion, will respond to repeated calls and come within shooting distance.

Taken altogether, the performance was a most delightful insight into the lives of these little known birds, and the complexity and intricate succession of the various maneurres was remarkable. As I have said, at one of the pebble champing periods I become so interested that I made a noise and the 
three birds rose at once and whirred away, while I retraced my steps. I returned as carefully as possible and encountered a troup of small monkeys which passed close overhead, sending down a rain of dead twigs. They apparently have the habit of breaking off twigs when they are progressing leisurely, as I observed this same unnecessary amount of falling twigs and branches on several other occasions. When thus engaged they make a great racket, uttering now and then plaintive, inarticulate sounds. When once they spy you beneath them a sudden chorus arises like the greatly exaggerated swearing of a red squirrel, and off they go rapidly, silently, with not a sound of breaking branches.

Finding a good point of vantage not far from my gun and bag, I waited for Francis, squatting - coolie fashion - out of respect to the bête rouge which were numerous and enthusiastic at this point! I sat there five minutes and not a moment was devoid of interest. I accidentally snapped a stick, and like an electric spark came a sharp zizz! at my very elbow. I jumped as if an electric shock had indeed accompanied it, and then broke another stick. Again the $z i z z$ ! snapped in answer, and close to my resting place I discovered a "Six o'clock Bee," as the natives call these giant cicadas (Cicada grossa). Like the Curassow, he was on the qui vive for rivals and ready with his challenge. As often as I snapped a stick, he whirred out an answer.

A pair of Blue-and-yellow Macaws ${ }^{61}$ screamed. When heard in the distance, all harshness is eliminated from their voices, and an extremely human quality of sound is acquired, as of one person calling in a high tone to another. A Green Cassique ${ }^{150}$ whirred overhead, tolled his cow-bell and strutted with slow elaborateness. Suddenly a pair of Trumpeters ${ }^{25}$ came into view, but saw me at the same instant, and with loud chacks! fled in all haste. Going on to our meeting place I almost stepped on Francis, who had 
been quietly watching me and resting after having returned with a load of game.

We struck the broken twig trail on which we secured the old howling monkey yesterday, and a few hundred yards from the spot we heard the young male roaring. He had improved wonderfully on his falsetto yell of yesterday, and except for a general weakness of volume and an occasional break and tendency to get out of breath, he made a good showing in the vocal gymnastics of his race. Twice after this we ran across the youngster and each time he was howling, but entirely alone. He had not yet secured a mate and his mother and aunt had apparently deserted him upon his assumption of leadership!

A half-hour's walk close to the clearing this afternoon revealed birds everywhere in flocks, passing leisurely. Small Woodpeckers were tapping, Woodhewers picking and prying, Antbirds peering under leaves and twigs, and the Flycatchers audibly snapping up insects in mid-air. 'The jungle was filled with dee-dee-dees, chirps, chacks, low mewings and whistles, while a rain of falling leaves, ripe berries, dead twigs and bits of bark marked the progress of the flocks. I shot a number of birds which were new to me, one of which I could not find until after ten minutes' search. When I discovered it, a line of ants five yards long had formed and it was covered with their bodies. So swiftly do tropical scavangers work!

I secured a Wedge-billed Pygmy Woodhewer ${ }^{96}$ with its single young one, which must have left the nest that very day. Curiously enough, the latter perched as often as it clung to the tree-trunks, and keeping this in mind I found that the measurements of the two birds were very interesting. There was almost no difference between the length of the wings and beaks of parent and young, but the tail of the young bird was only $\mathrm{I}_{16}^{7}$ inches in length as compared with 
$4 \frac{3}{4}$ inches in the adult. From this it appears that the climbing habit is not developed as early in the young Woodhewer as in Woodpeckers, in which it seems instinctive from the first.

Resting my camera for a moment against the buttress of a giant mora, a small brown bird flew out and I recognized another Wedge-billed Pygmy Woodhewer. ${ }^{96}$ It flew to a sapling and peered at me around the side. When I did not move away it came nearer and voiced its disapproval by a five-syllabled cry, chik-chik-chik-chik-chik! This made me suspicious and peering down a narrow crevice formed by a deep fold in the buttress I caught a glint of white, and finally made out three eggs, one of which seemed to be freshly broken. A safer or cosier plare could not be imagined. The crevice was eighteen inches deep and only two inches wide, with the opening of the fold almost closed by a small dangling bush rope. The nest itself was only two feet above the ground. The eggs were pure white and were laid on a thin net-work of rootlets and fibres resting on the black mould which had collected in the crevice. The following day it took me two hours of hard work, cutting and sawing, to reach the nest, and when Milady spooned up nest and eggs, four good-sized scorpions came with them, unpleasant guests I should think! There were two eggs in the nest and a broken one on the ground outside which the parent had removed the night before. 'This egg had probably been broken by the hurried flight of the parent on the preceding day. The eggs were a broad oval in shape, dull white and both measured 20 by I6 $\mathrm{mm}$.

Four other pairs of birds were nesting on this side of the clearing, Yellow-winged Honey Creepers, ${ }^{136}$ Jungle Wrens, ${ }^{\mathbf{1 2 5}}$ two pair of White-throated Robins, ${ }^{127}$ and a Guiana Quail or Douraquara. ${ }^{8}$ This last I found wholly by accident as I was watching a dragon-fly which had been injured by a small 
Flycatcher. Good-sized pieces were bitten out of the two hind wings and one of the others was doubled and broken. Yet the brave little insect was far from giving up and managed to fly slowly, albeit with a heavy slant to one side, the loose wing making a whizzing sound as it vibrated. I followed to see its ultimate fate. As it passed the end of a log a green lizard leaped from a leaf and seized the unfortunate insect in mid-air, thus typifying the anlaga of bird flight. The lizard fell full length upon a rounded pile of dead leaves and like a bomb there shot forth the whirring form of the Quail, which scaled off between the trees.

We found the Douraquara ${ }^{8}$ had rocketted from a tunnel about a foot in length, made of twigs and dead leaves, which led to a round hidden nest cavity containing four white eggs, one of which was broken. On the following day the Quail had removed all trace of broken egg and shell. So completely was the nest a part of the jungle floor that never except by accident would we have discovered it.

Day after day, on every tramp we took we were more and more impressed with the myriad examples of protective form and coloration. As I have said before, it is the immense variety rather than the exactness of detail which makes these resemblances so effective. I became so confused at times that repeatedly I would net a falling leaf or blossom or even fire at an imaginary bird, or on the other hand fail altogether to notice some rare bird or insect until I passed on some distance and happened to turn around. For instance, while walking along I saw something drift down and catch on a leaf. I thought to myself, this is surely an insect, although a most remarkable mimic. Then $I$ bent over and examined it closely, lifting the branch close to my eyes, and decided it was nothing but a dead leaf, half curled and shrivelled up. As I turned away I swooped at it idly with my net and lo! it took to flight and cost me several yards of hard pursuit 
before I secured it again. The irregularity of its wings, their leaf-brown color edged with a line of yellow, and the remarkable drifting flight in full sunshine, all helped to deceive me. It was a moth, Gonodonta pyrgo.

The Goldbirds, ${ }^{115}$ although the size of large Thrushes, are absolutely indistinguishable in their garb of dull brown in the shadowy mid-forest, neither descending to the ground nor ascending to the sun-lit tree-tops.

Almost as common as the piercing wheé! wheé! o! of the Goldbirds was a less loud but penetrating Chuckle-de-deé! which we heard almost as soon as we entered the shadows of the jungle. Three days of intermittent search passed before we discovered the author of this omnipresent sound. The note seemed to come from the tree-tops and we unconsciously held in mind a bird at least the size of the Goldbird. Imagine our surprise when, after searching the branches with aching necks, we finally detected the bird in the very act, finding it perched only about ten feet above our heads. It was a veritable mite of a bird, the Golden-crowned Manakin ${ }^{110}$ clad in forest green with a tiny crown spot of yellow. From head to tail he measured less than three inches, and of all the marvels which we have encountered in our travels the most remarkable was how such a tiny creature, considerably smaller than our Ruby-crowned Kinglet, could produce such a tremendous volume of sound. His Chucklede-deé! can easily be heard a hundred yards away through dense forest.

Once identified it was an easy matter to locate these little Manakins. They loved the deep, damper parts of the woods and were ridiculously tame, perching quietly and calling continuously when one walked around within arm's reach. We discovered the nest of one of these birds a short distance from the mine clearing in a sapling about seven feet from the ground, a very frail affair suspended in the fork of a branch. 
It was merely a thin cup of fine bush threads and rootlets, while two or three small leaves were fastened to the bottom with strands of cobweb. One could see through it anywhere. It was only $I_{\frac{3}{4}}$ inches across and $\frac{3}{4}$ of an inch deep inside the cup.

The bird was on the nest and refused to leave until we lifted her off and photographed her. Then she flew and chuckle-de-deed with all her little power!

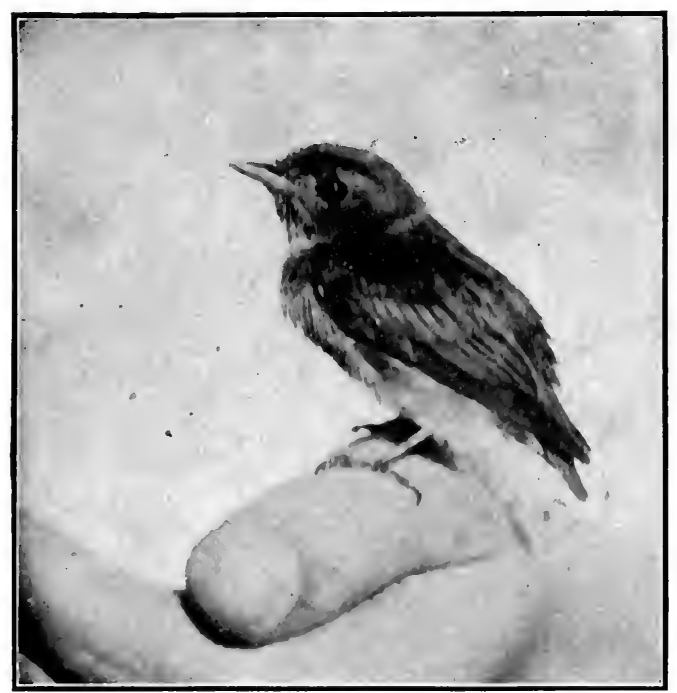

Fig. 139. Golden-Crowned Manakin lifted from Nest.

While insects were far from rare in the jungle itself, they were present in myriads in the little fallen-tree clearings. Blue Morphos flashed in and out of the thickets, while whitespotted, clicking ones, snapped back and forth. In the darker recesses the transparent Ghost Butterflies flew silently and almost invisibly, while Heliconias threaded the vines. Giant bees buzzed past now and then. One which I caught was an inch and a half long with tremendously 
thick and hairy hind legs, an orange collar across the front of the thorax and an equally broad band of yellow on the abdomen (Centis americana).

Among the most interesting birds which we found nesting were Dusky Parrots. ${ }^{66}$ About one hundred yards from the clearing we observed two red-breasted Parrots fly from a

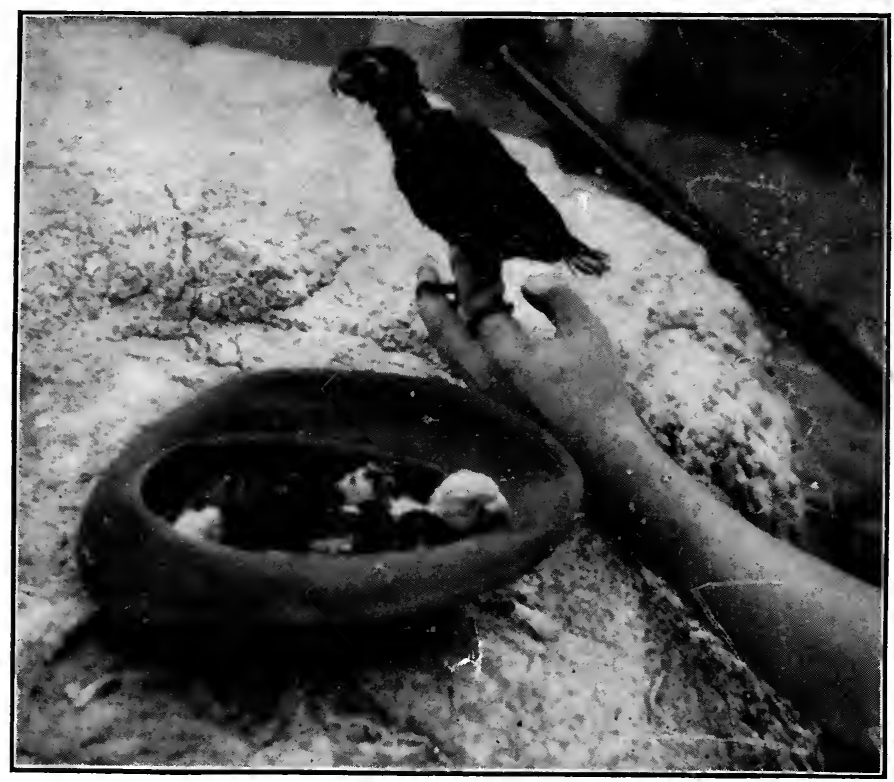

Fig. I40. Young Dusky Parrots.

hole about forty feet up in a tall dead kakeralli tree. We watched the tree, morning and afternoon for several days, often for an hour at a time, but neither saw nor heard anything of the birds. Fearing that we had been deceived in thinking they were nesting we had a black cut down the tree, but no sooner had the dust settled from the débris of rotten wood than a chorus of raucous cries arose, and four young Parrots, nearly fledged, were gathered into a hat. 
The quartet showed an interesting sequence of growth, there being several days' difference between each one. The youngest was clad only in quill-like blood feathers; number two had the scapulars, part of the crown, the breast and a half inch of the tail feathers out of the sheath. Number three was pretty well feathered except for face, throat, under wings and sides, while number four was to all intents and purposes a real Parrot! The way in which the old birds kept hidden was remarkable.

One day Milady and I started out with only the lay of the land and a compass for guide and walked straight toward that unknown region lying to the northwest. A whole chapter could be written of our observations on that single tramp, but I shall keep our notes for a future work on the natural history of this region and add to this already too lengthy account only a few paragraphs.

We saw many Lavender Jays ${ }^{161}$ restless and numerous, yet curious to know what manner of beings we were. Their alarm note Keeeow! accompanied us for a long distance. Later in the morning we spent some time watching a dense line of parasol ants. They were as gay as Fifth Avenue on Easter Sunday, being laden with the purple and white blossoms of some forest tree. The broad wavering banners interspersed with those insects which bore stamens and pistils lance-like, presented a most humanly comical appearance. The tiny creatures are so serious and in such a hurry and yet look so tipsy and political, that one never tires of watching them.

Black clouds and a high wind overtook us and we walked rapidly on, looking for some sort of shelter. We were lucky enough to discover a huge tree, hollow, even to the centre of the buttresses and this we made our headquarters during the storm. From each of four natural windows we watched the jungle life during the rain. A small patch of the black 


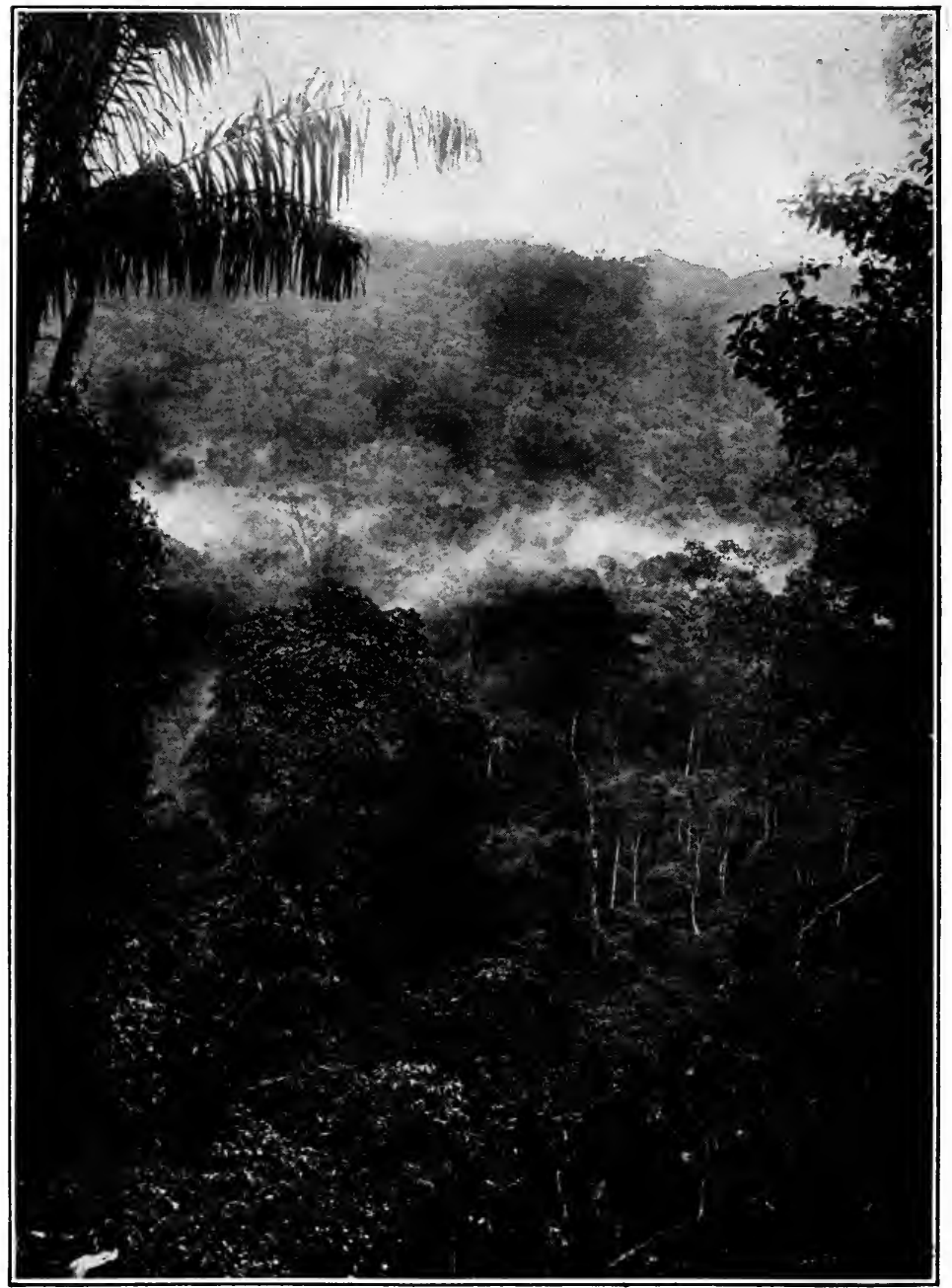

Fig. I4I. Early Morning in the Wilderness. 
caterpillars was near by on a light-barked tree, all reacting or not according to whether we ejaculated sst! or buzz! As before they were very conspicuous and made no attempt at concealment, although at a distance they resembled a black knot-hole on the trunk. But their rôle was evidently to

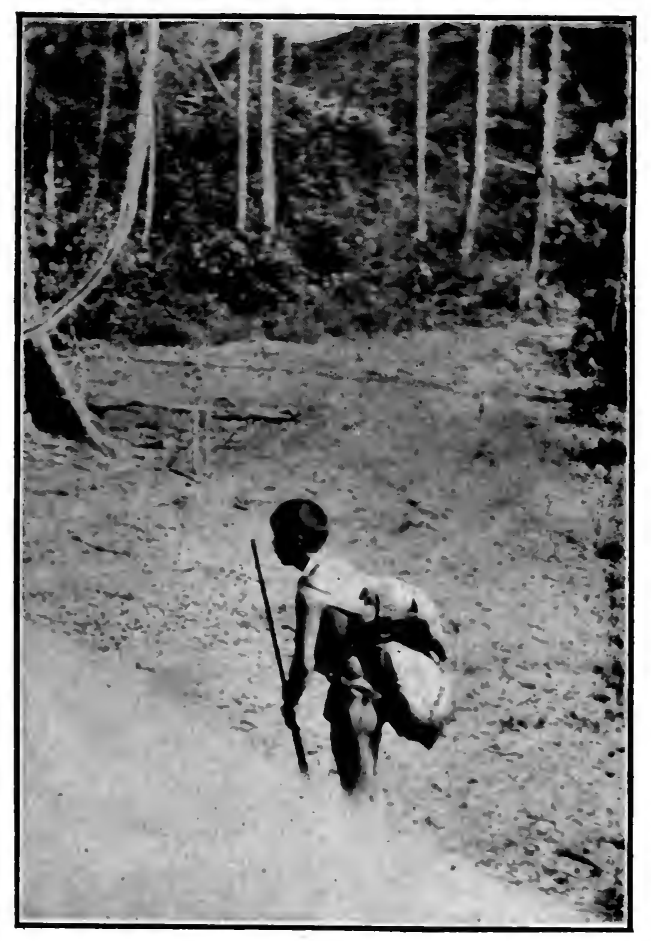

Fig. I42. Indian Hunter bringing in a Peccary.

depend on their threatening actions and their even more reliable stinging hairs.

On the very floor of our shelter a tragedy was enacted. A small wasp (Notogonia sp.) less than an inch in length with a splash of gilt on thorax and head, dashed upon a brown 
cricket (Gryllus argentinus) more than twice its size, and stung it. Then the wasp left its prey and ran off about eight inches to a round hole which it had excavated in the black wood mould. Back to the cricket again it came, turned it right side up, seized it by the head and began to drag it along. Although I can hardly credit the wasp with the conscious intention, yet its sting had certainly been delivered in exactly the right spot. The whole cricket was paralyzed except for the two front pair of legs. The motor nerves of these were unaffected and they kept up a convulsive pulling and pushing which aided the wasp greatly in its difficult task. Indeed the wasp did little but straddle its prey and steer, while the cricket pushed itself along.

Just before the latter disappeared still kicking into the hole, the wasp stung it again and laid a small curved white egg on one of the hind legs of the cricket. The hole was just the right bore to admit the body of the victim and was six inches deep.

As soon as the sun came out, huge metallic Buprestid beetles boomed about the trunk and the Woodhewers began their sweet scale-songs, and close over our heads a tiny Golden-crowned Manakin ${ }^{110}$ joined in with his Chuckle-de deé!, the effort almost lifting him from his perch.

$$
\text { * } * * \quad * \quad * \quad * \quad * \quad * \quad * \quad * \quad *
$$

In offering these notes on the jungle life about the Aremu clearing, I have purposely refrained from classifying them, as I wished the reader to realize how, in this region of superabundant life, events crowd in upon one - insect, bird, flower, animal-without apparent rhyme or reason. Yet they really pass in splendid sequence, the key to which lies in the ultimate relation of each to the other. Some day, if we do not delay until the destroying hand of man is laid over this whole region, we may hope partially to disentangle the web. Then, instead of a seeming tangle of unconnected events, all will be 
seen in their real perspective: The flower adapted to the insect; the insect hiding from this or that enemy; the bird showing off its beauties to its mate, or searching for its particular food. These things can never be learned in a museum or zoölogical park, or by naming a million more species of organisms. We must ourselves live among the creatures of the jungle, and watch them day after day, hoping for the clue as to the why - the everlasting why of form and color, action and life. 


\section{CHAPTER XI.}

\section{THE LIFE OF THE ABARY SAVANNAS.}

(By C. William Beebe).

$W^{E}$ had made two successful expeditions into the jungle or "bush" of Guiana, and now our third and last trip was to be in the open savanna region in the eastern portion of the Colony, near the coast. The first resident American to welcome us to British Guiana was Mr. Lindley Vinton who, with Mrs. Vinton, did all in their power to make our stay in Georgetown a pleasant one. Their house was made our home and certainly no strangers in a strange land were ever made more welcome than were we.

Mr. Vinton is a living refutation of the statement that continued residence in the tropics invariably results in loss of energy, for seldom, even in our own virile country; can one find a man more full of vitality. At the time of our visit he was interested in several large concessions, one of which was a rice growing proposition on the Abary River.

When he promised "Canje Pheasants," or Hoatzins ${ }^{11}$ in his back yard, and thousands of Ducks flying past every day, we smiled as we remembered the Hoatzins in the depths of the Venezuelan mangroves. But, exaggerated as we believed his enthusiastic reports to be, we were glad indeed to accept his invitation to spend a week at the bungalow on the rice plantation. We ultimately found that he had actually understated the conditions of bird life on the Abary!

On April I 2 th, Milady and I took the funny little compartment train for Abary Bridge, or, as our ticket read, Belladrum, which we reached at 9.30 after a two hours' slow ride. 
The land along the coast is all flat savanna, dotted for the first half of the journey with tumbled down coolie huts and tiny dyked fields of pale green young rice. Later for some distance these give place to large groves of cocoanuts. On the left, stretch the seawall dykes, relics of Dutch industry, perfected by the English.

Throughout the entire journey, hundreds, sometimes thousands of birds were in sight, often for several miles in succession; but as exactly similar scenes were later visible and at closer range on our up-river trip, I will not repeat myself.

The train was stopped for our benefit at the bridge across the so-called Abary River, which proved to be a little stream only about a hundred and twenty-five feet wide. Loading our luggage and ourselves into a fussy little launch we chugged up-river for three hours.

Along the right bank - the lecward - for most of the distance, grew an irregular fringe of bushes and low trees. Bcyond, almost to the horizon, stretched the vast savanna, covered with reeds, rushes and tall coarse grass, each a pure culture in its place of occurrence.

Scattered over this great expanse were myriads of birds of many species, the only other visible living creatures being a small herd of half-wild cattle here and there.

For the first few miles two species predominated - as they had almost all the way from Georgetown - the Little Yellowheaded ${ }^{154}$ and the Red-breasted Blackbirds. ${ }^{155}$ Few more beautiful sights can be imagined than a cloud of these birds rising ahead of the train or launch, and scattering far and wide over and through the reeds. The general color of both is a rich black, which itself contrasts strongly with the green of the savanna. But when we add to this the brilliant yellow head and neck of the former and the scarlet throats, breasts and wing edges of the latter, the color scheme is one 
352 OUR SEARCH FOR A WILDERNESS.

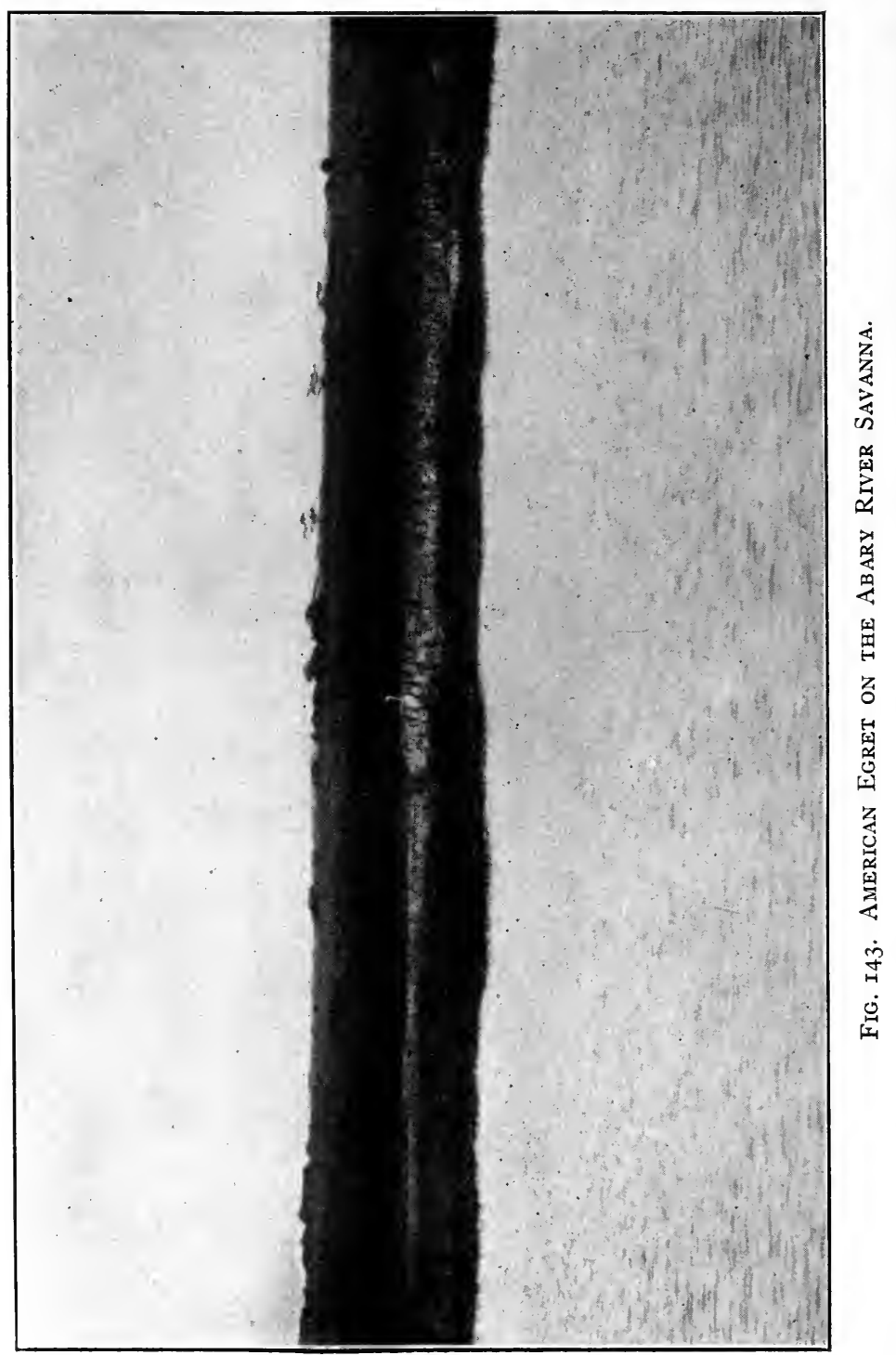


which is never forgotten. The two species would rise in distinct flocks, perhaps six or eight hundred of each, flow up and over the tall grass in two living waves of scarlet and gold, and then intermingle, the rain of red and yellow sparks being gradually quenched by the green expanse, as the birds settled among the shelter of the reeds. Of course these flocks were composed only of those individuals close to the track or the river bank. How many myriads were scattered over the savanna we shall never know. We must have flushed a great many thousand of these two species in the course of the day, and scattered among them were a few Guiana Meadow larks ${ }^{157}$ looking much like our northern birds.

Every few dozen yards over the savanna, a tall white figure stood motionless, silently watching us - American Egrets ${ }^{32}$ distributed for their day's fishing, hundreds dotting the marsh, each solitary, statuesque. Among them was a sprinkling of Wood Ibises ${ }^{28}$ and beautiful Cocoi Herons. ${ }^{31}$ These latter were much shyer than the others and all within a hundred yards of us would take to flight as we passed, leaving their more fearless comrade-fishers in full possession.

All these Herons soon became a common sight, and we swept mile after mile of savanna with our glasses, secing nothing but the white birds dotted everywhere. At last we were rewarded, and a giant white Stork came into sight, towering above the Herons, with black head and neck, and the sun reflected from the distended scarlet skin of the lower neck. The bill had the faintest of tilts upward and we knew we were looking for the first time at a living Jabiru, ${ }^{30}$ the biggest and perhaps the rarest wading bird of our continent. It stands fully five feet in height and the spread of the wings is about eight feet.

Soon another appeared a half mile farther on, and a third, and before our journey's end we had seen at least a dozen of these splendid birds. We have but one or two meagre 
descriptions of its nesting and I therefore have included among the illustrations a most interesting one taken by Dr. Bingham, showing a Jabiru on its nest together with its two half-grown young. These birds do not nest on the Guiana savanna but retire at the rainy season far into the interior.

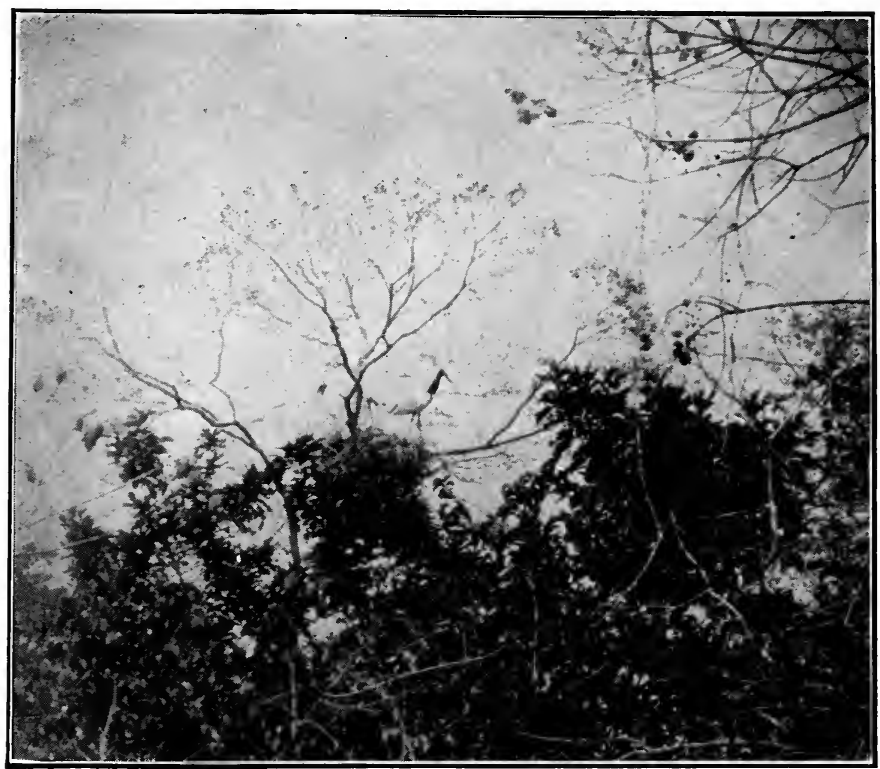

Fig. I44. Nest and Young of Jabiru. (Photo by Bingham.)

Spur-winged Jacanas ${ }^{23}$ in loud cackling pairs were everywhere, showing conspicuously against the green reeds - dark chocolate when at rest and flashing pale yellow in flight. Guiana Cormorants ${ }^{47}$ and Snakebirds ${ }^{48}$ rose or dived ahead of the launch, twenty of the former taking refuge in one small tree as we passed.

Hawks were abundant and one of the most numerous was the Cream-headed Hawk, ${ }^{54}$ which soared low over the sa- 
vanna or perched on the shrubs along the bank. Small birds showed no fear of it, often alighting in the same tree. From almost every bush along the river bank little Guiana Green Herons ${ }^{38}$ flew up from their nests, built close to the surface of the water. These herons "froze" like Bitterns when they alighted, standing motionless with the bills at an angle of $45^{\circ}$. Along the railroad they were semi-domesticated, flying fearlessly in and out of the coolie yards, and snatching bits of food from the very door-ways of the huts.

About eleven o'clock, on rounding a sharp turn in the river, we saw what appeared to be great expanses of burnt marsh. On and on we went and at last we realized that we were looking at vast phalanxes of Ducks. Suddenly, without warning, a living sheet of birds rolled up from the ground, hung a moment, then gained momentum and wheeled upward. Thousands began to rise at once, until for fifty or a hundred yards on each side of the river, there was an almost unbroken wave of birds, flying upward and backward. From this mass of life, giving forth a medley of shrill whistles which soon deepened into a perfect roar of wings, single lines of ducks detached themselves, shooting out in all directions, passing up and across the river, or right and left out over the savanna. They were Gray-necked Tree-ducks ${ }^{45}$ with a plentiful scattering of the Rufous ${ }^{44}$ and a very few White-faced. ${ }^{46}$ The great curving wave never ceased for a moment as we approached, but widened and thickened and wheeled over and behind us until the sky was pitted with their bodies. I took picture after picture with my Graflex, the ground glass reflecting a myriad of swiftly moving forms.

Then the Ducks which had first arisen, having flown in a great circle over the savanna, returned, and intersecting the newly arisen host, formed a criscrossing maze which carpeted the heavens with a close warp and woof of living birds. Even in Mexico, where we had watched the vast flocks of Ducks 
356 OUR SEARCH FOR A WILDERNESS.

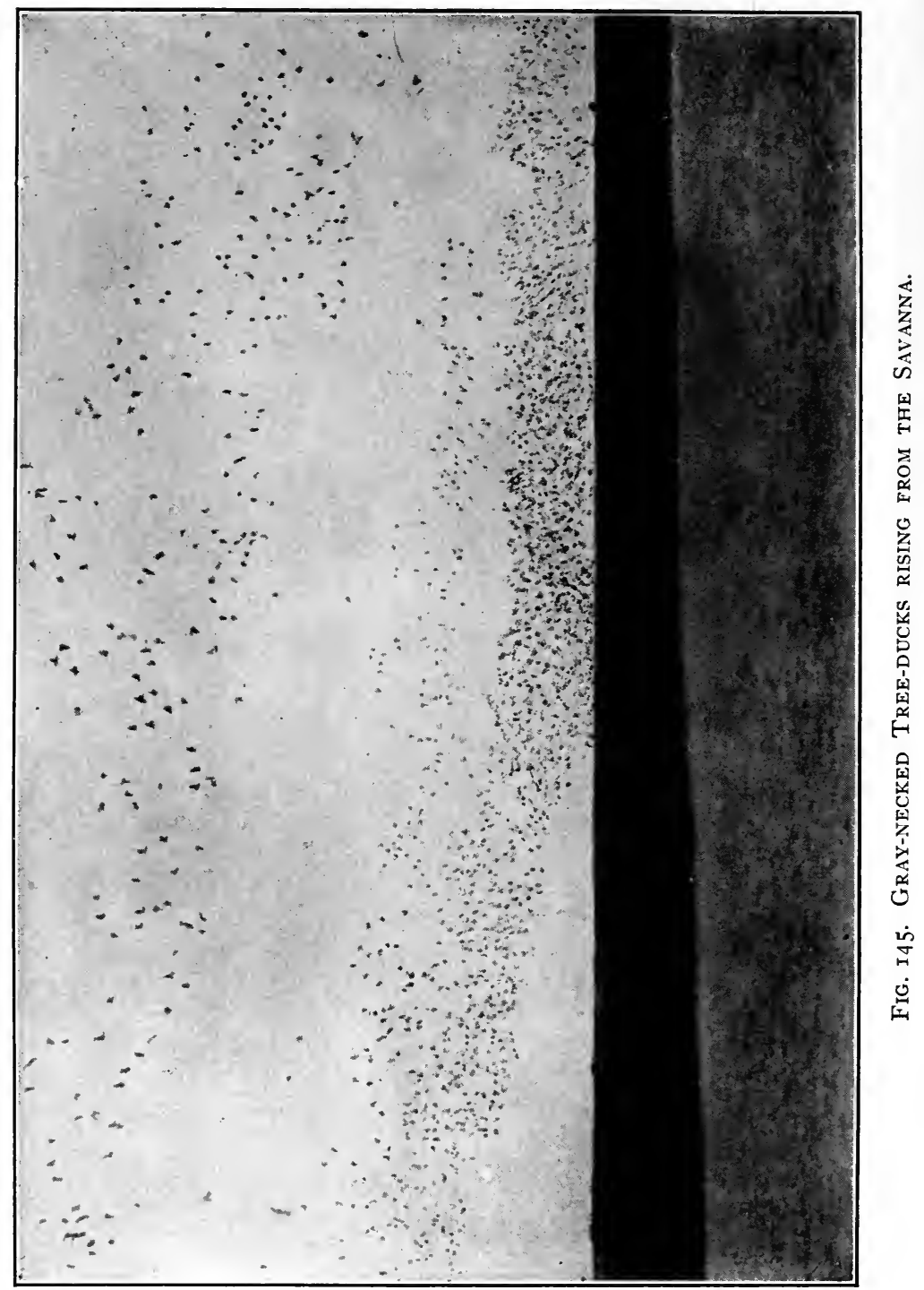


and Geese on Lake Chapala, there was nothing to equal this. The Ducks looked dark against the sunlight but whenever they veered, the white wing-bands flashed like mirrors.

We counted the birds in one short line near us and found there were four hundred and twenty individuals. No one could count those in even one of the flocks but there must have been at least twenty thousand in the first phalanx we encountered.

As we passed on, many hundreds settled again on their feeding grounds, where nothing was visible of them save a myriad heads and necks, stretched high and watching us curiously. As many others however flew far away, the dense matted flocks fraying out into long single or double lines, some of which must have been a half mile in length.

In this region these birds are Tree-ducks only in name, as later in the year hundreds of eggs will be found scattered over the savanna, and sooner or later the flocks will dissolve into pairs, each to nest on some low hummock in the marsh.

These Ducks never settle on the open water of the river on account of the many dangers swimming beneath, of which more anon. They sleep and feed and nest among the thick growth of reeds and grass of the savanna itself.

After passing the second main body of Tree-ducks we now and then heard a louder whistle of wings, and a family flock of four or five great black Muscovy Ducks ${ }^{43}$ would rush past; the leader, the drake, being almost twice the size of the members of his harum.

Small birds were not much in evidence from the launch, although Anis ${ }^{80}$ were abundant, fluttering awkwardly among the bushes, and the big Kiskadees ${ }^{101}$ were nesting about every hundred yards. This was the first time in the Colony that we had seen these latter birds nesting away from human habitations, so this open savanna region would appear to be their 
natural home, while the other yellow Tyrants frequent wooded river banks.

At one o'clock we came in sight of a barn-like shelter in which was housed a huge steam traction plough, and radiating out across the savanna were the lines of dykes which marked the great fields intended for rice planting.

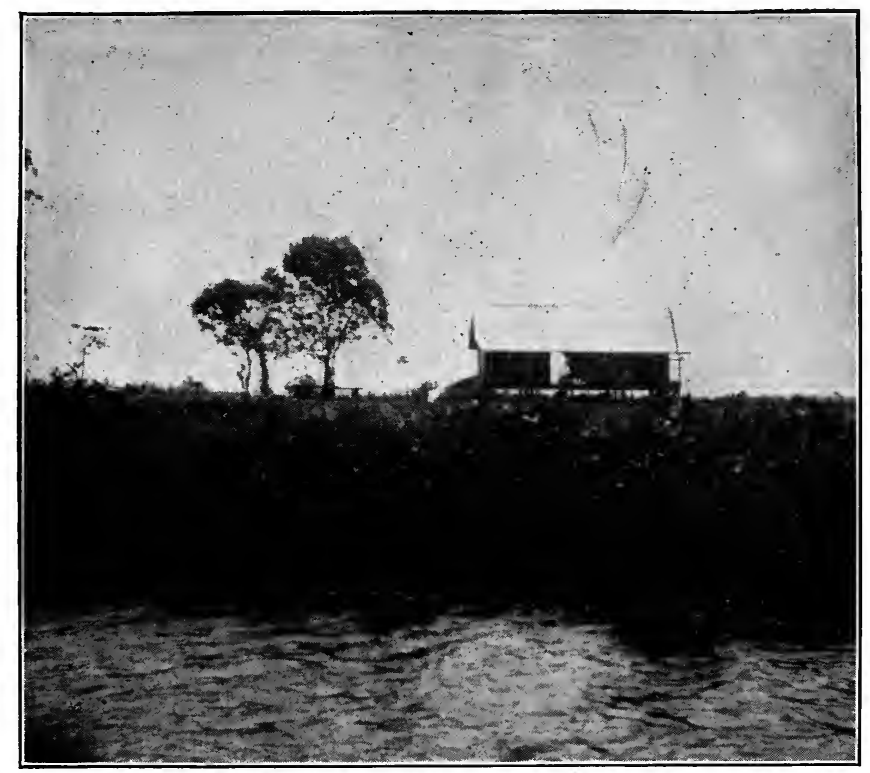

Fig. I46. Our Bungalow on Abary Island.

A few minutes more of steaming brought us to a landing place on a small island, with the bungalow in the centre. This islet and in fact this whole region has an interesting history. All this savanna was once a densely wooded jungle of mora trees, eta palms and other growth. In I837 a drought occurred of such extent that all the vegetation - trees, palms and underbrush - became dry as chips. The inevitable followed and a fire started in some way which swept this whole 
region, reaching in places even to the Demerara. Then floods came, broke through the loosened barrier of tangled roots, and infiltrated through the soil. Grass and reeds took the place of the great moras, and now, almost to the horizon, stretches the flat, open expanse of marsh. Indeed it is only to the west that trees are visible, where two miles away "eta bush" begins. In the tops of these palms the black Muscovy Ducks make their homes, feeding out on the marsh and bringing down their young - so it is reported - in their beaks.

Sixty years ago or thereabouts, many runaway slaves fled into the interior, most of them hiding in the recesses of the "bush" or high woods. These lived either with the Indians, in many cases intermarrying with them, or founded settlements by themselves. Some of these unfortunate blacks, however, made their way up the Abary and when they had come thus far - eighteen miles - finding no habitable land they set to work to make an island.

In the midst of this then (as practically now) unexplored region, these desperate men toiled at the black muck of the river edge, scooped it up and packed it on the foundation of reeds until a more or less dry island of about five acres had been formed. Here to-day we found a low mound of rich black mould, with nine good-sized isolated trees, several cocoanut palms and a few bananas. Corn planted here grows with wonderful rapidity.

The long occupancy and numerous inhabitants of the islet is attested by the thousands of pieces of pottery with which the ground is covered. On some I found a rude attempt at decoration, and the shape of the rims and handles were much like the primitive African art of to-day. There was probably a low hummock or mound as the nucleus for the island, and four or five feet beneath the surface several Indian stone axes have been unearthed - telling of still earlier human habitation - perhaps in the days of the jungle. 
Here we had planned to spend a week, but were prevented by an accident from remaining more than three days, but even in the short space of thirty-six hours of daylight we learned much of the life on and about this islet.

Our two other trips had been to tiny islands of cleared ground in the midst of a sea of the densest jungle; here we were marooned in the shade of a little isolated group of trees on a diminutive hillock of earth, bounded in all directions by an impenetrable marsh. If one so much as took a single step from the island, it was into three feet or more of water and tangled reeds, too dense to push a boat through. During the rainy season boats can be poled through, and at the dry season firmer footing is possible, but our visit was at a time betwixt and between. I have made a small rough plan of our domain on the Abary, Fig. I 47 .

The river was at this point only about seventy-five feet in width, flowing almost due south. As we ascended it, a narrow inlet became visible in the right bank, which led into a good-sized lagoon about as wide as the river, which had probably been formed by the excavation of the marsh. This lagoon bounded the north and part of the east sides of the island. The prevailing wind was from the east and this probably accounted for the line of small trees and bushes being almost altogether on the western bank.

We were welcomed at the bungalow by Mr. Harry, the young American engineer in charge, who, without the ornate phrases of Spanish hospitality, but in the simple American manner, put the bungalow and everything at the plantation at our disposal.

Nothing more different from what we encountered in the bush can be imagined. There, no sunlight save what sifts down through the tall trees; here, a blaze of light from horizon to horizon: there, hosts of living creatures, but as a rule single individuals of a species or in pairs; here, unnum- 


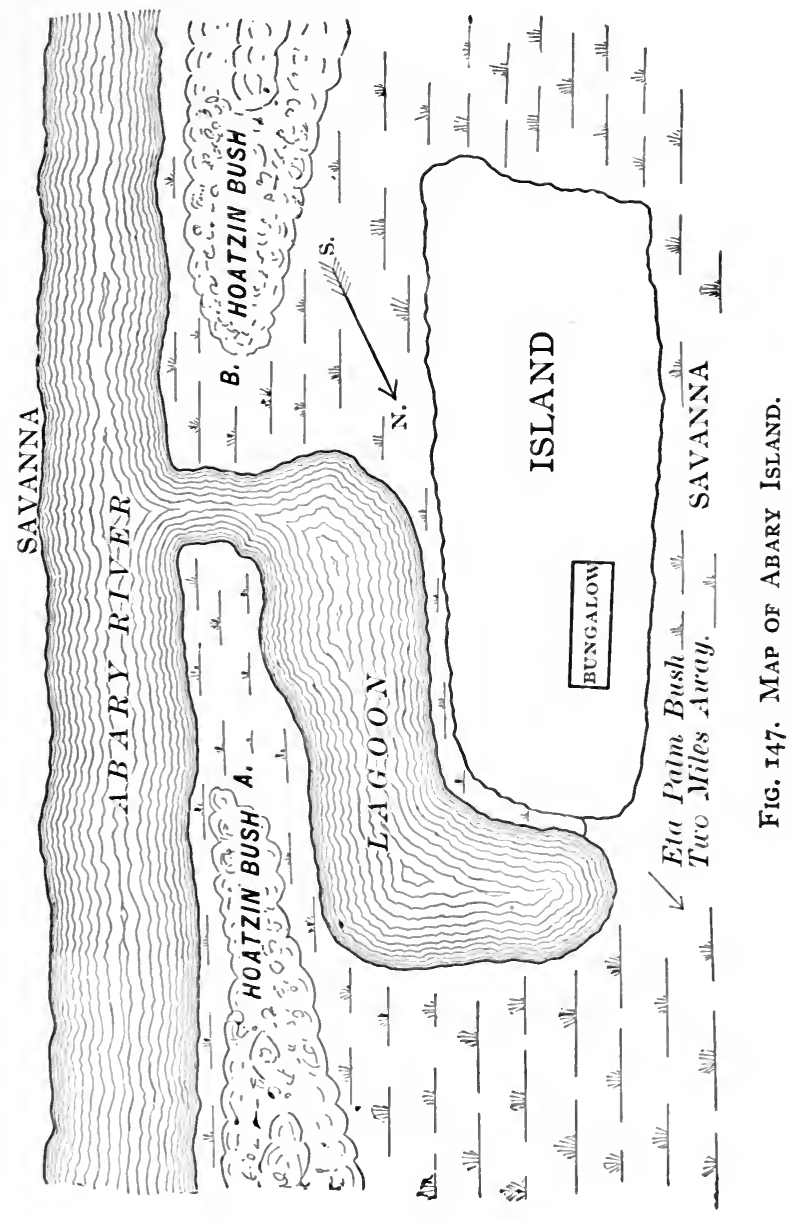


bered hosts in flocks of many thousands of the same species. It was a wonderland guarded by stern guardians; teeming with life on land, in the air and in the water. Not a moment of the day, or for that matter, of the night was free from sight or sound of some of these interesting creatures.

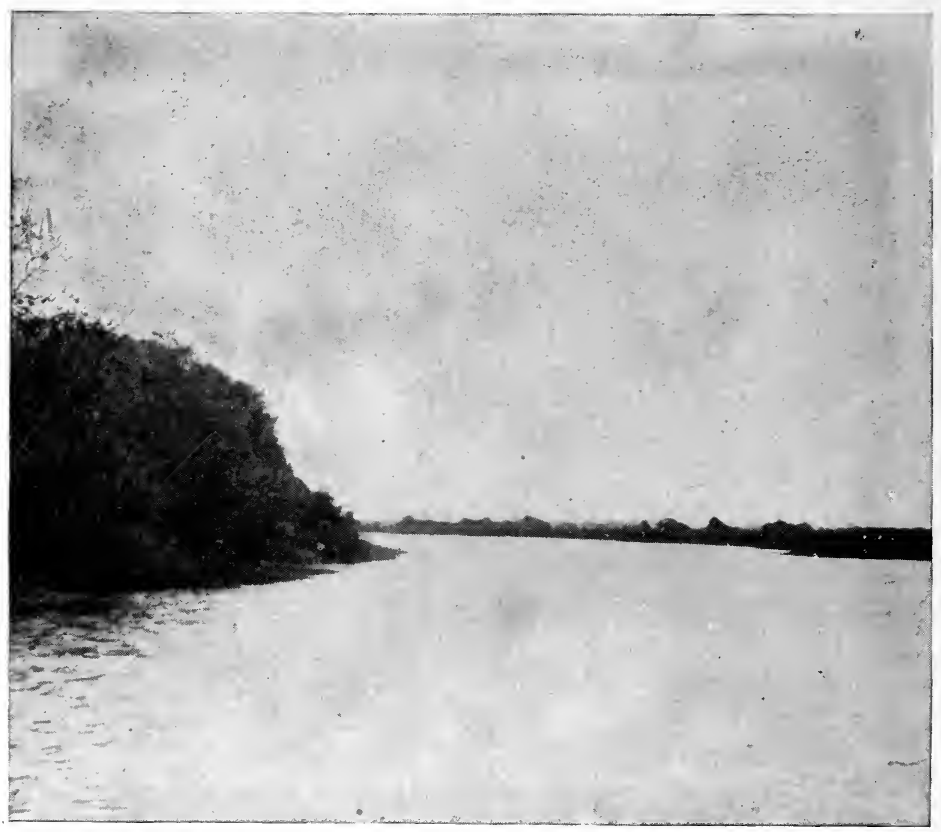

Fig. i48. Abary River, Showing High Growth on West Bank.

First as to the guardians. The sun we found to be a most terrible menace on the quiet open waters, and an exposure of an hour would have resulted in most painful blisters, and these in the tropics are of more serious moment than in the north. With broad-brimmed hats, however, there was no danger.

The day, even out on the marsh itself, was comparatively free from insects, but at 5.30 a few mosquitoes appear. By 


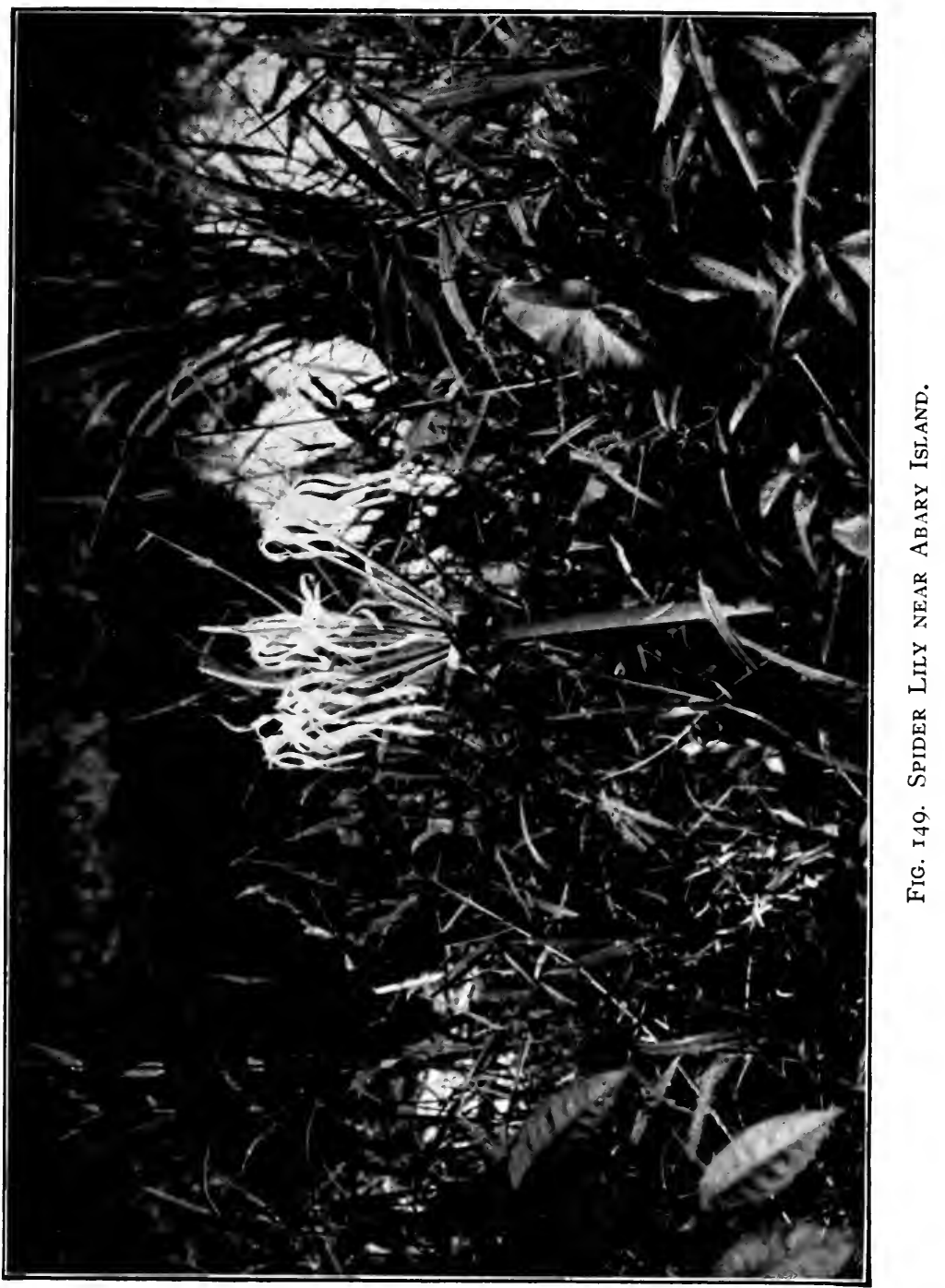


6 o'clock one would call them numerous, and between 6.30 and 7.30 they are legion and ferocious. One cannot sit still unprotected for a moment at a time. After 7.30 they all disappear, especially when there is a light wind, but at nine o'clock they are present in full numbers again. We slept the first night, or rather lay down, on cots with nets. The mosquitoes, or most of them, could apparently easily make their way through the mesh, but when swollen with blood failed to escape again. We slept but little, kept awake by the biting and humming of the wretches.

From daybreak when we arose until about nine o'clock sand flies held high revel, biting severely, after which all the insect pests vanished and one could decide to postpone suicide until the coming night! After this however we used close cloth nets, which defeated the efforts of the mosquitoes.

We found so much to interest us on and in the immediate vicinity of the islet that we made no extended trips either up or down the river. In the three days we lived there we observed the following fifty species of birds, nineteen of which (marked with asterisks) were nesting on the islet or within a few yards of it:

Red-underwing Dove (Leptoptila rufaxilla).

* Hoatzin (Opisthocomus hoazin).

* Wood Rail (Aramides cayana).

Purple Gallinule (Ionornis martinica).

Great-billed Tern (Phä̈thusa magnirostris).

Eye-browed Tern (Sterna superciliaris).

* Jacana (Jacana jacana).

Wood Ibis (Tantalus loculator).

Jabiru (Mycteria americana).

Cocoi Heron (Ardea cocoi).

American Egret (Herodias egretta).

* Guiana Green Heron (Butorides striata)

Horned Screamer (Palamedea cornuta).

Muscovy Duck (Cairina moschata). 
Rufous Tree-duck (Dendrocygna fulva).

Gray-necked Tree-duck (Dendrocygna discolor).

Guiana Cormorant (Phalacrocorax vigua).

Snakebird (Plotus anhinga).

Black Vulture (Catharista urubu).

Yellow-headed Vulture (Cathartes urubitinga).

Caracara (Polyborus cheriway).

South American Blue Hawk (Geranospizias caerulescens).

* South American Black Hawk (Urubitinga urubitinga).

* Rufous Kingfisher (Cryle torquata).

Parauque (N.yctidromus albicollis).

Goatsucker (sp?).

Green Hummingbird (sp?).

Little Rufous Cuckoo (Piaya rutila).

Smooth-billed Ani (Crotophaga ani).

* Cinnamon Spine-tail (Synallaxis cinnamomea).

* Pied Ground Flycatcher (Fluvicola pica).

* White-headed Flycatcher (Arundicola leucocephala).

* Cinereus Tody-flycatcher (Todirostrum cinereum).

* Guiana Kiskadee Tyrant (Pitangus sulphuratus).

* Lesser Kiskadee 'Tyrant (Pitangus lictor).

* Large-billed Kiskadee Tyrant (Megarhynchus pitangua).

* White-throated Kingbird (Tyrannus melancholicus).

Tree Swallow (Tachycineta bicolor).

Variegated Swallow (Tachycineta albiventris).

Barn Swallow (Hirundo erythrogaster).

* Gray-breasted Martin (Progne chalybea).

Red-breasted Swallow (Stelgidopteryx ruficollis).

* Guiana House Wren (Troglodytes musculus clarus).

* Black-capped Mocking-thrush (Donacobius atricapillus).

* Pygmy Seedeater (Sporophila minuta).

Little Yellow-headed Blackbird (Agelaius icterocephalus).

Red-breasted Blackbird (Leistes militaris).

Meadow Lark (Sturnella magna meridionalis).

* Yellow Oriole (Icterus xanthornus).

Little Boat-tailed (Guiana) Grackle (Quiscalus lugubris).

The most interesting of all were the Hoatzins, ${ }^{11}$ whose raucous squawks brought vividly to our minds the mangrove swamps of Venezuela where we had studied them last year. 
As I have said the east bank of the river is for the most part clear of growth, save for the reeds and grasses of the savanna. Along the western bank is a dense shrubby or bushy line of vegetation; occasionally rising to a height of twenty or thirty feet or again appearing only two or three yards above the reeds beyond. The brush grows altogether

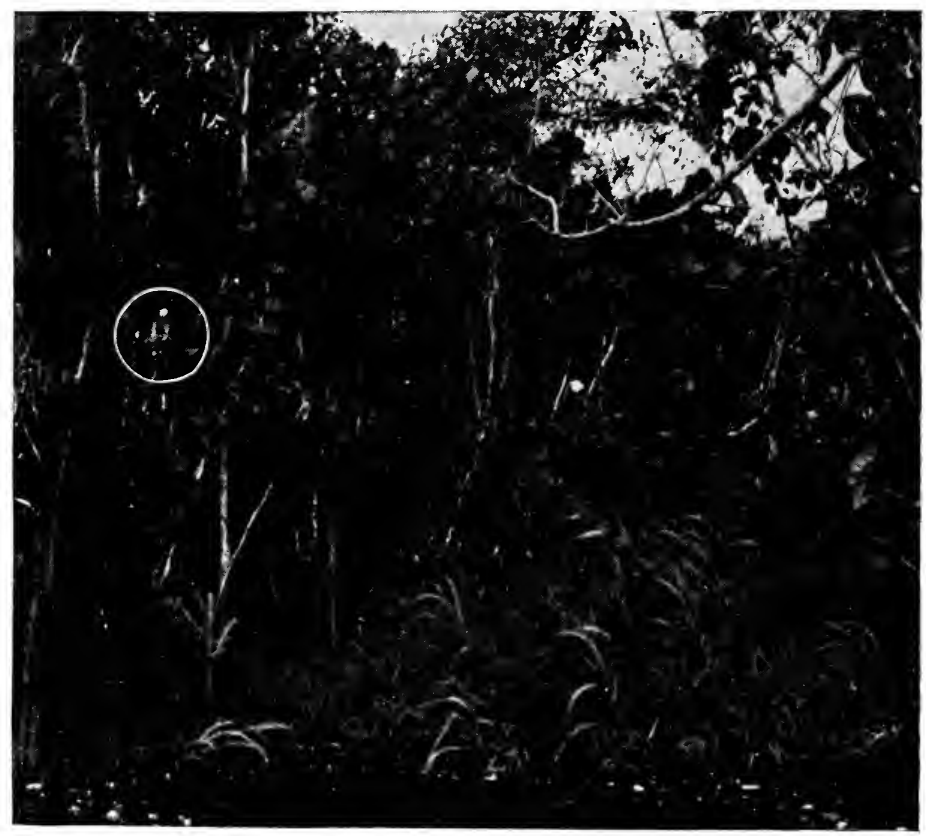

Fig. I50. NeST OF A HOATZIN IN THE MUCKA-MUCKA ON WHICH THESE BIRDS FEED.

in the water and consists chiefly of a species of tall Arum, or mucka-mucka, as the natives call it, frequently bound together by a tangle of delicate vines. Here and there is a low, light-barked tree-like growth. This narrow ribbon of aquatic growth was the home of the Hoatzins, and from one year's end to another they may be found along the same 
reaches of the river. In general, their habits did not differ from those of the birds which we observed in Venezuela. Throughout the heat of midday no sight or sound revealed the presence of the birds, but as the afternoon wore on a single raucous squawk would be heard in the distance, and we knew the Hoatzins were astir.

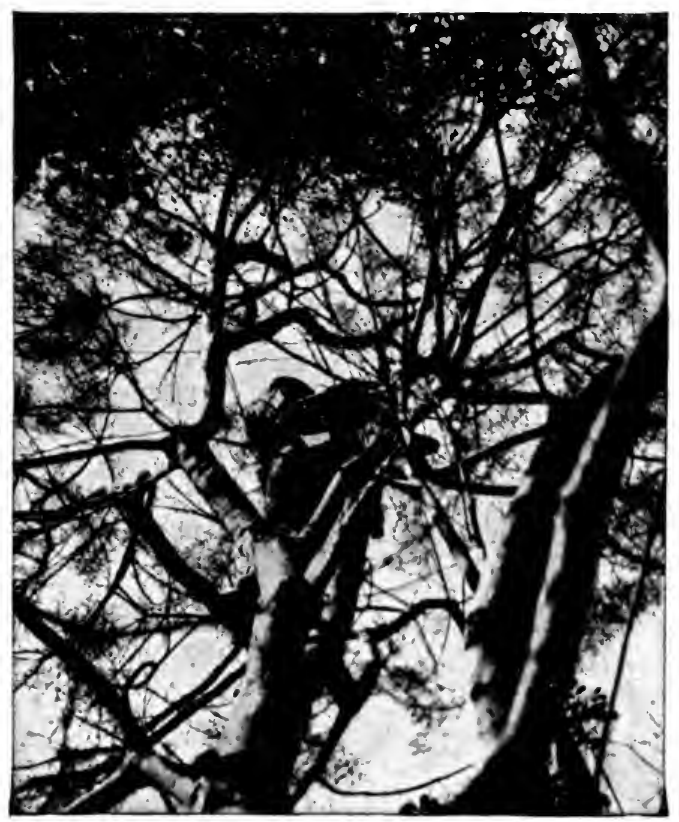

Fig. I5I. The Author Photographing Hoatzins.

Directly in front, between the bungalow and the river, as may be seen from my diagram (Fig. I47), the brush had been cut away on either hand for a distance of about sixty yards. Every evening from 4.30 to 5.30 P.M., the Hoatzins gathered on the extreme northern end of this wide break in their line of thickets, until sometimes twenty-five or thirty birds were in sight at once. Some would fly down to the low branches 
and begin to tear off pieces of the young tender shoots of the mucka-mucka. With much noise and flapping of wings, several made their way to a single bare branch which projected out over the cleared marsh. The first bird would. make many false starts, crouching and then losing heart, but the next on the branch, getting impatient, at last nudged him a bit, and at last he launched out into the air. With rather slow wing beats, but working apparently with all his power, he spanned the wide extent of cleared brush, then the ten feet of water, then fifteen yards more of stumps, and with a final effort he clutched a branch - and his goal was reached! After several minutes of breathlessness he continued on his way out of sight into the depth of the brush. The second Hoatzin would then essay the feat, but fail ignominiously and fall midway, coming down all of a heap among the stumps. Here a rest was taken, and for five or ten minutes the bird would feed quietly. Then a second flight carried it back to the starting point or to the end of the open space.

Sometimes when the birds alighted and clutched a twig, they would be so exhausted that they toppled over and hung upside down for a moment.

Watching the Hoatzins carefully with stereos for several evenings in succession we came to know and distinguish individual birds. Two, one of which had a broken feather in the right wing, and the other a two-inch short central tail feather, were excellent flyers and, taking their leaping start from the high branch, never failed to make their goal, going the whole distance and alighting easily. All of the others had to rest and one which was moulting a feather in each wing could achieve only about ten yards. This one fell one evening into the water at the second relay flight, and half flopped, half swam ashore.

One evening a Hoatzin flew toward us and alighted near some hens on the ground, but took wing almost instantly 
back to his brush-wood. A day or two before we came one of the birds had used a beam of the porch as a perch.

This general movement occurred at both sunrise and sunset and was always as thorough and noisy as we found it the first evening of our stay. For months, we were told, it had been kept up as regularly as clockwork.

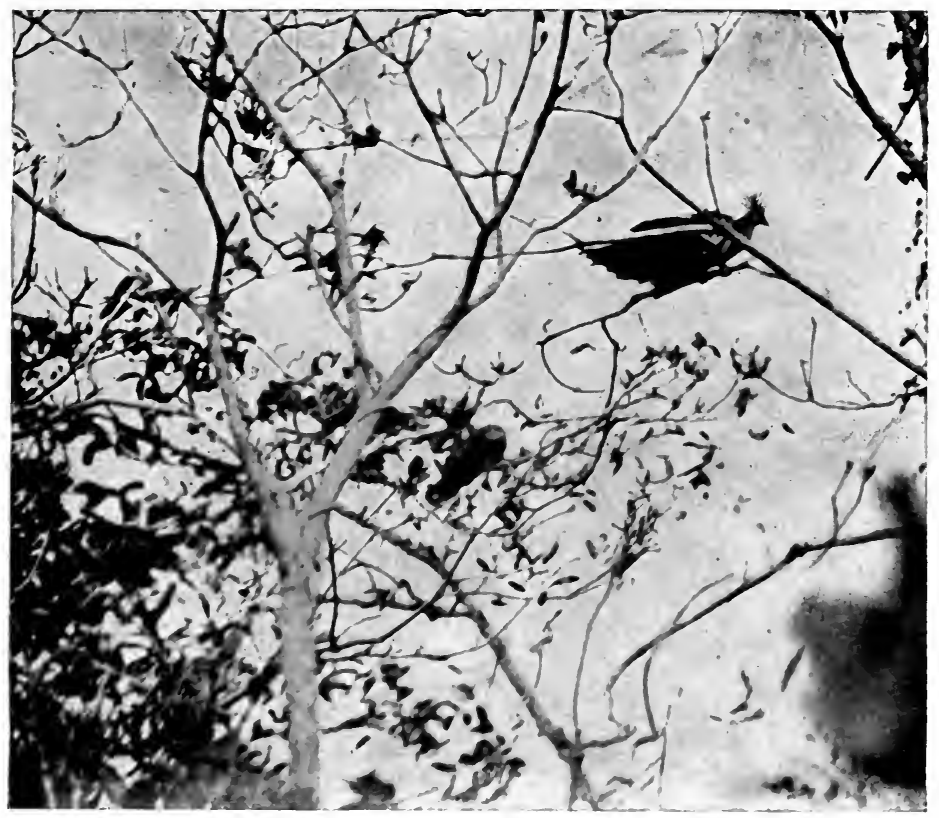

Fig. 152. (A) Female Hoatzin flushed from her Nest; the Male BIRD APPROACHING.

In the morning as the sun grew hotter the birds became quiet and finally disappeared, not to be heard or seen again until afternoon. They spend the heat of the day sitting on their nests or perched on branches in the cooler, deeper recesses of their linear jungle.

The last view of them in the morning, as the heat became intense, or late in the evening, usually revealed them squatted 
on the branches in pairs close together. On moonlight nights however they were active and noisy, and came into the open to feed. The habit of crouching or settling down on the perch is very common with the Hoatzins, and it may be due to the weakness of the feet and toes. I am inclined

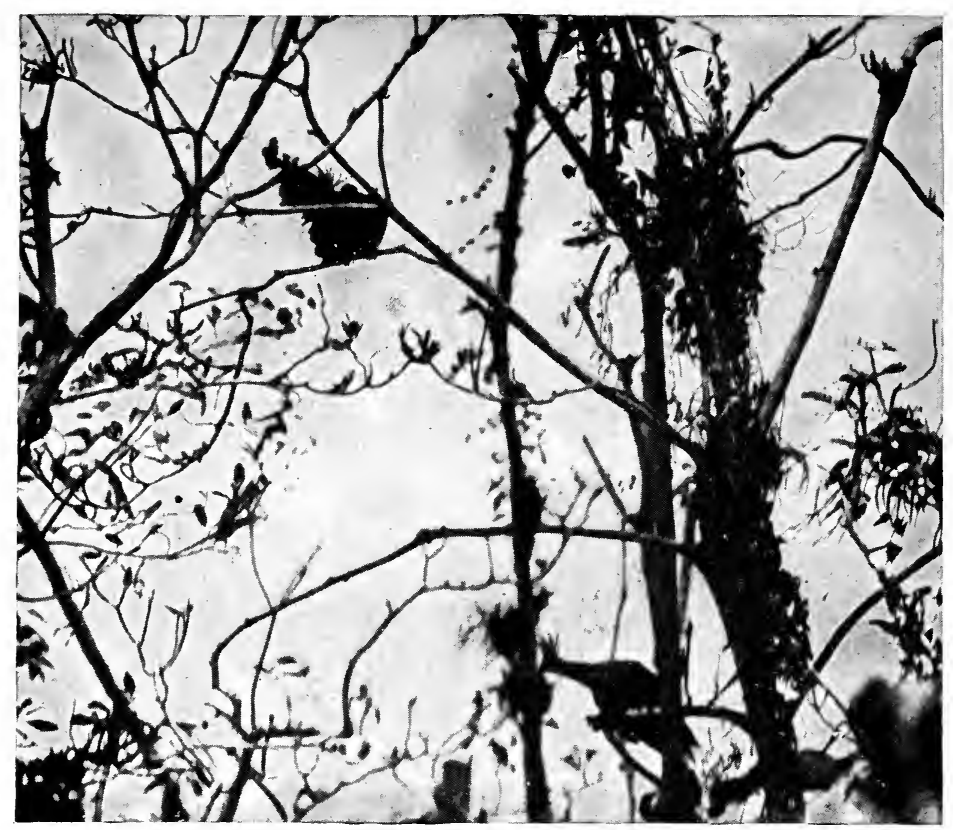

Fig. I53. (B) Female Hoatzin in the same Position, the Male havING FLOWN NEARER.

however to consider it in connection with the general awkwardness in alighting and climbing, as a hint of the unadaptability of the large feet to the small size of the twigs and branches among which they live. Inexplicable though it may appear, the Hoatzin - although evidently unchanged in many respects through long epochs - yet is far from being perfectly adapted to its present environment. It has a severe 
struggle for existence, and the least increase of any foe or obstacle would result in its extinction.

At the time of our arrival the Hoatzins had just begun to nest. They were utilizing old nests which, although so apparently flimsy in construction, yet were remarkably cohesive. The nests are almost indistinguishable from those of the "Chows" or Guiana Green Herons which were built in the same situations. The latter were usually low over the water, while the Hoatzins' were higher, from five to twelve feet above the surface of the marsh. The twigs were longer and more tightly interlaced in the Hoatzin's nest, and while the nests of the Heron crumbled when lifted from the crotch, the others remained intact. The Hoatzins placed their nests in crotches of the tree-like growths, or more rarely supported by several branched mucka-mucka stems. Both sexes aided in the building as we observed two birds collecting and weaving the twigs. Three sets of eggs which came under our observation numbered respectively 2, 3, and 4 . From what information I could gather, two seems to be the usual number.

The eggs are rather variable in shape. One which I have, from the Orinoco, is elliptical, while my Abary specimens are oval. The ground color is creamy white. The entire surface is marked with small irregularly shaped dots and spots of reddish brown, inclining to be more abundant at the large end. The brown pigment deposited early in the oviduct is covered by a thin layer of lime and thereby given a lavender hue. The size averages $\mathrm{I} .8$ by I.3 inches.

Hoatzins seem to be very free from enemies, although from year to year their numbers remain about the same. The waters beneath them are inhabited by numbers of otters, crocodiles, anacondas and voracious fish, so that death lies that way. They seem also to fear some predatory bird, for whenever a harmless Caracara Hawk ${ }^{53}$ skimmed low over 
the branches on the lookout for lizards, the Hoatzins always tumbled pell mell into the shelter of the thick foliage below.

We found that the best time to approach and photograph the birds was during their siesta. As we paddled along the bank they scrambled from their perches or nests up to the bare branches overhead, calling hoarsely to one another.

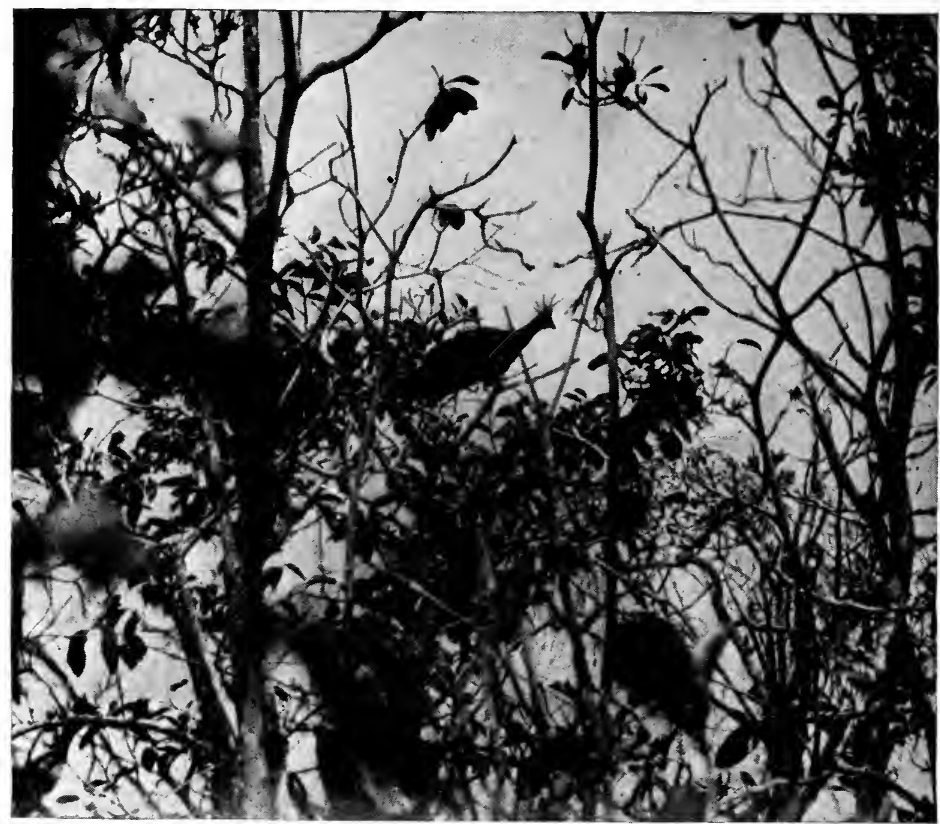

Fig. 154. (C) Male Hoatzin alarmed and about to take Flight.

Pushing aside the dense growth of Arums and vines, we worked our canoe as far as possible into the heart of the bush, to the foot of some good-sized tree perhaps a foot in diameter. Stepping from the boat to the lowest limb, Milady would hand me the big Graflex with the unwieldy but necessary 27-inch lens, and I began my painful ascent. At first all was easy going, but as I ascended I broke off 
numerous dead twigs and from the broken stub of each issued a horde of black stinging ants. These hastened my ascent and at last I made my way out on the swaying upper branches. (Fig. I5I.) From here I had a fairly clear view of the surrounding bush and if I worked rapidly I could secure three or four pictures before the Hoatzins took flight and hid amid the foliage.

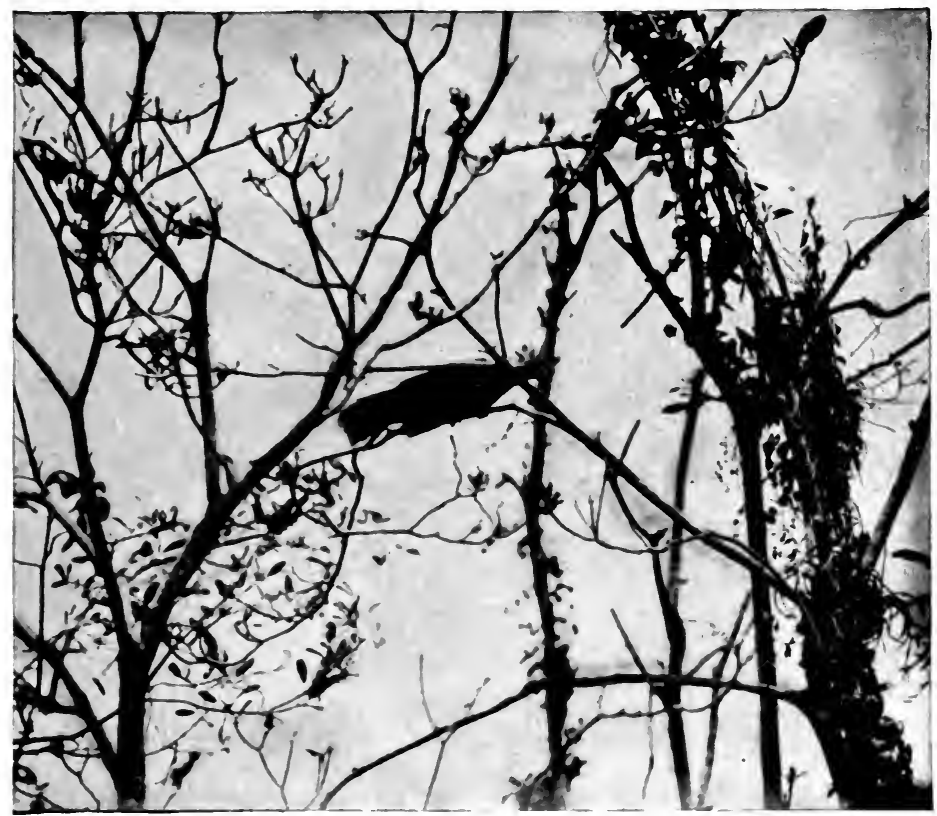

Fig. I55. (D) Female Hoatzin crouching to avoid Observation.

Of all my pictures that of Fig. I57 is the prize. We came upon a flock of Hoatzins late in the afternoon and were fortunate enough to get into a clear space and to photograph eleven on the same plate; the confused mass near the centre of the picture containing four individuals. Fig. I 48 shows the character of the country where we found the Hoatzins on 
Abary River, with the line of dense growth on one side and the level savanna on the other.

A study of an individual pair of birds is given in Figs. $\mathbf{I}^{2} \mathbf{2}$ to 156 , and the actions of these two birds were so typical of Hoatzins that an account of them will apply to the species in general. I made these photographs from a boat, standing on the thwarts while Milady guided it through the brush.

We flushed the female from her nest (marked by a circle in Fig. I 50) and she flew to a branch some eight feet higher (Fig. I52). The male then appeared from a tree beyond (centre of Fig. I52). We remained perfectly quiet, and the next photograph shows her tail-on, looking about, while the male, who has flown nearer, is watching us suspiciously. Fig. 154 shows the male on another perch, still more alarmed, and a moment later he thrashed his way out of sight. Meanwhile the female had rediscovered us and crouched down (Fig. I55) hoping to avoid observation, but as we pushed closer to the nest, she rose on her perch, spread tail and wings to the widest (Fig. I 56), her scarlet eyes flashing, and uttering a last despairing hiss, launched out for a few yards. At this moment, as may be seen in the same picture, a second pair of birds left their nest in the next clump of undergrowth and raised their discordant notes in protest at our intrusion.

The assertion which we made last year - Milady having been the first to observe it - that Hoatzins use their primaries as fingers, in the same way that the chicks and partly grown young use their wing claws, has been received with some doubt, and I am glad to offer a photograph (Fig. I56) as evidence. In the right wing of the Hoatzin, the thumb feathers are plainly visible, with their inner edges fretted away, while the first six primaries also show signs of severe wear, such as would be expected from the rough usage to which they are put. 
Attention is called to the apparent immobility of the crest, which is as fully erect in the crouching Hoatzin (Fig. I55) as in the same bird a minute or two later, alert and about to fly (Fig. $5_{56}$ ).

Thus it was that we took the first photographs ever made of these most interesting birds.

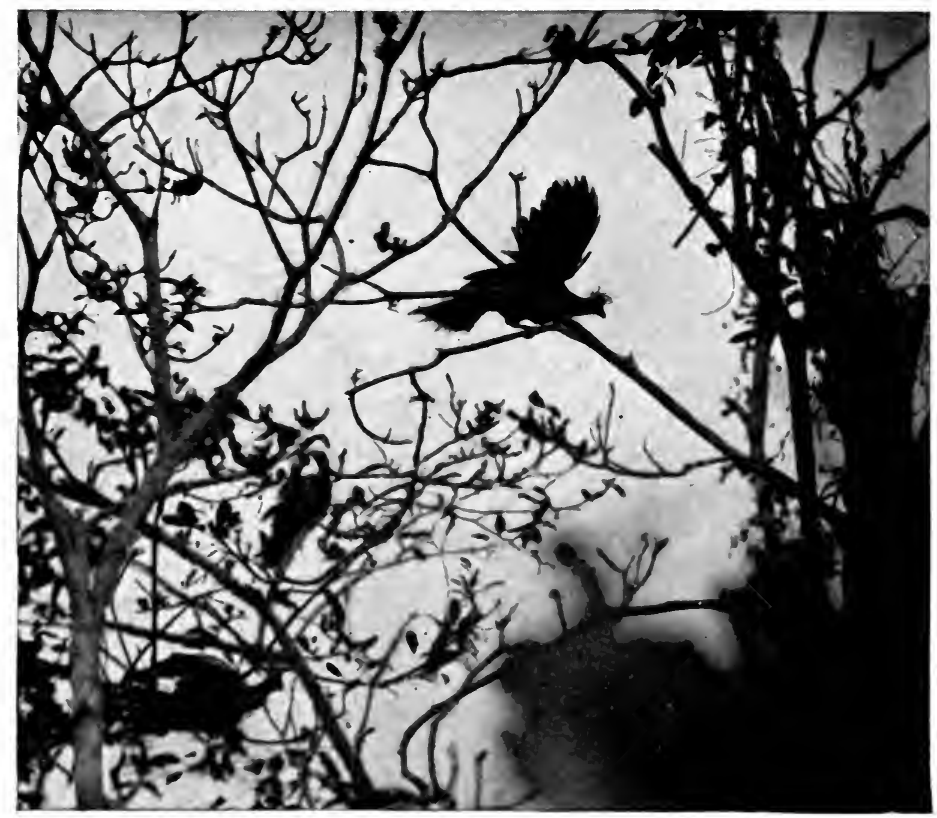

Fig. i56. (E) Female Hoatzin taking flight, with wings fully SPREAD; A SECOND PAIR OF BIRDS LEAVING THEIR NEST, IN THE BACKGROUND.

Insects were abundant on the island and if we had taken time we could have made an interesting collection. Three species of bright Orange butterflies were numerous (Euptoieta hegesia, Colaenis phaerusa and the familiar Red Silver-wing, Agraulis vanillae, of our northern fields), and with these were also a White (Pieris monuste) and a Yellow(Callidryas statira). 
The three commonest dragon-flies were Diastatops tincta, Erythrodiplax umbrata and E. peruviana.

There were two pairs of Black-capped Mocking-thrushes ${ }^{126}$ on the island and they afforded us much amusement. They are true cousins of the Catbird and Mockingbird, and from their actions would almost seem to have a strain of Chat blood! A pair lived in each of the brush clumps $a$ and $b$ (Fig. 147) and hour after hour would sit calling and answering each other. One pair (the two birds sitting close to each other) would shout in unison powie! powie! powie! rapidly a dozen times in succession. The other pair responded week! week! week! week! as often and as rapidly. At each enunciation the half-spread tails of the respective pair of birds wagged violently from side to side, exactly as if pulled with a string. As the utterances of each of the two birds were synchronous, the wagging was always in perfect time, but sometimes the "strings" got crossed with this effect (a); or this (b);
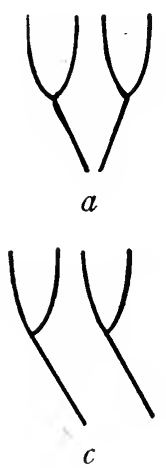

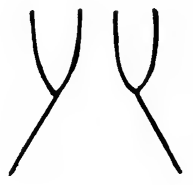

$b$

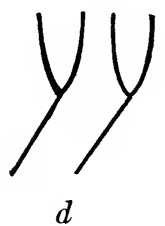

but almost every time the movement was in unison thus (c); or thus (d). These active, interesting birds have in addition an elaborate song, uttered singly, which these individuals were practising but which we had heard fully developed at La Brea in Venezuela. 


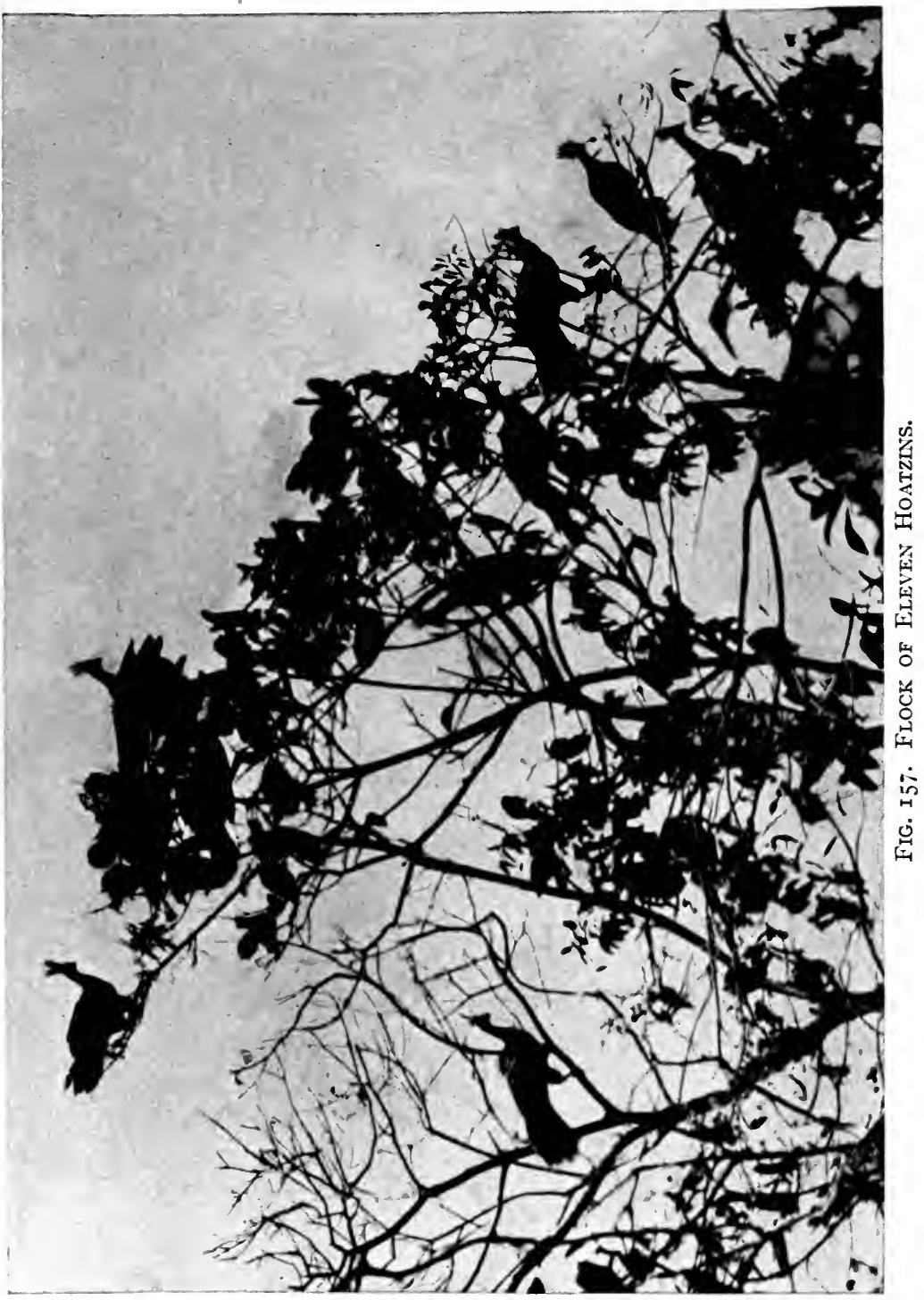


Purple Gallinules ${ }^{13}$ and Cayenne Wood Rails ${ }^{12}$ were seen every day but were not abundant. A pair of the latter were nesting near the island and well merited their native name of Killicow, screaming a confused chorus of syllables resembling these for five minutes at a stretch every morning.

Among the smaller marsh birds, Jacanas ${ }^{23}$ easily held first place, both in numbers and in action and voice, day and night. About every half hour through the day a group of these birds would set up a wild and frantic clacking, sounding as if a dozen hens were being pursued and had about given up all hope of escape. This was usually caused by the appearance of a crocodile, large or small, from beneath the lily pads. All the Jacanas within sight would gather at once and dance excitedly about on the surrounding pads until the pestered reptile sank again into the muddy waters. Several times we saw trios of these birds in play or combat, each holding the wings spread low and in front, ready to strike with the sharp spurs or to protect their own body by the buttress of feathers. They are very graceful in all their motions, holding the wings straight upward for a few seconds after alighting.

This being practically a treeless region, the birds were of necessity either terrestrial, aquatic or aërial, and the latter formed a not inconsiderable percentage. Terns were one of the most picturesque features of the savanna, flying over and around the island in small flocks, the large Great-billed fellows ${ }^{14}$ with black caps and wings, and the tiny Eyebrowed species ${ }^{15}$ reminding one of our Least Tern. Both beat back and forth, or hung fluttering over the lagoon, and now and then dropped plummet-like after a small fish.

The Swallows were legion - six species in all, forever swooping over the marsh or snatching sips of river water as they flew. The Variegated ${ }^{119}$ were the most beautiful, and we 
welcomed as old friends Barn ${ }^{121}$ and Tree Swallows, ${ }^{120}$ whose twittering forms brought our northern autumn marshes vividly to mind. Many Flycatchers and Seedeaters were nesting close by, while the beautiful Orioles ${ }^{159}$ clung to their pendent nests over the water, and a House Wren ${ }^{124}$ divided his time between inspecting his brood in a hollow stub at the foot of the bungalow steps, and singing his heart out, from the roof. The little "Rooties" or Cinnamon Spine-tails ${ }^{94}$ - absurdly Wren-like but in reality Woodhewers which have deserted tree-trunks for reeds showed us their homes, concealed in great untidy balls of twigs. As they flit here and there through the bushes and grasses, they let off a sound like a miniature rattle.

The mornings and evenings, here as elsewhere in the tropics, are the periods of greatest activity among birds and other creatures. In the afternoon, before the Hoatzins began to gather, great tarpon would play in the river, the shower of drops scattered by their leaps sparkling like silver in the slanting rays of the sun. The few in the lagoon are of small size, but tarpon in the Abary reach a weight of I85 pounds. A swirling in the shallows near the landing shows where an anaconda (Eunectes murinus) is stirring after his day's rest. His mate, ten feet long, has just been shot after having helped herself to the bungalow chickens - one each night for a week, and serpent number two (whose size our Arrawak Indian squaw cook places at a fabulous thirty feet or more!) must soon pay the same penalty unless he changes his diet.

Toward dusk all the Swallows of the world - or so it appears - fly past in loose bands or singly, northward toward the eta bush to roost, hundreds and thousands of them - Red-breasted, ${ }^{123}$ Banded, ${ }^{118}$ Barn,,${ }^{121}$ Variegated ${ }^{119}$ and Tree ${ }^{120}$ Swallows with scores of the Gray-breasted Martins. ${ }^{122}$ Then the fishers of the savanna appear, look- 


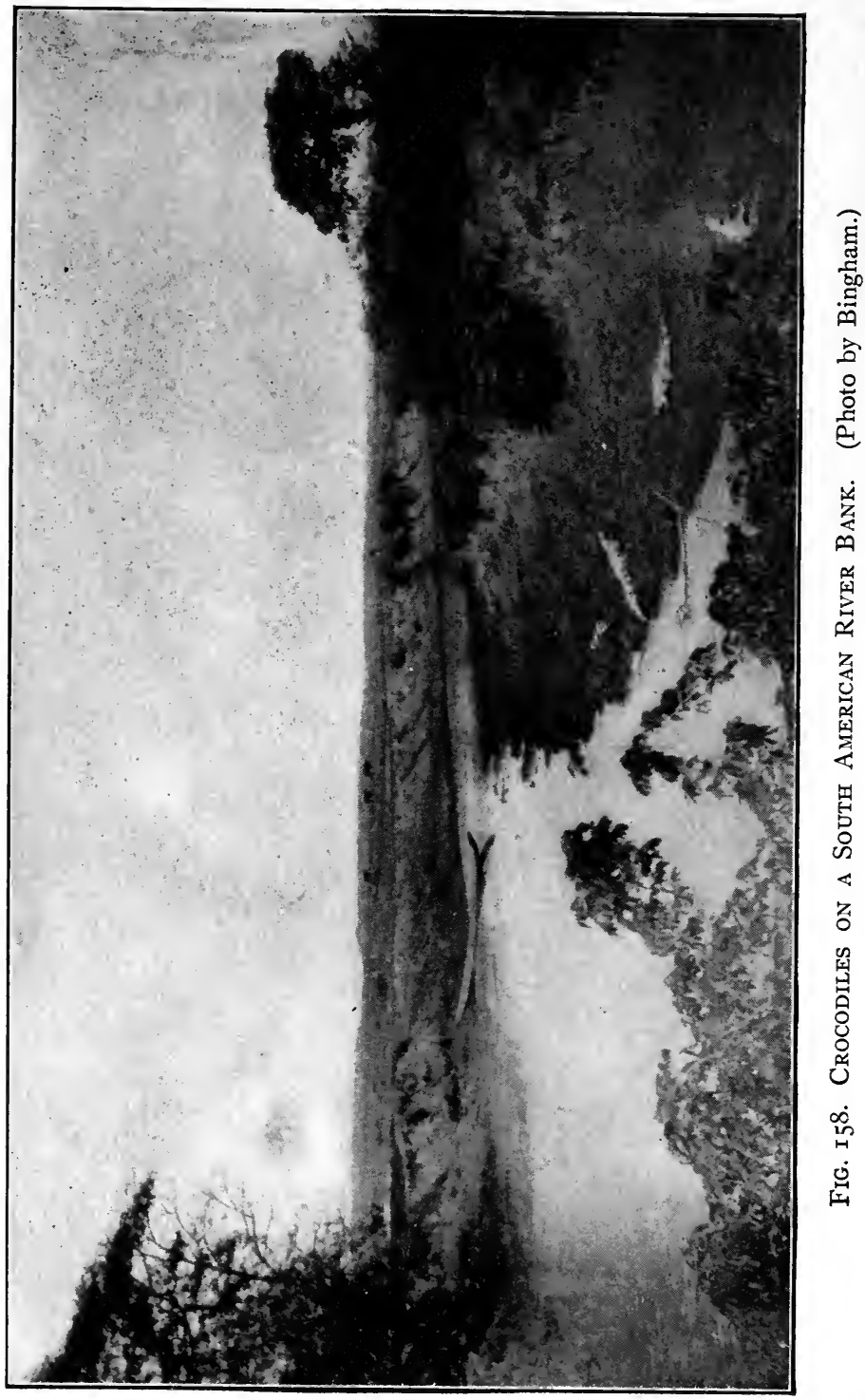


ing whiter and more ghostly than ever, against the dark clouds; flock after flock flapping silently over: a score of Egrets ${ }^{32}$ in an irregular line, then a dozen more smaller troops; Wood Ibises ${ }^{28}$ higher up and beating heavily, then - and our pulses quicken - a half dozen great Jabirus ${ }^{30}$ slowly throbbing toward the sunset. The Ducks prefer the river, and above the fluid tide a living river of birds sets upstream, hosts passing until long after dark. We paddle in the early dusk to mid-stream and the whistling stream of Ducks curves gracefully upward, descending again when beyond us. As we go up or down river, we find the bend always overhead; when we leave the river, the host resumes its horizontal flow again. Faintly from behind the house, from the edge of the distant eta bush itself, comes in the evenings a low sound, gaining in volume until the syllables may be framed to human speech - Mo-hóo-ca! Mo-hóo-ca! and we are listening to the evening call of the Horned Screamer, ${ }^{41}$ a bird known to us only from books.

The night sounds from the lagoon are full of mystery. Sea-cows souse and roll in the river and apparently at the very landing. Otters play and cough and utter gasping sighs which make one's flesh creep until we learn what they are. The legend of the Warracabra Tigers, which Waterton and all after him recount, may well have had its origin in these great river mammals, who are noisy, fearless and sometimes reach a length of six feet. A beautiful skin which I brought home measures five and a half feet from nose to tip of tail. Water-haas, or capybaras, probably add their share to the confusion, but the major part of the medley is due to crocodiles, who wait until night before beginning their active, noisy business of life, which, be it concerned with food, mate or play, requires a vast deal of splashing and bellowing. This latter is a deep abrupt roaring like the final roars of a lion's cadence. An eight-foot croco- 
OUR SEARCH FOR A WILDERNESS.

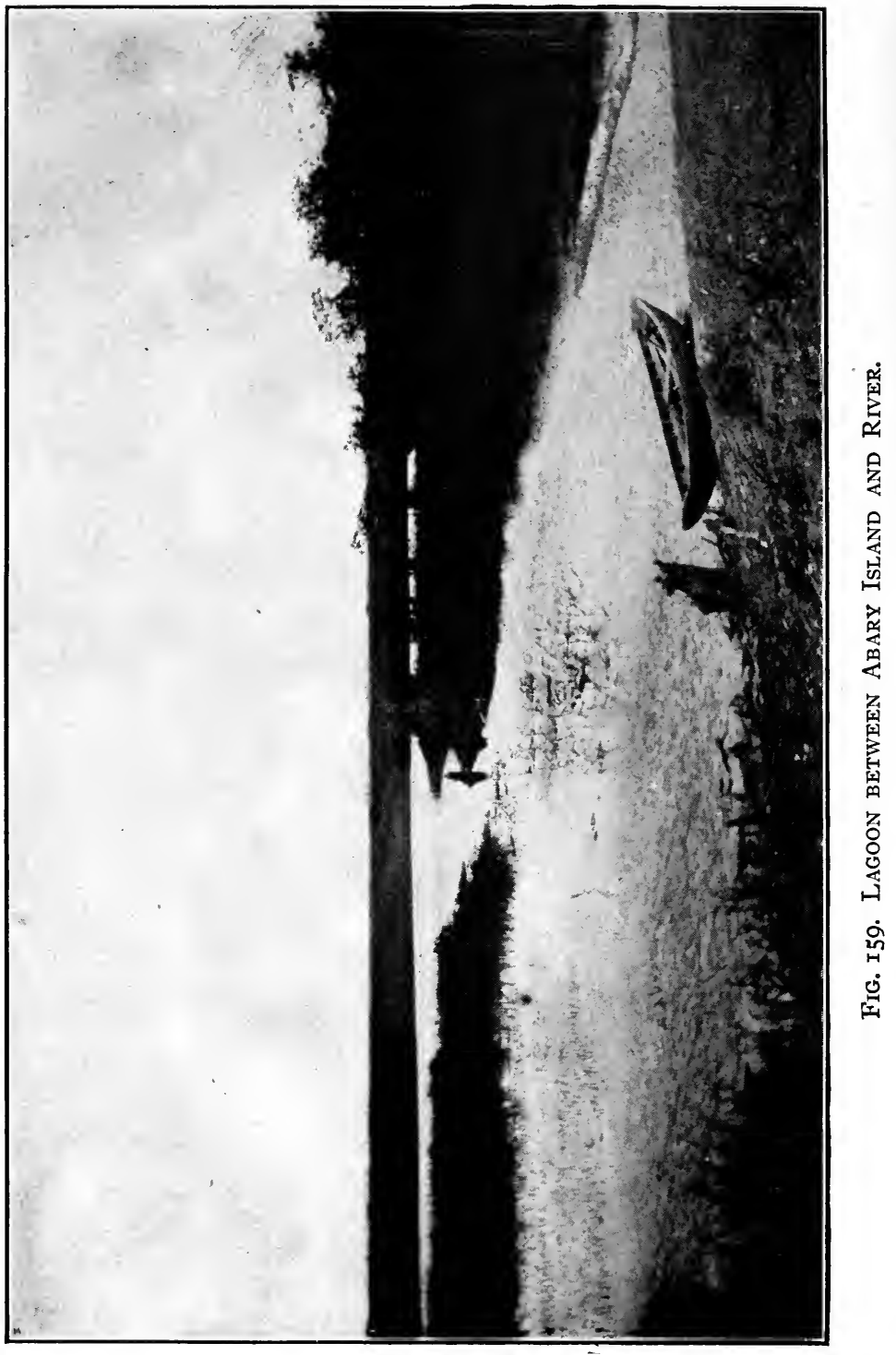


dile was shot in the lagoon a few days before, or rather shot at, as the beast seemed to be none the worse.

Small wonder that, when we consider snakes, crocodiles, otters and voracious fishes, that the gentle Vicissi Ducks prefer the safer vegetation of the marsh itself! The real birds of night were few - but with voices weird and awesome, in perfect harmony with this unpeopled waste. A pair of Parauque-like beings who in uttering liquid accents reiterated their names, mingled with the ever tragic toned questioning of another Goatsucker, pleading with us to end his agonized uncertainty - Whó-are-yoú ? Whó-are-yoú?

Early on the morning of our last day, April i 5 th, I awoke and peered out through the dimness of my muslin hammock net to catch the first hint of dawn. The east soon became lighter and the warp and woof of the cloth softened and disguised the scene which stretched before me from the edge of the veranda. As I lay there half awake, I seemed to see great towering moras, with their masses of dependent parasites, stretching high into the air. This passed, and the savanna became more distinct - the whistle of Ducks' wings overhead was almost incessant, with now and then the note of a Hoatzin. Dull thuds indicating some one at labor behind the bungalow and the sound of low negro voices added to the imagery and I seemed to be with the black men three score years before, laboring at their island, fighting disease and starvation - harassed by heat, insects and reptiles; ever on the watch for their pursuing masters while the orange headed Vultures soared overhead, waiting for their turn which sooner or later would come.

A bit of comedy broke in upon my dream - the voices of the negroes from their hammocks at the other end of the porch became audible for a moment.

"Wont you tak' a drink of sompfin to interact de cold?"

"No tanks, ah doesn't stimulate." 
Parting my hammock net, I found my vision of jungle growth had been prompted by a great bank of black cloud, out of which the sun leaped at that instant and lighted up the beautiful green and blue of savanna and river. Little Green Herons ${ }^{38}$ were fishing at the water's edge and a Jacana ${ }^{23}$ was leading her brood of three small chicks within

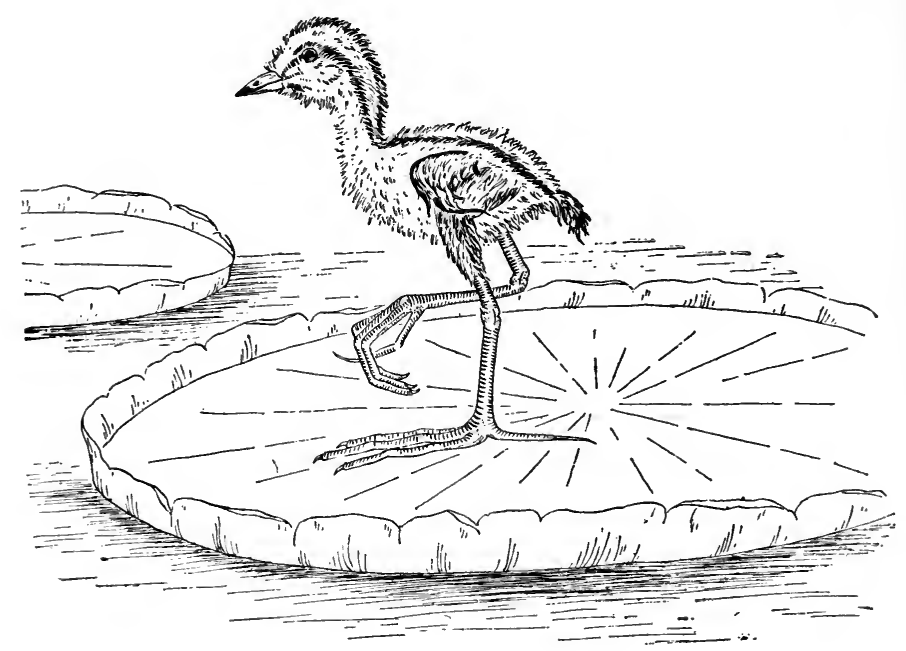

Fig. I60. Young SpUR-Winged Jacana.

a few feet of my hammock, down to a causeway of trembling lily pads. The youngsters were very tiny, clad in gray with a large black mark on the nape. Even in comparison with their mother their toes were of enormous length. They kept at her very heels and when she stopped for a moment crept beneath her wings. But at this concentration of weight the water would begin to trickle over the rim of the fragile pads and the mother would hurry on, flashing out the yellow of her wings every few steps, perhaps as a signal to her brood. 
Why every chick is not snapped up by hungry crocodiles or other aquatic ogres is a mystery. Every morning this and several other bands, all of three, would thread their way across the lagoon to the reeds beyond.

After breakfast about 8 o'clock, while I was reconnoitering for the best place to begin trapping the Hoatzins, as we wished to take some home alive, tragedy came, sudden and unexpected. A single pitiful cry brought me back to the house in an instant, and there was Milady, who but a moment before had been happily planning with Crandall about preparations for trapping, lying with a broken wrist. A hammock in which she had seated herself for an instant had come untied and given way and it was a miracle that the seven foot drop backward to the ground had resulted in only one broken bone. Game little lady, her first words were, "Oh! we can't get the Hoatzins"!

The remainder of that ${ }^{5} 5^{\text {th }}$ of April will ever be a misty dream in my mind. We bandied no words as to the value of Hoatzins in particular, or the whole world of science in general, versus Milady's hurt, but without confusion quickly organized our plan of action. I had the best corps of helpers one could want; Mr. and Mrs. Vinton, Crandall and Harry. One of us constantly dropped cold water on the injury, another threw together all our belongings; others worked like Trojans to assemble the launch engines, which had been taken apart for cleaning. In two hours we were on the throbbing little boat, passing the Hoatzins and hosts of Ducks with unseeing eyes.

Then two hours later at the railroad bridge came a quick run to the nearest telegraph office, where a sympathetic, 300 pound negro "mammy" presided over the instrument and wept copiously for the "po' lil' lady," while she clicked out an urgent message for a special train. She said "Ah am too sorry for to heah dat bad news," and when our proces- 
sion drew up at her little house to wait for the train she called out to Milady the comforting information that "In der midst of life we are in death!" This greatly amused the sufferer, and we settled ourselves for the long wait. As long as one has something to do, any helpful work, to keep one's hands or mind busy, it is an easy matter to control one's feelings in a critical emergency. But when one must wait quietly for hours, the long period of inaction is maddening. We tramped up and down the track, telephoning every few minutes to locate the progress of the special along the line. Then Crandall spied a big yellow-tailed snake (Herpetodryas carinatus) crossing the track. Here was an excuse for working off surplus steam, and we both made a dash for it. Crandall caught it by the tail as it was disappearing into the brush and we had an exciting ten minutes getting it unharmed into a snake bag, the active creature succeeding in biting us twice before we muffled it. Visitors to the Reptile House of our Zoölogical Park little imagine, when gazing at this handsome creature, what a relief to our tense nerves its capture meant.

At last the special came in sight and we set out on the wildest of rides to Georgetown. Having seen Milady in a doze on a sofa in the train, Crandall and I climbed up to the railed-in roof of the car and, with the wind beating down our very eyelids, watched the narrow escapes of dogs, cows, donkeys and coolies, from the track at the approach of this unlooked for train. The yellow and scarlet Blackbirds blew up like chaff on either hand. Egrets, Ibises and Jabirus watched in amazement from afar, or flew hurriedly off at the long drawn-out siren whistle, which hardly ceased across the whole country.

We met the single afternoon train, side-tracked to let us pass, and then had an open road to Georgetown. Slowing down, we passed through the station, on through the streets, to within a half block of Mr. Vinton's house. 
Here good Dr. Law took charge and, ten hours after the accident, fitted the shattered bone so skilfully that hardly a trace remains of the bad colleus fracture. The patient had no temperature at the time of the operation, the only ill effect being a short, sharp attack of malaria. I cite all these details chiefly to show the falsity of most of the universal slanders on a tropical climate.

Nine days afterward on April 24th, we sailed from Georgetown, homesick with desire to remain longer in this wonderland. The three short expeditions we had made, served only to whet our eagerness to search deeper beneath the surface, and glean some of the more fundamental secrets which Nature still hides from us. But we had fulfilled the bushproverb; we had "eaten of labba meat and drunk of river water" and we know in our hearts that some day we shall return.

Meanwhile the thought of that vast continent, as yet almost untouched by real scientific research; the supreme joy of learning, of discovering, of adding our tiny facts to the foundation of the everlasting why of the universe; all this makes life for us - Milady and me - one never-ending delight. 



\title{
APPENDIX A.
}

Classified List of Birds Mentioned in this Volume.

\author{
TINAMIFORMES.
}

I. Great Blue Tinamou - Tinamus tao Temm.

2. Guiana Crested Tinamou - Tinamus subcristatus (Cab.).

3. Little Tinamou - Crypturus variegatus (Gmel.).

\section{GALLIFORMES.}

4. Crested Curassow - Crax alector Linn.

5. Jacupeba Guan - Penelope jacupeba Spix.

6. Marail Guan - Penelope marail (Gmel.).

7. Red-tailed Chachalaca - Ortalis ruficauda Jard.

8. Guiana Quail - Odontophorus guianensis (Gmel.).

COLUMBIFORMES.

9. Red-winged Ground Dove - Columbigallina rufipennis (Bonap.).

ro. Red-underwing Dove - Leptoptila rufaxilla (Rich.).

\section{OPISTHOCOMIFORMES.}

II. Hoatzin - Opisthocomus hoazin (Müll.).

\section{RALLIFORMES.}

I 2. Cayenne Wood Rail - Aramides cayanea (Müll.).

I3. Purple Gallinule - Ionornis martinica (Linn).

\section{LARIFORMES.}

I4. Great-billed Tern - Phaëthusa magnirostris (Licht.).

15. Eye-browed Tern - Sterna superciliaris Vieill.

16. Laughing Gull - Larus atricilla Linn.

1. Black-tailed Skimmer - Rhynchops nigra cinerascens Spix.

\section{CHARADRIIFORMES.}

18. Semipalmated Plover - Aegialeus semipalmatus (Bonap.).

I9. South American Collared Plover - Aegialitis collaris (Vieill.).

20. Hudsonian Curlew - Numenius hudsonicus Lath.

2r. Solitary Sandpiper - Helodromas solitarius (Wils.).

22. Spotted Sandpiper - Tringoides macularia (Linn.).

23. Spur-winged Jacana - Jacana jacana (Linn.). 


\section{GRUIFORMES.}

24. Sun-bittern - Eurypyga helias (Pall.).

25. Common Trumpeter - Psophia crepitans Linn.

\section{ARDEIFORMES.}

26. Green River Ibis - Phimosus infuscatus (Licht.).

27. Scarlet Ibis - Eudocimus ruber (Linn.).

28. Wood Ibis - Tantalus loculator Linn.

29. Maguari Stork - Euxenura maguari (Gmel.).

30. Jabiru - Mycteria americana Linn.

3r. Cocoi Heron - Ardea cocoi Linn.

32. American Egret - Herodias egretta (Gmel.).

33. Snowy Egret - Egretta candidissima (Gmel.).

34. Little Blue Heron - Florida caerulea (Linn.).

35. Louisiana Heron - Hydranassa tricolor ruficollis (Gosse).

36. Yellow-crowned Night Heron - Nyctanassa violacea (Linn.).

37. Boat-billed Heron - Canchroma cochlearia (Linn.).

38. Guiana Green Heron - Butorides striata (Linn.).

39. Agami Heron - Agamia agami (Gmel.).

40. Amazonian Tiger Bittern - Tigrisoma lineatum (Bodd.).

\section{PALAMEDEIFORMES.}

4I. Horned Screamer - Palamedea cornuta Linn.

\section{PHOENICOPTERIFORMES.}

42. American Flamingo - Phoenicopterus ruber Linn.

\section{ANSERIFORMES.}

43. Muscovy Duck - Cairina moschata (Linn.).

44. Rufous Tree Duck - Dendrocygna fulva (Gmel.).

45. Gray-necked Tree Duck - Dendrocygna discolor Scl. and Sal.

46. White-faced Tree Duck - Dendrocygna viduata (Linn.).

\section{PELECANIFORMES.}

47. Guiana Cormorant - Phalacrocorax vigua (Vieill.).

48. Snake-bird - Anhinga anhinga (Linn.).

49. Frigate Bird - Fregata aquila (Linn.).

\section{CATHARTIDIFORMES}

50. King Vulture - Gypagus papa (Linn.).

5r. Black Vulture - Catharista urubu (Vieill.).

52. Orange-headed Vulture - Cathartes urubitinga Pelz. 


\section{ACCIPITRIFORMES.}

53. Caracara - Polyborus cheriway (Jacq.).

53a. South American Blue Hawk - Geranospizias caerulescens (Vieill.).

54. Cream-headed Hawk - Busarellus nigricollis (Lath.).

55. South American Black Hawk - Urubitinga urubitinga (Gmel.).

56. White-headed Chimachima Hawk - Leucopternis albicollis (Lath.).

57. Guiana Crested Eagle - Morphnus guiananensis (Daud.).

58. Swallow-tailed Kite - Elanoides forficatus (Linn.).

59. American Osprey - Pandion haliaetus carolinensis (Gmel.).

\section{STRIGIFORMES.}

6o. Southern Pygmy Owl - Glaucidium brazilianum phalaenoides (Daud.).

\section{PSITTACIFORMES.}

6r. Blue and Yellow Macaw - Ara ararauna (Linn.).

62. Red and Blue Macaw - Ara macao (Linn.).

63. Mealy Amazon Parrot - Amazona farinosa (Bodd.).

64. Yellow-fronted Amazon Parrot - Amazona ochrocephala (Gmel.).

65. Blue-headed Parrot - Pionus menstruus (Linn.).

66. Dusky Parrot - Pionus fuscus (Müll.).

\section{CORACIIFORMES.}

67. Great Rufous Kingfisher - Ceryle torquata (Linn.).

68. Red-bellied Kingfisher - Ceryle americana (Gmel.).

69. Pygmy Kingfisher - Ceryle superciliosa (Linn.).

70. White-necked Parauque - Nyctidromus albicollis (Gmel.).

7r. Feather-toed Palm Swift - Panyptila cayanensis (Gmel.).

72. Guiana Gray-rumped Swift - Chaetura spinicauda (Temm.).

73. Eyebrowed Hummingbird - Phaëthornis guianensis Bouc.

74. Guiana Rufous-breasted Hummingbird - Phaëthornis episcopus (Gould).

75. Guiana Long-tailed Hummingbird - Topaza pella (Linn.).

\section{TROGONIFORMES.}

76. Greater Yellow-bellied Trogon - Trogon viridis Linn.

\section{CUCULIFORMES.}

77. Great Rufous Cuckoo - Piaya cayana (Linn.).

78. Little Rufous Cuckoo - Piaya rutila (Illig.).

79. Greater Ani - Crotophaga major Gmel.

8o. Smooth-billed Ani-Crotophaga ani Linn. 


\section{SCANSORES.}

8I. Red-billed Toucan - Rhamphastos erythrorhynchius Gmel.

82. Sulphur and White-breasted Toucan - Rhamphastos vitellinus Licht.

83. Red-breasted Toucan - Rhamphastos Sp.

84. Black-banded Aracari Toucan - Pteroglossus torquatus (Gmel.).

PICIFORMES.

85. Paradise Jacamar - Urogalba paradisea (Linn.).

86. Yellow-billed Jacamar - Galbula albirostris Lath.

87. Rufous-tailed Jacamar - Galbula ruficauda Cuv.

88. Great Red-crested Woodpecker - Campephilus melanoleucus (Gmel.).

89. Great Ivory-billed Woodpecker - Ceophloeus lineatus (Linn.).

90. Yellow Woodpecker - Crocomorphus semicinnamomeus (Reichenb.).

\section{PASSERIFORMES.}

FORMICARIIDAE.

9r. White-shouldered Pygmy Antbird - Myrmotherula axillaris Viell.

92. Scaly-backed Antbird - Hypocnemis poecilonota (Pucher.).

93. Woodcock Antbird - Rhopoterpe torquata (Bodd.).

\section{DENDROCOLAPTIDAE.}

94. Cinnamon Spine-tail - Synallaxis cinnamomea (Gmel.).

95. Whistling Woodhewer - Dendrornis susuranus susuranus (Jard.).

96. Wedge-billed Woodhewer - Glyphorhynchus cuneatus (Licht.).

TYRANNIDAE.

97. White-shouldered Ground Flycatcher - Fluvicola pica (Bodd.).

98. White-headed Marsh Flycatcher - Arundinicoal leucocephala (Linn.).

99. Gray Tody-flycatcher - Todirostrum cinereum cinereum (Linn.).

ıоo. Yellow-breasted Elania Flycatcher - Elaenea pagana (Licht.).

1ог. Guiana Kiskadee Tyrant - Pitangus sulphuratus sulphuratus (Linn.).

102. Venezuela Kiskadee Tyrant - Pitangus sulphuratus trinitatus Hellm.

r03. Lesser Kiskadee - Pitangus lictor (Cab.).

104. Great-billed Kiskadee Tyrant - Megarhynchus pitangua pitangua (Linn.).

105. Streaked Flycatcher - Myiodynastes maculatus maculatus (Müll.).

106. White-throated Kingbird - Tyrannus melancholicus (Vieill.).

107. Buff-tailed Tyrantlet - Terenotricus erythrurus erythrurus (Cab.).

\section{PIPRIDAE.}

108. Golden-headed Manakin - Pipra erythrocephala (Linn.).

ro9. White capped Manakin - Pipra leucocilla Linn.

I IO. Golden crowned Pygmy Manakin - Pipra brachyura (Scl. and Sal.).

Irr. White-breasted Manakin - Manacus manacus manacus (Linn.).

I 2. Wallace's Olive Manakin - Scotothorus wallacii (Scl. and Sal.). 
COTINGIDAE.

II3. Black-tailed Tityra - Tityra cayana (Linn.).

Ir4. Cinereus Becard - Pachyrhamphus atricapillus (Gmel.).

I15. Goldbird - Lathria cinerea (Vieill.).

I 6. Pompadour Cotinga - Xipholena pompadora (Linn.).

I 7. Bare-headed Cotinga - Calvifrons calvus (Gmel.).

HIRUNDINIDAE.

I I8. Banded Swallow - Atticora fasciata (Gmel.).

I I9. Variegated Swallow - Tachycineta albiventris (Bodd.).

I 20. Tree Swallow - Tachycineta bicolor (Vieill.).

I 2 . Barn Swallow - Hirundo erythrogaster Bodd.

122. Gray-breasted Martin - Progne chalybea chalybea (Gmel.).

123. Red-breasted Swallow - Stelgidopteryx ruficollis Baird.

TROGLODYTIDAE.

124. Guiana House Wren - Troglodytes musculus clarus Berlp. and Hart. 125. Necklaced Jungle Wren - Leucolepia musica (Bodd.).

MIMIDAE.

126. Black-capped Mocking-thrush - Donacobius atricapillus (Linn.).

TURDIDAE.

127. White-throated Robin-Planesticus phaeopygus (Cab.).

128. White-breasted Robin - Planesticus albiventer Spix.

VIREONIDAE.

I28a. Brown-fronted Jungle Vireo-Pachysylvia ferrugineifrons Scl.

MNIOTILTIDAE

I2Sb. American Redstart - Setophaga ruticilla (Linn.).

FRINGILLIDAE.

129. Brown-breasted Pygmy Grosbeak - Oryzoborus torridus (Gmel.).

I30. Thick-billed Pygmy Grosbeak - Oryzoborus crassirostris (Gmel.).

I3I. Blue-backed Seedeater - Sporophila castaneiventris (Cab.).

132. Pygmy Seedeater - Sporophila minuta minuta (Linn.).

133. Yellow-bellied Seedeater - Sporophila gutturalis (Licht.

I34. Black-headed Scarlet Grosbeak - Pitylus erythromelas (Gmel.).

135. Black-faced Green Grosbeak - Pitylus viridis (Vieill.).

\section{COEREBIDAE.}

136. Yellow-winged Honey-creeper - Cyanerpes cyaneus (Linn.).

136a. Blue Honey-creeper - Cyanerpes caeruleus (Linn.).

137. Venezuela Bananaquit - Coereba luteola Cab. 
TANGARIDAE.

138. Purple-throated Euphonia - Euphonia chlorotica (Linn.).

139. Black-tailed Euphonia - Euphonia melanura Scl.

140. Violet Euphonia - Euphonia violacea (Linn.).

I4I. Black-faced Calliste - Calospiza cayana (Linn.).

142. Yellow-bellied Calliste - Calospiza mexicana mexicana Linn.

143. White-shouldered Blue Tanager - Tangara episcopus episcopus Linn.

144. Northern Palm Tanager - Tangara palmarum melanoptera Scl.

145. Northern Silver-beak Tanager - Ramphocelus jacapa magnirostris (Lafr.).

146. Southern Silver-beak Tanager - Ramphocelus jacapa japaca (Linn.).

147. Magpie Tanager - Cissopis leveriana (Gmel.).

\section{ICTERIDAE.}

148. Black Parasitic Cassique - Cassidix oryzivora oryzivora (Gmel.).

149. Great Black Cassique - Ostinops decumanus (Pall.).

150. Green Cassique - Ostinops viridis (Müll.).

151. Yellow-backed Cassique - Cacicus persicus (Linn.).

152. Red-backed Cassique - Cacicus affinis Swains.

I53. Guiana Cowbird - Molothrus atronitens (Cab.).

154. Little Yellow-headed Blackbird - Agelaius icterocephalus (Linn.).

155. Red-breasted Blackbird - Leistes militaris (Linn.).

156. Meadowlark - Sturnella magna (Linn.).

I57. Guiana Meadowlark - Sturnella magna meridionalis (Scl.).

I58. Moriche Oriole - Icterus chrysocephalus (Linn.).

I59. Yellow Oriole - Icterus xanthornus xanthornus (Gmel.).

r6o. Little Boat-tailed Grackle - Quiscalus lugubris Swains.

\section{CORVIDAE.}

I6r. Lavender Jay - Cyanocorax cayanus (Linn.). 


\section{APPENDIX B.}

\section{Native Guianan Names of Birds.}

Great Blue Tinamou - Maam.

Little Tinamou - Little Maam.

Curassow - Powis.

Guan - Maroodi.

Guiana Quail - Duraquara.

Chachalaca - Hanaqua.

Hoatzin - Canje Pheasant.

Purple Gallinule - Coot.

Guiana Wood Rail - Killicow.

Spur-winged Jacana - Spur-wing.

Skimmer - Scissor-bill.

Sun Bittern - Sun-bird.

Trumpeter - Warracabra.

Scarlet Ibis - Curri-curri.

Jabiru - Negrocop.

Wood Ibis - Nigger Head.

Tiger Bittern - Tiger-bird.

Herons - Chow or Shypook.

Cocoi Heron - Crane.

Horned Screamer - Mohuca.

Gray-necked Tree-duck - Vicissi.

Snake-bird - Ducklar.

Black Vulture - Carrion Crow.

Orange-headed Vulture - Governor Carrion Crow.

Caracara - Hen Hawk.

Owls - Night Owl.

Spectrum Parrakeet - Kissi-kissi.

Motmot - Hutu.

Hummingbirds - Doctor-birds.

Four-winged Cuckoo - Wife-sick.

Great Ani - Jumby-bird.

Smooth-billed Ani - Old Witch.

Toucan - Bill-bird.

Checked Ant-thrush - Dominique or Check-bird.

Cinnamon Spinetail - Rootie. 
Bell-bird - Campanero.

Gold-bird - Greenheart-bird - P̌̀-pī-yŏ.

Cinereus Becard - Woodpecker.

White-shouldered Ground Flycatcher - Cotton-bird.

Southern Scissor-tailed Flycatcher - Scissor-tail.

Guiana Kiskadee Tyrant - Kiskadee.

White-throated King-bird - Madeira or Gray Kiskadee.

White-headed Marsh Flycatcher - Parson-bird.

Cinereus Tody-flycatcher - Pipitoorie.

Yellow-breasted Elanea Flycatcher - Muff-bird or Muffin.

Guiana House Wren - God- or Guard-bird.

Necklaced Jungle Wren - Quadrille Bird.

White-throated Robin - Thrush.

Yellow Warbler - Bastard Canary.

Brown-breasted Pygmy Grosbeak - Toua-toua.

Thick-billed Pygmy Grosbeak - Twa-twa.

Blue-backed Seedeater - Blue-back.

Pygmy Seedeater - Fire-red.

Crown-headed Seedeater - Crown-head.

Plain-headed Seedeater - Plain-head.

Lineated Seedeater - Ring-neck.

Pee-zing Grassquit - Pee-zing.

Honey Creepers - Hummingbirds.

Yellow-bellied Calliste - Goldfinch.

Black-faced Calliste - Bucktown Sackie.

Violet Euphonia - Bucktown Canary.

Blue Tanager - Blue Sackie.

Palm Tanager - Cocoanut Sackie.

Silver-beak Tanager - Cashew Sackie.

White-lined Tanager - Black-sage Sackie.

Olive Saltator - Tom-pitcher.

Little Boat-tail Grackle - Black-bird.

Guiana Cowbird - Corn-bird.

Black Parasitic Cassique - Rice-bird.

Yellow-backed Cassique - Yellow Bunyah or Mockingbird.

Red-backed Cassique - Red Bunyah.

Red-breasted Blackbird - Robin Red-breast.

Little Yellow-headed Blackbird - Yellow-head.

Moriche Oriole - Cadoorie.

Yellow Oriole - Yellow Plantain Bird.

Guiana Meadowlark - Savannah Starling. 


\section{APPENDIX C.}

ALPHABETICAL LIST OF HOORIE ORTHOPTERA.

Acontista perspicua

Anaulecomara furcata

Colpolopha obsoluta

Creoxylus spinosus

Enopterna surinamensis

Gryllotalpa hexadactyla

Moncheca nigricauda
Posidippus degeeri

Prisopus flabelliformis

Pseudophasma phthisicus

Pterochroza ocellata

Schistocerca flavofascjata

Vates lobata

\section{NEW SPECIES OF MANTIS.}

Stagmomantis hoorie Caudell

ALPHABETICAL LIST OF HOORIE MOTHS.

Anacraga citrina

Anthocroca cuneifera

Apatelodes pandarioides

Apela divisa

Argeus labruscae

Argyrostoma nitidisquama

Attacus erycina

Automeris cinctistriga

Automolis semirosea

Azelina gammaria

Ballantiophona gibbiferata

Baeotarcha coemaroalis

Berberodes simplex

Capnodes subrutilans

Carthara ennomoides

Chrysocestis fimbriaria

Claphe braganza

Claphe mediana

Claphe morens

Claphe namora
Coenipeta bibitrix

Colla gaudialis

Dasygnia meterythra

Desmia funeralis

Dichromapteryx dimidiata

Dirphia tarquinia

Drepanodes agrionaria

Dyasia viviana

Eudioptis hyalinata

Epicepsis gnoma

Euagra collestina

Euclea cippus

Gonodonta pyrgo

Gonopinea albilunalis

Hadena regressa

Hylesia inficita

Hyperchiria liberia

Hyperchiria nausica

Ingura circularia

Iza rufigrisea

397 
Lepasta conspicua

Letis occidua

Leucinodes elegantalis

Lysana plexa

Maerodes columbalis

Malocampa eugenia

Melese castrena

Neritos coccinea

Neritos phaeoplaza

Olceclostera mira

Olceclostera satellitia

Orthogramma rufotibia

Pamea notata

Peosina helima

Phyllodonta cajanuma

Prepiella radicans

Pronola fraterna

Prumala ilus

Racheolopha confluaria

Racheolopha nivetacta
Racheolopha pallida

Racheolopha sarptaria

Racheospila intensa

Rifargia apella

Rolepa cuprea

Rosema zelica

Samea ebulealis

Samea gealis

Scolecocampa liburna

Stericta abrupta

Stericta multicolor

Stictoptera clara

Tachyphyle acuta

Tanasphysa adornatalis

Thysania agrippina

Tosale velutina

Trosea ignicornis

Urga parallela

Vipsophobetron marinna

\section{NEW SPECIES OF. HOORIE MOTHS.}

Acropteryx opulenta Dyar

Capnodes albicosta

Claphe laudissima

Emarginea empyra

Eois costalis

Hadena niphetodes

Hemipecten cleptes

Hylesia indurata

Illice biota
Ischnurges bicoloralis Dyar

Macalla pallidomedia

Neophaenis aedemon “

Paracraga amianta "

Rifargia phanerostigma "

Saccopleura lycealis " "

Thermesia dorsilinea "

Trosia nigripes " "

Zatrephes cardytera

NEW GENERA AND NEW SPECIES OF HOORIE MOTHS.

Dichocrocopsis Minacragides -

Dichocrocopsis maculiferalis Dyar Minacragides arnacis Dyar

Hositea -

Hositea gynaecia Dyar

Incarcha -

Incarcha aporalis Dyar

Thyonoea -

Thyonaea dremma Dyar

Zaevius -

Zaevius calocore Dyar

The Photographs and descriptions of these new genera and species have been published in Zoölogica, Vol. I, No. 4. 


\section{INDEX.}

Illustrations are indicated by page numbers in Italic.

A.

Abary, Birds of, 364,365 .

Bungalow, 358 .

Island, 358,359 .

River, $350,360,362$.

Admetus pumilio, 189, I9o.

Aequidens, 68, 69 .

Agouti, I6o, 31 2, 315, 318.

Agraulis vanillae, 375 .

Amazon Parrot. See Parrots.

American Redstarts, accompanying army of hunting ants, 50.

Anableps anableps. See Four-eyed Fish.

Anaconda, 26, 27, 240, 379.

André, Eugene, x, 86, 89.

Anis, I 21, I3I, I33, $35^{8}$.

Accompanying army of hunting ants, 49,50 .

Greater, flock of, $156,{ }_{57}$.

Smooth-billed, 254.

Anna Regina, 2+2, 243.

Anopheles, 76.

Antbirds, 194, 302, 303, 304.

Accompanying army of hunting ants, 49 .

Scaly-backed, 324 .

White-shouldered Pigmy, 194.

Ant-eater, I 70.

Great, $256,257$.

Lesser, 305, 306 .

Ants, Black, (Neoponera commutata), 49 .

Battle with hunting ants, 52 .

Houses of, $48,49,{ }_{3} 8$.

Hunting Ants (Eciton), 49-54.

Battle with Black Ants, 52, 53.

Warfare in nests of other species, 54 .

Parasol, 49, 21 7, 218, 3+5.

Fungi gardens of, 49 .
Aremu, Camp on, 274,275 .

Gold Mine, 285-288, 287, 289.

Landing, 268.

Little, $244^{-28} 4,276,297$.

River, Big, 244, 268.

Argeus labruscae, 211.

Armadillo, 170, 324.

Atta cephalotes, $\mathrm{r}_{3} 8$.

Attacus (Hesperia) erycina, $2 \mathrm{I}$.

A utomeria cinctistriga, $2 \mathbf{1}_{3}$.

B.

Baboons. See Monkeys, Red Howling.

Bananaquits, 40.

Barama River, $158,216$.

Entrance of, 160, 16r.

Our tent boat on the, 159 .

Barima River, I 37 .

Barrabarra River, 219 , 222-225.

Barrimani Police Station, $15 \%, 160$.

Bartica, 244, 245, 246.

Bashew, 165.

Bats, Fruit-eating, I2r, 122.

Manner of aligh!ing, 43.

Number of species of, 122.

Scarab, 270.

Vampires. See Vampires.

Bee, Giant, 343, 344.

Beetles, Bark, 20I.

Brazilian, 268.

Buprestid, 291, 348.

Elater, Brown, 54, 55, 192.

Larva of small species of, 55

Longicorn, 288.

Tiger, 29I.

Bête rouge, I $44, I_{4} 6$.

Biara River, 220-222, 226.

Bingham, Dr. Hiram, xi, 255, 354.

Birds brought alive from British

Guiana to New York Zö̈logical Park, in6. 
Bird Protection Ordinance of British Guiana, II 5 .

Blaberus trapezoideus. See Cockroach.

Blackbird, Red-breasted, 35I, 353.

Yellow-headed, I25, 35 I, 353 .

Blacks. See Negro.

Bois Immortelle trees, 42.

Botanical Gardens, experimental botanical work, I3I.

Fauna of, I29-I3I, I33.

Brassias, $2 \mathrm{r} 8$.

British Guiana, climatic condition of coast of, I3r.

Bufo agua, I22, I23.

Buffalo, Water, I29.

Bunyahs. See Cassique, Red-backed and Yellow-backed.

Bushmaster, $I 82, I 83, \mathrm{I} 84,277$.

Bushrope, aërial roots of, 296.

Butterflies, black and white, I93.

Ghost, 343 .

Heliconias, 40, 343 .

Milkweed, 58.

Morphos, I4, I87, I93, 250, 343.

Orange shaded, $3 \mathrm{I} 3,3 \mathrm{I} 4$.

Two species of, $163,27 \mathrm{I}$.

Orchid, 250, $25 \mathrm{I}$.

Orange, $163,187,375$.

Owl, 40, 4I, 42.

Papilio, I93.

Red Silverwing, 375 .

Swallow-tailed, 132.

Transparent, 196 .

Yellow, I63.

C.

Calf - bird. See Cotinga, Bareheaded.

Caligo ilioneus, 40.

Calliste, Black-faced, I 27.

Yellow-bellied, I 27, I35, 243.

Callidryas statira, 375 .

Calomesus psittacus, I4.

Camaria Landing, 248, $25^{\circ}$.

Falls at Lower, $2+9$.

Upper, 250, $25^{\mathrm{I}}$.

Caño San Juan, 75.

Caños, exploring in dug-out, $2 I$.
Canthon semiopacus, 270.

Capnodes albicosta, 288, 289.

Captain Truxillo, 22, 30, 74, 75, 78, $82,83,90,91,104,108$.

Capuchin Monkey, 6, 20, 24.

Capybara, 22, 233, 254, 255, 282, $38 \mathrm{r}$.

Caracara, I3I.

Carey-Elwis, Father, Mission of, I63.

Carib, Fish. See Perai.

Indian hunter and children, $I 78$.

Indian huts at Hoorie, I79, I8I.

Indians, three generations of, $I 80$.

Carnegiella strigatus, 252.

Cassiques, I 25, I 29.

Big Green, Courtship of, 202.

Flocking of, 214 .

Nests of, 36, 37, 236 .

Notes of, 37, 56, 201, 338 .

Red-backed, I37, I39, I42, I 74, 215 .

Colony of at Hoorie, 202-209.

Eggs of, 205.

Embryo, 205.

Food of, 206, 207, 208.

Nests of, 204, 205, 206, 208.

Young birds, 205, 206, 207, 208.

Yellow-backed, 32, I37, I39, I42.

Nesting of, 33, 34, 35, 36, 25 I 253.

Castina licus, 250, $25 \mathrm{I}$.

Castus sp., I92, I93.

Caterpillar, black, 328, 329, 347.

Catfish, Crucifix, I3, I4.

Armored, 68.

Of Guiana, I64.

Centis americana, 344 .

Centrurus margaritatus, 39.

Cercoleptes caudivolvulus, 37 .

Chachalaca, Abundance near Guanoco, 38 .

Voice of, 23, 24.

Chameleon caterpillar, I9r, I92.

Chrysocestis fimbriaria, $2 \mathrm{I} 2$.

Choloepus, 279.

Cicadas, Chant of, 24.

Chinese music of giant species, 25 . 
Cicadas, Cicada grossa, 301, 302 .

Six-o'clock bee, 235, 338 .

Cinereus Becard, I3I.

Clavillina, 219.

Cockroach, 45 .

Coelogenys paca, 305 .

Colaenis phaerusa, 375 .

Congo Pump, I9I, 273.

Coolie, of British Guiana, 117,118 , I 50.

Indenture system, I48-I49.

Coolies and their wives fishing in Essequibo, 247.

Cormorant, Guiana, 218, 275, 354 .

Cotinga, 304 .

Bare-headed, 332.

Pompadour, I76, I 79 .

Cotton Bird. See Flycatcher, Whiteshouldered Ground.

Couchi-couchi. See Kinkajou.

Cowbird, Guiana, I25, 202.

Crab Oil. See Bête rouge.

Crabs, I44.

Dancing, I6, I7.

Enemies of, 19.

Inhabiting roots of mangroves, 17 .

Inhabiting trunks and branches of mangroves, 17 , I 8 .

Method of catching, I 9 .

Mimicry among, 17,18 .

Crabwood, I9I.

Crandall, Lee S., ix, I 25, I60, I 7 I, I $82,207,209,215,385$.

Creepers, Blue Honey, 201, 298.

Honey, 135, 160.

Yellow-winged Honey, I 58, 340.

Crew. See Sloop.

Crocodiles, I4, I5, 57.

Canal of, $130,380,38 \mathrm{r}, 382$.

Of the Aremu, $27 \mathrm{I}$.

Cuckoos, Chestnut, I3I.

Cumaca trees, 269.

Curassow, $255,282$.

Crested, courtship of, 332, 333, $334,335,336,337,338$.

Curlews, 8.

Cuyuni River, 244, 248, 254, 259, 269.

Flowers of, 263.
Cuyuni River, Rapids of, 258,260 , $261,262,263,264,266,267$, 270.

D.

Deer, I60, I70, 246, 310, 3II, 3 I 9.

Savanna, 320.

Dendrobates trivitatus, 293, 294.

Desmodus rufus. See Vampire.

Dicotyles labiatus. See Peccary, White-lipped.

Dicotyles tajacu. See Peccary, Common.

Dirphia tarquinia, $2 \mathrm{II}$.

Dolphins, 30 .

Douraquara. See Quail, Guiana.

Dove, Red-winged Ground, I3I, I39.

Dragon Fly, 270, $27 \mathrm{I}$.

Diastatops tincta, 376 .

Erythrodiplax umbrata, 376 .

Erythrodiplax peruviana, 376 .

Dress suitable for woman on jungle trips, 195, 196.

Drowned Forest of Hoorie, I98202.

Ducks, Gray-necked Tree, 355, 356, 357 .

Muscovy, 3o, I35, 357, 359 .

Rufous Tree, 355 .

Vicissi, 383 .

E.

Eagle, Guiana Crested, ${ }_{3} 37$.

Eciton, 49, 50.

Egrets, American, 137, 234, 352, $353,38 \mathrm{r}$.

Snowy, 8, 64, I54, I 58 .

Elainia. See Flycatchers.

Electric eels, I 70.

Encounter with curiara in the Guarapiche, 22.

Epidendrum fragrans, 22, 23.

Epidendrum nocturnum, $24 \mathrm{I}$.

Epidendrum odoratum, 269.

Essequibo River, 134, 24., $2+5$.

Euchroma goliath, 29r.

Eudioptis hyalinata, 2 I 2.

Eunectes murinus. See Anaconda. 
Euphonia, I39.

Black-tailed, 40.

Purple-throated, 3 I9.

Violet, 240.

Euptoieta hegesia, 375 .

\section{F.}

Farnum's I58, 2I4, 2I5.

Felis concolor, 60, 6r.

Ferns, tree, on Little Aremu, 278.

Filo, 77, 84 .

Flamingo, 234.

Flycatchers, Elania, I3I, I32.

Gray Tody, I3I.

Kiskadee, 37, II2, I I 4, I 20, I2I, I3I, I35, I42, I48, 239, 247 , 357 .

Streaked, accompanying army of hunting ants, 50, $5 I$.

Tyrant, II6, accompanying army of hunting ants, 5 .

White-shouldered Ground, 65, 66, I3I.

White-headed Marsh, 65.

Flying Fish, Fresh Water, 252,265 , 269.

Salt Water, 253.

Forest, drowned, I99.

Four-eyed Fish, 14, I6, 19, 57, 237, 239.

Devoured by Crocodile, I 5 .

Eyes of, I9.

Fowler, Mr., 275, 277.

Francis, Jungle craft of, 316,317 , $318,320,321,322,326,332$, 333,338 .

Frederick, I47-I48, I5I, I 52 .

French, Mr., 248.

Frigate-bird, 234.

Frog, Bleating Calf, 277.

Castanet, 242.

Freight engine, 214, 277.

Roaring, 277.

Wing-beat, 238, 277 .

G.

Galictis barbara, 32I.

Gallinules, I29.

Purple, 378.
Georgetown, II 2.

Beauty of, II 6 .

Botanical Gardens of, 123.

Chief points of attraction of, I 2 I.

Inhabitants of, I I2, II4.

Museum of, 123.

- Sea Wall of, $I I 9$.

Street life of, II6-II8.

Street of, I I 3 .

Typical day of, I20, I2I.

Gillett, Father, 226, 227, $228,230$.

Gold Bird, 187, 188, 189, 193, 220, 246, 275, 307, 315, 342 .

Gold, Long Tom process, $185, \mathrm{I} 86$, I87.

Mines. See Aremu, Hoorie.

Panning, I85, I 86 .

Golden Shower Orchid, 220.

Gonodonta pyrgo, 342.

Grackle, Little Boat-tailed, I28.

Grassfinches, 48.

Grell, Ellis, x, 86, 87, 90 .

Green-heart Bird. See Gold Bird.

Green River Ibis, 253.

Grosbeaks, Black-faced Green, I76.

Black-headed Scarlet, 3I5.

Brown-breasted Pigmy, I2I, I27.

Thick-billed Pigmy, I42.

Gryllus argentinus, 348.

Guanoco, Children of, IOO, IO4.

Dances at, 97-IO3, IO4.

Fever at, 106.

First night at, 90-93.

"Headquarters" at, 87, 88, 97.

Inhabitants of, 97 .

Priestless chapel at, $\mathrm{IO}_{5}$.

Quarrel with United States of America, 98, 99.

Revolutionary reports at, $98,99$.

River of, 86.

Suffering that came to, 106, 107.

Village of, 32, 86 .

Women of, 106.

Guan, I44, 235, 255, 313.

Jacupeba, $32 \mathrm{I}$.

Marail, I79.

Guarapiche River, 20, 80, 8I, 82.

Guarauno Indians, 29.

At Caño Colorado, 83 . 
Guarauno Indians, Papoose, I07.

Squaws, 85 .

Wandering tribes of, IO3.

Guard Ship, 75, 76 .

Venezuelan soldiers on board of, 76.

Guava, Water, 263.

Gulls, Laughing, I34.

H.

Haasnoot, Captain, I Ir.

Haetera piera. See Butterfly, Transparent.

Harrison, Prof. J. B., 123 , 125.

Harry, Mr., 385 .

Hawk, Caracara, 371, 372.

Chima-chima, White-breasted, 62 , 64.

Cream-headed, 354, 355 .

South American Black, I64.

Heliconia butterfly. See Butterflies.

Heliconias, Scarlet, 58, 60.

Hemiptycha (Umbonia) spinosa, 2 I 3.

Herons, Agami, 2 I9.

Boat-billed, 234 .

Cocoi, 8, 234, 245, 268, 355.

Guiana Green, I 29, 355, 37 I .

Immature Blue, 64 .

Little Blue, I5, I $_{54}$, $5_{58 .}$

Louisiana, $\mathrm{I}_{54}$.

Yellow-crowned Night, 154.

Herpetodryas carinatus, 386.

Hoatzins, Eggs of, $37 \mathrm{r}$.

Enemies of, $37 \mathrm{I}, 372$.

Flight of, 28, 29.

Flock of, 377 .

Food of, 29, 2 I9.

Habits of, at Abary, $366,367,368$, $360,370,372,373,375$.

Nesting of, 29, 366, $37 \mathrm{I}$.

Number at Abary, 350 .

On the Guarapiche, $2 \delta$.

Photographing, 367, 372, 373, 374.

Sedentary life, of, $28,29$.

Use of wings, 374 .

Voice of, 26, 28, 365 .

Young of, 28.

Hodgson, Sir Frederick, x, 125.
Homalocranium melanocephalum, 45, 46.

Hoorie mine, Average daily temperature at, 170 .

Bungalow, r70, 209.

Creek, I64.

Crossing stream on road to, $I 67$.

Drowned forest of, 198-202.

Fauna around, I 70, I71, 209.

Flora of, 192, 194, I95.

Indian life near, I79-r84, I89, I90, I9I.

Insects of, 209-2r 3 .

"Little Giant" at, 175 .

Mine, I67-169, 172.

Wilderness trail to, $165^{-167}, 168$.

Hoplias malabaricus, 68, 69 .

Hornaday, Dr. William T., xi.

Hositea gynaecia, 2 I 2.

Hummingbird, Long-tailed, 325 .

Rufous breasted, 307 .

White eye-browed, 307 .

Hydrochoerus capybara. See Capybara.

Hyperchiria liberia, $2 \mathrm{I}_{3}$.

Hyperchiria nausica, 21.3.

\section{I.}

Ibis. See Green River. See Scarlet. im Thurn, Sir Everard, house of, I+2, I 43 .

Indian and the Law, I5I, I $52,{ }_{53}$.

Boys in dug-out, I 62.

Three-year olds at home in woodskin, $I 38$.

Insects. See Hoorie.

Mounting of, 2II, 2 I 2.

$\mathrm{J}$.

Jabiru, 353, 35t, 38r.

Jacamar, home of, 26.

Paradise, $\mathrm{I} 7 \mathrm{I}, \mathrm{I} 73$.

Jacana, Spur-wing, 63, 64, I29, 354, $378,38+385$.

"Josefa Jacinta." See Sloop.

Jaguar, 63, r6o, 293.

Jays, Lavender, I 73, $174,3+5$.

Jelly-fish, 4.

Jones, Mr. B. Howell, x.

Jumbie Birds. See Anis. 
K.

Killicow. See Rail, Cayenne Wood.

King, Howie, I29, I48.

As magistrate of Morawhanna, I49-I 5I.

Garden of, 146.

House of, I42.

Kingbirds, White-throated, 137 .

Kingfishers, Feeding on insects, I6.

Red-breasted, I63.

Rufous, I99, 282.

Kinkajou, 37.

Kiskadee. See Flycatchers.

Kites, Swallow-tailed, I54, 250.

\section{L.}

Labba. See Paca.

La Brea, x, 30, 59. See also Pitch Lake.

La Ceiba, 20.

Our floating home at, 18 .

Lilies, Spider, $57,58,225,363$.

Lizards, At Morawhanna, I46.

Protective coloration of, 43,44 , 45.

Tegu, 24, 146.

Loricates. See Catfish, Armored.

Lotus, 126.

M.

Macaws, 8

Blue and Yellow, I37, 338 .

Maestro, I4, 77, 80, 84, 85, 87.

Manakin, Golden-crowned, 342, $343,348$.

Gold-headed, 44

Wallace Olive, 322 .

White-breasted, 44, 45 .

White-capped, $3 \mathrm{II}$.

Manatee, I25, I7 O 22I, 222, 224, $38 \mathrm{r}$.

Mangrove, Flowers of, I 5 .

Jungle, description of, 9-I 2.

Manner of preparation of, Io.

Map of trip through, 2.

Red, I35, I 53.

Sunset in Mangrove wilderness, So.
Mangrove, White, I35, I53.

Wilderness, 95 .

Young plants, $I I, 58$.

Mantis, 213, 289.

Stagmomantis hoorie, 2 ro.

Map, of Abary Island, 361 .

Of three expeditions into British Guiana, $I I O$.

Of trip through Mangrove Wilderness, 2.

Marciano, 215, 222, 223, 234, 237, 238, 240, 242, 243.

Marlborough Police Station, 237.

Maroodie. See Guan.

Martins, Gray Breasted, II2, 244, $245,247,379$.

Matope, 253, 256, 258.

Mazaruni River, 244, 246, 248.

Steamer, I34, I4I, I42.

Maximiliano Romero, IOI-I02, I06.

Mecistogaster sp., 270, $27 \mathrm{I}$.

Mesomphalia discors, 268

Mission, on Morooka River, 225.

Wairamuri, 23I, 233.

Monkeys, Capuchin, 6, 20.

Marmoset, 300 .

No fear of railroad, 56,57 .

Red Howling, Description of, 325326.

As food, 329.

Voice of, 20, 56, I42, I70, I97, $277,293,325$.

Monstrera, 279.

Mora Passage, I35, I46, I53, I74, I75, 3OI.

Mora Tree, I35, I37, I38, 269, 296.

Morawhanna, I35.

Typical Indian House of, 136 .

Home of Mr. Howie King at, I42.

Morooka River, 225, 23I.

Agriculture on, 233.

Morpho butterfly. See Butterflies.

Morpho metellus, $3 \mathrm{I} 4$.

Mosquitoes, I $2,30,39,76,86$, I I 2-II 4, I 2O, I4 I, I44, 2 I4, $235,362,364$.

Moths, Hawk, 2 Iо.

Moon, 210.

Owl, 2r3. 
Moths, Waltzing, 46, 47 .

Mountains of Venezuela, $30,3 I$.

Mount Everard, I35, I37, I39, I4O, I4I.

Bête rouge of, I44-I46.

Mucka-mucka, 219, 238, 251, 366.

Muricot, 198 .

Mycetes seniculus. See Monkey,

Red Howling.

Myrmecophaga jubata, 256, 257.

\section{N.}

Negro of British Guiana, $I I 7$, II9.

Neoponera commutata, 49.

Nicholson, Mr., 253, 254, 256, 332.

Notogonia sp. See Wasps.

Nyctobates giganteus. See Beetles, Bark.

O.

Odocoileus savannarum. See Deer, Savanna.

Odontochila cayennensis. See Beetles, Tiger.

Odontochila confusa. See Beetles, Tiger.

Odontochila lacordairei. See Beetles, Tiger.

Opossum, I44, 308, 309.

Orchids, fragrant white, 22, 23.

Orinoco River, 4.

Orioles, Moriche, I42.

Yellow, I 21, I 27, I 29.

Ospreys, 156.

Otter, $163,28 r$.

\section{P.}

Paca, 160, 305.

Paddlewood, I9I, 301, 325.

Palm sheath, rocking toy, 100 .

Covering flower of palm, IOZ.

Papilio polydamus, I32.

Parauque, I48, 263.

Paria, Gulf of, 5,75 .

Parrakeets, 30 .

Parrots, Amazon, Mealy, I 74, 20I, $233,234,235$.

Blue-headed, flocking of, $\mathrm{I}_{57-158}$.

Dusky, 344.
Parrots, Dusky, Young of, 344, 345.

Yellow fronted, 66, I35, 146.

Eggs of, 67,68 .

Home of, 64 .

Island of in Pitch Lake, 62, 63.

Nest of, 65, 66 .

Young of, 67,68 .

Passiflora laurifolia. See Passion Flower.

Passion Flower, 272, 273.

Paxillus leachii, 20I.

Peccary, common, 160, 170, 233, $255,256,347$.

White-lipped, 256.

Pepe-yo. See Gold Bird.

Perai, I6o, I70, I98.

Peridromia feronia, 43.

Peripatus, discovery of and description of, 46 .

Perseverance Landing, $25^{8}$.

Petroea arborea, 187.

Phosphorescence off coast of British Guiana, I I I.

Pickersgill Police Station, 239, 240.

Pieris monuste, 375 .

Pigmy Owl, 40.

Pipe-fish, I6o.

Pipitoori. See Flycatcher, Graȳ Tody.

Pistia stratiodes. See Shell Flower.

Pitch Lake, of Venezuela, 30, 59, 88 .

Daily life at, 94-96.

Digging pitch, 90 .

Early morning trips to, 55-61.

Flora of, 63,64 .

History of, 9I-92.

Jungle railroad to, $55,56,57$.

Loading cars at, 93 .

"Mother" of, $6_{1}, 62,63$.

Plover, 8.

Poc-a-poo, 235.

Poeciloptera phalaenoides, 132, I33.

Polybia sp., 299, 300.

Pomeroon River, $234^{-240 .}$

Ponton. See Guard Ship.

Porcupine Tree, 36, 37 .

Pork-knocker, $187, \quad$ I88, 256,258 , $287,288$. 
Port of Spain, 3, 4.

Street life of, Irg.

Protective resemblances, 4I, 42, 43, 44.

Pseudauchenipterus nodosus, 13.

Psidium fluviatile, 263. .

Pterochroya ocellata, 213.

Puff-fishes, I4, I 5 .

Puma, South America, 60, 6r.

Purple heart trees, I63.

Pyrophorus sp., 54, 55.

Q.

Quadrille-bird, I88, 309, 310, 321, 330.

Quail, Guiana, 340, 341.

$\mathrm{R}$.

Racheolopha nivetacta, $2 \mathrm{II}$.

Rail, Cayenne Wood, 378.

Robins, White-breasted, I I6.

White-throated, 322, 323, 324, 340.

Rhyncophorus palmatum. See Weevil.

Rodway, James, I 23, I32.

\section{$\mathrm{S}$.}

Salapenta, 146.

Saman Trees, I32, I42.

Sandpipers, 8.

Solitary, 263.

Spotted, 58, I 56.

Sapadillo, I 21, I 27.

Scarlet Ibis, 7, 8, 8I, I 53, I 54, ${ }_{55}$.

Scorpion, 39, 46.

Battle with Caterpillar, 29I, 292.

Whip, I89, I9o.

Screamer, Horned, $38 \mathrm{r}$.

Sea-cows. See Manatee.

Seedeaters, 60, 142.

Blue-backed, I7I.

Semiotus ligneus, 192.

Serenades, by negroes from Pitch

Lake, roo, ror.

Serrasalmo scapularis, I60.

Shell Flower, 218.

Shypook. See Heron, Guiana Green.
Silk Cotton Trees, 163.

Sigh heard in the Mangrove forest and explanation of, 26 .

Simitú, 272, 273.

Skimmers, 8, I35, I48.

Sloop, Anchored in Guanoco River, 72.

At La Ceiba, $I 8$.

Description of, 3, 7 1 .

Description of crew of, 77

Entering Mangroves, 5.

First night on board, $72-75$.

Loss of, 108.

Saying good-by to, 93 .

Sloths, 37, 61, 170, 246 .

Three-toed, 279, 280,281 .

Snake-birds, 30, I37, 251, 252, 354 .

Sphingurus prehensilis, 36,37 .

Spider lilies. See Lilies.

Spider, Pedipalp. See Scorpion.

Sproston, 248.

Squirrels, Orange and gray, 24.

Stagmomantis hoorie. See Mantis.

Stomolophus meleagris, 4.

Stork, Maguari, 155, I 56 .

Sugarcane, experimented on in Botanical Gardens, I3I.

Sun-bittern, 25, 60, 86.

Suddie, 243.

Swallows, Banded, I62, I75, I76, 200, 265, 379 .

Barn, 247, 379 .

Emerald and white, 24 .

Red-breasted, 379 .

Tree, 379 .

Variegated, 247, 265, 378, 379, $38 \mathrm{r}$.

Swift, Feather-toed, I44.

Nest of, I43, I76.

Gray-rumped, 289, 292.

Palm, 56.

T.

Tacuba, 269, 279.

Taliput palm, I25, I 28 .

Tamandua tetradactyla. See Anteater, Lesser.

Tanager, Black-faced, I31.

Blue, I27, I39, I42, I 7 I. 
Tanager, Magpie, I38, I39.

Palm, 37, I16, I39, 142, 144, I47, I7I.

Silver-beak, II6, I39, I7I, 240, 292.

Tapakuma, Lake, 24I.

River, 240, 24I.

Tarantulas, 100, Ior, 199, 215, 218, 219,265 .

Tapir, 144, 255 .

Tarpon, 379 .

Tayras, $32 \mathrm{r}$.

Tegu Lizard, 24, 146.

Teius nigropunctatus. See Tegu Lizard.

Temperature, of Hoorie, 170.

Of Mangrove Forest of Venezuela, $\mathrm{I} 2$.

Tern, Great-billed, $154,378$.

Least, 378 .

Yellow-billed, 8.

Testudo tabulata. See Tortoise, South American.

Thrush, Black-capped Mocking, 40, 376.

Thysania agrippina. See Moth, Moon.

Thurn, Everard F. im. See im Thurn.

Tiger Bittern, 282.

Tiger, Warracabra, $38 \mathrm{r}$.

Tinamou, Great Blue, Description of, 48 .

Discovery of nest and eggs of, $47,48$.

Guiana Crested, 3I8, 3 I9.

Little, 330.

Tityra, Black-tailed, 177,179 .

Toads, of Georgetown, 1 22, I 23.

Telegraph, 238.

Tree, music of, I6I.

Tortoise, South American, 297, 298.

Toua-toua. See Grosbeak, Brownbreasted Pigmy.

Toucans, 30, $15^{8}$.

As food, 328 .

Black-banded Aracari, 174 .

Feeding of, 327,328 .

Red-billed, 174, 268, 326, 327 .
Toucans, Red-breasted, I 75 .

Sulphur- and White-breasted, I 74.

Trapping birds, I 25-I 29.

Tree-hopper, 213 .

Trinidad, 3,4 .

Trogon, Yellow-bellied, 250, 269.

Trumpeters, 60, II 7, I79, 255, 256, $330-332,338$.

Twa-twa. See Grosbeak, Thickbilled Pigmy.

Tyrantlet, Buff-tailed, $3^{1} 3$.

V.

Vampires, 227, 258, 263, 269, 277 .

Victoria regia, I $16,123,124$, I 29.

Vinton, Mr. and Mrs. Lindley, 35\%, 385 .

Vireo, Brown-throated, 322.

Vulture, Black, I I2, I 2 I.

King, I 37 .

Orange-headed, 292, 321, 383 .

W.

Waini River, I53, I54, I58, I60.

Walking Sticks, 289, 290.

Warracabra. See Trumpeter.

Wasps, 24, 25, 40.

Nests of, I3I.

Notogonia, 347 .

Protection of Cassiques by, 34, 35 .

Waterhaas. See Capybara.

Water Hyacinth, 218.

Water Lemon. See Simitú.

Weevils, Palm, 45 .

Welcome of Wilderness, 88-90.

"Who-are-you?" $38_{3}$.

Wilderness, early morning in, $3 f^{6}$.

Wilshire, Mr. Gaylord, x, I3+, I\$2, 227, 305 .

Mrs. Gaylord, x, I34, 21 5, 275.

Witch Birds. See Anis.

Withers, Mr., house of at Bartica, $246-248$.

Wood Ibis, 353, $38 \mathrm{~s}$.

Woodhewers, I3I, 194, 220, 246, 284 , $303,304,322,3.8$.

Accompanying hunting ants, 49.

Cinnamon spine-tail, 304,379 . 
Woodhewers, Clinging to trunk of tree, 50 .

Music of, 16r, 193.

Wedge-billed Pigmy, 339, 340.

Woodpeckers, 30 .

Guiana Ivory-bill, 200, 201.

Red-crested, 48, 292, 3II, 3I2, 3 I3.

Yellow, 40, $4 I$.
Wren, Guiana House, II 2, I20, I42, 247, 307, 308, 379 .

Jungle, 340 .

Marsh, 324.

Necklaced Jungle. See Quadrille-bird.

Z.

Zaevius calocore, 212. 


\section{THE AMERICAN NATURE SERIES}

In the hope of doing something toward furnishing a series where the nature-lover can surely find a readable book of high authority, the publishers of the American Science Series have begun the publication of the American Nature Series. It is the intention that in its Dwn way, the new series shall stand on a par with its famous predecessor.

The primary object of the new series is to answer questions which the contemplation of Nature is constantly arousing in the mind of the unscientific intelligent person. But a collateral object vill be to give some intelligent notion of the "causes of things."

Whilc the coöperation of foreign scholars will not be declined, the books will be under the guarantee of American experts, and generally from the American point of view; and where material crowds space, preference will be given to American facts over others of not more than equal interest.

The series will be in six divisions :

\section{NATURAL HISTORY}

\section{This division will consist of two sections.}

Section A. A large popular Natural History in scveral volumes, with the topics treated in due proportion, by authors of unquestioned authority. $8 \mathrm{vo}, \quad i \frac{1}{2} \times 10 \frac{1}{4}$ in.

\section{The books so far publisht in this section are:}

FISHES, by David Star Jordan, President of the Leland Stanford Junior University. \$6.00 net; carriage extra.

American INSECTS, by Vernon L. Kelnogg, Professor in the Leland Stanford Junior University. \$5.00 net; carriage extra.

BIRDS OF THE WORLD. A popular account by FraNk H. Knowlton, M.S., Ph.D., Member American Ornithologists Union, President Biological Society of Washington, etc., etc., with Chapter on Anatomy of Birds by Frfoneric A. Lucas, Chief Curator Brooklyn Museum of Arts and Sciences, and edited by Ronent Ridgway, Curator of Birds, U.S. National Museum. $\$ 7.00$ net; carriage extra.

\section{Arranged for are:}

SEEDLESS PLANTS, by George T. Moore, Head of Department of Botany, Marine Biological Laboratory, assisted by other specialists.

WILD MAMMALS OF NORTH AMERICA, by C. HART MrrriaM, Chief of the United States Biological Survey.

REPTILES AND BATRACHIANS, by Lfonhand Stejneger, Curator of Reptiles, U. S. National Museum. 


\section{NATURAL HISTORY (Continued)}

Section B. A Shorter Natural History, mainly by the Authors of Section A, preserving its popular character, its proportional treatment, and its authority so far as that can be preserved without its fullness. Size not yet determined.

\section{CLASSIFICATION OF NATURE}

1. Library Series, very full descriptions. 8 vo. $7 \frac{1}{2} \times 101$ in.

\section{Already publisht:}

NORTH AMERICAN TREES, by N. L. Britron, Director of the

New York Botanical Garden. \$7.00 net; carriage extra.

FERNS, by Camprel. E. WAters, of Johns Hopkins University, $\$ 3.00$ net; by mail, $\$ 3.30$.

2. Pocket Series, Identification Books-" How to Know," brief and in portable shape.

\section{FUNCTIONS OF NATURE}

These books will treat of the relation of facts to causes and effects - of heredity and the relations of organism to environment. 8vo. $6 \frac{5}{8} \times 8 \frac{7}{8}$ in.

\section{Already publisht:}

THE BIRD : ITS FORM AND FUNCTION, by C. W. BEEBe, Curator of Birds in the New York Zoological Park. \$3.50 net; by mail, $\$ 3.80$.

$$
\text { Arranged for: }
$$

THF INSECT: ITS FORM AND FUNCTION, by Vernon L. Kellogg, Professor in the Leland Stanford Junior University.

THE FISH : ITS FORM AND FUNCTION, by H. M. Smith, of the U. S. Bureau of Fisheries.

\section{WORKING WITH NATURE}

How to propagate, develop, care for and depict the plants and animals. The volumes in this group cover such a range of subjects that it is impracticable to make them of uniform size.

\section{Already publisht:}

NATURE AND HEALTH, by Edward Curtis, Professor Emeritus in the College of Physicians and Surgeons. 12mo. \$1.25 net; by mail, $\$ 1.37$.

THE FRESHWATER AQUARIUM AND ITS INHABITANTS. A Guide for the Amateur Aquarist, by Otro Eggring and Frederick Ehrenberg. Large 12mo. \$2.00 net; by mail, \$2.19. 


\section{A M E R I C A N NATURE SERIES (Continued)}

IV. WORKING WITH NATURE (Continued)

THE LIFE OF $\Lambda$ FOSSIL HUNTER, by Charles H. Sternber. Large 12mo. $\$ 1.60$ net: by mail, \$1.72.

ShELL-FISH INDUSTRIES, by James L. Kellogg, Professor in Williams College. $\$ 1.75$ net; by mail, $\$ 1.93$.

THE CARE OF TREES IN LAWN, STREET AND PARK, by B. E. Fernow, Professor of Forestry, University of Toronto.

\section{Arranged for:}

Photographing NATURE, by E. R. Sanborn, Photographer of the New York Zoological Park.

CHEMISTRY OF DAILY LIFE, by Henry P. Talbot, Professor of Chemistry in the Massachusetts Institute of Technology.

DOMESTIC ANIMALS, by William H. Brewer, Professor Emeritus in Yale University.

INSECTS AND DISEASE, by Rennie W. Doane, Assistant Professor in the Leland Stanford Junior University.

\section{DIVERSIONS FROM NATURE}

This division will include a wide range of writings not rigidly systematic or formal, but written only by authorities of standing. Large $12 \mathrm{mo} . \quad 54 \times 8 \frac{1}{8}$ in.

Already publisht:

INSECT STORIES, by Veron L. Ker.oge. \$1.50 net; by mail, $\$ 1.62$.

Fish Stories, by Charies F. Holder and David Stakr Jomban. $\$ 1.75$ net; by mail, $\$ 1.87$.

\section{Arranged for.}

HORSE TALK, by WIILIAM H. BrEwER.

BIRD NOTES, by C. W. BEeBE.

\section{THE PHILOSOPHY OF NATURE}

A Series of volumes by President Jordan, of Stanford University, and Professors Bnooks of Johns Hopkins, Lut. of Yale, Tномsos of Aberdeen, Przibian of Austria, zur Strassen of Germany, and others. Edited by Professor Kelrog of Leland Stanford. 12mo. $5 \frac{1}{8} \times 7 \frac{1}{2} \mathrm{in}$.

\section{Arranged for:}

THE Stability OF TRUTII, by David Starr Jordan.

\section{HENRY HOLT AND COMPANY, NEW YoRK JANUARY, ' 10.}




\section{BEEBE'S THE BIRD ITS FORMI AND FUNCTION}

By C. William Beebe, Curator of Birds in the New York Zoological Park, American Nature Series, with frontispiece in color and 370 illustrations from photographs, $496 \mathrm{pps}$. $8 \mathrm{vo}, \$ 3.50$ net, by mail $\$ 3.80$.

The story of the evolution of birds unlocked from technical language. The treatment is popular, and the volume is intended for all naturelovers and students, and as an accompaniment to the identification book.

"It is no little compliment to Mr. Beebe's book to say that among American works it invites comparison only with Part II of the late Dr. Coues's classic 'Key to North American Birds' (published separately only in England) and the present volume is the first in this country to be devoted wholly to a study of the relations existing between a bird's structure and its habits.

"So many of the 370 odd illustrations were made by the author from living birds, either in nature or in captivity, that they constitute an actual addition to our sources of information."-The Nation.

"Told in simple language, by a man who has made bird life the study of a lifetime. . . . A new departure in the literature of bird study."-Reviezs of Reviezs.

\section{KNOWLTON'S BIRDS OF THE WORLD}

By Frank H. KNowlton, of the U. S. National Museum, with chapter on the Anatomy of Birds by F. A. Ltcas, Chief Curator, Brooklyn Academy of Arts and Sciences, and edited by RoBERT RIDGWAY, Curator of Birds, U. S. National Museum. American Nature Series. With 16 colored plates and several hundred text cuts. $\$ 7,00$ net. Carriage 40 cents extra.

A modern, popular account. Following several prelimiary chapters on the general appearance and structure of birds, their migrations, distribution, classification, etc., every known family, both fossil and living, has been passed in review and accorded approximately equal and even treatment. The treatment of the game birds has been made very full.

"So far as possible technical language is avoided. Any one can find out what he wants about any bird he is interested in. The scientific terms are there, but all he wants to know is put in language he can easily understand. 'The colored plates are remarkably good and the other pictures really illustrate. The previous volumes of this series have been remarkably practical and helpful. Dr. Knowlton's 'Birds' comes up to their standard in every respect. It will be welcome to ornithologists and still more to the general public."-New York Sun.

"Series of Nature books have appeared in rather surprising number, but the best of them is "The American Nature Series.". . Enough is given to make identification a simple and attractive task. The arrangement, and its classification of the subjects is so well executed that even the tryo will not become lost in his journey."-Spring field Republican.

"The author has succeeded admirably. The illustrations are excellent and numerous. The colored plates are well executed. Should be in every library as well as every school library."-Scientific American.

Special illustrated circulars on request.

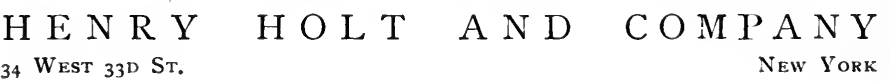


Tei:

geiv? 
Non

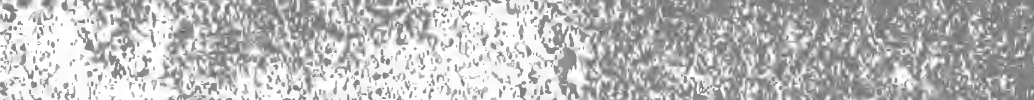

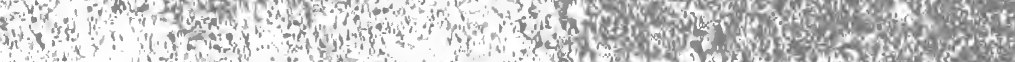

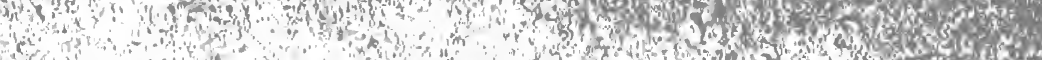

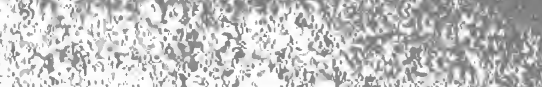

10

(1)

As.

然

75,2

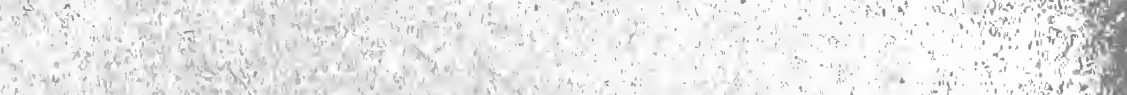




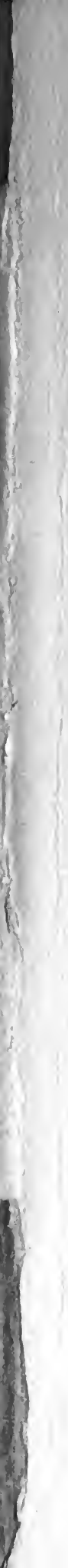




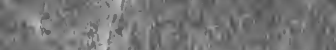

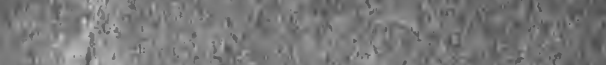

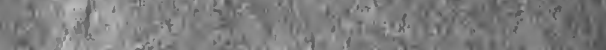

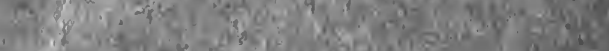

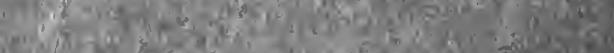

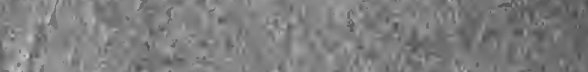

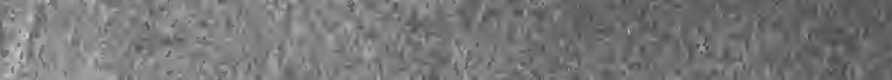

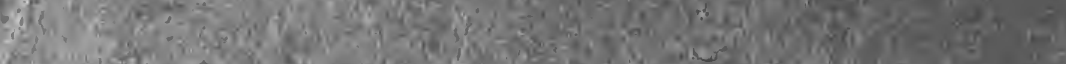

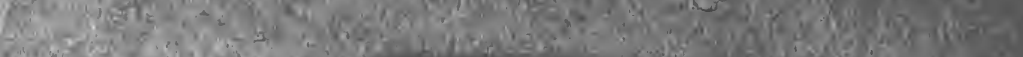

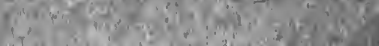
Q4 $2 x+3 y+y+2$

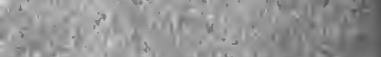

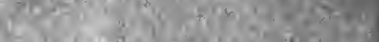

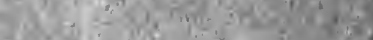

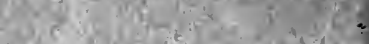

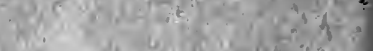
Q

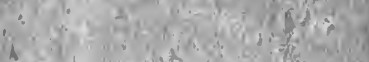

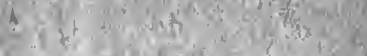

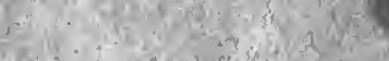

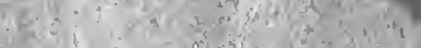

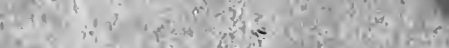

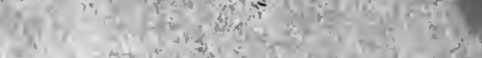

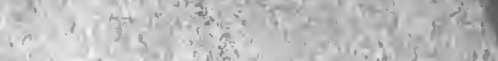

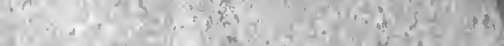

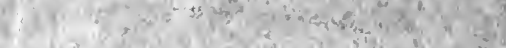

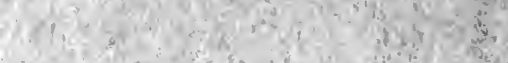

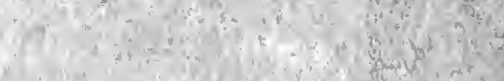

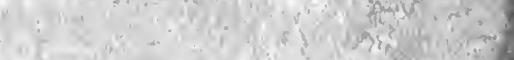

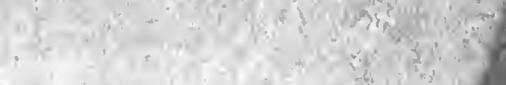

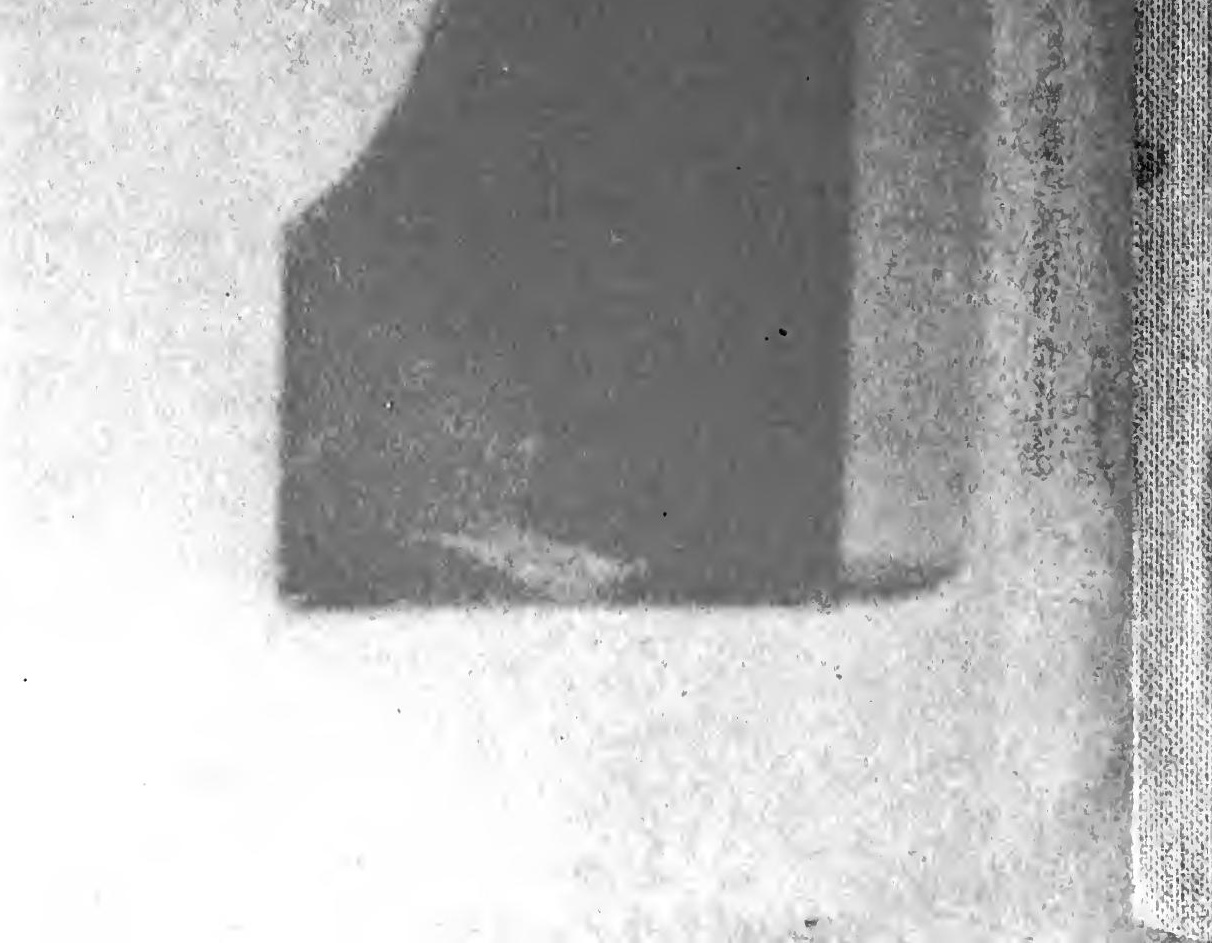




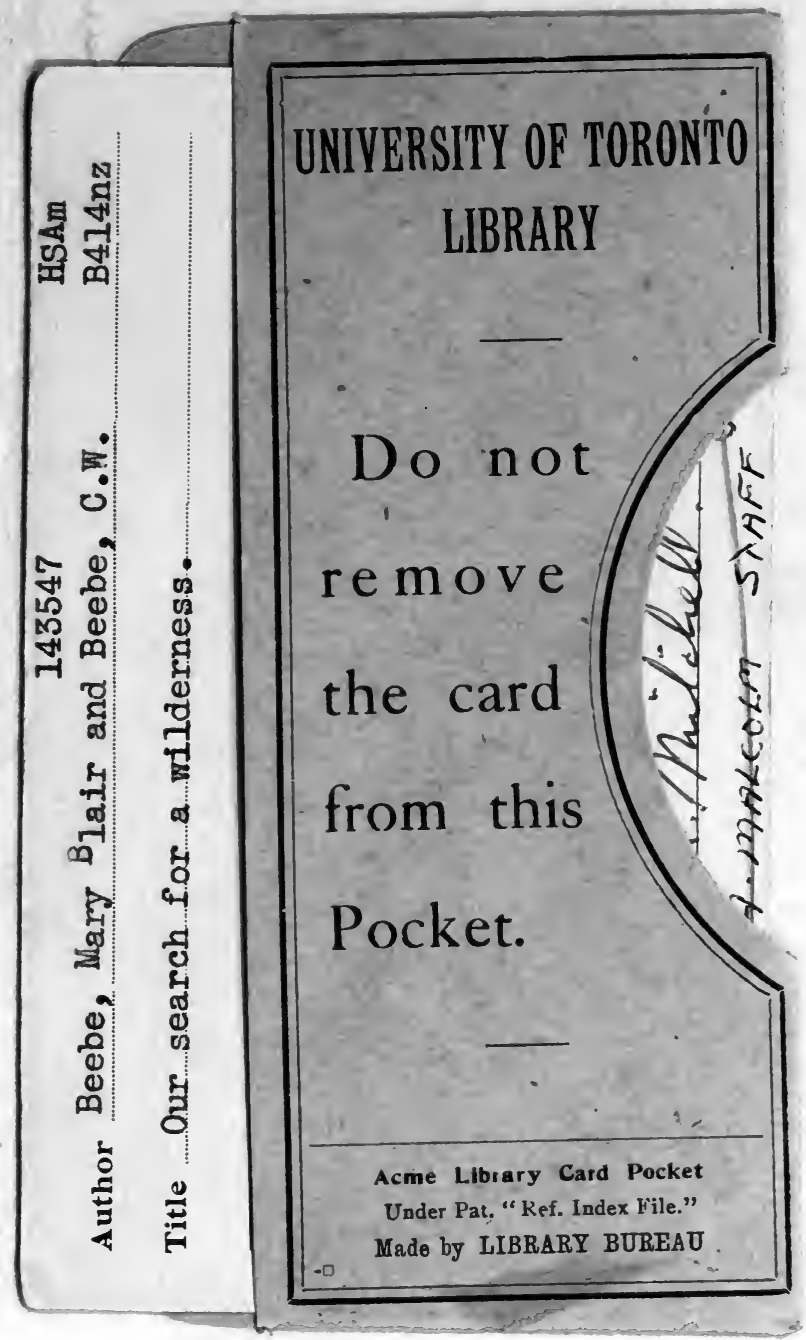




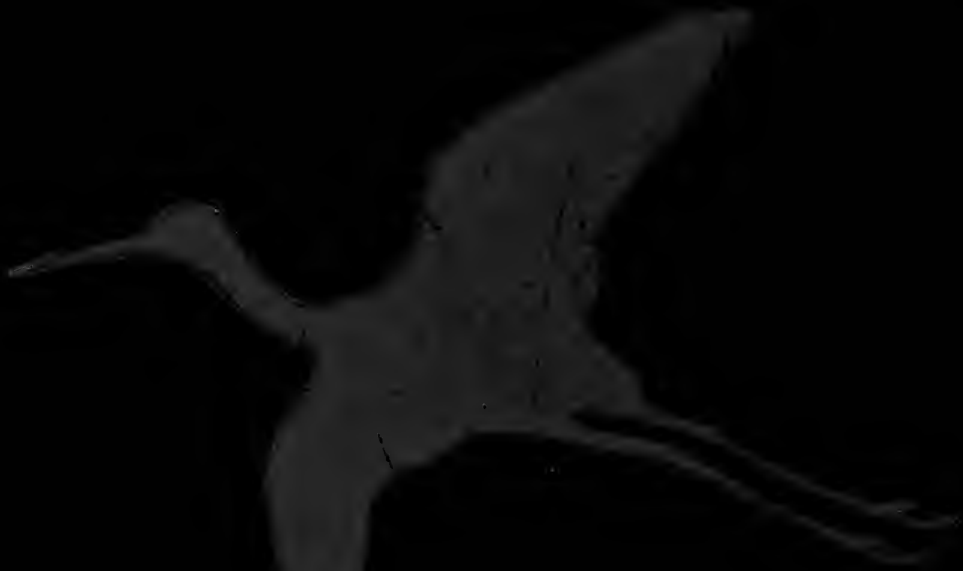

8 